\title{
IN THE EYE OF THE STORM
}




\section{ALSO BY BRIJ V. LAL}

Girmitiyas: The Origins of the Fiji Indians (1983)

Politics in Fiji: Studies in Contemporary History (ed. 1986)

Power and Prejudice: The Making of the Fiji Crisis (1988)

Broken Waves: A History of the Fiji Islands in the 20th Century (1992)

Pacific Islands History: Journeys and Transformations (ed. 1992)

Plantation Workers: Resistance and Accommodation (co-ed. 1992)

Tides of History: Pacific Islands in the 20th Century (co-ed. 1993)

Bhut Len Ki Katha: Totaram Sanadhya Ka Fiji (co-ed. 1994)

Lines Across the Sea: Colonial Inheritance and the Postcolonial Pacific (co-ed 1995)

Fiji Islands: Towards a United Future (co-author, 1996)

A Vision for Change: AD Patel and the Politics of Fiji (1997)

Research Papers of the Fiji Constitution Review Commission, 2 vols. (co-ed. 1997)

Electoral Systems in Ethnically Divided Societies (co-ed. 1997)

Crossing the Kala Pani: A documentary history of Indian indenture in Fiji (ed. 1998)

Another Way: The Politics of Constitutional Reform in Post-coup Fiji (1998)

Fiji Before the Storm: Elections and the Politics of Development (ed. 2000)

Chalo Jahaji: On a Journey of Indenture through Fiji (2000)

Pacific Islands: An Encyclopaedia (ed. 2000)

Coup: Reflections on the Political Crisis in Fiji (ed. 2000)

Pacific Lives, Pacific Places: Bursting Boundaries in Pacific History (co-ed 2001)

Mr Tulsi's Store: A Fijian Journey (2001)

Bittersweet: The Indo-Fijian Experience (ed. 2004)

Pacific Places, Pacific Histories: Essays in Honour of Robert C Kiste (ed. 2004)

The Defining Years: Pacific Islands, 1945-65 (ed. 2005)

On the Other Side of Midnight: A Fiji Journey (2005)

Encyclopaedia of the Indian Diaspora (Gen. ed. 2006)

Islands of Turmoil: Elections and Politics in Fiji (2006)

Texts and Contexts: Reflections in Pacific Islands Historiography (co-ed, 2006)

The Coombs: A House of Memories (co-ed. 2006)

Fiji: British Documents on the End of Empire (ed. 2006)

Turnings: Fiji Factions (2008)

A Time Bomb Lies Buried: Fiji's Road to Independence (2008)

Telling Pacific Lives: Prisms of Process (co-ed. 2008)

1987: Fiji Twenty Years On (co-ed 2008)

The 2000 Military Takeover in Fiji: A Coup to end all Coups? (co-ed. 2009)

Transnational Migrations: The Indian Diaspora (co-ed 2009)

The Loss of Innocence: Occasional Writings (forthcoming 2011)

A Vision for Change: Speeches and Writings of AD Patel (ed.forthcoming 2011) 


\title{
IN THE EYE OF THE STORM
}

Jai Ram Reddy and the Politics of Postcolonial Fiji

\author{
BRIJ V. LAL
}

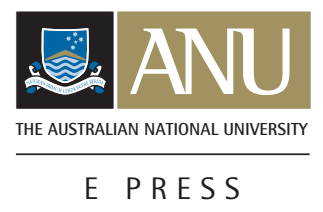




\section{ANU}

\section{E PRESS}

Published by ANU E Press

The Australian National University

Canberra ACT 0200, Australia

Email: anuepress@anu.edu.au

This title is also available online at: http://epress.anu.edu.au/eye_storm_citation.html

National Library of Australia

Cataloguing-in-Publication entry

Author: $\quad$ Lal, Brij V.

Title: In the eye of the storm : Jai Ram Reddy and the politics of postcolonial Fiji / Brij V Lal.

ISBN:

9781921666520 (pbk.) 9781921666537 : (ebook : pdf)

Notes: $\quad$ Includes bibliographical references.

Subjects: $\quad$ Reddy, Jai Ram, 1937-

Fiji--Politics and government--20th century.

Fiji--History.

Dewey Number: 320.99611

All rights reserved. No part of this publication may be reproduced, stored in a retrieval system or transmitted in any form or by any means, electronic, mechanical, photocopying or otherwise, without the prior permission of the publisher.

Cover design and layout by Lindy Schultz

Printed by Griffin Press

This edition (C) 2010 ANU E Press 
For the People of Fiji

History says, Don't hope On this side of the grave

But then, once in a lifetime The longed-for tidal wave

Of justice can rise up, And hope and history rhyme

Seamus Heaney 


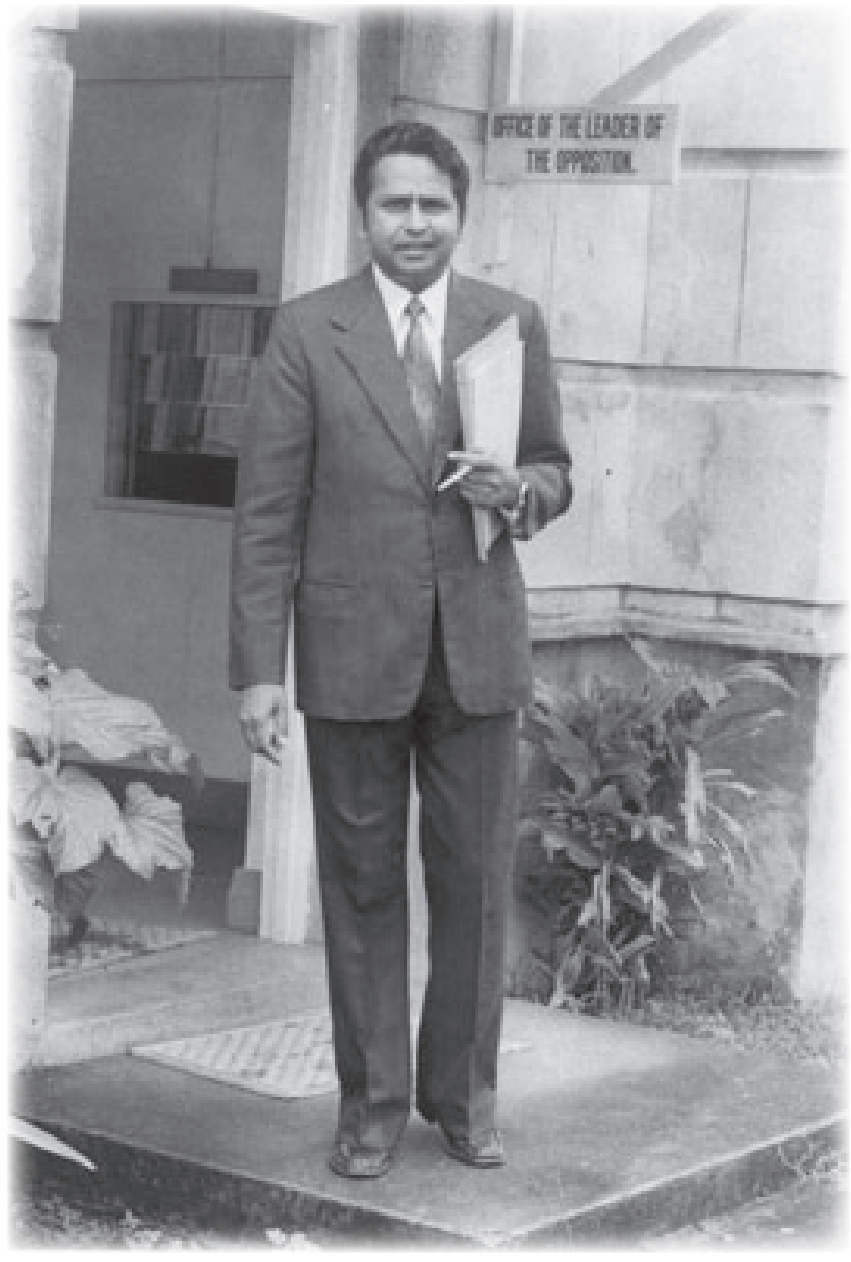




\section{MY FIJI}

I offer a vision which sees this beloved land of ours united in its diversity, forged out of adversity and built on trust. I offer you a vision of Fiji of which historians will say that, in the midst of our tragedy, we found courage and wisdom, and foresight and determination, to lead the nation away from the precipice into a prosperous future. I can only hope that my vision for this most wonderful of nations will fulfil its promise. I can only pray that we who have the moment at hand will find the courage, the strength and the determination to let the past be past, and build a nation that will stand not just to 20/20, but down through the centuries.

Jai Ram Reddy, 1993 


\section{JAI RAM REDDY - LIFE IN OUTLINE}

Date and Place of Birth: 12 May 1937, Lautoka Fiji

Education: Bar-at-Law, University of New Zealand, Wellington (1956-1960)

\section{Legal Qualification}

Barrister and Solicitor of the Supreme Court of New Zealand (admitted 1960)

Barrister and Solicitor of the High Court of Fiji (admitted 1961)

Work Experience (Legal)

Law Clerk, Bell Gully and Company, Wellington (1958-1960)

Staff Solicitor and Associate, AD Patel and Company (1961-1966)

Crown Counsel, Crown Law Office, Suva (1966-1968)

Principal Legal Officer, Crown Law Office, Lautoka (1968-1970)

Partner, Stuart Reddy and Company, Lautoka (1971-1988)

Sole Practitioner, Lautoka (1988-1997)

\section{Public Service}

Leader of the Opposition's nominee in the Senate (1972-1976)

First elected to the House of Representatives (Apr. 1977)

Leader of the Opposition (1977-1984, when resigned)

Attorney General and Minister of Justice (Apr-May 1987)

Member, Falvey Constitution Review Committee (July 1987)

NFP-FLP nominee to the Deuba Accord Committee (Sept. 1987)

Elected Member of the House of Representatives (1992)

Leader of NFP and Leader of the Opposition (1992-1999)

Member, Joint Parl. Select Committee on Constitution Review (1995-1997)

President, Fiji Court of Appeal (Mar-Aug 2000; Jan 2002 - Apr 2003)

Permanent Judge, International Criminal Tribunal for Rwanda (2003-2008)

\section{Honours and Recognition}

Fiji Independence Medal (1970)

Fiji Independence 25th Anniversary Medal (1995)

GOPIO Award for Political Leadership (NY. 1990)

Companion of the Order of Fiji (1998) 


\section{CONTENTS}

DEDICATION ...........V

JAI RAM REDDY — LIFE IN OUTLINE..........VIII

PREFACE...........IX

INTRODUCTION...........1

CHAPTER 1: INHERITANCE...........39

Roots and Routes...........42

Sangam and the Sadhus...........49

Education and Family...........54

Towards Law...........62

Colonial Foundations, Indirect Rule..........67

CSR and Sugar...........74

Constitutional Change............80

Towards Self Government............85

1965 Constitutional Conference 88

Testing the Waters...........92

Towards Independence...........96

CHAPTER 2: BAPTISM BY FIRE

The Independence Decade: Decline.

The Butadroka Effect...........126

Agricultural Landlord and Tenant Act (ALTA)...........132

Deepening Divisions...........138

Towards April 1977..........142

The Bombshell...........147

The D-Day: April 7...........157

Prime Minister: Not to Be...........158

The September Debacle...........171

CHAPTER 3: RUPTURE AND RECUPERATION...........191

Building Bridges..........192

Race and Land............196 
Government of National Unity...........204

NFP-Western United Front Coalition...........211

The 1982 General Election Campaign...........217

Chota Ghar and Beyond...........222

The Carroll Report and Four Corners..........227

The Russians Are Coming...........237

Fijian Paramountcy Again...........242

CHAPTER 4: BEFORE THE STORM..........285

Departure..........287

Instantly, Instantly..........292

Bad Old Days Are Here Again...........300

Fiji Labour Party...........305

Coalition............312

The 1987 Campaign...........320

CHAPTER 5: SUNSET AT NOON...........345

The Road to May $14 \ldots \ldots \ldots . . . .352$

D-Day and Week After...........367

Falvey and His Still-Born Report............387

To September 27 and Beyond............398

A Charter for Mayhem...........403

Deuba Accord: 'British Solution to a Fijian Problem'...........405

September Coup...........410

CHAPTER 6: TRANSITION..........433

CHAPTER 7: BACK FROM THE BRINK...........477

Towards the 1990 Constitution............479

Death of a Leader and a Dream...........487

To Participate or Not to Participate...........490

Confusion in the Fijian Camp...........500

The Race for Prime Minister...........503

The Rocky Road to Recovery...........511

Déjà vu...........521

1994 Elections............526

CHAPTER 8: NEW FOUNDATIONS............565

Setting Up the Constitution Review Commission...........567

Reviewing the Constitution...........579 
Submissions...........582

Diagnosis and Recommendations ...........594

The Report and the Reaction...........602

Joint Parliamentary Select Committee..........608

The Stormy Passage...........614

CHAPTER 9: THE DÉNOUEMENT...........661

The Road to $1999 . . . . . . . . .664$

The Campaign...........671

Issues in the Campaign...........682

Reddy's Exit: Badka Knows Best...........690

CHAPTER 10: THE ROAD TO ARUSHA...........713

BIBLIOGRAPHICAL GUIDE...........721

INDEX...........725

ABOUT THE AUTHOR...........735 



\section{PREFACE}

The struggle of man against power is the struggle of memory against forgetting.

Milan Kundera

Hindsight is dead sight after all, jealous of memory that breathes.

MG Vassanji

Jai Ram Reddy was the most significant Indo-Fijian leader of postcolonial Fiji until his departure from the political stage in 1999, just as AD Patel had been the greatest leader of the Indo-Fijian community in colonial Fiji until his death in 1969. Both men, from different historical eras, political contexts and experience of politics, espoused a vision for Fiji which failed to materialize in their own time, but which now stands vindicated. The unheralded father of Fijis independence movement, Patel died a year before Fiji became independent, though not on terms which he would have approved. His lifelong struggle for a democratic, equitable, and non-racial political culture in Fiji was vehemently opposed by his political opponents who privileged primordiality over political ideology, and for whom race in time became the inexorable fact of life in the political governance of the country. It is now widely acknowledged on all sides that preoccupation with race and the politics of racial compartmentalization without political partnership has been a major cause of Fiji's postcolonial difficulties. ${ }^{1}$

Reddy espoused the politics of moderation and, more particularly, the politics of consociationalism, that is, guaranteed group representation in parliament and mandatory power-sharing among the major communities embedded in the constitution itself and not left to the vagaries of the electoral process. He talked reconciliation in post-1987 Fiji, seeking solutions to the country's political and economic problems that were practical and 
incremental, not ideological and absolute, always seeking, wherever possible, the consensus middle ground. Principled pragmatism informed by a large measure of realism was the hallmark of Reddy's political philosophy. His consociationalist vision found expression in the once widely acclaimed 1997 Constitution of Fiji, of which he was a co-principal architect, although he himself was not destined to remain on the political stage long enough to ensure its success, or to protect it from insurgents, who finally tore it up in April 2009. In their 'defeats' suffered in the quest for social justice, human dignity and political equality, both Patel and Reddy stand tall, both concluding their political lives as statesmen of stature and integrity, though like the proverbial prophets, not finding honour, or even broad acceptance, among their own people in their own lifetime. Montaigne is surely right: 'There are some defeats more triumphant than victories.'

In an earlier book, A Vision for Change: AD Patel and the Politics of Fiji, I attempted a narrative of the political evolution of the Indo-Fijian community from the 1920s to the eve of independence in the late 1960s through the prism of the life and work of AD Patel. In this book, which may be read as a sequel to my earlier work, I seek to trace the contours of Indo-Fijian politics from the early years of independence in 1970 to the final years of the 20th century through the prism of Jai Ram Reddy's life and work. This volume, like the earlier one, is not a biography in the conventional sense of a written life of another person. It is more in the nature, I suppose, of a political history of the subject. The focus is not on Reddy the man and his interior life or his private emotional world. Such an approach would require a degree of intimacy with the subject that I do not possess. Moreover, that kind of project is beyond my competence and even inclination to pursue. Oedipus complex and all that are not for me. I accept for the purpose of this project that the public self is the 'real' self. Hence the focus on Jai Ram Reddy's public life and his engagement with the dominant political issues and concerns of his time shaped by the master narratives of colonialism and postcolonialism. This approach is entirely appropriate for historical enquiry because, as someone has said, the public life of public men, dead or alive, is 
the property of the people. Their lives in truth constitute a direct transaction with history. Given my approach, I hope this book will also be read as a collective portrait, a snapshot, of a people and a place at a particular moment in Fiji's late 20th century history.

I readily acknowledge the dangers of seeing the past through the experience of one individual. It is far too tempting, in this approach, to impute too much importance and impact to the actions and thoughts of one person when, as is so often the case, the person actually represents the consensus of a larger group of which he was merely a spokesman. The approach could also potentially frustrate an understanding of the deeper forces of change over time that transcends the range of personal experience. All that said, it is still true that some men and women do achieve a level of political eminence and practical authority in the affairs of their societies and are able, by force of personality and personal intervention, charisma or cunning, to mould events to suit their purposes and thus affect the course of history. I hope that Jai Ram Reddy will come across in this book both as an agent as well as a mirror of change, reflecting the dilemmas of the time in which he lived, and the strengths and weaknesses as well as the fears and fractures in the lives of the people he led for the better part of three decades.

'Biographers,' writes David Taylor, himself the splendid writer of George Orwell's life, 'very often fall catastrophically out of love with their subject.' ${ }^{2}$ He did not count himself among them. Nor do I. The aim of the biographer, says Patrick French, the writer of VS Naipual's equally superb authorized life, 'should not be to sit in judgment, but to explore the subject with ruthless clarity to the calm eye of the reader.' ${ }^{3}$ Open-mindedness and clarity: certainly; but I would add another attribute: sympathetic understanding. I have seen enough of politics at work from close range, enough of the role that contingency, emotion and sheer stupidity play in human affairs so as not to rush to judgment. I have seen enough decision-making done on the run, in the heat of the moment, without the privilege of leisurely reflection and detailed research, to approach the past with a proper sense of humility. Still, 'I have said all the good and all the evil,' as William Butler 
Yeats says in the preface to the Trembling of the Veil, 'I have kept nothing back necessary to understanding.'

That said, I should be candid with the readers at the outset. I am in broad sympathy with Jai Ram Reddy's political philosophy and approach to politics in Fiji and the fundamental transformation he sought to bring about in its political culture and orientation. The essential course Reddy attempted to chart for his people and his vision of their place in the larger scheme of things was intrinsically right. That it failed to ignite their imagination and caused them instead to desert him and all that he stood for is a matter for legitimate debate and discussion, but there is now a gradually gathering consensus across the political spectrum, even among his erstwhile opponents, that had it succeeded, Fiji would almost certainly have been spared the agony and turmoil it was later to encounter in its troubled journey towards the 21 st century. Reddy's defeat was, in my judgment, a hugely missed opportunity for Fiji, among so many other missed opportunities that haunt the country's forlorn landscape of the 20th century. 'What might have been' must surely count among the saddest phrases in the English language.

It is always difficult, in a book such as this, to strike a balance between the information that should be provided to enable readers to make their own judgments about a particular issue in debate, on the one hand, and the need, on the other, not to clutter the narrative with excessive extraneous detail that leaves little room for interpretation and context. The general level of scholarship on Fiji politics is sophisticated and varied enough, but much of it is inaccessible to the general public. The difficulty is compounded by the depressing absence of a vigorous reading culture in Fiji; and many journals which once served as vehicles for debate and discussion, on which I have drawn extensively, are now gone and old issues found, if they are found at all, on the bare shelves of a few public libraries. ${ }^{4}$ I have therefore provided as comprehensive a coverage of events in postcolonial Fiji as I have deemed it necessary for my purposes, and based my interpretation on the evidence provided. That evidence is both verifiable and ascertainable. 
There will be readers who will ask whether I have been objective and impartial in my interpretations. It is a fair question. I do not invoke an impartiality I do not feel. I am a part of the history I am narrating, not a cold observer outside or above it. As the distinguished historian of Japan, Tessa Morris-Suzuki, puts it, 'We live enmeshed in structures, institutions and webs of ideas which are the product of history, formed by acts of imagination, courage, generosity, greed and brutality performed by previous generations. ${ }^{5}$ I am no exception. I was in my early university years when Jai Ram Reddy entered the national political arena and have been, for most of the period covered by this book, an interested bystander, and a regular student of it, and for a brief moment, a minor participant in the history I now narrate. Reddy's story is inevitably refracted through the lens of my own personal experience and political perspective. It cannot be otherwise. It is, in an important sense, my story too. Facts don't speak for themselves, contrary to what we learnt in school all those years ago. They never do. They only speak when spoken to, and they silently answer questions we ask of them. And history can often be such an opaque, tangled web of myths, truths, emotions and intrigues, 'connected and divided,' as Isaiah Berlin puts it, 'by literally innumerable unidentifiable links — and gaps and sudden discontinuities too, visible and invisible.' ${ }^{6}$

Scholarship of any kind is always partial, in both senses of the word, however much we may be loathe to admitting it. In my research effort over the last three decades or so, I have followed the advice of that distinguished humanist and my onetime colleague at The Australian National University, Professor OHK Spate. 'The impartiality', Spate says, 'which evades responsibility by saying nothing, the partiality which masks its bias by presenting slanted facts with an air of cold objectivity — these are a thousand times more dangerous than an open declaration of where one stands; then at least those who disagree can take one's measure with confidence: 'that is why he said thus.' The important points, Spate continues, 'are that inference must be made based on evidence, as carefully verified as possible; and that the choice shall be made from the evidence, and not 
from pre-conceived ideas.' 7 That, I hope, will be the criteria used to judge this study.

Recognition, then, of one's position is important in any work of scholarship. There is another: humility. Hindsight should not hound history, nor the present prosecute the past. Monday morning quarterbacking, as the phrase goes in the United States, is tempting, but it is an indulgence best left to the faculty tea room. The case for authorial humility is wonderfully expressed in the words of the American panjandrum Teddy Roosevelt. 'It is not the critic who counts,' he writes, 'not the man who points out how the strong man stumbles or where the doer of deeds could have done them better.' The credit, he continues, 'belongs to the man who is actually in the arena, whose face is marred by dust and sweat and blood, who strives valiantly, who errs and comes up short again and again, who spends himself in a worthy cause; who, at best, knows, in the end, the triumph of high achievement, and who at the worst, if he fails, at least he fails while daring greatly. ${ }^{8}$ There should always be room for criticism and evaluation, for history at the end of it all, as someone has said, is an argument without an end; but it should always be tempered by a sensitive appreciation of context, contingency and circumstance.

This book has been in the making for far too long. It was begun in a Fiji very different to the one in which it was completed. I conceived the project sometime in the late 1990s, though precisely when I cannot now recall. But then things changed. There was, to start with, Jai Ram Reddy's defeat in the 1999 general elections. The following year, George Speight, a self-proclaimed but spurious Fijian nationalist, sprang his improbable quasi-coup against the government led by Mahendra Chaudhry. There then followed a period of uncertainty when the spirit of the constitution, in whose formulation Reddy had such a big hand, was disregarded or otherwise breached to placate powerful fringe elements in society. In December 2006, Commodore Frank Bainimarama carried out Fijis fourth military coup in two decades, unleashing forces which have the potential to alter Fiji's political fabric forever. A Fijian-dominated army confronting a Fijian- 
dominated government was not a scenario many people in Fiji would have contemplated a decade ago — or ever — nor the unceremonious humbling and humiliation of the central social institutions of indigenous Fijian community. 'Indigenous rights' was such a potent and inevitably polarizing rallying cry in the first thirty years of postcolonial Fiji: both the 1987 as well as the 2000 coups were justified in its name, but it now lies on the margins of mainstream political discourse in Fiji as indigenous Fijians have become the outright majority of the total population and control the levers of major public institutions in the country.

The principal cause of this change has been the enormous demographic transformation in Fiji over the last two decades with far-reaching political consequences. When Reddy entered politics in the 1970s, Indo-Fijians were close to fifty percent of the population. By the time he finished his career, they were reduced to about forty per cent, and declining further (through unceasing emigration and a low birth rate). This trend will continue long into the future. With this decrease has forever vanished the fear of 'Indian domination,' which, as this book will show, infected the body politic of Fiji like a deadly virus since the end of the Second World War when the IndoFijian component of Fiji's population exceeded the indigenous Fijians' for the first time. Space has opened up for public debate about intra-Fijian issues - provincial tensions and disparities, disputes about chiefly titles and entitlements, dynastic ambitions of leading chiefly families — which once remained carefully hidden from the public view, taboo subjects for public discussion. The ethnic and political concerns, which animated political debate in Fiji once, have lost their salience and potency. In an important sense, this book could well be read as an epitaph to an era of politics now vanishing before our eyes.

A word about the structure of the book is in order. The book is essentially a historical narrative treating, after an introductory chapter, the political developments in Fiji from the 1970s to the late 1990s. I have scrupulously followed the advice the King gave to the White Rabbit in Alice in Wonderland. When the White Rabbit asked the King, 'Where shall I begin, 
please, Your Majesty?' the King replied: 'Begin at the beginning, and go on till you come to the end, and then stop.' So it is here. The narrative is interrupted only once, in Chapter Six (Transitions), where I attempt an assessment of what went on before 1987, the year of the coups, and what followed afterwards. The date also provides a convenient break as an exact mid-point in Reddy's political career.

There is one other novel aspect of the structure that should be mentioned: the inclusion of 'Interlude' at the end of each chapter. This section includes a single, or sometimes several, pieces by Jai Ram Reddy himself on some aspect of the issues covered in a particular chapter. I have drawn on this material to construct my own text, so it is not absolutely necessary for readers to read this section to get the flow if they are minded to continue uninterrupted with the connected narrative; but if they wish to read Reddy's own thoughts about his fears and concerns, his position on issues and his vision for the future, they can do so, and in the process check my interpretation against the subject's own words. They can, to use Edward Said's words (borrowed from music), read the two sections 'contrapuntally.' I could have put the 'Interlude' section in an appendix at the end. But an appendix is an appendix after all. This book is both a coherent narrative as well as an archive of words spoken and written by the subject himself.

Many people have helped me with the research for this book, beginning with Mr Jai Ram Reddy himself. At first understandably reticent and wary about his political past being probed and paraded before the world, he cooperated fully with me, though from a discreet distance and with appropriate disinterestedness. He gave me all his papers and spoke to me candidly and at length but issued no direction and placed no restrictions on the use I could make of the material. He read the completed manuscript with care and corrected errors or distortions in it. Still, I should state emphatically for the record that this is not in any sense an 'authorized' biography, and that Mr Reddy should not be held responsible for the use — or misuse - I have made of the material he generously made available to me. I have also drawn freely and extensively on my own previous writings on Fiji history 
and politics and on the published record in the form of Hansard and newspaper reports, conference proceedings, internal party documents, and private papers. The story I tell here is thus constructed from this kaleidoscopic mass of information. I have not thought it necessary in a book like this to provide a minute documentation of every piece of evidence I have used. I give the readers my solemn word that every 'fact' mentioned and every quotation cited here is verifiable. The newspapers and the proceedings of the Fiji parliament are at the National Archives of Fiji in Suva. Reddy's private papers are with the Pacific Manuscripts Bureau at The Australian National University in Canberra. Regrettably, papers in private hands are not as accessible or as safe.

My research also benefited immensely from the generous conversations I had with scores of people from all walks of life, all over Fiji, over nearly a decade. Among them were Reddy's implacable political opponents as well as his colleagues. This has been one of the most rewarding and enjoyable aspects of my fieldwork. The memory of the copious bladder-bursting kava sessions, the rustic, thigh-slapping humour, the inebriated singing long into the night, the passionate late-night arguments unable mysteriously to be recalled at all in the morning, will remain with me. So, too, will the haunting faces of ordinary men and women, hidden from the public view, beyond the reach of official statistics and influence, ever ready to share whatever little they have, never complaining, going about their daily business with dignity and courage. 'Loyalty' is not just another word to them. It is the creed by which they live their daily lives. It is ordinary people like these, children of the soil - a Narend Reddy in Garampani, Tavua, or a Shardha Nand in Korovuto, Nadi (now gone) — who draw you to Fiji, who make the place what it is: endearing and loveable, and beyond the reach of words.

Some friends went beyond the call of friendly duty and offered to read portions of the manuscript for me. I am deeply indebted to them for their insights and judgments and corrections of factual and stylistic errors. They are too many to be named individually, and some I know do not want to be acknowledged publicly at all, but I must thank Ratu Joni Madraiwiwi, 
Kamal Iyer, Ashwin Raj, Jagindar Singh, Pramod Rae, and Biman Prasad in Suva, Janardan Reddy in Canberra, Karam Ramrakha, Robert Norton and Stewart Firth in Sydney, Doug Munro in Wellington, John Henderson in Canterbury, and Jacqui Leckie in Otago, for reading parts of the manuscript and making many helpful suggestions. To Bob Norton especially I owe more than I can express in words for the care with which he scrutinized the final draft, as from a different angle did the esteemed fiction writer Kaaron Warren.

Several old timers with whom I spoke were visibly distressed as they recalled the heartaches caused by the futile battles of the past now lying dormant in the vanishing memory of a passing generation, and wondered aloud whether there was any point at all in dwelling on them. The community had endured enough self-flagellation, they said. The past was past; the old protagonists were gone, unable now to refute or verify the story I tell here; old battle scars were disappearing, and there was need for closure, to move on. I understand their sentiments but do not share them. The past is never really past, as William Faulkner reminded us all those years ago. The past, as they say, is always present. Or, as Oodgeroo Noonuccal puts it, 'Let no one say the past is dead/the past is all about us and within.' There is no denying that parts of the story told here are indeed painful: the debilitating factionalism, the endless in-fighting, the patent falsehoods, the masterful cynicism, the political savagery and self-serving calculations and deliberate distortions nurtured for the sole purpose of gaining political mileage. The pornography of the naked grab for power on full display is never a wholesome sight.

All this, together with the undoubted achievements, is also a part of our history and our political heritage. It cannot be ignored or wished away. I live with the certainty that this book will be one among many, many conversations about Fiji in the years to come, and that Jai Ram Reddy's perspectives and interventions will be revised in the fullness of time as other accounts come to light. There will always be room for multiple perspectives on the past. That is the way it always is, and should be; and we all have 
our roles to play. It is the historian's job always to remember what others have forgotten, or conveniently chosen to forget. Or, as a few lines from an anonymous poem put it: 'The past is gone/Only fragments remain/My task is to find out/And tell the world.' In undertaking the task of remembering, Voltaire's advice is worth heeding as well: 'To the living one owes respect; to the dead one owes the truth.'

I thank institutions and individuals who gave me access to records in their possession. The first among them always will have to be the National Archives of Fiji where I have spent intermittent periods of research for nearly thirty years. Setareki Tale, the Archivist, Salesia Ikaniwai, the Chief Librarian, and her assistant, Asena Dame, were invariably courteous and helpful, as was the staff at the Parliamentary Research Library in Suva where I consulted unpublished official parliamentary records. At the Pacific Collection of the University of the South Pacific, Jainul Nisha and Leela Reddy bravely provided assistance with newspapers and other records. The staff at the Madras State Archives in Chennai were courteous and cooperative, as were district officials in Cudappah. Kamal Iyer opened up the rich and extensive archives of the National Federation Party to me along with his phenomenal memory of the recent political history of Fiji. Netani Rika, the editor of the Fiji Times, has my gratitude for permission to use photographs in the custody of his newspaper, and Margaret Keni my thanks for reproducing them. The photographs from the old (pre-1987) Fiji Sun are at the National Archives, and those from the now-discontinued magazines are appropriately acknowledged. At Radio Fiji, I was able to listen to some old campaign speeches that speak hauntingly to an era of politics now gone forever.

In Canberra, the Pacific Manuscripts Bureau made available to me the rich archives of the Fiji Independent News Service and other contemporary published and unpublished material which deal with the 1987 coups and their immediate aftermath. Ewan Maidment and Kylie Moloney have my sincere thanks for their assistance, as does the staff of the National Library of Australia for permission to consult material in their possession. The Aus- 
tralian National Archives in Canberra generously gave me access to their papers on postcolonial Fiji, as did the Public Records Office at Kew Gardens. For access to the latter, I thank Steve Ashton and Mandy Banton, and Niraj and Gabby for photocopying the relevant files for me after I had left the United Kingdom. Emeritus Professor Anthony Low was instrumental in putting my name up to the people at Kew Gardens and in recommending me for a Fellowship at Clare Hall, Cambridge University, where some of the archival material was first digested.

I thank my own Division of Pacific and Asian History in the Research School of Pacific and Asian Studies (as it then was) at The Australian National University for extended periods of leave over several years to complete this study. I should specifically mention Oanh Collins and Dorothy McIntosh who both helped me in innumerable ways that only dedicated support staff can do for word-obsessed but technically Luddite professors, truly remnant in their own time, but most especially for teaching me how to cope with my much-loved but temperamentally grumpy computer mysteriously given to wild mood swings and abrupt shutdowns. To my colleague and great friend Hank Nelson, I owe many conversations, wise and otherwise, in the Coombs Tearoom over the years, along with his collegial editorial pen gently put to good use and sagacious advice about the need to write to be read, rather than just to get ahead. Lindy Shultz designed the book as well as the cover with great care and professionalism and shepherded the manuscript through the production process.

Many people over the years allowed me access to material in their possession or wrote or spoke to share their thoughts and experiences. Among those who are not with us now, I would like to record my appreciation to Sir Vijay R Singh, HM Lodhia and Tomasi Vakatora. Among those still with us, I express particular thanks to Karam Ramrakha who was generous with recollections, Sir Timoci Tuivaga, Qoriniasi Bale, Sitiveni Rabuka, Ratu Joni Madraiwiwi, Harish Sharma, Ram Krishna, Vinod Patel, Ujagar Singh, Jag Nadan, Jagindar Singh, Kamal Iyer, Bal Govinda, Prabhudas Sidha, Pramod Rae, Attar Singh, Raman Singh, Imrana Jalal, 'Puchla' 
Maniratnam Naicker, Jagnnath Sami, Vishwa Nadan, Sharada Reddy, Richard Naidu, James Raman, Dilip Khattri, Vinod Tappoo, Hari Punja, Mary Chapman, Chen Bun Yung, and members of the incomparable Tamavua Talanoa Group (they know who they are). To all these good people, and to those who prefer to remain anonymous, go my heartfelt thanks.

Scholarly convention requires that I absolve everybody who helped me from all the shortcomings of this study. This is not entirely fair, for my views and conclusions have been influenced, in part at least, by the numerous conversations I have had especially with people in Fiji over the years. It could not have been otherwise. Still, habitually doing as I am told, I readily absolve everybody from my sins of omission and commission, except one: my wife, Padma, who should in good conscience be held fully accountable for all the things I have done, or not done, in the course of my enduring indenture to her for nearly forty years.

Brij V. Lal

Canberra and Suva Point, 2009

\section{NOTES}

1. I myself do not like to use the word 'race,' but have used it in the book because that is the word used in Fiji. Similarly, I prefer the use of 'Indo-Fijian,' but have used 'Indian' occasionally where the context demanded it. Readers unfamiliar with Fiji should know that 'Indian' is used to describe the Indo-Fijian community.

2. DJ Taylor, Orwell: The Life (London: Viking, 2004), 428.

3. Patrick French, The World Is What It Is: The Authorised Biography of VS Naipaul (London: Picador, 2008), xvii.

4. For example, The Review, The Weekender, The Hindustatni, Islands Business, Pacific Islands Monthly.

5. Tessa Morris-Suzuki, The Past Within Us: Media, Memory, History (London: Verso, 2005), 26. 
6. Isaiah Berlin, The Hedgehog and the Fox: An Essay on Tolstoy's View of History (London: Weidenfield and Nicholson, 1953), 93.

7. OHK Spate, 'Thirty Years Ago: A view of the Fijian Political Scene. Confidential Report to the British Colonial Office,' Journal of Pacific History (1990), 25: 103.

8. Quoted by Joe Klein in Time, 5 Jan. 2009. 


\section{INTRODUCTION}

Through a curious transposition peculiar to our times, it is innocence that is called on to justify itself.

Albert Camus

pril 2003. Jai Ram Reddy, his wife Chandra, and I drive to their
Teidamu farm house in his four-wheel drive to sort out his private papers kept there. Reddy is on his way to the International Criminal Tribunal for Rwanda in Arusha (Tanzania) as one of its permanent judges, and I would like his papers arranged and stored before he departs. It is a sad, slightly disconcerting drive. Not a free conversationalist even at the happiest of times, Reddy is quiet, forehead furrowed, concentrating on the rough, unmaintained road meandering up to the top. The green tin roof-top house has a slightly haunted, abandoned, look to it. It is at the bottom of a brown, tree-less hill, below which is an unruly, overgrown grove of specially planted mango trees, a fading reminder of the ambitions and dreams of happier, more optimistic times. The house on the twelve acre freehold farm was Reddy's much-loved private retreat from the alienations and asperities of public life, where he relaxed with close friends and family, and savoured the view across the rolling cane fields and dense mangrove forests to the glass-flat waters beyond the Nacilau Point. Once or twice, he had talked about refurbishing the place and retiring there. It is now unlikely.

The papers are in large, bursting cardboard boxes, damp and full of insects, strewn haphazardly across an empty, musty room. We drag them out into the open green patch, one by one. Reddy lights a fire with the aid of some kerosene he has brought from his brother's house where we had 
stopped earlier. As the flames splutter to life, we tear open the boxes. Slowly, carefully, we go through the papers. Since I will be their custodian, it has been agreed in advance, the decision about which ones will perish and which ones saved is left to me. This is very unnerving, making judgments about which reminders of a person's life will be saved for posterity and which ones will perish at my hands. I feel strangely like a priest presiding over a funeral ceremony, solemnly witnessing the final goodbye to a life just ended. Reddy is curiously indifferent, businesslike, concentrating on the job at hand, his mind completely preoccupied. A chapter in his life has closed, and he is moving on.

I am horrified when Reddy tells me that this is not the first time he has burned his papers. In 1984, when he resigned from parliament after an altercation with the then Speaker of the House, Tomasi Vakatora, thinking that his political career was over for good, he burned most of his papers, except some special and confidential correspondence on matters of State which are with me now. Gone, just like that, in that bonfire, were draft copies of speeches, newspaper cuttings, jottings, routine correspondence from political supporters, minutes and resolutions of long forgotten meetings. Such a 'criminal' act from a lawyer and a political leader, of all people, is unforgivable. I tell him so. He says nothing; there is nothing he can say.

Erasing the permanent markers of a lived life is nothing alien, I suppose, to those who believe in its inescapable temporariness or its ultimate futility. And most people in Fiji have a pretty dim view of history and the verdict of posterity anyway. When we are gone, we are gone, is how most people view life. Few have much sense of their place in the larger scheme of things; and introspection and solitude have never been among Fijis favourite pastimes. Onto the fire, the funeral pyre, go papers dealing with the routine operations of Reddy's law practice such as dockets and receipt books, pamphlets and papers from long forgotten foreign conferences, invitations to this social function or that, multiple copies of newspapers with stories by or about Reddy, facsimile correspondence, once so urgent, now 
crumpled and faded beyond legibility. The rest I keep. They are with me, preserved for future researchers.

After several hours in the hot sun, the 'cremation' is complete, the fire doused, and we head back to Lautoka, exhausted and covered in soot. As we reach the high point of the Teidamu Hill when the shimmering sea on the Lautoka side comes majestically into view, I ask Reddy an impossibly large and loaded question, not really expecting an answer, trying to create conversation on the slow drive back. 'How would you sum up your life in politics over the past thirty years?' 'It has been a wasted thirty years,' he replies instantly, without looking at me. 'I gave up thirty years of my life for nothing,' he continues, with a palpable trace of disappointment and hurt in his voice. 'All that sacrifice: for what?' He meant his political annihilation and the annihilation of his political party, the National Federation Party, at the polls in the 1999 general elections. Reddy lost for the only time in his political career, and his party failed to win a single seat in parliament, falling completely and utterly to a triumphant Fiji Labour Party led by his onetime friend and colleague and now his arch, unforgiving nemesis, Mahendra Pal Chaudhry.

Reddy's hurt is understandable: his comprehensive rejection by the Indo-Fijian community which he had led as its politically most prominent leader for nearly a generation, through some of the most traumatic times in its history: through coups and constitutional crises, through dangerous periods of threatened racial violence and religious bigotry that aimed unequivocally and unapologetically to deprive his people of their fundamental human rights. Through all these years of friction and division in the IndoFijian community that tarnished its image and hobbled its prospects, Reddy was always there, a calm, steady presence; and it was to him, more than to any other leader, that his people turned for advice and guidance and solace in their hour of need and despair, the man, as Peter Thomson, Permanent Secretary to Fiji's last Governor General, writes, 'who most clearly articulated Indian interests and on whom the mantle of leadership most comfortably fitted.' ${ }^{\prime}$ Now he was gone for good. His fate epitomizes the tragedy of 
modern Fiji. Reddy's colossal defeat and the reasons for it will become clear in due course.

There will be many assessments in the future of Fiji's post-independence years, and there will be contrasting views of Reddy's political role and achievements. Nonetheless, even his most ardent political detractors will surely acknowledge his seminal role, positive or otherwise, in the major political events of Fiji in the last quarter of the twentieth century. Josefata Kamikamica, the founding leader of the Fijian Association Party, summed up the feeling of most people in Fiji when he commented on Reddy's role in the constitutional review process in the 1990s that 'Reddy played a major role in the developments and he will be remembered for that.' ${ }^{2} \mathrm{He}$ was often in the eye of the storm, sometimes because duty called, and sometimes because he had no choice but to be there. The community's call had to be heeded, his private reservations or hesitations notwithstanding. Reddy's faults and failings were many, and he readily acknowledges them with a candour that is refreshing, especially in a politician. 'He is frighteningly honest,' the late Hargovind Lodhia, the veteran Nadi politician and NFP parliamentarian, once said to me. It is an assessment echoed by many others as well. 'I am a victim of my own honesty,' Reddy admits in a resigned kind of way. 'I have done and said things I felt.'

Rare among the political leaders of postcolonial Fiji, Jai Ram Reddy demonstrated a singular willingness to change and adapt as the circumstances demanded. With time, he embraced what Henry Fairlie calls the 'patience of politics,' a commitment to an open-ended process rather than to a pre-determined outcome. ${ }^{3} \mathrm{He}$ began his political career like many an Indo-Fijian politician in the cane belts of Fiji, acutely aware of the grievances of his people, their needs and interests, their rightful place in the larger scheme of things, but, like so many of them, only marginally conscious of the aspirations and predicaments of other communities, principally the indigenous Fijians. Pandering to the narrow communal interests of your own people, the more strident the rhetoric the better, was the sure, tried route to political power. Reddy played the game well in the early part of his career, 
surrounded and advised by many like-minded communal politicians and members of the legal profession, who were safe in the cocoon of communal representation and mind-set.

Unlike most, if not all of them, and most Fijian leaders of the time as well with the exception of Sitiveni Rabuka, however, Reddy transcended his limitations and transformed himself over a decade or so from a communal Indo-Fijian politician into a venerable statesman respected and admired, as few others, across the wide spectrum of the country. No one doubted Reddy's commitment to safeguarding the interests and welfare of his own community. His people's absolute faith in his integrity was unquestioned. What was remarkable, from that vantage point, was for Reddy then to understand the doubts, fears and predicaments of the Fijian people as few Indo-Fijian leaders ever had. Fijians were not the enemies of Indians, he said repeatedly throughout the 1990s, echoing the sentiments of AD Patel in the 1960s. It was their history that had kept them apart. He wanted to bridge that gap in a manner broadly acceptable to everybody. 'The issue,' he said, 'is how sentiments of the indigenous people are respected and at the same time the needs of other people living in the country are met." ${ }^{4}$ To that end, he devoted a substantial part of the latter half of his political career. That was the greatest personal and political accomplishment of his life in politics. Reddy's capacity for empathy and understanding was remarkable. Often, he said, 'it is not a question of whether I am right but whether we are capable of being able to understand and to appreciate the feelings of the members of other communities. What I may perceive to be right may not be so in other people [sic]. We have to break down those barriers so we can achieve this. If you want something changed, you will have to reconcile so that you can accept some of your opponents' proposals and your own proposals, where some will remain and some thrown out.'

Reddy achieved this transformation in thinking in several ways. First, he reached out for advice from a wide range of sources, beyond the conventional domain occupied by lawyers, businessmen, opportunists and hangers-on. It was a closed circle that brooked no dissension and admitted few 
'outsiders.' Reddy began his career moulded in that way, but changed later. He successfully encouraged younger professionals, who had frequently expressed disdain for the conventional style of politics, to join him in addressing and resolving the problems facing Fiji. He was confident in his own abilities and unafraid of intellectual argument and debate. He reached beyond the legal fraternity and the deeply power conscious party bosses to trade unionists, small businessmen, professional women, academics, and dedicated community workers. And they responded generously, not necessarily to the political party that Reddy headed but to him personally, attracted by his transparent 'sincerity of purpose,' as they said. By the late 1990s, Reddy was leading an exceptionally talented team of men and women, arguably the best slate of candidates the Indo-Fijian community has ever seen. After the defeat of the National Federation Party in 1999, when Reddy left, the core disintegrated, and the best and the brightest left for other shores, to the great loss of the Indo-Fijian community and the country, or simply lost interest in public life altogether. The promise of a new beginning was sadly short-lived, like a new-born infant dying without leaving the precincts of its birth place to experience the joy and promise of life outside.

Reddy also showed a remarkable ability to engage with Fijian leaders. He was warmly disposed towards Ratu Sir Penaia Ganilau, Ratu Josaia Tavaiqia, Ratu Josefa Iloilo, Ratu Mosese Tuisawau, Ratu William Toganivalu, Koresi Matatolu, Militoni Leweniqila ('a likeable rogue'), the nationalist lawyers Etuate Tavai and Kelemedi Bulewa ('with whom I could talk for hours'), for example; even the hard-line Apisai Tora for his personal affability notwithstanding his rabble-rousing nationalist politics ('I will get courtesy and respect from him. He will not shun me.') Reddy had genuine affection and respect for Ratu Penaia, 'an honourable adversary,' who reciprocated those sentiments through many small gestures of kindness, such as repairing frayed relations between Reddy and some of his Fijian parliamentary colleagues over drinks at the United Club, taking him along on a helicopter tour to hurricane-ravaged Kadavu, telling Sitiveni Rabuka to consult Reddy on important appointments 
despite the absence of the consultative provisions covering the Leader of the Opposition in the 1990 Constitution, acceding to Reddy's request for changes to the terms of reference of various enquiries, keeping the doors of the Government House open to him at all times. Reddy spoke movingly at Ratu Penaia's funeral, meaning every word he spoke. The speech is included in the book.

Reddy's relations with Ratu Sir Kamisese Mara, the preeminent Fijian leader of late 20th century Fiji, were different: always formal, outwardly cordial, but never close. 5 The two men were too much alike in their essential reserve and public shyness than they were prepared to admit, according to people who knew them both. Ratu Mara, Ratu Joni Madraiwiwi, the Roko Tui Bau and former Vice President and High Court judge, has recalled, was 'reserved, intellectual, generous and quick-tempered.6 ${ }^{6}$ Fiji's last colonial governor, Sir Robert Foster, described Mara as a "moody, shy and solitary man. ${ }^{7}$ These assessments could just as aptly apply to Jai Ram Reddy. Ratu Mara could not quite fathom Reddy in the way he had assessed Siddiq Koya, for example, though not his predecessor, AD Patel, whom he feared and respected. ${ }^{8}$ He had seen Koya from close quarters throughout the 1960s and early 1970s, and understood the dynamics of the Indian leader's explosive personality. He had a good measure of the man.

Reddy was different. He did not know the Alliance leader. He shared none of Mara's or Koya's understandings and assumptions that underpinned the independence compact. If the constitution permitted it, Reddy saw no reason why he should not compete for the highest office in the land. Mara's inability to 'read' Reddy, to 'frame' him for response, was an important part of the problem. ${ }^{9}$ Mara could never forgive anyone who stood up to him (as Semesa Sikivou found out to his cost) or challenged his authority to rule which he thought was his God-given privilege, along the lines of the Tongan royalty whom he admired deeply. 'His vindictive bouts of rage were legendary,' Peter Thomson has written. ${ }^{11}$ Reddy privately resented what he thought were Mara's Olympian aloofness and autocratic tendencies, even, or especially, his acts of slight and breaches 
of protocol. ${ }^{12}$ The Chief and the Indian, so to speak, did not see eye to eye on many issues of public importance, and were wary in private about each other's motives and motivations. Mutual misunderstandings between the two men contributed to problems in the 1970s and 1980s. In private, though, Mara respected Reddy's integrity and honesty. The two were 'beginning to be friendly towards each other,' Mara recalled in 1993, whereas with Mahendra Chaudhry, the other Indo-Fijian leader, 'I could never call each other friends right from the very beginning.' When asked by journalist Joe Nata with whom he would rather work, Chaudhry or Reddy, Mara replied: 'With Reddy without hesitation.' ${ }^{\text {13 }}$

Reddy's relations with Sitiveni Rabuka were in complete contrast to his relations with Ratu Mara. They were surprisingly open and relaxed, which bore great fruit for the nation. ${ }^{14}$ Reddy had not heard of Rabuka before the May 1987 coup. Not many outside the closed army and rugbyloving Fijian circle had either. The Fijian military, a completely Fijian institution, was a mystery to most Indo-Fijians; and most knew little about rugby, the Fijian game either. Reddy first met Rabuka after the September coup at a one-on-one meeting at Battery Hill, the military commander's heavily guarded residence near the parliamentary complex, arranged by a Suva Indo-Fijian lawyer close to the capital's Fijian political elite. Reddy was deeply angry and hurt at the wanton harassment of Coalition supporters taking place throughout the country, and he wanted to see Rabuka in person to convey his feelings to him. He spoke with some passion. The Indo-Fijian community did not deserve to be harassed, he said. If they were to remain, they had to be treated with the respect that all decent law abiding citizens deserved. Rabuka listened patiently. When he mounted a monologue on Fijian grievances to justify the coup, Reddy asked, 'Who do you blame? Why don't you do something about it? Discriminating against Indians is not going to help resolve the problems of the Fijian people.' Rabuka was polite and respectful throughout the exchange when he might have been expected to explode. Reddy left the meeting (and a very large tanoa bowl full of yaqona) somewhat puzzled about his adversary. 
There was more to the man than met the eye, he felt. The atmosphere of that meeting remained with Reddy for a long time.

The two men, one a coup maker and the other its principal target, were chalk and cheese in their training and temperament. Rabuka's erratic pronouncements and frequent flip-flops to duck and weave around the intrigues and machinations within his own ranks in the early 1990s frustrated Reddy greatly, causing much despair and heartache, but there was no personal animosity between the two. They were able, after several false starts and hiccups, to cooperate in the successful review and promulgation of the 1997 Constitution, and even forge a short-lived political coalition that fell to Labour in 1999. Reddy has called Rabuka's leadership of the constitution review process 'masterful,' the work of a true leader of men who demonstrated integrity, sincerity and commitment when it really mattered and when it made a material difference. ${ }^{15}$ Without him at the helm of Fijian leadership at the time, the outcome may well have been very different. Rabuka, Reddy said, was 'someone to whom you could turn, to discuss things with, raise issues, very, very, friendly, very, very, open, and you were heard. And had it not been for that kind of relationship we had established I doubt very much that we would have had the review of the kind we did. ${ }^{36}$

Rabuka trusted Reddy to keep his word once it was given. Trust: that is the most essential ingredient in any productive relationship. ${ }^{17}$ Rabuka valued Reddy's advice and listened closely to him in committee meetings, Mary Chapman, the Secretary General to Parliament, has recalled. Reddy understood Rabuka's predicament and refused to take advantage of his numerous political misfortunes. Perhaps somewhere deep in his heart he even liked the man for who he was: sometimes misguided, sometimes evasive, a shrewd political animal, but essentially a decent, forgiving, warm-hearted human being. Reddy brought out the best in Rabuka. Had the RabukaReddy political project succeeded, Fiji would almost certainly have been spared much of the agony and trauma it encountered in the years ahead. So while the Chief and the Indian could not connect; the Commoner and the Indian did. 
By the late 1990s, Reddy had won the trust, affection even, of the Fijian people (to his enormous cost in the Indo-Fijian community which eyed any hint of political moderation and compromise with deep suspicion), culminating in his historic address to the Great Council of Chiefs in 1997. This was the first time an Indo-Fijian leader had ever addressed the Council. That event is etched deeply in Fiji's collective memory: one of the very best speeches he had ever heard, said American Ambassador to Fiji Don Givertz, adding, for good measure, that he had listened to many great speeches by great orators of history such as Dwight Eisenhower, John F Kennedy, Ronald Reagan and Bill Clinton; New Zealand Foreign Minister Don McKinnon called it a 'masterful performance.' The speech is included in the book. The only exception to the almost universal chorus of approval and praise was Mahendra Chaudhry, who curiously thought the speech lacked dignity. ${ }^{18}$

Among Indo-Fijians, Jai Ram Reddy as a political leader is cast in a mould different in significant ways to his distinguished predecessors. AD Patel, the founder of the National Federation Party, which Reddy led for much of his political career, was the greatest leader of the Indo-Fijian community in the pre-independence period. He is, truly, the unheralded father of Fiji's independence movement whose legacy is now sadly disregarded or otherwise dismissed in the officially-authorized versions of modern Fijian history. He died several months before his tireless efforts came to fruition, though in a manner which he would not have approved. Patel was, as Sir Robert Foster accurately told London in his last despatch before independence, 'an intellectual, sincere and dedicated,' whose opponents 'respected some of his qualities no matter how bitterly they disliked his views. ${ }^{19}$ Patel's Achilles heel was his commitment to the Gandhian ideals of politics, it was often said, though precisely why was never spelled out, unless it was a steadfast reluctance to compromise strongly held principles for short-term political gain. Reddy worked with Patel as a young lawyer and learned the finer points of the craft from him, especially the art of courtroom cross examination at which Patel was unmatched and would have shone in any 
jurisdiction, Reddy says. He also owed him his introduction to politics. In some respects, like Patel, Reddy was not in the thrall of the game of politics, its intrinsic challenges and endless fascinations, but what politics could do to bring about progressive social betterment of the people, that is, politics as a means to an end, not an end in itself. Reddy's ethical turn in politics also developed from Patel's Gandhian philosophy and from his spiritual mentor, Swami Rudrananda.

But there was an important difference between the two leaders. Patel spent his entire political life from the late 1920s to the late 1960s struggling against the racially compartmentalized structure of political representation and, beyond that, the foundations of the colonial project itself. He fought for the non-racial common roll system of voting. He believed in the eventual possibility of a non-racial state. But that vision essentially vanished when Patel died on the eve of independence. The Independence Constitution entrenched racial representation and race increasingly permeated the deepest sinews of public institutions and the public consciousness. It came in time to be viewed as a natural state of affairs. Any effort to solicit support from another ethnic group was invariably viewed as an attempt to divide that community, which often heightened tension and exacerbated latent ethnic hostilities (as in 1982). Reddy accepted that race would continue to be important in Fiji politics and sought to work around or rather with it, instead of dismissing it as 'false consciousness.' So, instead of seeking power through open competition, Reddy opted for power sharing through proportional representation in government. This would be his major contribution to the theory of political governance in Fiji.

Patel's successor and Reddy's immediate predecessor, Siddiq Moidin Koya, was as different from Patel as he was from Reddy. Rotund and with the ubiquitous, eye-catching bow-tie ever present as part of his elegant sartorial repertoire, Koya was as complex, conflicted and colourful a character as any. ${ }^{20}$ He came of political age under the dominant, overarching leadership of AD Patel in the 1960s, and whose able and loyal lieutenant he remained throughout, though whose political temperament and approach 
he did not always share. Born in the big, boisterous cane district of $\mathrm{Ba}$, Koya obtained his law degree in Tasmania and became a successful, much-feared criminal barrister. He was a strong man, in every sense of the word, who defended some of the most hardened criminals in the courts (but whose eyes could well up recalling his mother's death when he was just five). He had an instinctive understanding of the hopes and fears of the Indo-Fijian farming community whose interests he championed passionately. He was a belligerent, chest-thumping orator, full of fire and fury, which inspired his supporters and intimidated his opponents. 'If you are the son of one father and one mother, come out in the open [and challenge me]' was his favourite taunt to his opponents. Agar ek ma baap ke beta ho to ... . Few did, or dared to. Koya inspired fierce loyalty but also generated great hostility among his party followers, which eventually led to his marginalization within his own party and premature departure from the political scene in the late 1980s.

Koya was a born politician of considerable political talent, skill and personal magnetism, but he was also a product of his age and circumstances, and was not able to transcend them. He was, as his one time colleague Karam Ramrakha says, a 'crisis' leader. That is an accurate description. The great issues which had brought him to prominence in the 1960s, sugar disputes and the struggle for independence, were non-issues after 1970. His style of politics, bellicose, thriving on factionalism and 'cliquism,' to use a much bandied about word of the times, and subservient to his unbending will and dominant personality, curiously old fashioned, was on the wane when his time came to bask in the sun. The electorate in the 1970s was more educated, more demanding of its leaders: real policies, not political rhetoric. Koya, for his part, brooked no criticism and was loathe to explain himself to anyone. He was the leader, and he knew best, and that, as far as he was concerned, was that. Sadly, the times had simply moved on, while Koya remained a captive of the past, his following diminished and his colleagues deserting. Koya's political philosophy is not clear. He accepted the tenets and practices of the Westminster system, or at least he never publicly questioned them, but he also accepted the reality of racial politics in Fiji. He 
had confided to London's emissaries that for him, too, as it was for Mara, a common roll was a long term goal, ${ }^{21}$ but had not worked out an alternative strategy, too preoccupied, as we shall see, with internal disruptions within his own party to forge an alternative national vision.

Relations between Siddiq Koya and Jai Ram Reddy have been the subject of much debate and whispered comments over the years since the two fought each other in the September 1977 elections. In public perception, they are portrayed as sworn enemies, daggers drawn, un-reconciled to the end. The embers from that distant fire are still faintly aglow in conversations with the older generation. Many harsh words were spoken during the campaign, and some of them are reproduced in this book. But for Jai Ram Reddy, political difference did not translate into personal animosity. $\mathrm{He}$ could never really dislike Koya, he says. There was an element of empathy between the two, even affection for each other. They shared a broad South Indian cultural background; both were renowned lawyers from the cane belt; the two families had known each other for decades, and the Reddys were great supporters of the Federation Party. Indeed, in the early days, Reddy was thought to be a 'Koya man,' his chosen successor. Reddy brought Koya back into the NFP parliamentary team in 1982. Koya reciprocated Reddy's sentiments, nominating him for the 1992 general elections. He praised Reddy for his 'marvellous' reconciliation efforts. 'We will look to him for guidance at all times,' said Koya of Reddy in 1985, 'and not only when crisis develops.' Between 'the two of us,' he continued, 'there has been understanding and compassion, despite our differences.' ${ }^{22}$ And in 1992, Koya added that the 'Dove/Flower split was more an internal matter [for the NFP] which was healed when they fought together on one platform in the 1982 elections. ${ }^{23}$ It would be worthwhile to keep all this in mind when reading of the political turmoil of the 1970s and 1980s.

Jai Ram Reddy, like Koya, came from the cane belt of western Viti Levu (Vitogo, Lautoka), but there was difference in style and approach between the two. Easy bonhomie with the masses was not Reddy's forte. Whereas Koya could work a roomful of supporters with practiced ease and 
charm, Reddy was always ill-at-ease in a crowd, socially comfortable and relaxed only in the company of close friends. While Koya emoted effortlessly with the people, Reddy could not. Reddy was aware of this trait of his, but he simply could not bring himself to do what did not come naturally to him, wrapping his arms around other people's shoulders, making small talk about family and business. Koya was at home making meandering speeches full of 'masala' which kept his audiences enthralled for hours. He was the complete master of the theatrical stage. Reddy, on the other hand, while a spellbinding orator, was always controlled in his public speaking, clinical, precise, withering in the manner of a brilliant barrister (which he was), as if dissecting a case before the courts, not a theatrical speaker wooing a crowd with enticing homilies full of rustic images and metaphors.

People compare Jai Ram Reddy to AD Patel in his oratorical brilliance (totally exaggerated, Reddy says of the comparison). I have heard Patel only on tape, and his way with words and images and metaphors is mesmerizing. He is truly unrivalled as the most learned and eloquent orator in the annals of Fijian political history of the 20th century. Reddy I would regard as the finest orator in Hindi I have heard in person: emotional, intense and passionate, capable of turning even the most sceptical of minds around, reducing people to tears or to deep, explosive anger against injustice and discrimination. In his time, he had no match in Fiji. 'Before you can inspire with emotion,' Winston Churchill once said, 'you must be swamped with it yourself. Before you can move their tears, your own must flow. To convince them, you must yourself believe.' These words aptly capture Reddy's oratory. His speeches always reflected his deepest convictions, not always to his political advantage, as this book shows. Recall his words: 'I have done and said things I felt.'

Politics of the conventional cane-belt type was not in Reddy's character. 'A leader must never lie to the people,' Reddy says. 'He must tell the people the truth as he sees it, and then lead them from there.' Honesty and integrity, a capacity for sustained hard work, a willingness to consider the other person's feelings and thoughts are other attributes of good leadership, 
according to Reddy. He exemplifies what Henry Fairlie identifies as an important attribute in a successful politician. 'The first task of a politician,' he writes, is to reconcile the multiplicity of conflicting interests and wills which exist in any free society, and to produce from their conflict a policy which if not approved, will at least for the time being, be acquiesced in by all of them.' A successful leader operates by the rule of thumb and from the accumulated experience of himself, of his colleagues and his party, not from abstract principles etched in stone. 'It is largely a matter of judging the occasion: when to stand firm, when to give way; when frankness will bring rewards, when a little bit of hypocrisy will save a lot of trouble, when to sit back and wait, when to act decisively; when to provoke opposition, when to mollify it. ${ }^{24}$ Reddy exhibited as well as transcended these attributes in the latter half of his political career.

Reddy's critics as well as admirers have often said that Reddy was 'a reluctant politician.' They are both right, pointing to his great strengths as well as his great weaknesses as a political leader. Reddy saw politics not as a lifelong vocation but as an instrument to achieve specific goals. One does not have to be in parliament to serve the people, he said repeatedly to those who missed out on party tickets and threatened to stand as independents. There was not a single election in postcolonial Fiji in which Reddy actively sought selection. He was often persuaded to enter the contest at the last minute and that, too, under considerable pressure from his colleagues. This was not theatre: his reluctance was genuine, but sometimes misunderstood. Even in the September elections of 1977, the most heated in the history of the Indo-Fijian community, he did not want to stand against Koya because of his deep concern that it might irrevocably split the party, but was persuaded at the last minute to enter the fray by respected party elders. Politics did not come naturally to Reddy, good though he was at it. The law, the art of advocacy, was his real, abiding passion, and he regretted his frequent absences from it; politics was duty and responsibility.

Transcending narrow political agendas, Reddy was able to see the larger picture into which he tried to situate the broader interests of his own 
vulnerable community, while his opponents tended their own backyards assiduously. They very clearly understood the truth of the maxim that all politics is ultimately local, as the American politician Tip O’Neill once said. Reddy as the national leader of the Indo-Fijian community, and as the Leader of the Opposition at the most critical period in Fiji's postcolonial history, did not have that luxury. Simply too much was at stake. But reluctance was not a fatal weakness in Reddy, nor a serious character flaw. He was no drooping lily. Once the battle was joined and Reddy was in the ring, his political opponents discovered to their great cost just what a tough and unrelenting competitor he could be. Swami Bhaskar Aryana, a former teacher and spiritual mentor of the Ramakrishna Mission, was once told by a colleague pointing to Jai Ram, then a student at the Sri Vivekananda High School in Nadi, 'He may look like a cat, but he roars like a lion.' It was a prophetic assessment echoed by many others. ${ }^{25}$

For Jai Ram Reddy, the interests of the National Federation Party were obviously important to protect, but more important, overall, were the interests of the Indo-Fijian community, and if working with his other Indo-Fijian rivals was needed for that purpose, he would not hesitate. An example: the Fiji Labour Party leader Mahendra Chaudhry repeatedly vowed to 'wipe out the NFP' in the early 1990s, but Reddy did not hesitate to make a joint submission with him for the review of the 1990 Constitution. ${ }^{26}$ Nor did he fail to campaign for a Labour candidate, Gaffar Ahmed, in a Ba by-election in 1995 against some former NFP rebels, and Reddy loyalists, who had formed a new Janata Party to fight Labour, in the same manner that the NFP Youth had done a decade earlier. 'Even the Leader of the Opposition is with us today,' Chaudhry proclaimed triumphantly, Kamal Iyer recalls. ${ }^{27}$ For Reddy, again, the unity of the community was paramount, not the narrow political interests of his party or his own political fortune.

Chaudhry wanted Reddy's political blood, but well into the late 1990s, Reddy still spoke, to his closest friends and colleagues, much to their dismay, of the Labour leader as his natural successor as the leader of the Indo-Fijian community, not any aspirants within his own party. Harish Sharma recalls 
a conversation this way. Reddy had asked him, since he (Harish) would be retiring from politics at end of the parliament's 1994 term, to resign as his deputy sometime in 1997 to give him about eighteen months to groom a successor. 'I can't think of a better person than Mahendra Chaudhry,' he told Sharma. Sharma replied, 'Give me time, but I will resign.' Three or four days later, Chaudhry made the headlines by accusing Reddy of selling out the interests of the Indian community by agreeing to one fewer Indian communal seat during the negotiations for the 1997 Constitution. Reddy was outraged at the untruthful allegation (see later discussion). When Sharma went to Reddy's Opposition office the following morning, Reddy said, 'I know why you are smiling' when Harish asked, 'Do you still want me to resign?'

Reddy knew the dangers of coalescing with Sitiveni Rabuka's deeply unpopular Soqosoqo Vakavulewa ni Taukei (SVT), but went ahead anyway because that, he said, was the honourable thing to do. How could you possibly jettison a party with whom you had worked to revise the constitution, even if that party had much baggage and a tainted leadership? Further, he agreed that should the NFP-SVT Coalition win power, the SVT would provide the next prime minister. This was a genuine act of political concession and understanding in the larger national interest, to assuage Fijian fears about their proper place in Fiji. The concerns of the indigenous community could not be ignored or wished away, Reddy said; they were real and they had to be acknowledged. The concession was an act of a mature vision, not of cowardice his political opponents said it was. And he was acutely aware of the vulnerability of his own community. To the language of violence that underpinned Fijian political discourse in the years after independence — 'blood will flow' — the Indo-Fijians had no answer. That was the brutal reality on the ground. If leadership meant anything, it meant reconciling essentially irreconcilable interests. But for adopting that approach, Reddy paid the ultimate political price at the hands of Mahendra Chaudhry, of all the political leaders, who had expressed similar sentiment earlier, but failed to honour it when the moment of truth came. 
Reddy was by nature a moderate, pragmatic politician who expressed disdain for the politics of extremism, as he said over and over again. 'In the context of multiracial societies, demands don't work,' he said. 'We have to work slowly through consensus building exercise where we are able to identify areas of agreement and areas of disagreement and find compromise solutions. ${ }^{28}$ 'I am not interested in the tired old rhetoric of racial politics,' he said on another occasion. 'I am weary of pointless bickering, ugly innuendos and raking over old coals. There are issues and challenges before us which are more important then who wins the next elections, or whose skill as a debater or public speaker is the most persuasive. None of us does his or her community any service by perpetuating the recriminations and narrow racial perceptions of the past.' This was sensible thinking and good advice, but politically counterproductive in a racially polarized atmosphere which provided all the incentives for ethnic chauvinism which many a politician exploited to their advantage, and very little incentive for moderation and accommodation.

During the course of his twenty-year political career, Reddy moved, as already indicated, from being an 'open' multiracialist to what might be called a 'consociational' multiracialist. ${ }^{29}$ The culture of unrestrained competition bred suspicion and hostility threatening violence at election time. It had bad history. Instead, Reddy favoured the approach of 'compartmentalized' cooperation. 'Let us each be in our separate compartments if you like,' he said in 1992. 'Let communal solidarity prevail and I do not begrudge Fijian leaders for wanting to see that their community remains united. That is a very natural desire. Let the General Electors be united. Let the Indians be united; let everybody be united, but from our respective positions of unity let us accept that we must co-exist and work together with each other. That is a more realistic approach. ${ }^{30}$ Politics in Fiji would always have an ethnic dimension, he argued, and it was better to accept that reality than to deny it. The consociational features of the 1997 Constitution, in whose formulation Jai Ram Reddy had a major hand, reflect this philosophy, especially its compulsory power sharing provisions. 
That 1997 Constitution represents Jai Ram Reddy's single greatest achievement, the pinnacle of his political career, not the least because of the fraught context in which it was fashioned. But the magnitude of the achievement was not sufficiently appreciated, especially by his own people, with shallow political memories, who took the successful review exercise for granted, and wanted the immediate satisfaction of their mundane everyday needs. Less than a decade earlier, the Indo-Fijians had endured the souldestroying miseries caused by the Sunday Ban, the desecration of Hindu and Muslim places of worship, and a constitution that had robbed them of fundamental human rights. A decade later, all their rights were restored and, for the first time ever, Indo-Fijians were given an equal opportunity to participate in the affairs of state. Through persuasion and persistence, Reddy had helped Fijian leaders inside and outside parliament, including those in the Great Council of Chiefs, to move away from a hard line adherence to the principle of 'paramountcy' of Fijian interests to embracing the principle of equal 'partnership.' This peaceful transition from paramountcy to partnership was an achievement of fundamental importance, realized through consensus and dialogue, in the full glare of public scrutiny and in the face of deep scepticism. Indo-Fijians are now belatedly recognizing their mistake in not rallying behind the new power-sharing arrangement.

It was good for Fiji that a leader like Jai Ram Reddy was at the helm of the Indo-Fijian community at a critical time in Fiji's post-coup political evolution when things could easily have gone wrong, or turned nasty in the hands of other untested, impatient hands. The coup in 1987 had placed a knife on the throat of the Indo-Fijian community, and the indigenous nationalists in the Taukei Movement and in the Methodist Church were baying for its blood. 'Reddy the Gun, Bavadra the Bullet,' 'Bavadra the Boat, Reddy the Captain' the placards proclaimed in tense protest marches in major urban centres throughout Fiji just before the first coup. Reddy's own law offices in Lautoka were torched, and arsonists attempted to firebomb his house, with his wife and children inside it. After the second coup in September 1987, Reddy went into hiding to escape certain physical danger. 
If caught, he would have been killed or severely hurt by the rampant Fijian nationalists, so deep was their anger towards him.

Reddy was the most feared as well as the most hated Indo-Fijian leader after the coups, seen by many Fijians as the key architect of the defeat of the long-reigning Alliance party, the evil, manipulating, mastermind behind the Coalition leader Dr Timoci Bavadra. Ratu Mara, in a non-approving tone, had dubbed Reddy the 'guru' of the Coalition, the chief orchestrator of his defeat. ${ }^{31}$ Reddy's refusal to capitulate or vanish quietly from the public stage simply incensed his foes even further. 'Haven't you had enough?' Ratu Mara once erupted when Reddy refused to accede to the demands of the Fijian nationalists, his angry words repeated ominously by others. 'Mr Reddy, in this country, you take what we give you. No more', a Fijian soldier told him in Nadi soon after the first coup. The protest marchers demanded his head on a platter. And yet, he returned to the political stage after the dust had settled to successfully negotiate with the very same Fijian leaders who had aided and abetted the coups and sought the political diminishment of the Indo-Fijian community. His conciliatory and understanding approach, his ability to look further than his personal hurt and anger, was fundamental to the political transformation that took place in Fiji in the 1990s.

Therein lay a great paradox. How could a political party suffer such a humiliating defeat when its leader enjoyed such widespread national respect? This is one of the more perplexing mysteries of Fijian politics in the latter half of the 20th century. The decline has to do, in part, with the changing demographics of Fiji; the arrival on the scene of more strategically focused and better organized parties; and the longstanding and ultimately crippling divisions within the Indo-Fijian community itself. Reddy was the undisputed leader of the NFP by the early 1990s, but he was not a 'party machine' man. He kept a watchful eye on its internal proceedings, mediated in disputes when these arose, offered advice to branch officials and supporters, but did not take an involved interest in the party's internal affairs, not the least because he was deeply immersed in the broader affairs of the 
nation. That was left to others, including people who were new comers to the party. The grassroots apparatus of the party, once so vibrant and powerful, had become moribund by the late 1990s, party branches withered on the vine, or defected to the rival organizations. Perhaps some of the party's own leaders took the peoples' support and confidence in them for granted, complacently basking in the afterglow of the successful review of the 1990 Constitution and expecting a grateful electorate to return them to parliament as a matter of course.

The contrast with Mahendra Chaudhry, who effectively succeeded Reddy as the leader of the Indo-Fijian community, and to whom he will invariably be compared in the future, could not be greater. Chaudhry was a tough, tenacious leader, not one to flinch from a fight, a trait widely admired among his supporters at home in the tradition of confrontational politics nurtured in the cane belt of Fiji. He was not only the dominant, unchallenged leader of his party, as Reddy was of his once, he had complete control of the party machinery, putting loyalists in positions of power and using them effectively to attain his political goals, whatever they might be. No one in the party dared speak without his express authorization. Dissent was suppressed in the name of party discipline, and dissidents unceremoniously expelled for questioning party policy or the leader's judgment, including party founders such as Tupeni Baba and Krishna Datt. For many of his supporters, Mahendra Chaudhry was the Labour Party. ${ }^{32}$ One could not be imagined without the other.

Chaudhry was a political practitioner par excellence, completely at home in the brutal cut and thrust of politics, in fact thriving on it, unlike Reddy who found wheeling and dealing behind the scenes personally distasteful. Reddy was scrupulous in his observance of protocols and processes of the undertakings he gave; as a lawyer he operated 'strictly within a reverence for the law. ${ }^{33}$ For him, the process was just as important as the outcome. 'There are no shortcuts in politics,' he said often. For Chaudhry, on the other hand, ends often justified the means. This may be a result of his long years in Fiji's trade union movement. If deals had to be made to 
get the results, Chaudhry would not hesitate to sanction them. There must be a place for principles in politics, a frustrated Reddy told his audiences in the 1990s. For Chaudhry, the simple, enduring principle of politics was the attainment and exercise of power. If to get into power a deal had to be made with the Fijian nationalists, even those dedicated to the annihilation of the rights of the Indo-Fijians, then so be it. This was cold, calculating politics at its best, or at its most ruthless and cynical.

Reddy viewed things differently. 'Our strategy is very simple,' he said. 'It is based on sincerity of purpose and on the recognition of the fact that the only way to move forward is through dialogue and discussion to create an environment in this country where people are beginning to think again. ${ }^{34}$ For Chaudhry, however, every move was a tactical manoeuvre. Reddy's policy of peaceful dialogue was for Chaudhry 'a policy of selling out Indian interests bit by bit,' a feat, he accused the NFP leader of being accomplished at. Reddy believed sincerely that the Coalition between Labour and the NFP would endure, each party respecting the independence and integrity of the other, but cooperating on important issues for the greater good of the Indo-Fijian community. There was no other way. For Chaudhry, the Coalition infrastructure was intended to enable him to consolidate himself in power and to work from there to eliminate his rival altogether.

Just two examples of the difference in approach between the two leaders will illustrate the point. In 1992, Sitiveni Rabuka won the elections but did not have enough numbers to form government and become prime minister, being challenged for leadership from within his own party. He approached both Reddy as well as Chaudhry for support. Reddy declined point blank, no matter what political cost to himself or his party. Important principles were at stake. How could he support a man who had carried out the coup, caused untold suffering to his people and had not repented for his treasonous actions? How would he be able to explain his support for Rabuka to the people who had voted for him? Chaudhry took a different position altogether, although, like Reddy, he too had been a victim of the 1987 coup. He offered Rabuka his support as a matter of real politick in 
exchange for an (legally unenforceable) undertaking to address some of his concerns, and in the hope that the tail might be able to wag the dog. 'What fool wants to be in opposition if you can be in government,' Chaudhry often said. Getting into government was the main game for him. Everything else was secondary. To that end, Chaudhry marshalled his resources and applied his considerable political talent. His great tragedy was that when his time came for national leadership, he was not able to transcend this vision. To the end, he remained a politician, a formidable one, to be sure, but a politician all the same. Reddy, on the other hand, lost many battles, including his humiliation at the polls in 1999, but he departed the political scene a greater man than when he first entered it.

In the 1999 general elections, Chaudhry's Labour Party gave its last preferences to the NFP, placing it well below political parties, such as the Christian Democratic Alliance, which was diametrically opposed to its own policies, wanting Fiji to be made a Christian state and advocating the entrenchment of the principle of Fijian paramountcy. It was cold-blooded politics at its most brutal: the NFP was Labour's greatest threat and it had to be eliminated at any cost, notwithstanding the fact the two parties' philosophy were broadly similar and that they had cooperated as coalition partners before. Reddy lamented the sacrifice of principle to political expediency, but for Labour the principle was about winning the election. In politics, Labour believed, 'my enemy's enemy is my friend.' As it turned out, Labour won the battle, but lost the war. In 2006, Chaudhry once again lent his political support to the executer of Fijis fourth military coup, Commodore Frank Bainimarama, vainly justifying his participation in the military regime on the grounds that the deposed democratically elected government was corrupt (but in which his own Labour Party had several senior ministers because of the power-sharing provisions of the constitution). A Labour leader supporting a military coup left many heads shaking in disbelief, but there was nothing inconsistent in Chaudhry's approach: he was being true to his political philosophy in which politics is, first and foremost, about the attainment and exercise of power. So, if a military coup had to be condoned 
to remove a democratically elected government of which Chaudhry disapproved because it was alleged to be corrupt and racist, he had no qualms about it. ${ }^{35}$

Great leaders succeed not only by virtue of their own instinct, skill and courage, but also because they have able and loyal deputies. Ratu Mara had Ratu Penaia Ganilau. For many Fijians, Mara was a remote, inaccessible figure, and many probably also questioned his commitment to the Fijian cause as well. But no one ever doubted where Ratu Penaia stood on the defense of Fijian interests: firm, immoveable. He was the one Fijian leader everyone trusted to protect the interests of his people in the teeth of all the opposition in the world. No one doubted his attachment to his culture or to his people. And if he gave the green light to follow Ratu Mara, then they did so unhesitatingly, knowing that at the end of it all, Ratu Penaia would always be there. AD Patel had Koya. 'AD was AD,' 'Puchla' Maniratnam Naicker, one of Koya's most ardent supporters, told me, a revered if somewhat remote figure; Koya was their man. He was well connected to the grassroots; they trusted him as they trusted few others; he inspired his followers and they, in turn, gave him their complete loyalty, which made Patel's overall task much easier. Koya was the perfect lieutenant. As leader in his own right, though, he was not the same man. He could not command the complete loyalty and support from his colleagues for reasons that are explored in this book. It may also quite possibly be that some lieutenants are not destined to make good commanders.

It was a similarly the case with Reddy and Chaudhry. Reddy could be likened to a commanding general, possessing an acute understanding of the lay of the land, a strategic vision, and the ability to forge coalitions to form a broad front. Chaudhry would fit the bill perfectly as a great field commander, in constant touch with the troops, inspiring them with his courage and manoeuvres, tactically astute and bold, but lacking the attributes that transform field commanders into successful commanding generals. Chaudhry was at his best and most effective as the second-in-command, but as leader in his own right, he made fundamental errors of judgment (such as 
joining the military administration in early 2007) for which his people may yet pay a terrible price, and embroiling himself in activities which tarnished his reputation.

Reddy's political tragedy was somewhat like Koya's. Towards the end of their careers, the political world both the leaders had inherited and moulded had changed beyond their full grasp or easy comprehension. They had become remnants in their own lifetime. In Koya's case, as mentioned before, the issues which had shaped his career, earned him his enormous political capital, and along with it the adulation of the Indo-Fijian community, had become spent forces by the time the rein of leadership came into his hands. By then, the long simmering disputes in the sugar industry had finally ended with the Denning Award in 1969, and the great debate of the 1960s about whether the Fiji should have common roll or communal roll had effectively been resolved in favour of the latter. A product of the post-war period full of anti-colonial and anti-CSR rhetoric, which formed a steady fiery diet of the Indo-Fijian electorate, Koya found it difficult to adjust to the sober realities of politics in the post-independence era. He changed but did not change enough to meet the needs and demands of the new times.

Reddy faced a somewhat similar dilemma. The great personal sacrifices he had made over a decade of intense negotiation and fluctuating fortune over the review of the 1990 Constitution had resulted in the successful promulgation of a new, more inclusive, more multiracial one. By the time he faced the electorate in 1999, the new constitution was an accomplished fact, over and done with. Reddy wisely wanted to give the new constitution time to acquire a life of its own, to become entrenched in people's consciousness. 'We should learn to walk before we should attempt to run,' he told his political rallies. The electorate, encouraged by Labour, wanted more: good health care, affordable education, minimum wages, social security and employment, and the sooner the better. It responded enthusiastically to these bread and butter issues. 'The constitution won't put food on your table,' Labour told the electorate. They fell for the slogan. Reddy's more abstract appeal for moderation and introspection and about the need to build 
the foundations of a new future, fell on the deaf ears of a people wanting instant satisfaction of their needs, and Labour was the party to deliver it.

By the late 1990s, the character of the Indo-Fijian electorate had changed considerably from what it had been in the early 1970s. The steady emigration of skilled professionals and the educated classes, people who were concerned about the long term future of the community and the country, and who had formed the backbone of the NFP support, had robbed the party of its powerful support base, its party functionaries and financiers. Many of those left behind were among the desperately poor and they warmed up to Labour's vaguely socialist rhetoric about empowerment and opportunity. Chaudhry, not Reddy, was their saviour. Reddy's choice of well educated and otherwise qualified people as candidates in the election made perfect sense from a rational point of view: to put people in parliament who could make informed contribution to national decision-making. To run a good government, you need good people in parliament, Reddy said.

But Labour adroitly used this against the NFP, portraying it as the party of the rich and the professional elite. For its part, it chose people from the community, many with elementary formal education, some barely able to speak English, or read only haltingly speeches prepared for them by others, but who were a regular presence at community functions, in constant circulation among the people at the grassroots level. They were the grassroots. 'People Power' played big in the countryside; Reddy called it 'Parliament by Proxy.' The quality of the candidates for Labour was of secondary importance; the victory for the party was what mattered in the end. Reducing the expectations of the electorate to the lowest common denominator has been one of Labour's more enduring, if also more unfortunate, contributions to Fiji's political culture, and a marked reversal of the trend under the leadership of Dr Bavadra. It was also a reflection of the changing times, which Labour understood well and harnessed to its considerable electoral advantage.

Reddy's political career can be divided quite neatly into two phases. The first was from 1977 to 1987, and the second from 1987 to 1997. In the 
first phase, Reddy spent nearly all his time putting out fires in his own fractious community, in his own squabbling party hovering on the verge of complete disintegration. The issues over which the people split seem so petty and parochial in hindsight: a position of a branch functionary here, appointment to a board or a statutory organization there, sealing off office doors to bar opponents from within the party, staging boycotts of party proceedings because some leader was unable to have his way, ripping into each other in vicious newspaper leakages when internal matters should, and could, have been resolved out of the public view. Unhopeful of winning national power, the party turned on itself with a viciousness that both surprised and delighted its opponents. Internal competition and rivalry for position is in the nature of political parties everywhere, and the National Federation Party was no exception.

What exacerbated its problems was that division and friction became its dominant themes, almost its rationale for existence, with the result that the party could not articulate a larger vision for the nation. The NFP was always in the news for all the wrong reasons, principally about the debilitating leadership ambitions and struggles of its hierarchy. It could not, and rightly so, be taken seriously as the government-in-waiting even by its own supporters, let alone the nation at large. In 1981, a disgusted Reddy condemned the boycotts and walkouts which had become a hallmark of the party's annual conventions. 'We are a party seeking the reins of government, but here let alone govern, we cannot even elect a branch official. If this is the way to run the party, you might as well close it up. ${ }^{36}$

The second phase of his career was more rewarding for Reddy. After the coup of 1987, he had once again been thrust into the public arena as the paramount leader of the Indo-Fijian community, its representative to the other side of the political divide at home and to the international community at large. He sat on various committees trying to draw up a better constitution for Fiji, attended meetings and rallies abroad and worked tirelessly at home to shore up the morale of his people in the darkest time of their lives. But Reddy did not have an unfettered run even so. In the 1990s, 
he was fighting the Fiji Labour Party for the unity and leadership of the Indo-Fijian community, just as he had been fighting factionalism within his own party in the 1970s and early 1980s. But in the 1990s, real issues were at stake, none more important than a fairer constitution for his people, and building bridges with the leadership of the Fijian community. Reddy took the lead on both these matters and achieved a degree of success that had appeared unimaginable a few years earlier.

Jai Ram Reddy of the 1990s was in many ways a different man to what he had been two decades earlier. 'We human beings also evolve,' he once said, 'and I am not the same Jai Ram Reddy I used to be. I have seen, I have experienced, and I have learnt. I would like to think that I have become a bit wiser. ${ }^{37}$ He told the Andhra Sangam convention in 1996 that he had to 'walk a political tightrope and work towards realizing the aspirations of the people of Fiji. I realize that the success of my community depends on the success of every other community in Fiji. ${ }^{38}$ In the 1970s, Reddy had no, or little, national profile, apart from his formal role as the Leader of the Opposition. He was very much an 'Indian' leader, addressing Indian audiences. He had none of Ratu Mara's advantages of political longevity and experience. He rarely gave media interviews that admitted the public to his inner thoughts and doubts. On the contrary, he was positively media averse. By the 1990s, Reddy had transformed himself. He gave important addresses to non-Indian audiences on a whole range of topics, outlining his vision for the future. The interviews he gave to the press were full and informative, as he laid his ideas out before the public with clarity and precision. He was engaged in a mammoth task of political transformation, and he was determined to carry the people with him. New technology helped (cassette tapes, videos, television); traditional gatekeepers of information had lost their role and relevance. 'Most sensible people have been listening to Mr Reddy for some time,' said Graham Rouse in $1998 .{ }^{39}$ It was not a sentiment that could have been so freely expressed, or admitted, two decades earlier.

Looking back at the life of the National Federation Party, it can be said that there were two truly glorious periods in its history. One was the 
1960s when it articulated a vision for Fiji different to the one offered by the Alliance Party, when it presented itself seriously as a credible alternative government. It set the pace and tone of the national political debate. It took positions on important issues of the day. It called for immediate independence for Fiji and for Fiji to become a republic with an elected Fijian head of state. It was for the nationalization of the gold mines and the end of the CSR regime in Fiji. The NFP was the dominant, unchallenged voice of the Indo-Fijian community, and it was respected by all as such both in Fiji and abroad. For most of the 1970s and the early 1980s, the party lost its way as it turned endlessly upon itself over leadership and other parochial issues. The second productive phase was the 1990s when the party, although challenged by Labour for dominance in the Indo-Fijian community, played a major role, with Reddy at the helm, in national healing and in initiating dialogue and negotiation with its once bitterly opposed political foes to 'take the country forward,' to use a currently fashionable phrase.

What is clear from the record is that the NFP reached its greatest heights when it was united under a single leader, AD Patel in the 1960s and Jai Ram Reddy in the 1990s. The 1970s and 1980s were years of missed opportunity for the NFP. The contrast with the fortunes of the Alliance Party of that period could not have been greater. The Alliance had an unchallenged leader in Ratu Sir Kamisese Mara. There were private mutterings about his autocratic tendencies and his closeness to certain people and not others, but no one dared to challenge his authority publicly. Only once was Mara's leadership challenged (by Ratu William Toganivalu) over his close association with Sir Vijay R Singh, the Attorney General. ${ }^{40}$ Secure in his position, Mara presented himself as a strong, credible national leader. $\mathrm{He}$ undoubtedly was. He was admired and respected across the political divide, however much some of his policies and positions might have been contested. The Alliance Party conducted its affairs with professionalism in private, behind closed doors, in stark contrast to the way the NFP managed its internal affairs: on the front pages of the newspapers. The impression thus created was of a party well run and managed and united. The astute politi- 
cian that he was, Mara kept reminding the people of Fiji of the weak and divided opposition which could not be trusted to run anything, including a lottery. 'Keep Fiji in Good Hands,' the slogan went. The Alliance's greatest days, from the early 1970s to the mid-1980s, coincided with the NFP's most miserable ones.

To outsiders, the Indo-Fijian community appeared a monolith, menacing and uncompromising in its demands. There were of course certain issues on which the community had common concerns, such as land and underrepresentation in the public sector. But what this study also shows is the wide divergence of opinion in the community on matters of even the greatest importance to them. The National Federation Party split irrevocably in the late 1970s on the Agricultural Landlord and Tenant Act, for example; and the divisions hobbled the party for a long time. In the 1990s, differences over how to review the flawed 1990 Constitution once again split the community in half. Cultural and religious groupings affected political affiliations too. In the 1990s, it was said, for instance, that people should vote for the Fiji Labour Party and Mahendra Chaudhry because it was time for a 'North Indian' to be leader of the community which in the past had been led by a Gujarati (AD Patel), a Muslim (Siddiq Koya) and a South Indian (Reddy). Appeals to voters on cultural and religious lines are a common, if not publicly admitted, feature of politics in the Indo-Fijian community. Every avenue is explored, every opportunity exploited for political advantage though any impropriety assiduously disavowed to the point of denial. This study reveals the inner tensions and divisions which may not be easily visible to those unfamiliar with the internal contours of the Indo-Fijian community. Reddy's task, then, were twofold: to keep his own fractious community united and focused, and, as the Leader of the Opposition, to keep the government of the day in check.

The latter task was not an easy one for Jai Ram Reddy, or any other Indo-Fijian political leader, given Fiji's multi-ethnic character and the way politics were organized there. The government was always in the hands of the indigenous Fijians, while the Opposition was invariably led 
by Indians. Debate in parliament predictably degenerated into a 'racial' contest. It was a minefield in which one had to tread very carefully. Every issue of public policy was seen through the prism of race, so that any criticism of the government was construed, for political purposes, as an Indian attack on a Fijian government. Demography did not help: the two major communities were evenly divided numerically, and each had a distinctive understanding of its proper place in the broader scheme of things. Certain assumptions and understandings underpinned Fiji's political culture in the post-independence years. 'Blood will Flow,' it was so common to hear in the 1970s and 1980s, if Indo-Fijians touched Fijian land or threatened Fijian political control.

Fijian fears of dispossession may have been manipulated by the ruling elite to keep themselves entrenched in power, but they were also real for many ordinary Fijians languishing in the subsistence sector as other sections of the community appeared to march purposefully towards modernity, or failing to achieve success in the ruthlessly competitive money economy. When political control was finally wrested from the Fijian establishment in a democratic election in 1987, a military coup removed the government, in the name of protecting Fijian interests. But the last two decades have turned the table. As Indo-Fijians left the country in ever increasing numbers after the coup of 1987, (almost one hundred twenty thousand in twenty years) dwindling to around a third of the population by the early years of the 21st century, some of the old Fijian fears about being dominated diminished as Fijians realized that they were the outright majority of the population and will never be outnumbered again. It was that realization together with Reddy's patient, persistent approach that opened up the way for dialogue on the constitution and other matters.

Like other Indo-Fijian political leaders before him, such as AD Patel and Siddiq Koya, Jai Ram Reddy is rapidly becoming a forgotten figure of Fijian politics, uncelebrated as national icons like Ratu Sukuna, Ratu Mara or other notable Fijian paramount chiefs. There are no public monuments to their great sacrifices and achievements, no public recognition of 
the role they played in shaping Fiji's history. It was as if this was the natural order of things, the way things were meant to be. For a long time, such was the nature of the politics of cultural representation and symbolism in Fiji that the public face of Fiji always had to be Fijian. Public attitude is shifting slowly, but only ever so slowly, as travel and technology open up new horizons and increase contact with the outside world, as communication barriers crumble, and as leaders once worshipped as gods are shown finally to have feet of clay.

There is also something else at work: amnesia, ignorance, and indifference. There is simply no consciousness of history in the community, no sense of the need to engage with it. The schools are silent. Memory of the past is shallow. To illustrate, in September 2008, I asked a group of senior history students at a school in Nasinu if they knew who Jai Ram Reddy was. Not a single student in the class knew, not even Indo-Fijian students! They knew about George Speight, though, and Sitiveni Rabuka. Around the same time, a letter writer to the Fiji Times, Raj Singh, said that young people like him were 'so bored with that endless old stuff that they quickly flip to the next page as soon as they notice the name or picture of writers.' 'Younger Indian readers,' he continued, 'find articles on sports, weather or their horoscope more interesting. The world around us has moved on but some writers are still hanging on to the old stuff.41 That old stuff indeed!

The Nasinu incident distressed me greatly. It was then that all my dithering and doubt and diversions disappeared and I began to write this book. 'Where there is no vision, the people perish', the Proverbs (29:18) say. And TS Eliot reminds us that 'A people without history/ Is not redeemed from time.' I firmly believe, like so many of my pre-postmodern generation, that the act of writing and remembering can have the power potentially to rescue memory from the shallow graveyards of forgetfulness and obscurity that are so commonplace among our people. It is the one conviction that has kept me going through all these years of arid hopes and dashed expectations. 'Words,' Winston Churchill once said, 'are the only things that last for ever. ${ }^{32}$ 
Finally, to return to Reddy. It is exactly a decade that Jai Ram Reddy departed the political scene but his ghost, so to speak, continues to haunt the table of his political opponents. The blood does not wash away easily. His name is still taken in vain by his opponents to justify or criticize this policy or that cause, open an argument or close a debate. Reddy has his detractors, but there are also many thoughtful people who appreciate the magnitude of his contribution to the public life of Fiji. They would share Richard Naidu's broad assessment: 'Jai Ram Reddy, who survived the rough and tumble of politics for more than 20 years with his reputation for integrity intact, without succumbing to the compromises of politics in a coup-ridden country, surely ranks heads and shoulders above any other politician of his generation. ${ }^{43}$ Or political sociologist Steven Ratuva's judgment: 'Jai Ram Reddy was, and still is, the only Indo-Fijian leader capable of assuming the heights of multi-ethnic statesmanship. He was the only Indo-Fijian leader ever trusted by the Fijians. He was genuine and humble and indigenous Fijian leaders saw these virtues clearly and related to them. ${ }^{44}$ Sadly, what was virtue to one community, the indigenous Fijians, was vice to another, the Indo-Fijians. The irony could not be greater.

At a farewell function held for defeated and retiring parliamentarians in 1999, Dr Apenisa Kurusiqila, the Speaker of the House of Representatives, paid handsome tribute to the former Leader of the Opposition. The two men had got on well together. Reddy recalled how the Speaker had used the moral authority and facilities of his office to promote friendly interaction between the two sides of the House during the fractious 1990s, fostering an atmosphere that, he hoped, would be conducive to meaningful dialogue between the two main communities and their principal political leaders. His hope had not been in vain. Dr Kurusiqila, Reddy said, was one of the gentle, unsung heroes of the successful reconciliation process in the late 1990s. There was hardly a dry eye in the audience as Dr Kurusiqila spoke, Mary Chapman recalled. He spoke with characteristic generosity and good judgment about what Reddy had done and accomplished in the most difficult of circumstances in the 1990s, the man who had helped make it all 


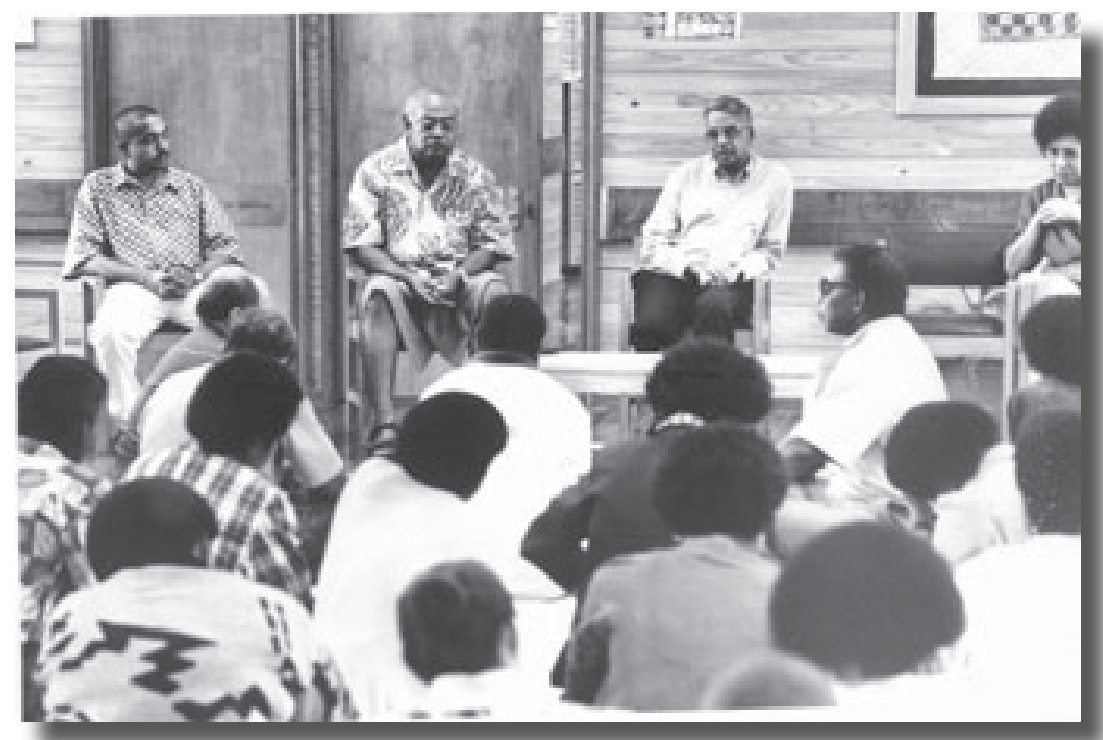

Dr Kurusiqila farewelling, Jai Ram Reddy, Parliament House, 1999. On the extreme left is Kamal Iyer, Administrator of the Office of the Leader of the Opposition, and on the extreme right is Mary Chapman, Secretary General of Parliament.

Photo courtesy of the Fiji Times.

possible through his persistence and perseverance. At the end of his political journey, Reddy stood tall in defeat. His voice breaking, Dr Kurusiqila said, 'Jai, parliament will not be the same without you." ${ }^{45}$

Reddy was moved. 'This is not the end of the road for me,' he managed in the midst of welling emotion. Indeed it was not. Soon afterwards, another door would open for him in a faraway land, in Tanzania, where he would cover himself with glory and honour that he never found among his own people, in the land of his birth. 


\section{INTRODUCTION}

\section{NOTES}

1. Peter Thomson, Kava in the Blood: A Personal and Political Memoir from the Heart of Fiji (Auckland: Tandem Press, 1999), 127.

2. The Review Magazine, 'Mood for Reconciliation,' (Jan. 1998), 21.

3. See his The Life of Politics (London: Methuen, 1968), 177.

4. Fiji Times, 4 June 2001.

5. The background to Ratu Mara is in his memoirs: The Pacific Way: a Memoir (Honolulu: University of Hawaii Press, 1997).

6. Joni Madraiwiwi, A Personal Perspective: The Speeches of Joni Madraiwiwi (Suva: University of the South Pacific, 2008), 271.

7. Sir Robert Foster, 'Fiji: final despatch before independence,' 8 Oct 1970, in Foreign and Commonwealth Office (FCO) 32/606, no.1.

8. Wrote Mara of Patel: 'He had been a brilliant lawyer, an eloquent speaker, a charismatic leader of his party and a doughty opponent. But it has to be admitted that political negotiation with him had proved difficult, and on occasion impossible. In particular he was irrevocably committed to the policy of common roll as a first step, not as an aim for the future, which we were prepared to concede.' Pacific Way, 97.

9. Some have gone so far as to assert that Mara 'hated' Reddy whom he regarded as an 'upstart.' See Jim Anthony, The First International Conference on the Political Crisis in Fiji: A Report (7-9 July, 1988 International Movement for Democracy in Fiji, Honolulu), 14-15. Anthony adds that 'Mara hated AD Patel. He liked Koya as long as he could keep Koya under his thumb.'

10. Sikivou was not even accorded a farewell morning tea when he left the Alliance Cabinet after many years of service. It did not help that Sikivou was a commoner.

11. Thomson, Kava in the Blood, 162.

12. Such as in 1982 during the Queen's visit to Fiji when Ratu Mara put Reddy last in a long line, after the members of the diplomatic corps, to greet Her Majesty, when protocol demanded that he should come after the cabinet ministers. 
When the Queen finally reached Reddy, Prince Philip asked him: 'And which country do you represent?' Reddy replied: 'I am Her Majesty's Leader of the Loyal Opposition.' The Queen noted the remark and made a point of seeing Reddy again to say goodbye before retiring for the night.

13. The Weekender, 6 Feb. 1993. In an interview broadcast posthumously on Fiji TV, Ratu Mara changed his tune, but by then he was playing politics. Mahendra Chaudhry was prime minister and his daughter, Adi Koila, was a minister in his government. Reddy was by then out of politics.

14. Rabuka's early life and his execution of the 1987 coup are covered in Eddie Dean and Stan Ritova, No Other Way (Sydney: Doubleday, 1988); also John Sharpham, Rabuka of Fiji: Authorised biography of Major-General Sitiveni Rabuka (Rockhampton: Central Queensland University Press, 2000).

15. It is an assessment shared by James Raman, a member of parliament and of the Joint Parliamentary Select Committee on the Constitution Review. Personal communication, Sept. 2009.

16. John Sharpham, Rabuka of Fiji, 321.

17. That certainly was the basis of my own relationship with Tomasi Vakatora on the Fiji Constitution Review Commission.

18. He reportedly made the comment in a radio interview.

19. FCO 32/606, no.1, 8 Oct. 1970

20. A warm tribute, 'The Life and Trials of Koya,' is in the Fiji Times, 17 Apr. 1993.

21. Among them, Sir Leslie Monson, Deputy Under-Secretary of State for the Commonwealth, 1967-1972. A summary of the larger decolonisation debate, which is covered in my A Time Bomb Lies Buried: Fiji's Road to Independence, 1960-1970 (Canberra: ANU E Press: SSGM Monograph Series, no 1, 2008).

22. Fiji Times 19 Aug. 1985.

23. Fiji Times, 12 May 1992.

24. Fairlie, The Life of Politics, 23.

25. For example, Peter Thomson, Kava in the Blood, 127, where he writes that 


\section{INTRODUCTION}

Reddy often had a 'rather meek manner' with 'a slightly bemused, almost hurt expression on his face,' but that these 'outward appearances belied a dogged inner resolve.'

26. Chaudhry's threat is in The Review Magazine, Aug. 1992.

27. The agreement apparently was that neither Labour nor NFP would contest the seat won by each other, but to actually campaign for the other party was another matter.

28. Quotes from Reddy's speech to the General Voters Party, 1993.

29. The essential features of consociationalism are a grand coalition of elites representing the different segments of society, mutual veto over matters of particular concern to the different communities, proportionality in representation, and segmental autonomy that allows for the maintenance of different cultural identities. See Arend Lijphart, 'Consociational design for divided societies.' Journal of Democracy, 15:2 (2004), 96-109, and more generally his Democracy in Plural Societies: A comparative Exploration (New Haven: Yale University Press, 1977).

30. The Weekender, 30 Apr. 1993.

31. Pacific Islands Monthly, June, 1987.

32. See Nemani Delaibatiki's assessment, 'Where's Labour heading to,' in Daily Post, 23 May 1995.

33. Thomson, Kava in the Blood, 127.

34. The Weekender, 16 July 1993.

35. In 2009, a year after Chaudhry was dropped from the military cabinet and a few months after the 1997 Constitution was abrogated, Chaudhry joined forces with Qarase to petition the international community for an early return to parliamentary democracy!

36. Fiji Times, 22 June 1981.

37. Interview in The Review Magazine, Jan. 1998, 21.

38. Fiji Times, 8 Apr. 1996.

39. The Review Magazine, Jan. 1998. 
40. This is according to Tomasi Vakatora who recalled the incident vividly as he had to forego his usual Saturday game of golf to attend an emergency meeting.

41. Fiji Times, 14 Nov. 2008.

42. David Reynolds, In Command of History: Churchill Fighting and Writing the Second World War (Penguin, 2005), 525.

43. The Review Magazine, 16 Aug. 2003.

44. The Review Magazine, 1 Aug. 2003.

45. Reddy recalled this in his eulogy for Dr Kurusiqila, 31 Jan. 2001. 


\title{
CHAPTER 1: INHERITANCE
}

How dull it is to pause, to make an end

To rust unburnish'd, not to shine in use.

Alfred Lord Tennyson, Ulysses

\begin{abstract}
Tai Ram Reddy was born at Lautoka Hospital on 12 May 1937, the eldest child of Pethi and Yenkattama Reddy. The place of birth was unusual for those days when most children were born at home. So, too, was the mode of birth: caesarean. There was celebration in the Reddy household for the first born, a son, a celebration made all the more poignant because of the death of an earlier child, a girl, either during childbirth or early infancy. Pregnancy could be precarious even at the best of times, and infant mortality, while declining, still tore at the heart of many a family in rural Fiji. Old timers were on hand to advise on the proper rituals and cultural protocols to follow to avert another potential tragedy. So Jai Ram was symbolically handed over to another lady immediately after he was born for adoption as her own son, thereby hopefully breaking the chain of evil luck which had brought down the earlier child. It is an old Indian custom familiar to me, but it has now vanished beyond recall. The ritual worked; Jai Ram survived, and four other children followed: three boys and one girl. They now live in Fiji and in the Indo-Fijian diaspora in Australia and New Zealand, while some of the younger generation has moved across the Pacific to North America. In this respect, the Reddy family's history of dispersal replicates the broader experience of the contemporary Indo-Fijian community.

The day Jai Ram was born also happened to be a public holiday. The Colony of Fiji was celebrating the coronation of King George VI. The Fiji Times carried long, adulatory columns, proclaiming the new mon-
\end{abstract}


arch 'Fully Equipped for Task,' possessed of 'Amazing Industry,' and his consort, Elizabeth, having 'Sincere Love of an Empire,' with 'Capacity for Thoroughness' and 'Charm Unspoiled by Greatness.' The syrupy tone was unsurprising. This was the high noon of the British Empire, unequalled in power and wealth and prestige in entire human history, and Fiji was among the most loyal and dutiful of Queen Victoria's far-flung colonies. Red patches on school atlases proudly proclaimed vast stretches across the globe under the undisputed authority of Pax Britannica, and school children were taught to accept this accomplished fact with open pride: an empire upon which the sun never set (which led our sometimes eccentric primary school teacher, Mr Austin Sitaram, to quip that the sun never set because God could not trust Englishmen in the dark!) Within a decade the mighty juggernaut that was the British Empire would begin to disintegrate, with India leading the mutiny in 1947, followed shortly afterwards by colonies in South and Southeast Asia and those on the African continent. The United Kingdom was truly on its way out as a great imperial power as Harold MacMillan's 'Winds of Change' reached the shores of the Pacific islands in the early 1960s. A world which once seemed so impregnable and powerful, unshakeable in its foundations and unfathomable in its reach, came to an end as Jai Ram Reddy and children of his generation, who had grown up on Reed Brett's British History, 1783-1936, came of age.

The Fiji Times of 14 May carried another contributed column, a farewell address to Mr CE Elliot of the Colonial Sugar Refining Company from members of the Sangam cane growers of Rarawai, Ba. ${ }^{1}$ The growers expressed 'regret' at Mr Elliot's departure. 'During your supervision of our industry on behalf of your Company we have at all times received the greatest kindness and consideration at your hands and we trust that your successor will by his diligence and integrity endear himself to us in the same manner as you have.' The growers, it seems, were particularly grateful for Mr Elliott's interest in Sangam's educational efforts. 'Your interest in the Sangam's School will always be remembered with gratification for your assistance,' they said. This was not idle grovelling. Surprising as it may seem, 
the CSR was strangely generous in its concern about education, especially when it would have made economic sense for it to keep the children of cane growers illiterate and under its thumb. The Company provided its own freehold land as well as much practical assistance to establish many community-based primary schools for Indian children in the sugar cane belt of Fiji. Just as it was for the colonial government, so too was the 1930s the high noon of CSR's power and influence in Fiji. Over the next two decades, its once iron-clad hold over the cane growers would be challenged and eventually dismantled. As a child growing up in the heartland of the cane growing country, Reddy had a ringside seat as the great dismantling unfolded. One of his uncles, Sesha Reddy, was among the growers' leaders who fought against the CSR in 1943.

The late 1930s were a watershed period in Fiji's political evolution. ${ }^{2}$ Colonial power was then at its peak. There was only sporadic and largely ineffectual questioning of the values and assumptions which underpinned the colonial order. Some of it came from such Fijians as the rebel Apolosi Nawai, a self-proclaimed messiah of ordinary Fijians, against Fijian chiefs and the colonial order they supported. Some came from Indian politicians after the end of indenture in 1920, demanding equal representation in the colonial legislature with the Europeans. The pressures were successfully resisted. Fiji was a colonial backwater in a remote corner of the world and untouched by the currents of political thought swirling in other oceans. Communication was sparse and its people lived in self-contained, segregated, communities. Fiji, the comforting colonial metaphor went, was a threelegged stool upon which the three principal communities, Fijians, IndoFijians and Europeans, made their own separate and unique contributions. This was pure myth making. There was no necessary balance between European capital and Indian labour, for example; and the moral authority and legitimacy of the colonial order was not universally accepted but was always contested to varying degrees by different groups. Nonetheless, the myth prevailed. It provided the justification for an unequal, raciallyordered society. 
The years following the Second World War, in whose shadow people of Jai Ram Reddy's generation came of age, were a time of profound social, economic and political change in Fiji. The increasing population put pressure on land and the natural resources of the colony. ${ }^{3}$ The resulting resistance these provoked among the Fijian owners created tension that often derailed the prospects of amicable political dialogue among the leaders of the different ethnic communities. The inequitable racially compartmentalized world of political representation in the colonial legislature was challenged by various ethnic groups, but mostly by Indo-Fijian leaders, and found wanting. The demand for change grew and slowly gathered pace with time. Growing up, Reddy witnessed a fundamental transformation in modern Fiji society and politics, whose cruel legacies he would inherit when he entered politics a few years after Fiji became independent in 1970. We shall examine in detail the political changes leading up to independence in the second half of this chapter, and the legacy they bequeathed to Fiji's post-independence leaders, but we begin first with Jai Ram Reddy's background.

\section{ROOTS AND ROUTES}

Jai Ram Reddy's grandparents came from India as indentured labourers. They were of South Indian ancestry. His paternal grandfather, Byanna Reddy, came aboard the Elbe III in 1903 from the Cuddapah district, then in the Madras Presidency but now in the province of Andhra Pradesh. He was a Kamma, descended from the warrior caste, the kshattriyas, as they are known in other parts of the Indian subcontinent. Jai Ram's maternal grandfather, Iyyappa Reddy, also journeyed on the same ship bringing the first full consignment of indentured labourers from South India. He was from the district of North Arcot of the Reddi caste. From 1903 through to the final shipment of indentured labourers arriving in 1916, over 15,000 South Indians had gone there. North Arcot was, by far, the largest supplier of South Indian indentured labour, and Cuddapah among the smallest. 
The other major suppliers were Madras District, Vizagapatnam, Godavari, Nellore, Kistna, Salem, Coimbatore, Malabar and Tanjore.

However, South India was not a major recruiting ground for more widespread Indian indentured labour, except for Natal where it was the major supplier (some 160,000) between 1860 and 1911. Some British West Indian sugar colonies discouraged the recruitment of South Indians because they were said to be 'moody' and 'prone to suicide.' This was certainly so in Fiji where a disproportionate number of South Indians took their own lives on the plantations for reasons ranging from an inhumane pressure of work to stress emanating from the cultural dislocation and neglect suffered by a minority community. ${ }^{4}$ The majority of the South Indians were recruited under the 'Kangani' system of family or village supervised migration to Malaya, Ceylon and Burma. Emigration to these Southeast Asian destinations was, by and large, of short duration, while emigrants to the more distant colonies tended to settle permanently, although nor always or everywhere. The Fiji Census Report of 1931 reported that 'family repatriation is commonest with the Madrasi, who is reported to retain longest his connection with his home country and ancestral lands. ${ }^{5}$ Perhaps this was also a reflection of their marginal, unsettled condition in Fiji.

Fiji began recruiting in the South when sources in North India started to dry up. Indian indentured emigration was initiated to provide cheap labour for work on the sugar plantations of the colony. The majority of the indentured recruits in the latter half of the 19th century were from the impoverished regions of the great Indo-Gangetic plains, especially the eastern districts of what is now the province of Uttar Pradesh: Basti, Gorakhpur, Gonda, Faizabad, Azamgarh, and Bahraich. The first shipment arrived aboard the Leonidas in May 1879 and the last on Sutlej $V$ in $1916 .{ }^{6}$ By then, some 60,000 Indian indentured labourers had gone to Fiji from the subcontinent. All did so on a five year contract or agreement — hence girmit — which specified the conditions of the employment, the remuneration for service rendered, the medical and accommodation facilities on the plantations. Above all, the Agreement provided for a return passage back to India 
at the labourer's own expense after five years, and free after ten years of 'industrial residence' in the colony. In the end, only about 24,000 individuals returned. The majority decided to make their permanent homes in Fiji, and never again saw India even though their motherland remained their main cultural reference point and their spiritual and emotional sanctuary until the very end. Most settled in the cane belts of Viti Levu and Vanua Levu.

Jai Ram Reddy grew up, like so many of his peers, with stories about the indenture experience. The memory of humiliation was fresh in the minds of the older folk, and many girmitiyas were still around to tell their stories of pain and suffering. Indenture, Reddy recalls being told, was a 'horrendous experience,' for those who lived under it, resulting in the 'degradation of man, woman and child.'7 His uncle Krishna Reddy, who lived well into his eighties, told stories that had a deep impact on the young Jai Ram. In his own words: 'One of the stories that he used to tell us was how he, as a little boy, would wait for his mother to come back from the fields after a day's work into the lines, how he used to say that she was so tired at the end of the day that she would not be able to identify the particular unit or cubicle in which she lived so that she would have to be guided by this little Krishna Reddy into the correct room. We heard stories about how women were also indentured and went out in the fields at five in the morning and worked throughout the day till late in the evening until they finished their task, how sometimes they would give birth in the fields, often unaided and unassisted. We heard about the degraded conditions that existed in the labour lines, of meagre incomes, of insufficient rations. Above all, of course, was the humiliation, insults and violence the indentured workers were subjected to.'

This moving rendition of the indenture experience is common enough, and forms an enduring part of the Indo-Fijian folklore and cultural ideology: the violence, the exploitation, the broken families, the back-breaking work in the fields, the overseers' whips, the diseases (diarrhoea and dysentery in particular) which killed people in the hundreds, the heartbreaking infant mortality rates, the collapse of social and moral values and struc- 

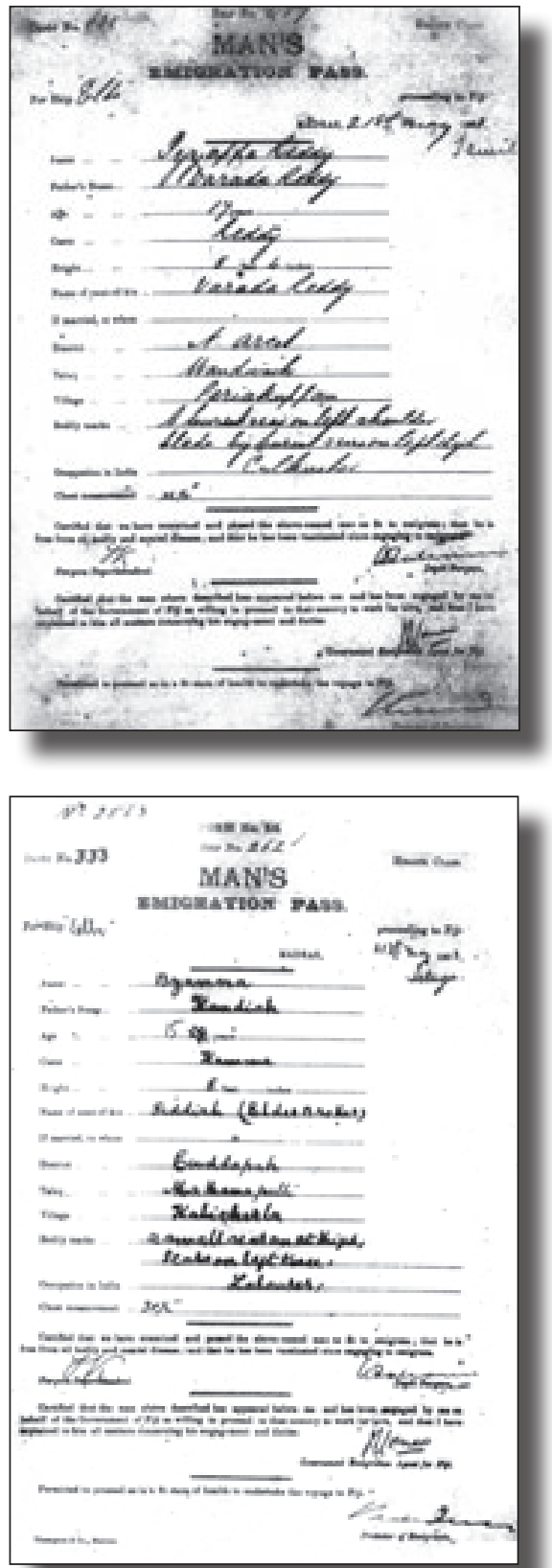

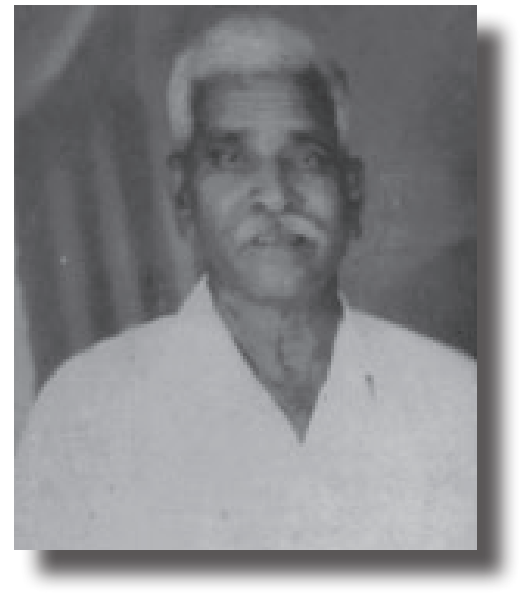

Iyappa Reddy, Jai Ram's maternal grandfather, a progressive social worker, one of the founders of Lovu Sangam Primary. Below: Byanna Reddy, his paternal grandfather. Photo courtesy of Janardan Reddy.

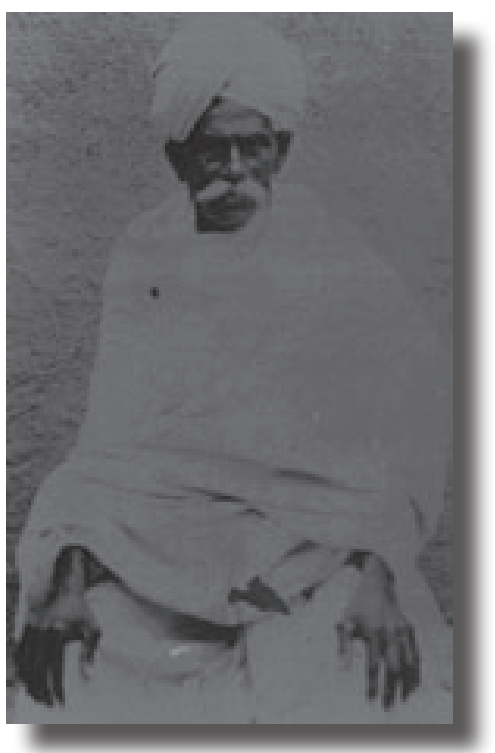


tures in the confined quarters of the labour lines, the overwhelming sense of hopelessness and despair, of being trapped and terrorized and unable to escape. All this is, of course, true to varying degrees. ${ }^{8}$ Nonetheless, it is important to remember that indenture in Fiji was not a life sentence (as it was in some of the older colonies, such as British Guiana, where indentured labourers depended on the plantations for generations), but a limited detention of specified duration.

After five, or at the most ten years, people became free, settled on land near the sugar mills, established new homesteads, raised families, built communities, and simply got on with life. If indenture was the site of fragmentation, it was also simultaneously the site of reconstitution, as old values and practices were discarded (the caste system, for instance, or rituals and protocols of hierarchy and social distance that so defined traditional Indian society) and new ones adopted that emphasized individual initiative and enterprise and, in an important sense, the common humanity of the people. The rupture with the past was neither permanent nor complete; there were continuous linkages and seepages across the line throughout. In truth, the passing of the old order was not always mourned either. To those who had no hope of redemption in this life, or the next, or the one after, because that is the way the gods had ordained their fate, Fiji offered a fresh, unencumbered start, and they gladly accepted the new opportunities with both hands. There was the memory of pain, to be sure, but there was gain also in the form of social emancipation and the creation of a more egalitarian social and moral order.

The Reddis and the Kammas (which means an ear ornament) were prominent and proud cultivators in Southern India, and many were village leaders in their communities as well. The Madras Census Report of 1901 describes the Kammas, Kapus or Reddis, Velamas and Telagas as descendants from the same stock, originating in a distant past from the warrior caste. ${ }^{9}$ Legend has it that they had been banished to remote parts of the country by a king of the family of Parikshat because one of them had pronounced him to be a bastard! Many well-to-do families in Southern India, I have 
been told, come from among their members. People in Cuddapah and North Arcot will not hesitate to regale a visitor with the great and glorious achievements of these two communities. They will tell him about Sir Venkata Reddy Nayudu, for example, a leading member of the Kamma community, who was elected to the first and second Legislative Council of Madras in the early part of the 20th century and who later served as India's Agent General in South Africa. Or about Sanjiva Reddy, the President of India from 1977-1982.

Everyone remarks upon the toughness and resourcefulness of the Kammas and the Reddis and their readiness, even eagerness, to take on a fight if a cause has to be defended, or if family honour is at stake. 'They are as a rule fine, well-built class of cultivators, very proud and exclusive,' wrote Rev. J Cain of the Kammas in 1879. HA Stuart thought them 'most industrious and intelligent cultivators,' and they were 'without peers. ${ }^{10}$ Several well known proverbs in South India attest to the Kammas' industry and independence. Kamma vani chetulu kattina nilavadu (though you tie a Kamma's hands, he will not remain quiet); Kamma vandlu cherite kadama jatula vellunu (if Kammas come in, other castes go out); Kamma variki bhumi bhayapadu tunnadi (the earth fears the Kammas). In old days, and even now, lines on the ground are readily drawn. Personal honour counts for a lot, and no affront were easily forgotten or forgiven. Memories run deep. Fear is an emotion despised by everyone, even the poorest of the poor. Even today, in rural parts of Cuddapah, a hard, rough, unforgiving country, singed by the Telangana peasant rebellion of the late 1950s (as portrayed in the great Shyam Benegal film Nishant) the Reddis and the Kammas are feared as landlords for their 'overbearing manner,' as one person told me. Jai Ram Reddy, then, comes from a proud and independent background, from a stock unwilling to bow to any man, and born to lead. Still, however 'respectable' a background they came from, in Fiji, all Indian indentured labourers were simply 'coolies,' units of labour to be exploited for maximum profit by the planters. It was the denial of the humanity of the individual men and women, the wilful negation of their cultural identity by those in 
authority, whether colonial officials or CSR overseers, which was perhaps the most heartless aspect of the indenture system.

While this was so for all indentured labourers, the situation of the South Indians was especially difficult. As late comers to Fiji, they were sent to remote and isolated areas to serve their indenture, away from fellow South Indians and Jahajibhais, people who had come on the same ship. Separating people from the same ship or region was a strategy the CSR employed to prevent 'ganging up' among the labourers. The South Indians lived and worked among North Indians whose culture and language they did not understand, but which they nevertheless had to learn as best they could in order to survive and to negotiate their way around in the new environment. They bore the full brunt of North Indian (Aryan) cultural prejudices about the darker skinned South Indians (Dravidian). Their languages, customs and mannerisms were cruelly mocked and mimicked. Tamil and Telugu, some people said, sounded like stones rattling around in a lota, brass pot. They were called Khatta Pani, the eaters of sour (inferior) food, generally a people belonging to a lower, unsophisticated, social order. ${ }^{11}$ They remained for the most part on the outer, uninviting fringes of community functions and festivities in areas where they were a minority. It is no wonder then that South Indians on the plantations committed suicide in proportionately larger numbers at the turn of the 20th century than any other group.

The dominant Indo-Fijian cultural tradition that emerged from the crucible of the plantation system in Fiji was essentially North Indian in character, to which all the minority communities had perforce to subscribe. Hindi, or more accurately Hindustani, had to be learned because after the end of indenture in 1920, it was adopted as the official lingua franca of the Indo-Fijian community and the official language of communication within it. Some recall a time in the 1940s when South Indian children were refused admission to some Indo-Fijian primary schools because their Hindi was poor, which, as it was an examinable subject, might somehow lead to a lowering of standards. It is also likely that many of these schools were community-run, and preference was therefore given to those who had 
contributed to their establishment in the first instance. Reddy himself went to Lovu Sangam, started in response to the difficulty South Indian children encountered in getting admission to Drasa Indian School (though he was not among them). Iyyapa Reddy was one of the founders of the school. From Lovu, Jai Ram was sent as a boarder to Penang Sangam, where his headmaster uncle was transferred; staying with teachers was somehow felt to improve a pupil's chance of success in exams. That may have been so, but his Penang years were deeply unhappy ones for Jai Ram; he desperately missed his parents and his aunts, and the various comforts of affection that the first-borns automatically enjoy. He has bad memories of Penang even now. Once or twice he tried to escape, only to be returned and told to study hard. Jai Ram did not.

\section{SANGAM AND THE SADHUS}

Characteristic of the irrepressible Indo-Fijian spirit, the South Indians did not despair. In 1926 they formed an umbrella organization for the entire South Indian community called the Then India Sanmarga Ikya Sangam. ${ }^{12}$ Its purpose originally was not religious in the narrow sense but cultural, to unite under one banner South Indians of all creeds and castes. Its flag featured the symbols of all the three major faiths, Hinduism, Islam and Christianity: the Hindu Trishul, the Muslim half Crescent of the moon and the Christian Cross. One of the early presidents of Sangam, I am told, was a Muslim, a Koya. But the broad, inclusive base did not endure. In time, as the Indo-Fijian community set down its root and groups within it began to define their own unique cultural identity, Sangam came to be identified with the followers of Hinduism, and temples and fire walking became inextricably linked with it. In time, religion, not culture, became the primary marker of identity in the Indo-Fijian community. And so it remains today.

The leading spirit behind the formation of Sangam was Sadhu Kuppusamy, described by AD Patel as 'the greatest Indian in the history of Fiji.' This was no mean assessment from the great Indian leader, who was himself deserving of that accolade. The Sadhu was born in Konoor, 
Madras, in 1890 and came to Fiji as an indentured labourer in February 1912. He completed his indenture at Yaladro, Tavua, after which he settled at Rakiraki, initially as a two-horse ploughman for the Melbourne Trust Company and a part-time teacher of Tamil and Telugu to children from the home of TAJ Pillay. Kuppuswamy, 'this humble man clad in a dhoti, of no worldly possession, armed with his abiding faith in the Almighty God, committed to serving his fellow human beings,' as Reddy recalled, was unlettered in English but was proficient in both Tamil and Telugu and had deep knowledge of the Hindu scriptures. 'He knew religion,' Reddy has said. 'He understood the spirit of religion' and 'the meaning of the dignity of man.'

The Sadhu came to realize quickly that the greatest need of his people was social and cultural betterment. Education was key and to that end he devoted all his energies. But he conceived of education in the broadest sense. The preservation of language and culture were central to his project. 'If you want to kill a people, kill their culture, kill their language,' he said. 'I would rather die,' he continued, 'than to see my culture and language killed.' He promoted the teaching of Tamil, Telugu, and Malayalam in Sangam temples and schools. These schools began with nothing but the willingness of parents to sacrifice for the education of their children. They clearly saw education as the only way out of the poverty and predicaments which had so blighted their own lives. 'Some [parents] would contribute a half a dozen sheets of iron - that was the contribution of one family', Reddy has recalled. 'Some would contribute a few pieces of timber. Some would contribute a few shillings; others would contribute their labour. In this way, small schools over Fiji started.' Sadhu Kuppuswamy's example of sacrifice and service impressed Reddy deeply. 'He had a message of hope and he was very effective in taking that message to the masses of people and drawing out of them some of the noblest qualities that are latent in all of us.'

For all his efforts and initiatives, the Sadhu realized that he needed more assistance, greater expertise in the fields of Indian religion and culture. With the help of AD Patel, he wrote to the Ramakrishna Mission in Madras 
for help. The result was the arrival, in 1937, of Swami Avinasananda, a tall, bearded man, learned in the South Indian languages and cultures and proficient in English. He was also a professor of Sanskrit and former principal of the Surat National College. With Patel he toured all the major centres of South Indian settlement in Viti Levu, impressing upon the people 'the need for welding the Sangam into a well-united centralized organization under the care and guidance of the Ramakrishna Mission.' He asked Patel to become the general manager of Sangam, which he did, besides acting as the manager of its several schools for many years. The Swami struck up an unexpectedly close rapport with the then governor of Fiji, Sir Arthur Richards, and later Lord Milverton, one of the more enlightened governors of colonial Fiji. ${ }^{13}$ The colonial officials were impressed with the Swami's erudition and determination. Among other things, he extracted from the Governor the promise of assistance for schools, which Richards readily gave. Richards also promised to make Nadi the cultural centre of the South Indian community in Fiji, but he left the colony soon afterwards. The war intervened and Swami Avinasananda left Fiji in February 1938, but not before he had enlisted Patel's help to formally register the Sangam as a limited liability company without the words limited in the title.

Upon returning to India, Swami Avinasananda sent Swami Rudrananda, a Ramakrishna Mission monk, to Fiji. He arrived in Fiji in 1939 and remained there till the end. ${ }^{14}$ The Swami was a man Reddy admired greatly. He was among his great mentors, along with AD Patel. Based in Nadi, Rudrananda, the man of the saffron cloth, devoted his entire life to the welfare of the people, especially the sugar cane growers of Fiji. $\mathrm{He}$ was the growers' representative on the Sugar Board and a senior advisor to Lord Denning who conducted an enquiry into the sugar industry in 1969. 'Don't talk religion to a man with an empty stomach,' was one of his favourite sayings as he toured the cane country of Viti Levu. Rudrananda feared no one, treating everyone alike and not sparing anyone, including prime ministers, as Daryl Tarte recalls, if they crossed his path or disregarded his advice. ${ }^{15}$ His high-pitched voice and the wagging finger were much feared 
by the mighty and the minions alike. It was Rudrananda's spirit of fearlessness and public service that Reddy spoke of, often in awe and with complete respect.

Swami Rudrananda, like Sadhu Kuppuswamy, quickly realized the importance of education in its broadest sense for the Indian community in Fiji which was then scattered, largely illiterate and barely conversant with its own cultures and traditions. The Ramakrishna Mission in Nadi organized a mobile library service, the Gyana Rath. Gathering on Sundays, Swamiji, AD Patel, Pandit Ram Oudh Sharma, HM Lodhia and others held discourses on the Gita. In August 1948, the Mission started the Sarada Sangam Press which published several newspapers: the Sangam in Tamil, Jagriti in Hindi, Vakalelewa ni Pasifika in Fijian and, perhaps the most important of them all, The Pacific Review which, at the time of its publication, would have had to be the finest, most literate weekly in the entire Pacific, possibly even in Australia and New Zealand. The early issues are a gem to read even now. Their intellectual and literary span was remarkable, with beautifully written articles on literature, philosophy and the great ideas of mankind. The 1950s and the early 1960s were the heyday of cultural renaissance in the Indo-Fijian community, and Swamiji and AD Patel were heading it in the cane belts of Fiji. They were well ahead of their times.

In 1951, Swami Rudrananda tried to amalgamate the Sangam and the Ramakrishna Mission into a single organization. Sadhu Kuppuswamy supported Rudrananda's vision, but many in the Sangam community were outraged. The Sangam's assets were being used for purposes other than for which they had been accumulated. What was the need for a printing press when there were so many other pressing problems facing the community, they asked? Was this a ploy by AD Patel to consolidate his political base? And why should Sangam alone bear the burden for the entire Indian community when other Indian cultural organizations were ploughing their own narrow burrows? Funds collected for and by Sangam should be used first and foremost for the purposes of the organization, the opponents said. 'Hadap lihis,' some people said of Swamiji's actions. 'He 
has snatched it all away from us. ${ }^{16}$ A court case halted the transfer, and an agreement was reached whereby the Sri Vivekananda High School was transferred to the Ramakrishna Mission and Sangam was allowed to run its own schools separately. Swami Rudrananda's attempted amalgamation efforts split the South Indian community bitterly, right down the middle, and soured relations for decades. Echoes of those distant disputes are still faintly audible in conversation with the passing generation. And a separate Andhra Sangam today is a visible reminder of the old divisions now fading with the passage of time and the passing of the pioneers. Many who disagreed with the Swami would be among those who would join the Alliance in later years: Krishna Subba Reddy, then a school teacher, who instituted the court case, would be an Alliance parliamentarian, and Manikam Pillay its Attorney General.

Swami Rudrananda's actions may well have been ill-advised and premature. The Indo-Fijian community was culturally fractured; parochial passions ran deep; and there was no overarching sense of a larger identity with common, enduring interests. But there was no malice or greed in Swamiji's thoughts. Consolidation made perfect sense, and that, as far as he was concerned, was that. There was no reason for debate or discussion, which led some to call him a 'dictator.' Once his mind was made up, Swamiji brooked no dissent. What Jai Ram Reddy said of Sadhu Kuppuswamy was equally true of Swami Rudrananda. 'He was not a parochial man. He may have been the founder of Sangam but his vision for the country and the people was much wider, much larger.' As for Patel using the Sangam to further his own political agenda, Reddy responds sharply: 'What was his political agenda? Was it not also the agenda of the Indian community? He was fighting for the broader interests of the people, not for any one section of it.'

Like Swami Rudrananda, Jai Ram Reddy's overarching vision transcended the cultural boundaries of his own community and its narrow, inward-looking concerns. On that even his fiercest opponents agree: he is not a culturally narrow-minded man. His circle of friends is eclectic. His 
wife is a North Indian. He is a Hindu in the broad spiritual and not ritualobserving, temple-going sense. Reddy is both proud of his South Indian heritage and comfortable with it, but he is not imprisoned by it as some others are, unwilling and unable to forget or forgive past cultural insults and slights, bearing grudges. As a child, Reddy learnt Telugu and spoke it fluently until he attended primary school, but that is now almost gone. The same is true of speakers of other minority languages for whom 'Fiji Hindi' is the mother tongue. And in one of those delicious ironies, Reddy, who spoke only Telugu as a child, emerged as the finest Hindi orator of his generation.

\section{EDUCATION AND FAMILY}

The Sri Vivekananda High School (now College) in Nadi opened in 1949. The opening of that school was an event of singular importance in the social and cultural history of the Indo-Fijian community. It was nothing less than a revolutionary act of defiance of colonial authority. SVH was the first non-Christian, non-government secondary school in Fiji, opening the way for many others in later years. The colonial Education Department raised objections about finance, the quality of instruction and employment opportunities for the school leavers. But AD Patel ('The Father of the School,' as MR Balaganapathy, the principal, recalled), Swami Rudrananda and Sadhu Kuppuswamy (and one Mr Ridley), ${ }^{17}$ the principal founders of the school, pressed on, convinced that their vision was right and that there was great need for higher education among Indo-Fijians. Nothing would stop this determined group from pursuing their goal to liberate their people from the mental bondage of colonial rule, as they put it. Jai Ram Reddy was one of the earliest batch of students to attend SVH. 'When I was ready to go to secondary school,' he has recalled, 'there were no secondary schools which would accept people like me. I came from a farming background, and it was not easy for people like me to enter a secondary school, a government secondary school, for Indians at the time.'18 'Had it not been for that school [SVH],' he asks, 'what would have become of people like me and many hun- 
dreds of thousands of other people from rural parts of Fiji? Where would we be and where would our children be?' Where indeed! Sri Vivekananda College remains one of Fiji's premier secondary schools.

For all his other strengths, Jai Ram Reddy was an indifferent, perhaps even a mildly rebellious, student. His mind at school was not fully focused on learning. His performance in exams was erratic: at the top of the class one year, somewhere in the middle heading towards the bottom the next. Unthinkable now because of the universal esteem in which he is held, he was at school a prankster, an irrepressible character full of youthful mischief, sneaking out at night to steal fruit from neighbouring farms, cutting down mosquito nets. For his many continuing acts of errant, unrepentant behaviour, he was expelled from the school hostel, finding lodging at the home of Shaukat Ali Saheb, a family friend and a fellow Telugu, from Lautoka. Reddy passed his Fiji Junior exam, but his overall performance was uneven. He was good in History and English, but Mathematics floored him completely, to the great puzzlement of Master PND Moosad, the senior teacher in many subjects, who was otherwise impressed with Jai Ram. For his inconsistent academic record, the school decided to defer his sitting the Senior Cambridge exam by a year, which disappointed him greatly. He therefore left SVH and in 1954 joined the DAV College in Suva.

Suva had its own distractions, principally movies, and Reddy's errant ways persisted. It came as no surprise that Reddy failed his Senior Cambridge. He was not the only future lawyer to do so though: another was Narayan Singh Arjun. But this failure was an inconsequential setback. It had already been decided to send Reddy to New Zealand to do law. In April 1955, Jai Ram proceeded to Wellington and enrolled in the University Entrance class at the Wellington Technical College, which had been arranged for him by the family of Shaukat Ali Saheb. Hussein Saheb, Shaukat's younger brother, was a student there. Then things changed. Reddy did exceptionally well, and was the only 'non-accredited' student in the entire College to pass the University Entrance exam that year. The following year he enrolled at the Wellington Law faculty. Reddy had always wanted to be a lawyer, as 
many boys of his generation (and those following) did. Lawyers had status and connection in society; they were looked up to; and, more importantly, they could fight for the people, as others such as AD Patel were doing. Sesha Reddy encouraged his young nephew in this thought. As it happened, the Ba-Lautoka corridor before the 1960s was notorious for its many murders, so there was money to be made in law as well. Reddy graduated from the university a Barrister-at-Law in 1960 and returned to Fiji the same year.

The decision to send Jai Ram to New Zealand had not been made lightly. Going overseas was expensive, and his father Pethi Reddy (1910-1994) was not at all well off. ${ }^{19}$ In fact, in his early years, he had led an itinerant life, moving from place to place, from Nabila and Naviyago to Matawalu and Drasa and many other places besides making ends meet on meagre income earned through farming and dairy business. He was a resourceful man, however, and never gave up. Pethi's father, Byanna, returned to India in 1922, and his mother died when he was only ten. He was brought up in the family of the warmly remembered matriarch Parvatama, who had come to Fiji on the Elbe with her own three children. The early lessons taught by hardship were learnt well. In 1947, Pethi Reddy finally bought some freehold land at Teidamu, where the family eventually settled, gradually expanding the farm to eighty seven acres. The farm remains in the family. But the education of children weighed heavily on the minds of all Indo-Fijian parents who often went into debt to give them whatever education they could afford. Jai Ram's father was no exception.

Pethi Reddy (also known as Bada — older — Sesha) was a quiet, industrious man, a lifelong vegetarian, appropriately nicknamed 'Sadhu,' and close to the progressive views of the Arya Samaj. But Pethi's younger brother, Sesha Reddy, (Chota Sesha, younger) was a complete contrast to his elder brother. For his time, he was a highly educated man, having attended the Marist Brothers High School in Suva for three years. People say that Jai Ram has his uncle's fighting temperament. Sesha was involved in politics. He was an active member of the Maha Sangh, and his name appears in archival documents relating to that organization. He was active in the 1943 


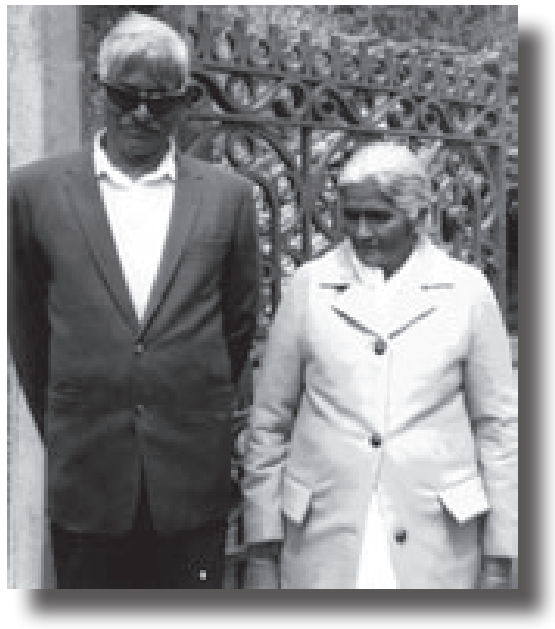

Jai Ram's parents, Pethi (Bada Sesha) and Yenkattama Reddy in New Zealand, ca. 1970s.

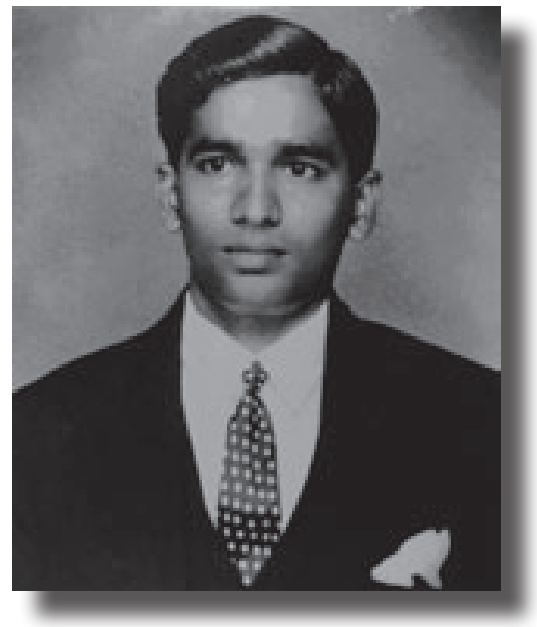

Jai Ram's paternal uncle, Sesha Reddy, ca. 1945. Both photos courtesy of Janardan Reddy.

strike, and was close to AD Patel. But Sesha died tragically young in 1945, while still in his late twenties, from a ruptured appendix, though some said his early death was a punishment from the gods for defiantly participating in a fire walking ceremony without prior preparation and in breach of the prescribed ritual protocol to prove that there was not much to walking on fire. He also broke the community's social rule by marrying a North Indian girl (as Jai Ram would do in his own time).

Sesha lives on though in stories that have been passed down in the family over the years. Jai Ram tells this story. Once on their farm at Bila, Drasa, an American soldier from a nearby military camp came to the Reddy household armed with a pistol and demanded alcohol. There was none in the house. Sesha was incensed at the soldier's rudeness and temerity. He seized the pistol, grappled the soldier to the ground, beat him senseless, dumped him into the back of a small dairy truck, drove straight to the Lautoka Police station, and threw out his body there, in full view of every- 
one! Family honour was nothing to trifle with. The poor American soldier did not know the Kamma code. All that Reddy remembers of that incident is blood all over the matted bamboo floor of the house.

On another occasion, a maternal uncle badly beat up a black American soldier, probably for similar indiscretion. When the soldier ran into a nearby cane farm to escape more beating, they torched it to prevent him from escaping. There is another story of violence that is vaguely recalled in the family, involving Jai Ram's maternal grandfather, Iyyappa. He was a proud and progressive man who for some reason had fallen on hard times, making a meagre living from bits and pieces of carpentry in the settlement, and hitting the bottle hard. One day, feeling estranged from his family, he shot his wife and then killed himself. Violence also ended the life of Jai Ram's maternal great-grandfather, Venkataswamy, who was shot by a CSR overseer (of the Drasa Sector) while he was on his way to attend a rally organized by Sadhu Vashist Muni, the charismatic and mystical Indian spiritual leader who was visiting Fiji in the early 1920s and subsequently deported by the government for 'interfering' in local affairs. ${ }^{20}$ The overseer was 'punished' by being transferred to Nausori. Jai Ram's paternal grandfather Byanna died in India in 1945. It is said that plans were in train for him to be brought back to Fiji (his passport had been arranged), but he was fleeced of his travel documents and money in Calcutta on his way back, and died there.

That world of Jai Ram's youth has now vanished beyond recall: the back-breaking work from dawn to dusk, the isolation, the struggle merely to survive, the encircling poverty, the practice of witchcraft and magic in the community, jadu tona. It is difficult to believe now, but there was a time when people ate the food they themselves grew, when there were no paved roads, no piped water, little contact with the outside world. Distinguished Australian anthropologist WEH Stanner wrote of the Indo-Fijian farming community in the 1940s this way: 'Thousands of families suffered under a crushing burden of private debt. Peasants and labourers lived frugally, worked long hours for extremely low wages or incomes, and saved with 
desperate application to keep alive, to repay loans and mortgages, to buy freehold land, to remit funds to India, to discharge customary social obligations requiring expensive outlays, and to acquire a competence for old age or return to India. ${ }^{21}$ American geographer JW Coulter captures well the rhythm of village life in the early 1940s; it is a world that would be familiar to Jai Ram:

The regular work of Indian farmers in Fiji is in contrast to the irregular easygoing life of the Fijians. The Oriental rises at halfpast five, harnesses his oxen, and plows from six to eight. He breakfasts at home or in the field on roti and milk and tea (roti is bread made from flour and fried in ghee). He resumes plowing until ten; at that time, his oxen are unhitched to lie in the shade during the heat of the day. Shortly after ten, he milks his cow, and from ten-thirty to twelve hoes, weeds or cuts fodder along the ditches or roadside. At noon he lunches on rice, dal or rice curry, and milk. In the early afternoon he hoes again, cuts more grass, or does odd jobs about the house. From three to five he plows. Supper at six consists of rice curry and chutney and milk. There is smoking and conversation by a kerosene lamp until bedtime at eight. In the evenings groups of Indians who have been working in the fields all day trudge home in the dusk, carrying lunch pails. ${ }^{22}$

The precise details would vary from place to place, but the overall portrait is authentic. This was the only world people knew, and loved. They depended upon each other for the completion of routine agricultural work and for their survival as a community because Indians had ceased to be of concern to the colonial officialdom after the abolition of indenture in 1920, except as subjects for rudimentary administration. It was in this self-contained, self-sustaining world that ordinary Indian people celebrated life and mourned its passing, adjudicated disputes and regulated social discourse, marked the passing of seasons and the advent of festivals: Diwali, Holi, Mohurram, Eid, Shiv Ratri, Ram Naumi, Mariamman puja, fire walking 
and many others specific to the various communities. That rural world in which Jai Ram grew up is now disappearing, as native land leases are not renewed, as the once vibrant sugar industry declines, and as uprooted people seek new opportunities in the haphazardly resettled communities on the fringes of urban areas.

For children growing up in Fiji in the 1940s and 1950s, India was, as it had to be, the principal cultural reference point, manifested most visibly in the ubiquitous, gaudy pictures of various gods and goddesses (and of Mahatma Gandhi and Jawaharlal Nehru as well) plastered on the bamboo walls of thatched houses. Contact with India was never quite broken as had happened in some other places, such as the Caribbean. Jai Ram's emotional world was formed by the romantic Hindi cinema, which began arriving in Fiji from the late 1930s: endless tales of unrequited love, unfulfilled desires, unbridgeable chasm between dreams and realities. ${ }^{23}$ Every boy aspired to be a Raj Kapoor or a Dev Anand or a Dilip Kumar, the trio who dominated the Hindi cinema in the 1950s and 1960s, and fell hopelessly in love with the latest heroine: Waheeda Rahman, Meena Kumari and, of course, the incomparable Nargis of Mehboob's Mother India fame, and Raj Kapoor's (not so) secret off-screen love. Dilip Kumar and Nargis were Jai Ram's favourites; they were everyone's favourites. The darkened cinema hall in the 1950s provided a relief and a rare escape from the mundane realities of life on the farm, with such memorable movies as Anarkali, Barsat, Aah, Awara, Andaz, Rattan, Anmol Ghadi, Babul, Dard, Mahal, Daag. Their music, by turns sentimental and haunting, touches the heart even today, at least of those of my post-war generation. By the 1960s, going to the movies was the major social event of the week in IndoFijian areas. Dressed in their finest clothes and jewellery, people went to the theatre to see, and to be seen.

It was from the Hindi movies that Jai Ram picked up music, like most romantically inclined boys of his generation (and mine too). He was particularly fond of the tragic love songs of Talat Mehmood, which he sang at weddings and other social occasions whenever the opportunity arose. 
His singing skills were honed during his student days in Wellington, as often happens. He does not sing now, at least not in public, or that I know of. He gave up public singing when he embarked on his political career. Singing and politics do not go well together, he says with a smile. But his private passion for music remains and is well known to his close friends, who are sometimes pressed to perform at suitably lubricated social gettogethers, with varying degrees of accomplishment, it has to be said, and often to much mirth and hilarity in the quintessential Indo-Fijian way. Jai Ram has particular fondness for ghazals, Urdu love and romantic songs, and film songs from his childhood. Aaj jaane ki zid na karo (Do not insist on leaving tonight), Ye zindagi usi ki hai, jo kisi ka ho gaya, pyar men hi kho gaya (The world belongs to those who embrace love), Dil jalta hai to jalne de (Let the burning heart be), Ham aaj kahin dil kho baithe (Today I lost my heart somewhere).

Movies and music might suggest a soft, perhaps even sentimental, side to Jai Ram Reddy. There is, and it is accessible to few beyond his immediate family. But there is a hard side to him as well. Many of his longstanding friends and colleagues have recalled to me one of his traits with some puzzlement: his habit of cutting people off completely, of having absolutely nothing whatsoever to do with them, if he feels they have somehow slighted him, or said or done something that offends his sense of honour and propriety. Then the curtain falls. In time he forgives, but he does not forget. Sometimes, long forgotten battles are recalled after a drink or two and the offender taken to task clinically and often to his great discomfort, but the anger subsides quickly after the point has been made. Normality then returns to the conversation. It is truly remarkable, in view of this, how those at the receiving end of Reddy's ire never hold grudges against him, how fiercely loyal they remain to him. Loyalty is a trait Reddy cherishes above all else. And he reciprocates it in ample measure too. It is a trait that soldiers value greatly on the battlefield. It is an integral part of the warrior ethos too. And Reddy has the warrior tradition in his cultural background. 
TOWARDS LAW

What brought Jai Ram Reddy to public notice first were his abilities as an advocate. Following his graduation, he began his career in 1960 as an associate in the law firm of AD Patel, who was then the country's most well known criminal lawyer. Reddy's skills at advocacy, fine-tuned under the tutelage of the great master, were observed early on. Magistrate Arthur Jeddere-Fisher, known for his 'sometimes subversive approach,' as his obituary puts it, offered Reddy a place on the bench as a magistrate. It was a flattering offer to a man still in his late twenties, but Reddy declined because he wanted to gain more experience as an advocate. Jeddere-Fisher then recommended him for the Crown Law Office to Attorney General Justin Lewis, QC, and Reddy accepted appointment as Crown Counsel. He rose quickly through the ranks to become the Principal Legal Officer, a singular achievement in late colonial Fiji, before returning to private practice in 1970 when he joined as partner the law firm of Stuart and Company, which he eventually took over. In 1972, the progressive, rapidly localizing Chief Justice, Sir John Nimmo, offered Reddy the post of Director of Public Prosecutions, a huge compliment to such a young lawyer, and Reddy was sorely tempted to accept; but he declined it to remain in private practice at Lautoka at the urging of his new law partner Ken Stuart who had taken over the western operations of the law firm of Munro Leys.

Over time, Reddy and his associates, notably the esteemed lawyer Bhupendra Patel, sometime legal advisor to the National Federation Party, built the firm into one the largest and most respected in Fiji. The firm was dissolved after the coups of 1987, a casualty of the violence and chaos that followed in their wake. The law office was the target of arson orchestrated by members of the ultra nationalist Taukei Movement. Reddy reminisces about his time at the Crown Law Office and his years at Stuart Reddy and Company with great fondness. Law was his passion, and what made all the difference was that he was accomplished at it, among the very best of his generation. And he recalls gratefully the help and professional encouragement and training he got from members of the Bar and the Bench during 
his salad days, from Bruce Palmer, his immediate superior at the Crown Law Office, and Judge Ronald Knox-Mawer, who was based at Lautoka, among others.

Qoroniasi Bale, the former (deposed) Attorney General of Fiji, regards Jai Ram Reddy as one of his two heroes, the other being the great jurist and Fiji High Court judge Ghananand Mishra, arguably one of the finest judicial minds ever to have occupied the local bench. Mishra, Bale says, had a fine analytical mind, calm decision making ability and the rare capacity 'to use the right words to express jurisprudential issues and realities of life.' Ratu Joni Madraiwiwi has called Mishra a 'legal titan,' and 'a fortress of rectitude and integrity that was never breached. ${ }^{24}$ Bale admires Reddy for his integrity, dignity, courtesy, eloquence, ability to think on his feet and a logical assembling of thought and its precise expression. These are his words, not mine. It was Bale who indirectly (through the Chief Justice) invited Reddy to join the judiciary as President of the Appeal Court.

Integrity is a word many lawyers use about Reddy. Imrana Jalal recalls a case involving domestic violence in which Reddy was the defense counsel. When Imrana convinced Reddy in a private conversation that the man he was defending was indeed guilty, Reddy picked up the phone straight away and told the man to settle forthwith. Once, Attorney General Justin Lewis asked Reddy to prosecute a case in Lautoka. Reddy visited the scene of the crime and made an assessment that convinced him that the man charged was innocent of the crime he was alleged to have committed. He told the Attorney General that, in all conscience, he could not lead the prosecution. Lewis accepted Reddy's decision, and handed the case to Ghana Mishra, then in the Crown Law Office, who successfully prosecuted the man. Chanan Singh recalls hiring Reddy to defend him in a murder trial for a fee of three thousand dollars. ${ }^{25}$ Reddy successfully defended Chanan, reducing the murder charge to manslaughter. But when Chanan could not pay the full amount at once, Reddy took half the fee and asked Chanan to forget about the rest. Chanan tailored him a suit in compensation instead. Stories such as this abound. Chen Bun Yung, Reddy's protégé and junior partner 
and former Fiji Law Society president, says that Reddy had no sense of what fees to charge. His business sense was apparently inversely proportionate to his legal talents!

Reddy describes in the essay at the end of this chapter what he considers to be the essential ingredients of good advocacy: industriousness, hard work, imagination, courtesy, mastery of the case, an intuitive understanding of human nature, and an ability to maintain an even temper. Reddy exhibited all these traits in ample measure. Certain traits of Reddy were emphasized and admired by those lawyers I spoke to during the research for this book. The first was his mastery of the art of cross-examination, of obtaining evidence favourable to your client, weakening the evidence that has been adduced against him, and, if possible, destroying the value of the evidence by calling into question the credibility of the witness. An essential prerequisite for successful cross-examination is an acute understanding of the human character. Another necessary trait is good oratorical skill and command of the language, the use of simple unadorned words, direct and persuasive. 'Presence' is another important attribute in a good advocate. Charisma might be another word for it, a special ability to influence and inspire. Police Prosecutor, Assistant Superintendent of Police Sur Sen, once told me that whenever Reddy appeared in court in his later years, court officers often showed him greater deference than they did to the judges and magistrates, such was his personal aura. Judge Erik Møse, former President of the International Criminal Tribunal for Rwanda, remarks on another Reddy trait that others have noted: his uncanny ability to get to the essence or the bottom line quicker than most. 'He immediately saw the core of the matter,' Møse says, 'irrespective of its complexity. When addressing intricate legal problems, he drew on his extensive judicial experience, profound insight and a human touch. He possessed the rare gift of being open-minded but yet principled, co-operative but firm. ${ }^{26}$ The qualities that Reddy exhibited in his professional life as a lawyer, of integrity, ability and understanding, he would display in his public life as well. But these were not immediately apparent or easily grasped by the public. An important 
reason for this was Jai Ram Reddy himself. He was never a self-advancer. He disliked talking about himself and his achievements. For instance, he had done a tremendous amount of legal work for the Sugar Master Award for a nominal fee, but he never claimed credit for it. He was, as Judge Møse says, an outstanding success as a judge Arusha but he rarely talks about it, and does so reluctantly when pressed. He cared little about his historical legacy, which is why his personal papers are so sparse. He was content simply to apply himself to the task at hand, to do his best, and let things be. This self-effacement is rare in public figures.

A law degree was not the only asset Reddy gained during his years in New Zealand. He also met his first wife, Anne, the daughter of the university's professor of geology. They got married in 1962. From that marriage came two children, Sanjay (who tragically died young a few years ago from a brain tumour) and Helen, before the couple separated in 1970. In 1972, Jai Ram Reddy married Chandra Wati Singh, an attractive Hansard reporter in the Legislative Council, as Mary Chapman, the former Secretary General of the Fiji parliament, has recalled, when Reddy was in the Crown Law Office. It is a pity that Chandra will not find more mention in a book devoted to her husband's political life and career. She is a woman of great strength of character, an astute observer of the political scene and a good judge of people. She remains Reddy's inner sanctum, his sanctuary from the ravages of public life, fiercely loyal and totally devoted; and like so many Indo-Fijian women of her time and cultural background, has put her husband's career ahead of her own. But her personal contributions are noteworthy in their own right Jai Ram's heightened sensitivity to gender issues comes from Chandra. The NFP's fielding strong, professional women candidates in winnable seats in the late 1990s was a milestone achievement. Reddy privately regretted that he could not do more because of the constraints and assumptions of the male-dominated culture of the Indo-Fijian community. Chandra was the first wife of an Indo-Fijian politician to take active part in the activities of a political party. For many years, she headed the Women's Wing of the National Federation Party and introduced such 


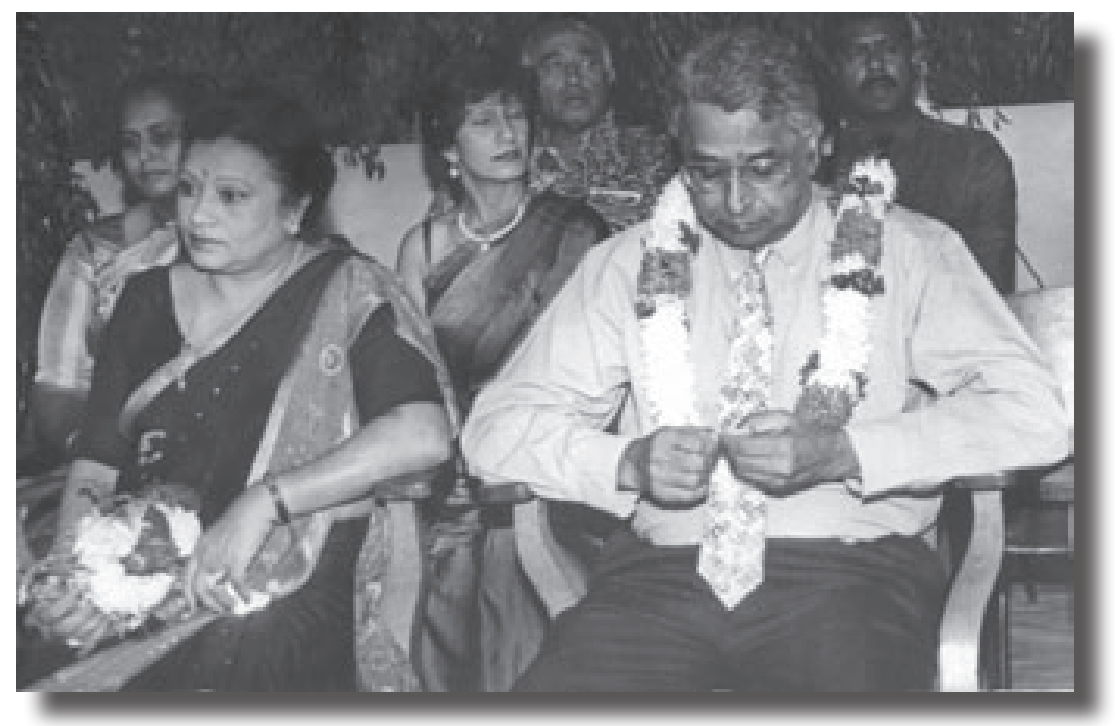

Chandra and Jai Ram Reddy at a civic function in $B a$, ca late 1990s. Photo courtesy of the Fiji Times.

progressive social thinkers and activists as Imrana Jalal and Shamima Ali to meetings of NFP women. She participated actively in national multiracial women's fora, with other women leaders such as Emelita Wilson, to advance the cause of women's political rights. Jai Ram and Chandra have a daughter, Sandhya, a lawyer, and a son, Prashant, both now living in New Zealand.

Jai Ram Reddy came of age in a world of great social change and transformation. He was born when the British Empire was at its peak and the power of the all mighty Colonial Sugar Refining Company unchallenged. They would both disappear from Fiji in the next thirty years. He grew up in a closely compartmentalized world characterized by petty racial discrimination and by the humiliation and exclusion of non-Europeans from the public domain. He witnessed from close quarters the entrenchment of a political arrangement by the colonial government, albeit with the concurrence of some of Fiji's own political leaders, which had the effect of 
marginalizing his people from their just share of power. With the imminent departure of the colonial rulers arose the difficult scenario of Indo-Fijian leaders having to deal with their Fijian counterparts on their own, without an external intermediary, on such sensitive issues as land and the constitution. His own people had emerged from the shadows of indenture to enjoy a modest degree of prosperity, but deep cultural and social divisions remained which would continue to divide the community and hobble its prospects in the future, a future in which Jai Ram Reddy would play a pivotal role. But it is time now to return to the beginning, to the origins of colonial Fiji and the legacy it bequeathed to subsequent generation of Fiji leaders. This rather lengthy detour is necessary to provide background and context to the legacy that Jai Ram Reddy inherited and with which he grappled all his political life.

\section{COLONIAL FOUNDATIONS, INDIRECT RULE}

Fiji became a British Crown Colony on 10 October 1874 when growing European pressure on Fijian land and labour and their entanglement in internal Fijian rivalry for power and political ascendancy forced the self-styled Tui Viti, Ratu Seru Cakobau, to cede the islands to the United Kingdom. The unconditional transfer was solemnized in the 'Deed of Cession' whose contested interpretation about what the Fijian chiefs had ceded, or did not cede, to the Crown, about how and in what ways Fijian interests would remain 'paramount' in Fiji, would embroil Indo-Fijian political leaders in continuing controversy for decades. The Deed opened a parenthesis in Fijian history which the Independence Order of 1970 formally closed nearly a hundred years later. Britain accepted Fiji's cession reluctantly, after turning down earlier offers, because the archipelago was remote from the centres of commerce and trade, and showed little immediate economic potential. Sir Arthur Gordon, the first substantive governor — the instruments of Cession were accepted by Sir Hercules Robinson, the Lieutenant Governor of New South Wales — was instructed by the Secretary of State for the Colonies, Lord Carnarvon, to make the new colony economically self- 
sustaining in the quickest possible time, with reduced fiscal largesse from London. ${ }^{27}$ Gordon was a governor with a refreshingly unorthodox turn of mind, well connected to the Colonial Office bureaucracy (being the son of Scottish aristocracy) and imbued with a large sense of self-confidence and destiny. They all placed him in good stead. The decisions Gordon made during his time in the colony — he left for New Zealand in 1880 — were to lay the foundations of modern Fiji, with what consequences we all know only too well.

Every political leader in Fiji, Jai Ram Reddy included, has had to grapple with what some have called the 'Fijian problem.' That is, the absence of the Fijian people from the mainstream commercial sector of Fiji, and in education and the professions. The colonial government and a succession of postcolonial Fijian governments adopted a variety of racially-based affirmative action policies over time to redress the balance. But, though well-intentioned, they caused great controversy and derailed many a sensible discussion on the subject. This is not surprising given the prominence of the 'ethnic' factor in national politics where most issues of public policy were viewed through the omnipresent lens of race. The issue continues to haunt political discourse in Fiji, though perhaps less forcefully now that the demographic balance has shifted decisively in favour of the indigenous Fijians, and when it is readily acknowledged, because supported by verifiable facts, that poverty and disadvantage stalk every community in roughly equal measure, and now is no longer confined to one segment of the population.

The 'Fijian problem' has its direct roots in Gordon's 'native policy.' This policy, adopted at the time of Cession, attempted to shield the indigenous population from the pressures and demands from the outside world. Fijian society in the late 19th century was in an acute state of distress. Nearly a quarter of the population had perished from an epidemic of measles accidentally introduced by a man-of-war from Australia, and Social Darwinist assumptions about the survival of the fittest predicted the extinction of the Fijian race in the not-too-distant future. Increasing 
pressure from local planters on Fijian land and labour contributed its own share of anxiety to the native population. Aware of the plight of dispossessed and marginalized indigenous communities in other colonies of European settlement - Maori in New Zealand, for example — and convinced that the Fijian people would share a similar fate of dispossession and destruction if not protected by explicit government policy, Gordon prohibited the commercial employment of Fijian labour on European plantations. He also decreed legislation which required the indigenous population to remain in their villages, close to their subsistence roots, following the time-honoured guidance of their traditional leaders. Fijians would pay tax in kind, not in cash, like everyone else, so that they could meet their obligations to the state while maintaining their subsistence lifestyle. 'Native Regulations' determined the rhythm of village life, along with a pre-determined Program of Work for the people. A separate Fijian court system adjudicated disputes internal to the community. A Great Council of Chiefs was formalized soon after Cession to advise the Governor on matters close to the heart of the Fijian people. And so things remained throughout the 20th century. Gordon's Fijian policy had the effect of creating a 'state within a state,' effectively closing the doors of the indigenous community to the outside world and to external forces of change, however desirable or progressive these might be.

The policy was enlightened, even if it was at the same time in the enlightened self-interest of the colonial administration. An undisturbed populace, untouched by unsettling modern forces, would naturally be more amenable to administrative management and control than one without firm moorings. But in time, a well-intentioned, protective policy became encrusted by debilitating orthodoxy. ${ }^{28}$ As time moved on, the social and economic landscape of Fiji changed dramatically. While the rest of the population got enmeshed in the growing cash economy and, from around the middle of the 20th century, entered the medical, legal and teaching professions in ever-growing numbers, Fijians continued to live in the traditional subsistence sector, watching resentfully from the sidelines the 
progress of the other communities and holding them accountable for their own difficulties. The colonial state may have initiated the policy of subsistence isolation for the Fijians, but Fijian chiefs entrenched it. Ratu Sir Lala Sukuna, the most influential of them all and the colonial government's chief advisor on Fijian affairs, preferred that his people live in their villages in the age-old fashion even when the times and needs had changed dramatically. ${ }^{29}$ The controlling institutions and mechanisms of the Fijian Administration were reinforced, not relaxed, after the Second World War, and traditional chiefly power firmly entrenched in leadership.

Compounding the problem of economic disparity between Fijians and Indo-Fijians was the fraught demographic situation, as already mentioned before. After World War II, the Indo-Fijians exceeded the indigenous population for the first time and eventually became the outright majority, spawning real and imagined Fijian and European fears of 'Indian domination.' As a result, race, to the exclusion of virtually everything else, became the principal delineator of political discourse in the colony. 'Race is a fact of life in Fiji,' Ratu Sir Kamisese Mara said repeatedly throughout his career, so much so that it almost became a 'way of life for Fiji' when the edifice of racial compartmentalization was being seriously threatened by forces of social and economic change buffeting the nation. Fears of ethnic domination and subjugation lay just below the surface of public consciousness. And the language of violence and retribution was freely used to silence those who questioned the fabric of the established political order. Dealing with the question of race, negotiating its treacherous bends and boundaries was one of the most intractable problems Jai Ram Reddy faced in his political career. By the time he attempted finally to come to terms with the issue, he was gone. Since the coups of 1987, Indo-Fijians began to migrate in large numbers with the result that by the turn of the $21^{\text {st }}$ century, Fijians had again become the dominant community in Fiji. In a decade or two, they will become almost two thirds of the population, finally putting to rest a ghost that had haunted Fiji's political landscape for several generations. 
Another of Gordon's Fijian policies would bedevil Fijian politics for generations and one which would become a deeply divisive issue, with significant consequences for Reddy's political fortune in the Indo-Fijian community. That was the question of land. Without land, Gordon surmised accurately enough, Fijian society would wither on the vine and die, as many indigenous communities around the world had done in the age of European expansion and colonization. Land was more than an economic commodity for the indigenous community, he understood; it was its very heart and soul. From the very beginning, then, Gordon wanted to preserve as much land in Fijian hands as possible. First, he decided to standardize and codify Fiji's widely divergent land tenure system. After hurried consultation, as Peter France has so ably pointed out, he decreed the mataqali to be the chief landowning unit, not the itokatoka or the yavusa. ${ }^{30}$ This standardization disadvantaged those areas of Fiji where the social structures were smaller and more decentralized; there were protests, but what was decreed into law remained law, and so it does still today. Further, not only was land to be held communally, it was to become inalienable as well, even among Fijians, thus limiting their independence over the property they owned. This has remained an issue of contention among Fijian landowners ever since.

Gordon established a Land Claims Commission and directed it to determine the amount of land which had been legitimately alienated by European settlers before Cession, and the amount which remained in Fijian hands, hoping that large amounts would be found to be un-alienated. The land enquiries concluded that 83 per cent of all land in Fiji, or 3,714,990 acres, was 'native land.'31 About 8.15 percent (368,390 acres) was declared to be legitimate freehold land, and like freehold property elsewhere, a disposable commodity on the open market. Much of the freehold land was owned by large European planters (the Bull brothers in Dreketi, for example, the Tartes in Taveuni, and JP Bailey in parts of Viti Levu), the Colonial Sugar Refining Company and large trading firms such as Morris Hedstroms, Burns Philp, and Carpenters, among others. About four percent was declared Schedule A and B lands. These were 
lands which were pronounced vacant at the time of Cession or whose mataqali had become extinct. The Crown was declared its custodian to use it in the interests of the colony as a whole. But now they have been returned to the native owners. As a result, today over 90 percent of all land in Fiji is in inalienable Fijian ownership. Issues surrounding the transfer of Crown land came to the fore in the late 1970s and early 1980s, when the Alliance government attempted to convert it to native land, driving a wedge between Ratu Sir Kamisese Mara and Jai Ram Reddy, and derailing embryonic talks about a government of national unity.

The ownership of native land is enshrined in law, and has never been questioned by any Indo-Fijian leader, including Jai Ram Reddy. But the terms and conditions on which the land was leased to mostly Indo-Fijian tenants did become an issue. In the early part of the 20th century, the CSR secured leases for its tenants by leasing land directly from the Fijian landowners themselves to maintain stability in the production of sugar cane. In some areas, Indo-Fijians made their own private arrangements with the landowners, to no one's general satisfaction, since bribery and corruption frequently crept into the dealings as prospective tenants tended to 'pick the eyes of the land,' leaving large tracts idle and unused. As cane production expanded and as pressure mounted for more land in the 1930s, the Government of India pressured the colonial government of Fiji to intervene to assist the vulnerable Indian tenant community. A more regularized system of leasing would have to be put in place to encourage good husbandry. The result, with the active encouragement of Governor Sir Arthur Richards and with the support of Ratu Sir Lala Sukuna, was the creation of the Native Land Trust Board in 1940. Entrusting the management of native land to a statutory body, even one chaired by the Governor himself, was unparalleled in the British Empire, underlining the deep, unquestioning trust Fijian chiefs had in imperial authority. It also made perfect sense at the same time, removing the potential for conflict between tenants and landlords who belonged to different ethnic groups and had different aspirations and needs and paving the way for more considered and planned use of the land. 
The Board assumed the responsibility for leasing and managing lands on behalf of the landowners. Large areas of native land were 'reserved' for future Fijian use, and land not deemed to be needed for that purpose was released to Indo-Fijian tenants. But haphazard practices of leases had not ceased entirely, and the need arose for some legislative framework to provide stability. This had been one of the recommendations of the Burns Commission which reported on population trends and the pressure on natural resources in Fiji in 1960. ${ }^{32}$ The result, after years of intermittent discussion, was the introduction of the Agricultural Landlord and Tenant Ordinance (ALTO) in 1966. Under the Ordinance, leases were to be given out for an initial period of ten years with the provision for extension for two further ten-year terms if the land had been cultivated in a manner consistent with the practice of good husbandry. ${ }^{33}$ The grounds for the termination were carefully prescribed. Rent was to be assessed by a Lands Tribunal at fair market value. Landlords could not demand any payment in excess of the specified amount. The tenant would not pay any premium upon the extension of the tenancy for any improvement he had made. And he would be entitled to compensation for improvements he had made if the lease was not renewed. A most important inclusion in the Ordinance was the so-called 'relative hardship clause' according to which the landlord could only refuse to re-lease his land if he could plead greater hardship than the tenant, which he could do with the greatest of difficulties. As this tended to favour the tenants, the new provision came to be resented by many Fijians.

It was an unsatisfactory solution, everyone agreed, and AD Patel, then the leader of the Indian community in the Legislative Council, supported the Bill with what he called a feeling of 'great ambivalence.' It was not a perfect piece of legislation, and provided no long term solution; but it did buy valuable time. 'We are by this Bill providing an immediate relief and remedy,' Patel said, 'which may last for twenty years and within those twenty years this country, I hope, will make great advances in economic development which will result in relieving the existing pressure on the land and increasing the prosperity in the country which will result in increasing the number 
of tenants of all races. ${ }^{34}$ Patel's latter day critics, who thought he, being a large freehold landowner himself, was behind the ten year provision, did not appreciate the constraints of the times, the tenacity of the Fijian opposition or the subtlety of legislation that actually secured for tenants rights and privileges that no earlier legislation had done. And since the new legislation banned sharecropping, Patel stood to lose much financially. ALTO, as Trafford Smith of the Colonial Office pointed out to Governor Jakeway, was an improvement on the English practice itself. ${ }^{35}$ The tenancy would be heritable and Trafford Smith noted, 'The guarantee of security of tenure rests not so much in the actual length of the lease as in the stipulation that the tenant may only be evicted on limited and justifiable ground.' In fact, a longer lease could potentially militate against the tenant's interests because the landowner could then more justifiably plead greater hardship and so repossess his land. Everyone hoped that within a generation, attitudes might change and a more amicable solution found. When the issue came up again in the mid-1970s as the ten-year leases under ALTO began to expire, the National Federation Party was bitterly divided in its response. As we shall see, one faction improbably wanted a permanent resolution of the problem, against the ever determined opposition of the Fijian side, while the other, more pragmatically conscious of Fijian sentiments, settled for longer, more secure leases. This would be one issue which would preoccupy Reddy for all his political life. The land problem remains unresolved.

\section{CSR AND SUGAR}

Securing the protection of the indigenous Fijian society was one vital component of Gordon's policy for Fiji. Another was promoting the rapid economic development of the nascent colony. But the immediate prospects looked bleak. The local European planters were in straitened circumstances themselves, many facing ruin, following the collapse of the cotton boom of the 1860s with the end of the American Civil War. In any case, the local planters did not have the resources for the kind of large scale economic development Gordon had in mind. Before coming to Fiji, Gordon had been 
the Governor of Trinidad and Mauritius. There he had seen at first hand the successful operation of the plantation system of agriculture. That mode, he decided, would be the most appropriate for Fiji. And he settled on sugar cane as the preferred crop for the new colony.

Sugar cane was being grown on a small scale by individual planters, and the crop had shown promise. To grow it on a scale that could drive the economic engine of the colony, Gordon invited the Australian Colonial Sugar Refining Company (CSR). ${ }^{36}$ The CSR, established in 1854, was Australia's largest grower and miller of sugar cane. The Company arrived in Fiji in 1882 and remained there until 1973, three years after Fiji became independent. The CSR's story in Fiji is central to our narrative in several vital respects. By 1900, CSR had become the largest miller of sugar cane in Fiji, producing around three quarters of the total output. Soon it would become a monopoly. Because of its size and preponderant contribution to the colonial economy, the Company exercised disproportionate influence in Fiji's economic and especially political affairs. For many years, one of its officials sat in the colonial legislature representing the interests of the Company. For many Indians in the sugar belt, the Company was the government, sarkar. Its word was law.

Until the early 20th century, the CSR grew all its cane on its own estates by employing Indian indentured labour. A decade later, it began to sell off its plantations to individual European planters, many of whom were its former employees and plantation managers. These plantations too were worked by indentured labourers. But as the shortage of labour loomed, following the impending end of indentured emigration in 1916, the planters sold their estates to Indians (those who could afford to buy them). In the 1920s, the CSR began to split up its plantations into ten acre plots and leased them out to former indentured labourers. The ten acre farm system remained the pattern for Fiji throughout. The ten acre plot was big enough, with good husbandry, to be economically viable, but not too big for the growers to become independent, or independent-minded. One important consequence of the ten acre farm was that farming families realized early 
that there was no future on the farm for all the children; and Indian families in the early days were large. Most families decided to invest in the education of their children, especially boys, in the hope that they would have a career outside agriculture, albeit in colonial times only a lowly career in the civil service. Those who could afford it sent their children for higher education overseas, preferably to become lawyers and doctors. Jai Ram's father was among them. For many years, the cadre of Indo-Fijian professional class such as doctors, lawyers, accountants and teachers, came from this humble background. Now, many of them have left for overseas.

The CSR ruled the sugar industry with an iron hand, dictating the varieties of cane the growers could plant and insisting on a certain prescribed minimum standard of farm husbandry. It conducted its financial business in absolute secrecy, refusing to open its book to scrutiny, even to the government. Growers were left in the dark about how the proceeds of the sugar industry were determined, how the cake was divided. They often complained, frequently to no avail, that they were cheated of their just share of revenues. Indenture may have ended, but the Company's attitude to the growers had not changed much. The Company knew best: it was the Ma-Baap of the industry, the parent. As parent, the Company did not hesitate to crack the whip (chabuk) when it felt necessary or simply to assert its authority. It got its way during indenture when protests were muted and strikes few. ${ }^{37}$ But when indenture ended and people had tasted a modicum of freedom and independence, they refused to buckle under. The first of the strikes rocked the industry in $1921 .{ }^{38}$ But more serious strikes took place in 1943 and in 1960. ${ }^{39}$ These had important implications for political developments in Fiji in the 1960s as the colony lurched towards independence, poisoning race relations and frustrating political dialogue among the principal leaders. They would cast a long shadow well into the 1970s when Reddy was at the helm of Indo-Fijian leadership.

By the late 1930s, in response to the changing circumstances and growing numbers, the growers began to canvass plans for a sugarcane growers union. The result was the 1937 formation of the Kisan Sangh whose prin- 
cipal players included Ajodhya Prasad, MT Khan, Dildar Shah and a few others. It was a signal achievement in the face of intense opposition from the CSR, which did everything in its power to disable the new organization, seeing it as a clear threat to its hitherto unchallenged hold over the growers. By 1941, about 75 per cent of the growers, nearly three thousand, were members of the Kisan Sangh, which by 1943 had a limited capital of ten thousand pounds sterling. The government advised the CSR to recognize the union, which it did reluctantly. Initially, there was unity among the farmers, and the Kisan Sangh was able to negotiate a ten year contract with the CSR as well as extract concessions from it, including providing written receipts for cane proceeds and allowing growers' representatives to be present at weighbridges to check the weight of cane. For its part, the CSR gave the Sangh the responsibility of appointing sirdars, gang leaders. These leaders wielded enormous power in the cane farming community.

But then things began to go wrong. Since this is still a matter of huge controversy in the Indo-Fijian community and because it affected its inner political configuration for decades, it is important to cover this ground in some detail. ${ }^{40}$ Concerned about the hidden agendas and sometimes irregular activities of the Kisan Sangh leaders, the most prominent members of the Indian community at the time stayed away from the organization. These included AD Patel, Vishnu Deo, Said Hasan, SB Patel, among others. Chattur Singh, outwardly a Sangh supporter who had narrowly defeated AD Patel in the 1937 election for the Legislative Council, wrote to the Governor on 16 July 1940 about Sangh's 'harmful' activities in the Indo-Fijian community, and sought to have the Kisan Sangh declared an 'unlawful association for the duration of the war.' Kisan Sangh members, he said, were similar to 'fifth columnists,' that is, 'members of a clandestine subversive organization within a country to further an invading army's military and political aims.' They assaulted those who refused to join their organization or do the bidding of its leaders, forced people to sign papers in the middle of the night, and burned their opponents' cane. Swami Rudrananda, who would remain a lifelong friend of the cane growers, told Dr VWT McGusty, the Secretary 
of Indian Affairs, on 10 July 1941 of the Sangh's tactics of 'gangsterism' and of not disclosing its financial records to its members who had paid their subscription. And Rudrananda was not the only one to so characterize the affairs of the association. Swami Avinasananda had advised the South Indians to tend to their social and cultural life and not to get embroiled in the affairs of the Kisan Sangh.

Many of the Sangh's early members were North Indian independent contractors who grew their cane on native leases or on freehold land, not as tenants of the CSR. The South Indians, late comers to Fiji, worked either as employees of the CSR or as its more vulnerable tenants. They complained bitterly that the CSR evicted its tenants at will if it disapproved of them, paying minimal compensation for their assets, charged land rent greatly in excess of that which it paid to the Fijians, prohibited the planting of food crops on its land, asked tenants to work in the mills or on the tramline free of charge, and insisted that they buy manure and fertilizer necessary for cultivation at a price dictated by the Company. The Sangh's reluctance to intercede with the Company on their behalf, not surprising given its developing close relationship, dismayed many South Indian tenants. So it came as no surprise when in June 1941, a new farmers' association was launched, the Akhil Fiji Krishak Maha Sangh, or Maha Sangh for short. Its leaders were AD Patel, Sadhu Kuppuswamy, MN Naidu, Swami Rudrananda, Krishna Reddy, Moidin Koya, Lakhpat Maharaj, Bechu Prasad, Madhavan Nair, Tulsi Ram Sharma and others. People have often and predictably accused AD Patel of fomenting dissent in the farming community for his own political purposes, but they fail to recognize the actual reasons why division occurred in the first place, nor how widespread the dissatisfaction with the organization then actually was. The political ramifications of the division in the Indo-Fijian farming community were significant and enduring. In the late 1950s, in preparation for the re-negotiation of a new contract with the CSR, the Maha Sangh leaders joined other growers associations to form a Federation of Cane Growers to provide a joint, united front to the Company. ${ }^{41}$ Among those who left the Kisan Sangh around this time 
to join its rival was Siddiq Koya. But the unity was short-lived. During the 1960 strike, factions of the Kisan Sangh, led by Vijay R Singh, broke away from the Federation and advised their followers to start harvesting, effectively crippling the strike.

Throughout the 1960s and beyond, the strike was a cause of great controversy in the Indo-Fijian community. When Lord Denning was invited in 1969 to conduct arbitration into the sugar industry and adjudicate the terms of a new contract between the growers and the millers, the Kisan Sangh approached AD Patel to form a united front. Patel refused flatly: he could not cooperate with people who had stabbed the growers in the back at a time of their greatest need and then accused him of exploiting farmers to advance his own political career. The Federation of Cane Growers made their own submission to the arbitration proceedings which, Denning later said, influenced the content of his recommendations. With the Denning Award, which was in favour of the growers, the affairs of the sugar industry were settled for a decade or more, but the simmering tensions between the rival cane growers unions would continue to smoulder for the next few decades.

One important consequence of the 1960 strike was the consolidation of the Federation of Cane Growers. Initially concerned with matters in the sugar industry, it haphazardly morphed into a quasi-political organization called the Citizens Federation which contested and won the three Indian communal seats in the 1963 elections. On 21 June 1964, the constitution of the Federation Party was formally adopted. The party committed itself to 'create, promote, foster and preserve the national consciousness among the citizens of Fiji irrespective of any distinction of community, religion, race or sex,' to encourage 'political, economic, social and cultural integration, contact and understanding by pursuing the ideal of seeking 'Unity in Diversity,' and to 'obtain self-government for Fiji by all legitimate and peaceful means.' Talking of 'advancement of the citizens of Fiji', of integration and selfgovernment at a time of water-tight communal compartmentalization, must have sounded radical and threatening to those in authority. ${ }^{42}$ 
Initially, the Kisan Sangh members supported the Alliance Party (more below) and when it collapsed in 1987, threw their weight behind Labour. Maha Sangh members formed the bedrock of the National Federation Party. In the 1990s, the Fiji Labour Party leaders captured the National Farmers Union, which attracted members of the by now moribund Kisan Sangh. Soon, the NFU became a rival for the Maha Sanghbased Federation-leaning Fiji Cane Growers Association. While the FGA won significant victories in cane growers' elections for the Sugar Cane Growers Council, at the national level, the NFU delivered the sugar belt vote to Labour. Mahendra Chaudhry was its founding General Secretary, a post he held unchallenged for nearly all the time, even when he was an interim minister in the post-2006 military administration: as Minister of Sugar no less. Chaudhry gradually converted the sugar cane belt into his own constituency, and worked assiduously to nurture and redress its grievances. What was once a solid Federation territory had become over time the solid support base for its bitter rival and eventual annihilator.

\section{CONSTITUTIONAL CHANGE}

By the mid-1950s, Fiji had undergone a dramatic change since its pre-war years. In 1956, the total population of the colony was 345,164 of which IndoFijians accounted for 48 per cent, indigenous Fijians 43 per cent and Europeans 3 per cent. The increase in the Indo-Fijian population was the result of four factors: a higher fertility rate, a lower infant mortality rate compared with the Fijians, the early marriage of Indo-Fijian women, and a higher proportion of female children. ${ }^{43}$ These figures, and the population projections they forecasted, rang loud alarm bells. By 1967, it was predicted, the Indo-Fijian population would increase to one-quarter of a million while the Fijians would not reach that number until 1980. The disparity both in the actual size and in the projection between Fijian and Indo-Fijian populations not only caused official concern, it poisoned race relations in the colony, leading to improbable calls in the 1950s for the steady deportation of Indo-Fijians to the remoter parts of the Empire such as the New Guinea Highlands and, 
even more unrealistically, to the Marquesas, which was a French territory. ${ }^{44}$ The debate would continue to linger well into the 1960s as talks got under way for independence. Family planning was introduced, following the recommendations of the Burns Commission in 1960, but Fijians were quietly told to ignore it; for them, increasing, not decreasing, the indigenous population was the imperative of the day, their sacred duty to their 'race.'

There were other developments which were gradually changing the face of Fiji. The old barriers of isolation were breaking down as a result of improved local and international transport and communication. There was a rapid increase in primary and secondary education. In 1946, there were 438 schools with 36,000 pupils. ${ }^{45}$ Ten years later, there were 479 schools with 60,000 pupils. The number of Fijian schools — that is, schools which admitted only Fijian students - increased by only a negligible amount from 306 in 1946 to 310 in 1955, while the number of Indo-Fijian schools in the same period increased more significantly from 106 to 149 . Numbers by themselves do not reveal the full story, however, even though Fijian schools outnumbered the Indo-Fijian schools by almost two-to-one. Around ninety percent of the Fijian schools did not go beyond grade five (only 32 of the 300 schools did), while amongst the Indo-Fijians, 84 of the 141 primary schools, or sixty per cent took their students up to the final year, grade eight. This disparity was evident in other fields as well. In 1958, for instance, there were no professionally qualified Fijian lawyers and only one dentist and one medical doctor. In contrast, there were 38 Indo-Fijian lawyers, 12 medical doctors and eight dentists practicing in Fiji. The gap in the educational and professional achievements of the two communities - a result of cultural, historical and economic circumstances - would arouse great debate in Fiji and would be a principal concern of its leaders from the 1960s onwards.

Throughout his political life, Jai Ram Reddy would be involved with Fiji's constitutional politics, as we shall see, especially after the 1987 coup. In the 1990s, he was deeply preoccupied, firstly with the review of the racially imbalanced and discriminatory 1990 Constitution which had been decreed into existence by the President to entrench Fijian control of Fiji's political 
process, and secondly with the formulation of a new, fairer constitution in the late 1990s. In the 1970s, he was critical of the 1970 Independence Constitution for the manner in which it had subtly locked the Indo-Fijian community into a position of political inferiority by giving the Fijian representatives in the Senate the power effectively to block all legislation proposed by the democratically elected government of the day. His criticism may have been valid, but Reddy did not know of the compromising role his own leaders had played in the independence negotiations, nor of the pressure from London to devise a political arrangement at independence which had all the paraphernalia of genuine parliamentary democracy, but which left Fijians firmly in control.

In 1977, Reddy finally came face to face with the contradictory, if not actually irreconcilable, assumptions and understandings which had underpinned that fraught document. He was determined to have a constitution in place that was transparent in its logic and direction and would give his people their just and fair share of power. It is necessary now to take a fairly long detour of the pre-independence constitutional debates which Reddy watched from the cockpit of Indo-Fijian politics, in the law office of AD Patel, where he was a staff solicitor, and whose legacy he would inherit when the time came for him to assume the leadership of the Indo-Fijian community in the 1970s. The 1960s was a time of great passion and excitement in Fiji, and for the Federation Party as well, as the country joined in the great debates about the kind of political culture a multiracial society like Fiji should have, about the relative merits and demerits of common roll and communal roll, about the form of political independence appropriate for the country. Fiji would not have such a lively and productive conversation again until the 1990s.

One feature of Fiji's political evolution which haunts Fiji to this day is its racial character. ${ }^{46}$ From the very beginning, the colonial government decided that political representation in the Legislative Council, the legislation-forming branch of government, would be racially compartmentalized. A completely racial system of voting lasted from 
1904 to 1966 when a limited cross-voting system was introduced. The second feature of Fiji's electoral system was the principle of balance between the three ethnic communities. This in practice meant a gross over-representation of the Europeans who were always a tiny minority in the population, but the government justified their disproportionate presence on the grounds of their preponderant contribution to the colony's economy. And Fijians opportunistically supported the idea to keep at bay the threat of Indian domination. The 1937 Letters Patent defined the composition of the Legislative Council as follows: 15 Unofficial Members comprising five each of Fijians, Indo-Fijians and Europeans and 18 Official Members. The latter were normally heads of government departments. Three additional Members ensured that government motion would always succeed. Three each of the Indo-Fijians and Europeans were to be elected from communal rolls and two nominated by the Governor. All the five Fijian members were to be nominated by the Governor from a list supplied by the Council of Chiefs. This structure lasted from 1937 to 1963 when new Letters Patent came into effect. By then, the world had changed and Fiji had moved on.

Indo-Fijians got the franchise in 1929. Before 1916, when Indian indentured emigration ended, the interests and concerns of the Indian indentured labourers were represented in the Legislative Council by the Agent General of Immigration. From 1916 onwards, they were represented by a single nominated member, the first of whom was the wealthy and wellconnected Rakiraki farmer Badri Maharaj, selected controversially over Manilal Maganlal Doctor, the overwhelmingly preferred candidate of the Indo-Fijian community. Manilal, a lawyer, had arrived in Fiji in 1912, sent there by Mahatma Gandhi himself in response to representations from the local Indian community for a lawyer to assist them in their dealings with the colonial officialdom. An uncompromising defender of the rights of the Indian community in Fiji and a brilliant debater, Manilal quickly became the target of the colonial government which deported him in 1920, ostensibly for his leadership role in the strike of that year, but technically because 
he was not a British subject but a member of a principality in Mysore which was not under direct control of the British. He was thus an 'alien' who could be punished for 'meddling' in the colony's affairs.

The Indo-Fijian leaders welcomed the franchise, but not its communal character. They demanded an immediate introduction of a common, non-racial, roll where every voter's vote had equal value. They moved a motion to this effect in the very first sitting of the Legislative Council in 1929. A vigorous debate followed. Fijians would have nothing to do with the idea, while Europeans opposed it on the grounds that as representatives of the 'British race,' it was their duty to safeguard the interests of the Fijian community which the introduction of common roll would somehow threaten. When the motion was defeated, the three recently elected Indian members, including Vishnu Deo, walked out and boycotted the Council's proceedings. They returned to the Legislative Council later, maintaining a rhetorical, ideological commitment to the idea but accepting the reality that the introduction of common roll anytime soon was practically impossible. For all practical purposes, the idea lay dormant for nearly thirty years when it was resurrected by its most relentless advocate, AD Patel, as Fiji embarked on the path of independence.

Most major Indo-Fijian leaders supported the common roll but there were sections of the community which were opposed and were often actively hostile to it. Principal among them were the leaders of the Fiji Muslim League, the umbrella organization of the dominant Sunni sect of Islam. From the very beginning, and especially from the 1920s onwards, influenced by communal political trends on the Indian subcontinent, they rejected the idea on the grounds that common roll would lead to the Hindu dominance of Indo-Fijian politics. No Muslim could ever expect to be elected on Hindu votes, they argued, a notion which was disproved when Siddiq Koya won from a predominantly Hindu electorate in Western Viti Levu in 1963. Not only did the leaders of the Muslim League not want common roll, they also wanted separate representation in the Legislative Council as well. ${ }^{47}$ This they demanded on the grounds that Muslims were 
not 'Indians,' but by virtue of their distinctive religious and cultural practices, a separate community altogether. This was a false notion because during indenture, the boundaries of culture and religion were freely transgressed, leading to many mixed religious marriages, thus undermining the claim of cultural purity. Some Europeans opportunistically supported the idea to fragment the Indo-Fijian community but retracted their support when confronted with the tricky proposal by AD Patel that since the Muslims, if they were to be treated as a separate ethnic group, were bigger in number than the Europeans, they should have the same number of seats as them too! But the demand persisted well into the 1990s. The colonial government tacitly acknowledged the Muslim view and ensured that one of its Indian nominated members was always a Muslim. After independence, the Alliance Party under Ratu Mara courted the leadership of the Muslim League which quietly supported the party. But many Muslims did not, and remained with the National Federation Party.

\section{TOWARDS SELF GOVERNMENT}

By the late 1950s, the end of the British Empire was in sight. ${ }^{48}$ In 1959, a new governor, Sir Kenneth Maddocks, arrived from East Africa with the mandate to gradually introduce constitutional change towards greater internal self-government. A White Paper introduced in 1961 outlined its broad direction: The number of Unofficial Members, that is, elected and nominated representatives of the people, would be increased from fifteen to eighteen, six for each of the three communities. And universal franchise would be introduced, giving the Fijian people the vote for the first time. The proposal was debated in the Legislative Council, with Fijian members rejecting outright any suggestion of even limited moves towards greater internal governance. If Fiji were to become independent, Ratu Penaia Ganilau and Ratu George Cakobau told their fellow Legislative Council members, then it should be returned to the indigenous Fijians, who had ceded the islands to the British Crown in the first place. For them, the matter was as simple as that. The debate provided an airing of views and deeply held con- 
cerns, but Fijian leaders realized they could not veto the proposals. London was determined to move on. After the elections, the government advised that a quasi-ministerial arrangement involving a three-person Membership System would be introduced, giving elected representatives of the people supervision over a collective of the government departments. In July 1964, AD Patel became the Member for Social Services, Ratu Mara the Member for Natural Resources, and John Falvey the Member for Communications

Patel's two chief political concerns throughout the 1960s were independence for Fiji and a common electoral roll. He had a deep and abiding distrust of the colonial government which he held responsible for racial division in the country. Its removal, he argued passionately, was absolutely necessary for improved race relations and social and political progress in Fiji. From that position he did not retreat despite fierce opposition from Fijians and Europeans alike who wanted the continuation, not the termination, of colonial rule. Indeed, in the early 1960s, Ratu Mara saw no value in independence at all, and for good reason, too, given the absence of Fijians in the higher echelons of the civil service and the professions. As Patel persisted, Fijian and European position hardened, expressed in the now famous 'Wakaya Letter', to Nigel Fisher in 1963, in which the Fijian Affairs Board laid down the preconditions for any move towards greater internal self-governance. ${ }^{49}$ These included firm guarantees on Fijian landownership, parity in the civil service, the special recognition of Christianity in the public life of Fiji, and a link to the Crown along the lines enjoyed by the Channel Islands. The letter was a secret document at the time. But its symbolic as well political significance is beyond doubt. London knew precisely where the Fijians and Europeans stood.

Patel and other Federation leaders expected London to play the role of an honest broker, and devise a constitutional solution broadly acceptable to all communities. But in this thinking they were mistaken, and their faith in British impartiality sorely misplaced. The mind of the Colonial Office was heavily influenced at the very outset by a secret memorandum written in 1960 by Julian Amery, Parliamentary Under-Secretary of State for the 
Colonies, who had visited Fiji that year in the middle of a crippling strike in the sugar industry. It was a document whose tone reverberated in all serious talk about Fiji throughout the 1960s. Because it was a secret memorandum, its existence was unknown outside the official circles. It deserves mention in some detail. Amery was a well connected Conservative (his father, Leopold, had been Secretary of State for India in the 1940s), supremely self-confident and with a penchant for sharp, unequivocal judgments. He was characteristically blunt in his assessment. 'The Fijians and Indians are more distinct as communities than Jews and Arabs in Palestine, Greeks and Turks in Cyprus or even Europeans and Bantu in South and Central Africa', he wrote..$^{50}$ The Fijians feared Indian domination, he said accurately enough, and had hardened their attitude to constitutional reform. They regarded the Burns Commission recommendation for the gradual abolition of the separate system of Fijian Administration 'as an attempt to give the Indian community control of the land by breaking up the traditional Fijian community.' It had to be remembered, too, Amery continued, that it was the Fijians who had been the 'loyal' community - the reference here being to their enthusiastic participation in the Second World War as opposed to the Indo-Fijians' unenthusiastic response. The Fijians provided 75 per cent of the armed forces. 'The islands could hardly be governed without them, let alone against them.' Amery continued:

We must, I think, accept that it is impractical to think in terms of a single Fijian nation or of a common roll at any rate for the foreseeable future. Any suggestion of this is bound to arouse Fijian suspicions that the Indian would dominate by counting heads. The moderate Indian leaders recognize this. This points to the conclusion that we shall have to recognize the equality of the Indian and Fijian communities irrespective of their numbers. There is no other way of reconciling both pledges in the Deed of Cession and those in Lord Salisbury's Despatch, let alone to keep communal peace. We should, therefore, let it be known that any constitutional advance must be so designed as to preclude the domination of one of the two main communities by the other. 
The broad thrust of Amery's prognosis was accepted, despite the searching comments of senior officials such as Sir Hilton Poynton, but some of his other recommendations were rejected. The idea of a separate system of Indian administration was not only unacceptable in principle because of London's long-term commitment to multiracialism, it was impracticable because of the loose structure and dispersed settlement pattern of the Indo-Fijian community. Fijians needed help and protection, officials in London agreed, but they had to be taught to 'face up to the modern economic realities,' and officials favoured the gradual racial integration, not segregation, of public institutions. There was, however, one serious change from the substance of Amery's advice. He had recommended separate but equal representation of Fijian and Indo-Fijian interests. As the 1960 s proceeded, London changed its mind. The primary aim of its constitutional policy then became the devising of a constitutional structure that was nominally democratic to outward appearances to satisfy especially the United Nations Committee on Decolonization (Committee of 24), but which would leave the Fijians firmly in control. Protection and entrenchment of Fijian paramountcy was foremost in the minds of officials in London. Indian demand for parity, acknowledged politely, would simply have to wait.

\section{CONSTITUTIONAL CONFERENCE ${ }^{51}$}

It was in this atmosphere, then, charged and with positions already staked out, that Fiji's first ever constitutional conference was held in London. The conference opened at Marlborough House on 26 July. The positions of the three groups were clear. The Fijian group wanted the recognition of the principle of Fijian paramountcy in the form of two additional seats - nominated by the Great Council of Chiefs - and the complete rejection of common roll, though the Colonial Office thought Fijian leaders were 'prepared to listen to proposal from the British side and to give them a fair hearing' because their 'confidence in British integrity is complete.' No proposals came from the British side. The Indo-Fijian side wanted common roll and 
self-government, leading inexorably to independence, with continuing links to the Crown. The European position was identical to that of the Fijians.'

Ratu Mara, speaking for the Fijians, expressed gratitude to the British for their benign and beneficent administration of the country, and saw no need at all for abrupt change to Fiji's relations with the United Kingdom. 'We have declared that independence is not our goal because we have never found any sound or valid reason to attenuate, let alone abandon, our historical association with the United Kingdom.' On the contrary, he hoped that the United Kingdom 'will share with us our prosperous future, as she has always willingly and unstintingly shared our past and our present.' Speaking for the Europeans, John Falvey told the conference that many people were content with the status quo, and the demand for independence was confined to a small minority. Many in Fiji, he said, 'are well content with our present, and quite new constitution,' and there were but a 'few who are seriously critical of the administration of our country since 1874 .'

Federation leader AD Patel could not disagree more. The conference, he hoped, would produce a new constitution that would lead to 'complete independence in the not too distant future.' He spoke about the enduring importance of political freedom of the type developed democracies enjoyed. 'Political liberty, equality and fraternity rank foremost among the good things of life and mankind all over the world cherishes and holds these ideals close to its heart. The people of Fiji are no exception.' He hoped the conference would mark the 'beginning of the end of a form of government which stands universally condemned in the modern world.' He, too, had 'faith and trust in the British people and the UK Government' to work out a just and fair solution for Fiji, but warned against the dangers of preconditioned thought and the politics of expediency. Coming from any other anti-colonial leader from any other colony, Patel's rhetoric would have been unexceptional; but it jarred especially when Fijian and European leaders were totally opposed to independence and so extravagantly effusive in their praise of colonial rule and all it stood for. 
The mind of the Colonial Office was already made up. The proceedings of the conference clearly show London not playing a fair, mediating role. Eireen White, the Under-Secretary of State for the Colonies, held separate consultations with Fijian and European delegations, but none was held with the Indians. She made no attempt to give a sympathetic hearing to their proposal. Andrew Deoki's compromise proposal for a limited introduction of common roll towards the end of the conference was rejected because 'it came too late.' But too late for what, Patel asked, again to no avail. The conference produced the result that European and Fijian leaders wanted. Fijians now had fourteen seats, Indo-Fijians twelve and Europeans ten. In the new proposals, an outright Fijian majority was assured, because of solid European support, and thus a Fijian Chief Minister. European privileged position remained intact, despite giving up two seats. And IndoFijians lost parity with Fijians, despite being the majority community in Fiji. Further, nine of the twelve Indo-Fijian seats were to be contested on completely communal rolls and the remaining three on cross-voting lines. That is, in these seats, the ethnicity of the candidates would be specified, but everyone would vote without racial restriction. It was, in effect, an extension of the communal system of voting.

The Federation Party objected vigorously to the constitutional proposals. It criticized the United Kingdom delegation for not pointing out to the Fijian and European delegations the desirability of accepting even a limited number of common roll seats. It lamented not only the loss of political parity with the Fijians, but also the increased isolation of the Indo-Fijian community. The Chinese were put on the same electoral roll as Europeans, and Rotumans and other Pacific Islanders were added to the Fijian roll. The Indo-Fijian community now stood completely alone and isolated as the result of deliberate policy. Ironically, everyone else had common roll except the Indians! Patel reminded London of the spirit of Lord Salisbury's Despatch which promised equal rights to those Indians who had decided to settle permanently in Fiji. The composition of the Legislative Council and the method of election, he said, were 'unjust, unfair, impracticable and 
undemocratic,' adding: 'They will harden the existing racial division and make practical integration of the different communities, which is vitally necessary to the building of apolitically homogenous and democratic nation, extremely difficult, if not impossible. ${ }^{52}$ The Federation Party threatened to boycott the final session of the conference but did not do so 'out of respect for the Secretary of State.' It accepted the outcome on protest. Anthony Greenwood, the Secretary of State, admitted that the constitution was not perfect but thought sufficient progress had been made towards multiracialism in the cross-voting proposals, and urged everyone to make it work. Patel regarded cross-voting not as a progressive but a retrogressive step.

Soon after the conference, Fijian and European leaders were pressed upon to form a political organization to carry their message to the people. In this, they received unexpected support from Governor Sir Derek Jakeway, who urged the formation of political parties which would 'encourage political alliances which cross barriers of race and which will provide a firm and enduring basis on which all the communities of Fiji can move forward in partnership towards full control of their common destiny.' He even asked the Colonial Office to find someone from the Conservative Party to help the Fijians organize politically. His sympathy for the Fijians was well known. He may have acquired this from his stint as the Chief Secretary of Sarawak, from where he had come to Fiji. His antipathy towards the Indo-Fijian leaders may have developed from his time in British Guiana where Cheddi Jagan had accused him of political partisanship and demanded his recall by the Colonial Office.

Jakeway's encouragement led to the formation of the Alliance Party. On 27 November 1965 at a gathering of Fijian, European and a group of anti-Patel Indian leaders, the idea was formally proposed and a steering committee formed, consisting of Ratu Mara, Vijay R Singh, Ajodhya Prasad, Richard Kearsley, Semesa Sikivou and Shaukat Ali Saheb. The Alliance Party was formally launched in Suva on 12 March 1966, promising to provide for the people of Fiji a government 'which will be uniformly just and stable, maintaining our settled institutions although we must be 
prepared if need be to review them.' The founding institutional members of the Alliance, besides the Fijian Association, were the Suva Rotuman Association, All Fiji Muslim Political Front, Chinese Association, National Congress of Fiji, General Electors Association, the Fiji Minority Party, the Rotuman Convention and the Tonga Association. Ratu Mara was elected its President, and James Shankar Singh was one of its Vice Presidents, along with David Ragg and Baldwin March, with Dr Linday Verrier as General Secretary.

\section{TESTING THE WATERS}

In September 1966, Fiji held a new general election under the 1965 constitution. It was an important contest fought for the first time between two political parties, the Federation and the Alliance. The Federation Party campaigned on the platform of 'One Country, One Nation, One People,' with 'no special privileges by reason of race, religion, birth, or sex.' The Alliance defended the constitution and the colonial government's policy of gradualism. The result was predictable. The Alliance won twenty five seats (all Fijian and European communal) while the Federation won nine, all of them Indian communal, and none of the cross-voting ones. The logic of the 1965 constitution had worked; Fijian leaders were in the driver's seat, albeit through a contrived constitution. In the Indo-Fijian electorate, particular interest focused on the battle between AD Patel and Ajodhya Prasad for the Southwest Viti Levu Indian seat, between two men from opposing political parties and political persuasions who had been bitter foes since the late 1930s. In the end, Patel won easily, with 7601 votes to Prasad's 4025. Ratu Mara, as the leader of the Alliance Party, was appointed Leader of Government Business, while retaining his Natural Resources portfolio for a few months before handing it over to Doug Brown. Vijay R Singh, Patel's most bitter opponent, with a sharp mind and an eloquent tongue, was appointed Member for Social Services and Charles Stinson, a Suva businessman, Member for Communication and Works. 
The Federation Party protested its exclusion from the Executive Council, pointing to Paragraph 39 of the conference report, according to which the 'Governor would continue to appoint the unofficial members of the Executive Council in his discretion but would provide for appropriate representation of the various communities in the unofficial element of the Executive Council. ${ }^{53}$ As the Federation Party represented the Indo-Fijian community, it claimed that it was entitled to be invited into the Executive Council. Trafford Smith agreed with this view, saying that the 'Secretary of State no doubt had in mind that the [Executive] Council would be formed on all-party basis as hitherto,' referring to the Membership system. This clearly was a fall-back position, in case the Alliance did not win the elections. But now that it had, 'Fiji had crossed a major Rubicon,' and an undertaking was breached. Ratu Mara, for his part, did not want the Federation Party in government because its policies, he said, were diametrically opposed to his party's and because the Federation in all probability would insist on the exclusion of Indian members of the Alliance from the Executive Council as a precondition for participating. This Mara was loath to accept. He had the mandate to rule and that was all that he needed. The first chance to form a broad-based government of national unity was thus missed at Ratu Mara's insistence, but on this more later.

The new Alliance government lasted a year when the Federation Party walked out of the Legislative Council in protest. AD Patel accused to the government of restricting debate on important issues of public policy — of 'hastily using the guillotine' — and of not consulting the Opposition. But there was another reason. The Party had accepted the 1965 Constitution under protest, as an interim arrangement, until a more democratic outcome could be achieved. As the election results showed, the constitution had completely marginalized the Indo-Fijian community. Making matters worse was the statement made by visiting Secretary of State, Herbert Bowden, that there was no urgency for another constitutional conference as the 1965 Constitution seemed to be working satisfactorily. Patel saw the 
ploy. Satisfactorily for whom, he asked? On 1 September 1967, exactly a year after the new Alliance government had been sworn into office, he moved a motion in the Legislative Council and then staged a walkout. The motion condemned the 'undemocratic, iniquitous and unjust provisions [which] characterize the existing constitutional and electoral laws of Fiji,' which had 'hampered the political advancement of Fiji along democratic lines,' and called upon the United Kingdom to 'call a constitutional conference immediately to ensure that a new constitution is worked out based on true democratic principles without any bias and distinction on the grounds of colour, race, religion or place of origin or vested interest, either political, economic or social or other so that Fiji may attain self government and become a nation with honour, dignity and responsibility as soon as possible.'

The country simmered with palpable political tension as preparations began for the by-elections the following year. The Federation Party now adopted 'Independence Now' as its principal political platform. 'Smash the Constitution Before It Smashes You,' Patel told his rallies, 'Independence Our Salvation.' The party was out to prove that the overwhelming majority of the Indian community supported it and, therefore, rejected the 1965 Constitution. The occasion also provided Ratu Mara the opportunity to test his strength in the Indian community and to prove that he, too, had substantial support in it. Mara told London that he was expecting to win one or two Indian communal seats. The Indian community, he said, was realizing that 'he was genuinely determined to safeguard their interests,' and Patel himself was 'clearly losing ground. ${ }^{54}$

Mara's surprisingly optimistic assessment of his political support among Indo-Fijians was misplaced — and not for the last time either because the by-elections returned all the nine Federation Party members with increased majorities, from 65 per cent of the Indian votes in 1966 to 75 per cent in 1968, with Patel returning with the largest majority of them all: 7903 to MV Pillay's 2772. Three factors played a part in the Federation's win: first it presented itself as the true and authentic voice of the Indo-Fijian community, unlike those Indo-Fijians sitting on the Alliance benches, 
second, it fielded a superior slate of candidates; and third, it promised to overhaul the Eve contract when it expired. That pro-CSR contract had bankrupted scores of cane growers throughout Fiji. Mara was stunned, and retreated to his home in Lau where he remained incommunicado, even to the commander of the Fiji Military Forces, Colonel Frank Rennie, who was hoping for some guidance from the Chief Minister on the threatened riots. None came, with Mara allowing the threatening developments to take their course for a while. Strategic silence was a tactic he would employ again on many later occasions. ${ }^{55}$

On 12 September, three days after the election results were announced, Ratu George Cakobau, the Vunivalu of Bau, called a meeting attended by some two thousand angry and threatening Fijians. They opposed independence in favour of internal self-government, and rejected common roll altogether. Tensions ran high. Calls went up to tighten all legislation concerning Fijian land, demand prompt payment of all rent, abolish ALTO, and reclaim all expiring leases. In Vatukoula, three thousand Fijians marched with their faces blackened to symbolize war. In Suva, at a large meeting attended by many leading Fijians, it was resolved that 'the control of the country should be returned to Fijian hands, by force if need be.' Others called for Patel to be deported. Mara was miffed, saying that the Fijian people 'feel betrayed and intended to have their interests safeguarded.' 'Let there be no violence,' he said with a hint of menace, 'but let it be clearly understood that the Fijian people have spoken in no uncertain terms and they cannot and must not be ignored. ${ }^{56}$ Patel was undeterred; he was not one to flinch in the face of adversity. 'The people have given their verdict in no uncertain terms that the people of the Colony want freedom and equal political rights.' Two decades later, Jai Ram Reddy would face a similar wrath from the Fijian nationalists, displaying placards calling for the deportation of Indo-Fijian leaders and the emasculation of the rights of the Indo-Fijian community.

The by-elections tested Fiji's fragile experiment in multiracialism. Patel had proved that the Federation Party represented the overwhelming 
majority of the Indian community in Fiji and that it could no longer be ignored in future political discussions. His people would have their proper place at the negotiating table. But this proof had come at a great cost to race relations and caused a hardening attitude on the Fijian side which viewed increased Indian support for the Federation Party as a naked grab for power. The Fijian determination to stand their ground and refuse concessions was also out in the open. But the by-elections had also exposed the realities on the ground. Fijian leaders realized that they could not continue to oppose independence forever. It would be better for them to negotiate independence while they controlled the government and had a clear majority in the Legislative Council. The by-election was a sobering wake-up call to all parties to begin good-faith negotiations on a more realistic rather than predetermined basis. The time for procrastination had long passed.

\section{TOWARDS INDEPENDENCE}

The 1968 by-elections changed the political dynamics in Fiji, with London admitting that the 'circumstances in Fiji are against us. ${ }^{57}$ In the past, London had feared Fijian insurrection if changes introduced did not meet their approval; now it was anxious that Patel's successors -'people of a different calibre' - might resort to strong-arm tactics, 'or even have recourse to violence.' The Special Branch had reported to London that Apisai Tora, the militant Western Fijian leader, had been promised a large sum of money allegedly by Koya 'if he would pledge his support for certain courses of action,' including 'physical persuasion.' ${ }^{58}$ After the 1965 constitutional conference, Koya had threatened to break away from the Federation Party against Patel's supposedly 'passive attitude' and non-violent approach to the outcome of the conference, and was talking about forming a 'Subash Party,' after the Indian nationalist leader Subash Chandra Bose, who was committed to overthrowing the British from India by force. The rift between the two men was patched up, but the old cordiality was gone. ${ }^{59}$ In December 1968, Jakeway left Fiji, telling London on the eve of his departure to eliminate the 
communal rolls and replace them with cross-voting. He was succeeded by Sir Robert Foster, who had come to the Pacific after long service in Africa as District Officer and Provincial Commissioner in Northern Rhodesia and as Secretary of Native Affairs and eventually Deputy Governor of Nyasaland. Fiji began its journey towards independence with Maddocks' African experience, and it was concluding it with Foster's similar background.

That the Indo-Fijian side wanted an early constitutional conference for independence was not surprising. What did surprise Suva and London was that Fijians themselves were now demanding the same thing, though for very different reasons. ${ }^{60}$ Their demand was based on a pragmatic assessment of the political realities on the ground. First, Fiji could not forever remain immune to international scrutiny, such as that demanded by the UN Committee of 24, or protected from proportional representation or majority rule, both of which were unacceptable to the Fijians. Full internal self-government would remove Fiji from UN scrutiny. Second, Indo-Fijian population was increasing, and further delay would make it more difficult for Fijians to insist that the political control of Fiji be handed over to them or at least a 'political structure in which Fijian influence is paramount.' Third, once the complete control of internal affairs had been handed back to a body which was acceptable to Fijian opinion, Fijian interests could then be protected without external interference. The public stand of the Fijian leaders was: no independence, at least no yet, no common roll and deep gratitude to the United Kingdom for all manner of things; but privately attitudes were changing, or at least were more flexible. Ratu Mara's erratic and sometimes contradictory attitude to independence seems to have been calculated and strategic. He clearly wanted to extract maximum concessions from London for his people while he still had time on his side, and held all the right cards.

By mid-1969, it was becoming clear in London and in Suva that a conference to decide a new constitution for a fully self-governing, if not completely independent, Fiji would have to be held sooner rather than later, especially in view of the agreement on this by both the major parties. Full 
common roll and single-member constituencies were considered unrealistic because they were unacceptable to Fijians. The reason was simple. As one official in London put it, 'Fijians cannot afford to take the risk that voting may develop along non-racial lines since there is much at stake for them to be wrong.' The official went on: 'These arguments of the Fijians can never be adequately countered because there always comes a point when logic is swept aside and emotion is given free reign. ${ }^{61}$ Developments elsewhere reinforced Fijian political conservatism, especially the race riots in Malaysia. Mara continued, on the eve of independence in 1969, to push for the 'Bahamas model' for Fiji, which provided for a large measure of internal self-government, with certain powers - external affairs, internal security, the police force and public service — retained by the Crown but with the provision for gradual devolution of these responsibilities to the elected government. Whether this was another of his bargaining ploys, I cannot say.

In August 1969, representatives of the Alliance and the Federation parties began a series of informal, secret talks about a new constitution for Fiji to identify areas of agreement and disagreement between them. In an atmosphere marked by cordiality, the leaders talked frankly and freely about their concerns and fears. AD Patel predictably pressed his case for common roll and immediate independence. He was to attend just one meeting before dying of a heart attack on 1 October. On 8 October, Siddiq Moidin Koya succeeded Patel as the leader of the by now National Federation Party (when Mohammed Apisai Tora's National Democratic Party joined the Federation Party) and as the Leader of the Opposition. Koya broke the potential political impasse when negotiations resumed. Over several months of private discussions, NFP conceded ground to the Alliance on virtually every important issue. For Koya, common roll was now surprisingly a non-issue. He told Sir Leslie Monson, the Under-Secretary of State at the Foreign and Commonwealth Office, that he, Koya, would be satisfied if Mara could be persuaded to say that he would reconsider common roll as a long term objective, perhaps over the next ten to fifteen 
years. When Lord Shepherd offered this as a proposal in London during the conference, Karam Ramrakha objected vigorously saying that common roll was a central plank of the party's platform, not a long term objective. The party duly noted this on paper for the benefit of the Colonial Office, but what Ramrakha did not know fully was the position of his own leader, whereas both the Alliance and the United Kingdom did.

Lord Shepherd offered a way out of the common roll-communal roll impasse. At some point after independence, he suggested, Fiji could appoint a Royal Commission to look into and to recommend the most suitable electoral system for Fiji. And he told the NFP delegation that while he personally preferred common roll, the United Kingdom would not force the issue nor try to get the Alliance side to accept the idea. It was for the Indian leaders in Fiji to bring the Fijians to their side. That, and that alone, would form the basis of an enduring solution. Koya apparently thought the recommendations of the Royal Commission would be binding. Mara disagreed completely although he did say in 1970 that the findings of the Royal Commission would be 'taken into consideration and then become a part of the constitution otherwise its recommendations could be subject to whim and fancies of any Parliament. ${ }^{62}$ In 1975, a Royal Commission was appointed, led by the eminent British jurist Sir Harry Street. The Alliance rejected any change to the electoral system, on the grounds that the present system of guaranteed communal representation had worked and altering aspects of the constitution so early in its life could open the floodgates for other changes. It was a spurious argument because no consequential changes to the constitution could be made without the support of both sides of the House.

The NFP's case was argued by a London barrister and later the Legal Advisor to the Commonwealth Secretariat, Thomas Kellock QC, in favour of proportional representation and a government of national unity and concord.$^{63}$ But the hearings before the Commission aroused little public interest. The Street Commission recommended the Single Transferable Vote as the most appropriate electoral system for Fiji ${ }^{64}$ For all practical purposes, the 
report was still-born. It was not even debated in parliament, as Reddy would comment later. The Alliance had no reason to. The 1970 Constitution had worked to its immense political advantage and the party saw no reason for change. By then (the mid-1970s), with the exception of a few, the NFP had also been seduced by the idea of guaranteed racial representation in parliament. The NFP also agreed to go into independence without an election. 'It is fully appreciated by the Opposition that this proposal gives a position of advantage to the Government of the day,' Mara informed Governor Foster. ${ }^{65}$ 'They accept this and have said they will fully support a Prime Minister during the period when the final details are being worked out, particularly with regard to elections. This was precisely the outcome that Fijian leaders had long wanted and the United Kingdom had fervently hoped for: Fijian leaders, in control, taking Fiji into independence. When a clearly surprised Governor probed him further about the concessions he had made, Koya explained that he did not want the prevailing cordial atmosphere disrupted, that he wanted a completely successful conference (unlike 1965), that he 'thoroughly trusted' Mara, and that he preferred to go independence with him rather than rather than with someone else who a pre-independence election might throw up.

The idea that Mara could be challenged by another Fijian leader on the eve of independence was simply unthinkable. He was the preeminent Fijian leader of the day, unchallenged and unchallengeable, standing tall (literally as well as metaphorically) above everyone else by virtue of his intellect, experience and traditional status as a paramount chief. More to the point, Koya and his fellow Federation leaders had probably come to accept that even the remote possibility of a government led by them might not be acceptable to the Fijians, all the paraphernalia of parliamentary democracy notwithstanding, that they would be safer remaining in Opposition, with the Fijians in charge. The fears and anxieties and the threatened Fijian reaction to the Federation's by-election victory were all too fresh in their minds. The Colonial Office was surprised at the Federation's concession, but accepted it as a pragmatic assessment in view of the prevailing circumstances. 
Koya later told his party and the Indo-Fijian community generally that they should be grateful for the many concessions the Fijians had made. They had not insisted, for instance, on a 'belonger' status for non-indigenous residents of Fiji, which they could easily have done. If he were their lawyer, he said in 1970, he would have successfully argued their case: denying the privileges of full citizenship to the non-indigenous residents. This is what Koya said during the parliamentary debate on the independence constitution: 'If I were not the Leader of the Opposition and if I was not born in Fiji and held a brief for the Fijian people in the 1965 constitutional conference, I would have made the Britishers sit up and think what they are doing to the Fijian people. It was their country in 1874 and it was their country in 1965. I want those Indians who are criticizing the Fijians to know that there was nothing to stop the Fijians saying, 'You give the country back to us. The immigrant races, such as Europeans, Chinese, Rotumans and Indians are here as our guest. ${ }^{\prime 66}$ Parenthetically, a few years later, Koya changed his mind, saying that 'Everyone was a settler in Fiji, who had arrived in the islands by design or by accident,' and that 'land belongs to God, not to human beings. ${ }^{67}$

Ratu William Toganivalu, one of the Alliance's more independentminded parliamentarians, took umbrage at Koya's claims, saying that the Great Council of Chiefs had never made citizenship an issue and that the 'belonger' business had never been raised in any of its proceedings. By implication, he was saying that Koya's claims were an insult to the chiefs. He was right. Koya's claim was indeed strange, and stranger still coming from the political leader of the Indo-Fijian community. Nowhere in the Commonwealth, whether in Africa, Asia or the Pacific Islands, had this issue ever been raised. Citizenship was invariably conferred on all those who were born in the country or met the appropriate citizenship requirements at the time of independence. It simply could not have been otherwise. Simple commonsense dictated the practice, to avoid unimaginable chaos and disruption and international litigation. And recent history was witness to it as well. Koya could be strangely cavalier. 
He once dismissed Salisbury's Despatch, by which the party had placed so much store in the past for its promise of equality to Indian settlers in the colonies, as 'Just a piece of paper.' ${ }^{96}$

Both Suva and London did everything in their power to ensure a successful, consensus conference. Lord Shepherd was aware that the method of voting might be the one sticking point between the parties. To avoid failure on this issue, he got both the Alliance and the NFP to agree, in advance in Fiji, that if no agreement could be reached on the method of election, both parties would agree to abide by the electoral provisions of the 1965 Constitution - the very same constitution that the party had rejected again and again and over which it had boycotted the Legislative Council, precipitating a divisive by-election and potential race riots! Ratu Mara was opposed to any form of common roll whatsoever and, furthermore, to any substantial reduction in the overrepresentation of the Europeans and Part-Europeans. He threatened to walkout of the conference if the UK delegation pressured him further to acquiesce. He would then return to Fiji to lead the Fijian resistance to the United Kingdom's plans for Fiji. That was a prospect London could not countenance in any circumstance, and Mara was fully aware of the strong suit he held in his hands and which he was prepared to play to get his way.

London's position on independence for Fiji was summarized well by Sir Leslie Monson, who visited Fiji in October 1969. Independence on the basis of Fijian paramountcy was the way forward, he reported. ${ }^{69}$ 'We will not in the end be able to justify, either in conscience, or in political terms, in our own country, a solution that does not ensure that independence will leave Fijians in control.' If Fijians did not get paramountcy, 'the risk is that they will take by force and by unconstitutional means that which they consider to be theirs. This could produce an extremely serious internal security situation, in which we should have difficulty in protecting the Indian community.' The fear of violence was probably exaggerated, though the memory of 1968 was fresh in many minds. What of the interests of the Indian community? They would have to be content with strong 
constitutional protection of their basic human rights. In time, 'the Indian side will concede that Fiji should go to independence under a constitution which would, at any rate for a time, give the Fijian side a constitutional advantage. This is the best for which we could hope... and do not think we should give up any opportunity of achieving this because of anxiety to relieve ourselves early of our defence and internal security responsibilities for the area.'

The 1970 Constitution provided for a bi-cameral legislature. ${ }^{70}$ The Senate comprised twenty two members: eight nominees of the Great Council of Chiefs, seven of the Prime Minister, six of the Leader of the Opposition and one of the Council of Rotuma. The GCC nominees exercised the power of veto over all legislation that touched Fijian interests, including the Fijian Affairs Ordinance, the Fijian Development Fund Ordinance, the Native Land Trust Ordinance and the Agricultural Landlord and Tenant Ordinance. At any given time, indigenous Fijians made up almost two thirds of the Senate, because both the Prime Minister and the Leader of the Opposition included them among their nominees. What this meant in practice was that the Fijian members of the Senate effectively had the power of veto over all legislation approved by the House of Representatives. The idea of an Upper House with nominees of the Great Council of Chiefs and with watertight protection for Fijian interest came from the NFP, hoping that concession there might open up more room for democratic space in the Lower House. London knew from experience elsewhere in the colonies that upper houses were 'rather out of fashion' and generally ineffective, but with the NFP and the Alliance on the same side of the issue, it let the matter pass.

The House of Representatives was in essence an enlarged version of the post-1965 Legislative Council, comprising a mixture of communal and cross-voting (now called national) seats. Of the fifty two seats, Fijians and Indians each had twelve communal seats and the General Electors three. Of the national seats, Fijians and Indians each had ten seats and the Generals five. The old pattern was maintained. General Electors, always a tiny 
minority of the population, continued to occupy a position of privilege in the parliament, with the full support of Fijian leaders. Indians retained an illusion of parity with Fijians. And Fijians enjoyed paramountcy by virtue of their dominance in the Senate and in the Lower House through the support of the General Electors. General voter over-representation was a concern for the United Kingdom, which wanted it reduced substantially, but Mara objected. The old colonial formula of Parity (for Indians), Privilege (for Europeans) and Paramountcy (for Fijians) remained firmly entrenched in the independence constitution

Fiji achieved its independence without the strife which had often accompanied decolonization in other parts of the world. That was a cause for quiet celebration. But everyone knew, deep in their hearts, that independence had not resolved any of the underlying concerns of the different communities about power sharing, about the best way to share the fruits of development, about their proper place in the larger scheme of things. These remained unarticulated, hidden from the public view. In his last despatch to London, Sir Robert Foster wrote:

A calm search for a just solution to the problem of representation has in the past proved virtually impossible: feelings ran far too deep. One is therefore bound to regret that in effect a time bomb will lie buried in the new Constitution, and to pray that it may be defused before exploding. The two parties have however publicly committed themselves to an act of faith which must give reasonable ground for hope. ${ }^{71}$

Reasonable hope: that, finally, was all that could be hoped for, as Fiji basked innocently and uncertainly in the feel-good afterglow of independence. 


\section{INTERLUDE}

\section{JAI RAM REDDY: ADVOCACY SKILLS ${ }^{72}$}

Here in Fiji, all Barristers and Solicitors are advocates in as much as they appear before our Courts to plead a cause on behalf of their clients. An advocate is by definition someone who is propounding views on behalf of someone else, views to which he may not necessarily subscribe. His task is essentially to advance the cause for which he is instructed. The success with which he is able to plead a cause on behalf of his clients depends upon the skills that he is able to bring to the task. And the purpose of this talk, as I understand it, is to attempt to identify those skills. What are the skills that go into the making of a good advocate? Let me say to you at once that I do not feel qualified to answer that question, nor do I believe that the so-called skills lend themselves to any easy or precise description. All I can hope to do is to give you my impression of what I consider some of those skills to be.

We all know only too well that advocacy is not something that you can learn at a law school or in the Chambers of any Barrister. Advocacy and the skills that go with it is something that can only be learnt by experience. And that fact is the reason why so many fail. A young advocate is expected to perform before he has had a chance for any real schooling or rehearsal. That was certainly true of my generation of lawyers, and it is true of most now. There is a belief that no sooner you have acquired a degree in law, have been admitted to the Bar, donned the wig and the gown, you are ready to have a go. That is a myth. Most young practitioners are in a great hurry to get into Court. The result can be and often is disastrous. Let me illustrate to you what I mean. 
I recall one of my first days in Court. It was before the Senior Magistrate sitting at Nadi. It was a civil case, a claim by a licensed moneylender for money lent on interest. I was for the plaintiff, my opponent was an experienced Counsel of many years standing. A variety of defenses were pleaded. I need not go into the details of the case, nor my performance, or the lack of it. Suffice [it] to say that the end of the closing address, the Magistrate immediately proceeded to deliver his judgment. He, of course, dismissed the claim with costs, and then turned to my client and said: ' $\mathrm{Mr}$ Parkar Singh, let me give you a piece of advice, and it is free: next time you decide to litigate, see a lawyer.'

You can imagine what that comment did for my self confidence, not to mention my ego. A number of things happened on that fateful day. First, as I have already said, my self confidence took a severe blow. Second, I lost my client. Third, I made a dreadful impression on the Magistrate (and it was to take a long time before I would repair that damage). Fourth, I possibly lost one or more potential clients who were sitting in the public gallery of the Court (although at that time I desperately hoped that they did not grasp the full implication of what the Magistrate had just told my client).

While this episode proved expensive to my client, it was a salutary lesson for me. It drove home to me how inadequate my learning at the University had been to prepare me for the task I was undertaking. It dawned on me then that learning to be a lawyer had just begun, even if in such an inauspicious way. Almost three years later, I was to hear the same Magistrate say exactly the same thing to another litigant represented by a new practitioner. Mercifully, this time, I was on the other side.

I believe it is extremely unfair, for any legal system, to let loose on often illiterate, trusting and simple people, as is the case in Fiji, 
lawyers not yet ready to undertake the task for which they are supposed to have the skills. There are few professions that are allowed to experiment on the people, as lawyers do.

Good advocacy is largely a matter of learning and hard work, although innate skills must play a part. To be effective in Court, or before any Tribunal for that matter, Counsel should ensure that he has identified the specific issues requiring determination by the Court, both of law and facts; has mastered the facts of the case to the smallest detail; is able to present those facts in such an orderly fashion that it is readily understood by the Court; and, finally, has a good grasp of the law applicable to the facts and the issues requiring determination and is able to explain the law in a way that is easily understood.

The object of all advocacy is to persuade a Judge to accept the view that you are putting forward. That being so, one needs to present the case in such a way that it is acceptable. Judges are human. Before you satisfy his reason, indeed reach it, you must gain his ear. The more willing a Judge is to listen to you, the greater the chances of him being receptive to your arguments. It has been said that two things are all important to the advocate: the manner and the matter. And it is true, is it not, that sometimes even poor matter produced with good manners attracts attention? Conversely, good matter presented poorly and without due courtesy does not command attention. Yet, this simple truth is overlooked by so many Counsel at such great cost to themselves and the cause they advocate. There can be no excuse for discourtesy to the Court. I am aware that courtesy is a two way thing, and that Counsel also deserves to be treated with courtesy.

But I believe that the primary responsibility in this area rests with Counsel. In my years of practice, I have rarely known a 
Judge who has not responded in a like manner to due courtesy extended to him. A rude and unnecessarily belligerent Counsel is no advocate at all. Courage is the mark of a good advocate. But belligerency must not be confused for courage.

First and foremost, every would-be advocate has to ensure that he learns the art of speaking clearly, directly and simply. This is a matter of practice. The audience, Judge, assessors, witnesses, opposing Counsels, should not have to strain to hear you. Only then will they give effortless attention to what you are saying. It is not unusual to see Counsel carrying on in a dull, monotonous tone, not caring or even conscious about whether they are being heard or not. Nothing distresses a client like the knowledge that his advocate is not being heard. Remember that his day in court is very important to him.

An intimate and sympathetic understanding of human nature is an important tool in the armoury of any advocate, as is an understanding of the culture and ethos of the people in whose midst he practices his vocation. It is a little disconcerting, but nonetheless true, that ordinary people, be they witnesses or assessors, are more likely to be moved by raw emotion such as by hate or love or lust or rage or sorrow or joy or hope or fear, then by the reality of calm and dispassionate logic. When making submissions, be it to a judge or assessors or in cross examining hostile witnesses, the advocate is required to entice, to flatter, to cajole, to push, all in order to advance the cause for which he has been instructed.

In the United States recently, there was the celebrated trial of OJ Simpson. From all accounts, the emotions, hopes and prejudices of the Jury were fully exploited by highly accomplished advocates, and all this may have played an important part in the ultimate result in that case. And in that format, that is, in trials before a Jury, certainly an advocate does require skills that are very special. 
Some of the most celebrated advocates in the history of the English legal system have been men who possessed extraordinary skills for histrionics, for high drama, who possessed the art of the dialectician, and the gifts for great heights of oratory.

In modern times, and certainly in trials before a Judge sitting alone, these special skills are perhaps of marginal value. Indeed, they can be a handicap. If you are before a judge sitting alone, as is often the case in Fiji, it is best to keep to simple language conforming to the standards of the best prose. While rhetoric has its place in advocacy even before a Judge sitting alone, it has to be kept under tight control as there is no substitute for calm logic, a clear sense of design, and complete control of temper and emotion.

Generally speaking, Judges sitting alone become a little impatient with rhetorical flourishes. There is the story about a Counsel who opened his case to a Judge sitting alone. Before long he was in full flight, giving full expression to his undoubted talent for rhetoric. The Judge simply tapped on his desk and said, ' $\mathrm{Mr}$ Blank, there is no Jury.' Counsel apologized and began again, only to lapse into his ways. For some time, the Judge suffered it, then tapped on the desk again. 'Usher,' he said, 'switch on the light over the Jury Box: Mr Blank does not believe me.'

Every advocate has to understand that while lay assessors will be swayed by emotions, there is little to be gained by making it obvious to them that you think so. No assessor will ever tell that he was swayed by 'emotion' into reaching a given conclusion. He will tell you that strict logic, and that alone, took him to the conclusion. In short, an advocate must not play with the emotions of the assessors, because they will see through it fairly quickly. Therefore, even as you are addressing the assessors, it is important to present your address in the form of well built arguments, 
while the emphasis and appeal can be emotional. The facts have to be marshalled to form the steps of the arguments in order to lead them to the conclusion that is desired, and in such work rhetoric has its place. As I said earlier, it has to be controlled. What that means is that an advocate must learn when it is suitable and when it is not.

Other than making speeches, an advocate is also called upon to handle the evidence which he calls in support of his case. An advocate will only be able to do this if he is thoroughly familiar with the facts, and has sorted those facts that are relevant from those that are not relevant. He has to do this before he has stepped inside the Court.

The object of any Examination-in-Chief must enable a witness to make his own impression on the court. He will never be able to do that if Counsel insists on asking leading questions. In my view, it is very bad practice for Counsel to lead a witness, particularly on disputed matters of fact, and especially so in criminal cases. Evidence elicited by asking leading questions diminishes the value of the evidence, because in truth it is the advocate that is giving the evidence, with the witness merely assenting. The witness has no opportunity of making his own impression.

The art of Examination-in-Chief is to take the witness by short steps and simple questions. The questions should never suggest the answer required. They should be so framed that they cannot fail to produce the answer wanted. Long questions merely confuse the witness, particularly so when they have to be translated into Hindi or Fijian as is the case in Fiji. Short questions make the task of the interpreter easier. The witness finds it easier to answer simple questions and gains confidence as the Examination proceeds. 
It is not possible to teach anyone how to cross examine. It is possible to study examples of it. Probably the best way of receiving instructions on it is to listen to someone who knows how to do it. But let me make some general comments on this subject. In my view, the importance of cross examination is probably overrated, although it remains a powerful weapon, particularly when the evidence adduced is patently dishonest or grossly mistaken. There is an impression in some quarters that cross examination is the art of asking many questions about many things. The longer it lasts the better it is said to be. This belief partly accounts for the very prolonged trials that we have in this country I recall prosecuting a murder case in the Lautoka High Court (then called the Supreme Court) in the late sixties, when the trial within a trial lasted for some thirty days, most of it taken up in cross examination of police officers. When the matter went on Appeal to the Fiji Court of Appeal, the record consisted of some five volumes. Looking to the relevant bits of evidence was bit like looking for a needle in a haystack. The most effective cross examinations are often the shortest, although I accept that there are some cases where it has to be extensive, particularly in cases where the evidence is clearly fabricated.

Questions in cross examinations have to be directed to a particular end. They should be directed to enhance your case and to diminish your opponents'. For example, if you are defending a murder case, and on the facts the only line of defense available to you is provocation, then you cross examination should be focused on that issue and that issue alone. If you are meandering all over the place, on peripheral issues not relevant to your defense, then you only help take away from the one issue that is all-important. In my own experience, particularly in a criminal case, I find it useful to first determine your line of defense (consistent, of course, 
with the instructions of your client) and then to identity the weaknesses in the prosecution's case and confine your cross examination to those two areas.

Cross examination is a dangerous weapon. If a witness has not given any evidence adverse to your client, leave him alone. Do not ask questions for the sake of it. Never afford a witness the opportunity to say one thing that could be fatal to your client. We have all been victims of that at one time or another. Over the years, I have seen Counsel fall victim to that one question again and again.

Let me give you an example. Some years ago, I was representing a man charged with arson. The only evidence against him was his alleged confession made to the Police. He claimed that the confession was a fabrication, and that in any event he had been beaten up and otherwise oppressed. He gave evidence in support. I called the accused man's relative as a witness, but only to prove that the accused was taken from his home late at night and that the time he had spent in the company of the Police was well in excess of what the Police made out.

This relative had accompanied the accused with the Police to a school where the interview took place. I did not adduce any other evidence from this witness. The Prosecutor then cross examined him at great length. His last question was: 'While you were in the school compound, did you hear any noise coming from one of the classrooms?' The answer was 'Yes, it was the sound of distress, it sounded as if someone was being beaten up, or words to that effect. The Judge threw out the confession. In his ruling, he made a great deal of the fact that this evidence had come out, not in evidence-in-chief, but in the cross examination of the witness and that he was inclined to believe it in that it had at least given rise to doubts in his mind. 
The danger with cross examination lies not only in what is asked, but how it is asked. Some practitioners seem to think that cross examination is the art of examining crossly. There is little point in bullying a witness. This approach often creates sympathy for the witness, both with the Judge and with the assessors. It is said, and quite rightly, that the most deadly cross examination is often the most courteous. We must remember that most people who come before our courts are simple people unfamiliar with formal Court surroundings. Some are illiterate. Bullying and badgering such people is hardly fair. From my experience, most Judges take very unkindly to such practices.

By and large, most witnesses who come to give evidence are obviously truthful persons. (I was intrigued to read only the other day that in 1967, a Counsel told the House of Lords: 'In criminal cases a large number of the clients are rogues and in many civil cases the clients are unreliable.') You cannot change the character of the evidence given by a truthful witnesses by cross examination, except to make it stronger. The more you cross examine the more obvious it will become that the witness is telling the truth. With such witnesses, it is best to ask only essential questions and get them out of the witness box as soon as you can. The longer they stay in the box, the deeper the impression they make against you.

The work of an advocate is not easy. For a variety of reasons, legal proceedings can cause severe headaches for advocates. It is difficult not to sympathize with the defense counsel who is said to have told the Jury in his closing speech: 'I am doing my job to the best of my ability with what I have had to work with.' That is the lot of an advocate, having to work with the case he has and not the case he would like to have had. An advocate is always working under pressure, pressure from the Court and pressure 
from the client. There is a report of a case in which the Judge severely reprimanded Counsel because the case listed for two weeks had taken 75 days to try. The Counsel's closing speech lasted 28 hours, and was criticized by the Judge for its lack of structure and its irrelevant content. 'You required prompting from the prosecution and the Court,' remarked the Judge, 'and even from the foreman of the Jury.'

No matter how hard an advocate tries, the Judge may not appreciate his efforts. The Judge of course does not always say so, but the advocate is expected to know and understand it. So it is with your clients; you are invariably judged not by how you performed, but by what results you secured. That puts an enormous burden on the advocate. An advocate can expect to lose as many cases as he wins. $\mathrm{He}$, therefore, requires a thick skin. He has to get accustomed to being told that what he has so confidently submitted 'is without foundation in law or fact or common sense.'

An advocate also faces a moral dilemma. Every advocate knows that acting in the interests of a client does not always promote the interests of society in general; and there is always the matter of his conscience. Every advocate has to comply with the complex code of ethics. The code purports to reconcile his duties to his client with his duties to his society. Clearly, there are limits to the extent to which he can and should act as a mouthpiece of his client.

There is a fine line between good advocacy which focuses on the strength of his case and appeals to the emotions of the court on the one hand, and sharp practices and sham theatricals calculated to mislead the Court on the other. There is always a point where an advocate's obligations to his client end, and obligations to society begin. 


\section{NOTES}

1. A conventional account of the CSR is Michael Moynagh, Brown or White? A history of the Fiji sugar industry, 1873-1973 (Canberra: ANU Pacific Research Monograph Series no 5, 1981).

2. A convenient discussion of these issues is my Broken Waves: A history of the Fiji Islands in the 20th century (Honolulu: University of Hawaii Press, 1992).

3. This is discussed at length in Sir Alan Burns et.al, Report of the Commission of Enquiry into the Natural Resources and Population Trends of the Colony of Fiji, Legislative Council Paper 1/1960.

4. See my 'Veil of Dishonour: Sexual Jealousy and Suicide on Fiji Plantations,' Journal of Pacific History (1985): 20, 135-155.

5. Quoted in Dharma Kumar, Land and Caste in South India (Cambridge: Cambridge University Press, 1965), 137. This excellent book provides insights into the society and political economy of South India in the late 19th and early 20th centuries.

6. This is treated at length in my Girmitiyas: The origins of the Fiji Indians (Canberra: Journal of Pacific History Monograph, 1983). More generally, see KL Gillion, Fiji's Indian Migrants. A history to the end of indenture in 1920 (Melbourne: Oxford University Press, 1962).

7. This is from a talk reprinted in a Sangam souvenir magazine, given to me courtesy of Mr Jag Nadan.

8. I treat the historiographical debate about indenture in my Chalo Jahaji: On a journey through indenture in Fiji (Suva: Fiji Museum, 2000).

9. Quoted in Edgar Thurston, Castes and Tribes of Southern India (1909, rep 1987), Indian Educational Service, 94-95.

10. Ibid. 98-99.

11. In South Africa, where South Indians outnumber North Indians, the latter are derisively called 'Roti,' leavened bread, good-for-nothing!

12. This is based on potted history of the organisation in its annual souvenir magazines published at the time of its annual convention in April of each year. 
The precise details of the actual leading lights of early Sangam, its benefactors and supporters are in Bal Govinda, 'The Arrival of Indians in Fiji and the Formation of Then India Sanmarga Ikkya Sangam,' unpublished manuscript, ca 2001.

13. This is based on Sangam files at the National Archives of Fiji, but see my Vision for Change for a summary.

14. For valuable information, see M.R. Balaganapathi, Swami Rudrananda: The visionary reformist, undated 31 page manuscript sent to me by the author.

15. See Stewart Firth and Daryl Tarte (eds), 20th Century Fiji: People who shaped the nation (Suva: University of the South Pacific, 2001), 133-34: 'He was a fiery man and when angered his flinty eyes blazed and he gesticulated fiercely.'

16. I base this on my conversation with many South Indian community leaders over a long period of time.

17. AD Patel singled this person out for praise for his effort on behalf of the school. He was in all probability in colonial district administration or an officer of the CSR.

18. Reddy had Natabua Secondary School in mind, a government school for Indian children started in 1918.

19. I am grateful for information on the Reddy family history to Janardan Reddy who has written a small monograph on it.

20. Numerous people have told me that Government House was struck down by lightning the day the Sadhu was deported, suggesting divine retribution.

21. WEH Stanner, The South Seas in Transition: Post-War Rehabilitation and Reconstruction in Three British Pacific Dependencies (Sydney: Australasian Publishing Company, 1953), 179.

22. JW Coulter, Fiji: Little India of the Pacific (Chicago: University of Chicago Press, 1942), 93. One of the villages he studied was Laqere, across the river from my own. I have attempted to describe life in my village, Tabia, in the 1950s and 1960s in my Mr Tulsi's Store: A Fijian Journey (Canberra: Pandanus Books, 2001). For another evocation, see Rajendra Prasad, Tears in Paradise: A Personal and Historical Journey, 1879-2004 (Auckland: Glade Publishers, 2004). 


\section{INHERITANCE}

23 An excellent guide, with an introductory Fiji perspective on Indian movies, is Vijay Mishra, The Bollywood Cinema: Temples of Desire (New York: Routledge, 2002).

24. Joni Madraiwiwi, A Personal Perspective: The speeches of Joni Madraiwiwi (Suva: Institute of Pacific Studies, 2008), 277.

25. Chanan was our immediate neighbour in Tabia, Labasa. He still runs his tailoring business in Suva.

26. Erik Møse to Brij V Lal, personal correspondence, 20 Feb. 2009

27. A somewhat dated account of Gordon's life is in JK Chapman, The Career of Arthur Hamilton Gordon: First Lord Stanmore, 1829-1912 (Toronto: University of Toronto Press, 1964).

28. The distortions Gordon's policies caused to the workings of indigenous Fijian society are treated in Peter France, Charter of the Land: Custom and colonization in Fiji (Melbourne: Oxford University Press, 1969).

29. An account of the Fijian leader's life is in Deryck Scarr, Ratu Sukuna: Soldier, Statesman, Man of Two Worlds (London: Macmillan, 1980).

30. Peter France, Charter of the Land. Custom and colonization in Fiji (Melbourne: Oxford University Press, 1969).

31. See Josefata Kamikamica, 'Fiji native land: Issues and challenges', in Brij V Lal and Tomasi Vakatora (eds), Fiji in Transition: Research Papers of the Fiji Constitution Review Commission vol.1 (Suva: University of the South Pacific, 1997), 259-290. Also Isireli Lasaqa, The Fijian People: before and after independence (Canberra: Australian National University Press, 1984), $5 \mathrm{ff}$.

32. Sir Alan Burns, WT Watson and AT Peacock, Report of the commission of Enquiry into the Natural Resources and Populations Trends of the Colony of Fiji, 1959 (Legislative Council Paper 1/1960).

33. This is based on the text of the Agricultural Landlord and Tenant Ordinance published in the Fiji Royal Gazette.

34. Legislative Council debate reproduced in the publication National Federation Party: Uniting Fiji (Suva, NFP, 2008), 39. 
35. Letter from Trafford Smith to Sir Derek Jakeway, 31 Aug 1964 in CO 1036/1458, no 64

36. On the history of the CSR, see Michael Moynagh, Brown or White? A history of the Fiji sugar industry, 1873-1973 (Canberra: ANU, Pacific Research Monograph Series, no.5, 1981).

37. See my Chalo Jahaji: On a journey through indenture in Fiji (Suva: Fiji Museum, and Canberra: Division of Pacific and Asian History, 2000).

38. See K Gillion, Fiji Indians: Challenge to European Dominance, 1920-1946 (Canberra: Australian National University Press, 1977).

39. See my $A$ Vision for Change: AD Patel and the politics of Fiji (Canberra: National Centre for Development Studies, 1997).

40. For a full account, see $A$ Vision for Change, 59-82. The confidential files upon which this account is based are available at the National Archives of Fiji. A self-serving and factually slanted account by a participant is in Ajodhya Prasad, A History of the Kisan Sangh (in Hindi). Prasad was later a founding member of the Alliance Party.

41. For more on this, see generally my $A$ Vision for Change.

42. The quotes are from a copy of the constitution in my possession.

43. For this, apart from figures from the census reports, I am grateful to Dr Satya Srivastva for her research on population and Indo-Fijian women in Fiji.

44. See my Broken Waves, 143-146.

45. These figures are extracted from Fiji Annual Reports published by the Colonial Office, London.

46. For a detailed discussion, see Ahmed Ali, 'Fiji and the Franchise, 1900-1937,' unpublished PhD dissertation, ANU, 1973, a sadly unrevised version of which was published posthumously in 2008 .

47. For more on this, see Ahmed Ali, Plantation to Politics: Studies on Fiji Indians (Suva: Fiji Times, 1980), 107-129.

48. For a detailed documentary history of the move towards independence, see my Fiji: British Documents on the end of empire (London: the Stationery Office, 
2006). Detailed reference will therefore be kept to a minimum.

49. The full letter is reproduced in my Broken Waves: A history of the Fiji Islands in the 20th century (Honolulu: University of Hawaii Press, 1992), 189.

50. 'Policy in Fiji,' CO 1036/612, no. 11.

51. The discussion below and the quotes come from Chapter 3 of my Fiji: British Documents on the end of Empire, Document numbers 53-84. A summary is in my A Bomb Lies Buried.

52. See generally my Vision for Change, 209-211.

53. The Conference report (9 August 1965) is in CO 1036/1510, no. 2.

54. AJ Fairclough to Sir Derek Jakeway, 29 June 1967 in FCO 32/59

55. Frank Rennie, The Regular Soldier (Auckland, 1986), 286. Mara is reported as having said, 'We might let things take their course for a while.'

56. Fiji Times 27 Sept. 1968.

57. JH Lambert to JDB Shaw, 19 July 1968 in FC032/31.

58. See Fiji Intelligence Report, C0 1036/1216, no. E91 and E 2/88.

59. The meeting took place at the residence of Navin Patel, in Ba. Navin's parents were Charotari Patels, like AD.

60. See GP Lloyd to JC Morgan 15 Nov. 1968, FCO 32/401, no 3.

61. GTP Marshall to EJ Emery, 1 May 1969, FCO 32/401, no. 81.

62. Reported in Fiji Times, 8 Aug. 1975. Mara is reported in Fiji Nation vol. 1, no.18 (1970), 1, urging flexibility on constitutional dialogue. 'No one should think that even when the Constitution is approved and we have resolved all our ideas on representation, that this is the last step and that all is immutable forever.'

63. The submission itself was prepared by Raj Vasil of the Victoria University of Wellington, with the assistance of Jai Narayan, Irene's husband.

64 See Report of the Royal Commission Appointed for the Purpose of Considering and Making Recommendations as to the Most Appropriate Method of Election Members to, and Representing the People of Fiji in, the House of Representatives, Fiji Parliamentary Paper 24/1975. 
65. Letter from Sir Robert Foster to EJ Emery, 23 Dec 1969 in FCO 32/405, no. 229.

66. Quoted by Jai Raj Singh, Fiji Sun, 20 Sept. 1977.

67. Hansard, 9 Oct. 1975.

68. Hansard, 27 May 1977.

69. Minute by Sir Leslie Monson to Lord Shepherd, 10 Oct 1969 in FCO 32/404. no. 154

70. See Fiji Constitutional Discussions: Report on Lord Shepherd's visit to Fiji, January 1970, in Legislative Council Paper 1/1970.

71. ' Fiji' final despatch from Sir Robert Foster to Sir Alec Douglas-Home, 8 Oct 1970, FCO 32/606, no.1

72. Talk given to a workshop organized by the Director of Public Prosecutions (Nazhat Shameem) in the mid-1990s. 


\title{
CHAPTER 2: BAPTISM BY FIRE
}

\author{
Where has the tree gone that locked \\ Earth to the sky? What is under my hands that I cannot feel? \\ Philip Larkin
}

\begin{abstract}
Tai ai Ram Reddy was appointed to the Senate in 1972 by Siddiq Koya, which he accepted after some months of private deliberation. His term in the Senate was unremarkable, certainly in contrast to what was to follow in the late 1970s. He was, for the most part, an interested bystander, not an active participant, in Indo-Fijian politics and had no ambition for a political career, let alone political leadership of the Indo-Fijian community. Law was his passion not politics. But given his reputation and status as a leading barrister and his cultural background, it was inevitable that he would be drafted into politics sooner or later, whether he liked it or not. It turned out to be sooner rather than later. Reddy was thrust into national prominence in the April 1977 general elections and was caught in the whirlpool of chaos that followed in the National Federation Party. It was not an especially happy or productive time for him in politics. The 1970s were a dark time for the National Federation Party, whose public quarrels about leadership and other matters of no lasting significance split the party and bitterly divided the Indo-Fijian community from which it took a very long time to recover. For some, the wounds are still raw beneath the surface, more than thirty years later. Getting the party's house in order and introducing a semblance of unity and purposefulness to its work would consume virtually all of Reddy's energies in these unhappily wasted years. This chapter revisits the old battlegrounds of Indo-Fijian politics of the 1970s, the issues over which pitched battles were fought, the fractured legacy they produced
\end{abstract}


which Reddy inherited during the early part of his political career, and the manner in which he tried to heal the wounds of the past. The contentious debates over race and land which so dominated the political landscape of the 1970s would continue to hobble effective political dialogue well into the next decade and beyond. In different forms and to different degrees, they are still with us more than three decades later.

\section{THE INDEPENDENCE DECADE: DECLINE}

The independence decade did not begin well for the NFP. The purposeful cohesiveness which had characterized the party in the 1960s was evaporating. Then, the NFP set the agenda for debate on the most important challenges facing the country: the terms and conditions of independence, the reforms in the sugar industry, the nature of economic development desirable and appropriate for Fiji, national identity and cultural preservation. It was a party of ideas and vision and viewed widely as a worthy and respected opponent of the ruling Alliance Party. In the 1970s, however, the NFP was reduced to a pale shadow of its former self, bereft of ideas, squabbling, often at war with itself, and with all its energies consumed by internal strife, unable to perform effectively on the national stage as a government-in-waiting. Siddiq Koya's top-down leadership style came in for criticism less than a year after independence. In June 1971, Abhay Awasthi, an important party functionary in Suva, circulated a paper for internal discussion in which he outlined the party's weak spots. 'The main weakness is in the leadership of the party,' the paper began. 'The President [Koya] has failed to maintain the dignity — standard — quality control of the party's machinery. This is an intolerable failure and accounts for the highest percentage of decline - frustration and weakening of party spirit among the rank and file of the membership. The past procedures and precedents have been totally ignored.' The party secretariat was 'almost defunct.' Then there was the 'negligence on the part of most of our members of Parliament.' 'The neglect of their constituents constitutes is not only the breach of faith deposited with them but a clear fraud of the constituency allowances they draw for services they 
should render to the electors they represent,' the paper said. The ordinary party members themselves were to blame to some extent because 'we have petted our leaders too much for too long — we have been too lenient on them - we left the destiny of the party solely in their hands. There was no check on their activities.'

In March 1972, RD Patel, AD Patel's younger brother, the party's Treasurer and member for the Ba communal constituency, reportedly resigned but kept it a secret 'in the interests of the party.' He would formally resign from the NFP in 1975 in disagreement with Koya over his proposal for a compulsory deduction of $\$ 2.50$ per ton for the Sugar Price Stabilization Fund, about which more later. A few months later, Karam Ramrakha, the stormy petrel and intellectually agile General Secretary of the party, resigned briefly after a failed attempt to challenge Koya's leadership, admitting to being 'outdone, outmanoeuvred and useless,' ${ }^{2}$ and saying: 'We are faced with false festivals, false forums and false facades which conceal the real basic problem' which was that the NFP seemed 'doomed to eternal opposition because of voting patterns which showed little signs of change.' Koya dismissed the challenge as 'normal happening' in a democratic party, but as he would discover a few years later, the matter was not as simple as that. 'Under the late Mr AD Patel,' wrote Ahmed Ali, historian and later an Alliance parliamentarian and cabinet minister, 'the party had always displayed a united front - his personality dominated all; Koya seemed to lack Patel's stature, magnetism and authority. ${ }^{4}$ Nonetheless, as Pramod Rae points out, despite all the dissatisfaction with Koya's style, there was no challenge to his leadership in the parliamentary caucus until 1977.

The confusions and divisions were evident as the party prepared for Fiji's first post-independence general elections in 1972. Factions developed as those not selected as candidate aired their displeasure in public, not for the last time in the party's history, as will be seen later. 'Its past was undermined,' Ali wrote, 'and the differences of the leaders infect their supporters who, in certain cases, put loyalty to their patron above loyalty to the party.' RD Patel did not want Koya to campaign in his Ba constituency while Koya 
kept Patel out of Lautoka. Preoccupied with debilitating internal friction, the NFP entered the campaign unprepared. It offered the electorate an unbelievably fanciful basket of promises: immediate water supplies to all areas, free and compulsory education up to at least two years of secondary school, free medical services, old age pension, a social security system and a new shipping line, the abolition of the basic tax and the nationalization of the gold mine along with the promise to make Fiji a republic with an elected Fijian head of state. It was what the Fiji Times chief-of-staff, John Carter, called a perfect example of 'impulsive populism.' Promises had to be made; it was the way things were done in elections; but no one took them seriously, or indeed in this case could take them seriously, including probably the party leaders themselves.

The NFP made the tall promises knowing very well that they would not come to power anyway, and many did not think Koya was a credible alternative Prime Minister. Ahmed Ali again (and I quote him because he was one of the few who wrote extensively about the elections): 'SM Koya seemed to have lost his former lustre. Even his followers were disgruntled; some found him ineffectual, others branded him an autocrat, and the diehards could not forgive him the compromises of bi-partisanship [during the independence negotiations]. He failed to convince the Fijians and the Europeans that he was a suitable alternative Prime Minister.' The contrast with Ratu Sir Kamisese Mara was stark. The Alliance leader, once reticent and shy and uncertain of his moves, had grown visibly in confidence since assuming power in late 1967 as Chief Minister, making him 'an attractive personality drawing all races towards him. He seemed to generate trust and hope.' International accolade and many honorary degrees confirmed his steadily growing stature at home and abroad. Even those who disagreed with the Alliance found its leader appealing.

The Alliance won the elections comfortably, capturing thirty three of the fifty two seats in the House of Representatives to the NFP's 19. The Alliance's hold on the Fijian constituency was strengthened, from 67 per cent in 1966 to 83 per cent in 1972. The Indian communal vote for the 
NFP slipped from 78 per cent in 1968 to 75 per cent in 1972. More worrying for the party, nearly 24 per cent Indo-Fijians voted for the Alliance. The Indo-Fijians in the Alliance were not, as they said, Changu Mangu, hoi polloi, but people of credibility and stature in their own community, such as Kishore Govind, a future high court judge, Sir Vijay R Singh, MT Khan, James Shankar Singh, Manikam Pillay, the last four serving in the Alliance cabinet for various periods of time. Other supporters outside parliament included businessmen YP Reddy and Mahendra Motibhai Patel, the Jadurams of Labasa, Faiz Sherani, president of the Fiji Muslim League, transport magnate Shreedhar Maharaj, President of the large Sanatan Dharam Pratinidhi Sabha of Fiji, the powerful Mishra clan, the Deokis and many others like them, and many leading lights of the Arya Samaj as well. The Indian Alliance clearly comprised an influential group of people.

Some knew which side of the bread was buttered, so to speak, and prided themselves on their pragmatism about how to get ahead, while there were many who genuinely believed in the Alliance's multiracial philosophy and promise, among them James Shankar Singh. This was the height of Indo-Fijian support for the Alliance party, the highest percentage of Indian communal votes it would ever get, along with the best calibre of candidates it would put up in elections. Before the decade was over, all the leading lights of the Indian Alliance would leave the party for a variety of reasons, including dissatisfaction with Ratu Mara's leadership and his gradual proFijian tilt, and heading, again for a variety of reasons, to the fold of the National Federation Party and later, from there, to the Fiji Labour Party.

The NFP's dismal performance among Fijians - winning only a paltry 2 per cent of the total communal votes - was expected, but still disappointing. It had hoped for a much better result, placing hope in the merger of Apisai Tora's and Isikeli Nadalo's National Democratic Party with the Federation in 1969 through the much-touted 'Operation Taukei' to attract more Fijians, but without success. (The original Taukei Movement, Reddy once quipped, was the creation of the Federation Party!) The initiative was no challenge to the Fijian Association whose infrastructure and influence 
reached out to the furthest villages in Fiji. Ratu Julian Toganivalu and Ratu Mosese Varasikete were eminent, highly educated Fijian members, along with Ro Asela Logavatu, but they were all chiefs without followers among their own people, and no match at all for Ratu Mara and the other paramount chiefs (Ratu Edward Cakobau, Ratu George Cakobau, Ratu Penaia Ganilau) who were the pillars of the Fijian establishment and tutored by the departing British for national political leadership. How to penetrate the Fijian heartland, firmly in the control of Fijian institutions such as the Great Council of Chiefs and the Methodist Church, would be one of the greatest challenges Reddy would face during his time at the helm of the National Federation Party, a challenge which would lead him eventually to re-think his approach to Fiji politics, from one based on an open competition for Fijian votes (which led to charges of Indo-Fijian leaders trying to divide the Fijians for their own political gain and of the Alliance employing similar tactics among the Indo-Fijians) to a more structured consociational style of politics with political parties sharing power through multi-ethnic coalitions and governments, drawing their strength from the unity of the respective ethnic communities.

\section{THE BUTADROKA EFFECT}

The elections had only temporarily eclipsed the deepening schisms in the NFP, which came to the surface as soon as they were over. Koya's fortunes as political leader continued to plummet. What had once been seen as Koya's great strength was now perceived as his great weakness. In 1969 and 1970, Koya had used up a great deal of his own political capital in developing an amicable working relationship with Mara, eager, as we have seen, to avoid taking any steps which might derail Fiji's smooth transition to independence. Koya trusted Mara, he told officials of the Colonial Office, as the one Fijian leader with whom he could work. The two had traveled the world together to assure sceptics that the country had gone into independence through bi-partisan support. Mara told the Decolonization Committee of the United Nations, with Koya by his side, that the NFP leader had 'played 
a notable and constructive part in our moves towards independence,' that their 'objectives were identical in their own separate ways. ${ }^{6}$ There were regular breakfast sessions at the Travelodge in Suva between 'Sid' and 'Kamisese.' The hotel guests were told how the two men together ran the country.

Within a short time, however, the euphoria of the early feel-good cooperation between the two leaders vanished. Mara was now safely ensconced in power, and keen to exercise it, to stamp his authority on the national scene. The early 1970s were golden years for the Alliance leader. He enjoyed enormous popularity at home and unqualified respect abroad for his advocacy of multiracialism and his stated commitment to democratic values and principles. Under his leadership, Fiji was firmly on its way to peace and prosperity. Overseas honours came in droves in the form of honorary degrees and invitations to address international gatherings. The world saw him as the undisputed leader not only of Fiji but of the broader South Pacific region as well, the founding father of regional cooperation, the advocate of the 'Pacific Way' the title of his memoirs. With the world eating out of his hands, Mara now had less political need of Koya than he had in the late colonial period and in the early years of independence. The NFP leader had served his purpose, and Mara was moving on to greater and greener pastures on his own. 'Mara first used him [Koya] to drive a wedge within the party and then cut him adrift so he had nowhere to go,' wrote Karam Ramrakha. ${ }^{7}$ It was not for no reason that Apisai Tora often called Mara Machiavellian.

Ratu Mara had his own political constituency to placate, especially those who thought him too conciliatory and accommodating towards the non-Fijians, more mindful of their interests and concerns at the expense of those of his own people. Relations between the two men cooled to the point of no contact in the mid-1970s. Mara claimed in June 1977 that from January 1974 to 21 January 1977, Koya had not replied to any one of his letters to him, not even acknowledging receiving them as a matter of courtesy. ${ }^{8}$ This, if true, is an incredible dereliction of duty because the Constitution 
provided for a consultative role for the Leader of the Opposition in making high level appointments in the judiciary and the public service. ${ }^{9}$ Relations deteriorated to such an extent that the Alliance leader threatened to resign after the September 1977 elections if Koya were returned as Leader of the Opposition. He would ask someone else in his party to take over because he could not simply work with the man. 'I have had enough of the four years I have had with him,' he said. ${ }^{10}$ Whether the Alliance leader was serious in his threats or not, it is difficult to tell: but one thing we do know is that Mara was in the habit of making such dramatic threats periodically to rally everyone behind him, playing upon his sense of indispensability to the nation. In this instance, he was probably hoping that his public utterances against Koya might assist his rivals (which they did). But of the soured relations between the two men there was no doubt.

Personality and circumstance played a role in the developing impasse between the two men, but the problem went beyond personalities. It is a truism that in ethnically polarized politics, moderation tends to be the loser, or comes second best. Concession and compromise are always viewed suspiciously as signs of failure and defeat, and the effort to widen the multiracial base of parties as a tactic to divide and conquer. This was not an aberration in Fiji; it was, in fact, a direct result of the kind of political culture that the 1970 Constitution encouraged. And yet, neither Koya nor Mara saw the connection between the two. Jai Ram Reddy would face a similar dilemma in the late 1990s. His effort to work cooperatively with Sitiveni Rabuka to review the flawed 1990 Constitution, his forming a coalition with him to contest the 1999 election and offering the Prime Ministership to the leader of the SVT party, should the Coalition win the elections, were all advertised by his opponents as the signs of a weak leader willing to 'sell' the interests of his own people for his short term gain, though what these short term gains were, no one elaborated. History has a curious way of repeating in Fiji.

The first threat to the politics of moderation came from Sakeasi Bakewa Butadroka, the founder of the Fijian Nationalist Party in 1974. From the province of Rewa (where he had once been the chair of the Provincial 
Council), he represented the neglected and generally poor Serua-Namosi hinterland in Southwest Viti Levu. Butadroka was an Assistant Minister for Cooperatives in the first post-independence Alliance government. ${ }^{11}$ Independent-minded and theatrical, not enamoured of the hierarchical social structures and cultural protocols of eastern, more Polynesian parts of Fiji, Butadroka aired his nationalist views privately within his party on many occasions over many years, but was ignored because what he was proposing was deemed to be 'impracticable.' Getting nowhere with his plans, he erupted on the national scene with a new party and a new emotive slogan: 'Fiji for Fijians.' His new trademark red bow tie, he said, symbolized the spilling of (Indian) blood if Fijians were not in political control. On 9 October 1975, on the eve of Fiji's fifth year of independence, Butadroka moved a motion in the House of Representatives that 'This House agrees that the time has arrived when Indians or people of Indian origin in this country be repatriated back to India and that their travelling expenses back home and compensation for their properties in this country be met by the British Government.' ${ }^{32}$ The motion, seconded on a pro forma basis by the Alliance's Kishor Govind to get a debate going, unleashed a torrent of unprecedented emotion across the floor of the House.

History, human rights, constitutional protection, the sufferings of the past, the importance of tolerance in multi-ethnic societies, all found their place in the wide ranging debate that grabbed the national attention as few other issues did. Butadroka's point was simple. The Indo-Fijians were the bottleneck to Fijian progress, the noose around their neck. The Indo-Fijian community continued to progress while the Fijian 'commits suicide in his own country.' The Fijian people were not consulted about their introduction, and at independence, Fiji should have been returned to the Fijian people and their leaders. The indigenous Fijian 'race' should always be in political control of the country, not vulagis, foreigners, who had prospered through the generosity of the taukei, the indigenous people. The leaders of the Fijian people had hoodwinked them for far too long. Ratu Mara came in for a particularly vicious attack. He was accused of 'thinking only of his 
name and honour,' when he 'sold the Fijian interests at the wholesale rate.' Butadroka was nothing if not a powerful, charismatic speaker, by turns theatrical and threatening, serious and disarming, one of the truly instinctive politicians on the Fijian side of politics. Apisai Tora was another. ${ }^{13}$

Ratu Mara condemned the motion in 'the strongest terms possible,' although he was acutely aware of the effect Butadroka's rhetoric had on the average Fijian in the villages. He introduced an amendment to the motion: 'To reaffirm the credit due to the Indians as well as to Europeans, Chinese and Pacific Islanders for the role they have played, are playing and will assuredly continue to play in the development of Fiji, and in particular their concern and willingness to support Government's policy in helping the Fijian people to improve their economic situation as quickly as possible.' Hoping for a bi-partisan opposition to the motion, he sent a draft to the NFP before the debate, but received no reply: not surprising in view of the ruptured relations between him and Koya. Questions were asked. Why did Mara mention other communities when the specific target of the original motion was the Indo-Fijian community? Because, he said in his defense, this was the first 'eviction' motion to come before parliament, and he wanted the other communities to know that their interests were also safeguarded by his government. And the second part of the amendment was designed simply to tell the Fijians that other communities were, indeed, trying to help them in different ways, directly and indirectly.

But politically all this was not enough for Koya and many in his party who thought Mara as usual was playing politics again, trying to have it both ways, an allegation angrily denied by the Alliance leader. Koya moved an amendment to Mara's amendment: 'That this House reaffirms that Indians along with all other races who are settled permanently in Fiji and their descendants are full and first class citizens, that Fiji is their homeland, that they are here to stay permanently and having regard to the Constitution of Fiji, this House calls upon every citizen and every organization in Fiji regardless of its ethnic, religious or political background to denounce publicly any person or organization which interferes with or disrupts the 
multiracial harmony of Fiji.' Siddiq Koya was in full cry. Butadroka was 'pathologically sick' he said vehemently, and his motion should not have been entertained in the parliamentary chambers in the first place, because it was against the spirit of the Constitution and breached the Public Order Act by prejudicing public peace, inciting hatred and inflaming racial dislike. Mara's amendment did not 'go far enough,' for a people 'looking for an assurance that Fiji is their home.' Koya said in his trademark style: 'We are not here under license; we are here as of right. Full stop!' Ratu Mara's outright refusal to endorse Koya's proposed amendment, or some modified version of it, was too much for the Opposition leader. It was the straw that broke the camel's back.

While Butadroka's motion was still being debated in parliament, Koya told a party rally at the old Suva Town Hall that the Alliance had in store plans to do legally what Butadroka was proposing to do illegally. $\mathrm{He}$ had proof of this secret plan, he thundered, which he would reveal to an independent commission of enquiry. 'My cup of disillusionment has come to the brink,' Koya said, and promised that the NFP would 'completely re-examine its relations with the Alliance and prepare to struggle to maintain the constitutional rights of Indians, Europeans, Chinese and other communities in Fiji. ${ }^{14}$ Mara was incensed at the allegations directed at him. If Koya could provide even a shred of evidence to back his claim, he would resign as Prime Minister and from parliament altogether. Koya did not respond. Perhaps he simply could not. There was no 'evidence.' The 'concept of multiracialism,' Koya said ruefully as he pondered the events of the past few weeks, 'has now become just words on paper, or perhaps words written on paper. Just words on paper, words spoken in the air. ${ }^{35}$ In this assessment, he was not wrong. Race relations were indeed the poorest they had been for a long time.

Butadroka's unsettling 'Deport the Indians' message made the headlines in Fiji and across the world. It came just a year after Idi Amin had summarily expelled long-term Indian settlers from Uganda. If it could happen in Uganda, many pondered privately, why could it not 
happen in Fiji? The Indo-Fijian community was squarely in Butadroka's gun sight, but there was another: the dominance of the eastern chiefs in the Fijian scheme of things. They owned nothing, he told his rallies, and yet they made all the decisions about the present and future of the Fijian people. He had the issue of land leases in mind, as we shall see. In some ways, Butadroka was making the same case as Tora had been doing in Western Viti Levu for more than a decade: the 'pernicious' presence of the eastern chiefs at the pinnacle of Fijian power, which was galling especially as western Viti Levu carried the nation's economy on its shoulders: pine, gold, sugar and latterly tourism. The anti-Mara and anti-Lauan sentiment formed an important cornerstone of Butadroka's political views. His personal dislike of the Alliance leader was complete. And his distrust of the Indo-Fijian community was not as narrowly bigoted as some believed. Ratu David Toganivalu, himself a man of wide multiracial friendships and sensible views, said that while many Fijians might not share the wording of the motion, deep down many shared the 'hidden sentiments that it expresses.' 'This is how we feel at times; at certain moments in times of anger this is what we say.' He was honest enough in his admission, but his words simply deepened the Indo-Fijians' sense of anxiety: to be told that this is how they were viewed by the Fijians, as foreigners and interlopers, after a century of living in the islands.

\section{AGRICULTURAL LANDLORD AND TENANT ACT (ALTA)}

No sooner was this motion debated in parliament than another perennially tricky issue raised its head: land. The land leases given under the ALTA were coming up for renewal. The original formula of $10+10+10$ had left everyone dissatisfied. The tenants complained that the leases were too short, causing great uncertainty in their minds and impeding long term planning and investment in agriculture. The landowners complained that the hardship clause in the legislation, which required them to prove that they would suffer greater hardship than the tenants if the leases were renewed before an independent tribunal, had left them at the mercy of outsiders. 
In practice, they found, hardship was extremely difficult to prove. In 1976, after nearly a decade of intermittent and interrupted work, the government introduced the Agricultural Landlord and Tenant Bill in parliament. The Bill proposed that the three ten year terms be replaced by a straight thirty year lease, that is, initial $20+10$. It recommended further that rent be assessed at six percent of the Unimproved Capital Value (UCV) of the land by a Committee of Valuers, comprising four persons, a chairperson and three valuers representing different sectors of the profession. Their principal task would be to determine and declare the unimproved capital value of different classes of agricultural land (A, B, C) rather than the individual values of each holding (which was impossible anyway). The UCV would be determined every five years at six percent per annum. The hardship clause was removed; now, if tenancy was not extended, it would only be on grounds of bad husbandry, giving the landlord the right to re-let. And the prohibition on the payment of premium by tenants and its acceptance by landlords was also removed. Premium equivalent to one year's rent was to be paid twice during the twenty year extension: in full, in advance and on the first day of extension.

NFP's Karam Ramrakha led the charge against the proposed legislation. A drafting error had inadvertently offered, or appeared to offer, fifty year leases, which some in the NFP erroneously and opportunistically claimed the Alliance had deliberately reduced to thirty years. Privately everyone conceded the drafting mistake. But their principal objection turned on the procedure of valuation, which Ramrakha said was the 'greatest killer.' The standard concept on which valuers worked was sales, 'but where land is a scarcity, where land mark up is artificially high, to take these sales was an oppression.' He suggested that rent should be based on what a 'willing tenant' could pay a 'willing landlord' provided they negotiated at arm's length and there was no compulsion or oppression on any side. Ramrakha asked for the bill to be deferred by six months for more reflection and analysis. Failing that, he would be happy if the rent fixing mechanism was given a twenty four month trial period to assess its suitability and fairness. The 
Alliance would not budge. ALTA was the best they could offer, nothing more, if they were to carry the Fijians with them.

Koya objected to several provisions of the Bill. To start with, it would not provide a 'permanent, durable solution.' What would happen when the present leases expired because the amendments did not set up any machinery for further leases for tenants who would then be left at the mercy of the landlords? He stressed that the valuation of a fair market rent would be difficult as there was 'no free market in land.' The value of land would be in relation to the market forces. If the value of freehold land went up, so would the value of agricultural land. He suggested that productivity and yield be used as rent-fixing criterion. He opposed the concept of share-farming. He said that the Crown land should be treated as a separate category altogether. No Crown tenants should be ejected, and Crown leases should be given in perpetuity. He suggested the setting up of a national land commission which would recommend land policies and review land leases from time to time. The land commission idea would be revived by Mahendra Chaudhry two decades later, but the Alliance could not reasonably be expected to accede to the demand. Land, after all, was power, Fijian power, and any attempt to dilute it, or take it away from the domain of Fijian institutions, such as the Native Land Trust Board, could not be countenanced for purely political reasons, if nothing else. Koya also thought that since ALTO was an expiring piece of legislation, and since the economy would suffer massively if the leasing arrangement was not regularized, he could strike a better bargain by insisting on longer leases. ${ }^{16}$

Between the initial meeting of the NFP Working Committee which had advised its parliamentary group to abstain from voting and the eve of the vote, several parliamentarians had a re-think. Eight of them wrote to Koya on 14 October (1975) to reconvene a meeting of the parliamentary board to reconsider the issue. "We have discussed the matter at length and some of us now feel that not supporting the Bill will be detrimental to the interests of the tenants. ${ }^{37}$ Koya refused outright, saying that nothing had changed materially for another meeting to take place. The original deci- 
sion to oppose the Bill would remain. But things had indeed changed. For one, the Alliance made it very plain that this was the best they could offer, and still carry the Great Council of Chiefs, the Fijian Affairs Board and the Native Land Trust Board with them. 'I can only commend the generosity of attitude this shows,' said Ratu Mara. 'It will certainly not be the Government's fault if this effort to improve the legislation is not allowed to take effect. ${ }^{38}$ Fijian landlords around the country let it be known that any longer term leases were simply out of the question.

Attorney General John Falvey convinced Ramrakha and others that their fears about the legislation being abused by the landlords against the tenants were ill-founded. And the Fiji Law Society and some of the country's top Indo-Fijian lawyers, Ram Krishna, Bhupendra Patel, PD Patel, Rishi Shankar, GP Shankar, Manikam Pillay, and RD Patel offered similar advice. ${ }^{19}$ A specially commissioned opinion from Australian lawyer, Ken Handley QC, confirmed it. At the end of if all, though, was the simple, brutal fact: with the Fijian establishment not willing to budge an inch on the issue, and drawing a firm line in the sand, there was no way a permanent solution could be found for the lease problem. Thirty years was no solution, everyone agreed, but it was better than what the existing legislation provided. Again, everyone expressed the hope that in thirty years, the atmosphere might be more conducive to further dialogue, especially if more Fijians entered commercial agriculture, thereby removing race from the equation. Koya, for his part, wanted the problem resolved once and for all, though how in the face of the Fijian opposition he could achieve this unilaterally remained unclear. His critics accused him of gimmickry, of playing to the gallery of a perennially vulnerable Indo-Fijian agricultural community for purely political purposes.

In the end, eight NFP parliamentarians crossed the floor and voted for the Bill. Among those who supported the Bill was Jai Ram Reddy, then in the Senate (but who resigned his seat there upon voting for the Bill against his leader's advice). Other prominent people outside parliament who supported the Bill included the influential Swami Rudrananda and 
MV Pillay, the future Alliance Attorney General, who argued that it was a positive Bill, even if a small step, in the right direction. 'If we reject the Bill,' argued Ramrakha, 'then we will be back again in the same old place and some farmers would lose their land after their leases expire. We feel that there are some good things in the Bill and hence we are asking people to accept in it in their best interest. ${ }^{20}$ 'There was no perfect solution to the land problem,' Jai Ram Reddy argued, 'but there could be no solution at all if the issue was dodged.' He said that a neutral and independent committee of valuers would minimize direct confrontation between tenants and landlords. ${ }^{21}$ Once the UCV was established, it would be gazetted and everyone would know about it. This would avoid individual landlords and tenants getting their own individual valuers to assess individual holdings. If tenants disagreed with the valuation or rental assessment, they could challenge it before the Central Agricultural Tribunal and, if still unsatisfied, could ask the Tribunal itself for an independent assessment. Rental on agricultural leases would be based not on the income derived from the land but on its capital values which, Reddy said, 'is fair.' It was also fair that tenants would receive compensation upon non-renewal or non-extension of leases.

Speaking to farmers in Uciwai, Lomolomo and Malomalo, Reddy said that the land issue was being unduly politicized. Some politicians 'keep the land issue alive for the coming general election. There is nothing live to harp on during election time next year and that's why some of them are trying to pour kerosene on the fire to keep it on.' People should not be 'fooled by thunderous speeches.'22 Perhaps he had Koya in mind. ALTA was a sensible, pragmatic solution to a perennially intractable problem. 'I am convinced in my heart that the solutions of the type we are seeking do not come for the asking,' Reddy said. ${ }^{23}$ Nonetheless, Reddy would be blamed again and again for 'selling out' Indian interests on land. An NFP parliamentarian from Ba and a strong Koya man, called the day the Bill was passed 'a dire black day on which the common people had been sold out. ${ }^{24} \mathrm{He}$ was not alone in echoing that sentiment. If only Reddy and others 


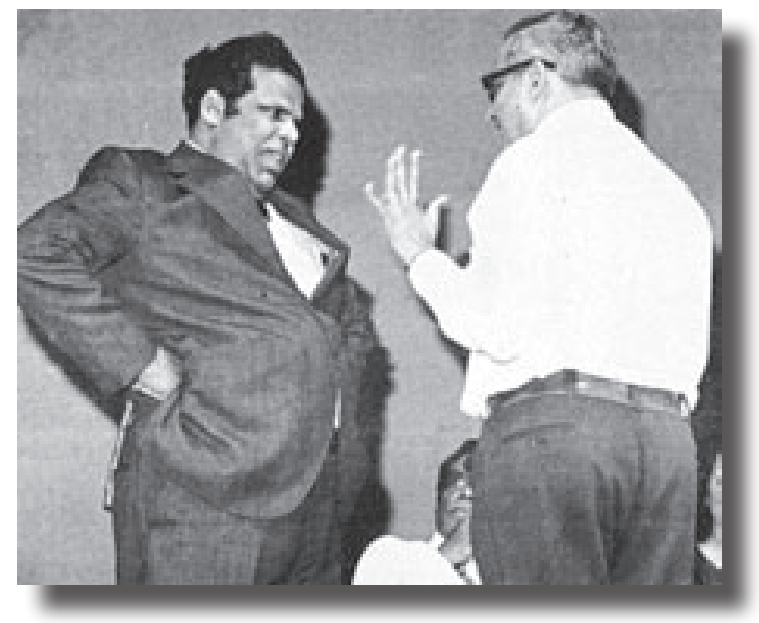

NFP implodes: Koya and Ramrakha confront each other over ALTA at the Suva Town Hall, 1976. Photo courtesy of Fiji Sun.

had supported his leader, the critics of the Bill said, the Indo-Fijian community would not have the land problem to face.

Reddy was unrepentant. As late as March 1998, he praised ALTA as a progressive piece of legislation. ${ }^{25}$ It improved the situation of the tenants and brought greater stability, he said. 'But let us not overlook one thing. The landowners to their credit did not reclaim one inch of their land in 1976. Every single agricultural lease was extended.' He said in February 1999 that no solution would be viable unless it was 'accepted by those who own the land and those who want to use it.' He coninued, 'I have brothers, uncles, aunts, relations and friends, all of whom are sitting on leasehold land. Just as I seek to understand the feelings of insecurity, often despondency of these people, I also think about what the landowners must think, how they must feel and what their aspirations might be. For practical and just solution of this problem, I think it is essential that we step into each other's shoes, be it momentarily, to see how others see the problem, because that understanding is essential in our search for just solutions. ${ }^{26}$ Reddy was ridiculed by his opponents for adopting this stance. The Fiji Labour Party would trash ALTA in the 1990s as a document of abject surrender, with Reddy as its principal architect, which, of course, he was not, because he was not an 
elected member of parliament when the Bill was passed. When the Qarase government sought to replace ALTA with another piece of legislation, the Native Land Trust Act (NLTA), which gave the landowners more say, Labour immediately did an about turn and defended ALTA as the best solution available. The unassailable truth articulated by Reddy remains.

\section{DEEPENING DIVISIONS}

The ALTA debate brought the internal divisions in the NFP out in the open, much to the growing dismay of its supporters and to the gleeful delight of its opponents. A Suva Town Hall meeting, after the Bill had been passed (on 10 November 1976) nearly erupted in a fist fight, with Koya and Ramrakha wagging fingers at each other on the stage in full view of the media and in front of some five hundred at the meeting (at which I was present). Koya called those who had supported the passage of ALTA 'bajaaru,' street prostitutes. ${ }^{27}$ People thought he had Irene Jai Narayan in mind when he uttered those offensive words. He might have, but it was also political speech-making of the old style, rough and hard, no-holds barred, but now the media was watching closely, and national elections were just around the corner. The abusive language was jarring when the NFP leader probably knew in his heart that a permanent solution to the land problem could never be had against the determined opposition of the Fijian landowners. But political points had to be secured. 'I think his days are numbered,' said Ramrakha, quite prophetically, as it turned out. ${ }^{28}$ Ugly epithets flew freely about 'gundaism' and 'gangsterism.' Retaliating, Koya wanted the six Indian NFP parliamentarians who had voted for the Bill removed from the Opposition benches in parliament, ${ }^{29}$ but not, interestingly enough, the two Fijian members who had also voted for it: Isikeli Nadalo and Atunaisa Maitoga. ${ }^{30}$ And he had the locks to the Opposition office changed to keep the backers of ALTA out. He also tried unsuccessfully (for the time being) to have Irene Jai Narayan replaced as the Opposition nominee on a Parliamentary Select Committee and Karam Ramrakha as the Opposition Whip. 
More trouble was in the offing when RD Patel resigned as Speaker of the House of Representatives and from the NFP because 'cancers of cliquism and opportunisim' were eating away the heart of the party. Dissatisfaction with Koya's leadership style was one issue, but what finally triggered Patel's resignation was his leader's refusal to support a proposal for a $\$ 2.50$ per ton deduction to establish a sugar price support fund. The fund had a long history. It was started by the United Kingdom's Ministry of Food shortly after World War II to cover war damages to the infrastructure of the sugar industry in the colonies, and to give the colonial producers some stability and funds for development purposes. Compulsory grower contribution to the fund was terminated following the recommendations of the Eve Commission in 1961, and the contributions reimbursed to the holders of contracts. This created some confusion as those who had sold their land contracts or had moved to other areas and acquired new contracts did not receive any reimbursement. Close to about $\$ 97,000$ remained in the fund after contract holders had withdrawn amounts equivalent to their contribution and credit. The Denning Arbitration in 1969 recommended a minimum guaranteed price per ton of cane. This fund could be used to augment the price in the lean years when the price of cane was less than the guaranteed minimum; and cane price following Lome were high. The deduction would guarantee a minimum price and, as a bonus, would be tax free. It would be free from other deductions as well as from attachment from the farmers' creditors. The farmers would be able to will their contribution, and in times of crisis, borrow against the sum they had contributed. ${ }^{31}$ To prevent a confusing situation from the past recurring, the fund would be in the name of the individual contract holder and not the contract itself, which could be sold to someone else. The proposal was supported by Swami Rudrananda, who had unparalleled knowledge of the sugar farming community and of the sugar industry generally.

At first, Koya was inclined to support the proposal after he and Mara had returned form a joint trip to Europe, but then changed his mind, which contributed to the complete breakdown of relations between the two lead- 
ers. ${ }^{32}$ Koya recalled how in the past farmers who had lost their land to the Fijians had also seen their funds being paid out to them. He refused to accept the proposals for the various safeguards mentioned above. He also feared that the funds would provide the government with a nest egg at the expense of the growers. Koya was falling out with Mara and saw no good reason to lend him a helping hand politically. In hindsight, the stabilization scheme seems eminently sensible, a kind of compulsory national provident fund for cane growers, but it was not to be. It was another of those missed opportunities that stalk the corridors of Indo-Fijian history. Koya did not realize it at the time, or perhaps he never did, that having Swamiji as an opponent was a fatal mistake. He was an immensely powerful figure in the cane growing community whose advice carried great weight. He was, with AD Patel, a leading figure in the 1943 strike and on sugar matters was always with Patel throughout the 1950s and 1960s. People were incensed when they heard a rumour that some fanatical Koya supporter had tugged at Swamiji's saffron attire. For Hindus, insulting people of the cloth is an unspeakable crime.

Koya's fate was sealed the moment he alienated the Swami. One by one, people who were once with him began to leave. In Lautoka, an ardent Koya supporter and an influential figure locally, Sardar Veerasami Mudaliar, criticized Koya's leadership, ${ }^{33}$ as did Pratap Singh, former Ba branch president. In Nausori, Councillor Krishnanand Chaudhry expressed no confidence in Koya. Many prominent party members resigned, including CH Patel, Madho Tikaram and Asha Bhai Patel. Ratu Julian Toganivalu switched his support to RD Patel and became a bitter critic of Koya's style of leadership, as did Wilfrid Sugrim, a former mayor of Lautoka, Maulvi Mohammed Hussain of Rifle Range and another prominent resident, Waliji. $^{34}$ Koya was widely criticized for defending in court the sacked Alliance Commerce Minister MT Khan on corruption charges instead of being present in parliament when important bills, including ALTA, were being debated. Many were disillusioned with Koya's silence over the maverick Vijay Parmanandam re-joining the party, without explanation or 
apology, after a stint on the Alliance benches and after savagely criticizing his former party members. He was and always remained a Koya man. And Ratu Mosese Varasikete Tuisawau resigned from the NFP to join the Fijian nationalists. Religion entered politics — not in September 1977 elections, as is widely thought, but in March of that year. At a meeting in Raviravi, Ba, a speaker told Jai Ram Reddy to his face that Muslims numbering around three thousand in the district and surrounding areas would not support him. ${ }^{35}$ We don't know the reason for this provocative declaration, though it was probably connected to Reddy's support for ALTA and his support for Swamiji, to whom he was close. Reddy's supporters were angered by the remarks, saying the incident 'would not have happened if Mr Koya had taken steps [to control his followers]. ${ }^{36}$

Koya was in strife while his arch rivals were enjoying the limelight. In January 1977, the Fiji Times voted Ratu Mara 'Statesman of the Year,' calling him 'far-sighted, thoughtful, brooding, sometimes moody, occasionally querulous, icy and witty — these are just a few aspects of the Mara character. They add up to an extraordinary personality.' Mrs Irene Jai Narayan was declared the 'Woman of the Year': 'Imperious yet gracious, icy yet affectionate, somber yet humorous, earthy yet intellectual. Mrs Narayan exudes that rare quality of character which makes stars and politicians - charisma.' Koya was no stranger to adversity or negative comparisons, but it was important, bearing in mind the events which were soon to follow, that on the eve of the general elections, the NFP was deeply divided and the character and quality of Koya's leadership had become a corrosive issue for the party. It had been an issue for a long time. Some influential party leaders had never wanted Koya to succeed AD Patel, preferring, if no suitable compromise candidate was available, to have the NFP run by a committee. 'How far can power-madness go,' asked RD Patel, who was to oppose Koya in the forthcoming elections. 'If he could do this to his own colleagues only as Leader of the Opposition [changed the locks to the Opposition office to keep some of his own colleagues out] what would he do if he were to become Prime Minister? ${ }^{37}$ Patel's characterization of Koya might under- 
standably be dismissed as the jaundiced ruminations of a political foe, down and out in the wilderness, but sadly for the NFP leader, many in the party were asking the same question. His time was running out.

\section{TOWARDS APRIL 1977}

As the NFP prepared for the April 1977 general elections, some in the party did not want Koya both as party president and party leader. They wanted the two posts separated. Hitherto, beginning with AD Patel, the two positions were held by the same person, giving him considerable power over both party as well as parliamentary matters. Koya would hear none of it and refused to budge, regarding himself, as one of its founders, to be the guardian of the party's best interests. As party president, he wielded considerable influence over the selection of candidates for elections, besides effectively controlling the party machinery. Irene Narayan, in particular, refused to accept Koya's leadership. She had understandably taken great offence at being called a 'bajaaru' by Koya. She moreover fancied herself a potential leader in her own right, and a better one too by her reckoning, committing herself fulltime to the position. Rival branches were being formed in the constituencies, with once loyal NFP supporters threatening to stand against each other. Once again, party elders turned to Reddy to stop the unfolding chaos. At an emergency meeting in Lautoka, Reddy proposed the separation of the positions of party president and party's parliamentary leader. His proposal was accepted with acclamation and relief by the party's supporters. Irene Jai Narayan became party president and Koya its parliamentary leader. A punctured tyre seemed to have been repaired, just in time, for elections were just around the corner, but no one in their hearts really believed that the worst was over for the party. Reddy's name 'should go down in the history books of Fiji,' Koya enthused, though he remarked privately when his once right hand man Veerasami Mudaliar nominated Mrs Narayan for president: 'This is the first time in my life I have been outplayed. ${ }^{38}$

By early 1977, it was clear to everyone that there were two factions in the NFP. One was led loosely by the Ramrakha-Narayan group, based in 
Suva, and other led by Koya with its support base in the cane belt. Daggers were drawn, and there was no trust between them. The problem arose when it came to selecting candidates for the general election. A solution was found when the party elders, including Koya, personally pleaded with Reddy to chair the selection committee, and both sides accepted him as the best person for the job. The full committee comprised seven members each of the Koya and the Narayan-Ramrakha factions and two 'independents:' Ramanbhai Patel of Lautoka and Balakrishna Sardar of Ba. ${ }^{39}$ The decision of the Selection Committee would be final, Reddy said, adding that no amount of 'illegal meetings' and 'campaignings' would have on any impact on its work. 'The settlement must succeed,' he added, 'and no one should sabotage it. ${ }^{40}$ That, in the circumstances, was too much to hope for. To avoid accusations of self interest in the selection of candidates, the party leaders offered Reddy the safe Ba-Lautoka Rural Indian communal seat at the outset. Reddy was accused by some, such as 'Naulu' Puran Singh, of 'filling his own plate' before thinking of anyone else, and of harboring future leadership ambitions. ${ }^{41}$ 'I do not want to become party leader,' Reddy told those who suspected him of plotting his way to the top. But many minds were already made up either way. Those who missed out on selection held Reddy personally responsible for their political demise and rounded on him at their rallies. But Reddy's performance as the chairman of the selection committee was widely praised as 'nothing short of brilliant.' 'He lived up to every expectation,' recalls Karam Ramrakha. ${ }^{42}$ Koya was equally fulsome in praise. 'Today is a historic day for Fiji,' he said. ${ }^{43}$

Still, at the end of it all, party unity was a sham for all to see that no amount of adroit internal patching up could hide. Party members were contesting against each other. RD Patel was standing as an independent against Koya, while in Navua, the district branch backed Vijay Parmanandam against the official NFP candidate. In Labasa, former NFP parliamentarian and Koya loyalist who had missed out on selection, Ram Jati Singh, openly declared his support for the 'independent' Vishnu Prasad against the official NFP candidate Sarwan Singh, a local Punjabi lawyer. ${ }^{44}$ Koya 
did not campaign in Vanua Levu at all. Publicly, he supported the official candidates, but privately encouraged the independents against them, leading Reddy to ask Koya to clarify his position. 'Most of the independents who are opposing the party are supporters of Mr Koya,' he said. ${ }^{45}$ The Fiji Sun added: "The fact that Mr Koya made this denunciation [of rebels and independents] in person only on Saturday after direct questioning from $\mathrm{Mr}$ Reddy destroys any effect the denunciation might have. ${ }^{36}$

It was a bitter campaign. In truth, the NFP was not fighting the Alliance at all; it was fighting itself. Political campaigns in the Indo-Fijian community are never for the faint-hearted. Even so, by the usual standards, this was a rough affair. There were violent clashes between rival supporters, stoning houses and smashing car windows, making menacing midnight phone calls. Fist fights broke out at rallies among supporters of rival candidates. Passions were aroused as never before because there is always an edge, an intensity to intra-family battles. RD Patel's own house was stoned several times, his car screen smashed. One of Patel's supporters was so traumatized when his house was stoned at midnight after he had spoken at a rally, that he immediately left the area for good, fearing for his life. Reddy still recalls the incident vividly. He was deeply disturbed by it. People could easily have been killed, he says. It was politics old style, rough and raw, tit-for-tat, 'physical persuasion' applied freely and fiercely across the board. Most candidates deliberately kept themselves well below the national radar, focusing on winning in their own constituencies, and uncertain about where the party leaders stood on issues.

Strangely enough, party secretary Karam Ramrakha admitted division in the middle of the campaign. 'One cannot really say that we are functioning as a happy united party at the moment.' For him, Koya's leadership was an issue and he promised to bring him down. 'Th 'The real question,' he said, 'is whether you run the NFP as a joint family system where everyone stays where they are, or whether you chase them about.' That, he said, was the 'real reason' behind the rift between the two factions. ${ }^{48}$ What sparked the rift, he continued, was the re-admission of Vijay Parmanandam into the 
NFP after he had defected to the Alliance. 'No right thinking party can allow a bloke to come in and go out like that just as if he was in his own little night club.' Who would lead the party if it won the election, he was asked. The leadership question is 'wide open now, he said, to be decided by the new parliamentary group. That was procedurally correct, although convention dictated that the person who leads the party to victory would normally be expected to lead it in parliament. Ramrakha's words were correctly read to mean no confidence in Koya.

Internal divisions over leadership and personalities apart, there were a few issues that ignited some passion in the campaign. Land and ALTA featured prominently, with attendant accusations about who had sold out to whom over what and for how much. So also did the government's admission and scholarship policies at the University of the South Pacific. In 1977, the government decided that Fijian students with 216 marks in their University Entrance exam would be eligible for government scholarship while Indo-Fijian students would need 261 marks for financial assistance. The issue caught on because for Indo-Fijians, education was the main avenue for economic improvement and upward mobility, and the gap seemed patently discriminatory. Mara likened the scholarship award to applying fertilizer to less fertile areas to make them productive, that is, to enable Fijian students to enter university on lesser marks and on less stringent terms in the hope that they might succeed later. He also reminded the NFP of the recommendations of the 1969 Education Commission that fifty percent of all government scholarships should be awarded to indigenous Fijians and the unused amount should be allocated on a 'parallel block' basis for other specifically Fijian projects. ${ }^{49}$ There had been no disagreement with the recommendations then.

That was true, but now was election time, and the issue promised good dividends for the party. The policy of discrimination, Koya said 'is bound to produce recriminations, frustrations, bitterness, the destruction of the image and the reputation of the university and indeed the Government of the day in the eyes of the world. ${ }^{50}$ Koya accused the government of not 
solving the land problem and of not fostering a sense of nationalism in the country. Butadroka's motion became an emotional issue, with Koya accusing the Alliance of failing to 'give an effective and appropriate assurance to the Indian community.' The absence of Indo-Fijians in the army was raised along their paltry presence in the higher echelons of the civil service. 'Anybody can be accepted into the army,' Colonel Paul Manueli, then head of the Fiji Military Forces, said, 'but we do not provide special meals. ${ }^{.51}$ It seemed a lame excuse, nothing more. Why not, it was asked, when exceptions were made for Fijians in other areas of public service? What about the Gurkhas, it was asked, who did not eat beef? The message, distilled to its bare essence, was simple: that the Fijian-dominated Alliance party would never relinquish control of the military, or dilute the Fijian presence in it, which it saw as the ultimate bastion of power for the Fijian establishment.

In the Fijian camp, especially in southeastern Viti Levu, Sakeasi Butadroka was making steady inroads into what had once been an impregnable Alliance stronghold. His 'Deport the Indians' platform appealed to many ordinary Fijians untouched by modernity, who were neglected and marginalized in the generally depressing subsistence sector while the Indo-Fijians appeared to be marching purposefully ahead, and seen as the cause of their misery. They responded similarly to the accusation that the Alliance had neglected them, taken them for granted, while pouring development aid into Mara's own maritime province of Lau. Butadroka was articulating a silent, sporadic Fijian grievance against the dominance of eastern islander Fijians on the national scene, a grievance that went back to the days of Apolosi Nawai during the early days of the 20th century. The Fijian Nationalist Party promised that the interests of the Fijian people would be paramount at all times, that the Fijians should always hold the positions of Governor General, Prime Minister, Minister for Fijian Affairs, Agriculture, Rural Development, Land, Home Affairs, Commerce, Industry and Cooperatives, strengthening of the Fijian Administration, establishing a Fijian Institute to educate Fijians in business and, of course, repatriating Indians back to India. Butadroka, in Ahmed Ali's view, was 


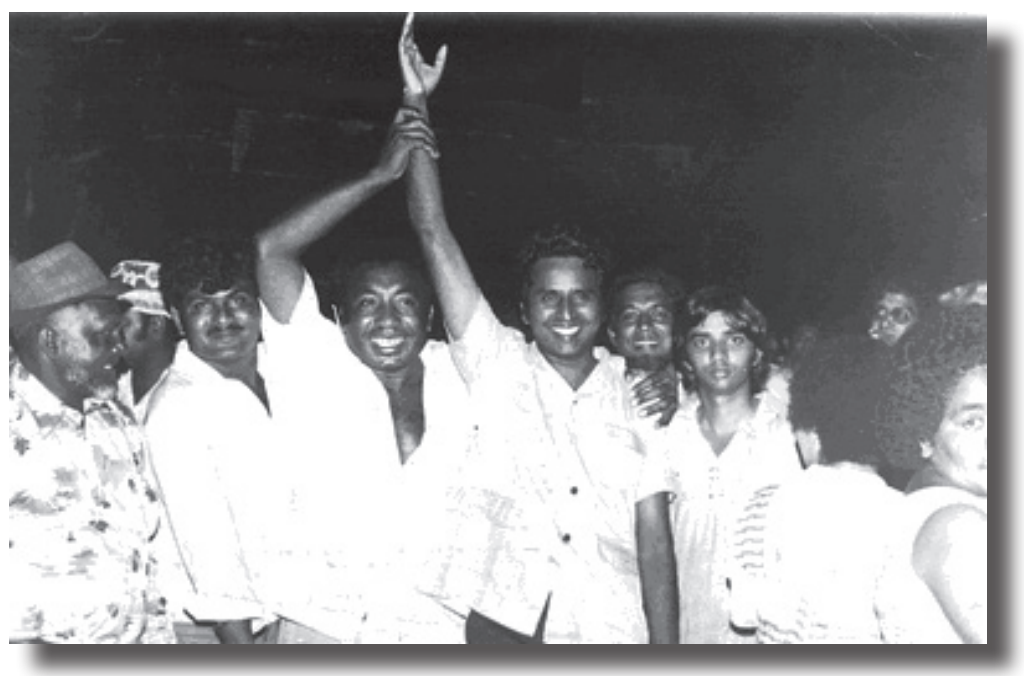

Jai Ram Reddy victorious in the April election. Photo courtesy of Fiji Sun.

capitalizing 'on prejudices and phobias that many disadvantaged groups in plural societies tend to have. ${ }^{52}$ That was true except that there were many disadvantaged groups among Indo-Fijians as well.

\section{THE BOMBSHELL}

On Monday 5 April, the final results were officially known, though by the previous evening the trend was clear. Jai Ram Reddy won his seat comfortably with 7481 votes to Alliance's Uday Singh's 2341, but the victory, he said, was 'an anticlimax of a sort' because the bitter infighting in the party that had hobbled its prospects and disenchanted its supporters. There was therefore nothing to celebrate. He was already looking ahead, beyond the party. 'I am going to work for the country', he said. Koya defeated Patel by 5312 votes to 3474. This was the lowest majority of votes in an Indian communal seat, which led Patel to claim that Koya had 'no moral right now to aspire as the leader of the parliamentary party. ${ }^{53}$ Whether Koya had the moral right or not was moot, but what was beyond doubt was that he had lost his firm grip on the new parliamentary team. Many new members 
were not beholden to him personally as they had been in the past, and their experience and outlook are different as well.

The greatest bombshell of the April general election was the victory of Sakeasi Butadroka and his Fijian Nationalist Party, which polled an astounding 24 per cent of the Fijian communal votes, causing the defeat of the Alliance. The NFP won 26 seats, the Alliance 24, Nationalists one and one independent (Ratu Osea Gavidi). NFP and indeed the country were caught entirely by surprise at their electoral triumph over the Alliance. They were caught 'with their pants down,' as Jai Ram Reddy put it in $1993 .{ }^{54}$ We now know why. Like any political party competing for power, the NFP should have been prepared for the eventuality of victory. But it was not. There was an air of apprehension, an eerie calm, surrounding the election results. There were no celebrations anywhere, none of the hooting of horns that usually accompanied election victories. The unspoken question on everyone's mind was whether an 'Indian-led' government would be acceptable to the Fijians whose emotions had been aroused by Butadroka's fiery nationalist rhetoric. The once unthinkable question had been asked: should Indian people be allowed to belong to Fiji as full citizens. And the answer to it had not satisfied everyone.

No one was probably more shocked with the victory than Siddiq Koya himself. He acted swiftly though. Without the approval of his new parliamentary caucus, which had yet to convene, Koya went to SB Patel on Monday night (5 April) and asked him to telephone Ratu Mara on his behalf to explore the possibility of a coalition government led by Ratu Mara himself, with Ratu Penaia as his deputy. Koya would accept a Mara-led coalition government 'even if it meant him being excluded from Cabinet. ${ }^{\text {.5 }}$ His chief concern, he reportedly said, was to address the anxiety of the Fijian people. SB Patel had long been an advisor and confidante to Indian leaders behind the scenes, a man of wide connections and trusted and respected by everyone as a fair intermediary (but who had been ignored by Koya for some years). ${ }^{56}$ The approach to Patel was the first overt sign of Koya's lack of confidence in a government led by him. It was a realistic assessment. The 
country was not ready for an 'Indian' prime minister yet. Patel rang Mara on Tuesday at 7:30 in the morning. Mara, still smarting at his defeat, flatly declined the coalition offer.

Around the same time, Koya asked Kuar Battan Singh to plead with Mara to continue as Chairman of ACP/EEC meeting scheduled to take place in Suva at the time. ${ }^{57}$ Singh was a close personal friend of Ratu Mara's, their friendship going back decades when Mara served as a district officer in the Nausori region. Mara agreed, but only in his capacity as a caretaker prime minister, not as a leader of a coalition government. And still looking for a way out of what seemed to be developing as a potentially fraught situation, Jai Ram Reddy was encouraged to issue a statement over the radio outlining reasons why a coalition government led by Ratu Mara was the best option at the time. The statement was intended to rally public opinion in favor of a coalition government, in essence, repeating the proposal SB Patel had privately put to Mara earlier, with Koya's full knowledge and support.

Reddy's statement became one of the most controversial 'events' of the time. For years later, it was recalled as an act of treachery by a man against his own leader, which had effectively undermined the NFP's prospects of forming the new government and put an ineradicable stain on the image and reputation of the Indo-Fijian community. What precisely, then, did Reddy say? 'I don't believe that a government by the NFP would be viable at this time.' The careful choice of words is important. He did not say that the NFP was 'unable to form a government' as his critics freely told the press; he had raised the issue of viability. It was a fine 'lawyerly' distinction, as Mara recalled later, that went above the heads of most people. Reddy had articulated what was, in fact, the consensus opinion at the time. The NFP did not have a workable majority in parliament, Reddy said, with only twenty six members to the Alliance's twenty four and one each for the Fijian Nationalists and Independents. There was more to forming a government than simply having ministers, Reddy argued. 'Several questions arise here. Firstly, would an NFP Government have the unquestionable loyalty of the civil service, the armed forces, the police, and so on? I am not 
saying that it would not, but these are some of the considerations that one takes into account in deciding whether the Government would be viable or not.' Reddy was again expressing the widely shared fears of the Indo-Fijian community, not casting doubt on the loyalty of the services as the latter part of his statement clearly shows. The third point Reddy made concerned the question of acceptability. 'Would an NFP Government be acceptable to all the ethnic groups in Fiji? Anyone might say that the voters have given their verdict. There may be something there but several factors have worked in these elections and you have Butadroka's statement that he would like to see an NFP victory simply to show to the Fijians that Fiji does not belong to them. I do not know to what extent this factor has contributed to the gain that the National Federation Party made but certainly this is something that one must bear in mind.'

Reddy also raised questions about the complications that could arise in the Senate. 'If the NFP becomes the Government, you are going to have a situation where the Prime Minister would have seven nominees in the Senate and the combined strength of the Great Council of Chiefs' members and the Leader of the Opposition's members will be something like 14, and if they have made a mind to, they could frustrate legislation by delaying it and this is another practical consideration that one must take into account.' The final consideration, which caused the greatest controversy, concerned the question of leadership. Reddy asked the question: 'Does the National Federation Party have a person of the stature that he can truly claim to be the leader of the people of Fiji?' He answered: 'I do not believe we have one at the present time.' Further, 'a large majority' continued to look to Ratu Mara for leadership. That was a true assessment and everyone agreed with it, including Koya himself. All that Reddy did was to say in public what Koya was saying in private: that, in the circumstances, it was better for Ratu Mara to lead the country than for someone else.

When asked later, Reddy said that he had made the statement in the context of a broadly-based national government. 'It was not intended to reflect upon the ability of any member on the Opposition benches. It was 
made with sincerity believing in the essential truth of the statement.' Reddy added that 'the results of the elections were unexpected from our point of view. We did not quite realize it would turn out this way and that many factors have contributed to it. Only three weeks ago — that was at the height of the crisis in the party — we were wondering whether we would retain the 19 seats we had in the old House.' Finally and most importantly, he said, 'the point that is to be borne in mind is that a coalition government, which I think is the ideal, would really be quite consistent with what the Alliance has advocated all along, namely sharing and caring.' It would be a government made up of all the ethnic groups of both parties. This truly representative government would be consistent 'between what the Alliance has advocated all along and what I am suggesting now. So I do believe that a coalition under the leadership of the Prime Minister, Ratu Sir Kamisese Mara, would, in the circumstances, be the ideal solution, but I must again add that these are my personal views.' The last is true only in the narrow sense. The statement had not been approved by the NFP's parliamentary board, but its contents were widely canvassed and approved, including by Koya himself. Reddy told a meeting in May 1977 that before he gave that statement, 'I told him about it and he approved. It is shocking that today he is still making an issue of it.' 'It's a damn lie now to say that no one knew about the statement I gave. It's the truth: get used to it. ${ }^{58}$ When Reddy asked Koya why he had not come to his defense when he was being bitterly attacked, Koya made light of the issue. 'I do not defend people who are innocent. I only defend those who are at fault. You must be innocent. You do not need a lawyer. ${ }^{59}$ We shall return to Reddy's statement later in the chapter.

In Suva, Ratu Mara had tended his resignation immediately after the election results were known. 'I am enjoying being Leader of the Opposition already,' he quipped. 'I have time to look after my own affairs, and time to be with my family. ${ }^{90}$ He cleared his office and moved to a rented accommodation in Lami on the outskirts of Suva. The symbolism of Mara, a high Fijian chief, living in rented accommodation was itself potent. Why did Mara decline the offer of coalition? To join a coalition would compro- 
mise his political principles, he said. It would play straight into the hands of Sakeasi Butadroka because 'Fijians will be flocking to his side.' It would also mean 'betraying' people who had stood by him all along but who had been defeated by the Opposition. 'Let us be quite frank,' Mara said. 'I was not being invited to join in power sharing. I was being begged to bail out the Opposition from a position which they did not feel capable of sustaining.' He continued: 'Our party made it plain from the outset that it was not prepared to enter a coalition government. I said in my first election broadcast: I have never deviated. So if the Opposition thought that there was any possibility of a coalition then it can only mean they did not believe me. And I am sorry if that is so. ${ }^{61}$

The time for coalition had passed, Mara said. Having won the election, it was now the NFP's responsibility to govern without further delay. Could the NFP with such a slim majority form an effective government, Mara was asked. 'I have already stated that if I have a majority of one, I can govern this country, and quite effectively.' However, Mara agreed to lead an Alliance caretaker government, and agreed further to meet the NFP at Government House on 7 April to sort out the arrangements. Mara's hasty resignation led Dr Lindsay Verrier, the eccentric medical doctor who was once the secretary of the Alliance Party, to say that a 'government of mature minds, when it resigns, does it with care, with dignity and with respect. It doesn't slam its desk drawers and rush for the lift. ${ }^{62}$ But that is precisely what the Alliance Party did. What Mara wanted, and what the Governor General offered, was a 'lifeline to a government in office which is desperately keen to have another bite at the cherry. ${ }^{63}$ What is remarkable about those four or five confusing days is the absence of direct communication between the principal players on the scene. There was no direct line between Mara and Koya. They both talked through intermediaries, or through the media. One piece of news that made the rounds was that Mara had said that no formal proposal had come from the NFP for a coalition government, which is why he had not 
considered the subject. Reacting to the news, or rumour, the entire NFP parliamentary group decided, on the evening of 5 April, to make a formal offer of coalition to the Alliance Party. The proposal, it was resolved, should be come from the President of the National Federation Party, Irene Jai Narayan, to the President of the Alliance Party, Ratu Sir Kamisese Mara.

Koya himself drafted the letter (see next page) and had Mrs Narayan sign it as president of the party. ${ }^{64}$ The letter was delivered to Mara's residence by Ramrakha at $8 \mathrm{pm}$. The NFP members awaited his response at the Opposition office. When none came by 11:30, they retired. Next morning, Wednesday at 7:30, Irene Jai Narayan rang Mara to seek his response to the proposal. Mara promised to get back to her by 11 . At ten minutes past 11 , he rang to say that he would not consider the proposal for a coalition for reasons he later articulated in the media. With the firm no now confirmed, NFP said that it was ready to form government.

The Governor General, Ratu Sir George Cakobau, summoned the NFP and an Alliance delegation to Government House to get their views on the formation of a new government. The Alliance did not attend, mistakenly thinking that the NFP was in the process of forming a government which would then make the meeting moot. This misunderstanding was again the result of no contact between the two parties. Ratu George, reading from a prepared text, ${ }^{65}$ informed the NFP delegation, comprising Irene Jai Narayan, Atunaisa Maitoga, Karam Ramrakha and Jai Ram Reddy, of the Alliance's rejection of the Coalition proposal and asked the party to 'inform him forthwith whether it proposed to form a Ministry.' ${ }^{66}$ The NFP delegation informed the Governor General that they would 'proceed without delay' to form the next Government of Fiji;' 'elect a leader under its prescribed procedure' which provided that the elected Members of the House of Representatives of 'should elect a Party Leader from within its ranks;' 'request His Excellency to appoint the Party Leader as the Prime Minister of Fiji;' and ask him 'to swear in the Prime Minister and members of Cabinet today.' Ratu George 'took note of the view of the delegation, 


\section{MATIONAL PEDZRATICH PARTY}

5th Apri1, 1977.

The Prosident,

Alliance Farty,

SUV i.

Sir,

I have the honour to infore you that a

formal meetin: of the neviy elected Nembers of

Parlianont took place this ovenimp. At this

aeoting, it wes decidad that in the national interestan

official offer should be Hisde to your Party to form

and aceopt coalition covemuent in the oiroutatancea

nou prevailing. This offer is boing made following

the infornal diacuasions betwen our Mr. K.C. Ranraxtha

and your good self on the 4 th instant.

The concopt of a coslition would of course nuan that Cabinet would consist of reabers from both vides. Cnce the concept car be accepted in principle wo awsicat further negotiations, and talks should take plisco.

\section{A delezation conslating of Nessre S.M. Koya}

K.C. Ranrakha, Captain Atunaisa Kaitoga and mysele 1o propared to call on you at this evening and diacues this mateer with you and your side.

Our larliawentary Party weeting has been adjourned tili later in the voning, and wo would be most oblifed if this mattr could bo treated as urgent. Our telephone nubbers sre $211-590$, or $211-444$, ardi wo would apprectate your reaching ue at this nutiber.

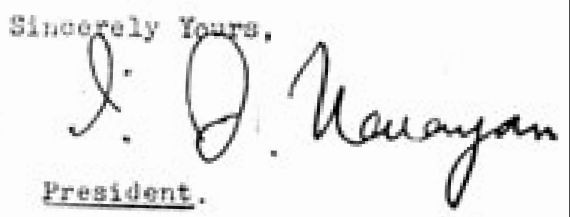

NFP's much maligned letter to Ratu Mara exploring a coalition government. Courtesy of Fiji National Archives. 
and stated that his office would wait to hear from them during the day and would be in a position to attend to the swearing of the Prime Minister and Members of the Cabinet. ${ }^{97}$

The delegation then returned to the NFP parliamentary office to elect a new party leader and, in effect, the next Prime Minister of Fiji. What transpired between about 11 am and $4 \mathrm{pm}$ is still shrouded in considerable controversy about who supported, or did not, support whom. But the most important facts are known with reasonable certainty. Two names were put up for leadership, Siddiq Koya and Captain Atunaisa Maitoga, who had won the Vanua Levu Fijian National seat against Alliance's Ratu Josefa Iloilo. Maitoga was new in parliament, having entered it in 1972 after defeating Ratu Penaia Ganilau. He would soon disappear from the public view without a trace. Why his name was put forward and not someone else's with greater experience and authority, such as Ramrakha or Irene Jai Narayan, is best left to idle speculation. Putting up an unknown lightweight against the party leader, indeed one of its founders, was a cruel blunder, a fateful mistake, from which the NFP would take a long time to recover. Apisai Tora thought Koya's election would be a mere formality. He, and many others, were therefore shocked to discover that the first ballot had ended in a tie, 13-13. 'I thought Captain Maitoga would have three or four votes,' Tora recalled, 'but when there was a tie, I knew there was going to be trouble.' In the second round, one of Maitoga's supporters, Timoci Naco, reportedly defected to the Koya camp, thus handing him the victory $14-12 .{ }^{68}$ Koya then asked Tora to make a swearing-in appointment at Government House for noon.

That had to be postponed till $1 \mathrm{pm}$ because no consensus could be reached on the allocation of cabinet portfolios. Some members hesitated to serve in a Koya cabinet. Others refused if Tora was offered the position of Deputy Prime Minister. When Koya announced Subramani Baswaiya as his choice for Finance Minister, Boyan Crampton threatened to storm out of the meeting. Crampton had defeated Alliance's Dan Costello for the Northern General National seat and wanted the Finance portfolio as his 
just reward. 'If you walk out, you stay out,' Koya told him sharply, upon which Crampton decided to stay. Still unable to agree, Koya asked the Fijian members of the party to have an emergency meeting in an adjacent room. 'We thought if the Indian members could not reach an agreement we will work out among ourselves seat allocation and tell Mr Koya to assist him,' Tora recalled.

The appointment with Government House postponed to $4 \mathrm{pm}$ had to be delayed further. Meanwhile, the Fijian group presented Koya with their list for the different portfolios: Maitoga for Deputy Prime Minister, Ro Asela Logavatu for Lands and Mineral Resources, Timoci Naco for Agriculture, and Isikeli Nadalo for Fijian Affairs and Rural Development. Chandra Pillay agreed to serve as Minister for Urban Development, Housing and Social Welfare. Irene Jai Narayan was offered the Education portfolio which she said she would accept only if Koya gave her an unqualified assurance that he would not ceremoniously dump her as he had done in the past. Koya refused to give that undertaking, according to Mrs Narayan. Koya asked Reddy to become Speaker, saying 'Jai, it will be good to have someone like you in that position.' Reddy agreed; he remembers those words vividly. He urged others to rally behind Koya as well. He said to Ramrakha, who reluctantly agreed to accept the post of Attorney General, 'Karam, we have got to help him. ${ }^{69}$ Time was of essence. Reddy was concerned about the continuing delay and, recalled Harish Sharma, urged Koya to go to the Government House immediately. Other portfolios could be allocated later. Ratu Osea Gavidi, the independent parliamentarian from Nadroga, agreed to support the NFP, but would not be part of the government. Butadroka declared 'No Dice' to an invitation to support the NFP. 'My party does not want an Indian government to run the country and I take it that the NFP is an Indian political party.' Even a million dollars would not buy his vote, he quipped. 


\section{THE D-DAY: APRIL $7^{71}$}

9:15 National Federation Party parliamentarians assemble at the Opposition office, Government Buildings

9:45 NFP President Mrs Irene Jai Narayan, KC Ramrakha, Jai Ram Reddy and Captain Atunaisa Maitoga leave Opposition office for Government House

10:00 At Government House, the NFP delegation tells Ratu Sir George Cakobau of the NFP's decision to finally form a government

10:15 NFP delegation leaves Government House and returns to Opposition office

10:45 Ramrakha on behalf of the NFP issues a statement that it would form a government and that whoever would be appointed party leader would be the new Prime Minister. Independent parliamentarian Ratu Osea Gavidi arrives at Opposition office with Apisai Tora

11:00 NFP members vacate Opposition office and move to members' room to elect their parliamentary leader

\section{Leader and Cabinet}

11:00-2:00 NFP parliamentarians elect Siddiq Koya as leader and Captain Atunaisa Maitoga as deputy leader. Members interviewed for their preferred portfolios

3:15 The NFP tells the Governor General's Private Secretary that its leader is ready to be sworn in as Prime Minister

4:15 Siddiq Koya leaves Government Buildings for Government House to be sworn in as independent Fiji's second Prime Minister

4:20 Ratu Sir Penaia Ganilau leaves Government House by private Range Rover

4:45 Koya leaves Government House after being told Ratu Sir Kamisese Mara has been sworn in as Prime Minister

5:00 Ratu Mara calls a meeting of Alliance parliamentarians in his office to form his Cabinet. Koya confers with his parliamentarians

6:00-6:30: The events of April draw to a close after statements by Ratu Mara and Ramrakha 
PRIME MINISTER: NOT TO BE

Soon after 4 pm, Koya left for the Government House with Subramani Baswaiya, Ro Asela Logavatu and Timoci Naco. Upon arrival, the group was told that the Governor General had already appointed Ratu Sir Kamisese Mara as the new prime minister. This he had done acting in his 'own deliberate judgment.' The Alliance leader had been summoned to the Government House at 3:45. Mara accepted the appointment, he said, in the same manner Fijians had always heeded the call of chiefs: 'I obeyed the command of His Excellency the Governor General, the highest authority in the land and my paramount chief. I obeyed him in the same manner that thousands of Fijians obeyed their chiefs when they were called to arms - without question and with the will to sacrifice and serve. ${ }^{72} \mathrm{He}$ expressed 'complete surprise' at the invitation to form a minority government. 'I think I must be the first Prime Minister in history to be appointed in a bula shirt. ${ }^{73}$ Reading a statement reportedly drafted by the Chief Justice, Sir Clifford Grant, Ratu Sir George said:

In the recent elections the people have Fiji did not give a clear mandate to either of the major political parties. It therefore became the duty of the Governor General under the constitution to appoint as Prime Minister the member of the House of Representatives who appeared to him best able to command the support of the majority of the members of the House. The Governor General has not been able to act sooner as it was not until this afternoon that he was informed who had been elected leader of the National Federation Party. The Governor General, after taking all the relevant circumstances into account, has come to the firm conclusion that the person best able to command the support of the majority of members is the leader of the Alliance Party, Ratu Sir Kamisese Mara. In compliance with the constitution and acting in his own deliberate judgment, the Governor General has accordingly appointed Ratu Sir Kamisese Mara as Prime Minister. The Prime Minister is now in the process of forming government. ${ }^{74}$ 
The Alliance made much of the fact, and as Ratu Mara said on several occasions later, that he had no choice but to accept the appointment because the country 'was drifting rudderless without a government for four days." 75 This is an overstatement. The final results were known on 4th, and the NFP informed the Government House of its ability to form a government on the 7th. In most democracies of the world, the period of transition is often much longer, lasting several days, if not weeks. The Alliance could have been asked by the Governor General to continue in a caretaker mode until the new government was sworn in within a few days. That would have been the correct procedure to follow. In the event the Alliance refused to obey the Governor General's orders for whatever reason, the Governor General himself could have assumed executive authority until the new government was sworn in.

The constitution expressly authorized the Governor General to assume direct control in the event of an emergency or when the safety of the state was at peril. The latter was clearly not the case, but the Governor General had the constitutional power to act on his own. The delay simply became an excuse to orchestrate the result he wanted. The 'crisis,' which was in truth no crisis at all, was opportunistically manufactured. 'What we told the Governor General,' Koya told the nation, 'was that we would exhaust all avenues of ascertaining whether a coalition government could be set up headed by Ratu Mara.' It was an historic gesture without parallel, he said, and magnanimous too, made in the 'wider interest of the nation and with regard to the future.' What was astounding, Koya went on, was that the Governor General had appointed a minority government without prior consultation with the NFP, which had the moral as well as the legal right to form the next government. The Alliance was playing hard ball. It knew of the internal problems in the NFP and did not want to make life any easier for them, hoping to use the contrived 'crisis' to their advantage at the next elections. As Siddiq Koya said, 'the talk of a caretaker government arose only because the Alliance Party took it upon themselves to tender their resignation without waiting for another day or another hour after they found 
out that they had been beaten at the polls. ${ }^{, 76}$ This was not the last time, as we shall see, that Ratu Mara would accept a controversial appointment, justifying his action as being in the national interest.

Koya cried foul and pledged to regain what he said was rightfully his and his party's. It was a curious situation alright, Ramrakha recalled: there was a government in place without a majority, and there was a majority in parliament without government. ${ }^{77}$ The Alliance could not accept defeat 'in the ordinary way,' Koya argued, adding: 'If they did not believe in democracy, and they have exhibited they do not, they should have told us long ago instead of indulging in secret meetings and last-minute decision to change from one stand to another.' The Alliance's decision to accept the invitation to lead a minority government, Koya said, 'was an insult to the Indian community and its self-respect.' 78 ' Mara was planting fear in the minds of the people, Koya claimed. 'One day Ratu Mara may be called the Idi Amin of Fiji,' he thundered. 'I am watching him very carefully. ${ }^{79}$ Mara had often said that it was not only NFP's right to form the new government but its duty to do so, but when offered the opportunity to lead a minority government, he had accepted it without hesitation.

Why, then, was Siddiq Koya not appointed Prime Minister? That question continues to be asked and raised in political rallies against the supporters of those who had allegedly 'prevented' Koya from claiming the top political office, or 'stabbed him in the back' as the phrase went, and still does. Did some of his own colleagues secretly contact the Governor General and inform him of the internal dissensions and of their unwillingness to serve in a Koya-led government? Was the Governor General constitutionally correct in appointing Mara Prime Minister? Was Koya not supported because he was a Muslim in a Hindu-dominated party? And what were the consequences of Reddy's intervention? We have already disposed of the argument that the delay was, or could have been, an important factor in influencing the Governor General's decision to appoint a minority government.

The religion argument had its moment of play in the subsequent history of the NFP. Koya himself told an Indian journalist, Syed Naqvi, 
in 1987, a full decade after the events, that 'Jai Ram Reddy and his supporters, all NFP members, withheld support because they did not want a Muslim Prime Minister. ${ }^{80}$ Why he accused Reddy later of being the Hindu ringleader when Irene Jai Narayan and Karam Ramrakha were more experienced and prominent leaders of the party, when Reddy had actually asked Koya to get sworn in first before worrying about the composition of his cabinet, is perplexing. Interestingly, Koya never made that accusation against Reddy personally in Fiji. Indeed, he returned to parliament under Reddy's leadership later, and said that relations between him and Reddy were characterized by 'understanding and compassion despite our differences. ${ }^{81}$ Koya had previously in all general elections since 1963 won his seat from constituencies which were predominantly non-Muslim. And he was elected leader of a party the majority of whose members were Hindus. Among his staunchest supporters (as would be shown in the following September elections) were Hindus, including Subramani Baswaiya, Koya's choice for Finance Minister, Ram Sami Goundar, Shardha Nand, Vijay Parmanandam, Ujagar Singh, Kallu Karan Singh, and many others, all NFP members. And in the 1992 elections, Koya endorsed Reddy's candidature. His colleagues withheld their support from Koya not because he was a Muslim, although for some this may have been an issue, but because of the kind of politician he was and the positions he had taken on issues of great importance to the Indian community, including sugar and land. Opinion against Koya had polarized over a long period of time, it should be remembered, not just during the campaign. Many of his own colleagues had crossed the floor to vote for ALTA against their leader. Their opposition to Koya was thus political, not religious.

Koya knew the truth and was careful himself never to repeat the religious argument in public; but he was too astute a politician to quash the suspicion for good. He had nothing to lose but everything to gain politically by its persistence. When the subject was raised with Reddy a few years later, he said this: "We fought Mr Koya because we differed on issues rather than because he was a Muslim. When the Prime Minister [Mara] was attacking 
Mr Koya, nobody said that he was doing so because he was a Muslim.' He continued: 'Why don't' they tell you that for eight years we accepted $\mathrm{Mr}$ Koya as Leader, worked under him and helped him win elections. Now after five years we have brought him back and given him a ticket. Not only him, we have given four safe seats to our Muslims, two communal and two safe national seats which we will win, and if God wants, then in the future, the Leader of the Party can again be a Muslim.. ${ }^{82}$ Koya, for his part, said that 'I have always admired his ability and we are certainly going to miss him,' when Reddy resigned from parliament in $1984 .{ }^{83}$

Koya told his colleagues after returning from Government House that Ratu George had given two reasons in defense of his action. One was security. As recalled by an eye witness, Ratu George said to Koya, 'Sid, the security reports are bad.' Koya responded: 'Sir, leave security to my government.' To which the Governor General replied, 'No, I have already appointed Ratu Mara as Prime Minister. ${ }^{94}$ The other factor in the equation was his view that Ratu Mara was the man most likely to command majority support on the floor of the House. If the latter is correct, then it is fair to assume that some members of the NFP must have informed the Governor General of their plan to vote for Ratu Mara for Prime Minister. Two prominent leaders fingered early and often as the probable culprits were Karam Ramrakha and Irene Jai Narayan, both of whose dislike of Koya and their long opposition to him was public knowledge. So, it made sense to suspect them. But both denied under oath in parliament, swearing on the Bhagavad Gita and the Ramayana respectively, ever communicating with Government House on the matter. ${ }^{85}$ Swearing by religious texts is taken most seriously by Hindus, for telling lies on oath is believed by all devout followers of the faith to bring the most severe divine retribution not only on themselves but on other family members. The curse lasts for generations. Religion is never taken lightly among Indo-Fijians. Going by the oath alone, I have no reason to doubt Ramrakha's and Narayan's claim of innocence in the matter. Their only communication was that which was authorized by the parliamentary group. But Koya remained unconvinced, saying that remarks by Ratu Mara 
'insinuated' that Narayan had written a secret letter pledging her support for the Alliance leader. Ratu Mara, having 'insinuated,' refused to clear the air. It made political sense for him to have his opponents squabble among themselves. But there was no proof and no evidence, the claim clearly intended to malign Mrs Narayan. ${ }^{86}$ This led Narayan to say 'very plainly and frankly that I will never cooperate with Koya and Tora. It is against my principle.' But of course she would a few years later, without fruition.

It is highly unlikely that junior members of the party would have contacted Government House on their own, though Koya accused defeated independent candidate against him, RD Patel, of contacting the Governor General. ${ }^{87}$ Be that as it may, the written record is clear. In an open letter to the Governor General, written on 25 May (reproduced), all 26 NFP parliamentarians accepted Koya as their leader and indicated their willingness to serve under him. The letter said: 'We assure Your Excellency that we stand as a united party and that each and every signatory to this letter will serve as a Minister under Hon SM Koya as such responsibility is allocated to him under the Constitution of Fiji.'

As Dr Shams-Ud-Din Sahu Khan, a constitutional lawyer with a doctorate on the Fiji (1970) Constitution, pointed out, the Governor General could act in his own deliberate judgment, but he had to go by more than a hunch or suspicion. 'Even if the NFP did take some time to choose a leader, and even if it was not a unanimous decision, it does not necessarily follow that those who opposed Mr Koya's appointment would oppose him in parliament.' 'This is one of the principles of democracy,' Sahu Khan continued. 'There is bound to be opposition but when the majority expresses its support for a leader, that person is the leader. ${ }^{98} \mathrm{He}$ argued that 'unless it could be shown that there were at least two or three members of the NFP supporting Ratu Mara, the Governor General's action had no constitutional basis.' The claim then that Koya was not made Prime Minister because of divisions in the party, because he was 'stabbed in the back,' rings hollow.

Not much at the time was publicly made of the 'security' argument, but circumstantial evidence, mentioned then by many close observers, alerts 


\section{Leader of the Opponition's crfice. \\ Govertanet fulddings, \\ ICVA}

$25, h y, 13 n\}$

His Docellency the Cevernef-Generel.

Covertantit Houst,

sing.

Tour Dectitescy,

$\mathrm{W}$, the undersigned atakers at the Mouse of Meprewentorives request you to inalte the Leodex of the eajouity porty it the Howa of Represtentatives meally the Non. Mr So-Koya to fara the governaent of Tijl wo in tur cobaidered vieu conands whort of the nojority af the senters of the House of Repreantatives.

Wh easure your Decellency that we stond as a vilted party and that eoch and tvery signatory to this letter will wive es o Ministes ander Han Mr S.M. Koyo es suck responatBility is ello ted to his under the Coestitstion of rijl.

\section{Youra faithfully,}

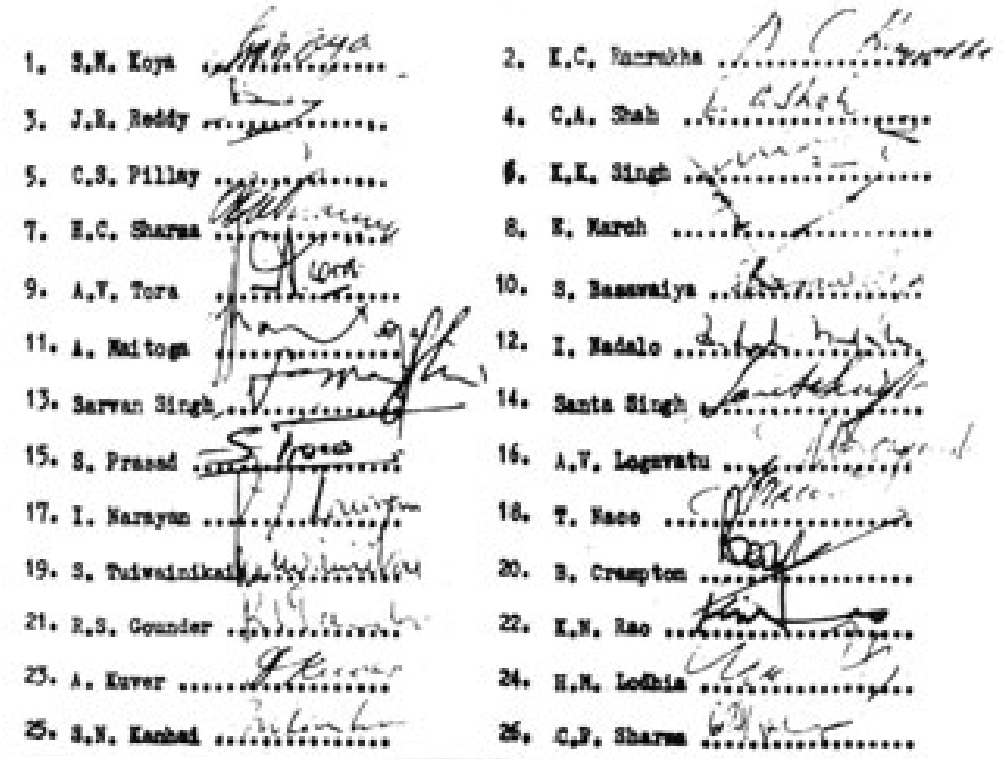

Letter refuting claims that NFP did not support Koya for Prime Minister. Courtesy of Fiji National Archives. 
us to other possibilities and explanations. It was said that just before Koya and even Ratu Mara arrived, a black car, with Ratu Penaia Ganilau in it, was seen leaving Government House. Of all the high Fijian chiefs, Ratu Penaia was the most widely trusted by ordinary Fijians as the uncompromising champion of their rights, their most powerful defender in government. $\mathrm{He}$ was the one chief with ears closest to Fijian opinion on the ground. He, it is speculated, went up to Government House to warn the Governor General of the potential consequences of appointing an 'Indian' as Prime Minister, and Ratu George Cakobau listened to him. It should be remembered that Ratu Penaia was also in the Government House, this time as Governor General, when the coup took place in 1987 . He was widely believed to be the patron and protector of Sitiveni Rabuka.

If Ratu George Cakobau had security as one reason not to appoint Koya Prime Minister, then the importance of Ratu Penaia in the equation becomes significant. It then does not matter what Ratu Mara did or did not do, whether he had foreknowledge of what was about to transpire at Government House, whether Koya turned up late or if he had turned up at the moment the victory of his party was announced, his fate was already sealed the moment the election results became known. He would not have been appointed Prime Minister under any circumstance. The delay in forming government provided the Governor General the perfect excuse to deny Siddiq Koya his due. 'The enormous lesson that the Federation people must learn,' Dr Lindsay Verrier wrote, 'is, of course, the cost of not being ready. If they had been able, at the moment the final poll was declared, to present a list of their leader and his or her Cabinet, the matter would have closed then and there. ${ }^{89}$ It might have, though it is doubtful. The excuse for executive intervention would have been different, but an intervention there would have been. Minds about that were already made up.

Ratu George Cakobau was not the neutral, impartial Head of State that people sometimes assumed him to be. His own political background needs to be borne in mind as well in assessing the final outcome of the crisis. Throughout the 1960s, he had been the most ardent defender of Fijian in- 
terests, the clearest and most unrelenting advocate of the view that at independence, Fiji must be returned to Fijians who had ceded the islands to the United Kingdom in the first place. Cakobau had been a prominent presence at the post-1968 by-election rallies at which Fijians in their hundreds throughout Viti Levu had threatened to unleash race riots, terminate land leases, deport Indian leaders just because the NFP had been returned with larger majority. This was to be expected, to some degree, as Ratu George was, after all, the Vunivalu, the Warlord, of Bau and the highest chiefs of all besides being a direct descendant of the chief who had ceded Fiji to the United Kingdom in 1874: Ratu Seru Cakobau. It was his traditional cultural responsibility to stand by his people.

An incident in the 1970s also indicates Cakobau's inclination to act on his own advice, contrary to the constitutional requirements of his office. In 1977, when the position of Chief Justice became vacant, upon the expiry of Sir Clifford Grant's contract, Ratu Mara nominated Sir Ronald Kermode as his nominee for the position while Opposition Leader Jai Ram Reddy recommended High Court Judge Ghananand Mishra. Ratu George disregarded the advice of both the Prime Minister as well as the Leader of the Opposition (to whom he had written earlier) and appointed Timoci Tuivaga as Chief Justice instead. ${ }^{90}$ Not only did the Governor General disregard the Westminster convention of the Head of State acting on the advice of the democratically elected government of the day, he also breached one of its most enduring traditions. Whether Ratu Mara or Siddiq Koya had the confidence of the parliament to form government was not for the Governor General to pre-empt, but for the House of Representatives to decide. Ratu George's intervention robbed the House of one of its most important functions. The Governor General, and the Governor General alone, and not Jai Ram Reddy or Karam Ramrakha or Irene Jai Narayan, prevented Siddiq Moidin Koya from becoming Fiji's second Prime Minister.

Mercifully, in light of Fiji's subsequent experience when heads of states chose to play God with the constitution, the impasse did not last for too long. In May, at the first sitting of the House of Representatives, the Alliance 
moved a vote of confidence in the government, hoping for some defections from the NFP to its side, putting the dissidents in the party on the spot. But Tora moved an amendment 'that the will of the people of Fiji as expressed through the secret ballot should be respected in order to maintain parliamentary system of government in Fiji and therefore requests His Excellency the Governor General not to dissolve the Parliament, should an advice in that behalf be tendered, but to invite the Leader of the majority party in the House, namely the Leader of the Opposition, to form Government.' The Governor General could have used his 'own deliberate judgment,' taking into account the unanimous NFP support for Koya, to appoint him Prime Minister. He did not. Instead, he heeded Mara's advice to dissolve parliament and call for fresh elections. There was inconsistency here: in one instance, he acted in 'his own deliberate judgment,' and in another on the Prime Minister's advice (in the same crisis). The Alliance counted on regaining its lost Fijian ground, and the NFP feared losing some of its national seats which it had won through the narrowest of victories to the Alliance. For the recently defeated party, early elections offered much promise.

To revert to Reddy, the question to be asked is why did he make that statement at all? It should have been made by the party's three most senior leaders: Koya, as party Leader, Irene Jai Narayan as party President, or Ramrakha as the General Secretary. Some things are now clear. First, although a freshman, Reddy enjoyed respect in the party and was already regarded as a future leader, and the statement reflected his stature and authority. Second, the statement also reflected truly what Reddy was all about. He spoke his mind, honestly and truthfully, without regard to the political consequences of the statement for himself or anyone else. What was good for the country was first and foremost in his mind. This is what Reddy said at the time: 'I honestly believe that the time has come for people of moderate views who love this country and respect each other and care for all humans to come together and join forces for the welfare of this country. ${ }^{91}$ The 'real' politicians in the party shared his view, and were glad that Reddy had uttered publicly what they all felt privately. 
Many had voted against Koya in the past because they disapproved of his style of politics. Deep in their hearts they probably felt that Koya was not a suitable Prime Minister material. But they all refrained from speaking out publicly for fear of political retribution, or falling out of favor of one faction or the other, not knowing which one might come out on top in the end. Many did not know which side of the bread was buttered, as the expression goes in Fiji. As Irene Jai Narayan said, Reddy was a 'person with the courage of his conviction' who was 'honest enough to make that statement because that statement of his reflects the genuine fears of the Indian community. ${ }^{92}$ The third thing that can be said is that Koya had foreknowledge of the statement, encouraged it, but when Reddy was attacked for his 'stab-in-the-back' statement, he said nothing publicly, dodged the issue completely. ${ }^{93}$ Koya's strategy was simple. He had put Reddy in the front line, but refused to provide him support when it was needed. This, Karam Ramrakha said, was classic Koya modus operandi: 'always to sit back, wind up his soldiers, and let the pawns march into battle. He rarely made the accusations himself. ${ }^{94}$

For decades, Reddy's statement caused great debate in the IndoFijian community. It was thrown back at him constantly throughout his career, especially by people who had never carefully read it, as an act of supreme treachery by a man against his own leader at moment of great crisis, as well as opportunity, for the party and the community. One letter writer to the Fiji Times, future Lautoka lawyer Rajendra Chaudhry, called Reddy's statement 'the most baseless, self-defeatist and politically immature statement of the times. ${ }^{95}$ There were many who echoed that view in meetings and political rallies that followed. But there were supporters as well. Throughout, Reddy was unrepentant, pointing instead to both the accuracy as well as the prophecy of his remarks. In 1993, he told journalist Joe Nata (who would later do time in jail for supporting George Speight's coup): 'In a sense I was very prophetic. I saw ten years earlier what happened in 1987 and this time with a Fijian Prime Minister [Dr Timoci Bavadra] at the helm and seven well educated Fijians in Cabinet.' 
His detractors, he said, 'who cling to what I said then should have at least given me [some] credit.' He continued: 'We just did not have a working majority. It would be childish of many to pretend that these cleavages and divisions did not exist. ${ }^{, 96}$

There are two things about the April debacle that remained with Reddy. He was incensed at the persistent allegation that he had deliberately undermined Koya's chances of becoming Prime Minister by his statement over the radio. He later recalled how he was hounded like a common criminal by his detractors for speaking the truth as he saw it, for his courage of conviction. The charges of disloyalty stiffened his resolve to clear his name which then catapulted him into politics. And the second is a lingering regret about something he should have done at the time but did not, which probably deeply disappointed Koya. He should have insisted at the first parliamentary caucus after the April elections that Koya be nominated by the party for Prime Minister without holding elections for leader as the party constitution required. After all, Koya had taken the party to victory, and he should have been allowed to take it into government without the formality of an election. That would have been the just and fair thing to have done. But why didn't he? He was a new member of the parliamentary caucus, he says, and more senior members of the party, including Ramrakha and Irene Jai Narayan, insisted that the proper protocols and procedures should be followed. Given the battles of the recent past, they had no reason to shortcircuit established party rules. Rules became an excuse to punish Koya for his past sins and lapses.

The mood of those tense few fateful days in early April 1977 is difficult to capture now. There was a pervasive sense of fear and apprehension. The talk around the tanoa bowl was subdued. A bus driver recalled: 'I froze. My foot remained on the clutch lever for fifteen minutes. I wondered what would happen now. ${ }^{97}$ An event had occurred which had not been anticipated and in the eyes of many, should in fact have never happened. But what is perhaps most remarkable in hindsight is the calm manner in which the Governor General's decision was received by the people on all sides 
of the political divide. There were no protest marches, no rallies around the country, no court challenges contemplated. Koya carefully aimed his criticism at the Alliance party and its leader, but even that was surprisingly muted. No one criticized the Governor General. There were no calls for his resignation. For acting in a similar fashion the Australian Governor General, Sir John Kerr, was mercilessly hounded out of office and forced into voluntary exile.

In Fiji, Ratu George's decision was accepted as fait accomplis. It was even received with relief. Ratu George had done what most people across the political landscape had wanted in the first place, including many supporters of the National Federation Party. Instead of anger, there was a palpable sense of gratitude, despite formal, almost obligatory protest in the parliamentary debates, and Ratu George continued to enjoy wide public respect. Not even Koya's most ardent supporters questioned his controversial intervention. Instead, they turned upon each other. It was Ratu George's good fortune that his fateful decision escaped close public scrutiny. But the Governor General's critical role cannot be denied. It was he who had robbed Koya of his right to form government. In this regard, Karam Ramrakha's assessment was accurate. Whatever the allegations about betrayal and treachery, the 'brute and undeniable fact,' he said, 'is that when Mr Koya went to the Governor General to become the Prime Minister, the Governor General, and the Governor General alone, refused to make him prime minister. We have a written constitution,' he said, 'and it is a pity that the constitutional processes were not allowed to take their course.' Jai Ram Reddy simply characterized Ratu George's intervention in the political crisis as a 'palace coup.'

On 26 April, when the newly-elected parliament met, Karam Ramrakha proposed a 'bold' plan to force the Governor General to give power back to the NFP. 'The Governor General's refusal to let NFP form a Government has been distorted to mean our failure,' he wrote to his parliamentary colleagues. This propaganda, he said, was being spread not only by the Alliance but by some the party's own supporters. 'The party must 
correct this false impression.' To that end, he proposed to appoint a NFP Speaker, have him suspend the standing order to enable a no-confidence motion to be passed and the House to be adjourned sine die. 'In this way, we at least show we have control of parliament. We then write to the Governor General to exercise his deliberative judgment to set up NFP Government in power.' The NFP had lost government and it should not lose parliament 'otherwise we would be condemned for ever.' It was a bold plan alright, but with little prospect for success. As Sir Vijay Singh pointed out, 'A motion of no confidence in a government is as important a motion as could be introduced and it is unthinkable that any impartial and responsible Speaker would grant leave allowing its introduction by surprise and without notice.' Any Speaker 'who duly complies with such application would soon lose the confidence of the House and respect of the public at large. ${ }^{98}$

The decision to hold general elections in September was not welcomed unanimously by members of the National Federation Party. In fact, opinion was sharply divided. Some in the party, including Koya, thought that early elections would play straight into the hands of the Alliance. $\mathrm{He}$ was right in that assessment. Some parliamentarians who had been elected from marginal national constituencies feared losing their seats. And their loss, because many of them were supporters of Koya, could jeopardize Koya's chances for continued leadership. Some indeed saw in early elections a chance to eliminate once and for all any residual influence Koya had in the party. For his part, Koya was having talks with Jonati Mavoa, Leader of the House, to have the minority government remain in power for a year 'to calm things down.' That was not to be. The Alliance had everything to gain and nothing to lose by going to an early election.

\section{THE SEPTEMBER DEBACLE}

The patch on the punctured tyre, to use Vijaya Parmanandam's metaphor, that the National Federation Party had by then become, was quickly ruptured. Accusations about treachery and betrayal flowed freely in the media. Passion ran high. Fist fights broke out in meetings called by rival factions. 
Reconciliation efforts were attempted, but came to naught. Koya's view that all the sitting members of parliament should be re-endorsed for election was not accepted, nor the suggestion that Vanua Levu be declared a 'neutral zone' for four unopposed national candidates. Eventually two factions crystallized, one around Koya, the Dove, and the other around Ramrakha and Irene Narayan, the Flower. The groupings were named after the symbols the Supervisor of Elections allocated to the two factions, denying the party symbol, the mango tree, to both of them. (Initially, the Dove faction had been offered a tractor and the Flower faction a fork, but neither had any campaign appeal or rallying power) As one observer put it, the tree that AD Patel had planted and which had provided shade and nourishment for so many for so long, had been destroyed by his followers. 'One group offers a piece of hibiscus bush instead [while] the Koya bird is flying around in confusion because it has no tree to rest on. ${ }^{99}$

After the April elections, Jai Ram Reddy was no longer 'a prominent Lautoka lawyer,' but a household name in the Indo-Fijian community. People talked about his captivating speeches and his dignified demeanour. Adhishwar Padarath reported that most NFP supporters were beginning to regard Reddy as the next leader. ${ }^{100}$ But Reddy himself was reluctant to contest the elections, having had his fill in the first fractious round. He even contemplated giving Koya a seat by a united party so as not to split it, for he knew that once parallel candidates were fielded, the splits in the party and the community at large would inflict deep and lasting wounds. But party elders prevailed upon him to stand; not only stand, but to stand against Koya himself whose political demise they regarded as necessary for the peace and stability of the Indo-Fijian community.

There were many who thought if there was one person who could take Koya on and defeat him on his own turf, it was Reddy, not Karam Ramrakha, whose name was mooted, or anyone else. When Reddy agreed, the Flower troika of Ramrakha-Narayan-Reddy was created, but with no single face for the faction. At a meeting in Lautoka on 11 September, Mrs Narayan said that Jai Ram Reddy would become the leader if he won. 
Her precipitous announcement pleased many. Reddy was a mesmerizing speaker, a fresh face, a voice of reason and moderation untainted by the political goings-on of the past. He inspired trust and confidence. He was a straight shooter. But Reddy's rapid elevation angered Ramrakha As a senior party man, he thought he deserved consideration for the top job. For all his undoubted abilities, Ramrakha did not have a strong base in the areas where it really mattered: in the heartland of the cane growing country. The view there was that it was only natural for the party leader to come from an area where the party was born, and that was western Viti Levu. His plea to delay formally anointing the Flower leader, at least until he returned from Nauru, where he had gone on legal business, was rejected. Ramrakha apparently had Ratu Julian Toganivalu in mind as the next leader of the NFP to give it a broader base, a new face, somewhat in the manner of what the Fiji Labour Party did a decade later when it appointed Dr Timoci Bavadra as its leader. For Reddy, the Lautoka meeting was not to elect him leader, but merely to endorse a decision taken earlier that he would be the party's parliamentary leader if he won. ${ }^{101}$

Once the battle was joined, all of Reddy's hesitations and doubts disappeared. His commitment to victory at the polls was unwavering. ${ }^{102}$ Alliance quietly supported Reddy. Fred Caine told a rally in Lautoka that if given a chance, he would vote for Jai Ram Reddy, who 'was a person with dignity in parliament. ${ }^{103}$ Ratu Mara, for his part, added fuel to fire by saying that there was 'a greater possibility, a brighter possibility of racial harmony, if the Flower faction emerges as the opposition majority than Dove. ${ }^{104}$ Interestingly, the Alliance did not field a candidate in the Reddy-Koya contest, apparently because no one suitable was willing to be drawn into the fray. As the leader of the Flower faction, Reddy toured all the constituencies, speaking at all the major rallies and featured as their main attraction.

Old, familiar issues dominated the campaign. ALTA came in for its fair share of mention, and questions of betraying and misleading the community filled the airwaves and dominated the campaign rallies. Questions 
were raised about the kind of leader the community needed to heal rifts within the community and build bridges with the other side of politics. Every household in the constituency was visited and re-visited, family, kinship, cultural and religious affinities and relationships mobilized for support. It was ever thus in Indo-Fijian constituencies at election time, but more intensely, more personally, so in this campaign than ever before. Covertly or overtly, everyone did it though assiduously denying any impropriety in public. The emotional fervour of the election rallies is difficult to capture now: the power and passion of words, the electrifying speeches and huge rallies, the enforcers ready on the side for any violence, which was an ever present possibility, lurking just beneath the surface. The September election was for the NFP nothing more than 'intra-party violence.' There was no time or space for big ideas and vision, no thought at all about winning the elections and forming the next government. That everyone conceded would not happen. The focus now was on trying to win for each faction as many seats as possible. It was a sad reflection on how far the National Federation Party had fallen. The embers from that September fires would linger long into the future.

It was a different story in the Alliance camp. It was well organized, well funded and purposeful, determined to woo back its traditional supporters and so regain government. Its focus was on Fijian voters; it knew it had no chance among the Indo-Fijians. Ratu Mara outlined his strategy to Wesley Barrett on 2 May, quoting an anonymous letter he had received, which said: 'The election has taught me several things. I learned that in Fiji's situation, the best propaganda in the world cannot break the tree syndrome. The tree touches on emotions and feelings that go far beyond party politics. Now I fear that the 'tabua' [the symbol of the Fijian Nationalist Party] is going to start to have the same meaning for the Fijians. That, in my estimation, is the most urgent problem facing the Alliance. ${ }^{105}$ To meet that challenge, Mara suggested a number of strategies. The Fijian Affairs organization had to be revitalized and made functional through rural development projects. Local party workers and coordinators in each 
tikina makawa, should be closely in touch with the Turaga ni Vanua.' The Fijian members should 'know the relevant veitaragi vanua records and cultures of his constituency, and that includes planting of crops, catching of fish, prawns, etc, building of houses and specific variants to yaqona ceremonies. Do not impose Bauan or Rewan ceremonial responses where they have their own.'

For the Alliance, it was back to the basics. And a clear warning was sounded in private and in public. Supporting Butadroka would jeopardize every gain the Fijians had made over the years. Worse of all, it could hand over power to the Indians, and nothing could be more unpalatable than that prospect. Their land rights would be in jeopardy, their future 'in their own homeland' endangered. The Alliance was what stood between the Fijian people and disaster. The campaign of consolidation was successful. Butadroka lost his seat to the Alliance's Tomasi Vakatora (The Fijian nationalist leader was in jail for breaching the Public Order Act by threatening racial peace and harmony). The Fijian Nationalist vote, 25 per cent of the Fijian communal votes in April, had declined to 12 percent. In the September elections, the Alliance captured 47 per cent of the total votes cast and over 80 per cent of the Fijian communal votes. It won 36 seats in parliament. The status quo was restored to the relief of many, and not only among the Fijians.

Among Indo-Fijians, the voter turnout was high, not surprising given the intensity of the campaign. The NFP, both factions combined, won 45 percent of the total votes cast and the overwhelming majority of the IndoFijian votes. The election was a clear victory for the Flower Faction which won twelve of the fifteen NFP seats. The only Doves to win were Vijay Parmanandam in Navua, RS Goundar in Rakiraki, and SN Kanhai in Nasinu-Vunidawa. In the most intensely contested seat of the entire general election, Jai Ram Reddy defeated Koya by 5638 votes to 4306. It was not a victory that Reddy savoured. He had beaten Koya and effectively ended his political career, but the victory had come at a great cost to the Indo-Fijian community, which lay divided as never before. The wounds would take a 


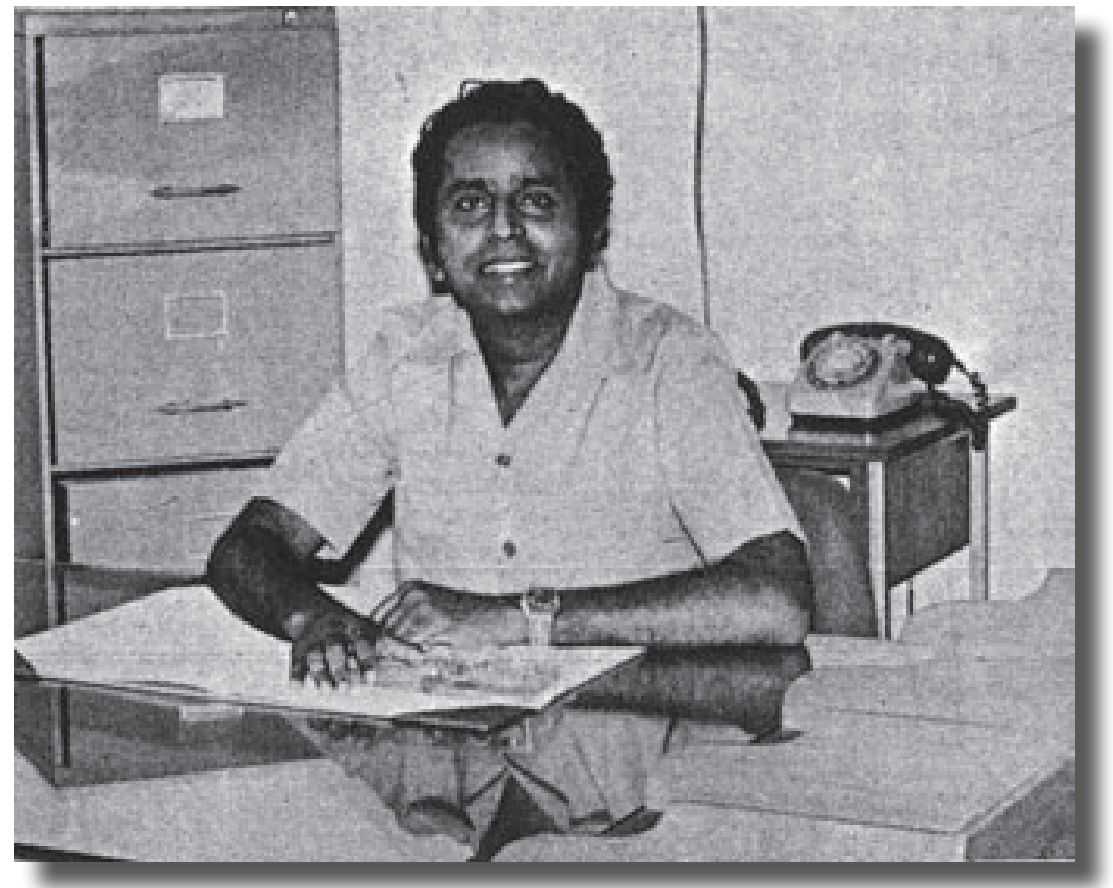

Jai Ram Reddy, newly appointed Leader of the Opposition, September 1977, in his spartan office. Photo courtesy of Fiji Sun 'Reddy for Action,' the caption read.

long time to heal. Perhaps the one lasting legacy of the September elections was the widening division between Hindus and Muslims. The 1970 s were the darkest years for the NFP. The party which had been in the forefront of the independence movement in the 1960s, with a powerful alternative vision for the country's future, had been reduced to frustrated, squabbling impotence. It had spent much of the decade fighting itself rather than fighting the Alliance, too hobbled by internal divisions to articulate a national vision as the government-in-waiting. Healing the cleavages and divisions of the past, retrieving the National Federation Party from the smouldering pit of near self-destruction, would be Jai Ram Reddy's principal task for the next few years. 


\section{INTERLUDE}

\section{JAI RAM REDDY: THE CUVU NFP}

\section{CONVENTION ADDRESS, 1981}

I extend to you all a very warm welcome to the 1981 annual convention of the Party. Some of you have travelled a long distance to be here today. Your attendance at this Convention, which is possibly the last before the next general elections, is much appreciated. The decisions we make today are bound to have far reaching effects for the party and the country. Equally important will be the way in which we make these decisions. Dignity and restrain should characterize our deliberations.

All eyes are on us at Cuvu today. As we prepare to go into the 1982 general elections, seeking a mandate to govern, we must remember that such mandate will only come our way if we can prove beyond all doubt that we are worthy of the trust we are asking the people of this country to repose in us. A disjointed, bickering and conflict-prone party will not inspire much confidence. People at odds with each other while in Opposition are not likely to behave any differently in Government. That simple truth must be self-evident to all. A party that seeks the reins of government has to be disciplined, efficient, and in all respects thoroughly businesslike. I appeal to one and all of you to conduct yourselves in a manner calculated to enhance the image and reputation of our Party.

You will recall that some two years ago we embarked upon a plan to reorganize the party and to get it functioning on proper Constitutional lines. We now have duly constituted branches with proper membership, and rules for election of office bearers and the selection of branch delegates. I know of the hard work put in by the branch officials and our organizing secretary to achieve this. I am 
grateful to them for their sincere devotion to the Party cause. What is now important for all of us is to adhere to our Constitution and the rules, and our inability to do so will not inspire much confidence in our capacity to organize and live by the Rule of Law.

The task ahead is however no easier. We must continue to make branches more active, to increase their membership and to gear them up for the colossal job which the party will have to face before general elections. That will be the registration of voters. My information is that the authorities are thinking of compiling completely new Rolls. Although I have yet to be convinced of such a need, should they seek new Rolls, as they are likely to do, that will certainly create an incredible state of affairs. Imagine yourself faced with an election tomorrow. The first task then would be to compile Electoral Rolls in order to be able to conduct that election. In most democracies worth their name, the Rolls open soon after an election and close soon before the next one. In those countries once a voter gets on a Roll, he remains there until death. He can, of course, move his name from one polling station to another. I do not know why this simple exercise cannot be carried out in Fiji. Again, it is not clear what is wrong with the 1977 Rolls, or why it cannot be updated. But I do express serious concern at the proposed state of affairs.

You must remember that if our supporters care not registered, there is no way we can win an election, no matter how effective our campaign. So let us not be complacent. I also gather that the task of coordinating the registration of voters for the elections will fall on the district administration, and the burden of registration upon the political parties If this happens, then we will have an enormous job ahead of us. A systematic and well organized registration campaign, to ensure that our supporters are registered is an absolute must. One cannot overemphasize the magnitude and importance of this task. 
The party must also have policies. People of this nation are entitled to know what an NFP government will do. Whether we will be radically different from the Alliance; whether we will have any leaning to the Left or to the Right, or whether we will pursue a middle course. Every investor and businessmen is already asking these questions. We must give them, and the nation, a clear answer.

I am happy to report to you that with the help of a few well wishers I have now in my possession a comprehensive Manifesto for the party. I am sure that when this Manifesto is published, it will put to rest a lot of unworthy speculations about the aims of our Party. I will at an appropriate time submit this document to the Policy Planning Committee of the Party, so that it can be adopted for use at the next general elections.

However, I will today raise a few issues fully covered by the Manifesto because, time and again, the NFP has been misquoted, sometimes deliberately, to allay fears in the minds of the people, particularly the Fijian people and the Business sector about our stand on issues like land and commerce.

I know that some politicians are going around saying that if the NFP came to power it will take away the land of the Fijians. This is not only nonsense, but irresponsible propaganda. No one, I repeat no one, can or will take away anyone else's land. We are all committed to live by the laws. And the supreme law of the land is the Constitution of Fiji. That Constitution protects the ownership of all land and especially Fijian land in a way which is probably unique in the world. Section 63 of the Constitution states that any law affecting Fijian land cannot be changed unless two-thirds of the members of the House of Representatives and the Senate and 6 our of 8 nominees of the Great Council of Chiefs vote in favour of the change. In other words, 3 nominees of the Great Council of Chiefs can veto any proposed change. 
It is perhaps worth reminding the country and our Fijian friends that it was the NFP which proposed the creation of the Senate at the London Constitutional Conference in 1970. This was done for the protection of the Fijian people, and their special rights, including those to their land. It was this gesture on our part which made the Prime Minister, Ratu Sir Kamisese Mara, want the Great Council of Chiefs to thank the then Leader of the Opposition for his supportive attitude during the Conference. It is therefore ironical that the NFP should today be accused of wanting to interfere with that very right which it initiated for the benefit of the Fijian people.

However, to remove any doubts, let me reiterate in the most clear and unequivocal terms, that the NFP has no desire whatsoever, whether in power or otherwise, to interfere with the rights of ownership of the land of Fijians, or for that matter of anyone else. We are committed to the Constitution and to the rule of law. We will live by that and no one, absolutely no one, need have any fear on this score. I think this places a duty on all of us gathered here to counter such baseless propaganda. Our Fijian members have a special responsibility in this regard. They should explain the provisions of the Constitution in Fijian to their people. It is a great pity that men should exploit the fears of fellow men for political gain.

While I am on the question of land it must also be mentioned that ours is a nation of tenants. So to achieve greater employment opportunities and national development, the tenants too must have reasonable security. No citizen should live under a constant threat of eviction. To allow such a state is to deny a basic human right. All our people: the Fijians, the Indians, the Chinese and the Rotumans, yes all, are entitled to feel secure in the land of their birth.

Any discussion on the subject of land tends to become emotional. This is not the answer. It should be possible for us to discuss the 
subject rationally and with understanding for the feelings of others, both the owners and the tenants. This can only be done if there is goodwill, cooperation and understanding between those who own the land, be they private freeholders, Native owners or the Crown, on the one hand, and those wishing to use that land, on the other. Any Government of this country has a crucial role in creating the right climate for such a cooperative endeavour. No one will lose by allowing useable land to be opened up for development. On the contrary, the landowners, tenants and the nation stand to gain. The landowners by having their land developed will derive additional income, and the tenants will gain by acquiring a means of livelihood and a measure of security for themselves and their dependents. The nation will gain by becoming more self-reliant and making greater foreign exchange savings. All this will also mean more jobs and better living standards for all our people.

This brings me to the question of employment. Unemployment is the single most pressing issue that confronts Fiji today, and will continue to do so in the foreseeable future. Let me say at once that this is a difficult problem, and one which is not unique to Fiji. There are no easy solutions. However, the problem has to be tackled methodically and vigorously, because nothing can be more disruptive to our national existence and to peace and tranquility than a large army of unemployed, specially the young. It has been repeatedly stated that Fiji is an agricultural country; that the greatest potential for job creation lies in this sector. Our aim should only be self-sufficiency but it must also look at becoming exporters of many agricultural commodities, processed or otherwise. We already have an excellent base with sugar cane.

Fiji has a competitive advantage in producing sugar. It has the knowledge, expertise, and the infrastructure for necessary expan- 
sion. Consequently, the expansion of the sugar zone provides the easiest course of expansion for promoting developments to cover all geographic areas which have climatic conditions suitable for sugar growing. The scope for this initiative is the greatest in Vanua Levu (areas adjacent to Seaqaqa) and Tavua/Rakiraki. The Yaqara cattle farm which involves a sub-optimal use of land should be subdivided for the extension of the sugar zone. The extension of the sugar zone will also provide an opportunity for many Fijians to enter commercial agriculture. At the same time, the extension of the Vatukoula/Ra areas will also constitute an important regional development policy in view of the many uncertainties surrounding the economic lives of the Vatukoula gold miners.

Also marine resources in and around Fiji waters constitute great wealth, and a source of nutrition. We should seek to provide all assistance to develop a viable local fishing industry (unlike the present one which relies almost solely on foreign fishermen, foreign vessels and a government fishing company living off tax payer's money. The development of the fishing industry will also provide another commercial opportunity for the Fijian people, who are a sea-faring people with a natural aptitude for fishing.

The NFP has also been branded from time to time as a party with a policy of wholesale nationalization of business. It is not only madness for anyone to be thinking along those lines, but also suicidal for a country like ours to even attempt to do so. Far from it, the NFP recognizes that under the Alliance Government, rapid expansion in government consumption has led to an unduly large tax burden on income earners, and has consequently reduced incentives for people to work and for businessmen to invest. We will attempt to lower the tax burden. In any event, a 
NFP Government will not allow the ratio of direct and indirect taxes to gross domestic product to exceed that borne by tax payers in 1981.

Taking into account the consumption pattern and nutrition requirements in the poorest section of our society, we will remove certain regressive elements in the tax system introduced by the Alliance. In particular, the indirect taxes on imports of basic food items such as wheat, rice and canned fish will be abolished. Rice and canned fish should not be subject to taxation until such time as sufficient structural adjustments takes place in the rice growing and fishing industries, and it becomes clear that production process is under way which could lead to self-sufficiency in these commodities.

In order to stabilize the economy, and to contain the rising tax burden, which has acted as strong disincentive for workers and businesses, we will contain the real operating expenditure of the Government, and will not allow it to exceed the real growth in the economy. This can be achieved by making an all-out effort to rationalize the operating expenditure of the Government, and by eliminating waste; examining critically the existing functions of the Government Departments, and looking for ways of consolidating a number of their functions. Non-essential, outmoded and counterproductive institutions and functions of Government departments will be eliminated. In addition, we will conduct international relations prudently, taking into account the costs and benefits of overseas representation of Fiji Missions.

At home, for domestic capital formation in the economy, we will accord it a high priority in view of the rising unemployment and low economic growth. In this area a two-pronged approach is possible. Firstly to increase budget allocation for high quality capital projects. In view of the shortage of funds the capital market must be designed 
to give priority to those projects which are justified by their economic rate of return. We must undertake thorough project evaluation as an important instrument for screening projects. Secondly, the Government will need to work closely with private entrepreneurs and provide the necessary stimulus to increase investment and employment opportunities. In particular, the impact of Government regulations on private investments will be closely scrutinized, and the Business and Industrial Development Corporation (BIDC) which is a glaring example of counterproductive regulating body will be abolished.

No nation can prosper without freedom and protection of its citizens. The NFP will guarantee freedom under the law. Protection of the individual citizen is a prime duty of any Government. Strong action is needed to check the serious rise in crime and violence. The best deterrent to crime is a likelihood of being caught. We will strengthen the police force.

For the last four years, I have been advocating a new style of government, an open government. NFP will eliminate unnecessary secrecy concerning the working of the government, and will review the operations of the Official Secrets Act, so that government is more open and more accountable to the people. The functions and powers of government have expanded so much in recent years that the traditional safeguards of the citizen no longer suffice. Although we will reduce government activity and interference, a better system of control and examination of decisions by individuals concerned, public bodies, and local authorities which affect every citizen is also needed. Parliament during recent years has often passed legislation which has infringed individual rights and has given wide discretionary powers to Ministers. We will closely examine ways of safeguarding more effectively the rights and freedoms of individual citizen. 
In closing, ladies and gentlemen, let me remind you that the whole country is watching us. It will judge our Party on the performance and outcome of this Convention. It will need to be convinced that when we disperse today, we do so as a strong and united Party. A Party not only willing to go into the next general elections but also ready and able to provide Fiji an alternative Government, a government which is honest, responsible, stable and decisive. The presence of so many of you here today reassures me of the strength of our Party. It also revitalizes our hopes and aspirations for the future.

Ever since becoming the leader of this Party, I have concentrated on two things. Firstly, to work towards the reunification of the Party [and] Secondly, to give the Party a Policy Base. I am convinced, and no matter what others say, that our Party is united and will remain united, because the rank and file want it that way.

Although we have been small in numbers in Parliament, we have tried to protect the public interest by raising issues of national concern. We have opposed Government where we had to and we have supported them where we were able to do so. We have worked to maintain a healthy political climate by confining actions as far as possible to issues rather than personalities. We have worked to maintain good race relations and to expose the Party to the people, fortunately to people of other races.

I know that some of you here may not agree with everything I have done. That is only natural, and I lay no claim to perfection. What we need is for every one of you to help prepare the Party for victory in the next elections. Let me assure the nation that if we win, we will form a Government. The fiasco of April 1977 will not be allowed to be repeated. 


\section{NOTES}

1. The letter is summarised in Ahmed Ali, 'The Fiji General Election of 1972,' in Journal of Pacific History (1973), 171-180. Awasthi, who now lives in Melbourne, has confirmed to me his authorship of the letter.

2. Ramrakha to Lal, 17 Sept. 2004.

3. Pacific Islands Monthly, Oct. 1972. Ramrakha says he was promised 11 votes, but got only 4. He returned to his former duties in due course, chastened.

4. Ahmed Ali, 'The Fiji General Elections of 1972.'

5. Private communication. Rae was for a while an administrator in the Leader of the Opposition's office.

6. Ratu Sir Kamisese Mara, The Pacific Way: A Memoir (Honolulu: University of Hawaii Press, 1997), 105-106.

7. Ramrakha to Lal, 19 May 2003.

8. Fiji Times 1 June 1977.

9. A note of caution: Mara made a similar allegation against Jai Ram Reddy which I discovered to be patently false on account of incontrovertible documentary evidence. See later.

10. Fiji Times 5 Sept. 1977.

11. See Robert Norton, Race and Politics in Fiji (St Lucia: University of Queensland Press, rev. ed. 1990), 111-120.

12. For the implications of Butadroka's politics, see Ralph Premdas, 'Constitutional Challenge: The Rise of Fijian Nationalism,' Pacific Perspective, 9:2 (1980), 3-44.

13. Once when asked why he employed Indians on his poultry farm and not Fijians, he responded: 'Don't mix poultry with politics!'

14. Fiji Times, 16 Oct. 1975.

15. Hansard, 25 May 1975.

16. For this I am grateful to Pramod Rae, one-time administrator in the Leader of the Opposition's office.

17. Fiji Times, 10 Nov. 1976. The signatories included Anirudh Kuver, Harish Sharma, HM Lodhia, Irene Jai Narayan, Isikeli Nadalo, Surendra Prasad, 
Sarwan Singh, Atunaisa Maitoga and Karam Ramrakha.

18. Fiji Times, 9 July 1976.

19. Fiji Sun, 10 Nov. 1976.

20. Fiji Sun, 12 Nov. 1976

21. In a speech in Cuvu, briefly reported in Fiji Times 13 Nov. 1976

22. See Fiji Sun, 16 Nov. 1976.

23. See Senate Hansard, 24 Nov. 1976 for Reddy's contribution to the debate on ALTA.

24. Fiji Times 19 Nov. 1976.

25. Hansard, 5 Mar 1998.

26. Hansard, 10 Feb. 1999.

27. See Adishwar Padarath's report in Fiji Sun, 17 Nov. 1976.

28. Fiji Times 19 Nov. 1976. MT Khan, Alliance Minister, refused to support the Bill and was sacked from the party, while Fred Elbourne, retiring Alliance member of parliament, was reportedly offered a Senate seat or a national seat if he refused to support ALTA. Among those present when the offer was made were Apisai Tora, Vijay Parmanandam, Ujagar Singh and CP Bidesi.

29. These were: KC Ramrakha, Irene Jai Narayan, Harish Sharma, Himmat Lodhia, Anirudh Kuver and Sarvan Singh.

30. See Fiji Sun, 22 Nov. 1976

31. For this I am indebted to Mr Karam Ramrakha for information and advice.

32. According to Robert Norton, Koya told SB Patel in 1977 that his (Koya's) stand on the $\$ 2.50$ issue was a mistake, but by then it was too late. Norton to Lal, 30 July 2009.

33. Fiji Sun 17 Mar 1977. See also FS 20 March and FS 7 March.

34. Fiji Sun, 17 Mar. 1977.

35. Fiji Sun, 3 March 1977.

36. Fiji Sun 9 Mar. 1977.

37. Fiji Sun, 1 April 1977.

38. This according to Karam Ramrakha who overheard the remark. 
39. Fiji Sun, 4 April 1977.

40. Fiji Sun, 10 and 25 Jan. 1977.

41. I owe this to Karam Ramrakha (3 Jan. 2001) who recalls Reddy being visibly upset at the accusation, to the quiet amusement of Siddiq Koya.

42. Fiji Times, 15 May 1984.

43. Fiji Sun, 10 Jan. 1977.

44. Fiji Sun, 9 March 1977.

45. Fiji Sun, 21 March 1977.

46. Ibid.

47. As recalled by Pramod Rae. Personal communication from Pramod Rae, 23 October, 2009.

48. Fiji Times, 26 March 1977.

49. The recommendation was in Education for Modern Fiji: Report of the 1969 Fiji Education Commission. The Commission was chaired by Sir Philip Sherlock.

50. Ahmed Ali, From Plantation to Politics: Studies on Fiji Indians (Suva: Fiji Times and Herald, 1980), 196.

51. Fiji Times, 18 March 1977.

52. Ali, Plantation to Politics, 193.

53. Fiji Times, 4 April 1977.

54. The Weekender, 2 April 1993.

55. This according to what SB Patel told Robert Norton on 1 Aug. 1977. Norton to Lal, 30 July 2009.

56. According to Norton, this is what Patel said to Koya when the latter approached him: 'Hey, Sid, well, well, after all these years you come to me for help.'

57. See Hansard, 25 May 1977.

58. Fiji Sun, 3 May 1977.

59. Hansard, 25 May 1977.

60. Fiji Times, 6 April 1977. 
61. This statement was published in the two dailies. My quote comes from typescript obtained from the Fiji Broadcasting Commission.

62. Fiji Sun, 26 May 1977.

63. Verrier's assessment, Fiji Sun, 2 June 1977.

64. See Hansard, 25 May 1977. Also Fiji Times, 20 Sept. 1977.

65. Written, it was widely speculated at the time, by Chief Justice Sir Clifford Grant.

66. According to Karam Ramrakha, the Governor General took Koya's full name, 'Siddiq Moidin Koya,' and asked that he come and be sworn in as prime minister as he commanded the majority support. Koya preferred not to go to Government House because he said Mara might not be amenable to a coalition government with him in it.

67. Letter published in Fiji Times, 9 Apr. 1977.

68. This information I owe to Karam Ramrakha.

69. Ramrakha's acceptance of the Attorney General's position is confirmed in his correspondence with me, 5 Sept. 2006.

70. See Fiji Times, 23 April 1977.

71. From Fiji Times, 9 Apr. 1977.

72. Fiji Times, 9 Apr. 1977.

73. Fiji Times, 26 May 1977.

74. This statement was published widely the newspapers, and broadcast over Radio Fiji. But see Fiji Times, 9 Apr. 1977.

75. Hansard, 25 May 1977.

76. These quotations are from the Fiji Times of April 1977. My photocopies do not have the dates on them.

77. Hansard. 31 May 1977.

78. Fiji Times, 11 April 1977.

79. Fiji Times, 12 September 1977.

80. 'Marooned at Home: A Demoralised (Fiji) Indian Community,' India Today, 30 Nov. 1987, 99. 
81. Fiji Times 19 Aug. 1985.

82. Fiji Times 9 June 1982

83. Fiji Times, 21 May 1984.

84. As recalled by Pramod Rae, 16 Oct. 2009.

85. Fiji Sun, 2 July 1977.

86. Fiji Times, 22 Sept. 1977.

87. Hansard, 25 May 1977.

88. Fiji Times, 11 May 1977.

89. Fiji Sun, 9 Apr. 1977.

90. Based on Jai Ram Reddy's official correspondence on the matter, in my possession.

91. Fiji Times, 26 May 1977.

92. Hansard, 26 May 1977.

93. Fiji Sun, 23 May 1977.

94. Fiji Sun, 7 March 1987

95. Fiji Times, 23 May 1977

96. The Weekender 23 April 1993

97. Karam Ramrakha to Lal, 10 Oct. 2006.

98. Fiji Times, 27 April 1977

99. Fiji Sun 25 Aug. 1977.

100. Fiji Sun 23 Aug. 1977.

101. Fiji Times, 29 Sept. 1977.

102. Fiji Times, 5 Sept. 1977.

103. Fiji Times, 22 Aug. 1977.

104. Fiji Times, 5 Sept. 1977.

105. This letter is in a file of papers Len Usher gave to the John White Commission and is in the Commission's papers at the National Archives of Fiji. 


\title{
CHAPTER 3: RECUPERATION \& RUPTURE
}

\author{
All great leaders have had one characteristic in common: it was \\ the willingness to confront unequivocally the major anxiety of their people \\ in their time. This, and not much else, is the essence of leadership. \\ John Kenneth Galbraith
}

6T have only had a short experience of Mr Reddy', Ratu Sir Kamisese 1 Mara said in December 1978, 'and I have a lot of admiration for him. Whether I like it or not, I think it is good for the country for a man like that to help run it." Finance Minister Charles Walker was equally laudatory in his praise for the NFP leader. Reddy would make 'an excellent spokesman for us in the North/South dialogue,' he said. 'I sincerely hope, if we get a composite team, he would be on it.' ${ }^{2}$ Len Usher, former journalist and Alliance functionary, called Reddy's criticisms of government policy 'penetrating but at the same time both responsible and constructive.' 'Reddy,' an independent observer wrote, ' was viewed by many as a plausible alternative Prime Minister. People were impressed with his cool eloquence, and his transparently balanced, reasonable views on fundamental issues. There was something reassuring about his style and personality.' ${ }^{3} \mathrm{Clearly}$ Jai Ram Reddy impressed both his political friends as well as his opponents as 'intelligent, thoughtful and calm,' 'not personally ambitious' but genuinely concerned about the future of Fiji. ${ }^{4}$

The accolades were not surprising. The hallmark of Reddy's political modus operandi was caution and moderation in the two roles he had to perform in parliament: one as the leader of his party and of the Indo-Fijian community, and the other as a watchdog over the government. The government was invariably Fijian-led and dominated, with the ever present danger 
that any criticism of government policy could easily be misconstrued, as it often was, as an 'Indian' attack on 'Fijian' leaders and institutions. 'All my political life,' Reddy once said, 'if I can avoid it, I don't talk about race. I'd rather talk about issues.' But what began so promisingly and augured well for dialogue across the political divide, soured within less than five years. A once constructive and responsible political leader would be described as devious and dangerous, with whom the Alliance leader, Ratu Mara, could not work. Internal bickering within his own party and constant acrimonious exchanges with the government side frustrated Reddy. He would leave parliament, for good he thought, in 1984. Such were the exigencies of political transformation in early postcolonial Fiji.

\section{BUILDING BRIDGES}

Reddy's first task upon winning the September elections was to unite a deeply divided party and to heal the festering wounds of the past. It was not an easy mission. The embers of the recent past were still alive. In June 1978, Reddy proposed a three point peace plan to unite the two factions. The Dove faction, Reddy said, should 'immediately stop heaping scorn and abuse in public meetings on other party leaders,' that every one carried out 'their personal dealings in an atmosphere of trust, understanding and tolerance,' and that and all the fifteen sitting NFP members should become united under a joint opposition. ${ }^{5}$ This was akin to asking the Doves to lay down their arms peacefully and surrender unconditionally, commit political suicide, a former Dove told me. Vijay Parmanandam, the rebel parliamentarian and maverick, remained a bitter Reddy foe to the end. The political unity that Reddy sought, Parmanandam said, would be like a puncture patch on an overheated tyre, likely to break any time. For him and some of his colleagues, the removal of Jai Ram Reddy from the political scene was the prerequisite for reconciliation in the party. After the September 1977 elections, Siddiq Koya retreated to his Lautoka law practice, defeated but not down, still with strong following in many parts of the country. Reddy brought him back into a reunited party. Perhaps that was the price he had 
to pay for reconciliation and unity, knowing full well that the re-entry of the former leader would revive factionalism again. Koya would contest the 1982 general elections under the NFP's banner, but his body language and public posture suggested a decided lack of enthusiasm for the party leadership which had once worked under him. For him, not being the head of the party he had helped form was an unnatural state of affairs, and he would not let others forget it either. As late as 1981, Koya was staging walkouts from party conventions when unable to have his loyalists installed, or generally have his way in party matters, leading Reddy to denounce walkouts as a 'disgraceful' feature of the party's past.

The NFP, Reddy said, was nobody's 'private domain.' Koya remained unrepentant. He was fond of saying 'Ham jaise party ke banaya hai, waise bigaad bhi sakta hai.' Just as I made the party, I can destroy it as well. I vividly recall an NFP rally at the Suva Civic Centre in 1982 at which Koya made a grand appearance in the middle of the proceedings, while all the speakers had been on the podium for over an hour, drawing applause and attention to himself as he walked down the isle. He was in the party, but not quite of it. Perhaps Koya knew in his heart that his best days were over. He was no longer the dominant, domineering figure he had been a decade earlier. 'If someone says we have already got unity, I'll say it's not completely true,' Reddy conceded truthfully in Mach 1980. But if 'someone tells me we have progressed some way to achieving unity, I'll say it is true.'

Beyond the party itself, Reddy was concerned to unite the Indo-Fijian community politically. The impetus for this came from an official visit that Reddy made to the United States in 1980 under a leadership program sponsored by the American embassy in Fiji. He toured widely, including in what was once the Deep South. What impressed him most on that visit, he said, was the manner in which Black politicians, Democrats and Republicans alike, could put aside their political and ideological differences and come together in a joint caucus to discuss issues of particular concerns to their people. If the Blacks could do it in the United States, why couldn't the IndoFijians in Fiji, he asked himself. With that goal in mind, Reddy reached out 
to Indo-Fijians on the other side of the political divide in a way his predecessors could not because of the bitter fights they had in the past, especially in the emotionally charged atmosphere of the 1960s. Thirty years later, Karam Ramrakha still could not bring himself down to forgiving Sir Vijay Singh for his hurtful taunts about Indian leaders being cowardly and unpatriotic in a 1967 Legislative Council debate during which the Federation Party staged a walkout. Siddiq Koya similarly found it difficult to reconcile with his old foes and share the same platform with them. Reddy's strength and advantage was his freshness on the scene and his lack of a political baggage. Not narrow political advantage but the larger interests of the Indo-Fijian community were foremost in his mind. He emphasized the commonality of interests that united his people, not the quite real differences which divided them. He talked at length to people like James Shankar Singh and found in them a receptive audience. He reached out to the former Indian Alliance heartland by praising leaders like Ajdhoya Prasad, once a sworn enemy of the National Federation Party.

The timing was opportune. By the late 1970s, Indo-Fijians in the Alliance were on the outer, neglected and un-consulted by the party leadership on major policy issues. They were, in truth, always the weakest spoke in the Alliance wheel and, with a few exceptions, people without clout or credibility in their own community. Not having delivered a much-cherished single Indian communal seat to the Alliance hurt them deeply and for which they were not forgiven. The leading lights of the Indian Alliance were either publicly humiliated or forced out from the party. Among them was Sir Vijay R Singh, a founder of the Alliance party, who was forced to resign as Attorney General over his role in a court case involving the Flour Mills of Fiji. Insiders said Sir Vijay was asked to leave because he had Ratu Mara ears, rather too much for the comfort of many in the Cabinet. Mara, inexplicably, refused to come to his rescue, being conveniently away from Suva when his cabinet colleagues sacked the Attorney General. The manner of his sacking, by a cabinet and not the Prime Minister, as Sir Vijay later reflected, was probably unprecedented in the history of the Commonwealth. 
Another casualty of the Alliance's disdain for its 'non-performing' Indian members was the Tavua politician, lawyer and Minister of Commerce and Trade MT Khan over alleged corruption, for which he was later acquitted. Khan had left the NFP in 1968 to join the Alliance. He rejoined around 1980, but died soon afterwards.

The latest casualty was James Shankar Singh, president of the Indian Alliance, no less, who resigned from the Alliance, bitterly claiming that the Indian members of the Alliance were used by Ratu Mara as his 'footstool,' and treated liked 'coolies.' 'It is my sad experience,' Singh said, that 'throughout the existence of the party Indian Alliance leaders and members have been made tools or vehicles of convenience by the party leader, and once the general election is over and Ratu Sir Kamisese conveniently seated in the Prime Minister's chair, he treats them like a bunch of coolies. ${ }^{8} \mathrm{He}$ had 'irreconcilable differences' with the Alliance leader whom he described as 'uncompromising, arrogant and dictatorial." These were strong words from a genuinely mild-mannered man well regarded across the communities, but they were fairly widely shared. Said Armugan Pillay, the Assistant General Secretary of the Indian Alliance in June 1982: 'People need better treatment. This is a party where democracy has no place at all. If one differs from the party leader, than he is a marked man. We in the Alliance are treated as third class members. ${ }^{10}$ Most of the Alliance 'refugees' found a welcoming home in an inclusive NFP, much to the quiet dismay of some of the older members with strong memories of bitter past fights, who now felt neglected and on the margins of the party's affairs.

Harish Sharma, a long-time Reddy deputy, expressed their feelings this way. Referring to Sir Vijay Singh's admission to the NFP, Sharma told Reddy: 'I can't trust this man, if you see his record. The man will dump you the moment he is finished.' Reddy snapped at him: 'Here I am trying to unite the people, and he is such a big political fish. The problem with people like you is that you can't trust anybody." ${ }^{\prime 11}$ Sharma, having made his point, did not respond. Sure enough, Sir Vijay resigned from parliament in 1985 to become the Chief Executive of the Sugar Cane Growers Council. And 
Reddy and Fiji's first Indian knight fell out in the 1990s over the latter's tacit support for the Fiji Labour Party and his niggling newspaper columns against his own former party, and would never reconcile. No one doubted Sir Vijay's intelligence and his command of the English language. He was sharp and witty, but they questioned what they loosely called his 'consistency. ${ }^{12}$ In the late 1970s and early 1980s, Reddy was busy transforming the NFP into a 'broad church' for the Indo-Fijian community and former opponents were welcome to join it.

A very similar development was taking place on the Fijian side as well. According to Sir Vijay Singh, the turning point for the Alliance came after the April 1977 elections when it lost 25 per cent of the Fijian communal votes to the Fijian Nationalist Party. It was then, Sir Vijay told me, that Ratu Mara went 'soft' on his multiracial philosophy to accommodate the more radical elements of the Fijian community. ${ }^{13}$ He realized anew the accuracy of the advice that David Butler, the Oxford (Nuffield College) political scientist, had given him on the Independence Constitution that Fijians would have political control provided they were united. To consolidate Fijian unity, Mara was prepared to put aside the needs and aspirations of the weakest element of his party which included, as James Shankar Singh pointed out, more admission of Indo-Fijians into the military and the opening up of more land already available rather than reclaiming swampy land near the sea. ${ }^{14}$ Soon after losing the April 1977 elections, Mara set about recapturing the Fijian constituency, urging unity without which, he said, everything which the Fijian people held dear could be jeopardized. But his problems were not over yet. There was rumbling in Western Viti Levu which would evolve into a major political headache for him in a few of years' time.

\section{RACE AND LAND}

With positions solidifying along ethnic lines, the politics of race once again came to the fore, coalescing around a number of predictable issues. Education was one of them. In 1979, Irene Jai Narayan moved a motion in parliament expressing grave concern at the mishandling of the admission of 
students, especially private students, to the University of the South Pacific. Private students were required to pay $\$ 3000$ admission fee. ${ }^{15}$ The NFP asked the government to reduce it to a more realistic, affordable figure. The government was caught in a bind. 1976 was a bumper year when 895 students had passed their University Entrance exams, 295 more than expected. To qualify for government scholarship, Indo-Fijian students had to have a mark of 260, while Fijian students required only 210. Figures showed that from 1971 to 1977 , more Indo-Fijians got admission with scholarship to the university than Fijians, but figures in the abstract meant little to those who had missed out and now faced a bleak future. ${ }^{16}$ Education was one commodity the Indo-Fijians valued more than any other. It was their passport to hope. Ratu Mara reminded the NFP of the recommendations of the 1969 Education Commission, which had recommended reserving 50 per cent of the scholarship for Fijian students on a 'parallel block' basis (directing the unallocated balance of scholarships to other specifically Fijian needs) and providing assistance to repeating Fijian students where they had demonstrated 'serious and sustained application to his studies. ${ }^{17}$ Tomasi Vakatora was blunt: this was nothing but a disingenuous ploy on the part of the Indians to get a greater share of the education cake than was their due. 'If you want that [more scholarships] why go about in a devious way? Why do you just not stand up and honestly say that you want more scholarships for Indians?' ${ }^{\prime 18}$.

It was not an issue of race, Reddy would say later, nor was it a case of Indians adopting a knee-jerk opposition to all efforts to help Fijians. For more than a decade, the NFP had accepted 'that the Fijian people are in need of special help in the fields of education and commerce and industry. In the former case, the reservation of $50 \%$ of places at USP is the manifestation of that policy. The granting of soft loans by the Development Bank to ethnic Fijians in order to help them in commerce is another example. Similarly, much of the rural development effort is geared to help the Fijians better their standard of living. Massive assistance to the Fiji Pine Project is yet another example of special assistance primarily aimed at helping one section of the 
community but indirectly helping the whole. We recognize that this effort must continue. Indeed we must look at ways and means by which more effective use can be made of our resources to bridge the gap between the haves and the have nots. ${ }^{, 19}$ But the presumption that all the 'haves' belonged to one community and all the 'have nots' to another was the real problem. De-racializing important issues of public policy would be an intractable problem in a country obsessed with racial characterization of everything.

If discrimination in the education sector was one pressing and persistent matter of concern to the Indo-Fijian community, glaring disparity in the civil service was another. In December 1979, Reddy raised this issue in parliament. ${ }^{20}$ The statistics about the absence of Indo-Fijians from the top echelons of the civil service were as stark as they were startling (see table on facing page). Of the four District Commissioners, only one was IndoFijian (Narsi Raniga), and of the six High Commissioners, only one (Satya Nandan) was an Indo-Fijian.

Reddy accused PSC chairman, Joseph Sykes, of breaching Section 105 (9) of the constitution which covered appointments to the civil service. It stipulated that 'each community in Fiji receives fair treatment in the number and distribution of offices to which candidates of that community are appointed on entry.' And he reminded the parliament of the Public Service Commission Constitution Regulation 1974 which provided that in the event of two or more applicants being available for appointment, 'preference shall be given to that officer who in the opinion of the Commission has the most merit for appointment to the post.' Said Reddy: 'I cannot believe that there are no Indians in the Service who, by merit, are not in a position to be moved up to these decision-making levels, so that some parity is maintained, as the constitution requires... The one thing that emerges from an examination of the constitution is that the PSC itself is unable to make any of these appointments without the concurrence of the Right Honourable the Prime Minister and I think as Leader of the Opposition, I am entitled to ask him, that how is it and why is it that this imbalance has occurred at this level of our Civil Service.' The imbalance, Reddy said, was an issue of 


\section{HEADS OF DEPARTMENTS}

Secretary to Cabinet

Foreign Affairs

Public Service Commission

Home Affairs

Solicitor General

Finance

Labour

Educaton

Fijian Affairs

Agriculture \& Fisheries

Commerce \& Industry

Health

Urban Devt \& Housing

Posts and Telecommunications

Works and Communication

Transport \& Tourism

Auditor General

Information

Cooperatives

Forestry

Mineral Resources

Social Welfare

Lands

Youth \& Sport
Dr Isireli Lasaqa

Jioji Kotabalavu

Joseph Sykes

Mosese Buadromo

Qoriniasi Bale

Winston Thompson

Satya Nand

Filipe Bole

Ratu E Kanaimawi

Robin Yarrow

Laisenia Qarase

Dr Jona Senilagakali

Bhuwan Dutt

John Manikam

M Tukituku

Robert Dodds

Tamessar Bhim

Don Diment

J Nacoke

H Williams

Ron Richmond

Rev. V Liga

T Rupeni

Inoke Tabualevu

great concern to his community. Ratu Penaia Ganilau, the Deputy Prime Minister, rejected outright any allegation of 'political manoeuvring and unfair treatment,' saying that there was no interference in the work of the PSC by the Prime Minister or anyone else. And the insinuation that Mara 
had influenced decisions was vehemently denied. But the glaring absence of Indo-Fijians at the top echelons of the civil service could not be. That was the main point of contention.

The facts could not be ignored. And they were not surprising. Mara knew very well that the future of his government depended upon consolidating Fijian support, and appointing Fijians to the top positions was a part of that strategy. The position of Indo-Fijian civil servants would continue to deteriorate over the next decade, their numbers rapidly thinning at the top. In 1995, Reddy repeated what he had in effect said a decade earlier. An attempt was under way to 'ensure that all strategic levels of government are staffed by loyal personnel which in effect means that indigenous Fijians are placed in positions of command in order to create an 'out group', namely the Indo-Fijians. ${ }^{21}$ When Reddy spoke, only six of the thirty one permanent secretaries and seven of the thirty two deputy permanent secretaries were Indo-Fijians. The culture of political patronage and ethnic 'preferencing' in appointments would ensure the continuation of the disparity in the future. In raising the issue of racial disparities in the civil service, he was not playing the card of racial politics, Reddy stressed. 'Whether I ask that question here or not, people are asking that question and I would be a naïve fool if I pretended that this is not a problem and is not an issue that people are talking about. I feel that the sooner the air is cleared and answers are given, the better it will be for all concerned.' A decade or so later, Reddy was making the same point, saying that he was not asking for dominance nor for charity. 'I am asking you to treat the Indian civil servants as you treat your own people. Since you have the political power, dispense it justly. ${ }^{22}$

While discrimination in education and the public service were stirring public emotion, the perennial topic of land raised its head again. The issue this time was not leasing arrangements but the reserving of Crown land. In 1975, the Alliance government decided to reserve (for future Fijian use) some 62,240 acres of Schedule A and Schedule B land, affecting some 192 leases and at least five government projects. These were land which were declared unoccupied or where the original mataqali had become extinct 
around the time of Cession. Surprisingly, the new reserves policy was not announced publicly through a news conference, as all major decisions of the government usually were, but to a meeting of the Great Council of Chiefs. On 2 May, Jai Ram Reddy wrote to Ratu Mara, informing him that he had decided to raise the issue in parliament but had been dissuaded by Ratu Penaia Ganilau, who had advised private discussion among the three of them. 'Ratu Sir Penaia gave me the assurance that government will take no further action in this matter, namely, the Governor General will not be asked to sign the relevant proclamations and the status of Crown land will not be changed.' 'On that assurance,' Reddy continued, 'I agreed not to raise the matter immediately but to participate in the proposed discussion to see if some acceptable agreement can be reached. ${ }^{23}$

No discussions took place. Reddy wrote to Mara again, on 27 February 1980, when it seemed certain that the government would go ahead with the plan. 'I would have thought that the government would be seeking to preserve such Crown lands as there are to settle evictees from native lands as pressure from land owners grows to farm their own land.' He continued:

I believe the government decision is wrong, and it cannot be justified on any account, particularly where it will involve throwing out tenants on Crown land, who have always believed that they were secure on them and have carried out substantial improvements. Besides, this move will be seen by them as an act calculated to make life more difficult for them in this country - which many of them believe is theirs also. On what basis does one justify evicting one landless man to put another on it? Frankly, I am extremely distressed about what is proposed. This single decision more than any other in the ten years of independence will help ruin the kind of inter-racial relations we would like to see develop in this country.

Reddy raised the subject in public for the first time at the NFP convention, questioning the 'secretive' nature of the transaction. ${ }^{24}$ 'Given Fijian strength in this area and the Indian vulnerability,' he asked, 'is it necessary 
to take over what little Crown land there is and literally to convert it into Native land?' 'You may have the power to do it,' he continued, 'but the power to do what is right and good is also the power to do what is wrong.' 'I would have thought that a reasonable government would preserve as much Crown land as possible consistent with the principles of fairness to all in order to settle future evictees from Native lands now waiting to be resettled.' For Reddy, the reserving of Crown land was yet another attempt by the government, deliberate or not, to weaken the Indian community and thereby compound its vulnerability.

Ratu Mara denied any impropriety. Writing to Reddy on 3 April, he said that 'the policy to reserve Crown land for allotment to Fijian proprietary units is not new.' He reminded Reddy of Section 18 (1) of the Native Land Trust Act which authorized the Governor General to set aside as much Crown land as he deemed necessary for the use of the landowning units. This was the provision which had been invoked in 1975, after consultation with the Great Council of Chiefs. Reddy disagreed with Mara's interpretation. He had 'grave reservation' about the applicability of the particular section cited by the Prime Minister. 'It is not without significance,' he wrote to Mara on 9 July 1980, 'that successive Colonial Governors do not appear to have found it necessary to invoke Section 18 (c) of the Native Land Ordinance to displace sitting tenants of Crown land.' He doubted if that provision was 'intended to be used literally to convert large areas of Crown land into Native land by a simple administrative device of a proclamation. Indeed that Section seems wholly inappropriate to the post-independence situation in Fiji.'

Once the matter entered the public arena, Mara went on the offensive. Addressing the Alliance convention at the Trade Winds Convention Centre in October 1983, he reminded Reddy of the generosity of the Fijian people, the concessions they had made for the greater good, such as agreeing to ALTO and ALTA and to 50 percent of the fifty year leases in the Seaqaqa Cane Scheme. He went on: 
It is well known that 83 percent of the land is owned by the Fijians, but as Professor Spate found out, all the eyes of the land have been picked out by the immigrants. All the best Fijian land is under lease and the majority of the tenants on the best lands are Indians. Most of the valuable properties in urban areas are now occupied by the Indian people. Their ownership, like the tentacles of an octopus, has embraced retail commerce, industry and transport. The Fijians in the name of equity have not asked for an equitable share in these. They abide by the constitutional rights and protection given to property.'

The Alliance had not resorted to the Bumiputra-style affirmative action policy in Fiji. The Fijians had given much, yet 'even the pieces left in the hands of the landowners are being demanded again by the Leader of the Opposition for the section of the community which dominates our economy.' 25

The cumulative picture that the Prime Minister's response, intentionally or otherwise, portrayed of the Indo-Fijian community was one full of greed, never satisfied, always seeking advantage wherever they could find it. Broadly speaking, this was the Fijian view of the Indo-Fijian community. Mara accused Reddy of public posturing, playing to the gallery. Reddy denied this. 'To answer those who are accusing me of raising this issue at my Party's Convention, I can only say that I have corresponded with the Prime Minister on this subject and it was only after it became clear that no solution was in sight that I informed the Prime Minister in writing of my intention to raise the subject at my Party's Convention.' He continued: 'I might be disappointing some who may wish to use this issue for their own political gains but it is no secret that the National Federation Party has never questioned the ownership of Fijian land and it does not do so now.'

In an interview in 1978, Reddy was asked about his views on the land problem. He talked about it in a balanced way. To achieve a viable solution, the interests and concerns of both the landlords and the tenants had to be considered. 'It is not simply an economic problem,' he said. 'It is a complex 
of economic, social and political issues, and it is perhaps ironical that at the centre of it all is fear and suspicion that the unscrupulous on both sides will exploit. ${ }^{26}$ 'To the Fijian people land is very close to their hearts - it is part of their culture and tradition; they see land as the basis of their security and very existence. They also see it as a bulwark against their apparent backwardness in commerce and industry.' The Indian tenant knew that it was in the nature of leases that they would expire one day. What would happen then? 'And because the Indian community comprises the bulk of the tenant community, they see their insecurity in this respect as a threat to their very existence in this country.' The constitution did not help, for the tenant knew that the same constitution 'that gives him citizenship also protects the Fijians' ownership of the land, and he is deeply conscious that certain rights flow from that fact and one of them is the landowners right to dispossess him.' The problem was not insoluble, Reddy said, but it would require 'goodwill, honesty and forthright discussion.' He urged the government to produce a long term policy on land. Maintaining the status quo was no solution. 'Land by itself (like anything else) is not important; what is important is what we produce out of it.' 'The greatest potential for future growth in our country,' he continued, 'is in agriculture — there is no doubt about it — and maximum use has to be made of our land resources.' This was true. But it was also the source of great power in the hands of the Fijian political elite. A whole range of complex vested interests ensured that there would be no easy resolution of the problem. It would re-appear on the political radar a decade later, but again without resolution.

\section{GOVERNMENT OF NATIONAL UNITY}

In 1979, Dr Ahmed Ali, a former secretary of the Alliance party and an academic at the University of the South Pacific, prepared a paper on a possible government of national unity at Ratu Mara's request. The idea of power sharing in some form had been floating around for some time, but this was the first time that it was being committed to paper. The Ali paper dwelt heavily on the problems of governments in crisis-prone plural societies. 
Those elements neglected in national decision making tended to 'become more disenchanted with the government and country and with little reason for loyalty to a system which excludes them through no fault of their own apart from their attachment to a political party in which they genuinely believe,' Ali wrote. ${ }^{27}$ This was clearly an undesirable state of affairs. The paper rejected coalition as a solution 'because a coalition is always a temporary measure devised for times when no group possesses a reasonable majority to govern on its own and joins in a loose association with another or others merely to keep the country going' until the next elections. The coalition arrangement was not good for Fiji for two reasons, the paper argued. First, compromise might be required, 'but the country's crucial problems do not lie in resorting to compromises' What was required was 'all groups accepting to assist the disadvantaged, especially in one ethnic group agreeing to help another.' That point is obvious, and it would require compromise. The second reason for the coalition arrangement's unsuitability was that bargaining might be required, and 'the bargaining is likely to be mildly successful at the best and a complete failure at the worst.' Why this should be so, the paper did not elaborate.

The best solution lay in a government of national unity 'which draws upon the best talents in the country having in mind simultaneously adequate representation of the various ethnic groups in Fiji.' A 'national government wherein all communities are participants could act confidently and decisively' fending off accusations of ethnic bias. And, finally, 'a national government would present the nation with the example of a group of persons from different communities working together for the general good of the whole country, not primarily for any section or sections of it. The picture of leaders in harmony would register in other minds and spread to the people as whole.' The paper continued in this very generic mode about the need for balanced participation and adequate representation of all the major communities 'to obtain consensus for critical policies thereby nullifying the likelihood of a sense of alienation developing in any one or more ethnic groups through apparent or real neglect.' But beyond the elementary state- 
ments in the paper, there were no concrete ideas about how power might be shared, how the concept might actually work in practice.

Ali met with Reddy in April 1979, but NFP leader told him 'that in order to have any fruitful discussion, the Prime Minister and I should personally discuss this rather than through an intermediary. ${ }^{28}$ No discussions took place, though Mara claimed that he had 'a preliminary discussion with him on a Coalition Government, and gave him a paper as a prelude to further discussions. ${ }^{29}$ But then on 3 March 1979, he admitted that he had not discussed the idea with Reddy at all. 'I felt that if I had gone to the Leader of the Opposition without discussing it with my colleagues in the Alliance that in itself would start prejudice in their minds.' ${ }^{30}$ Mara sent a copy to Reddy apparently 'as an opener to talks' on government of national unity. Why, on this important issue, the phone was not picked up or some arrangement made to facilitate a face-to-face meeting, remains a mystery. Reddy read the paper and had it returned to Ratu Mara, without comment or advice, absolutely denying slipping the paper under the door of the Prime Minister's office, as Ratu Mara later alleged. Reddy recalled his reaction this way: 'I expected that when the Prime Minister gave me the paper that I would take it and read it and, at some stage, he would discuss it with me. I thought that is how it would work. It didn't happen. He raised it publicly, and it was floating around but I never heard from him officially.'31 Mara took Reddy's silence, or rather non-response, to mean rejection of the concept, and Reddy has continuously been blamed for the collapse of the proposal. $^{32}$ 'It has been said that the NFP rejected the proposal for a government of national unity,' Reddy wrote to Mara on 20 December 1982, 'but as we see it, a proposal was never made.'

Mara went public and accused Reddy of rebuffing the idea. 'We are not unmindful of the fact that the price for the establishment of dialogue on the Government of National Unity demanded by the Leader of the Opposition - the undermining of the constitutional protection afforded to Fijian interests — is too much for any Fijian leader to entertain. The price makes mockery of the constitution which emerged from the consen- 
sus and compromise reached at the London Constitutional Conference in 1970. ${ }^{33}$ Precisely what constitutional protection given to Fijians Reddy had jeopardized remained unstated. In his defense, Reddy said that 'the fact that so sensitive an issue as a government of national unity was raised for public discussion without real attempt to discuss the issues directly with the Opposition and thereby virtually forcing the Opposition to respond to the proposal in a public way and in an open forum and the rapidity with which the idea was rejected leaves me wondering whether the whole exercise was not a public relations gimmick, an exercise in public meditation in order to give the government a facelift. 34 'One thing that has clearly emerged from the recent debate,' Reddy said, 'is that no government of national unity can or will work in Fiji if emotion rather than reason is allowed to dominate public discussion on important issues.'

Ratu Mara appropriated the high ground on the subject, but while he talked about the virtues of a coalition government, he rejected it when the opportunity offered itself. The first was in 1965 when, as we have seen, the report of the constitutional conference of that year provided for a broadbased government. Mara had won the 1966 elections, and he would not have the Federation Party in his Cabinet. Their policies were too dissimilar, he had said. The second opportunity came in 1975, when the NFP proposed to the Street Commission the idea of a 'government of national unity and concord,' consisting of all parties. The Alliance government rejected the report outright, without even tabling it in parliament. The third opportunity presented itself in April 1977 when the NFP made the offer of a coalition government. The offer was rejected outright because Mara thought he was being asked to bail out a beleaguered opposition 'from a position they did not feel capable of sustaining. ${ }^{, 35}$

Karam Ramrakha recalled that when Mara talked of coalition, he 'was basically talking of us becoming part of his consultative group and therefore a 'prisoner' to the majority.' 'I am glad it did not eventuate,' he continues, 'not that Mara was ever genuine about it. He used to shout Coalition as a sort of mantra to destroy us, and to make us feel we did not want to work 
with him. ${ }^{36}$ Ramrakha’s view is inadvertently supported by Ratu Mara himself. When the NFP-FLP Coalition refused to join the Governor General's Council of Advisors in 1987 because only two of them were invited to join it (Harish Sharma and Dr Timoci Bavadra), the overwhelming majority being Alliance Party members, Mara said that their refusal was yet 'another opportunity for a government of national unity missed. ${ }^{37}$ It was a very curious idea of a government of national unity indeed, to say the least. Reddy's fears of being co-opted and destroyed were apparently well founded.

In June 1980 at the NFP convention in Ba, Reddy subjected the Ali paper to searching criticism and what he thought were its hidden political agendas. He wondered whether Mara wanted 'the National Federation Party as a substitute for the now almost defunct and discredited Indian Alliance. ${ }^{38} \mathrm{He}$ asked two questions which, he said, required immediate answers. 'First, if the NFP wins majority of seats at the next general elections, will the Alliance agree to serve in a coalition headed by the NFP?' And, second, 'if the Alliance was to retain power at the next general elections, will they still invite the NFP to participate in a government of national unity?' Instead of raising the issue in public, Reddy advised Mara to raise it first with the Fijian Association, the dominant part of the Alliance. Reddy reminded Mara of his refusal to form a coalition with an 'Indian-dominated party' after the April 1977 elections because that would be playing straight into the hands of nationalists like Butadroka. Nothing had changed, Reddy said. The NFP was still Indian-dominated. Precisely what kind of coalition or government of national unity Mara had in mind was never clear. Reddy said: 'The Prime Minister's apparently contradictory and irreconcilable stand on this important subject of conciliation and his subsequent statements, have created the widespread suspicion that the only kind of coalition the Prime Minister has in mind is one that will be led and dominated by the Alliance.' Reddy's hard hitting response led to the Fijian Association resolution at their 16th annual convention in 1981 to leave the matter 'in abeyance.' A Vice President of the Indian Alliance, Hasan Raza, welcomed Reddy's response as a 'blessing in disguise, for in a 
government of national unity, the members of the Indian Alliance would have been the first casualty. ${ }^{39}$

What motivated Mara on the subject remains unclear, but he did say that a change of government 'may not go down well' with sections of the community. As will be made clear shortly, the Alliance was facing problems within its Fijian ranks and a government of national unity might have been a way of keeping the Alliance in power. At least that was Reddy's assessment. He accused the Alliance of failing, after ten years in power, to educate the people 'on the most fundamental tenet of democracy,' which was 'the right of the majority to change a government, irrespective of racial considerations.' He said: 'For any leader, least of all the Prime Minister, to suggest that a duly elected NFP government could not go down well with the Fijian people does not auger well to both parties' commitment to multiracial harmony in this country.' Fiji had enjoyed ten years of multiracial harmony, Reddy said, and personally he had 'no reason to think that this will not be the continuing feature of our national life in years to come. ${ }^{40}$ Mara was prescient, even though he might have been motivated by narrow political motives; but Reddy also could not see why, if elected, the NFP could not rule although he had raised the question of the viability of a government by the NFP a few years earlier. He had learned the lessons and the past would not be allowed to be repeated. With the wisdom of hindsight, Reddy regrets the turn the discussions on government of national unity took. $\mathrm{He}$ says now, knowing what he does, that he might have raised his concerns in public in a more general way, without compromising the substance of his thesis, keeping the door open for private discussions, but whether that approach would have borne fruit, bearing in mind Ratu Mara's own stated views on the matter, is not certain.

When Sitiveni Rabuka mooted the idea of a government of national unity in the mid-1990s, Reddy elaborated on his deeper concerns because what appeared a noble concept on paper had to be thought through carefully before it could be given practical effect. 'It is not just putting together a dozen people of different races or as simple as four Indians joining the 
Rabuka cabinet and pursuing his policies. It means reconciling seemingly irreconcilable interests. A government of national unity is only possible if you have an agreed program and agreed objectives that you are going to work towards.' With an agreed program, no party could manoeuvre itself into a situation where it had no control over the government's program which it could not criticize. 'If you go in there not knowing what you are in for, not knowing what a government of national unity is supposed to do, it will be worse for inter-communal relations if you withdraw prematurely. It will create a worse disaster than the one we have on our hands now. It will be portrayed as unwillingness of the Indians to work cooperatively with other communities, and it will be bad for us. ${ }^{41}$ By the early 1990s, Reddy was thinking not so much about a government of national unity under a flawed constitution, but another form of political power sharing arrangement whose scope and focus has already been mentioned.

But all this was far from Reddy's pressing concerns in the early 1980s, which were to give the NFP a viable platform as the alternative government. The lessons of 1977 had been learnt. This time, the NFP would be ready to form government if it won the general elections. To that end, Reddy created a shadow cabinet to bolster opposition performance in parliament. Irene Jai Narayan assumed the portfolio of Finance and Economic Affairs. H M Lodhia was appointed spokesman for Trade and Industry, SN Kanhai Education, Harish Sharma Law, Administration and Justice, Senator Colin Weaver Tourism, Transport and Civil Aviation, and Senator Subramani Baswaiya Land and Agriculture. More appointments were promised, the idea being to introduce a degree of professionalism and prior preparation in the party's front bench. There had been a shadow cabinet under Koya, but it was in truth more shadow than substance when all the energies were spent on internal party battles. The absence of Fijians in the shadow lineup is glaring. How to increase the party's support base among Fijians was Reddy's most formidable political problem, and to this task he began to turn his serious attention. 'It is very important,' he said, 'that more of us try to get to know leaders of other races, to get closer to them and under- 
stand how they feel.' Fijians, he said, would come to the party if 'they found the NFP sincere about Fijian problems, and this could be demonstrated to them. ${ }^{42}$ It was an admirable ambition but idle because electoral politics in Fiji was structured in such a way that cross-ethnic appeal for votes was always viewed suspiciously as an attempt to divide a community, not as a genuine effort to enlarge the common space. Fijian leaders appealing for Indo-Fijian votes were seen to be dividing the community. And vice versa. Reddy would shoulder his share of blame, with grave consequences for himself and his community.

\section{NFP-WESTERN UNITED FRONT COALITION}

By the early 1980s, Sakeasi Butadroka was no longer the threat he had been in the mid-1970s. He had been in jail for breaching the Public Order Act prohibiting the incitement to racial hatred, and his party was in disarray. The ground from under its feet had been cut by the Alliance's assiduous courting of the Fijian voters. But just as the embers were being doused in southeastern Viti Levu, a new threat emerged in western part of the main island where Fijian feelings against the Alliance coalesced around the pine industry. Pine (pinus caribaea va hondurensis) began to be planted in Fiji in the late 1950s and early 1960s, and by 1979, 28,000 hectares were under pine, mostly in the dry and arid hills of western Viti Levu between Sigatoka and Nadi. To govern the operations of the pine industry, the government established the Fiji Pine Commission in 1976 to 'facilitate and develop an industry based on the growing, harvesting, processing and marketing of pine and other species of trees grown Fiji. ${ }^{43}$ But the pine industry was not the exclusive domain of the Fiji Pine Commission. The other major partner was the landowners, assisted by the Forestry Department. The Commission invited proposals from interested companies to harvest the mature pine. Four proposals were received: from the MK Hunt Foundation, Shell/New Zealand Forest Products, British Petroleum (BP) Southwest Pacific Limited, and the United Marketing Company (UMC) owned by a convicted US businessman, Paul Sandblom. The Commission accepted the BP proposal 
because it appeared more flexible and promised a rational, more sustainable development of the industry. The landowners, led by Ratu Osea Gavidi, leaned towards the UMC proposal because it apparently recognized legitimate landowner rights, offered them a greater share of the profits, and allowed them participation at all levels of the industry. The Fiji Pine Commission remained unconvinced, and the government declared Sandblom a prohibited immigrant because of his previous criminal conviction. It might be added parenthetically that this was neither the first nor the last time that Gavidi would associate himself with foreign entrepreneurs and fortune hunters with dubious financial credentials, in the process undermining his own credibility in the public eye.

The simmering tensions between the landowners and the Fiji Pine Commission, and through it the government, erupted in the open as landowners boycotted several of the Commission's pine planting programs. To the western landowners, the Alliance government's approach and determination to have its own way was yet another unacceptable interference in their right to utilize their resources as they themselves saw fit. The landowners preferred 'the establishment of a decentralized, socially compatible, technologically appropriate and economically viable processing system for both native and exotic forests [and assisting] direct participation [of landowners] in the exploitation of such forest resources. ${ }^{44}$ In short, the landowners wanted direct control and the bulk of the proceeds from the industry. As Gavidi said, 'I am committed to promoting the pine industry, the interest of the landowners, and indeed of Fiji and I am not about to surrender this obligation for the private gain of any company or person, Mr Sandblom included. ${ }^{45}$ The government, on the other hand, preferred a more centralized control of a resource that had the potential to become a major revenue earner for Fiji. The interests and concerns of the landowners had to be balanced against many other competing interests.

The pine dispute brought into sharper relief longstanding private resentment among western Fijians at the perceived iniquitous treatment at the hands of the eastern chiefly establishment. It served to highlight other 
grievances such as the paucity of western Fijians in the civil service and other statutory bodies, disparities particularly glaring — and galling — in view of the overall western contribution to the national economy. The issues came into sharp focus during a parliamentary debate on the allocation of $\$ 435,868$ to renovate certain historic sites on the chiefly island of Bau. Tui Nadi, Ratu Napolioni Dawai, attacked the motion as unjustified, and pointed to the more pressing needs of western Fijians such as water supply, roads, and dormitories for school children from outlying areas studying on the mainland. Dawai resigned from the Alliance and joined Gavidi. A new political party, Western United Front, was launched in traditional Fijian style on 17 July 1981 in the presence of some twenty ranking chiefs from various districts of western Viti Levu. Gavidi, elected president, outlined the party's goal: to protect and encourage the unity of western Fijians, protect the interests of landowners and defend their rights to develop their resources according to their aspirations, to seek changes in the Ministry of Fijian Affairs and Rural Development to improve the lives of western Fijians, and to improve the educational facilities of western Fijians and provide them opportunities in commercial and industrial enterprises.

The list of grievances and the proposal to address them seemed familiar enough. They had been raised before by, among others, Apolosi Nawai and Apisai Tora, and Tora would continue raising them well into the 1990s. But Tora, the longstanding advocate of western interests, was not with WUF. He had joined the Alliance party after resigning from the NFP in 1979, although privately he probably applauded the daring challenge to the eastern Fijian establishment. Another high western chief, Ratu Mosese Varasikete Tuisawau, a leading Fijian light of the NFP in the 1960s and editor once of the party's Fijian newspaper, had also left the party in 1979 and joined the Fijian Nationalists, eventually becoming their president. So the western front was not as overarchingly western nor as solidly united as it was portrayed to be. Western United Front was the handiwork of a few individuals and in truth centred around the disputes in the pine industry alone, little more. But the new party potentially offered the NFP new op- 
portunities. The departure of Fijians of seniority had fatally narrowed the NFP's multiracial appeal and membership. The emergence of the Western United Front offered the party an opportunity to expand into the Fijian community through the new channel. For the WUF, the NFP also provided all the infrastructure and financial resources of a well established party to expand beyond its regionalist base. At first, though, the Western United Front had flirted with the Fijian Nationalists to form a joint, progressive front, but the effort was abandoned when an irate Butadroka reportedly assaulted Solomone Momoivalu, an Alliance minister of state, for accusing him of practicing voodoism to attract Fijian voters.

After a series of meetings involving Jai Ram Reddy, Siddiq Koya, Irene Jai Narayan and Ratu Osea Gavidi, a NFP-WUF Coalition materialized on 11 January 1982 in the presence of Ratu Apimeliki Varakuka, Penaia Browne, Sunia Naulago, Raba, Isikieli Nadalo, Tui Nawaka, Ratu Osea Gavidi (Snr) and Ratu Osea Gavidi, and Sekonaia Niukula representing the Western United Front, and RS Goundar, Jai Ram Reddy, Siddiq Koya, Shardha Nand, SN Kanhai and Koresi Matatolu representing the National Federation Party. The exact terms of the arrangement were never publicly stated, but in the Coalition Bulletin, Reddy declared:

In this arrangement, each party is to maintain its independent identity and objectives. In other words, there is no submergence of one party into another. It must be remembered that the two parties are totally independent, with interest that each would like to protect. I don't envisage that where parties are independent and are being led by strong leadership with principles that they themselves espouse, there is any real danger of anyone becoming subservient. It is a partnership of equals.

Speaking at the launch of the NFP-WUF Coalition, Reddy said that a coalition merely for the sake of winning a majority of the seats in parliament or for simply toppling the government was not good enough. He wanted the parties first of all 'to establish areas of common ideals — of which there were many — and to iron out any differences in policies. Ultimately, the 
partners should be equipped to work as a Government on clearly defined and agreed policies or, of [the] occasion arose, to function as supportive partners in Opposition.' Each party would select its own communal candidates but would cooperate and consult each other in selecting candidates for the four Fijian national seats (by a joint committee comprising Reddy, Koya, Gavidi and Nadalo) to be shared equally by the coalition partners. Koya suggested the idea of co-chairs of the campaign and his proposal for Reddy and Gavidi to be the co-chairs was accepted with acclaim. On 17 April, Reddy was unanimously elected the leader of the NFP-WUF coalition and the decision ratified by the NFP's Working Committee in Tavua. The resolution, Reddy said 'should put an end to the speculation, misgivings and doubts that existed in the minds of people about the leadership issue.' The time was now to 'concentrate on real issues important to us all. ${ }^{36}$ This is what Reddy told the convention:

Let me assure you that the Coalition between the NFP and the Western United Front is not one of convenience, nor is its sole purpose to topple the Alliance. It is an attempt to bring together people of different races and backgrounds in an endeavour to create a nation out of our diverse communities. It is a sincere attempt to build a bridge of understanding and appreciation of the hopes and aspirations of the different people who comprise the Fiji family. It is not an attempt to politically isolate a section of the community. It is an attempt to establish for Fiji a genuine multiracial government in which all sections of the community are seen to be participating in making decisions that will affect them and their future. The Coalition was born out of a conviction, deeply felt and held, that one thing we cannot afford and do not need is the isolation of one half of the total community from participating in government in a real way. No nation was built on slogans, however impressive. All our people must be made to feel wanted and part and parcel of the total Fiji family. ${ }^{47}$

The coalition of an exclusively Fijian splinter party with a predominantly Indo-Fijian party was seen by its supporters as heralding a new era in Fijian 
politics, presenting the Alliance with a more formidable challenge than it had faced from the NFP alone. It was Jai Ram Reddy's first foray into consociational politics, with two race-based parties cooperating for national governance. To its opponents, though, it was simply an expedient political arrangement with the sole purpose of dislodging the Alliance from power. Speaking to a thousand strong Fijian Association meeting in Rakiraki soon after WUF was launched, Ratu Mara denounced the new party as a 'disruptive' force which 'preached ridiculous political ideologies. ${ }^{48}$ Speaking in Fijian on the radio, Mara warned the Fijians about the dangers of the Coalition. The National Federation Party, he said, was trying to achieve power it had failed to do at the London constitutional conference, implying that what the Coalition was doing was breaching some undertaking given in London. It was not the last time that this interpretation would be raised in Fiji, as we shall see.

Reddy did not share that understanding, if it was an understanding at all. He said: 'I feel nothing in the constitution of Fiji or of the Declarations made at the time [of independence], are incompatible with the coalition we are trying to form. Let me remind the people of Fiji that the Prime Minister himself has been advocating a coalition which he said we turned down. Of course I disagree with him. We have never turned down a coalition. We offered to go into coalition. We offered to go into serious discussions which have never eventuated; but the point I would like to make is that there is nothing in the constitution which says the NFP should not ever govern either with or without a coalition. So this attempt to link the constitution with this coalition arrangement is rather a curious one, strangest of all that has been made in relation to the coalition. ${ }^{49}$ Seeking to plant seeds of doubt about the coalition in Indian minds, Alliance alleged that the NFP had done a 'political deal' with the Fijian Nationalists. Reddy dismissed this as nothing more than a fabrication 'to destroy me and the National Federation Party.' It was 'unnecessary for any political party to resort to this kind of thing to win the election.' In reality, no strategy, however unpalatable or unethical, was superfluous in a tense and close campaign. 


\section{THE 1982 GENERAL ELECTION CAMPAIGN}

The 1982 campaign for the NFP was of a different kind to those it had mounted in the past. In both the elections of 1977, the party was fighting its own internal battles, first and foremost, more so in September than in April, rather than contesting the Alliance for national leadership. But in 1982, all the doubts and hesitations of the past were, or appeared to have, gone as it made a serious and concerted effort to dislodge the Alliance. To pre-empt any questions about who might lead the party if it won power, Reddy had the parliamentary board endorse him as its nominee for Prime Minister if the party won. Some members complained about this being a breach of the party's constitution, but the practical realities on the ground won the day. 1977 was not to be repeated. There would be no more bickering about leadership post-election. Reddy made a serious effort to reach to audiences beyond his own traditional constituency, and he made a good impression. The Alliance saw Reddy as a serious threat, a credible leader. Its own private briefing documents supplied to its candidates described Reddy as 'Made for unity,' 'Liked by many Fijians,' 'He is policy oriented,' 'Intelligent, thoughtful and calm,' 'He is seen to be safe,' and 'Seen by some not to be personally ambitious but seems to care for Fiji. Understandably, Reddy became a particular target for the Alliance in the campaign.

The NFP's preparedness for the campaign was evident in its election manifesto, a carefully thought-out policy document of eighty two pages quite unlike any other before it or since. The NFP had policies on all major aspects of society and economy: production and income, project identification, fiscal and monetary policy, measures to reduce inflation, trade, exchange rate and balance of payment, agriculture (the sugar and copra industry), cocoa and rice, animal husbandry and the dairy industry, land and land tenure, forestry and fisheries, industrial relations, Fijian affairs, rural development, communications and tourism, energy, health and education, youth, women, social welfare, the culture and the arts. 'Good Government,' Reddy said, 'is not simply, or necessarily, to be seen in terms of investment and wages, important though these are. It is about justice and equality; it 


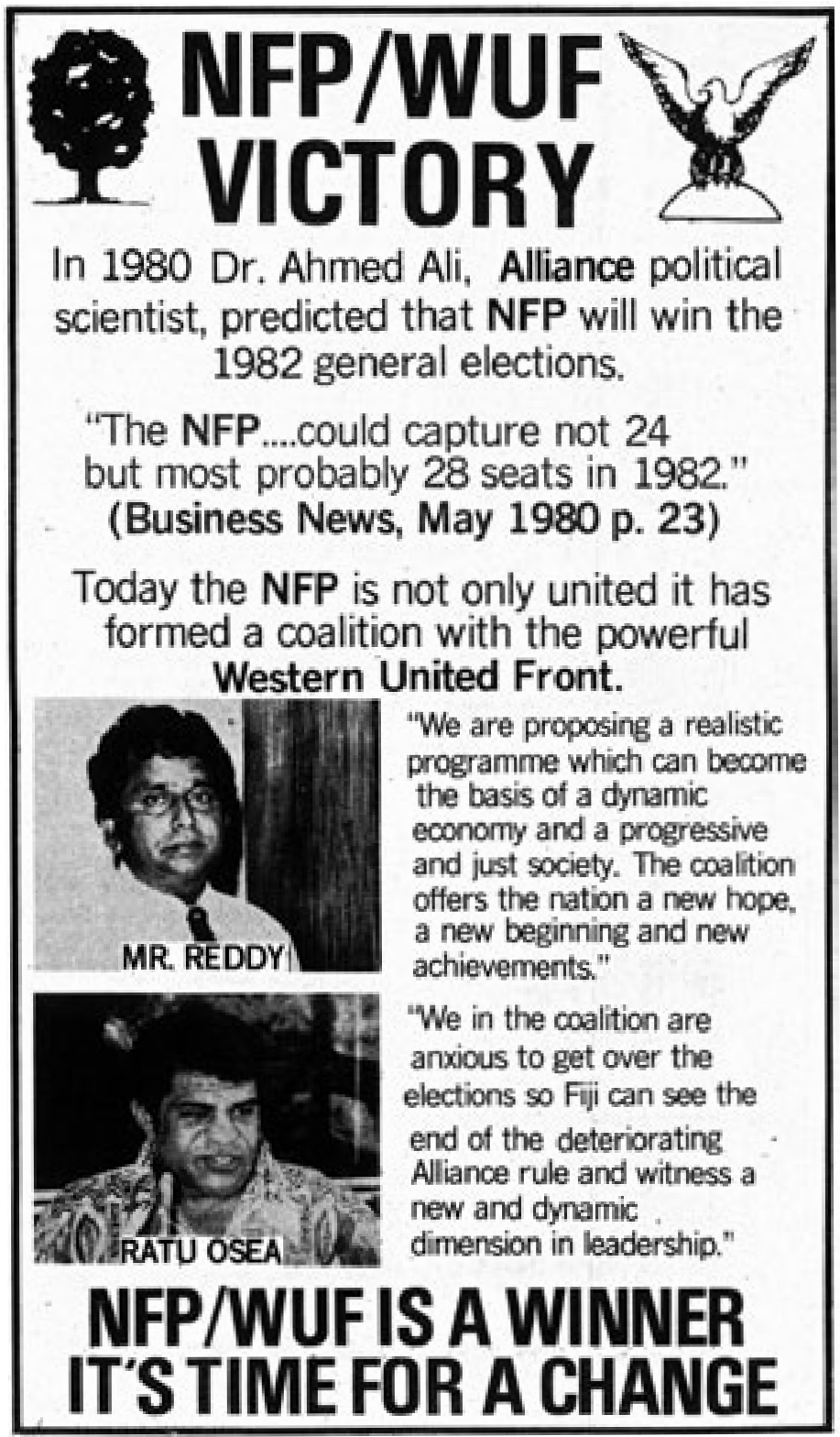

A typical election campaign advertisement, 1982. Courtesy of Fiji Times. 


\title{
NATLONAL FEDERATIOY PARTY \\ AND \\ WESTERN INITED FRONT \\ COALTHON
}

\author{
MANIFSIO \\ 1532 CEYEALI ELECTIONS
}

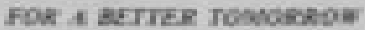

is about care and protection of the unemployed, the underpaid, the needy, the handicapped, the pensioners; it is about building a humane society and making people aware of the needs and aspirations of those less fortunate than ourselves. Good government was an 'attitude of mind nationally created and felt.' It was about 'inculcating in the people of Fiji a sense of national unity and common destiny.' The thoroughness of its preparation for the elections showed that the NFP meant business; it was ready to assume power if it won the elections. In newspaper advertisements and in radio debates - there was no television in Fiji then - the NFP matched the Alliance word for word, diatribe for diatribe. For every attack, there was a rapid counter-attack, which led Mara, who was clearly perplexed to see such a revitalized Opposition, to call the NFP campaign 'relentless, deceitful and prejudicial to good order. ${ }^{50}$

NFP's most thorough election manifesto to date, 1982, which perplexed the Alliance Party. NFP meant business. The party machinery, for once, was working smoothly. Gavidi appeared to have gravitas and charisma; he was young and articulate, and an effective speaker on the campaign trail. And Reddy was at his eloquent best. He inspired confidence and enthusiasm among his supporters. His speeches were thoughtful and policy-oriented, 
as the Alliance had feared. He was a galvanizing presence at the helm of the party. And he had experienced campaigners in his team as well. These included especially Sir Vijay R Singh, a sharp and effective speaker. His admission into the party had rankled some old faithful supporters, as we have seen, who thought Sir Vijay should have 'done time' before being rewarded with a blue ribbon seat, but all that seemed to be forgotten now. Siddiq Koya was quiet on the campaign trail, sidelined, not the fiery orator of the past at the centre of things. His quiet demeanour puzzled some but was a plus for others. Many of Koya's supporters had either quietly shifted to the Alliance or were biding their time for some other alternative. Even his opponents accepted that this was Reddy's moment in the sun and that his leadership was secure.

The 1982 campaign was more 'issue-based' than those in the past. The economy emerged as a major issue. Reddy attacked the Alliance's management of the economy, with ammunition derived from official statistics. It relied heavily on a gloomy picture of the economy painted by the highlevel Financial Review Committee which had prophesized bankruptcy of the country to the tune of $\$ 51.7$ million by 1983 unless current trends were reversed. It raised the 'certain prospect of massive unemployment' which developments in pine, fish and copper industries were unlikely to alleviate. The unemployment rate, which had been steadily increasing, was 16 per cent in 1981, and it especially affected young school leavers. Inflation (11 per cent), mounting squatter problems, rapidly increasing food imports (which had soared by 270 per cent between 1971 and 1981 while the population had increased only by 25 per cent), the widening foreign trade gap form $\$ 153$ million in 1980 to $\$ 271$ million in 1981 and a generally sluggish growth of the economy ( 3 per cent) were all issues the Coalition raised in the campaign, frequently supported by a barrage of confounding statistics. But beyond merely criticizing, the Coalition put forth its own proposals for generating employment and growth.

The Coalition also made an issue of the conduct of government under the Alliance. It argued for a 'parliamentary' democracy where the parlia- 


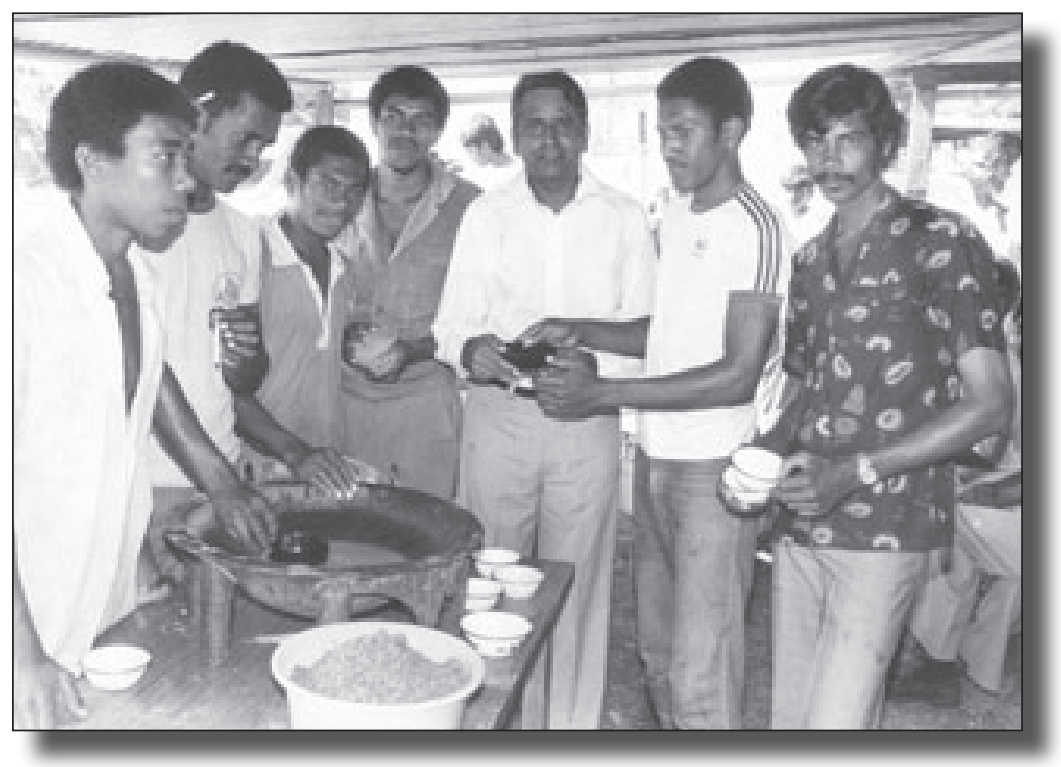

Reddy with supporters at the Natabua Primary School polling booth, 1982.

ment, not the cabinet, was supreme, as it had seemed to become under the Alliance. Troops had been committed to Lebanon and Sinai on the decision of the cabinet and not the parliament, and, as already seen, some large tracts of Crown land in Viti Levu had been reserved without any parliamentary debate. The Coalition proposed to halt this trend through the use of 'parliamentary committees, with members drawn from all parties and different sections of our society.' This, it argued, would not only widen discussions on a wide range of issues but also lessen dependence on foreign consultants and advisors. Along with advocating open government, the Coalition pressed the idea of a truly multiracial cabinet, reflecting the interests of all sections of the community. It pointed out that while Indians comprised half the population, there was only one elected Indian in the cabinet, although how many 'elected' Fijians there would be in a Coalition cabinet was wisely left unsaid. In response to all this, the Alliance paraded experience and purposeful management of the economy, and, above all, its 
leader. Mara was not the same invincible figure of the 1970s, politically tall and awe-inspiring, but he was still the best Fiji had.

\section{CHOTA GHAR AND BEYOND}

Campaigns on paper are very different to what actually goes on the ground. But what was remarkable about 1982 was that the Coalition was able to match, often more than match, the Alliance's paper war. It was until then the most even, and most enlightening, election campaign postcolonial Fiji had experienced, or so it seemed to me from my vantage point as the chairman of the national panel discussions broadcast live on Radio Fiji. Ideas and alternative visions once again entered the national political discourse that were absent in the 1970s. But dry facts and abstract concepts, powerful though they might be, can take a party so far and no further. On the hustings, words are spoken both to enlighten as well as to entertain. Belittling an opponent is an entertaining part of the deal. Rustic metaphors convey messages that audiences understand perfectly. It was at a campaign meeting in Labasa that Reddy, getting carried away by the intensity and theatre of the moment, uttered words that would return to haunt him for a very long time. Reddy had witnessed how Mara was moving around the country, visiting Indo-Fijian electorates as he had not done before, being led to believe by the more ardent members of the Indian Alliance that an Indian communal seat might finally be within reach. Reddy was campaigning in Nasinu and was told that a minister and his running mate on the crossvoting seat were in the area and had been invited to open a private home. That struck him as odd at the time, 'but it sort of stuck in my mind.' The Alliance was so desperate, he said in Hindi in his Labasa address, that their leaders were willing to open even a 'small house' (chota ghar) to get Indian votes. He did not mention Ratu Mara by name, but a connection to him was quickly made.

I was at the Labasa Fire Station rally that day and knew instantly the faux pas Reddy had committed. Reddy himself realized his unfortunate choice of words the moment he had uttered them, but what was done was 
done; there was nothing he could (or would) do about what he had said. The Fiji Times reporter, Umendra Singh, reported the speech for the national daily. For a few days nothing happened, but then the words were picked up the Alliance campaign committee, and the world crashed on Reddy's head. The words translated into English as 'toilet,' and Reddy was excoriated unmercifully for his 'toilet remark.' Mara, the astute politician facing a tough contest, feigned deep hurt and promised never to forget them or forgive Reddy. A high chief had been 'insulted,' the name of his vanua dragged into the mud. This was yet another instance of Indian insensitivity to Fijian cultural protocols. How dare Reddy utter the words? And so it went.

The uttered word acquired other associations. A week earlier, Ratu Mara had opened the King Fahd Islamic Library in Labasa. Reddy's toilet remarks, some Muslims said, was a direct reference to the opening of the Library! Not only had Reddy apparently offended Fijians, he had also managed in the same breath to offend the religious sensibilities of the Muslims as well, who were already disinclined to support him and his party. 'Mr Reddy so cunningly directs his remarks towards the Muslim community,' wrote Mohammed Mazhar Khan of Samabula (a fictitious name because there was no one under that name in the telephone book). Reddy, he continued, behaved 'sordidly and shabbily in relation to our religion' and 'Muslims of this country will not sit back and let such remarks go unchallenged,' urging all Muslims to 'unite and show their strength and solidarity by voting in the coming elections against people and their party who maliciously enjoy themselves by condemning others' religions. ${ }^{51} \mathrm{VH}$ Samad, General Secretary of the Vanua Levu Muslim Youth Movement, responded in a similar vein. In Suva, Faiz Sherani, President of the Fiji Muslim League, suggested that around 25 per cent of the Muslims had left the NFP for the Alliance. 'Mr Reddy and his colleagues have always abused the Muslims and their religion. He has lost the support of the majority of the Muslims who once believed that the NFP would include Muslims. ${ }^{, 52}$

'I never used the word toilet,' Reddy said in his defense. He was speaking in Hindi. 'The point I was making was in no way calculated to insult or 
injure either the Prime Minister or the Fijian community.' The point he was emphasizing, he continued, was 'that it is in the nature of democracy that at the time of elections, those in power must come to the people and are seen to be doing some very ordinary things which they would not be doing in normal times. In other words, I was emphasizing how much democracy means to the ordinary and common people. ${ }^{53}$ This may have been his intention, but his choice of words was poor, and everyone knew that a 'small house' in colloquial Hindi meant the toilet, although strictly speaking, chota se chota ghar, which is what Reddy said, literally means 'the smallest of the smallest houses.' Reddy was not allowed to forget the 'insult' long after the campaign itself was over. As late as 1996, Tomasi Vakatora told me that despite all that Reddy had done and said since that general election, there were Fijians, particularly from Lau, who had not forgotten his 'insulting' words.

Another of Reddy's statements became a topic of heated debate in the campaign. Reddy had said that if the NFP-WUF Coalition won, it would introduce a Singapore-style of government. What he meant was that the cabinet would be genuinely multiracial and the bureaucracy merit-based..$^{54}$ 'In the Cabinet of twelve Ministers,' Reddy pointed out, 'there is only one elected Indian Member serving as Minister, which makes it a lop-sided racial Cabinet and it was in that context, and that context alone, that I mentioned Singapore, where a multiracial community and a multiracial government ensures that people of all races are equally represented in government.' Reddy's proposal put the constitution at risk, Ratu Mara told his election rallies. Singapore was a republic, and the Coalition's secret plan was to make Fiji a republic and sever Fiji's ties with the Crown. This had been its policy since the late 1960s. Ratu George Cakobau, the Governor General, would have to go. Fijian rights, particularly rights to land, would be in jeopardy.

Addressing a thousand-strong Fijian rally at Raiwaqa, Apisai Tora said that making Fiji a republic had been a long term goal of the NFP, and Reddy was merely following a well-laid out plan of deception. 'This is the kind of thing which can injure the Fijian race,' he said. 'This is dangerous (rerevaki) and frightening (vakadomobula) thing if it happened 
in this country. You will ask why the NFP want a republic. ${ }^{35}$ Reddy was confounded by the astonishing distortion. This was political campaigning at its most brutally raw. 'It must be blatantly clear to one and all,' he responded 'that it would be a physical impossibility for any one political party to bring about these changes — which we don't want - because of the firm entrenchment of our constitution.' He went on to list the safeguards for the protection of Fijian interests. 'Therefore I can only assume that this is a red herring thrown in by the Prime Minister to excite public opinion, to confuse the real issues that confront us as a nation and to polarize the people into racial compartments.' This, he said, 'was not the way to take the country forward.' Stirring an already well heated pot further, Ted Beddoes raised the bogey of the common roll. If the NFP came to power, he told his rallies, they would introduce common roll and the General Voters would have no guaranteed representation in parliament. 'Common roll issue is being raised for purely political ends,' Reddy replied. 'Mr Beddoes knows very well that the constitution is entrenched — it can't be changed unless both sides agreed. Every child in Fiji knows that.' And he advised the General Voters not to be hoodwinked by 'these bogeys, non-issues.'

The attacks and the counter attacks heightened tensions and heated the rhetoric. 'Keep Fiji in Good Hands', Alliance told its supporters if they wanted to have 'Business As Usual.' Once again, its chief asset was its leader, Ratu Sir Kamisese Mara, who campaigned vigorously throughout Fiji, and once again silently harbouring the hope of wresting at least one Indian communal seat from the National Federation Party and capturing, improbably, between 25 percent to 30 percent of the Indian communal votes. This was not the first or the last time that the Alliance leader had bad advice or bad intelligence about his chances in the Indian communal seats. They were rock-solid Federation territory. Knowing how close the contest was, Mara upped the ante by betting on the popular perception of his indispensability to the future of Fiji. He would resign - take a vow gracefully, to use his words - if his party did not win thirty seats. ${ }^{56}$ That was his old true and 
tried tactic to rally wavering supporters to his side. In the end, he did not win thirty seats, only twenty eight, but refused to resign. He was not the only Fiji leader to renege on his words. A few years later Koya threatened to resign 'instantly, instantly' if his candidate lost a by-election. He remained leader until he was forced to leave by his parliamentary colleagues.

And, true to form, Mara tried to set the cat among the NFP pigeons by saying that if Reddy did not 'get a commanding majority' in his seat, 'his future is going to be at stake,' adding hopefully that he 'wouldn't be surprised if the old warhorse Sid Koya comes out on top again, ${ }^{57}$ incidentally, the very same man he had vowed never to work with again! Reddy, Mara said, had prevented Koya from becoming Prime Minister. ${ }^{58}$ Mara was not too subtly fanning the embers of the Flower-Dove fire of the previous decade. Reddy rejected Mara's charge as 'astounding and untrue,' adding: 'We are amused to find that Ratu Sir Kamisese Mara's heart is now bleeding for Mr Koya. It is more strange coming from Ratu Sir Kamisese Mara who spent years publicly quarrelling with Mr Koya and privately exhorting Alliance supporters to oust Mr Koya from the Lautoka seat. ${ }^{59}$ For his part, Reddy predicted thirty seats for his party, with the promise that there would be no hesitation about forming a government this time. "We are prepared for the event and are ready to physically move out of the Opposition office into Government. The nation can expect a very balanced and multi-racial cabinet.'

To Mara's hint that he would find it difficult to work with Reddy, the NFP leader was blunt: 'We are also, frankly, getting a bit tired of being told who he will work with and who he won't work with. ${ }^{60}$ Mara's claim to resign if he did not win thirty seats was a 'bluff' the Alliance leader had called often 'just to entice people into coming to him and saying they want him to stay and lead them forever.' At a two-thousand meeting in Nadi in June, Reddy responded to the fear expressed by some Indo-Fijians that there would be no peace if Ratu Mara lost the elections. There were real concerns in the countryside about the renewals of land leases. 'Blood-will-flow' type statements were floating around in the settlements. 'Is that the kind of peace you want, one that is dependent upon the continuation and the existence of 
one individual? What kind of peace is that? What kind of future is linked up with the survival and political existence of one individual? It's a worthless future, if that is what people believe.' The future, he said was 'what you make of it; your future is not in the hands of Ratu Sir Kamisese Mara. Our future has to be rooted a little more deeply in a conviction that is held and felt that this is our motherland. ${ }^{\prime 61}$ This was typical of many speeches Reddy gave throughout the country, trying to instil pride in his people, stiffening their spine, asking them to stand up for their rights, to believe in themselves.

\section{THE CARROLL REPORT AND FOUR CORNERS}

As the campaign entered its last phase, all the previous drama faded onto the margins as an Australian Broadcasting Commission's public affairs program, Four Corners, aired allegations about the misuse of Australian aid money by the Alliance party to boost its campaign for the election. The charge focused around Clive Speed, an Australian media consultant, working in the Prime Minister's office. The ABC program also aired the contents of the 'Carroll Report' ('Report of Consultants to the Prime Minister of Fiji on the Economic and Political Outlook and Options for Strategy and Political Organization') ${ }^{62}$ prepared by Australian business consultant Alan Carroll, strategic consultant and advisor Jeffrey Race, head of the Thailand-based company Asian Strategies and consultant to multinational 'service' organization Business International, Jeff Allen, director of Australian Industries Development Association (AIDA) and Melbourne-based market researcher Rosemary Gillespie. The report was commissioned by businessman Mahendra Motibhai Patel, an Alliance party member and a close friend and confidante of Ratu Mara's. Aside from an economic report for Patel, the team also prepared a special report, with the participation of some leading Alliance functionaries (Dr Ahmed Ali, Len Usher) and even civil servants such as cabinet secretary Dr Isireli Lasaqa, on the political situation in the country, and provided advice on how the Alliance Party might go about the campaign and win the election by targeting its opponents. 
The report recommended a number of tactics to deal with the opposition and with internal critics. The consultants suggested, among other things, the need to 'conduct an image-building campaign emphasizing such themes as re-birth, renewal, new sense of movement, or the like,' the appointment of impartial commissions of enquiry into the Native Land Trust Board and the pine industry about which there was substantial public dissatisfaction; 'stronger commitment to mobilizing the energy of the private sector;' consolidation of Fijian support 'while expanding the Alliance's support among the Indian community;' establishment of a think tank, and so on. There was nothing exceptionable about these innocuous recommendations. But what proved controversial and grabbed the national attention were the more divisive recommendations in the report. To the Nationalists, the Alliance was advised to say: 'We hear what you are saying; we have well-thought out and responsible programs. Our opponents are madmen.' To the voluntary and involuntary dropouts from Cabinet: 'either let them leave happy (appointments) or make sure they understand they will be sorry if they challenge the Alliance (get something on them). 'Combine divide and rule with stroking,' For Sakeasi Butadroka: 'either buy him off or take him out of running.' As for Osea Gavidi, 'since he is going to jail anyway, best to pile on all effort and accelerate prosecutions so that he cannot run.' On Jai Ram Reddy 'We have got to hit Reddy, but what can we hit him with? Questioning Reddy's ability to control other NFP members; saying 'NFP cannot form government, that they could not before, and so on. Say NFP has no strategy, no ability to perform.' 'Toe-cutting' was recommended, along with encouraging Muslim leakage to the Alliance by keeping alive the old Reddy-Koya rift. ${ }^{63}$

In the course of their investigations, the Four Corners team interviewed Mara in Taveuni. During that interview full of pointed questions about Clive Speed and the use and abuse of Australian aid money for party political purposes, the Alliance leader felt ambushed, and angrily walked out of the interview. The team then travelled to Lautoka to talk to Reddy, and showed him parts of the draft report. At a meeting in Waiyavi on 22 June, 
Reddy generally described the contents of the report he had gleaned from the pages he had read. Four days later, at Coalition rallies in Rakiraki and Tavua, Reddy revealed the identity of the expatriates who had prepared the master plan for the Alliance party detailing strategies which it should use for the general election. ${ }^{64}$ Clive Speed was accused not only of helping the Alliance with its media campaign, but also of passing political information — 'situation reports' — to Alan Carroll.

The Alliance's response to Reddy's allegation was contradictory and confusing. On 26 June, Ratu Mara at a five hundred-strong rally in Naulu, Nasinu, effectively denied the allegations, labelling them 'really stupid... attempts to bamboozle and mislead the electorate. ${ }^{65}$ The Alliance campaign, he said, was under the general direction of Isimeli Bose, Len Usher and Ahmed Ali. Suspecting, correctly, that Reddy might not have the report in hand, the Alliance challenged him. 'Why doesn't he release the report? He claims to have seen it and he claims to know what it contains. We challenge him to release the whole report. What is in the report that he is afraid of? There is nothing in the report we are afraid of.' When Reddy repeated the allegations and named the consultants who had prepared the report, Ratu Mara on June 27 acknowledged both the report as well as the identity of the consultants who had prepared it. Reddy pressed on. It was Allan Carroll, he said, who had recommended Speed and Mara and Cabinet Secretary Dr Isireli Lasaqa had travelled to Australia to recruit him. 'A new dimension has been added to the campaign by the allegations of Mr Reddy that outside advice was sought on strategies to preserve the rule of the Alliance Government,' wrote the Fiji Sun in its editorial of 28 June. 'The implications of Mr Reddy's allegations [of] tax payers and aid money being used to support one party in power are such that they will need to be seriously addressed and rebutted to the satisfaction of all.'

With the political temperature rising as a result of all the claims and counter-claims swirling around, Reddy dispatched Sir Vijay R Singh to Sydney to obtain the papers and the report (which researcher Rosemary Gillespie gave him, travelling from Melbourne to Sydney). Sir Vijay also 
obtained a copy of the tape after it was broadcast on the ABC, and returned with them to Fiji. The tape was viewed by a small group of party strategists, including Reddy and a couple of senior Fijian members, such as Ratu Osea Gavidi, for their 'take' on the tape. The group agreed that the tape should be widely distributed to all the campaign centres. In the end, some four hundred copies were made and distributed. The tape became a campaign sensation. In the days when there was no television in Fiji, watching the tape at meetings and public halls made for an electrifying atmosphere. The program highlighted a number of contradictions and inconsistencies. Mara's claim that he and his officials had 'found' Clive Speed was at variance with what Carroll himself had written to Mara. Isimeli Bose's statement that he was a part of Burns Philp contribution to the Alliance and that his salary was partly covered by that company was denied by Mara, while the company itself refused to comment. Mahendra Motibhai Patel was found in the awkward situation of being presented with evidence contradicting his denial of any role in providing contacts for Rosemary Gillespie in Suva. Later he admitted commissioning and funding the report on his own, without involving the Alliance Party. Again, this claim was at variance with the contents of the covering letter from Alan Carroll to Ratu Mara referring to his team of four as 'your consultants.'

At first the Alliance seemed to be stumped, stuttering in its response and unsure of what more Reddy might have in his arsenal, or how the whole saga might continue to unfold. Still, Mara made a whirlwind tour of western Viti Levu condemning the TV team's visit 'as an act of political sabotage against a sovereign nation.' The team, he said, falsely, had collaborated with the Coalition to discredit the government; 'they tried to bully people into speaking to them without revealing the purpose of their interviews.' He said that it was only on 5 July that he had read the report and found 'some of the ideas it contained unacceptable and repugnant to everything the Alliance stands for.' In any case, there was no evidence that the party had used or implemented any of the advice given by the consultants. But the NFP thought it had struck gold. It was electrifying drama to see local big-shots being in- 
terrogated by intrepid journalists, their assertions challenged and refuted, to see a visibly angry Ratu Mara walk off the interview set. Nothing like this had ever happened in Fiji elections before. And Reddy was absolutely certain that the Alliance had made a concerted effort to exploit religious and cultural divisions in the Indian community in a blatant manner unprecedented in Fijian electoral history. Repeated reference to Muslims and Gujaratis by the Alliance in the campaign was proof enough of that, he argued. ${ }^{66}$

It was not long after the program was screened in Fiji that the Alliance campaign team seized upon an extraneous and incidental opening remark in it about Ratu Mara being a descendant of Fijian chiefs who once 'clubbed and ate their way to power,' a clumsy, cryptic reference to the practice of cannibalism in the islands in the pre-colonial era. The truth or otherwise of that remark was not at issue, many Fijians privately conceded, pointing to the many cannibal jokes that did the cocktail rounds in Suva. ${ }^{67}$ The issue was 'insult,' and the fact that the remark was made by foreigners made it even worse, or so it was said. 'As far as the Fijians are concerned [the main issue has been] the aspersions cast on the Fijian traditional system,' said Ratu Mara. ${ }^{68}$ 'By telling the people of the country that Ratu Mara's ancestors clubbed and ate their way to power,' asserted Ratu Sir Josua Rabukawaqa, an authority on traditional cultural protocol, 'the television producer was also saying 'beware of this man; he has in his veins the same blood.' 'Such a deliberate attempt to denigrate a chief legitimately installed by custom, constitutes a conspiracy against the Fijian people, their customs and traditions.' A suggestion such as this would be offensive at any time, 'but when it is put on television and repeatedly placed before the eyes of all and sundry to cast aspersions on the character of a recognized leader of greatness and integrity, then the insult and offence multiply and arouse fears of threat to one's culture and therefore one's existence as a cultural community. ${ }^{69}$

The Alliance made other wilder allegations that, viewed from the vantage point of hindsight, show up some of the silliness of the campaign, but which were effective at the time. One Alliance advertisement accused Reddy of being a racist because he had referred to the consultants as expa- 
triates. 'Is this intended to incite racial feelings against people who come to make Fiji their home and who are here to assist the development of Fiji? Is this what the Opposition means when they talk about Mr Reddy as a leader with anti-colonial mentality? ${ }^{70}$ Coming completely from the left field, Dr Ahmed Ali asked whether, as Prime Minister, Reddy would break diplomatic ties with Australia, and whether he would bring the Russians into the Pacific! No wonder Reddy had little time for Ali. In Lautoka, four hundred Fijian women, led by Senator Akanisi Dreunimisimisi, marched from Namoli village to Reddy's Thomson Street home, carrying banners saying: 'Reddy You Must Apologize to the PM,' 'Reddy You Are Muddy,' 'Reddy Five Corners,' 'The Four Corners Program from Australia is Bogus,' 'Reddy You have Divided the Indians.' Several angry speeches were made in front of the house after which Adi Salote Lewanavanua left the petition in Reddy's mailbox as he was not at home at the time. ${ }^{71}$ In Suva, thousands marched in support of Mara. More was to come in the days ahead.

The Four Corners program had the net effect of uniting the Fijians behind Mara. Minds were closed; one's cultural heritage had been denigrated and that was enough for many. Jonate Mavoa, a senior Alliance government minister and one of the more astute observers of the political scene, made a further point of some note: 'By widely screening that program throughout Fiji, the NFP aligned itself with and adopted what was said in the program about Fijian chiefs, and in particular, the Prime Minister.' That was the NFP's major strategic error in the campaign. Reddy and NFP had no foreknowledge of the Four Corners program, had no hand in its preparation, did not know of its existence until the television crew came to Fiji. The program was made for an Australian audience and designed to show how Australian foreign aid was being misused by the Alliance. The makers of the program, all left-leaning Australian Labor Party supporters led by Peter Manning, intended primarily to embarrass Malcolm Fraser's Liberal government and its alleged support for right wing causes and organizations. It would have been politically prudent for the NFP not to associate itself with the program as closely and as enthusiastically as it did. Reddy 


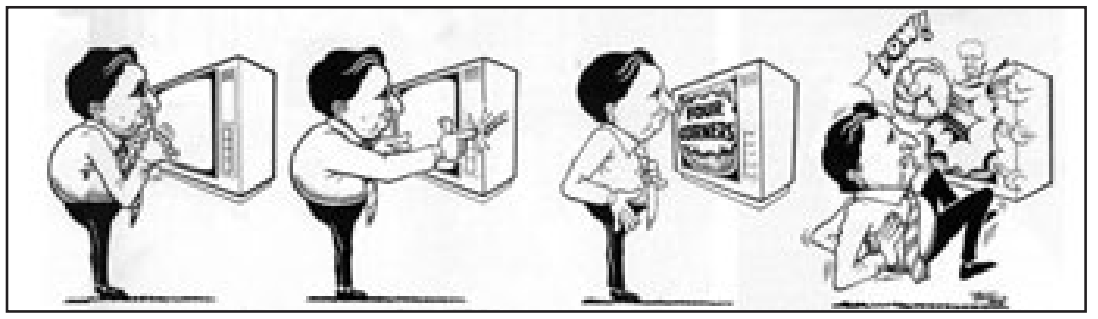

The Four Corners saga unfolds. Cartoon courtesy of Islands Business News.

might not have done that, some suggested, if he had listened to wise counsel from senior people within the party, such as Irene Jai Narayan whom, one writer suggested, he had not included in his 'inner sanctum of advisors. ${ }^{72}$ Most probably, the 'special writer' was Vijendra Kumar, editor of the Fiji Times, and close to Irene Narayan. There was criticism, too, that Reddy had aligned himself too closely with Sir Vijay Singh upon whose advice he seemed to place much weight.

Reddy was unrepentant. Did he think the cannibal quote was offensive? No, he said. 'It merely records a historical fact. ${ }^{13}$ Why was the program screened so widely? 'I would say to reveal the truth. My primary concern was that the Alliance had commissioned such a thing as Carroll Report and that it contained such highly questionable tactics.' If only the Alliance had said 'Yes, of course, we had commissioned a Carroll Report, but we never implemented it; here it is and showed it to the public. There would [then] be no need for me to get that program from Australia.' Denying its existence, covering it up, was what had led Reddy to pursue the matter. But then Reddy said something that showed his true character: 'I felt it my duty that the truth be known to the people of Fiji. There have been a lot of people who have said to me since the election that we would have won had we not shown that film in Fiji. I took the view then and I take the view now, quite irrespective of the consequences, it was my duty as the Leader of the Opposition, possessed of that information, to make it known to the people of Fiji. That was my primary duty and I would not have shirked from that duty, quite irrespective of the consequences.' 
This was not the first time that principle would take precedence over political expediency for which Reddy would again pay a heavy price. To the accusation that Reddy was an anti-Fijian racist, Vijendra Kumar wrote: 'Mr Reddy is not by the remotest stretch of the imagination, a racist, or antiFijian. On the contrary, he has been sincere in his talk of national unification. But you cannot shout sanity. ${ }^{74}$ 'In the final judgment,' he said, 'he has been bested in the old game of power politics by a seasoned and skilful practitioner of the art.' He might usefully have added the word ruthless as well. A Fiji Sun editorial put the controversy surrounding the Four Corners program this way: 'The people most responsible for this situation reaching the current proportion are those who in their moves to counter the Four Corners programme seized on the 'cannibal quote.' To trumpet this as a racial insult to all Fijians was politically expedient at the time, but it is showing signs of getting a little out of hand.' To extend the cannibal quote to suggest Australians did not think that Fiji should not have the government it does was irresponsible, 'bordering on the dangerous.' It continued: 'Doubtless the remark in the context of the programme designed incidentally by Australians for Australian audiences, could have been omitted without damaging the programme but to single it out, repeat it and extend it to the lengths seen over the past few months amounts to a calculated use of one race which will not do that race or the well-being of all Fijians much good. ${ }^{75}$

Alliance won twenty eight seats to NFP's twenty four. It was a much closer result than was expected given the division in the party of a few years back. Reddy continued to have his detractors both inside and outside the party, but no one could, or did, challenge his authority as leader. He had rescued his party from potential oblivion. Reddy handily won his Lautoka communal Indian seat with 8503 to Alliance's Surendra Prasad's 2334 votes, the latter having briefly been a NFP parliamentarian but who had switched to the Alliance when denied a party ticket. The new parliamentary line showed only a few recognizable Dove faces: Ram Sami Goundar, Siddiq Koya, Vijay Parmanandam and Shardha Nand. The rest were either former Flower faction or variously aligned or sympathetic to it. Perhaps it is not appropriate to see the result in 
terms of Dove and Flower. Perhaps people rallied behind Reddy because they saw him as a credible leader, and his approach to politics more attuned to the needs and temper of the times. The overall voter turnout among Indo-Fijians was around 85 per cent to 86 per cent for the Fijians. Western United Front fared badly, not winning a single seat. Party leader Osea Gavidi lost narrowly (4862) to the Alliance's Apenisa Kurusiqila (4926). Overall, WUF won only about seven per cent of the Fijian communal votes. And Sakeasi Butadroka (3421) fell once again to the Alliance's Tomasi Vakatora (7492).

Reddy was expectedly elected the Leader of the Opposition, but his remaining detractors in the party continued to taunt him, reminding everyone of past disputes and squabbles. Among them was Vijay Parmanandam who wanted someone else to be elected the Leader of the Opposition, possibly Siddiq Koya, who was absent when the leadership was decided and who, in any case, did not have the numbers. Parmanandam continued to be a thorn in Reddy's side, despite being elected on the party's ticket. He accused Reddy and Sir Vijay Singh of contributing directly to the deterioration of race relations between Fijians and Indo-Fijians, blaming them for their 'uncontrolled and unwarranted utterances. ${ }^{76}$ No doubt he had in mind the 'toilet remark' and the 'cannibal quote.' And he took it upon himself to apologize to the Fijian chiefs for the 'insults' which Reddy and Sir Vijay had in his view heaped upon them. Reddy ignored him. The NFP members staged a walkout when Parmanandam attacked Sir Vijay during his budget reply. Parmanandam knew his days in the NFP were numbered and decided to make life as uncomfortable for Reddy as possible, accusing the NFP leader of all manner of things, including soliciting communist aid in cash and kind when he, with Parmanandam, had attended a Socialist International meeting in Sydney at the invitation of the Australian Labor Party, a claim which Reddy vehemently denied and which the NFP rebel could not substantiate, because there was no substance to the allegations in the first place. ${ }^{77}$ Among the other participants at the same conference were Australian Labour Party leader Bill Hayden, New Zealand's Bill Rowling and India's George Fernandes, later that country's Minister for Defense. As 
far as Parmanandam was concerned, however, 'it was a communist meeting — socialist is another word for communist, after all,' said the maverick. ${ }^{78}$ But, by then, no one took him seriously except as a loose, unguided, canon.

Embers from the campaign refused to die. Navua experienced random acts of stone-throwing. Fijian landowners in western Viti Levu called for the eviction of Indo-Fijian tenants who had misled them into thinking that they would vote for the Alliance. In Toge village in Ba, tenants were told to return eight hundred acres of land leased out to them. In Nalato, some villages tried to ban Opposition politicians from entering the area. Landowners' spokesman, Navitalai Raqona, wanted tenants evicted for rental arrears and for 'not fulfilling pledges to vote for the Alliance.' Paramount chief of Sabeto, Ratu Kaliova Mataitoga, said his Christian principles had made him 'tolerate' his Indian tenants in the past, but since 'they are the ones who opposed us during the elections, I will have them no more. ${ }^{.79}$ Fortunately, few threats were actually carried out, for when common sense returned, the landowners realized that they more than anyone else would be the losers from the loss of rental income if leases were not renewed.

Within the NFP itself, there was much debate about the impact of the Four Corners program on the final outcome of the elections. A very widely held view about the paucity of Fijian support for the NFP and the Coalition generally was that Fijian support was coming but suddenly halted by Reddy's 'toilet' remark and the 'cannibal quote' of the Four Corners program. There can be no doubt about the impact of these, especially the latter. The Alliance's deft distortions of the remarks, when translated into Fijian and dramatized in emotional speeches around the country, reduced everything to one simple sectarian issue: insult to Fijian chiefs and traditions. But the impact of the television program should not be overemphasized because the attendance in somewhat larger numbers of Fijians at Coalition rallies than in the past did not necessarily mean their votes also. In any case, even western Fijian support was low. Moreover, the 'insult' theory does not give credit to the immense efforts of the Alliance party in regaining its natural constituency among Fijian voters. 
The lessons of 1977 were not lost: Fijian unity alone would ensure that political power remained in Fijian hands, as Mara had told a Fijian Association conference in Rakiraki in 1981. The Alliance made sure that Gavidi lost, to prevent further slippage from its ranks. Western United Front had no support outside the pine belt. Interestingly, the Alliance won an astounding 21 per cent of the Indian communal votes in four constituencies: Nadi, Ba, Ba-Lautoka and Lautoka. This had been the heartland of the 1977 elections where the fiercest battles were fought between the Flower and Dove factions. Overall, the Alliance captured some 16 per cent of the Indian communal votes. This was no mean achievement especially since all the leading lights of the Indian Alliance as well as many of its ordinary members had left the party in droves and joined the NFP. It was widely believed at the time that many Indo-Fijians who voted for the Alliance were in fact former Dove supporters still smarting from their ouster in the 1977 elections. Koya's vanishing presence on the campaign trail sent signals his followers did not miss. And it was also suggested that the slippage from the NFP to the Alliance would have been greater had it not been for the Four Corners program. There is some truth in that suggestion. The claim that the Four Corners led to the NFP's failure should, therefore, be put in its proper perspective.

\section{THE RUSSIANS ARE COMING}

A month after the elections, Ratu Mara travelled to Australia and there he dropped a bombshell to his favourite Australian journalist, Stuart Inder, the publisher of The Bulletin magazine. He alleged that the National Federation Party had received $\$ 1$ million from Russia to fight the general elections. Fijian candidates had been paid up to $\$ 10,000$ to stand against the Alliance. Large overseas funds were channelled to the NFP via Canada, Australia, the Middle East and India. 'The Soviet Union,' he said 'felt that with him gone, it could pick off Pacific Island States separately and gain permanent foothold in the South Pacific. ${ }^{80}$ The Indian High Commissioner to Fiji, Mrs Sonu Kochar, came in for severe criticism for her alleged interference in Fiji's internal affairs by trying, so it was said, to 
heal the rifts in the National Federation Party. It was later alleged, even more improbably, that Siddiq Koya, with the concurrence of Jai Ram Reddy, had procured the funds. The evidence was said to be a letter with his signature on it. Why Mara made the allegation in Sydney and not in Suva and that too after the elections were over when he had the information about the alleged Russian connection much before remained (and remains) a mystery. The Government of India denied Mara's allegations as 'unadulterated rubbish. ${ }^{\text {, }}$ Reddy called them 'false and baseless. ${ }^{\text {'82 'The }}$ Prime Minister very much needed to refurbish his image, particularly before the Australian people,' he said, referring to the controversy caused by the Four Corners program 'and what better tactic than to raise the bogey of foreign involvement in Fiji's general election.'

In the last days of the campaign, Mara had promised to appoint a Royal Commission of Inquiry to investigate the Carroll affair. Retired New Zealand judge Sir John White was appointed, but with narrow terms of reference, confining the enquiry to the allegations made during, and not after, the campaign. This meant that Mara's astonishing allegation about the one million dollar Soviet connection would fall outside the purview of the enquiry. Reddy wanted the Commission to investigate all allegations 'made before, during and after' the campaign 'to put the matter beyond dispute. ${ }^{83}$ But this was to no avail. The Commission was asked to determine the nature and extent of any infringement which may have occurred in Fiji that compromised protections guaranteed and safeguarded under the constitution, especially those relating to maintenance of democratic processes in Fiji. The Commission would determine whether the Alliance commissioned the Carroll Report, whether it implemented it, whether Clive Speed was appointed on the recommendation of Allan Carroll and whether the Four Corners team had collaborated with the NFP.

Reddy was furious, calling the terms of reference a 'pathetic attempt at cover-up. ${ }^{84}$ The terms of reference, he added, were drawn up without any consultation with the aggrieved party. 'A careful examination of the terms of reference will show that while the commission is empowered to 


\section{SECRET}

IN CONFILENCE

1. S.M.Koya of Suva, Fifl herein nake the solean confirmation for sels, ny colegue Mr. Jalram Reddy and our party in Suva Flf1 that we nre being helped in good will in the interest of our hation of F1j1, by the USSR Govt. to contest and put up our party condidates on sil seats in the forth-comolne FIJI General Exections.

In sansiueration, I am suthorloco to confirm that in ackno:ledgement and apprectation of the assistance and holp thus received, ard in the event that our party is able to forn the Government, our Govt. shall be :

a. co-operotive and saintain friendly political and ecomente relations with USSR,

b. ot al1 times w111ing, egreeable and receptable to permit USSR to organiso their scientific experiment base $1 \mathrm{n} /$ or round FIJI Islands, pork experimental ocean floats, whthout causing disturbance to Military stonding of F1gi Covt. and the Island, within International rules of athics, at their own cost,

c. through duo approval in Figl Parlianent/Seriate approve establishnent of USSR Embassy for South Paclfie, at a sultable station/s in Figl.

It is agreed that all such co-operation and political tie-up shall be only in keepling with the laws and rules of the land.

And upon defoult on our part, the USSR representative can encash the Bank Gurantec, seperately glven by me; expose this aoreenent against us any bhere they choose to, to seck enforcement of the terne. In case of adverse results the ogroement shall be null and vold ofter' guly ' 62 Sydney...... Hareh 1902.

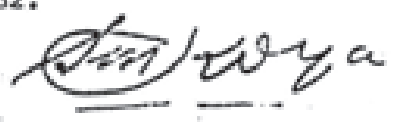

A badly mangled so-called Koya Letter. Courtesy of Fiji National Archives. 
inquire into the circumstances surrounding the various allegations and complaints made during the period of political campaigning for the 1982 general elections, yet when it comes to determining, the commission is restricted to infringements which may have been committed by a body or persons contrary to principles of fundamental freedoms and those that safeguard the democratic process in Fiji. This appears to be unnecessary constraint on the scope of the inquiry given the nature of the allegations and complaints made. ${ }^{95}$ Reddy wanted the allegation of Russian financial support for the NFP investigated by the Commission. 'We have repeatedly said that this allegation is false. The allegation has far reaching implications for the Opposition and indeed for Fiji. The people of Fiji are entitled to know from the Commission what its findings are on this issue. Is there any basis in fact or is this another propaganda ploy to discredit the Opposition?’ Reddy asked. Mara refused to budge; the terms of reference were fair and wide enough, he said, to conduct a full enquiry, but the Commission agreed to expand its work to include some of Reddy's concerns, at which point the NFP leader agreed to participate in its proceedings. ${ }^{86}$

After weeks of hearings in Suva at which all the major players in the election campaign gave evidence — interestingly, Reddy was not crossexamined by the Alliance — the White Commission issued a vague report: a 'whitewash,' many said. ${ }^{87}$ Among them was Rosemary Gillespie, the researcher who had been part of the Carroll team. 'Sir John in his report seems to be more concerned with the personal reputation of the witnesses rather than finding the facts.' She thought the report 'quite unsatisfactory,' and that 'people will be questioning his findings for a very long time. ${ }^{88}$ The Alliance was deemed to have commissioned the report and it was reasonable to assume that they had followed some of the recommendations, but the Commissioner noted that it had not been established that any repugnant recommendations had in fact been implemented as alleged. The NFP was cleared of all allegations of collaborating with the Australian journalists. The result of the inquiry into the Carroll report therefore was to show that 
none of the allegations and counter allegations between the main political parties 'of conduct amounting to infringements of stated principles' had been established. On the serious Russian allegation, which the NFP wanted probed, Ratu Mara claimed Crown Privilege and refused to cooperate. Sir John Falvey had told the enquiry at the beginning that 'The Alliance Party maintains that the Koya letter is authentic, that the original was in fact signed by Mr Koya and that money was paid to, or for, the benefit of the NFP in exchange for the promises made to the USSR in the letter. ${ }^{, 89}$ But soon afterwards, he inexplicably accepted 'without reservation a categorical denial by Mr Koya that he had ever signed the document or had any part in, or knowledge of, any such document. They [Alliance lawyers] agree that Mr Koya is a loyal citizen of Fiji. ${ }^{90}$ Such an immediate, unqualified, retraction of a serious allegation calls into question the veracity of the allegation made in the first place.

In all, the Russian allegation can only be seen as a bumbling attempt by the Alliance Party to sully the reputation of the NFP leaders who had come close to dislodging it from power. It is now beyond reasonable doubt, propaganda to the contrary, that Mara had no evidence to provide in the first place. The allegation against the Indian High Commission and against Russia was arguably the lowest point in Mara's long political career. Mara relied on the strategic advice of his Attorney General John Falvey. He and Len Usher appear to have been the masterminds behind the Russian allegation. They made the baseless allegation knowing, from the outset, that they would use the route of 'Crown Privilege' to prevent any investigation into an allegation which had seriously impugned the character of the Opposition and implicated a foreign embassy in sordid and unsavoury machinations. The National Federation Party had every reason to be aggrieved, but it decided not to make an issue of it. Ratu Mara later claimed that Reddy and Koya 'made strong, and in Mr Koya's case persistent, approaches to persuade me to try to have the whole enquiry called off.' He speculated on why this might have been. 'Was it because Carroll's survey gave some rather unfortunate accounts of some of their leaders, though these had 
been withheld from the previous versions given by the National Federation Party when they supplied copies to journalists?'91 Koya's version of Ratu Mara's recollection is lost to us, but Reddy flatly denies Ratu Mara's claim as 'plain rubbish.' 'We never asked for the enquiry to be abandoned. We persisted right through to the end.' The evidence supports Reddy. Interestingly, Siddiq Koya made an allegation of his own which was dismissed too easily at the time, but which cannot be dismissed out of hand in the light of subsequent events. He alleged that the forged 'Koya Letter' was part of a broader Alliance strategy of remaining in power. If the NFP had won the general elections in 1982, 'the Alliance party would have disclosed the content of the document to pave the way for the army to overthrow the government,' with the covert support of the American Central Intelligence Agency. ${ }^{92}$

\section{FIJIAN PARAMOUNTCY AGAIN}

Tension was evident when parliament met for the first session after the election. In breach of the Westminster convention, the Alliance nominated Tomasi Vakatora for the Speaker of the House without consulting the Opposition. Retaliating, the NFP refused to nominate the Deputy Speaker, whereupon Vijay Parmanandam, the embittered rebel, accepted the position in defiance of his party's directive. Mara's relations with Reddy were at a nadir. 'I have never known any Opposition leader who exhibited so much personal animosity as Mr Reddy did, not only during the election, but after the election. ${ }^{93}$ In truth, Reddy's only 'crime' was his 'effrontery' in mounting a sustained campaign which nearly succeeded in dethroning the Alliance.

In the Senate, fiery Fijian speeches flowed freely. Senator Inoke Tabua, a Great Council of Chiefs' nominee, told his colleagues that 'trouble would have erupted' if the Alliance had lost the general election. Fijians were ready to 'fight for the leadership of the country.' He added, helpfully, that he had nothing against the Indian community, but it was their leaders 'who should be deported from Fiji. ${ }^{94}$ Deported to where, he 
did not specify. Senator Tevita Vakalalabure, another GCC senator, concurred, saying that 'blood will flow' if the Indo-Fijians did not 'cling' to the Fijian people. If they did not, they should 'pack up and get out.' Who was Jai Ram Reddy, he asked? O ira oqo e sega odra somo. These people have no land. If he had seen the Four Corners program before the election, Vakalalabure said, he would 'rallied my people to start fighting. ${ }^{95}$ When Arthur Jennings suggested that Mara and Reddy meet in the middle of the parliamentary chamber and shake hands, the Macuata chief erupted: 'Chiefs do not cross. They (commoners) come [to them]. Let the mountain come to Mohammed. You want me — you come to me.' Fiji Sun editorialized: 'It is sad that little knives leave long scars. This is particularly apt to describe the extraordinary reaction by leading politicians to repeated references to bloodshed, violence, chiefly racial insults, mountains coming to Mohammed and the like. The reaction has been silence, which coming from a self-avowed multiracial party under and internationally respected Prime Minister can only be described as tacit approval. ${ }^{96}$

Racial vilification reached its crescendo at the Great Council of Chiefs meeting on the historic island of Bau which was opened for the first time in the Council's hundred-year existence by a reigning British Monarch, Queen Elizabeth II. The very symbolism of the occasion was potent. After the Queen opened the proceedings and left, the chiefs began their deliberations. There was more talk of blood flowing, retribution, of expulsion of Indo-Fijian leaders, of the dangers of 'insulting' chiefs. Trade unionist Joveci Gavoka said that Indians were worse than dogs 'At least dogs wag their tail in appreciation, but the Indians will never be satisfied.' The brother of the Governor General, Ratu Tevita Naulivou, called for the exile of Indo-Fijian leaders and their families for insulting Fijian chiefs and for inciting racial antagonism. ${ }^{97}$ And Ratu Meli Salabogi from Ra said that his people were ready to 'fight for the motion.'

But it was the speech by Deputy Prime Minister, Ratu Sir Penaia Ganilau, that caused the greatest interest and aroused the deepest emotion. He was a leader Fijian people listened to. His voice choking and his eyes filled with tears, Ratu Penaia lamented the erosion of the foundations of 
traditional Fijian culture and the unprecedented questioning of Fijian leadership. Era sa kila na tani ni oqona yavu kaukauwa e vauci keda tu. Ni da san a kasere rawa, sa yaco na yaco na lomodra mera vei liutaki. 'The foreigners know that this is the bond that ties us together and if that is broken, then they would have their wish to rule. ${ }^{98}$ He pleaded for the unity of the Fijian people, hoping that 'Fijians who had been led astray would not be used to break the bond that tied them together.' Dr Wilisoni Malani, chairman of the Ra Provincial Council, moved a motion to amend the constitution to give Fijians two thirds of the seat in the House of Representatives and to reserve the office of Governor General and Prime Minister for them as well. The motion was put to vote twice, twenty two in favour and twenty one against in the first round and twenty seven for and fifteeen against in the second. Alliance members of the Council including Ratu Mara, Mosese Qionibaravi, Ratu William Toganivalu, Dr Apenisa Kurusiqila, Ratu Josaia Tavaiqia and Akriva Nabati abstained. Mara called the motion a 'waste of time.' Only three members voted against the motion. They were the Speaker of the House Tomasi Vakatora, Minister of Works and Communications Semesa Sikivou, ironically the two more nationalist-minded Fijians in parliament, and former Education Minister and now backbencher, Jone Naisara (all commoners).

When asked about his abstention, Mara said he was present in the Council in his capacity as a chief and was not obliged to explain his stance to anyone. Mara's stand provoked this response from Mohammed Razak Khan of Drasa, Lautoka: 'Now, those Ministers of the Crown who abstained may agree that they participated in the meeting not as Ministers of the Crown but as members of the Great Council of Chiefs and therefore 'wore a different hat,' so to speak.' But, then, Razak went on, 'If this argument were to be accepted than why can't the Chiefs of Fiji also accept the fact that any Chiefs who contested the General Elections did so as politicians, and not as Chiefs, and hence if any abuse came their way, they were the targets to them as politicians and not as Chiefs. 99 The motion may have been a 'waste of time, as Ratu Mara thought, and incapable of implementation anyway, however 
desirable it might have been for some. But it touched the deep reservoir of anxiety in the Indo-Fijian community, which was edgy ever since Sakeasi Butadroka's deportation call in 1975. What was particularly disturbing was that what had once been thought to be minority opinion among Fijians was in fact the majority opinion, if the Great Council of Chiefs represented the true views of the Fijian people.

In a strongly worded statement written by Reddy, the NFP condemned the motion. The motion, the party said, had nothing to do with insults to Fijian chiefs. 'It is now obvious that those indulging in the abuse of Indians are not reacting to any so-called insults heaped upon them but are reacting because the NFP-WUF coalition dared to challenge for power in the last general election and came within a whisker of wresting it from the Alliance.' The 'whole exercise,' the statement said, 'was carefully stage-managed to intimidate non-Fijians, especially the Indians and Fijian supporters of the NFP/WUF coalition.' The statement went on: 'It is also very clear that an entire community, that is the Indians, is being subjected to intimidation.' The party found it 'curious' that both Mara and Ganilau had not voted against the motion, which was clearly repugnant to their stated multiracial philosophy. Ganilau's defense of Gavoka's constitutional right to 'express his views however insulting they may be to half the nation's citizens' was unacceptable. ${ }^{100}$ 'Yet in the same breath,' the statement continued, 'he also defends the Council members' dissatisfaction with those who had exercised their constitutional rights to criticize the Alliance's political leaders during a political campaign because some of the criticisms were directed at chiefs.'

Speaking to an NFP meeting in Nadi soon after the Bau meeting, a clearly emotional Reddy asked his people not to tolerate insult. Making 'highly insulting and provocative remarks,' he said, 'appears to be part of an emerging campaign of hatred and ill-will towards the Indian community. It is no longer possible to keep silent. Things have to be said and said straight. There comes a time in the life of a community when it must be prepared to swim or sink. These insults and humiliations can no longer be allowed 
to pass for they are not isolated. A dangerous pattern has emerged. The assumption seems to be that Indians are fair game. It is in order to say anything you like about Indians. They can be abused, their ancestors ridiculed, their contributions ignored, their leaders referred to as kaisi bokola botoboto (the worst scum of the earth) in Parliament and with impunity.' Then he asked Indians not to be fearful. 'Fear is paralysis. It cripples and renders us worthless. It makes us victims of the bullies.' And he asked Indians to remain united. 'We have to stand together firm and united. Let no one divide you from within or outside. Those who seek to divide you are not your friends. If unity is good for some, it is good for others. The unity I speak of is a unity that will be your shield. It is a community's protection. We must be united to protect our fundamental rights as citizens of this country. Courage is made of sterner stuff. It arises out of one's convictions. It is a people's quest for justice and honour.' In November 1982, a clearly disappointed Reddy told close colleagues that he may have to discard the policy of moderation because it had been 'sadly ineffective. ${ }^{101}$

The five years between 1978 and 1982 changed the political landscape of Fiji. Reddy had consolidated his position as the leader not only of the National Federation Party but also of the Indo-Fijian community. The fractures and divisions of the past had been healed, though not completely. Reddy had made a serious and sustained effort to dislodge the Alliance from power. He had learned the hard way the brutal realities of the political contours of the country, and of the assumptions and understandings which underpinned national politics. His determination had ruffled feathers and wounded egos; his policy of moderation had been put to the test, along with his steely resolve to steer a calm, middle course. The years since 1977 had presented Reddy with many challenges, both from outside as well as from within which had tested his character and stiffened his resolve. The 'Vitogo Boy', as he was called derisively by some, suggesting softness and a tendency to wilt under pressure in the manner of the lajonia plant, was made of sterner stuff than his foes had imagined. The next five years would be full of even greater, unexpected, challenges for him. 


\section{INTERLUDE}

\section{I: STATEMENT TO THE SIR JOHN WHITE COMMISSION BY JAI RAM REDDY}

I was first elected to the House of Representatives in April 1977 as Indian member for $\mathrm{Ba} /$ Lautoka rural constituency. I was reelected in September, 1977 this time as member for Lautoka Indian communal constituency.

I was elected Leader of the NFP on the 28th of September 1977 and appointed Leader of the Opposition on the 30th of September 1977. I have since been the Leader of the NFP and the Leader of the Opposition.

The NFP/WUF held an election rally at Lautoka on Saturday 12th June 1982. An Australian television crew which I later learnt was the ABC team covered the meeting. I was informed during the meeting that the leader of the television crew, Mr Peter Manning, wished to interview me for the programme they were making for viewing in Australia. This information was given to me by Mr Dijendra Singh who was the Coalition campaign manager for Lautoka communal/ national constituencies. At this stage I was reluctant to become involved in such an interview and therefore declined. Furthermore, I had to proceed immediately after speaking at Lautoka rally to attend a similar rally at $\mathrm{Ba}$. I did not know or meet any member of the ABC Television crew on that day and nor had I met them before that day.

A week later on Saturday 19th June, 1982 I was in Labasa to address an NFP/WUF rally. In the course of that meeting I received a message that there was a telephone call for me at the Labasa Fire Station. I took that call and the person on the other end introduced himself as Mr Peter Manning of the ABC Television team. He told me that they had interviewed the Prime Minister in Taveuni and that the Prime 
Minister had walked out in the course of that interview. Furthermore, he said that these were matters in respect of which they wished to question me and my party. I then suggested to Mr Manning that he might like to call on me at my house in Lautoka on the following day, ie, Sunday, 20th.

On Sunday Mr Manning and his companions including Mr Jim Downs arrived at my house at 37 Thomson Crescent, Lautoka. Mr Manning asked if I thought foreign business interests, particularly Australians, were interfering in the political affairs of Fiji, and specially, in the 1982 General Elections. I said I did not think so, and that I certainly had no evidence of any interference.

He then asked me about Mr Clive Speed's presence in Fiji and about his activities. I told Mr Manning that Mr Speed's presence was a matter of some concern to the Opposition. I told him that it seemed odd that when the Ministry of Information was adequately staffed, a media consultant should have been brought in under Australian aid in the election year. (I knew then that Mr Don Diment, an experienced information man, was already acting as advisor to the Ministry. I also told Mr Manning that it seemed Mr Speed was involved in the Alliance Party propaganda work rather than confining himself to his civil service role. I later made such statements at various public meetings.

Mr Manning then asked me if I had heard about the report made by foreign advisors to the Alliance on strategies to be employed in winning the 1992 General Elections. I told him I did not know of any such report. He then showed me a report which was titled 'Strategic Issues Facing the Fijian Government.' He allowed me to glance through it before the interview. I had a quick glance through the document and my attention was particularly drawn to the page marked Private and Confidential. I took some notes from the document and especially that page. I asked if I could take a copy of the report but Mr Manning said he was unable to give me a copy. Mr 
Manning also showed me a copy of a letter from Mr Alan Carroll to the Prime Minister of Fiji accompanying the November 1981 report. I was then interviewed and my contribution in that interview is fairly represented in the Four Corners Programme. I was not told in any detail about the interview of the Prime Minister, nor about interview of anyone else. That was the first and the last time I met Mr Manning. I then decided that the information I received about the existence of the Carroll Report and its contents should be made public. I first spoke on the subject on or about the 22nd of June, at Lautoka.

When I first spoke on the subject I did not name the members of the Carroll team but merely asserted that some expatriates had prepared a plan for the Alliance Party to follow in the 1982 General Election campaign and that $\mathrm{Mr}$ Clive Speed was recruited as part of that plan. I deliberately did not name the members of the Carroll team as I wished to gauge the reaction of the Alliance. Shortly after the Prime Minister rejected my allegations, saying the campaign was under the direction of $\mathrm{Mr}$ Isimeli Bose and described my allegation as 'really stupid and an attempt to bamboozle the electorate.' In fact the Prime Minister's reaction appeared to me to be a total denial of the existence of any such thing as a Carroll Report, let alone its implementation.

On Saturday June 26, 1982, I spoke at two public meetings, one in Rakiraki and one in Tavua. At both these meetings I named the Carroll Team and the title of the plan and dwelt on the unsavoury tactics recommended in that Report. On Sunday June 27, 1982, the Prime Minister appeared to me make an about turn and admit that there was such a thing as a Carroll Report but he said it was only a public opinion survey. The Fiji Times of 28th June, 1982, reported the Prime Minister's reactions. 
Thereafter I continued to speak at public meetings about the Carroll Report. I was challenging the Alliance to produce that report and explain who had commissioned and paid for it. At that time I did not have the Carroll Report and was in no position to produce it myself. The various newspaper clippings put in evidence contain a fairly accurate record of what was said by me on the subject during this period and I therefore do not wish to recount them again in this Statement. In a paid advertisement appearing in the Fiji Sun and Fiji Times on 1 July 1982, the Alliance challenged me to release the whole report. This raised the question of my credibility, which point the Prime Minister was making.

As a result, I decided that it was important for the Coalition to try and get a copy of the Carroll Report and if that was not possible then at least a copy of the programme the ABC were to screen. It was agreed that Sir Vijay R Singh go to Australia for this purpose. At about the same time, I cannot now pin point the date, I also received a telephone call from Marion Wilkinson of the National Times of Australia who told me about foreign interference in the Fiji General Election and asked me several questions. My answers as appearing in the National Times of 4 to 10 July 1982 is a fair report of what I told her.

Sir Vijay R Singh returned from Australia on 4th July, 1982 and spoke about the Carroll Report on the same evening at a public meeting in Lautoka. I arranged for a private viewing of the Four Corners programme and also had Ratu Osea Gavidi see it the following morning before approving it for public viewing. I was keen to have Ratu Osea's reaction from a Fijian point of view. He told me he did not find anything objectionable in the film from a Fijian point of view and that it would be in order to show it publicly. However, he did express shock and sorrow after viewing the film. 
We arranged for copies of the film to be made and distributed to our various campaign centres. The allegation that the NFP/WUF Coalition collaborated with the ABC team in the production of the Four Corners programme to embarrass the Alliance is utterly false and mischievous.

As I read parts of the Carroll Report, it struck me how well some of the strategies in that report were being implemented by the Alliance. There was an almost undisguised drive to divide the leaders of the NFP and to fragment the Indian community. This was a complete contrast to calls for Fijian solidarity. Long before I had seen the Carroll Report I had publicly complained on more than one occasion about the Alliance Party's efforts to particularly divide the NFP leaders, and the Indian community along narrow 'provincial' and religious lines.

As early as 18th January 1982, the then Deputy Prime Minister was talking about the 'promise of large Muslim support' for the Alliance Party which he said had been openly discussed by Muslim people and that Senator Sherani was encouraging Muslim people to support the Alliance. This he said took place during Prophet Mohammed's birthday celebrations in the west.

A few days later, the Prime Minister added yet another dimension to the Deputy Prime Minister's pronouncements when he said that the Alliance was getting 'large Gujarati and Muslim' support which would more than off-set the loss of Indian support that the Alliance could suffer as a result of Sir Vijay R Singh joining the NFP. This was a new angle to political campaigning in Fiji. Although from time to time one heard of the need for the communal solidarity of the Fijian people and the General Electors from Alliance leaders, never before had I known of such blatant appeal for the support of sections of the Indian community based on religion and provincialism. 
The other matter that struck me was the way in which the Alliance had gone about wooing into its fold former NFP supporters who had missed on selection or were aggrieved with the NFP and use them to criticize the party and its leaders. The Alliance even went to the extent of encouraging a small group of NFP dissidents numbering no more than 50 and calling themselves the National Labour and Farmers Party in Lautoka. There was even talk of a coalition between this group and the Alliance with the PM making a special effort to meet them in Lautoka. I now have no doubt that this and other manoeuvres were activated to 'segment the market.'

The Alliance speakers at election meetings in the Lautoka area invariably spoke about the Alliance 'responsible leaders' against 'irresponsible leaders' in the NFP/WUF. Ratu Osea was reportedly described as a 'crook,' Tui Nawai, Ratu Napolioni Dawai, as a 'lunatic,' and I as 'stupid and 'Mr Nothing.' My opponent at many of these meetings devoted much time to attacking me for forming a coalition with what he called irresponsible Fijian leaders of the Western United Front. Invariably he contrasted this with praise for the PM and other Alliance Fijians as responsible leaders.

Even the Prime Minister made the astonishing and baseless statement that I had prevented Mr Koya from becoming the Prime Minister in April 1977. He also joined Dr Ahmed Ali in portraying me as an anti-Muslim.

The Alliance campaign in Lautoka Indian communal constituency included house-to-house calls and their campaigners told many of he voters that since I was of South-Indian origin, all the non-SouthIndian Indians should vote for my opponent, Mr Surendra Prasad. Many of my constituents informed me that Mr Prasad himself had visited their homes and told them that it was their duty to support 
him since was a Arya Samaji and a North-Indian. I had to spend a good deal of my time countering this propaganda in Lautoka.

The Alliance publicly exploited the Hindu/Muslim division within the Indian community; portrayed the NFP as a divided party; and NFP/WUF leaders as irresponsible. They even suggested I would sell out to the Russians. All this clearly indicated a style of campaigning which was not only very different from that undertaken by the Alliance in previous elections, but also showed foreign influence.

It was the need to gauge the depth of this influence, as well as to check if such influence was calculated to undermine the electoral process that I promised to press for a judicial inquiry.

I therefore hope, Sir, that his inquiry will not only find the truth, but will also, in terms of its reference, make meaningful recommendations to safeguard future attempts to undermine democracy and democratic institutions in Fiji.

\section{PAPER ON GOVERNMENT OF NATIONAL UNITY, 1979 AHMED ALI}

Plural societies, that is, states where are juxtaposed within a political system, communities with diverse cultural traditions, have experienced not a dilemma but a trauma in their efforts towards nation-building. The first task of the leaders in the post-independence era has been to weld into a nation peoples with strong ethnic allegiances. Their efforts have been constrained by existing economic resources or their inadequacy, the nature of the political system inherited from former colonial masters, and the desires of the people themselves concerning attachment to their cultures as well as the strength of the traditions themselves. 
Fiji has proved no exception to the rule though its ten years of independence have been characterized by political stability. Its various communities have continued to live side by side in harmony despite incidents arousing ill-feeling and occasional comments which have sent tremors of insecurity through one group or another. The world-wide inflation and Fiji's own disparities between its two major communities have frequently given cause for concern. All Fiji citizens agree that unless remedies are found the prevailing political stability would be threatened.

In Fiji, group attachment lingers despite contact between the various cultures for at least a century. Socially, people of different ethnic groups interact at weddings, funerals, cocktail parties and increasingly in schools and in sports. But intermarriage is rare and does not have the general approval of any community. Even where it occurs there are rules, which though unwritten, require strict observance; offenders can still pay the price of ostracism.

Fiji is also a very religious country as is evident from the devotion with which the various communities observe their rituals and festivals. Government for its part has recognized this by proclaiming as public holidays not just the important Christian occasions but also Diwali and Prophet Mohammed's birthday. While tolerance has been a feature of Fiji's religious history there have been occasions when religious attachments have been exploited. The second General Election of 1977 provides an obvious example. Religion has buttressed the various s religious identities found in the country and limited social interaction.

In addition there are crucial cultural differences among the various communities; these affect their social structure and outlook and influence their behaviour. Fijian society is kinship-based and accepts communal co-operation and traditional hierarchy for its development 
and preservation. Indians and Europeans tend to be individualistic and thrive in no-holds-barred competition, where material success is of prime importance and kinship relations of secondary value. The sensitive issue of land will serve as an illustration of different values. Fijians attach to their land a social-psychological significance and see it synonymous with their survival as a cultural entity; Indians and Europeans see it has having an economic function. Hence within the different emphases lies the potential for conflict.

The interplay of cultural diversity, deep ethnic allegiances and desires for preservation of the distinctness of each group all occur in an environment characterized by significant socio-economic disparities and different perceptions towards them. Fijians are absent from commerce and see it as Indian dominated whereas in fact only one sector of he Indian people are in it and only at the middle level. Big business still tends to be foreign-owned. Indians see Fijians as having $83 \%$ of the land and as being reluctant to allow them free use of it and in the process ignore: first, that this percentage excludes some of the most fertile tracts of Fiji's land and second, the reality that there are Fijian mataqali without adequate land for own well-being. Indian educational achievement has hitherto been better than that of Fijians but attempts to allocate scholarships on a 50-50 basis to redress the imbalance raise deep Indian fears of deprivation.

Given the magnitude of the problems confronting us and the need to solve these with justice for all a national effort based on consensus becomes imperative, The solutions demand both political will and political action but not by ethnic groups acting unilaterally, rather by their co-operating and jointly accepting decisions, not interpreting these for communal political mileage. It becomes crucial in our situation, as plural societies tend to be crisis-prone, that the Government of the day commands the faith and goodwill of all communities domiciled in Fiji. 
Towards this end we chose a form of representation in Parliament designed to guarantee membership for all our racial./ethnic groups. As a unifier this device on its own has proved insufficient. Indeed it has been negated by the trend in political behaviour and the nature of our political parties. Fijians have placed their faith in the Alliance of which they form the backbone. Indians prefer the National Federation Party whose strength has continued to grow among that community since 1966. In the first General Election of 1977, the National Federation Party though divided collected $75 \%$ of the Indian votes cast. In the second General Election, the two factions of the National Federation Party totalled $85.5 \%$ of the Indian votes, the Alliance lost $1.5 \%$ in six months. In other words, Indians do not see the Alliance as an alternative to the National Federation Party, they prefer Indian leaders organized separately to those associated in an organization with other groups. Similarly Fijians have favoured the Alliance and when in early 1977 they did not they turned to the Fijian Nationalist Party which received 25\% of the Fijian votes cast. Indeed the National Federation Party has found less than negligible support from Fijians. The General Electors alone have remained constant: with the Alliance. There is no reason to believe that this trend will change; if one goes by what has happened elsewhere it is likely to consolidate and polarize along firm racial/ethnic lines.

The racial pattern of voting has hitherto given us a government where the community which does not support the ruling party is likely to be under-represented in the decision-making process for formulating national policy. This has been evident from the limited Indian presence in the Alliance cabinets. If the Alliance were defeated, and April 1977 has shown that this is not impossible, and the National Federation Party emerged victorious, then the process would be reversed. Then Fiji will be confronted with a cabinet predominantly Indian and with inadequate Fijian and General Elector representation. 
The question then arises whether the country can afford to continue adhering rigidly to a mode of government wherein at present Indians, comprising $49.8 \%$ of the total population, do not possess in national policy formulation a voice commensurate with their size, talents and commitment. When one notes the level of Indian educational achievement and professional experience and expertise one must conclude that their insufficient involvement means that a small country like Fiji with its limited manpower resources is not making the best use of what it possesses and is thereby depriving itself of reaping the full benefit of its talents. Besides, instead of harnessing this pool in the service of the nation the government by neglecting it, is creating a sense of frustration among those ignored. They finding themselves left out grow more disenchanted with the government and country and with little reason for loyalty to a system which excludes them through no fault of their own apart from their attachment to a political party in which they genuinely believe. What is true of Indians today could also become the reality for Fijians later. Worse, Fijians in terms of educational qualifications and involvement in the cash economy are in a much poorer position than Indians, their sense of frustration then is likely to be greater and they could very well reach the point of desperation later. Hence Butadroka's proposed uncompromising solutions for rapid remedy are likely to be more attractive than the alternative of either the Alliance of the NFP. The persistence of the present pattern is therefore not only unsatisfactory but carries the threat of destruction of what has already been achieved.

An obvious solution is coalition. In the National Federation Party overtures of April 1977 this solution was much in favour. But a coalition is always a temporary measure devised for times when no group possesses a reasonable majority to govern on its own and joins in a loose association with another or others merely to keep the country going until a propitious time when the next general election 
might be called with the hope that some party will emerge victorious with a majority sufficient to give the country a definite direction. Second, a coalition is characterized by compromise, those coalescing modify their policies to make them acceptable to one another for the sake of clinging to the reins of government. For Fiji, there are two dangers in having such a coalition. First, the solutions to the country's crucial problems do not lie in resorting to compromises: their answer is to be found in all groups accepting to assist the disadvantaged, especially in one ethnic group agreeing to help another. Modification and bargaining for the sake of keeping power will not do; they will become ends in themselves and exacerbate social and economic disparities which might in the end polarize to a degree of intransigency which conflict alone might subsequently thaw. Second, the bargaining is likely to be mildly successful at the best and a complete failure at the worst. If failure results then the whole concept of co-operation among ethnic groups gets discredited; this set-back will have adverse long term consequences.

It has been said that a coalition is an interim measure before another general election. Such a general election tends to be acrimonious with each former partner attempting to usurp all credit for itself and attribute total blame to the other for any difficulties and failures. It would be an election characterized by vituperation, reminiscent of Fiji in 1968. Since our political parties have racial allegiances such an election following a coalition would heighten racial animosities and may even pave the way for violence. Such an outcome would negate the very purpose of a coalition. A primary aim of government in a plural society is to unify different ethnic groups, not to leave them even more divided after an election than before it. A coalition government wherein each party modifies its demands temporarily until the next election when hoping for victory it can proceed untrammelled is no solution. 
A second alternative is a government of national unity. Basically this will be reflected in a cabinet which draws upon the best talents in the country having in mind simultaneously adequate representation of the various ethnic groups in Fiji. The purpose would be to ensure adequate participation by all communities in the decision-making processes to obtain consensus for critical policies thereby nullifying the likelihood of a sense of alienation developing in any one or more ethnic groups through apparent or real exclusion. The distribution of cabinet places could reflect both proportions in the population as well as percentage control of various parties in Parliament and of the majority party as a result of previous election. It could even resort to an arrangement whereby all agree to sharing on the basis of Ethnic Group X providing the Prime Minister, Y the Deputy Prime Minister, $Z$ the Minister of Finance, $X$ the Minister for Fijian Affairs and Rural Development, Y the Attorney General and so on. Such an arrangement might on the one hand stabilize government and on the other placate those feeling insecure and neglected.

There are a number of advantages in shifting to this form of government. First, all leaders in the cabinet, irrespective of community or party affiliation, would be committed to a national policy which they would formulate and implement. It would be incumbent upon them all to explain to their supporters the reasons for their action. At present the tendency of the predominantly Indian opposition is to brand all government action as anti-Indian, thus Indians tend to perceive government as against them but legislating in favour of Fijians and General Electors. With the present minimal presence in Cabinet Indians can adopt the stance that they have had negligible voice in the determination of a particular policy and do not feel bound to support it irrespective of its merits. Fijians under a NFP government could do no less. A national government could remove this pretext of absolving oneself from being objective 
towards a national policy. Second, a national government wherein all communities are participants could act confidently and decisively. This decisive action with support from all leaders is essential if gaps between communities are to be bridged without any community disrupting the system because it may feel that it is being deprived for someone else's sake.

Third, a national government would present the nation with the example of a group of persons from different communities working together for the general good of the whole country, not primarily for any section or sections of it. The picture of leaders in harmony would register in other minds and spread to the people as a whole. One can illustrate the value of this from Fiji's recent history. The independence settlement was achieved through the political leaders meeting and agreeing with the result that the people accepted the constitution without condemnation or abuse of either groups of individuals. Contrast this with the 1965 Constitutional Conference when various leaders were divided even before leaving for London and the acrimony that followed.

Divided and squabbling, leaders make for a strife-prone people. Cooperating leaders create climate of unity wherein the people generally join. At this stage of our development it is easier to get leaders of goodwill together and for them to pursue a dialogue than it is for the mass of the population who do not share common values and have no way of communicating in a language of politics understood by all without the possibility of misunderstanding and distortion which would enhance distrust and suspicion instead of removing them.

There are of course some who would argue against a national government. One such view holds that if those in opposition were taken into government they would be given training which would not make them hesitant to take control if opportunity offered. While an element of truth exists in this contention it should not obscure the 
broader advantage. First, by observing the most capable members of opposition into government one would be giving them an exposure to both the complexities and constraints of governing Fiji. While it is true they will learn the art of government it is equally reasonable to assume that in the process they will be able to acquire some sympathy for the policies of those who have involved them in decision-making. Second, if a wider range from all communities obtain experience in managing the country then we will always have some leaders with the knowledge of charting the ship of state. Third, we will have a pool of people who can share power with one another irrespective of ethnic loyalty. While these will be benefits to those who might otherwise have languished in opposition what is of greater significance is that we will be able to get political leaders of all races and parties to think in national terms and not purely along sectional lines which exists at present and perpetuates divisions.

For a small country with limited manpower resources which has to draw on outside help until it has a sufficiently large cadre of trained and professional persons, the best way forward is to utilize all its talents effectively. Any system that excludes some purely on grounds of ethnic affiliation derived from an accident of birth is in the end self-defeating. In plural societies it is imperative to create an environment where national bonds emerge and strengthen and can restrain parochial loyalties from running amok, a national government becomes an essential step in that direction.

It is also noteworthy that plural societies which have experienced extreme crisis degenerating into violence have resorted to a national government to placate all groups. Malaysia, after May 1969, has ensured that its cabinet sufficiently reflects the presence of all its peoples despite the fact that the Malays are in the majority. Mauritius too has tried the method even to the point of postponing elections for some time. Where the ruling class has been insensitive to the interests of 
certain ethnic groups within its boundaries then one or some have dominated others. Trinidad and Guyana, despite the myth about the West Indies, reflect this pattern. The salient feature of life in these countries is ethnic distrust and disaffection coupled with periodic violence. The attempted creation of Biafra illustrated how an ethnic group thoroughly frustrated by what it considered the dominance of others risked secession, bloodshed and failure. On the other hand, European states such as Belgium, Switzerland, Holland and Austria confronted with deeply entrenched ethnic situations worked together to govern in the national interest in a system which has been called consociational democracy. The leaders provided the leadership for which they were chosen, their example of co-operation stabilized politics, permitted economic growth and ensured social harmony. The co-operation of leaders became another step in political development; it warded off strife and provided time for the establishment of understanding and paved the way for harmony ...

A government of national unity which will be based on the agreement of all communities will not be inclined to disregard a constitution which enables its existence. In plural societies constitutions are ignored and discarded when some group or groups feel that others are governing for their own selfish advantage. The threat to Fiji's Constitution lies in the racial dominance of one group to the detriment of the other, a government of national unity removes such a threat. In place of alienation of groups it brings confidence in the political system.

Some will contend that a government of national unity will bring to an end elections and parliamentary opposition. Elections would occur every five years as required by our constitution which will remain intact. What is likely to happen is that the present political 
parties will change in that they will have to produce policies based on national needs not those pandering to racial or religious entities centred around the personality of leaders. Those in cabinet will be made even more accountable as they would have to answer to a Parliament where the backbenchers are likely to combine and not merely vote according to the direction of their party. From these backbenchers there will emerge someone who would become the new-style Leader of Opposition. Though it may appear a paradox the parties in this system will retain their identity, backbenchers will not allow their leaders to ignore them and leaders will not wish to lose their backbenchers lest these campaign against them within Parliament and during the next election. Consultation among party colleagues will continue and there will be greater dialogue among all. It could very well be that the whole quality of our parties would be improved.

Our present system has given us elections where the exploitation of racial and religious divisions has paid dividends for many. Issues are always discussed on the basis of which race will gain, not as to whether the country will benefit. Decisions are always interpreted as being made for the advantage of one race or another. Whichever side considers itself deprived proclaims that this has been done for reasons of race. A government of national unity on the other hand will govern by consensus and be able to act decisively in the name of the nation. It will nevertheless be able to preserve ethnic identities, take note of the problems of different groups and resolve these without accusation of bias. In attempting an experiment with this form of government of consensus among leaders we have everything to gain and nothing to lose. 


\section{JAI RAM REDDY'S BA NFP CONVENTION ADDRESS, 1980: UNITY, SOCIAL JUSTICE AND GOVERNMENT OF NATIONAL UNITY}

I extend to you all a warm welcome to this Convention. This is the second Convention since we set in motion the machinery to reunify our Party. Since we last met at Nadi, we have made steady progress. We have now brought together the two rival groups in nineteen different branches. In a large measure unity has been achieved. We must build on this. As we approach the 16th Annual convention of the Party, our aim should be to consolidate our unity. Henceforth, the Party should become our first concern. Let us make it clear that the Party - the National Federation Party - the Party that the founding fathers conceived to protect the legitimate rights of people - the common man, the worker, the farmer, the small shopkeeper, irrespective of race or religion. That is our Party. It is our collective duty above all else to preserve the unity and integrity of our Party.

We must now look ahead. Any attempt to retrace the steps that led to our internal domestic dispute is bound to stir up old passions and irrational fears Every time we dig into that ugly past, we will find new issues to divide us. We must let our recent history rest in peace. Historians and philosophers can dredge up the remains for their own past time and pleasures. Our task is to look forward. Our task is to forget our individual misdeeds. Our task is to protect and preserve our home and domestic tranquillity. On the shoulders of each of you today I place this task.

At a national level there has been much talk of national unity. Preservation of our internal unity is vital prerequisite for any attempt at external unification. We cannot confront our political rivals from a position of weakness. We cannot promise to deliver on our side any bargain with the Alliance unless we are in a position to do so. We must remain united at all times to give credibility to our positions. No party would want to negotiate peace and harmony with one another unless each knows that it speaks 
with the authority of unified backing. Our solidarity then is vital not only for our own internal domestic affairs but equally as vital for extending that peace, that harmony, to all of Fiji.

Unity is strength. We must pool our energies and resources. Our best bargaining card with our compatriots on the other side is our unity. They must know that it is as good for us as for them. Trust is the key to our success. Trust is the healer of all wounds. Let us trust each other. Any attempt at division would be courting our own disaster committed by our own hands. We must pledge to work, to strive, and if need be, to suffer together in the cause of justice and fair play for all those who have placed their faith in us.

Over the past few months, as you are all aware, there has been much talk of a Government of National Unity. The Prime Minister has talked at various times about 'Coalition,' about 'Government of National Unity,' and about 'Consociational politics.' He has also talked about 'power sharing from a position of strength.' At various points in recent months, I have replied to the Prime Minister's proposals. It would, I believe, be true to say that there is much confusion in the minds of many as to precisely what is being proposed as the essential elements of a government of national unity or how it might be accomplished. In many ways, it is great pity that so sensitive an issue is having to be publicly discussed. Neither the Party nor I as its leader have received any formal proposals. All we have to go by is what been publicly said. Naturally these proposals have aroused much public interest and indeed expectations, and we must look at the issues raised critically to identify its strong points and weak points. My intention is that there should be full and free discussion among members at the Convention and when you return, with people generally throughout the country. We are not required to take any decisions on the subject at this stage. In any event, we are not in a position to take any decisions because firstly, the proponents of the idea have not asked for our decisions. Secondly, as I have already said, we do not know exactly what 
are perceived to be essential elements of the government of national unity — or how it might be accomplished — indeed, how it might work. At this stage, we can only talk about the general principles. The nuts and bolts of the proposals have not been spelt out.

There can be no disagreement on some of the basic issues. Communal politics is very divisive: indeed, we ourselves have said on more than one occasion that current government and political arrangements have had very unsatisfactory repercussions on communal politics in our country. Indeed, there are all the signs of growing national tensions and increasing frequency of communal injustices. As early as 1975, we were telling the [Street] Royal Commission looking at our electoral system that the country should opt for a government of 'Concord of National unity.' We warned the Commission against the dangers of racial polarization - and the need to avert those dangers. Consistent with those proposals and when the opportunity presented itself in April 1977, we offered to go into a Coalition with the Alliance. You all know we had then won 26 seats, the Alliance 24, the Fijian Nationalist Party I and independent 1.

In spite of many uncharitable imputations as to our motives in making that offer, there were many amongst us who sincerely believed that sharing power was not only the solution to the immediate problem of establishing a government, but one way of harnessing all our people in a collective endeavour at nation building. But our pleas were rejected. Our position has been consistent. There should be no doubt as to where we stand. Our position is crystal clear — any arrangement that is honourable and will lead to genuine power sharing is what we have consistently advocated.

An election is not an end in itself. It is a means to and end. What happens between elections is more important. Elections are held so that at the end of it there is an effective government able to govern. Therefore, apart from all other considerations, such as the need for greater participation and a more representative government, the hard realities of the political situation in Fiji as revealed by the April 1977 result suggest that sharing 
of political power, if a proper basis for it can be established, may be the only practical option for the foreseeable future. For this reason, it would be unwise for the NFP to shut out altogether the Coalition option, as the Alliance did both before and after the April 1977 elections.

Let me come to the Prime Minister's paper presented to the Alliance National Council meeting at Sabeto recently. Firstly, one cannot quarrel with much of the analysis in the Prime Minister's article, which has a very heavy academic bent. But one is struck by the glaring lack of any concrete proposals to which one can put practical application. The call to a government of national unity without specifying the underlying principles for sharing power and the machinery of operations left a yawning gap in the proposals. Having been built up in the first part of the article's commentaries about the divisiveness of the politics of communalism and specially its heavy toll of destruction on the national spirit and our economic and political endeavours, one is left with a very ill-defined and vague proposal of a government of national unity. I would like to look at aspects of those proposals a little more critically. I will do so frankly and forthrightly. My objective is to launch into some of the considerations that would inevitably arise as we seek to identify our interests and seek to forge a consensus for action. We must be prepared to face some ugly facts in our difficult endeavours to establish a joint course. Better face them now than to have them leap into our face later.

In his presentation to the Alliance Party at Sabeto, the Prime Minister again rejected Coalition. Let us examine his reasons. Firstly, he says that Coalition is always a temporary measure. That is not so. In fact, there need be no time limit on a coalition, and usually it need not be a temporary measure. For example, Australian coalition of the National Country Party [and the Liberal Party] is an ongoing one. There are several other examples. Continental countries such as the Netherlands, Switzerland, Belgium and Denmark know no other way of forming a government. In Italy, even the Communists have featured in coalitions. The Prime Min- 
ister in his statement went on to assert that there 'two dangers in having a Coalition.' Firstly, he says, 'solutions to the country's crucial problems do not lie in resorting to compromises,' and [secondly] he says that 'the answer is to be found in groups accepting to assist the disadvantaged specially in one ethnic group agreeing to help another.'

This statement is true if it presupposes that both major racial groups are in need of assistance from each other. But if the premise is that only one is in need of assistance, then it is a fallacy. The truth is that the two major racial groups are in need of assistance from each other albeit in different facets of our national life. If the Prime Minister's no-compromise formula presupposes that one group alone must lay down the policies and the other must join in merely implementing them by becoming part of a broadly based multi-racial cabinet, then such a system is doomed to failure. In fairness, I must add, that it is by no means clear that that is what the Prime Minister means because he also talked about such a cabinet 'formulating policies.' In as much as such a cabinet would comprise people representing different and often conflicting political interests, how would such a cabinet formulate policies if it does not compromise? That strikes me as the most fundamental flaw in the Prime Minister's case for a government of national unity. True, compromises may be difficult to achieve on crucial issues, but I see that as an absolute essential.

One thing must be clearly understood. In any form of government of national unity, the leaders must continue to command the trust and confidence of their respective followers of racial groups. That confidence can only be retained if the government of national unity is seen to be doing what is clearly in the interests of all the people. Whether one calls it Coalition, Government of National Unity or Consociational Politics — all terms dear to political theorists — the idea is the same. Its common denominator is consensus. In plural societies, stable and good government in the broadest sense must include and reflect the hopes and aspirations of the many components of that society. Consensus is the 
result of compromise. To say that we want the politics of consensus but no compromise is a contradiction in terms. It is a proposition which is rather difficult to understand. Unless, of course, what the Prime Minister is saying is that the NFP should join the Alliance in a Government of National Unity to sell the Alliance policies to the Indian people - a substitute for the defunct Indian Alliance. I do not think there are any volunteers in this hall!

The point I made earlier about the need for compromise can best be illustrated by examples. Now for more than a decade it has been accepted that the Fijian people are in need of special [assistance] in the field of education and [in] commerce and industry. In the former case the reservation of 50 $\%$ of places at the USP is the manifestation of that policy; the granting of soft loans by the Development Bank to ethnic Fijians in order to help them in commerce is another example.

Similarly, much of the rural development effort is geared to help the Fijians better their standard of living. Massive assistance to the Fiji Pine project is another example of special assistance primarily aimed at helping one section of the community (but indirectly helping the whole). We recognize that this effort must continue; indeed, we must look at ways and means by which more effective use can be made of our resources to 'bridge the gap' between the 'have' and the 'have-nots.' But it would be completely wrong to suppose that all Fijians are 'have-nots' and all Indians are the 'haves.' Such a crudely racial approach is not the answer. Can we shut our eyes to the fact that a sizeable number of Indians and others also fall into the category of the 'have nots?' The truth is that a large section of the Indian population falls into the category of 'have nots.' There is a general belief that all Indians are 'well off,' a myth that puts them in all in the 'Cumming Street' category. The truth is that a large section of the Indian population is extremely vulnerable. They comprise the poorest and the weakest section of the total Fiji community. They are the 'Bangladesh' and 'Vietnam' dwellers of Fiji. 
The largest group of unemployed comes from this section. They have no material security altogether [sic]. They are generally squatters. Their mobility is severely limited. They do not have a social security system to underpin their existence; they cannot fall back on the land because they have none. The greatest degree of undernourishment and poverty is to be found in this group. A survey conducted by a USP academic shows that unemployment amongst Indian youths is higher than among Fijians. The 'unemployed' amongst Indians no doubt come from this group. Unlike the Fijians who can fall back on the land, or the village, this section of the Indian community has nothing to fall back on. They are to be found both in urban and rural areas. In the rural areas, they are invariably casual farm labourers depending on seasonal work and living on land belonging to their employers [and] completely at the mercy of the latter. There has been no known survey to determine their numbers, but I suspect they comprise a sizeable proportion of the total Fiji population. Could a Government of National Unity ignore the plight of these people and yet call itself that? Any approach that focuses too much emphasis on race and not to those in need is not likely to attract much sympathy or acceptance.

Not all Fijians are poor — there is a growing class of Fijians who are among the most privileged in the country. Just as there are many rich Indians, there are many that are among the poorest. What we need to do is to develop a creed which will require the privileged in our society, be they Indians, Fijians or Europeans, to help those who are the weakest in our community irrespective of race, colour or religion. This can be done by selective government policies which will ensure that meaningful assistance is channelled to the weakest groups, determined not by race but by need. It is not beyond our collective capacity to conceive such policies. Such policies clearly formulated and explained are likely to find ready acceptance by all the racial groups. If this leads to that Fijians get more than the others, so be it; is it something all reasonable men would defend 
anywhere at any time. Because that is only just and fair. The constant and ever increasing emphasis on 'race' is not conducive to national unity; it has the opposite effect and will in the end create a deep chasm which will in time get deeper and in the end lead to serious disruption of our national life.

Now let me come back to the Prime Minister's arguments. He also says that 'modification and bargaining for the sake of keeping in power will not do - they will become ends in themselves [and] exhibit social and economic disparities which might in the end polarize to a degree of intransigency which conflict alone might thaw.' Modification and bargaining need not take place for the sake of 'keeping in power' but to ensure that government decisions do indeed meet the expectations of the people of Fiji; that they reflect the hopes and aspirations of the total Fiji community and not just sections of it.

Indians in this country feel uncertain and insecure; that is a fact. That sense of insecurity arises from several sources and one has been exploited for long enough. This sense of insecurity stems from the fact that many of them, and particularly farmers, are mere tenants with very limited security of tenure; and they realize that it is in the nature of a lease that it will expire one day, be it 20 or 30 years. Expressed in the most subjective terms, while the tenant knows that he has a place to live, he is not sure that his dependents will when he is gone. No one, and certainly no one in a position of leadership, can be insensitive to this fear. It is real and it is there.

I am mindful that recently the Agricultural Landlord and Tenant (Amendment) Act was enacted which gave the tenant a measure of security. But there is no denying that this was a temporary solution - and that this problem will have to be faced - and solutions found sooner or later. But far from looking at more enduring solutions acceptable to both landowners and tenants, other developments are taking place in the country which I find quite alarming and of which I am duty bound to report to you. 
The Government has decided and has embarked upon a policy of reserving large areas of Crown land (including Provisional Crown Schedule A and B) for Fijian landowning units who are said to have inadequate land. My information suggests that this exercise will affect some 62, 240 acres of Crown land and at least 192 existing leases and some 5 government projects. The power to convert Crown land to Native Reserve is said to be in Section 18 (1) of the Native Land Ordinance.

It will be noted that this Act was enacted at a time when almost the entire executive authority was vested with the Colonial Governor. Prima facie Section 18 (1) of the NLTB Act says that the governor could by simple administrative device of a proclamation set aside Crown land as reserve for landowning units who have inadequate land; a power which he would exercise upon an objective assessment of the needs of each landowning unit with insufficient land. I dare say a power which the Colonial Government would have never exercised to dispossess people already on the land as tenants of the Crown and solely dependent upon it. The power was in fact never exercised by a Colonial Governor: not an insignificant fact given Fiji's already potentially explosive and acute land problems.

Now let us examine some basic facts. In this country, $83 \%$ of all land belongs to the Fijian people: a right that all people respect. Their right of ownership has never been questioned and is now firmly entrenched in the constitution. Ownership entails rights to possession. This means that all those on Native leases, be it commercial or agricultural, may be required to vacate at the expiry of their leases, including any extensions granted by laws such as ALTA. A Minister recently put it in the House of Representatives in this way: 'The right of the owner is paramount. When a lease expires, you just move on.' This was during the Lega Lega take over debate.

Now, talking about one community helping another: this policy to reserve Crown land will result in many families — yes, human beings and citizens of this land — having to vacate their holdings at some point of 
time in the future. True, this will not happen immediately, but that is not the point. The rationale behind this policy is that some Native land holding units have insufficient land and should have more. The solution prescribed by the Government of the day is to make some others totally landless so that those with insufficient land can have more. You already have the problem of evictees from Native reserves, which is an ongoing process, about which you all know only too well. And now to compound matters, the government has embarked upon a policy which entails the reservation of Crown lands, including Crown freehold and ultimately the eviction of families living on them. I reiterate that the fact that this will not take effect immediately is immaterial, and does not make the policy any the less abhorrent.

Firstly, given the Fijian strength in this area — and the Indian vulnerability - is it really necessary to take over what little Crown land there is and to convert it to Native land? You may have the power to do it, but remember the power to what is right and good is also the power to do what is wrong. I would have thought a reasonable government would preserve as much Crown land as possible consistent with principles of fairness to all in order to settle future evictees from Native lands. There are hundreds of evictees now waiting to be settled. Incidentally, this policy was introduced by government as early as 1975. Were the people of this country told about it? Were those who will be directly affected told about it? If not, why not?

Secondly, if the justification is the need of some, should not the Government ensure that Native land is reallocated between those landowning units who have too much land and those who have too little? Or is this a device to gradually convert all Crown land to Native reserves? And after that, how safe are the freeholders?

The Indians need no reminding that they are a tenant community. This is an area in which they are already very weak and it seems to me that this policy is designed to make them weaker still. It is pertinent to raise these 
issues while we are talking about a Government of National. Unity. Can you sow the seeds of strife and sue for peace? Is this how we build national unity? Clearly, then, the NFP will never be a party to such policies so the question is: Will the Alliance adopt a compromising policy on this and other issues in a Government of National Unity? Or will they expect us to suffer in silence?

National unity cannot be built on slogans and expressions of goodwill alone. There has to be mutuality. People must see that the National Government is not a 'one way street.' If there is no compromise, a Government of National Unity is not possible. The whole of the Prime Minister's thesis is based upon the theme that we must all join in bridging the gap between the communities, yet there is not a hint of recognition that there are gaps on both sides that need bridging.

No one except the most foolish will quarrel over the idea of National Unity. Unity is a virtue; it gives strength. No doubt there is much to be gained by leaders working together. But in order to be able to do so, there have to be some common perceptions, some mutual understanding, some desire to give and take. Look around you: do you see many signs of that desire, in deeds, not just words? There has been much talk of racial polarization. Let us examine some factors at work.

One decade ago, our leaders, both Alliance and NFP, declared their political objectives in these terms:

The two parties stated their belief that the democratic processes of Fiji should be through political parties each with its own political philosophies and programmes of economic and social advancement of the people of Fiji cutting across race, colour and creed and all should work to this end. If that was an expression of hope that the two major parties would develop along non-racial lines offering the people of Fiji a real choice of policies and programmes, then ten years later we are able to say that that hope looks as distant as ever. Far from 'cutting across race,' the parties have 
become polarized along racial lines. The ruling party which secured 28 $\%$ [sic: $24 \%$ ] of Indian votes in 1972, and could justifiably claim to be a multiracial party, picked up no more than $14 \%$ of Indian votes in September 1977, and no more than 7\% in the recent Labasa-Bua by-elections. The NFP of course never could boast any more than token Fijian and General Elector membership. The reasons for this are not difficult to see. The Fijians have always believed in solidarity, and good luck to them. It is their virtue and no one can begrudge them that. Indeed, there is much we should learn from them. The General Electors who claim close ethnic tiles with the Fijians have given the Alliance solid support. It is only the Indians who, to borrow the Prime Minister's words, have 'great political diversity,' a polite way of saying the Indians are always divided.

But every action produces a reaction. Emphasis on 'racial solidarity' by one group does not go unnoticed by the other and produces a corresponding reaction. That is natural in the order of things. There have been other factors at work. The mid-1970s saw the emergence of 'Fijian Nationalist' movement in the form of Sakeasi Butadroka, and the Fijian Nationalist Party with their rapid solution!

Their stunning, if temporary, gains in the 1977 first general elections have led to a noticeable shift in the Alliance Party's approach to government. It has definitely assumed a more 'pro-Fijian' stance. This is reflected in much of what it says and does. While 'multiracialism' is still espoused, it is now very much a matter of slogans. There is very little multiracialism at work. This is reflected in almost all aspects of governmental work and activities, from its composition, its development strategies, especially appointments to boards, promotions in the civil service, its Crown lands policy everywhere. It is only the apologists who refuse to see and continue to make lame excuses. It seems to me that Fiji is implementing a policy designed to ensure that all strategic levels of government are staffed by 'loyal personnel', which in effect means that Fijians are placed in positions of command in order to deliberately create an 'out group,' namely the Indians. 
This sort of policy, if continued, will result in more distrust between the two major communities, which may become so embittered that, in the Prime Minister's words 'conflict alone may resolve.' And, of course, in economic terms, the result will be disastrous. Economic development cannot take place when the two major communities which complement each other in the production of goods and services do not work in harmony. We must know that one community cannot prosper when another stands to perish. If it ever comes to that, and I pray it won't, then the government would discover that its limited revenues would be diverted from productive economic activities to financing its security services and paying off political supporters.

These are the plain facts as I see them. And as the Leader of the Opposition party, it is my solemn duty to warn the country against these unhealthy developments.

The other factor of course is the electoral system itself. Having put the people into racial compartments, it is only natural that people should behave racially. Professor WJM McKenzie in his book Free Elections has dealt with the problem very definitively. He makes the point that 'communal elections strengthen communal feelings' because, as he puts it, 'in public debate appeals are made principally to the interests of each community and within each community the more violent and selfish spokesman of special interests outbids the moderates and public spirited,' and he goes on to make the point that people entering public life learn to talk the language of 'communal politics not that of national politics;' and furthermore he says and rightly that 'communalism only helps to defeat nationalism and destroys the possibility of national self government.' This truth is self evident. Political developments in Fiji in 10 years (and we all lament the fact that there has been racial polarization) has vindicated the truth of Professor McKenzie's observations. 
So, after 10 years as an independent country, we have no national cohesion, no 'nationalism,' only communalism. We do not even have a common name. We can't find one, maybe because we really do not want one! Worse, we are busy creating an 'out group' that is being slowly but surely pushed out of all strategic levels of government, the Cabinet, the Foreign Service, the Permanent Secretary level, the Boards and Authorities. And this trend is being carefully camouflaged by putting in some conspicuous positions token representatives from other communal groups.

The net result is a growing sense of alienation and frustration. In fact, there are all portents of conflict and confrontation. We seem to be at the proverbial precipice. The present form of government 'will not do for the 1980s' we are told. We agree: the present form of government will not do at all! If the proposal of a Government of National Unity is a serious attempt to find solutions, to turn back from the precipice, then it is commendable indeed and one this party is bound to give the most serious and earnest consideration. But if it is another attempt at window dressing - more public posturing lacking in serious intent - why, then we haven't learnt at all.

There is one other point that needs to be made. 'Consociational politics' is of course possible without any changes to the present system of government. All it involves is that the government should formulate policies, particularly on 'critical issues' and try in so far possible to obtain Opposition's critical support for such policies. This was the approach to the constitutional talks in 1970 and to the acquisition of CSR's milling operations by the Government. The Opposition then gave support to what were government positions.

Why is the Government not adopting this approach now? In fact it is doing the opposite. It rarely takes the Opposition into confidence. The attitude is: we are elected to govern and we will do what we think is right. Rarely has the government attempted to compromise. If the desire to compromise or 'reach consensus' does not exist now, why should we 
suppose it will emerge merely because we are all members of a multiracial Cabinet in the proposed Government of National unity? Or will it mean that the arena of conflict will be shifted from the floor of the House to the Cabinet? These are issues that need careful thought.

There are many more issues that will need to be looked at and resolved before any definite position can be taken. How will we achieve this Government of National Unity? The Prime Minister's statement says there will still be elections every five years. True, but will this concept involve a 'no competition' situation between the parties; ie, we merely agree on our respective areas of monopoly and do not oppose each other in those areas? How will we agree on who is to stand where? Will it also mean we do not criticize each other's record: a kind of 'one party situation?' Who will head such a government and how will this be determined? One could raise an infinite number of questions, most of which do not lend themselves to any easy answers. There is nothing to be lost in the two parties engaging in inter-party discussions along the lines of the 1970 constitutional discussions to see if any basis exists in fact to establish a form of government which will meet the needs of Fiji.

In conclusion, therefore, gentlemen, let me remind you that this is a subject on which views can differ and differ strongly. The important thing is to try and understand the very complex issues involved. 


\section{NOTES}

1. Fiji Times, 5 Dec. 1978.

2. Hansard, 10 Dec. 1980

3. Daily Post, 18 May 1999. The same piece appeared in Fiji Times 30 Apr. 1992.

The 'independent observer' most probably was Vijendra Kumar, the first local-born editor of the Fiji Times.

4. From an NFP 1982 election advertisement reprinting the praise.

5. Fiji Times, 5 June 1978.

6. Fiji Times, 22 June, 1981.

7. Fiji Times, 10 March 1980.

8. Fiji Times, 11 May 1982.

9. Fiji Times, 8 May 1982

10. Fiji Sun, 5 June 1982. In January 1987, Dr MB Patel said: 'A correct description of the Indian Alliance would be a broken leg, a broken arm, a broken wing and broken tail of the Alliance Party. It only comes into existence at election time. The leaders of this particular organ of the Alliance really have no say in the party. They are used.' See Fiji Times, 13 Jan. 1987.

11. Interview with Harish Sharma.

12. Some of Sir Vijay's fluency in English prose is on display in his privately published book, Speaking Out (Knightsbrook Publications 2006).

13. During my conversation with him, only for the second time in my life, at his South Brisbane home in June 2005, with Vijendra Kumar and Praveen Chandra.

14. Fiji Times, 16 June 1982

15. See Hansard, 5 Mar. 1979.

16. Hansard, 1 March 1979.

17. Education for Modern Fiji: Report of the Fiji Education Commission (Suva: Government Printer, 1969).

18. Hansard, 1 Mar. 1979. 
19. Speech to the NFP Convention, Ba, 1980.

20. Debate on the Appropriation Bill, 5 December 1979.

21. Speech to the 1995 NFP Convention.

22. Weekender, 19 Nov. 1993.

23. From Reddy's letter to Mara. But see also Hansard, 10 Dec. 1980

24. Quotes from a copy of the speech in my possession.

25. Fiji Times, 1 Nov. 1983.

26. Fiji Times, 14 Nov. 1978

27. Quotes are from a copy which is reproduced at the end of this chapter

28. Fiji Times, 10 July 1980.

29. From Ratu Mara’s address to the Alliance convention, 1 Nov. 1980.

30. Comment on Radio Fiji, 11 Nov. 1980. A typescript of it is in my possession.

31. John Sharpham, Rabuka of Fiji: The authorised biography of Major-General Sitiveni Rabuka (Rockhampton: Central Queensland University Press, 2000), 65.

32. For example, in Ratu Sir Kamisese Mara, The Pacific Way, 181-182.

33. From Ratu Mara’s address to the Alliance Convention, 1 Nov. 1990

34. Comment on Radio Fiji, 11 Nov. 1980.

35. From Ratu Mara’s address to the Alliance Convention, 1 Nov. 1980.

36. Ramrakha to Lal, 16 Feb. 2009.

37. Mara, The Pacific Way: A Memoir (Honolulu: University of Hawaii Press, 1997), 197.

38. Fiji Times, 12 June 1980.

39. Fiji Times, 1 Nov. 1981

40. Fiji Times, 10 July 1980

41. The Review Magazine, Jan. 1993.

42. Fiji Times, 19 Feb. 1980.

43..Fiji Pine Commission Act 5 of 1976. 
44. From the NFP-WUF Manifesto.

45. Fiji Times, 24 May 1982.

46. The Coalition Bulletin, 3 Apr. 1982

47. Speech to the NFP convention, 22 June 1982, from a copy in my possession.

48. Fiji Sun, 18 July 1982.

49. Coalition Bulletin, 1 Feb. 1982.

50. Fiji Sun, 9 July 1982.

51. Fiji Sun, 6 July 1982.

52. Fiji Sun, 10 July 1982.

53. In response to cross examination by Bhupendra Patel in the White Commission.

54. Fiji Times, 21 June 1982.

55. Fiji Times, 28 June 1982.

56. Fiji Times, 17 July 1982.

57. Fiji Times, 17 July 1982.

58. Fiji Sun, 19 May and 2 June, 1982.

59. Fiji Sun, 2 June 1982.

60. Fiji Times, 19 July 1982.

61. Fiji Sun, 6 June 1982.

62. I have a copy of the report on which I draw for this discussion.

63. Fiji Times, 6 July 1982.

64. Fiji Sun, 24 June 1982.

65. Fiji Sun, 28 June 1982.

66. In past elections, religion and culture were issues, but raised obliquely, not overtly as in 1982 . That was the most important difference.

67. Ratu Edward Cakobau's famous remarks about having a look at the passenger list for his dinner is well known. Sitiveni Rabuka's many cannibal jokes are equally well known. Ratu Mara once told Pandit Guru Dayal Sharma, editor 
of Shanti Dut, how when he was at Oxford, the English students there used to tease him about cannibalism, saying 'Can we see your cannibal teeth?'

68. Fiji Times, 17 July 1982.

69. In evidence to the John White Commission.

70. Fiji Times, 1 July 1982.

71. Fiji Sun, 10 July 1982.

72. Fiji Times, 19 July 1982.

73. This is from his 'Examination-in-Chief' by Bhupendra Patel before the John White Commission.

74. Fiji Times, 19 July 1982.

75. Fiji Sun, 17 Sept. 1982.

76. Fiji Sun, 7 Nov. 1982.

77. Fiji Times, 23 July 1982.

78. Fiji Times 23 August 1982.

79. Fiji Times, 29 July 1982.

80. Fiji Sun, 5 Aug. 1982.

81. Fiji Times 6 Aug. 1982

82. Fiji Times, 5 Aug. 1982.

83. Jai Ram Reddy to Ratu Sir Kamisese Mara, 29 Nov. 1982.

84. Reddy said someone like Lord Denning, who was retiring, should be considered for the Commission of Inquiry, a person 'who will tell them a few truths they richly deserve to hear.' See Fiji Times, 7 Aug. 1982.

85. Fiji Sun, 11 Sept. 1982.

86. Ratu Sir Kamisese Mara to Jai Ram Reddy, 22 Nov. 1982.

87. Sir John White, Report of the Royal Commission of Investigation into the 1982 General Elections, Parliamentary Paper 74/1983.

88. Pacific Islands Monthly, Jan. 1984: 11 
89. White, Report of the Royal Commission, 204.

90. Islands Business, June 1986.

91. Mara, The Pacific Way, 184.

92. Fiji Sun, 22 July 1983.

93. Fiji Sun, 21 July 1982.

94. Fiji Sun, 19 Sept. 1982.

95. Fiji Times, 15 Sept. 1982.

96. Fiji Sun, 19 Sept. 1982.

97. Fiji Sun, 5 Nov. 1982

98. Fiji Times, 5 Nov. 1982.

99. Fiji Times, 17 Nov. 1982.

100. Fiji Sun, 18 Nov. 1982.

101. Fiji Sun, 6 Nov. 1982. 



\title{
CHAPTER 4: BEFORE THE STORM
}

\author{
The sky is darkening like a stain \\ Something is going to fall like rain \\ And it won't be flowers. W H Auden
}

$\mathrm{n}$ emergency session of parliament on 15 December 1983 was debat-
ing a Supplementary Appropriation of $\$ 5$ million Christmas 'Cost of Living Adjustment' payment to civil servants as part of their settlement under the Nicole and Hurst job evaluation report. Siddiq Koya was on his feet, and in his speech referred to Alliance backbencher and millionaire Jim Ah Koy's challenge to the Opposition parliamentarians to accept a pay cut in view of the dire state of the economy. Finance Minister Charles Walker had already resigned his portfolio rather than authorise pay increase for civil servants of up to $\$ 25$ million. But the cabinet had already agreed to fund COLA and was seeking an additional sum of money for that purpose. Speaker of the House Tomasi Vakatora reminded Koya that Ah Koy was not the subject of discussion. 'Yes,' Koya retorted, 'but he was allowed to say and I am simply saying.' He meant the pay cut. Before he could complete the sentence, Vakatora asked Koya 'to come to the Head.' 'He was allowed, Sir.' Vakatora: 'Would you please resume your seat?'

Jai Ram Reddy, Koya’s parliamentary leader, leapt to Koya's defense. 'But he was allowed to say it.' Vakatora, a man of explosive temper, was visibly angry as he glared down at Reddy. 'You know the Standing Order says that when you speak, you should stand up and address the Speaker.' Remaining seated, Reddy shot back, 'I do not propose to stand up to you.' 'All right,' Vakatora declared, 'I order you to get out now.' 'You have me removed,' retorted Reddy angrily. He, too, was a man of quick temper. 
Vakatora: 'Police, escort him out. Take him out, out of the precincts of the House.' 'You can run this circus on your own,' Reddy fired back as he flung his glasses down on the table, picked up his papers and walked out, followed by all twenty members of the Opposition. No one was quite prepared for this dramatically unexpected turn of events. It all happened within a matter of minutes, leaving everyone bewildered. How did all this come to pass, some parliamentarians asked themselves as they walked out.

The die was not cast in stone just yet. Reddy was persuaded by his colleagues to write to Ratu Mara to see if there was a way out of the impasse. The following day, he wrote to 'Dear Kamisese' about the previous day's events. ' 'I do not know how you view the events in the House but I will be pleased to discuss the matter further with you should you feel that such discussion will be useful.' Mara saw the Opposition's quandary and the experienced and wily politician was just not going to let Reddy off the hook. On 21 December, Mara wrote to 'Dear Jai Ram,' saying that there was little that he could do to extricate the Opposition from the tangled web it found itself in. The NFP parliamentary board's decision seemed to him to have 'assumed an air of finality.' In that event, he told Reddy, there was no 'possibility of discussion with me as an option.' Reddy, the experienced politician that he too was, expected the predictable response.

On 29 February 1984, Ratu Mara rubbed the salt in a very raw wound by saying in a radio interview that the letter Reddy had written to him after the walkout was the first communication he had received from him since 'he returned the paper on Government of National Unity under the door of my office,' some three years back. If true, that would have been a reprehensible dereliction of duty on the part of the Leader of the Opposition. But Mara's claim was 'totally baseless,' and Reddy had Mara's replies to his letters to prove it. He had written to the Prime Minister on at least five separate occasions over a number of matters concerning the appointment of the Royal Commission of Inquiry into the 1982 elections, the Government of National Unity and the boycott of parliament. ${ }^{2}$ These did not include routine consultations between the Prime Minister and the Leader of the 
Opposition required by the constitution for senior appointments in the civil service and the judiciary. Mara's reaction simply reinforced Reddy's decision to leave parliament. This kind of politics, based on patently false facts, was not his cup of tea. His decision to stay out of parliament was 'irrevocable.'

\section{DEPARTURE}

Reddy's decision plunged his party into disarray once again, undoing all the thankless hard work he had of uniting the warring factions under a single leader over several years. But it also set him on a course which would change the direction of the subsequent history of Fiji. National Federation Party supporters throughout the country were distraught. Reddy had worked so hard for party unity and now he was on his way out. Many simply could not conceive of a bright future for the NFP without him at the helm. Without him, they feared, correctly as it would turn out, the party would revert to its old, destructive ways of factionalism and intrigue and self-destruction. Every branch president pleaded with him to re-consider his decision. Krishna Datt, addressing a thousand teachers at the 54th annual convention of the Fiji Teachers Union in Nadi, asked Reddy to return 'in the name of democracy,' for the sake of 'stability which is important for a fledgling democracy like Fiji.'

Reddy would not budge. 'Decision of the kind I took is not taken lightly,' he responded, 'and they are not changed lightly,' but he was touched by the warm support he had received. 'Not in my wildest dreams had I thought that so many people placed so much faith in me." Irene Jai Narayan said she was 'deeply saddened,' by Reddy's resignation from the parliament, and another senior member, Anirudh Kuver, lamented that 'we have no one among our ranks of his calibre." He was indispensable to party unity and future, everyone said. But as Reddy would later say, echoing the words of Charles de Gaulle, the graveyards of the world were full of people who were once considered, or considered themselves, to be indispensable. He had had enough of the sniping in the ranks of his own party, and relentless racial provocation from the government benches. $\mathrm{He}$ 
probably thought that he would achieve little by remaining in the House. But what precisely he would do outside he did not know. He was resigning from parliament, not from public life, he told his friends who pleaded with him to stay on.

Reddy's decision was at first welcomed by his parliamentary colleagues almost in a pro forma way. If nothing else, loyalty to the leader dictated that they walk out with him. But many had not contemplated a prolonged absence from the parliament, perhaps boycotting a sitting or two at most. That was what Vakatora had thought, too, he later said. But when the import of Reddy's decision finally sunk in, opinion divided quickly in the NFP parliamentary ranks. There were some, like Irene Jai Narayan, who thought that the walkout would be short-lived. Why should the party let a single man [Vakatora] defeat it, she asked her colleagues? Reddy's 'removal hardly warrants a full scale boycott,' she said. ${ }^{6}$ Siddiq Koya pressed for continuing boycott because Vakatora, he said, had insulted not only Reddy but the entire party. He would soon change his mind. Iqbal Khan, a Koya man, said sarcastically: 'We were elected to serve the people, not run away from parliament.' 'I think the party has made a silly decision [to continue the boycott]. The party leader takes too much for granted, and his popularity is declining.'

Quite a few of his colleagues shared that view privately, though not the declining popularity part. Harish Sharma spoke words which stuck with Reddy for a long time, words which were true enough in the theoretical sense but hurtful in the context of the moment. 'Party leaders come and party leaders go, but the party must go on.' The rift with the Speaker was too minor an issue to take such a big step. And if they stuck with Reddy and Vakatora remained in the Speaker's chair, they would stay out and fight a by-election to return to parliament. But what if Vakatora was still in the Speaker's chair? If by-elections were held, some feared NFP would lose closely contested seats, such as Iqbal Khan's which the NFP had won by a mere 407 votes, or Filimone Nalatu's which was won from the Alliance's Sakiasi Waqanivavalagi by 244 votes. The remaining Doves in the party 
would not be sorry to Reddy go. In fact, they quietly welcomed the opportunity to see him out of parliament for good.

Questions about loss and gain, about an appropriate and measured response, swirled in the Opposition room causing concern and friction. Nonetheless, when the time came, the NFP parliamentary caucus decided to uphold the decision of December 15 to continue the boycott. Only one NFP parliamentarian disobeyed the boycott decision and returned to parliament: Vijay Parmanandam. Meanwhile, at a meeting of the NFP parliamentary group at Tanoa Hotel in Nadi soon afterwards, a vote of confidence was passed in Reddy. 'Nothing will be greater than to see that bonds between the leader and the people kept united,' said Sir Vijay R Singh. 'In the process, we will be losers if we leave Mr Reddy's company, his contribution and the solidarity he gave to the party. We want Mr Reddy to reconsider his decision and continue as party leader in the interests of the party and the country. ${ }^{8}$ Reddy resigned on 15 May (The month of May has a curious resonance in Fijian political history!)

Tomasi Vakatora was roundly condemned by the NFP as the culprit who had precipitated the whole crisis by making 'perverse' decisions for the partisan political gain of the Alliance Party. Reddy believed Vakatora was being deliberately provocative and insulting to his side of the House. The Speaker's position in the Westminster system of democracy is a unique one. The Speaker enters parliament on a party ticket, and is appointed, with mock reluctance, to the Speaker's Chair with bi-partisan support. Once ensconced, he is expected to be fair and impartial in his rulings to all the members of the House and to conduct its business with decorum and dignity. Vakatora, it will be recalled, was elected Speaker unilaterally by the Alliance after the bitter 1982 general election and his deputy, Vijay Parmanandam, a renegade NFP member, offered his services without the approval of his party. The initial circumstances surrounding the appointment did not augur well for a smooth running of parliament. Opposition dissatisfaction with Vakatora grew with time. 
In June 1983, the Opposition moved a vote of no confidence in him over his decision not allow a parliamentary debate about the Transport Control Board because the matter was before the courts and, therefore, allegedly sub judice. It involved the circumstances surrounding the granting of an around-the-Viti Levu bus route to KR Latchan, an old political foe of Sir Vijay Singh's and a benefactor of the Alliance party. Vakatora held his ground and won the day although, as Sir Vijay correctly pointed out, 'Just because the Transport Control Board was a party to an action, it cannot place the Transport Control Board in such a manner that no reference may be made and no discussion about its activities takes place in the House." 'No chair can really rule on sub judice until he hears what the Member has to say, he argued, himself a former Speaker. Courts should not be used to stifle debate on important issues of public policy. It was a fine point of some subtlety which many a later Attorney General did not fully grasp.

Tomasi Rayalu Vakatora was a proud Fijian, a Fijian nationalist in the old, conservative sense, believing that Fijians, as the first settlers of the land, had certain rights and privileges which should automatically give them prior consideration in the nation's affairs. It was not for no reason that he twice defeated Sakeasi Butadroka in the heartland of strong Fijian nationalism in south-eastern Viti Levu. He was a strong and loyal supporter of Ratu Mara, their association going back to the 1950s, when he began his career as a primary school teacher in Lau, and met his wife, Wainiqolo, there. He took any criticism of his party leader and high chief personally. He was reflecting a widespread Fijian displeasure with Jai Ram Reddy's 'toilet remarks' and the allegations made on the Four Corners program about chiefs clubbing and eating their way to power.

Vakatora was pro-Fijian, to be sure, but he had also overturned Deputy Speaker Parmanandam's ruling that matters relating to Fijian chiefs should not be raised in parliament because chiefs were like royalty and, therefore, above public comment. Fijian chiefs were in the House as elected parliamentarians, not as chiefs, Vakatora ruled, and therefore legitimate subjects for debate and discussion. And he was one of only three Fijians, it will be 
recalled, who had voted against the Bau motion discussed in the last chapter. Vakatora was a stubborn man, too. Once he had made up his mind, nothing could change it. When accused of being politically active while still the Speaker, he said, 'I will not bow down to any political pressure in the exercise of my duty; [I] will continue to attend political meetings, but not speak. ${ }^{10}$ (One of his predecessors, RD Patel, not only attended political meetings but actually spoke at them: on the Sugar Price Stabilization Fund, for example).

There is another plausible explanation for Vakatora's behaviour other than his stubborn Fijian nationalism and his fierce Alliance loyalties. This was his almost religious regard for the observance of proper parliamentary protocol. Vakatora, as I found out later, was a stickler for standards and correct observance of procedure. In that regard, he was like many Fijians of his generation who had come of age in the late colonial period. He had risen from a primary school teacher to become Fijis first local Commissioner for Labour and later a Permanent Secretary. After retiring from the civil service, he was appointed an Alliance senator. For a man from humble beginnings in the Rewa delta, from the mangrove swamps, as his autobiography says, he was justifiably proud of his personal achievement. ${ }^{11} \mathrm{He}$ had advanced in life by observing the rules, and he expected others to do the same. He was, he told me, hugely irritated by the constant interjections from two former University of the South Pacific academics, Ahmed Ali and Satendra Nandan, who were treating the parliament 'like a classroom,' compromising its dignity. People walking in and out of parliamentary sessions without recognizing the Speaker and bowing to him, annoyed him greatly. He felt that the Opposition members were treating him with disrespect and discourtesy, and some of them probably were. So when Reddy refused to stand up and address the Speaker, his anger boiled over and he ordered the Leader of the Opposition out of the House. It was not a premeditated move on his part, though many Opposition parliamentarians at the time thought otherwise. Vakatora later called the incidence 'unfortunate' and expected the boycott to last for a day or two at most. ${ }^{12}$ That was not to be. 
Reddy's departure from parliament was unanimously greeted with regret and sadness. Letters of support and sympathy and understanding for Reddy poured in, from as unlikely persons as the former University of the South Pacific Vice Chancellor James Maraj, who hoped that Reddy would someday re-enter the political arena. ${ }^{13}$ New Zealand High Commissioner Lindsay Watt wrote on 30 May 1984: 'The political scene here is such that some peculiarly Fiji yardsticks probably need to be used in measuring political achievements.' 'Regardless of that however,' he continued, 'you are certainly assured of a worthy place in Fiji's political history.' His letter ended with the comforting suggestion that he would be 'bureaucratically benevolent' in expediting the renewal of his multiple visas to New Zealand when it expired in September.

\section{INSTANTLY, INSTANTLY}

As the NFP parliamentary board prepared to meet to elect a new leader now that Reddy was gone, the competition for leadership intensified. There were predictably two leading contenders, Mrs Irene Jai Narayan and Siddiq Koya, two old, unforgiving foes joined in the leadership battle once again. Narayan had held her Suva Indian communal seat continuously since 1966, and was a star performer on the party's stage, a compelling and charismatic speaker and a favourite with the grassroots supporters. She felt she had earned her dues to make a bid for the top position. Koya was one of the principal founders of the party, its battle-hardened field commander, who had been in parliament since 1963. Some branch presidents argued that the NFP leader should come from western Viti Levu where the party was founded and which was its power base. ${ }^{14}$ Balwant Singh Rakkha, president of the Ba branch and then an ardent Koya loyalist, arranged pocket meetings to lobby for Koya, much to the annoyance of the NFP Youth president, lawyer Anil Singh, who wanted the selection of the parliamentary leader to be left to the parliamentary board alone. ${ }^{15}$

That certainly would have been the correct procedure. Branch presidents should have had no hand in publicly influencing the selection of 
Reddy, RS Goundar and Siddiq Koya in happier times ca early 1980s. Photo courtesy of Fiji Times.

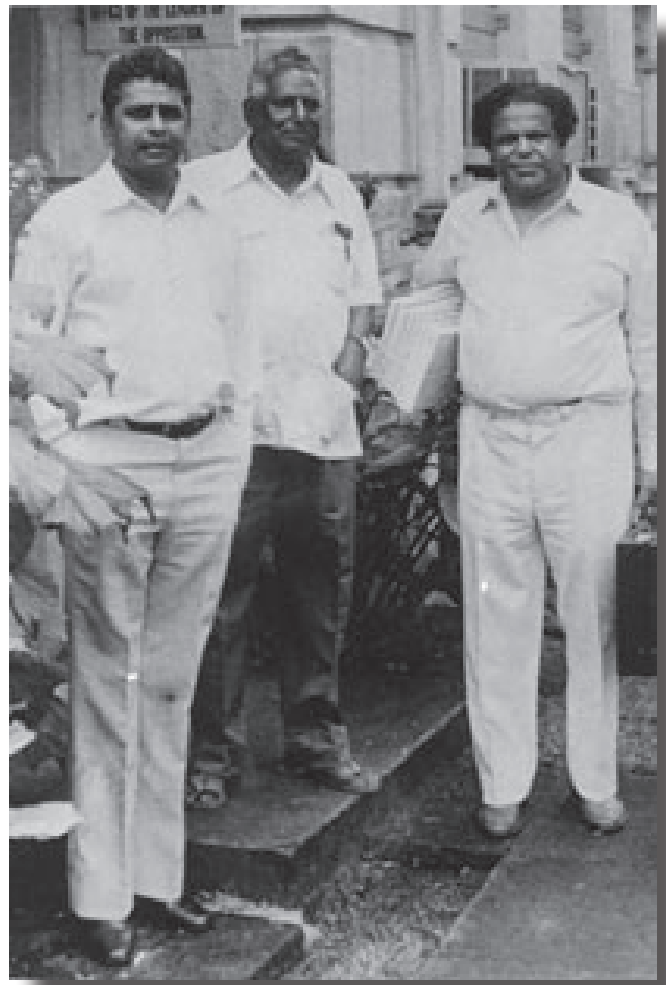

the Leader of the Opposition. That is the responsibility of the parliamentary caucus. But Koya knew that support for him among his own parliamentary colleagues was shaky. He prevailed and branch presidents, as well as the defeated leader of the Western United Front, Ratu Osea Gavidi, were allowed to address parliamentary caucus before the vote was taken.

For his efforts, Koya would reward Rakkha by nominating him as the official party candidate in a future by-election. The first ballot was a 9-9 tie. It was all eerily a repeat of 1977 . Koya was elected, on the second ballot, by 10-8 votes with the support, it was speculated at the time, of Isikeli Nadalo, Ram Sami Goundar, Mohammed Sadiq, Subramani Baswaiya, Ratu Soso Katonivere, Iqbal Khan, Filimone Nalatu, Shardha Nand, Anirudh Kuver and HM Lodhia. 
Mrs Narayan had the support of the rest, including that of Sir Vijay R Singh who would normally have been expected to support his cane belt colleague and Ba resident Siddiq Koya. Many things countered against Mrs Narayan, wrote Robert Keith-Reid. 'Male chauvinism, the fact that she was born in India and not Fiji, and some sentiment that it had been wrong of her to let it be publicly known that she disapproved of Reddy's boycott of parliament, were held to have been what went against her.' ${ }^{\text {'16 }}$ Vijendra Kumar saw Reddy's hand in Narayan's defeat. Her chances dimmed 'because it is evident that Mr Reddy does not to see her as leader,' he wrote. Reddy had apparently hinted that Koya was likely to emerge victor, which, Kumar surmised, was a 'clear indication as to where his choice lies. ${ }^{17}$ Reddy denies endorsing either candidate, though there is little doubt that he had a preference for Koya over Narayan. ${ }^{18}$ It made sense: he was a founder of the party, he was from the cane belt, and his hold on the loyalty and support of the grassroots supporters was solid. Koya's victory was orchestrated by Shardha Nand, an astute strategist and an operator par excellence and a former senior civil servant (in the Cooperatives Department), who had once said he "would lay down his life for SM Koya. ${ }^{19}$ A few years later, the two would part company permanently amidst great acrimony. Koya said that he had won the leadership because 'they'd rather the devil you know then the devil you don't.' But there were doubts about future stability in the party. Keith-Reid: 'The circumstances of Koya's restoration hint that he will have to exercise extreme patience and personal restraint if he is to keep the NFP together - two requirements which even the closest of his admirers agree he will find difficult to meet in view of his difficult and demanding character. $^{20}$

The parliamentary caucus unanimously voted Irene Jai Narayan the Deputy Leader of the Opposition. Still, there was no peace in the top echelon. Old hatreds and suspicions, plotting and infighting, once again returned with a vengeance. Koya could not forgive Mrs Narayan for her audacity in challenging him for the leadership and nearly succeeding in defeating him and for making snide remarks about his part-time leadership 
behind his back, according to a Koya supporter. A few months after being elected, Koya rang Speaker Vakatora and asked him to stop renovating an office in the Leader of the Opposition's chambers which the Deputy Leader proposed to use. She used to use Reddy's office when he was away from Suva. 'I don't want any changes,' he told Vakatora. Crossing Koya could be full of peril. But it also unnecessarily revived old animosities which lay just beneath the surface.

Within a year of assuming parliamentary leadership, Koya's once-dominant political career would effectively be over. His undoing unfortunately was largely the result of his own modus operandi. Koya's downfall accelerated when he alienated the Youth Wing of the party comprising some fine young talent and faithful workers. The Youth Wing wanted greater role and acknowledgement of the work they were doing, and had done, for the party. Youth were youth, Koya felt strongly, to be seen and not necessarily heard. As the party leader, and one of the founding leaders at that, he had every right to expect complete loyalty and support from them, subservience even, but not a seat at the table, which he thought should rightly be reserved for the adult members of the family. Koya spoke of father-son relationship and expected the son to respect the father. Anil Singh, the Youth president, retorted that while Koya expected respect from the son, he did not hesitate to kick him out when it suited him. 'Respect is a two-way thing. If he wants respect from us, he must also show us respect.'21 Singh resigned from the party in December 1984 when Koya refused to allow a Youth delegation to participate in the annual NFP convention. ${ }^{22}$ Koya dismissed the Youth Wing disparagingly: 'God created both elephants and dogs. The elephant works and the dog bites. The elephant will go on working even if the dog keeps biting. ${ }^{23}$

The dismissal proved to be the straw that broke the camel's back. Singh, a young Lami lawyer and former mayor of the town, represented not only the youth wing of the party, but he also had the support of the party's traditional establishment, including the business community, which had long been disenchanted with Koya's style of politics and his latent antipa- 
thy towards the Gujarati business community, a legacy, Karam Ramrakha recalled, of his old Kisan Sangh days of the 1950s. There was thus more to Singh's support base than met the eye. Singh asked Koya to resign and 'make way for a more enlightened leader who does not carry the prejudices and excess baggage of 1977.' 'The entrenchment of an incompetent clique of sycophants has become the major preoccupation of the party, he continued. 'In the process of installing this clique, intelligent and sincere party workers are sidelined and democratic decisions of the majority are continuously revoked to suit the whims of the few. ${ }^{24}$ What few had expected or predicted was the great passion and tenacity with which the Youth Wing would pursue its cause to get Koya removed as party leader.

Their opportunity came when the by-election for Reddy's seat was announced. Fourteen people applied but since Reddy and Koya could not agree on a single name, they referred the matter to the selection committee appointed by the party's Working Committee which would have both Koya and Reddy on it. The Committee, comprising LP Maharaj, Hari Sahay, Dr Subramani Govendar, Jai Raj Singh, Koresi Matatolu and Koya, met while Reddy was away in New Zealand. It chose Balwant Rakkha, a Ba-based medical practitioner, the man who had campaigned for Koya for the Leader of the Opposition against Irene Narayan. Wilfrid Sugrim, a former local Lautoka mayor, offered himself as a parallel NFP candidate if it came to that, evoking memories of the bitter September 1977 elections. Others who indicated availability included Lautoka lawyer Ram Krishna, accountant Mumtaz Ali and Michael Joseph Paligaru. The alternatives were credible. There was much praise and respect for Ali, a chartered accountant 'admired by many Fiji citizens of all races for his urbanity and diplomacy' who would have made 'an admirable compromise candidate for the Lautoka seat had the party factions been able to agree. ${ }^{25}$ Reddy himself liked Ali. But Koya had a visceral dislike of the man and that sealed Ali's fate. Ali's independentmindedness and liberal ways were too much for the NFP leader.

Rakkha's selection caused a furor, a Ba man chosen to contest a Lautoka communal seat. Was this a slap on Lautoka's face, the Youth 
supporters asked? But didn't Sir Vijay Singh contest from a constituency in which he did not live, Rakkha supporters asked in return? That was true, but he was contesting a national seat that traversed a large area, not a communal seat, Singh's supporters responded. He was, moreover, a 'senior politician' and a frontbench material with something to offer. ${ }^{26}$ Wasn't Ba less than an hour's drive from Lautoka, asked Rakkha's people? And so it went. But more important, Rakkha was a Koya man and Koya needed all the support he could get in the parliamentary caucus. Heated debate ensued during the selection process, and numbers were marshalled by both sides. Matatolu, the chair of the Selection Committee, pleaded — 'begged' to use his own word - for unity. 'You cannot have external power without internal discipline and integrity, he remarked. ${ }^{27}$ His concern indicates just how deep the rifts in the party were.

In January 1985, the NFP Youth chose Devendra Singh, a new comer to politics, ahead of another former Lautoka mayor Vinubhai Patel. Because of the tussle between Koya and the NFP Youth Wing, what should have been a straightforward by-election victory for the party in a blue ribbon NFP seat became, in effect, a referendum on Koya's leadership. As Vijendra Kumar, the Fiji Times editor, wrote, 'The entire party split and formed blocks behind the two candidates, making few bones about the appearance that they had made their decisions on the basis of whether they were pro, or anti, Koya. ${ }^{28}$ Koya dismissed the division in the party as a manifestation of its internal democracy. There was nothing to worry about. Perhaps so, though a Fiji Times editorial put the matter this way: 'It also can be said of the NFP that it is lacking in discipline and has been buffeted by intrigues and back-stabbing. In a truly democratic and disciplined party, all differences and disputes are resolved within the party. Those who defy party decisions are expelled. At election time, the party presents a united front - not rival candidates from within its own ranks. It seems the NFP leaders have not learnt a lesson from their 1977 debacle. ${ }^{29}$ They evidently had not, or did not care. 
As the campaign proceeded (Ba vs. Lautoka, some placards said, referring to the old football rivalry between the two districts) and the race tightened, Koya unnecessarily raised the stakes, and so stiffened the resolve of his already determined opponents, by promising to resign if his candidate lost the election. 'If the Indian community of Lautoka defeats Dr Rakkha, I am out politics. I will resign from public life,' 'instantly, instantly. ${ }^{30}$ In an election marked by a low voter turnout (4221 from the registered 12, 260) Devendra Singh beat Rakkha by 2209 votes to 2196. It was the narrowest of victories for a person who had burst upon the political scene from nowhere unannounced, but victory it was. Koya refused to resign, much as Mara had refused to do after he had won fewer than thirty seats in 1982. The threat of resignation was a gamble, theatrical gesture, not meant to be taken seriously. But times had changed. What might have been an acceptable campaign tactic a decade or so before sounded incongruous now. The electorate was different, more demanding; and the media was watching closely. Mara could 'do a Mara' and escape censure, but Koya did not have Mara's mana in his own community. The contrast with Reddy in this respect could not have been greater, a man of his word who had honoured his promise even at great cost to his party. During the campaign, Reddy stayed out of the fray completely even though he was then the party president. The Youth Wing placards carried pictures of himself and AD Patel, which insinuated Reddy's backing even if it was not formally given. Reddy called the gesture irresponsible, but refused to get dragged into the saga.

Reddy's absence from the campaign trail, and as president of the party no less, came in for criticism. Former NFP president, RS Goundar, said he was 'aggrieved and surprised' that Reddy had not given 'open and unqualified' support to the party's official candidate. ${ }^{31}$ Reddy rejected this as 'absolute rubbish.' He said he had been in New Zealand when a meeting in Sigatoka made the selection. The Youth Wing had approached him several times, but he had 'decided to keep himself completely out of the controversy. ${ }^{32}$ In any event, the fight was 'an internal party problem and he should not take sides because each camp was within the party. ${ }^{33}$ That said, he also 
did not have any good reason to make Koya's life any easier either because the latter had refused to discipline the unyielding Doves when they had continued to make life difficult for him after 1977. What goes around comes around, as the saying goes. There was another reason. Koya had picked Dr Rakkha long before the Working Committee met, making 'the whole selection procedure was a farce. ${ }^{34}$ Rakkha had himself told Reddy as much.

To have made a unilateral decision clearly in breach of party procedures for selecting candidates and then expecting the president to endorse it unreservedly seems strange. Reddy is, if anything, a stickler for following the correct procedure. This behind-the-scenes way of doing things Reddy abhorred and sought to discourage. For Koya, though, there was nothing strange or peculiar about it. He was the leader; he knew who the best candidate was and that, as far as he was concerned, was that. Koya needed a loyalist in his camp, and he knew Rakkha would be solid in his corner. But there was no lingering animosity between Reddy and Rakkha, and if there were hard feelings at the time, they did not last long. The two became very close friends and colleagues in the 1990s when Rakkha became the party president. 'I would not have lasted long with Koya,' Rakkha once told me. 'His time had passed,' another staunch Koya loyalist, Ujagar Singh, said. The irony of the result was not lost on the people. The by-election which had caused 'all the trouble' came about because Reddy 'did honour a promise to resign. But his political spirit stayed around to haunt his successor.'35

Koya refused to accept defeat and proceeded with unseemly haste to make life as difficult for Devendra Singh as possible. When parliament reconvened, he called the police to bar Singh from entering the Opposition Office, which as an experienced parliamentarian he knew very well he could not do. Clerk to parliament, Lavenia Ah Koy, reminded Koya that Singh was entitled to use the Opposition Office and its facilities even if he was not a member of the NFP. He was still an Opposition member of Parliament. ${ }^{36}$ When Speaker Vakatora endorsed Ah Koy's advice that all non-government politicians and parties were entitled to use the Opposition Office, Koya told Ah Koy that a concrete wall be put up to separate his 
parliamentary office from that to be used by Singh. ${ }^{37}$ Precisely what Koya, a senior leader of the Indo-Fijian community, hoped to achieve by this kind of heavy-handed behaviour is difficult to fathom. Perhaps Koya, being Koya, was out to demonstrate to the world that he was the leader whose views on party matters must invariably prevail. Common sense should have dictated building bridges with his opponents, not rubbing their noses in the mud. In retrospect, Koya's request seems so unfortunate. The whole unsavoury incident reflected poorly on his lack of generosity and magnanimity, and deepened feelings against him in the parliamentary caucus.

\section{BAD OLD DAYS ARE HERE AGAIN}

Throughout 1985, the NFP was quietly descending into chaos, reminding everyone of the futile battles of the past. The continuing spectacle of internal squabbling reached such a level that seven Fijian and General Elector members of the parliamentary caucus threatened to break away if the party did not resolve its internal problems. They included Isikeli Nadalo, Filimone Nalatu, Ratu Soso Katonivere, Arthur Jennings, Jim Smith and Temo Sukunaivalu. Koresi Matatolu was elected the leader of their group. ${ }^{38}$ It was a sad and embarrassing indictment of the state of affairs in the party, coming ironically from its non-Indian members. 'As long as Mr Koya remains leader, we will have conflict within the party,' one of them told the media. 'At the moment the party is divided because of the infighting and if a snap election is called tomorrow, we will be destroyed. The morale of the members and the party supporters is at all time low.' Koya's leadership was the main issue. 'In the ten months since he took over from Mr Reddy,' wrote Robert Keith-Reid, 'Mr Koya has arrived at a point at which all the work of construction achieved by the NFP since the shambles of 1977 has been undone. Half way through the life of the present parliament, the Opposition is a shattered force. ${ }^{39}$ Shardha Nand, Iqbal Khan and Noor Dean signed petitions asking Koya to remain leader while another rival group threatened to collect twenty thousand signatures calling for his removal. Temo Sukunaivalu threatened to resign from the 
party altogether 'because I am disgruntled with the leadership struggle and fragmentation within the party. ${ }^{40}$ Temo, from Ratu Mara's blueribbon Alliance province of Lau, was one of the most loyal members of the party. After all these years of ups and downs, he still remains a loyal NFP member. His threat to resign was a symptom of a deeper malaise afflicting the party, its rapidly declining fortune.

Things went from bad to worse as bad blood spilled out into the public. In July 1985, Koya fired Irene Narayan as his deputy, without notifying her of his decision in advance, as courtesy demanded when dealing with one of the most senior members of the party. 'Not once did he give me the slightest indication of what he was up to,' she said somewhat incredulously, despite an hour long meeting the day before. ${ }^{42}$ Satendra Nandan, who had resigned his Education portfolio a month before, said that Narayan 'was unanimously elected the deputy parliamentary leader by the parliamentary board and Mr Koya has no power to remove her. ${ }^{43}$ The difference between Reddy and Koya, Nandan said, was that one kept his word, the other did not. 'There is no doubt that the resignation of Mr Jai Ram Reddy from that position [as party leader] has created high moral, political and personal standards for others to follow.' 'We can now all see that the emperor has no clothes,' he said. ${ }^{44}$ HM Lodhia resigned his shadow Finance portfolio, but refused to vacate his seat. 'If anybody should have been displaced, it should have been Mr Koya,' said the new NFP Youth leader Chandu Lodhia. Vimal Madhavan wrote that Koya's 'dominating, at times arrogant, attitude towards his colleagues has not helped to continue the process that under Mr Reddy was welding the party back into one entity. ${ }^{95}$ "Where else would a party leader — and one elected by his parliamentary colleagues with a majority of one - dismiss his deputy who was elected unanimously by those colleagues? Isn't that just asking for trouble from fellow members of parliament and party's rank and file?' The Indo-Fijian community was better educated now, and was looking for a real alternative. Old style of doing things would not do. 'The NFP supporters cannot be rounded up by traditional leaders and delivered to the voting booth in droves. The poten- 
tial voters want proof that the party can deliver the goods before they will cast their votes for it.'

This was sound assessment, but Koya was not one to listen to a 'mere' journalist's judgment, even though that journalist happened to be the son of one of Koya's long time supporters and colleagues, James Madhavan. Koya argued that as the parliamentary leader, it was his prerogative to appoint whoever he wanted as his deputy. That may have been true in the narrow sense, but it also displayed poor political judgment, perhaps a reminder of how things were done in the past. Koya chose Koresi Matatolu, the leader of the rebel Fijian and General Elector group, as his deputy. This was partly to heal the widening rift within the party and partly, he said, to increase Fijian support for it to counter the inroads made among Fijians by the newly formed Fiji Labour Party. It did not need to be said that Matatolu, without a solid base of his own in the party, would be no threat to Siddiq Koya. A better course of action for Koya would have been to appoint two deputies, just as Mara had two Deputy Prime Ministers at the time. By the time this suggestion was put to him, he had already sacked Narayan. ${ }^{46}$ The following year, Koya won further skirmishes over party leadership by denying Senator Mumtaz Ali the position of party secretary at the NFP's Nausori convention, leading eventually to Ali's resignation from the NFP altogether. Whatever his motives, Koya's old ways, when he invariably had his way, when everyone listened respectfully and unquestioningly to the leader, raised serious questions about his suitability as the head of a party seeking the reins of power. Koya may have won a few battles, but he was, unfortunately for him, also rapidly on his way to losing the war. Sadly, the once great leader was imploding in full public view.

In December 1985, Koya's closest colleagues, Shardha Nand and Subramani Baswaiya, finally agreed that he had to go. 'There is no disagreement at all between us that Mr Koya should go,' said a spokesmen for the Koya group (Nand). 'But there is a slight misunderstanding as to who should replace him.' They wanted their leader to go gracefully and not be 'removed by force' as that would upset Koya's grassroots supporters. But if 
he refused, they would write to the Governor General to appoint another Leader of the Opposition. 'We do not want to use this method but we will have to if $\mathrm{Mr}$ Koya does not see sense. ${ }^{47} \mathrm{~A}$ confidential report prepared by Harish Sharma, Shardha Nand and NFP treasurer Navin Patel was critical of Koya's decisions and appointments. ${ }^{48}$ Why had he appointed Kallu Karan Singh to the Public Service Commission when the man had no apparent qualifications for it? Why had he appointed Ratu Osea Gavidi to the Senate when the Fijian leader had no real support? His sacking of Irene Jai Narayan was mentioned. And so it went. There was some talk of making Koya a shadow minister for sugar and putting him on the front bench next to the Leader of the Opposition, as a public recognition of his seniority in the party. 'He will be like a guru in the Opposition giving advice on every important issue.' But all this was no more than a symbolic gesture of contrived respect which could not hide the painful reality of the fall. It was a sad ending to a long career in the party. There was no other alternative. Koya relinquished the Opposition Leader's post to Harish Sharma in early May 1986, saying that it was time for change. It indeed was.

Further disaster for the NFP came in the by-elections caused by the resignation in July 1985 of Sir Vijay R Singh to accept the position of chief executive of the newly formed Sugar Cane Growers Council, to Koya's quiet satisfaction, as he had never worked well with the former Indian Alliance president nor forgiven him the insults and the barbs of the 1960s. Those memories were deep in the older generation. NFP chose James Shankar Singh, former president of the Indian Alliance, as its candidate for the North-Central Indian National Seat, the Alliance fielded wealthy Ba farmer Uday Singh (James' cousin) and the Fiji Labour Party chose Mahendra Chaudhry, the powerful General Secretary of the Fiji Public Servants Association and future long-term leader of the party. There was some debate whether the newly formed Labour Party should contest elections so soon, especially in a rural constituency where its strength was untested, but the decision prevailed to test the waters regardless. Chaudhry may have been a political novice, but he came from the sugar cane's heartland in western 
Viti Levu and was the General Secretary of the National Farmers Union. Chaudhry also had the publicly-declared support of Irene Jai Narayan. 'The Opposition is now so totally ineffective, it would be good to have a man of his calibre there,' she said. ${ }^{49}$

Labour, James Raman recalls, was confident of victory and prepared for a victory celebration long into the night, but the result surprised everyone. In the intensely fought campaign, Uday Singh won, capturing 8031 votes to James Shankar Singh's 5087 votes and Chaudhry's 7772. Uday Singh's victory was not altogether surprising; he was wealthy, well-connected and active in the local area, serving on various local bodies and committees. Two things though were surprising about the result. One was the low number of votes that the experienced former Cabinet Minister James Shankar Singh got. Most commentators in Fiji believed that the result would have been much worse for the NFP if they had fielded anyone other than James Shankar Singh..$^{50}$ And the other was the surprisingly strong support for the political novice Mahendra Chaudhry. ${ }^{51}$ What he got was Labour's minimum vote, it was clear to everyone. The writing for NFP was on the wall for all to see. Its days as the sole voice of the Indo-Fijian farming community were on the way out. 'The popular view now,' wrote Vijendra Kumar, 'is that the NFP and Sid Koya are spent forces in Fiji politics and that if $\mathrm{Mr}$ Koya continues in the leadership, then the NFP will continue to decline into political oblivion. ${ }^{, 52}$

Reddy watched the depressing fratricidal warfare in his party with growing concern. Old ways, the old divisions, old style of doing things, had returned to the party he had once united and led after the debacle of the mid-1970s. Reddy was elected president of the NFP in 1984, replacing Ram Sami Goundar, because its members wanted him to stay engaged and provide advice as an elder statesman. But he resigned from the position in 1985 and was replaced by Harish Sharma, the Nadi politician and lawyer. Reddy was out of active party politics, but he was constantly in demand at public functions. He had been instrumental in inspiring the revival of the Sangam from its moribund state caused by factionalism and frictions through a 
long-remembered speech about unity and purpose. He had become the organization's legal advisor in 1976. Sangam is a non-political organization, but with Reddy in the ranks, many of its members quietly joined his camp. He played a major though un-heralded role in the sugar industry's Master Award, providing legal advice for a nominal fee. And there were numerous community obligations to attend to.

Despite the well earned break, though, politics was never far from Reddy, nor would he be left alone. He was still the unquestioned leader of the Indo-Fijian community, the man to whom they turned in their hour of need even though he was not in parliament. No one could conceive of the NFP without him, party president or not. They valued his counsel and advice. He kept his ears close to the ground, though from a discreet distance and largely out of the public eye. Reddy realized that if the status quo prevailed, with the same players on the scene playing their old games, the divisions would continue and the party would eventually self-destruct completely. The lessons of the by-elections were not lost on Reddy or on any other close observer of the Fiji political scene. The NFP was imploding, losing its grip on its traditional constituency. The advent of the new, rhetorically left leaning and nominally multiracial Fiji Labour Party had changed the political equation which could not be ignored, or ignored at the NFP's peril. Equally, Labour realized that it too could not go it alone if it was successfully to challenge the Alliance.

\section{FIJI LABOUR PARTY}

The Fiji Labour Party was formed for many reasons. Many supporters of the NFP had long been disenchanted with the party's incessant, crippling internal warfare over the battle for leadership for well over a decade. With the way things were, NFP was no longer seen as a viable alternative to the Alliance as the government-in-waiting. ${ }^{53}$ The ineffectiveness of a divided and drifting opposition was brought into sharper relief by the manner in which the Alliance government was able to promulgate a number of far- 
reaching policies without much debate in parliament. The signs of a party entrenched in government and unheeding of public opinion were clearly visible. The Economist commented on a persistent source of complaint about 'rot setting in, an excessive use of influence through ministers and an increasingly fuzzy line between politics and business. This is not serious enough to cause alarm,' it concluded, 'but it is said to have worsened rapidly in recent years. ${ }^{54}$

On the domestic front, education and the economy occupied the centre stage, and the government's handling of both attracted much adverse publicity, once again helping the cause of the Labour Party. The Ministry of Education's policies, under Ahmed Ali, touched sensitive chords in the teaching fraternity, initiating a long and bitter dispute. The controversy revolved around a number of specific issues. One was the new Volunteer Service Scheme under which the government proposed to give new graduate teachers employment for up to two years, on reduced salary, until permanent teaching positions became available. Under the Scheme, the government agreed to pay a salary of $\$ 3000$ with the committee-run schools in rural areas meeting other costs such as housing for the teachers. This was a move away from the former practice of 'automatic absorption,' with the government justifying it in the name of fiscal constraint. Attorney General Qoriniasi Bale argued that the 'the obligation on the government is only to see the training of the student and on the student to serve. If he is not called on to serve, then the obligation is at an end. ${ }^{55}$ The Fiji Teachers Confederation called the Scheme unprofessional, ill-conceived, exploitative, and, above all, imposed by the Ministry of Education without consultation with it. The student graduates dramatized their cause by staging widely publicized and emotionally charged hunger strikes. The Confederation embarked on a massive two week protest strike in which reportedly 90 per cent of the teachers participated. In late November 1985, an independent arbitrator ruled the Volunteer Scheme unlawful, but by then much damage had already been done to the government and the suspicion entrenched of a party unheeding of public criticism. 
Equally vehement opposition greeted the Education Ministry's attempt to 'desegregate' the country's schools which happen by historical and geographical factors rather more than by careful design to be communal. ${ }^{56}$ In many cases, children in Fiji complete their entire primary and secondary education without contact with children of other ethnic groups. Fortunately, in the last decade or so, this feature has diminished as parents have tended to send their children to the best schools they can afford rather than to schools which prefer to have students of a particular ethnicity. In 1985, the Ministry of Education instructed three urban government schools to re-structure their admissions policy to ensure that the new intake was made up of 40 percent each by Fijian and Indo-Fijian children, with remaining 20 per cent filled by children from other ethnic groups. This initiative, the government hoped, would enhance its avowed goal of promoting some semblance of ethnic balance in the schools' student population, especially in elite ones with the best facilities and pass rates. The Education Ministry also required that 80 per cent of the places in the new intake for the selected schools be reserved for children from families with a joint income of less than $\$ 3500$. This, it was hoped, would demonstrate the government's commitment to the poorer sections of the community. And, finally, as an integral part of its reforming effort to promote ethnic integration, the Ministry planned to transfer teachers, sending Indo-Fijian teachers to Fijian schools and vice versa.

These policies attracted opposition from diverse quarters. The Fiji Teachers Confederation, whose members would be affected by the transfers, complained of lack of consultation. Their ire focused on the Minister of Education whose frankly adversarial 'I-know-best' approach hardened attitudes. Some teachers complained of victimization in transfer decisions because of their active role in the teachers' unions. The Fijian Teachers Association told the Minister that his policy 'was not in the interest of developing Fijian education, the preservation of Fijian culture and language and developing Fijian cultural values. ${ }^{57}$ Tupeni Baba, a prominent Fijian educator himself, told the Fijian Teachers Association 
Convention in January 1985 that while there was some need for special assistance for Fijians, probably for some time yet, it should 'be removed as soon as the need is not there and such a move should be initiated by the Fijians themselves. They should now be working out ways of removing such a special treatment because in the long run it will do damage to their self esteem and pride as a race.' He added that 'at no time in our history have we experienced as much politicization of education as we are experiencing now, and if this is allowed to continue it will undermine the development of professionalism of teachers, educators, educational administrators, and will open the schools to political abuse. ${ }^{58}$

The depth of the teachers' anger at the government showed in the extent to which the two racially divided unions, the Fiji Teachers Union and the Fijian Teachers Association, were able to minimize their internal differences and join forces to oppose the government. In at least one area of the teaching profession, the Ministry of Education was able, albeit unwittingly, to bring about a semblance of integration. Getting the teachers offside was a major strategic mistake for the government. Teachers play a powerful role in Fiji society. In rural areas, they are respected as guides and mentors, as exemplars of good behaviour, as interpreters of the outside world to the people. Their influence extends far beyond the reach of the classroom. By antagonizing them, the government had by extension antagonized a very large and well-connected section of the community. The teachers would form the backbone of the Fiji Labour Party. High school principal, Krishna Datt, would become its founding Secretary General.

On the economic front, too, the government faced much opposition. The years 1983 to early 1985 were bad for Fiji. A succession of tropical hurricanes and droughts had devastated the economy, causing damage estimated at $\$ 150$ million. Sugar production in 1983 declined by an alarming 46 percent, and this was accompanied by a sharp drop in the world sugar price by 25 percent since 1980. Funds earmarked for public expenditure had to be diverted for relief and rehabilitation work; in 1985, $\$ 7$ million had to be diverted for this purpose. This was a severe setback for the government, 
especially since in 1985 the economy was expected to grow at a meagre 1 percent compared to 7.8 percent in 1984. There were other problems as well. The external debt was rising. It had increased at an average rate of 21 percent from $\$ 194$ million in 1980 to $\$ 399$ million in 1984 . The government also had to deal with the burgeoning employee salary bill which already accounted for nearly half the annual budget and promised to become worse with the implementation of the Nicol and Hurst report (over which the Finance Minister Charles Walker had resigned).

To cope with the grim economic situation, the government unilaterally imposed a wage freeze for a year from 1 November 1984. The government explained its rationale for the drastic (draconian in the view of its critics) measure at an Economic Summit, which both the Opposition as well as the Fiji Trade Union Congress boycotted. 'Fiji is not bankrupt,' Prime Minister Mara told the Summit, 'but unless we bring some discipline and sacrifice into our national life we could move in that direction. ${ }^{59}$ The government expected the wage freeze to save about $\$ 36$ million which it proposed to use to create jobs in the agricultural sector, in areas such as irrigation for rice farming, cocoa projects, forestry re-planting and the construction of fisheries-related facilities. The savings would also alleviate the deteriorating balance of payment situation. The Fiji Trade Union Congress opposed the wage freeze, accusing the government of bypassing the Tripartite Forum. The Forum, comprising the FTUC, Fiji Employers Consultative Association, and the government, was formed in 1976 to reach 'a common understanding which affect the national interest such as industrial relations, job creation, greater flow of investment and general social and economic development in the country.' Although it had no statutory authority, all the three parties had 'voluntarily agreed to abide by the Forum's decision.' The government's decision now to act on its own, unilaterally, was seen as a slight, if not a slap in the face, by the FTUC. ${ }^{60}$

The trade unionists saw the wage freeze as yet another sign of a concerted effort to suppress the trade union movement in Fiji. Some saw in the wage freeze policy a collusion between the political elite and big business to 
keep wages down. Economist Wadan Narsey argued that a blanket wage freeze would especially affect the lower income families already near the poverty line. ${ }^{61}$ 'The net effect,' he said, 'is the wages and salaries freeze means a transfer of employees' savings to the employers, regardless of whether the employers will invest the extra savings.' He questioned the logic of asking the people to sacrifice their meagre income to improve the balance of payment. 'One must not kill the patient to cure the disease.' He also questioned the government's acceptance of the International Monetary Fund's argument - which was used in part to justify the wage freeze — that the Fiji salaries were too high by 15 percent. Too high compared to what, Narsey asked. In any event, he went on, the figure was misleading as it covered a very diverse range of people, from the grossly exploited labour force in the garment industry to highly paid senior civil servants who were already beneficiaries of pay increases. All workers were not peas in the same pod.

When the government announced its wage freeze policy, James Raman, the General Secretary of the Fiji Trade Union Congress, went to Mara to explore ways of resolving the impasse. Raman was widely considered a moderate compared to Mahendra Chaudhry, who reportedly refused to accept any compromise at all. As far as Chaudhry was concerned, the government had to meet its obligation; how it did it was its business. 'I will not be able to control my members unless the government does something about the wage freeze,' Raman told Mara, with whom he was on cordial, golf-playing terms. The Prime Minister was caught in a dilemma. He had already lost one Finance Minister, Charles Walker, over the Nicol and Hurst report, and he did not want to lose another, he told Raman. Mosese Qionibaravi, the new Finance Minister, argued that the government had an obligation to govern, and if tough decisions had to be made, he would not be afraid to make them, and face the consequences whatever they might be. Mara said to Raman, without rancour or anger: 'I have to do what I have to do, and you have to do what you have to do. ${ }^{92} \mathrm{With}$ those words, the two men parted company, each taking a path which would alter the course of Fiji politics forever. 
The Fiji Trade Union Congress organized its own summit in May 1984 to explain its opposition to government policy. Among Raman's list of grievances included the invoking the dormant provision of the Trade Disputes Act, restricting collective bargaining, implementing rates of pay inferior to negotiated scales, and resorting to supply side economics. "We seem to have reached a point of no return in our relationship with the government,' Raman lamented, 'so much so that threats have been held out to declare a state of emergency and calling out troop to man essential services in case of legitimate industrial action. ${ }^{33}$ On 6 December 1984, Raman told an anti-freeze rally in Lautoka: 'We must think whether this dictatorial kind of governing should go unchallenged. The time has come when we must analyze government actions and if the policies oppress us, we can also organize a party and run government. It will be the government's policies' he said, 'which will make the trade union movement political. ${ }^{64}$ In March 1985, the Fiji Public Servants Association, a large and powerful member of the FTUC, changed its constitution by 2914 votes to 326 to be 'free to associate itself with any organization in pursuit of workers rights.' On 6 July 1985, the Fiji Labour Party was formed, capitalizing on a groundswell of discontent with the wage freeze and a generally deteriorating economy. Dr Timoci Bavadra, a retired government health specialist, was elected President and Suva Grammar principal, Krishna Datt, the Secretary General.

The new party, its founding manifesto proclaimed, was intended to 'provide a real alternative to the political groups that currently dominate the affairs of our country.' At the heart of its ideological foundation was a commitment to democratic socialism. 'In seeking ways to overcome the many problems that face our nation and in choosing a path of national development we are committed to ensuring that this is done with the interest of the mass of the people as the foremost consideration. We believe that this is possible only through an adherence to the principles of democratic socialism. ${ }^{65}$ The Alliance government had run out of steam, 'blaming others for the overwhelming problems that currently face our nation, while ensuring that what little surplus we do produce goes increasingly to its wealthier 
supporters.' And the NFP, Labour argued, was a party that represented 'no real alternative.' It was dismissed as a party 'that represents the interests of a handful of businessmen and lawyers, often at the expense of those who they claim to represent.' It was, therefore, 'highly unlikely that the lot of most Fijians would be improved under NFP rule. There would only be a new cast of self-serving characters at the top.'

\section{COALITION}

Soon after the launch of the Fiji Labour Party, talk began of a coalition. Since the Alliance was out of the picture - nor would the Alliance have countenanced a coalition with Labour under any circumstances - the focus shifted to the National Federation Party. The Ba by-elections had taught Labour the lesson that competing with the NFP in the cane belt would be suicidal and play straight into the hands of the Alliance. Going it alone was not an option. And Reddy was convinced that a three-way battle between NFP, Labour and the Alliance would be ruinous for his party, many of whose members were already looking for another alternative. But there were dissenting voices in both camps. Some Labour members, such as Simione Durutalo, an academic and a fine political thinker who died tragically young. felt that Labour should not make a bid for power at the next elections, but instead consolidate its support across the board and make a serious bid for government after the next one. Coalescing with the NFP, he felt, would play straight into the hands of the Fijian nationalists who would portray Labour as simply yet another 'Indian' party, or a puppet of the National Federation Party.

Even Krishna Datt had said in July 1986 that as 'as both the Alliance and the NFP work within the framework of capitalism and FLP cannot share their ideologies. ${ }^{96}$ But he was overruled by the party hierarchy. Not ideological purity but defeating the Alliance and getting into government were the main priority. Some within the NFP were also concerned about political affiliation with Labour whose left-leaning ideological rhetoric they feared, while there were some who thought that the NFP should remain a 
purely 'Indian' party. Among them was Siddiq Koya, concerned about a coalition with Labour diluting NFP's role as the communal voice of the IndoFijian community. He reportedly floated the idea of a NFP coalition with the Fijian Association to counteract Labour. What dowry would Labour bring to the party, some asked? Reddy was unmoved by the critics. Perhaps more than the fate of the party itself, he was concerned about the impact of the division on the future of the Indo-Fijian community. He knew only too well from personal experience what long-lasting havoc division could cause. When the issue of the ideological differences between Labour and the NFP were raised with him, he dismissed the concern as of little importance. Mahendra Chaudhry might be a trade unionist or a socialist or whatever, he would say, but first and foremost he was an Indian who would never do anything to injure the broader interests of the Indo-Fijian community. $\mathrm{He}$ spoke from experience, having known Chaudhry as a strong supporter of the NFP in the late 1960s and the 1970s. The two men were friends, if not necessarily close.

In any case, Reddy asked, what alternative was there for the party in its current state of division and disarray? By October 1986, informal contacts began between Labour and NFP. Mahendra Chaudhry had several private meetings with Harish Sharma, with whom he got along well privately and whom he thought he could persuade to accept his point of view. ${ }^{67}$ Sharma was then the Leader of the Opposition. He was a cultured man, a published poet and a scholar of Hindi language and literature, but not a political animal like Chaudhry. The Western United Front also began to re-enter the picture, on the grounds that its 1982 coalition with the NFP was still alive and binding. For them, too, Sharma was the first point of contact. On 10 October, Sharma speculated about a three-way coalition involving Labour, NFP and the Western United Front, with WUF demanding to have a representative of its own on the selection committee. ${ }^{68}$ Sharma said the WUF was an 'equal partner with the NFP and its members have as much right to make suggestions as any member of the NFP,' adding that this had been the understanding since 1982 and it had not changed. ${ }^{69}$ 
When he realized the infeasibility of the idea, Sharma said that the Western United Front did not have the same pulling power it had in 1982, and that it would not be able to win a single Fijian communal seat on its own. As for the Fijian national seats, the NFP and Labour would be able to win these on their own in any case. As the Western United Front was a Fijian party, Sharma told Gavidi, 'and Labour has greater Fijian following, WUF would have to negotiate directly with that party about the Coalition. ${ }^{70}$ Sharma knew very well that Labour would not concede an inch of anything to anyone, let alone to a political party which was in its twilight. And WUF had nothing to offer which Labour would approve or could not itself offer. The truth was that NFP-WUF Coalition had, for all practical purposes, ceased to exist soon after the 1982 general elections, and the WUF approach now was little more than a last minute attempt to revive the party's flagging fortune.

The early informal discussions were discarded by the NFP's Working Committee which met in Ba on 9 October, much to Labour's chagrin which thought it had much better chance of success with Sharma at the helm. At that meeting, the party settled on a coalition arrangement with Labour in principle, and authorized Jai Ram Reddy to negotiate the pact. His negotiating team included Harish Sharma, President Balwant Singh Rakkha, Treasurer Vinod Patel, Legal Advisor Bhupendra Patel and the party General Secretary Harnam Singh Golian. It was a formidable group that meant business. It is interesting, too, that two of Koya's formerly staunch supporters, Rakkha and Golian, were with Reddy now and not with Koya who, as we shall see, would be singing a different tune altogether. The Fiji Labour Party delegation was led by Party President Dr Timoci Bavadra, Assistant General Secretary Mahendra Chaudhry, General Secretary Krishna Datt and Joeli Kalou. By November, the negotiations were complete. There is no written record of the proceedings, but its main features soon became clear. It was agreed that Dr Bavadra would lead the NFP-FLP Coalition, and Harish Sharma would be the Deputy Leader. Reddy would not stand in the elections, despite pleas from all sides. 
Leadership decided, there was the more contentious issue of seat allocation to consider. Half the Indian communal seats and half of the winnable national seats would be shared equally between the two parties. For Reddy the Coalition was broad church, a big family, all on the same side of the political divide, where minor matters of privilege, of who got what, did not matter much in the end. Those in the Labour camp had other ideas, though, hoping to use the opportunity of sharing seats to eventually displace, if not annihilate, the NFP altogether. Mahendra Chaudhry, the future would reveal, was not one to share the limelight with anyone. For him, as we shall see, associating with another political party or organization was always a strategic move. For the moment, it made sense to work within a broader structure to consolidate his position from which a bid for power could be made later.

The seat-sharing formula enabled Labour to project itself into the hitherto impregnable Indian communal constituencies, guaranteeing them six seats in parliament, while the NFP was spared the almost certain humiliation of losing some of its blue ribbon communal seats either to Labour or, more unthinkably, to the Alliance in the event of a serious split in the communal votes. Another notable feature was the acceptance by the predominantly Indo-Fijian NFP of Dr Timoci Bavadra as the leader of the Coalition. It represented a significant shift of opinion in the party which, just a decade earlier, had not accepted Ratu Julian Toganivalu as its leader. Jai Ram Reddy's hand is evident. It was not important who the leader was, he would say often; what was important was that your fundamental interests were protected. Balwant Singh Rakkha added that he would have no difficulty working with Labour under Dr Bavadra because 'in reality Labour was part of the NFP,' a characterization many in Labour would have scoffed at. ${ }^{71}$ And Reddy, like everyone else, saw in Dr Timoci Bavadra an essentially decent man, a bit naïve perhaps, but not politically manipulative or ambitious for himself, a man with a caring heart and an overarching vision for the country as a whole. In 1999, he would express the same view when the NFP agreed to have the leader of the SVT as Prime Minister and 
the NFP's leader Deputy Prime Minister if the NFP-SVT Coalition won the election. Reddy would be roundly condemned as a defeatist by the Fiji Labour Party, 'selling out' the Indian interest by accepting a subservient position, but Reddy's assessment was both realistic as well as visionary. The reality was that for the NFP to achieve any measure of power a coalition with another party with a Fijian leader and a political philosophy broadly compatible with its own, was the only route to proper representation in government.

Another result of the coalition arrangement was the formulation of a compromise manifesto which whittled down some of Labour's more radical sounding economic policies, such as encouraging worker participation in the management of industry, the imposition of a minimum wage, the nationalization of selected industries, reforms in the Fijian military which was in the danger of 'becoming little more than a band of mercenaries.' To remove any lingering doubt about where Coalition stood on the role of the private enterprise, Dr Bavadra said in his concluding election address: 'We plan to offer special assistance to foreign investors and streamline official procedures so as to prevent bureaucratic red tape from stifling business incentives. I reaffirm the Coalition's recognition and acceptance of the vital role of the private sector in the development of the nation. There is no threat. The private sector must remain. It will remain.' ${ }^{73}$

The Coalition had half-heartedly talked about promoting a nuclearfree Pacific. It was an almost obligatory gesture to the Labour's Party's vocal, intellectual left. The platform caught some international attention, especially at a time when New Zealand was vigorously pursuing its antinuclear policy under Prime Minister David Lange. The United States was worried about losing its long-time Pacific ally, Ratu Mara. The Cold War was still on. But during the campaign, Harish Sharma indicated his 'personal view' that he favoured strong links with the United States. Even the future Foreign Minister Krishna Datt told General Vernon Walters, United States ambassador to the United Nations then visiting Fiji: 'We are collecting a series of formula from other countries; we even have sought some 
assistance from the US as to their own collection of formalities which they might have with some other countries. ${ }^{74}$ Such pragmatism was common sense as foreign policy never played a major role in Fijian politics anyway.

From the outset, Labour insisted that they start with a clean slate of candidates and discard the old guard of the NFP who had been the cause of so much friction and factionalism in the party and the Indo-Fijian community generally. They did not want bad baggage imported into the new structure. It was therefore ironic that in later years, Labour would lament the fate of these people, including especially that of Siddiq Koya, and blame Reddy for it! The Coalition selection committee endorsed only five of the sitting parliamentarians, two of whom, Devendra Singh and Satendra Nandan, were already in the Labour camp (by crossing the floor): Navin Patel, Harish Sharma, and Temo Sukunaivalu. Among those who missed out were Siddiq Koya, Shardha Nand, Subramani Baswaiya, Iqbal Khan (mostly old Doves), Anirudh Kuver, WUF's Ratu Osea Gavidi, Isikeli Nadalo along with many other old stalwarts of the National Federation Party, including its Vice President, Koresi Matatolu, who had to make way for Dr Bavadra. Balwant Singh Rakkha was retained despite vigorous objection from Labour. Dropped parliamentarian Anirudh Kuver characterized NFP's seat allocation approach as a 'perfect example of extravagant zeal and a clear manifestation of political immaturity of the highest order. ${ }^{75}$ His disappointment was understandable: he was once the General Secretary of the party

As was to be expected, the dropped and the discarded would not accept their fate 'lying down,' as a favourite Fiji phrase goes. Once they got an inkling of the decision of the selection committee, they mobilized their troops into action. Throughout December 1986 and January 1987, they arranged a series of private meetings to mount a counteroffensive against the NFP team which had negotiated with Labour. Siddiq Koya told a motley NFP convention in Nausori organized by Shardha Nand, the principal instigator of the move, that the coalition agreement with Labour 'had many deficiencies and must be revised without delay.' 'I did support 
the Coalition,' Koya said in his message to the meeting (he did not attend in person), 'but regrettably I cannot support the procedure or the terms upon which the selection was carried out.' ${ }^{76}$ 'The NFP is not for sale,' Koya thundered, 'and neither is the Indian community. ${ }^{, 77} \mathrm{Had}$ he known 'what I know now, I would most certainly have vetoed any attempts to have a committee to negotiate Coalition. ${ }^{78}$ That was an empty threat. Koya could not have 'vetoed' anything, let alone the selection of the candidates authorized by the party's Working Committee, because he was neither the President, nor the Secretary nor the Leader at that time. Harish Sharma recalled: 'Mr Koya was present in two meetings in $\mathrm{Ba}$ in which the Coalition issue was discussed. Mr Koya was present when the mandate was given to Mr Jai Ram Reddy to lead the negotiating team to talk to Labour. Mr Koya was also present when the selection procedure was announced. It's a bit late in the day to raise an objection. ${ }^{79}$

The Nausori meeting decided to appoint Koya, even in his absence, to head a team of five to re-visit the terms of the Coalition. The committee was authorized to re-negotiate the selection of candidates with a 'view to ensuring the true representation of the people,' whatever that meant, to make the terms and conditions of the coalition public, and to have them formally approved by the joint NFP-WUF Working Committee. ${ }^{80}$ To boot, the Nausori convention resolved that the Ba meeting, which had authorized Jai Ram Reddy to lead the NFP negotiating team, was unconstitutional. Early in February, 1987 Shardha Nand filed a Supreme Court writ to have the Ba meeting annulled. ${ }^{81}$ It was NFP politics old style. Nand had been in this game for sometime, a clever, smooth operator, adept at bureaucratic infighting, manoeuvring to get himself into a position of power in the party. In December 1986, for example, he had tried to organize a petition by some of the sitting NFP parliamentarians to have Harish Sharma replaced as the Leader of the Opposition by himself. ' 'Labour got everything,' he said, 'and gave nothing away.' NFP needed a 'stronger leader' and he, of course, was the man for the job. The move failed because everyone saw through Nand's transparent ruse. 
Siddiq Koya, too, felt that the NFP negotiating team had conceded too much ground. Perhaps his trained and finely tuned political antennae told him not to trust the leaders of another political party seeking coalition too much, certainly not one led by such ambitious 'Young Turks' in the Labour Party. In hindsight, his suspicion seems well founded, but the reality on the ground constrained the choices available to the party leaders at the time. Why couldn't the leadership of the Coalition be rotated every two and half years in the five year life of the parliament, he asked? ${ }^{83}$ The Fiji Labour Party, he said, was a collection of defectors and disgruntled 'good boys' of the Alliance. ${ }^{84} \mathrm{He}$ had in mind people like the FTUC general secretary James Raman. Alluding to Reddy and the events of April 1977, Koya said, 'The Indians had a great chance then because they were given the mandate by the country to have an Indian as Prime Minister, but these same people stabbed me in the back then. ${ }^{85}$ It was a true and tried Koya line of attack when cornered, but by now the accusation carried no conviction. He had contested the 1982 election under the same man he was now accusing of stabbing him in the back and whom he would nominate for parliamentary elections later.

Reddy would not budge. He told the NFP Working Committee meeting that if they wanted him 'to support the party then I would do so only if there was a coalition of NFP and Labour' because as he saw it, 'a three way fight would be disastrous for NFP. ${ }^{86}$ Everyone agreed, and everyone also knew that the party could not do without Reddy. Speaking at the launch of the NFP-FLP Coalition at the Girmit Centre in Lautoka in February 1987, Reddy turned on the rebels, saying that they were nothing but 'Alliance puppets,' 'men without cause.' They were only about themselves. 'The "I" is the dominant consideration. "I did not get a ticket" is the cause, and in that cause of the "I" they are bent upon causing harm to the people of this nation,' he said. 'What is more unfortunate,' he continued, 'is that there is an element of vindictiveness in their approach. ${ }^{87}$ 'Political parties must cater for the legitimate political aspirations of the people,' Reddy agreed, 'but they cannot cater for the blind ambitions of selfish individuals.' 'Our people 
may be simple, but they can see and think clearly. They see them clearly for what they are: selfish, self-seeking men bent upon causing harm to the very people they profess to serve.' He continued:

Compromise and accommodation in politics is good. But there is a limit. We cannot run a party without discipline. We must insist upon discipline. Those who do not accept that have no place with us. We cannot repeat the mistakes of the past. There is definitely no room in this Coalition for people who have no political conscience. We certainly have no place for political double-dealers, for men who get elected on our strength and serve the cause of our opponents. It is time to say good-bye to them.

Why do you have to be in parliament to serve the people, Reddy often asked. Why couldn't they for once support the candidates chosen by the party? It was a fair question, but for many, parliament was, and still remains, the cherished ticket to perks and privileges and a brief moment in the public limelight which they would not otherwise ever have. Pet Puja, self interest, above everything else, is, alas, an all too common a human failing, and not only among aspiring NFP politicians. It is beyond doubt that given a party ticket to contest the elections, those critical of Reddy would have happily abandoned whatever cause they were championing and joined the Coalition. That is the way of politics in Fiji.

\section{THE 1987 CAMPAIGN}

The campaign for the general election began early in the year, partly in anticipation of a February poll. It was long and unremarkable lacking, for instance, the dramatic tension of the last stages of the 1982 campaign when the contents of the Carroll Report were revealed by the Australian Broadcasting Commission, or the intense and ultimately self destructive struggle between the competing factions of the NFP in the September 1977 elections. But the campaign had its own unique features that helped to define its distinctive character. Learning from past experience, both the Alliance and the Coalition dispensed with the laborious public spectacle of 


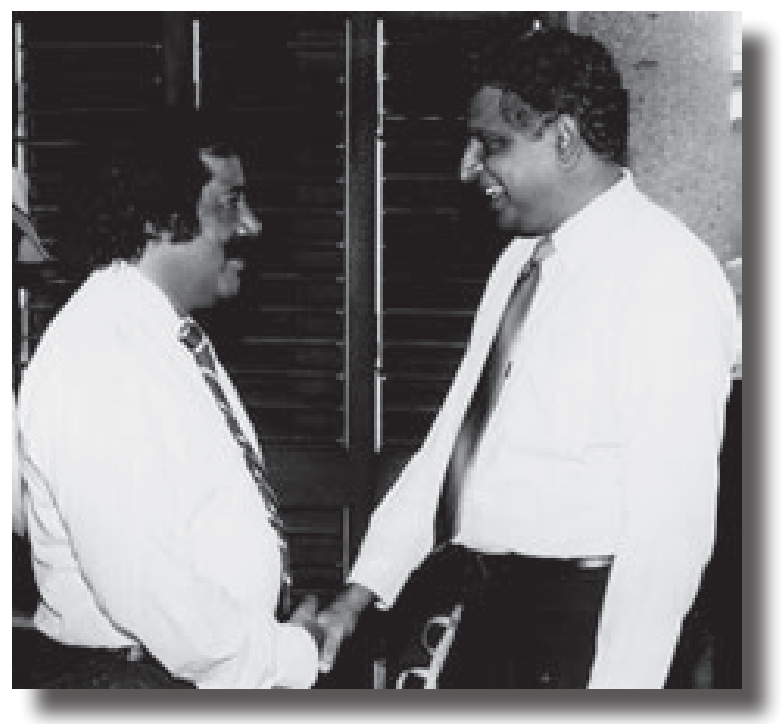

With Balwant Singh Rakkha, NFP President (above),

Feb 1987, and with Doctor Bavadra (below), July, addressing a post-coup rally. Photo courtesy of Fiji Times.

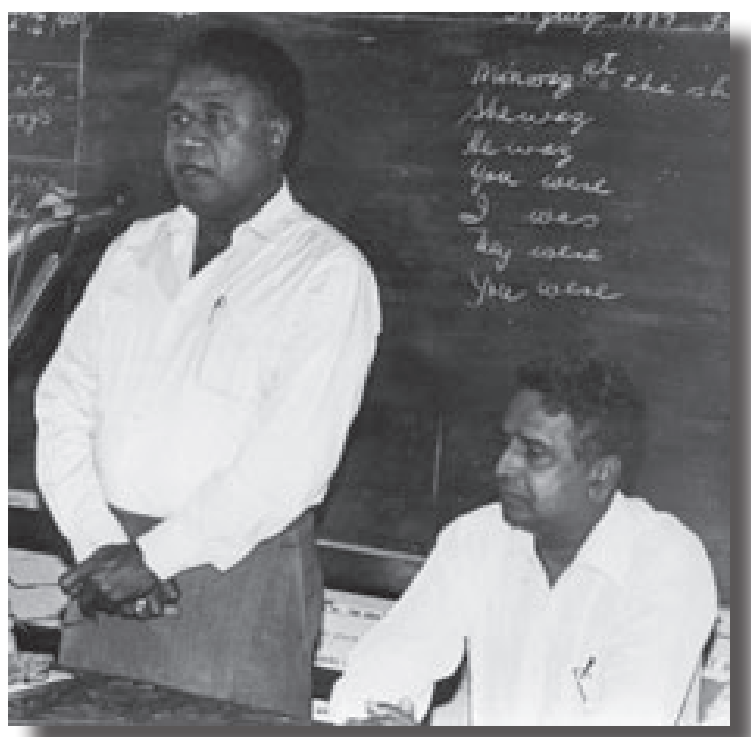




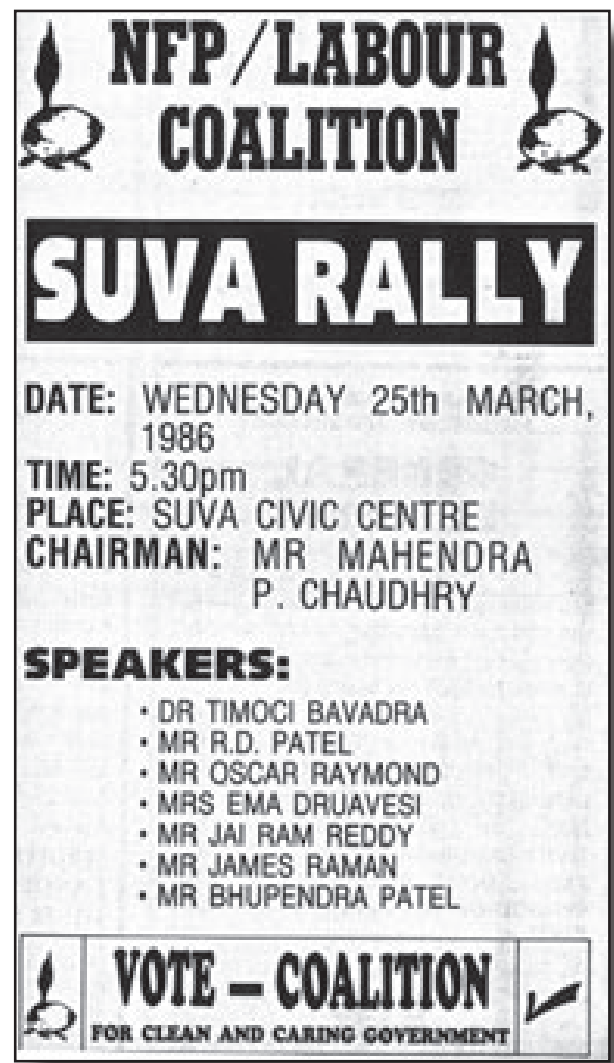

A typical NFP-FLP

campaign advertisement.

Note the absence of the NFP

symbol, the Mango Tree.

Courtesy of Fiji Times.

touring the country to select candidates from a list prepared by constituency committees. Now, candidates were selected from a list of applications. This more centralized approach gave the parties more time to focus on each other rather than deal with internal squabbles. It also produced an avalanche of defections as frustrated would-be candidates switched parties, though all suffered ignominious defeat at the polls.

Another significant difference between the 1987 election and previous ones was that, for the first time since the advent of elections in Fiji, the leaders of both the ruling as well as the opposition parties were ethnic Fijians. This fact diluted, though never completely eliminated, the exploitation of racial anxieties during the campaign, as we shall see. The Alliance 
sought to portray Bavadra as a Fijian in name only. In truth, Mrs Irene Jai Narayan said, taking the Fijian nationalist line, that he was a puppet of the Indo-Fijian political leaders, including Jai Ram Reddy, who were using him to realize their ultimate goal of political dominance. ${ }^{88}$ The divisive issue of race was supplanted by other emotionally charged distinctions, such as regionalism and class. Many Fijians saw in the election a contest between commoner Fijians from western Viti Levu led by Dr Bavadra and the traditional chiefly elite led by Ratu Mara. The Coalition Fijians talked freely about circumscribing the role that traditional chiefs should play in the modern, multiracial political arena, and this appeared to threaten the chiefs' own aspirations for an increased role for themselves.

Fijian institutions, which were once taboo topics for public discussion and comment because of their deep sensitivities, became the subject of open campaign talk in a way they had never been. Among them was the Native Land Trust Board, created in 1940 and responsible for the leasing and administration of all Fijian native land. The NLTB was a powerful indigenous institution. The Governor General was its president, the Minister for Fijian Affairs its chairman, with five members appointed by the Great Council of Chiefs and three appointed by the Fijian Affairs Board, and not more than two non-Fijians. The composition and function of the Board could not be changed except with the consent of six of the eight Great Council of Chiefs' nominees in the Senate. Despite its august status, the NLTB was becoming increasingly unpopular. The Carroll Report had found that only 44 per cent of the Fijians and 30 per cent of Indo-Fijians thought that the organization was doing a 'good job,' while 39 per cent of both communities thought the NLTB was doing a 'bad job.' In his inaugural speech launching the Fiji Labour Party, Dr Bavadra had said:

The NLTB must be democratized so that it comes to serve the interests of all Fijians and not just the privileged few and their business associates. In addition, more effort must be made to see to it that those whose land is being used get more for their money out of the NLTB. It is impossible at present to see how the level of 
administrative charges that are levied are justified on the basis of services performed. If the NLTB is to take the money that it does, then it must do more for those who it is supposed to be serving. It is also important that steps be taken to rationalize the benefits derived from land use in Fiji. The system must be rationalized so that all Fijians, not just a few, benefit more. In addition, a great deal more must be done to enable the people of Fiji to increase the productivity of their land. More services and better infrastructure must be provided. This may difficult, but ways must be found ${ }^{89}$

As part of its reform plans, the Coalition — it was originally Labour's idea - promised to establish a National Land Commission, comprising representatives of the government, the landowners and the tenants to keep a watchful eye on NLTB, adjudicate land disputes, and facilitate communication between the owners of the land and its users. The Coalition proposed to modernize and rationalize land usage to provide maximum benefit to its owners and a greater sense of security to its tenants. Opening up new areas and utilizing existing Crown land to meet the genuine needs of both Fijians and Indo-Fijians was a part of the Coalition's strategy. 'If the people are willing to work the land, be they Fijians or Indians or any other, we want to give them the opportunity to produce from land so far unutilized in order to feed their families and earn for themselves a living and in the process benefit the country.' The audacity of the idea is not as astonishing as simply the fact that it was raised at all as an issue in the campaign, without racial overtimes even though the Alliance could not resist making it a racial issue. In the past, any Indo-Fijian who dared to talk about land, in whatever context, would have been hounded mercilessly. Mahendra Chaudhry realized this to his great political cost during his brief tenure as prime minister in 2000.

The talk of a Land Commission gave Mara the opening he needed to raise deep-seated Fijian fears about being dispossessed. Setting up of a Land Commission was 'very dangerous thinking,' Ratu Mara told a Fijian Association rally at Lautoka, 'and Fijians should be very wary of it because it could lead to the slipping away of native land.' Who would be on the 
Commission, he asked. Was Bavadra 'not aware that a common identity would also mean that non-indigenous people would claim native land?'90 Dr Bavadra responded with devastating logic. 'As one of the architects of Fiji's constitution, he [Mara]should be fully aware that ownership of all classes of land is protected under the constitution.' 'All those who know the constitution,' he continued, 'know fully well that no changes to the Native Land Act are possible unless both House of Parliament sanction it by a majority of no less than three quarters., and four of the six Senators nominated by the Great Council of Chiefs concur.'

That being so, Dr Bavadra questioned Ratu Mara's motive in raising the land issue in such a provocative way, and wondered whether the Alliance leader had opted 'to abandon national leadership in favour of narrow political interests. ${ }^{91}$ The Coalition's rhetoric also sent waves of fear and concern among the hereditary chiefly classes. For the first time, a credible opposition was being led by an ethnic Fijian, a middle ranking chief from the traditionally neglected western parts of Fiji against sections represented by high chiefs from the maritime provinces. In a society where ascribed status, hierarchy and protocol are accorded the greatest weight and where traditional political ideology holds that the business of political leadership should ideally be the business of chiefs, Bavadra's ascension posed problems. Bavadra and his Fijian colleagues in the Coalition represented in many ways the coming of age of a new generation of Fijians while Mara and the other paramounts stressed their links with the past. They were, in truth, creatures and creations of the past.

The 'new' Fijians were urban-based professionals who had achieved success by the dint of their individual effort and sacrifices. They were men and women of achieved status and essentially middle class values. They still paid their dues to their villages and continued, as best as they could, to nurture the old links, but the process of distancing from their traditional roots was becoming increasingly clear and irreversible. For their livelihood as teachers, doctors, public servants, skilled workers, they depended on the infrastructure of the modern, multiracial community. Their social and 
material world had widened considerably as a result of their exposure to influences that could not even be imagined by their kinsfolk still in the villages. In 1976, 79, 314 (36. 3 per cent of the total Fijian population) lived in urban areas; in 1986, the number had risen to 107,780 (38.9 per cent). And the numbers were increasing.

In the villages, too, important changes were taking place which had the cumulative effect of undermining the basis of Fijian social structure and its institutions of leadership. The adoption of imported tools and equipment increased individual productivity and lessened the need for communal effort. The monetization of the village economy emphasized the primacy of the nuclear family over the communal group. The growing importance of cash crops - banana, ginger, sugar cane - and the growing links to the urban centres facilitated by improved communication, emphasized the need for individual initiative and enterprise ever more which went against the grain of traditional ethos. Changes in land use patterns, the tendency to lease other mataqalis' land directly outside the agency of the NLTB, and thus gain for many Fijians a measure of independence for the duration of the lease, all detracted from the former cohesiveness of the village life in which the institution of chiefly leadership was of prime importance. As geographer Gerard Ward noted, 'The combined introduction of new skills, new technology and money has weakened the functional cement which binds the native Fijian village society. This does not mean that the structure has collapsed, or will do so in the near future. It does mean that the risk of disintegration exists if other factors shake the edifice. ${ }^{92}$ Among those factors would be the Coalition's social and economic policies.

The Coalition Fijians also talked about circumscribing the role traditional chiefs should play in the modern multiracial arena, and this threatened the chiefs' own aspirations of increased roles for themselves beyond the confines of the village communal system. The Alliance, many of whose own leaders were high chiefs, saw no particular conflict at all. As Ratu David Toganivalu said, the ties between the turaga (chiefs) and the vanua (land, people) were indivisible; one could not exist without the other. 'They 
are the protectors of the rights of Indians and General Electors in Fiji.' The Coalition Fijians saw things differently: 'The chiefly system is a time-honoured and sacred institution of the taukei. It is a system for which we have the deepest respect and which we will defend. But we also believe that a system of modern democracy is one which is quite separate from it. The individual's democratic right to vote in our political system does not mean that he has to vote for a chief. It is an absolutely free choice. ${ }^{93}$

The criticisms of chiefs went further. The Coalition criticized the disparity which existed between the policies the chiefs espoused and the practices which they actually followed. The chiefs were entering the world of commerce and business and doing rather well for themselves, while they were exhorting their people to follow the path of custom and tradition: 'By restricting the Fijian people to their communal life style in the face of rapidly developing cash economy, the average Fijian has become more and more backward. This is particularly invidious when the leaders themselves have amassed huge personal wealth by making use of their traditional and political powers.' Such pointed words, spoken openly in public for the first time by Fijians themselves, could not by any stretch of the imagination be dismissed as a racially motivated attack on Fijian institutions, as criticisms by non-Fijians had been in the past. They encouraged dissent and debate among the restive Fijian youth and others in urban areas for whom tradition was no longer enough to survive on.

The disparity in the growth and development of the different provinces had been the subject of internal debate among Fijians for a long time. Sakeasi Butadroka had raised it at the national level in the 1970s. Now, a decade later, the Coalition had seized upon it again. And once again, Lau was the target. Senator Inoke Tabua, from Lau, had said on the eve of the elections: 'If the Prime Minister [Mara] steps down today, there will be trouble tomorrow. You push us too much and you are on the brink. ${ }^{94}$ Dr Bavadra had set the tone of the debate at the first Labour convention in 1986:

It is important that we remind ourselves that the government resources poured into Lakeba are derived from wealth produced 
by others in the country ... they only serve to increase regional inequality and take resources away from places where they could of more benefit to the nation. It is time that we stopped viewing the rest of Fiji as serving the interest of a few centres in the east. The people of Lakeba are entitled to a share in the national wealth, but just a share. It is time that we had a government that is more truly national in outlook. ${ }^{95}$

Ratu Mara denied the charge, but evidence showed that aid money and development projects funded by foreign sources did flow more generously into the maritime provinces than to other areas. And there was undeniable disparity in the allocation of scholarship money among Fijians. ${ }^{96}$ The civil service also had a higher proportion of 'islanders' over 'mainlanders.' The Coalition's balanced approach to regional development hurt more than the Lauan pride. It also threatened their continued privileges in the future. Their swift reaction was therefore not surprising. There were probably very good reasons for the glaring disparity between the provinces, going back to the beginning of colonial rule in late-19th century, when the friendly, collaborating regions were rewarded for their loyalty by the British and the resisting provinces punished. But that long and complex history mattered little in the intense heat of the election campaign.

In the 1987 campaign for the first time, Ratu Mara's personal as well as political record came under intense and unrelenting scrutiny, especially by and among Fijians. And the fact that it was a Fijian leader rather than an Indo-Fijian, and the head of an $i$ tokatoka (family group) from western Viti Levu at that, who led the charge against a paramount chief, the Sau ni Vanua ko Lau no less, the overlord for the entire Lau province, made matters worse, because he could not be dismissed as his former Indo-Fijian opponents often were. Mara was accused of being arrogant and dictatorial, pursuing policies which undermined the interests of workers and others at the bottom of the economic ladder, to the benefit of his big business supporters in the garment industry, for example, who had contributed to $\$ 52,000$ to the Alliance campaign chest, to prevent the passage of minimum 
wage legislation for the industry. His 1984 wage freeze policy came in for criticism as well as the bypassing of the Tripartite Forum. Then there were the unprecedented criticism of his alleged family wealth, including the leasing of the family-owned Marella House to the Ministry of Education on a rental reportedly higher than that recommended by the government assessor. Whether it was age or fatigue from the routine of intense campaigning, Ratu Mara was not the same forceful and energetic campaigner he had been in the past. His team, too, looked tired, displaying what one observer called a 'dangerous state of arrogant complacency." ${ }^{97}$

All this became evident during the last leg of the campaign. But things were different in the beginning. Confident of victory, the Alliance adopted a dismissive attitude towards the Coalition. Ratu Mara set the tone in November 1986 when, referring to the Labour politicians, he asked: 'What have the Johnnys-come-lately done in the promotion of national unity? ${ }^{98}$ He returned to this theme again and again throughout the campaign, contrasting it with his own and his government's long experience. He was determined to remain in harness. 'Time will come,' he said in a radio address, 'the time may not be long in coming when the leadership of this fair land must pass on to other hands. That is inevitable, but the hour has not yet struck! When it does, I will willingly lay down the burden and thank you for the privilege of serving you. Until then, I will answer the call. I will keep the faith. Ratu Mara will stay. ${ }^{99}$

Dr Bavadra became the target of a sneering newspaper campaign. In a typical advertisement, the Alliance said: 'Bavadra has never been in parliament. He has no EXPERIENCE. He has no INFLUENCE. The Council of Chiefs does NOT listen to him. The international scene where we will sell our sugar has NEVER heard of him. He cannot get renewal of leases for farmers. ${ }^{100}$ In the opening Alliance campaign address over the radio, Mosese Qionibaravi, the Deputy Prime Minister, had called Bavadra an 'unqualified unknown.' The Coalition was often portrayed as weak, vacillating and untrustworthy. One typical Alliance advertisement said: 'The opposition factions are fragmented and quarrelling 
among themselves. Their policies are confused and shift constantly as one group or would-be leader gains ascendancy. Principles are proclaimed as fundamental and are then dropped when pressures are applied by vested interests, or political expediency.' For its part, the Alliance was 'united in purpose, strong and fully accepted leadership, clear and consistent policies, and a political philosophy with values that have been proved by experience.' Of all the allegations against the Coalition, the one about squabbles for leadership was completely untrue. Bavadra was the Coalition leader respected by all and criticized by none. His humility and a common touch endeared him to the Coalition supporters and more than made up for his political inexperience and perhaps even a degree of naivety. The 'Doc' was their undisputed leader.

The Alliance's major concern was the slippage of Fijian votes to the Coalition, the same slippage which had caused its downfall in April 1977 and near-defeat in 1982. It appealed for Fijian unity and instilled concern, if not actual fear, about the consequences for Fijians of a Coalition victory. The unmistakable Alliance message was that only a government headed by a high chief could guarantee the security of Fijian interests. 'Fijians have the political leadership despite being outnumbered in this country,' said Mara menacingly. 'If they failed to unite that leadership would slip from them. ${ }^{101}$ And Mara accused the Coalition of trying to undermine Fijian leadership by taking up mainly Fijian causes with the intention of discrediting the Alliance, such as the Nasomo land dispute in Vatukoula, the plight of the cocoa growers in Vanua Levu, and competing claims of ownership of Yanuca Island in which his own wife, Adi Lady Lala Mara, was involved. Mara's overtly racial appeal surprised many. A Fiji Sun editorial said: 'In past elections, Ratu Sir Kamisese Mara called for political parties not to indulge in politics of fear, and not to fight the election on racial lines. But now the Prime Minister himself has begun a racially oriented campaign. His call for the Fijians to unite to retain political leadership is unwarranted. If every individual race began campaigning on these lines, the country would be in trouble.' ${ }^{102}$ 
Fijians were told not only to fear the loss of their land and cultural heritage, but were also warned about the danger of embracing foreign ideologies. In this regard, the Coalition's advocacy of democratic socialism came in for a particularly savage attack. Democratic Socialism was a system, the Alliance told its supporters, 'in which LAND, FACTORIES, MINES, SHOPS, etc are ALL OWNED by the STATE and the COMMUNITY. This is opposed to the present system in Fiji where ownership of Fijian land rests exclusively with Fijian mataqali, and businesses belong to individuals or shareholders in a public company.' The fact some Coalition (as indeed had some government ministers as well) had visited Moscow at one time or another, usually for a conference, was presented as further indisputable proof of the Coalition's nefarious socialist designs. Exaggerations and distortions are a regular feature of Fiji elections and probably of elections everywhere. Minor disagreements are blown up into major differences of principle and policy, criticism of individuals portrayed as an insult to their ethnicity, their vanua. The Alliance's strident attacks showed just how keenly aware they were of the closeness of the contest.

In contrast to the Alliance, the Coalition entered the campaign as the distinct underdog, under-funded and unable initially to match the Alliance in the media wars. The Coalition was a party of and for the poor, election rallies heard, which had the interests of the underdogs truly at heart and with plans for their betterment through balanced development, poverty alleviation plans and social justice programs. It charged the Mara administration with abuse of power and reminded the electorate of the mounting economic difficulties for lower income families. In his concluding campaign speech over radio, Bavadra said: 'Wage and salary earners remember the wage and job freeze; farmers remember their extreme hardships and insecurities; rural dwellers remember the high prices; parents remember the increased bus fares; squatters remember physical removal and neglect; teachers remember Dr Ahmed Ali's reign of terror in the Ministry of Education; students remember the pain of their hunger strike; the taukei remember that most of Fijian development money goes to a few provinces.' 
It was 'Time for Change,' he said. The theme caught the imagination of the voters, especially of the younger generation which had come of age during the long reign of the Mara administration since 1966, and which yearned for something different, someone new.

Rhetorical excesses and allegations aside, the campaign brought into sharp relief some genuine differences between the two parties. Leadership was one such issue. The Alliance projected an image of unity, purpose and experience. The Coalition, on the other hand, was portrayed as a bunch of professional critics whose view of the world was 'so flawed that it would not pass as seconds.' Ratu Mara was, once again, the party's trump card, its principal pulling power. He vowed to fight on to the end. 'I have not yet finished the job I started and until I can ensure that unshakable foundations have been firmly laid and cornerstones are set in place, I will not yield to the vaulting ambitions of a power crazy gang of amateurs, none of whom has run anything, not even a bingo party.' The future of Fiji and that the of the Alliance party were inextricably linked. Without his and his party's leadership, Mara said, Fiji would go down the path of 'rack and ruin', becoming another of those developing countries 'torn apart by racial strife and drowning in debt, where basic freedoms are curtailed, universities closed down, the media throttled and dissenters put into jail and camps. ${ }^{103}$ This was as stark a scenario as it was possible to paint at the time.

There was an added edge to Mara's campaign. He was especially irked that Indo-Fijians had preferred Bavadra over him as Prime Minister. Observed Indian High Commissioner TP Sreenivasan: 'He was sore that Indians wanted Bavadra rather than him as Prime Minister and he told me each time I met him that no one had done more for Fiji Indians than him. He would have understood if they had backed an Indian as Prime Minister, he said, knowing well that previous efforts to make an Indian the Prime Minister of Fiji had failed. ${ }^{104}$ Ridiculing Bavadra became an integral part of the Alliance campaign. But the more he was attacked, the more strongly his supporters rallied behind him. Ratu Mara's long incumbency presented a real challenge for Dr Timoci Bavadra. Unlike the Alliance leader, he was a 
newcomer to politics and virtually unknown outside the health and the trade union circles. By profession a medical doctor, Bavadra had held a number of senior positions in the civil service. He came from a chiefly background from Viseisei village in Vuda, though he himself was not a high chief. The Alliance's attempt to box him in as a puppet of the Indian leaders, as 'nothing more than a mere pawn of the evil, scheming Reddy', as then Fiji Times reporter Richard Naidu recalled, forced Dr Bavadra frequently to defend his 'Fijianness' as well as his party's platform..$^{105}$ By the end of the campaign, though, he had managed to turn public opinion decidedly in his favour. His unassuming character and common touch, accessibility and openness, and a certain infectious sense of humour and capacity for laughter, contrasted with Mara's characteristic aloofness, and projected an image of a compassionate man who could be trusted.

The Alliance campaigned on its record of experience and stability, while the Coalition drew support by launching a concerted attack against it. The Alliance, it said, 'had reneged on the fundamental principles of democratic responsibility and accountability It pretends to be democratic but in fact puts all decisions in the hands of a very few. This brand of democracy aids a few at the expense of the vast majority.' The Coalition accused the Alliance of perpetuating the politics of racial separation, similar in effect if not in name, it said, to the apartheid system of South Africa. The difference between the two was 'one of degree, not one of substance,' it said to calculated exaggeration. For its part, the Alliance reaffirmed its opposition to 'any suggestion of constitutional change that would weaken or destroy the principle of guaranteed representation of Fiji's major racial groups in the House of Representatives.'

To check what it saw as the abuse of power, the Coalition proposed an anti-corruption bill, a code of conduct for parliamentarians, and the abolition of all legislation that fostered secrecy in government, including especially the Official Secrets Act. Mara was dismissive, with some justification. 'Allow me simply to say that there is no country in the world today in which similar concerns do not emblazon the headlines. The fact 
is that these problems are a by-product of modernization. Fiji neither has a monopoly on these problems nor are they extensive and corrosive here.' 'I firmly believe,' Ratu Mara told his supporters, 'that these elections will be crucial to the future of our homeland. Let there be no doubt in your mind: Fiji is not so much at a turning point as it is at the crossroads. If we take the wrong direction, we will finish up in blind alleys, from which there will be no return and no way out.' ${ }^{106}$ Prophetic words: perhaps the Alliance leader had the premonition of something that escaped the others.

While everyone accepted Dr Timoci Bavadra as the undisputed leader of the NFP-FLP Coalition, everyone also accepted Jai Ram Reddy as his effective deputy even though he was not a candidate. One observer called Reddy the 'star performer in the general election,' saying that he had eclipsed Harish Sharma, the Leader of the Opposition, and even Bavadra who 'stood in Mr Reddy's shadow. ${ }^{107}$ Until 1987, Reddy's political campaign forays had been confined largely to the Indo-Fijian community. In 1987, for the first time, Fijians and General Voters saw him in action on the campaign trail as he addressed campaign rallies around the country. In contrast to Bavadra, Reddy was eloquent and charismatic, holding his audiences spellbound, speaking from the heart, often without notes, inspiring trust and confidence in the Coalition. He was the featured speaker at all the major Coalition rallies, their star attraction. For the Indo-Fijians, he was the man to whom they looked up. They reposed their complete trust in him. They often turned up at rallies to listen to him more than to any other person. Mahendra Chaudhry was then an inexperienced, halting public speaker and not nearly as well known nationally as Reddy. A theme of Reddy's speeches, to which he would return again and again later in his political career, was the need for the two communities to work together. In political integration lay the salvation of both the communities.

To Indo-Fijians, he spoke almost philosophically to shed their fears about not having their leases renewed if they voted for the Coalition, for example, or upheaval if their party won and to stand up for their rights as equal citizens of Fiji. A life lived in fear, he said repeatedly, was not a 
life worth living. 'Don't be like Jelly fish', he told a four hundred-strong meeting in Malolo in March 1987. 'Be bold and cast your votes in the April elections.' 'For far too long we have been caught in the quagmire of racial and communal politics,' he told another rally. 'The common man feels alienated while government is seen to be for rich friends, relatives and hangers-on. The test for our democracy and its institutions is its ability to accept change. ${ }^{\prime 108}$ To the Alliance's promise of roads, telephones and piped water, Reddy told his rallies, 'Nothing will be a greater tragedy than people who sell their rights for a few dollars.' And so it went. All the opponents of the Coalition that Reddy had put together were silenced. Koya was nowhere to be seen. Shardha Nand was dispiritedly fighting a battle he knew he would lose. And Ratu Osea Gavidi was in the political wilderness, fading fast, his Western United Front a distant and to some a disreputable memory. Jai Ram Reddy was the man of the moment, James Raman has recalled. 'He single handedly delivered us the Coalition victory. No one worked harder in the campaign than Reddy.'

Given the racial system of voting that Fiji had, national elections became, in effect, racial census. The communal seats were a foregone conclusion. Whether a national seat was winnable or not depended on the ethnic composition of the electorate. A national seat with a preponderance of Fijian voters was a safe Alliance bet, and likewise a safe bet for the NFP if it had greater number of Indo-Fijians. With that calculation in mind, attention focused on two national constituencies in south-eastern Viti Levu. The greatest attention focused on Suva, where Irene Jai Narayan was standing for the Alliance. In November 1986, fed up with internecine battles within the NFP to which she herself had contributed wittingly or unwittingly, and endless frustration as an Opposition backbencher, Narayan had joined the Alliance because she was 'absolutely convinced' that her new party would 'remain in power for years to come. ${ }^{109}$ She joined Alliance after flirting briefly with Labour, saying she would make up her mind after seeing 'what kind of following it has and what stand it takes on some important issues. ${ }^{\text {ग110 }}$ But the call was not hers to make anyway. Labour, for 
its part, feared that she might come with too much damaged political baggage and infect the new party with leadership tensions. The Alliance lost no time in parading Mrs Narayan as a prized catch, a formidable politician in touch with the grassroots who had represented Suva continuously since 1966. She had also been the president of the National Federation Party and Deputy Leader of the Opposition. 'I am happy to be in a happy home,' Mrs Narayan told her rallies.

Accordingly, the Alliance spent a considerable amount of resources and time in the constituency campaigning for her. Her running mate was the genial Fijian chief and Deputy Prime Minister, Ratu David Toganivalu whose wide, embracing friendship crossed cultural and ethnic lines. For his closeness to the Gujarati community, he was playfully nick named 'Gujratu David.' Their Coalition opponents were Fijian academic Tupeni Baba and Navin Maharaj, a businessman and former Alliance mayor of Suva. If anyone knew Suva inside out, it was Navin. He was the most astute and strategic-minded of campaigners, going about his business with a professionalism and commitment not often seen in Fiji election campaigns. And Baba developed as the campaign progressed into an articulate, if sometimes ponderously intellectualizing, speaker able to connect with the younger voters. The battle was truly joined. The business community's support for Toganivalu was neutralized by the Coalition's Harilal Patel, himself a Gujarati lawyer, who contested the Suva Indian communal seat.

Instead of being an asset, Mrs Narayan became a liability for her party. Her previous record of solid opposition to the Alliance was ruthlessly exploited against her. And her own unexpectedly virulent attack on her former party and her erstwhile colleagues, mounted with all the passion of the twice converted, damaged her prospects further, casting her in the role of an opportunist and a traitor. There was another unforgiving gender dimension to the campaign against Mrs Narayan. For Indian men to defect, transgress boundaries, switch sides, commit adultery, is less of a crime in the public eye than it is for women who are supposed to be the unblemished exemplars of duty and loyalty, in the manner of Lord Rama's wife Sita. 
They have to be pure and pristine. For that reason alone, many Indo-Fijians refused to forgive her. How dare she do this to us? was the question many asked. As one taxi driver told me at the time, if Mrs Narayan had fallen from the highest of mountains, he would have saved her by catching her in his lap. But how could he save her when she had fallen in his esteem. Jab nazar se gir gayi to kaise roki. So, in the end, the Alliance was left banking on the charisma of a single candidate for a crucial seat while the Coalition remorselessly turned the tables on her by digging up her political record against the Alliance.

Both Mrs Narayan (11 772 votes) and Ratu David Toganivalu (11 902) fell to the Coalition's Navin Maharaj (12 431) and Tupeni Baba (12 452). The margin was not much, but victory was victory. In another do-or-die seat, Joeli Kalou (13 445), a teacher and trade unionist, defeated Ratu Tu'uakitau Cokanauto (12 506), son of former Deputy Prime Minister Ratu Sir Edward Cakobau, and Fida Hussein (14 138), an ex-policeman, triumphed over Veer Singh (13 341) in a constituency with a large Muslim population. The NFP-FLP Coalition won 28 of the 52 House of Representatives seats while the Alliance captured the remaining 24. The voting figures confirmed the historic trend of predominantly ethnic patterns of voting, but some new trends were also visible. The Alliance support in the Indo-Fijian community was not as broad-based as it had been in the past. The party won only 15 per cent of the Indian communal votes. While communal Fijian support for Alliance remained high at 77 per cent, it was a notable reduction on the party’s 1982 figure of 84 per cent. Significantly, over 20 per cent of the Fijian voters cast their voters for parties other than the Alliance, with 10 voting for the Coalition. The shift was small, but pregnant with possibilities that the Alliance feared. None of the sense of tension and anxiety accompanied the defeat of the Alliance party this time. I had chaired the Fiji Broadcasting Commission's election panel discussions during the campaign when leading spokesmen from both sides presented their cases. Fiji had no television then. What impressed me most was the preparedness of the Coalition and its willingness, even eagerness, to assume the reins of power. The same confi- 
dence was evident in their fierce newspaper advertisements and rebuttals of Alliance allegations and criticisms.

At 3:15 on 12 April 1987, Alliance leader, Ratu Sir Kamisese Mara, conceded defeat. 'Fellow citizens,' he said:

We have come to the end of a long, hard campaign. You have given your decision. That decision must be accepted. While I am naturally disappointed at the outcome, I am proud that we have been able to demonstrate that democracy is alive and well in Fiji. We must now ensure a smooth transition to enable the new Government to settle in and quickly get on with the important task of further development of our beloved country. There can be no room for rancour or bitterness and I would urge that you display goodwill to each other in the interest of our nation. ${ }^{111}$

Dr Bavadra accepted the change of government graciously, thanking Ratu Mara for his longstanding contribution to the public life of Fiji. He said:

The peaceful and honourable change of government reveals yet again the deep democratic roots of our society and the profound unity of our people. I am touched by your goodness, warmth, compassion and respect. These are admirable qualities which make up the fabric of our society and which will sustain us in our future endeavours. ${ }^{112}$

He saw in his electoral triumph the dawn of a new era, full of new potential and opportunity. 'Together,' he said, 'let us write a new chapter, which, God willing, will be one which we and our children will be proud of.'

The veteran journalist and Alliance strategist, Sir Leonard Usher, wrote: 'It had been a long — too long — campaign, and at times some unpleasant elements of bitterness had crept in. These were now set aside. Democracy, clearly, was alive and well in Fiji. ${ }^{113}$ For the moment. 


\section{NOTES}

1. The exchange of letters is in the Reddy papers.

2. The Royal Commission letters were written on 2 and 29 Nov. 1982 and 7 Nov. 1983; on Government of National Unity on 20 Dec 1983, to which Mara had replied on 10 Jan. 1983, and on the boycott of parliament on 16 Dec. 1983, to which Mara had replied on 21 Dec.1983. On all three occasions, it was Reddy who had initiated the correspondence.

3. Fiji Times, 2 May 1984.

4. Fiji Times, 7 May 1984.

5. Fiji Times, 15 May 1984.

6. Fiji Sun, 18 Jan. 1984

7. Fiji Times, 13 Feb. 1984.

8. Fiji Sun, 7 May 1984.

9. Hansard, 10 June 1983.

10. Fiji Sun, 4 Feb. 1984.

11. His autobiography, privately published, is titled From the Mangrove Swamp (rev. edn 1998).

12. Fiji Times, 10 Feb. 1984.

13. His letter as well as Lindsay Watt's are in the Reddy papers.

14. Fiji Times, 16 May 1984.

15. Fiji Times, 19 May 1984.

16. Islands Business, 'The return of Koya.'

17. 'What Made Reddy Run,' Pacific Islands Monthly, June 1984, 22-3.

18. Which is why Lodhia voted for Koya and not Irene Jai Narayan, he told me.

19. Fiji Sun, 17 May 1984.

20. Islands Business, June 1984.

21. Fiji Times, 4 Mar. 1985. 
22. Fiji Times, 3 Dec. 1984.

23. Fiji Times, 18 Mar. 1985.

24. Fiji Times, 3 Dec. 1984.

25. Pacific Islands Monthly, June 1985, 12.

26. Fiji Times, 20 Mar. 1985

27. Fiji Times, 24 Dec. 1984

28. Pacific Islands Monthly, June 1985, 12.

29. Fiji Times, 12 Jan. 1985.

30. Fiji Times, 21 Mar. 1985.

31. Fiji Times, 25 Mar 1985.

32. Devendra Singh regarded Reddy as one of his 'gurus,' the other being RD Patel. Fiji Sun, 27 Jan. 1987.

33. Pacific Islands Monthly, June 1985, 12: 'Political Mayhem Rules Again in Fiji's NFP.' See also Fiji Sun, 27 Jan. 1985

34. Fiji Times 28 Mar. 1985.

35. Pacific Islands Monthly, June 1985, 12.

36. Fiji Times, 22 May 1985.

37. Fiji Times, 24 May 1985.

38. Fiji Times, 21 May 1985.

39. Fiji Times, 6 Apr. 1985.

40. Fiji Times, 29 Mar 1985.

41. Pramod Rae, who worked in the Opposition office says in private conversation that Koya had in fact told Mrs Narayan that he was contemplating making changes in the party, and that her position could be affected.

42. Fiji Times, 16 July 1985.

43. Fiji Times, 15 May 1985.

44. Fiji Times, 29 Nov. 1985. 
45. Fiji Times, 21 July 1985.

46. I am grateful for this information to Pramod Rae.

47. Fiji Times, 18 Dec. 1985

48. Fiji Times, 25 Feb. 1986.

49. Fiji Times, 29 Nov. 1985.

50. Pacific Islands Monthly, Mar 1986: 2 'Realignment of Fiji party forces is on.'

51. A detailed study of the by-election is in Vijay Naidu, The Fiji Labour Party and the By-Elections of December 1985 (Suva: School of Social and Economic Development (USP) Working Papers, 1985).

52. Writing in the Pacific Islands Monthly, 3 Mar 1986, 2.

53. Pacific Islands Monthly, Oct. 1985, 52.

54. Economist, 27 July 1985.

55. Fiji Times, 1 March 1985.

56. See 'Teachers Protest: Desegregating Fiji's communal Schools', in Pacific Islands Monthly (Jan. 1985), 53-55.

57. Fiji Times, 3 Nov. 1984.

58. Baba, 'Fijian Education in the Context of Modern, Multiracial Society,' Fiji Teachers Journal, May 1985, 27-31.

59. These quotes and figures come from papers presented at the forum, copies of which I have.

60. The government argued that since FTUC had become an active participant in an opposing political party which opposed government policies, it could then serve on government boards. Raman thought that the government was fearful of Labour and was therefore punishing FTUC. Fiji Times, 14 June 1986.

61. See 'The Wage Freeze and the Development Plan Objectives: Contradictions in Fiji Government Policy,' Journal of Pacific Studies, vol 11 (1985), 11-44.

62. Based on interview with James Raman, Aug. 2008.

63. Fiji Times, 4 May 1984. 
64. Quote from his speech on 6 Dec. 1984

65. The speech was originally published in South Pacific Forum (1985), 2: 1, 70-81

66. Fiji Times, 20 July 1986.

67. According to Anirudh Kuver, who was privy to the negotiations, the idea of a National Peoples Party (or Coalition), involving Western United Front, Labour and NFP had emerged as a possibility. See Fiji Times, 29 Dec. 1986.

68. Fiji Times, 10 Oct. 1986.

69. Fiji Times, 18 June, 1986.

70. Fiji Times, 16 Dec. 1986.

71. Fiji Times, 9 Dec. 1986.

72. According to Robbie Robertson, Labour's abandoning of its earlier stance was 'due less to the NFP influence than to the fact that by the end of 1986 the Labour Party deemed them counterproductive to its short-term interests, at least in their early presentational form.' See his Fiji: Shattered coups (Sydney, 1988), 39

73. Quote from the typescript of the final address in my possession.

74. Fiji Sun, 2 May 1987.

75. Fiji Times, 27 Dec. 1986.

76. Fiji Times, 24 Jan. 1987.

77. Fiji Times, 5 Feb. 1987.

78. Fiji Times, 25 Feb. 1987.

79. Fiji Sun, 24 Jan. 1987.

80. Fiji Times, 26 Jan. 1987.

81. Fiji Times, 16 Feb. 1987.

82. Fiji Times, 3 Dec. 1986.

83. Fiji Times, 18 Dec. 1986.

84. Fiji Times, 25 Feb. 1987.

85. Ibid. 
86. Fiji Times, 12 Jan. 1986.

87. Fiji Times, 23 Feb. 1987.

88. See Robertson, Fiji: Shattered Coups, 46.

89. Quote from Fiji Labour Party manifesto.

90. Fiji Times, 17 Aug. 1986.

91. Fiji Times, 19 Aug. 1987.

92. R.G. Ward, 'Native Fijian Villages: A Questionable Future,' in Michael Taylor (ed.), Fiji: Future Imperfect (Sydney: Allen and Unwin, 1986), 36.

93. Fiji Times, 22 March 1987.

94. Fiji Sun. 29 Sept. 1986.

95. Dr Bavadra's speech to the first annual convention of the Fiji Labour Party, 19 July 1986.

96. Figures are from the Fijian Affairs Board presentation to the Great Council of Chiefs in Somosomo in 1986.

97. Robert Keith-Reid, in Fiji Times, 6 Apr. 1985.

98. Fiji Times, 28 Nov. 1986.

99. From his final campaign speech on Radio Fiji.

100. Fiji Times, 15 Mar. 1987.

101. Fiji Times, 24 Sept. 1986.

102. Fiji Sun, 24 Sept. 1986.

103. From his final campaign speech over Radio Fiji.

104. TP Sreenivasan, 'A colossus who died lonely', The Rediff Special, 14 Feb. 2005.

105. Fiji Times, 29 Jan. 1987.

106. Ibid.

107. Daily Post, 'NFP: Rocky Road to Ruin,' 18 May, 1999. Reprint of an earlier piece. 
108. Fïi Times, 22 Feb. 1987. Also Fiji Sun, 2 Mar. 1987.

109. Islands Business, Dec. 1986.

110. Pacific Islands Monthly, Dec. 1985.

111. Fiji Times, 13 Apr. 1987

112. Fiji Times, 14 Apr. 1987.

113. Sir Leonard Usher, Mainly About Fiji (Suva, 1986), 146. 


\section{CHAPTER 5: SUNSET AT NOON}

Turning and turning in the widening gyre

The falcon cannot hear the falconer;

Things fall apart; the centre cannot hold

Mere anarchy is loosed upon the world

Y B Yeats

J

ai Ram Reddy was sitting third on Prime Minister Bavadra's right when soon after 10 O'clock on 14 May 1987, ten hooded soldiers entered the Fiji Parliament. 'Sit down everybody, sit down,' shouted one of them to everyone's consternation. 'This is a take-over. Ladies and Gentlemen, this is a military take-over. We apologise for any inconvenience caused. You are requested to stay cool, stay down and listen to what we are going to tell you.' Their leader, Lt Col. Sitiveni Rabuka, in powder blue safari suit with a pistol in his hand, then marched straight towards the Speaker's Chair occupied by his uncle Militoni Leweniqila without saying a word to him. ${ }^{2}$ Captain Isireli Dugu and his men stood armed and ready for action. 'Please stay calm, Ladies and Gentlemen,' Rabuka spoke in his characteristically strong baritone voice. 'Mr Prime Minister, please lead your team down to the right. Policemen, keep the passage clear. Stay down. Remain calm. Mr Prime Minister, Sir, will you lead your team now.' The parliamentarians, listening to a rambling — 'venomous' is the word Reddy used — speech by the rampaging trade unionist and Fijian nationalist firebrand Taniela Veitata about Mao Tse Tung and power coming from the barrel of the gun and much else besides, were genuinely perplexed. Some thought the military was carrying out a precautionary exercise in case things escalated with Fijian nationalists threatening to overthrow the month-old Coalition government. 
'What the fucking hell's going on,' Speaker Militoni Leweniqila reportedly asked, puzzled by the commotion in the aisle of the Parliamentary chamber, his profanity purged for posterity. 'Is this for real?' Dr Timoci Bavadra was heard asking a colleague sitting next to him. And when he refused to stand up and lead his team out of the House, soldiers leveled their guns at him and ordered him to comply. Education Minister Tupeni Baba protested when soldiers began ordering the members to march to the military trucks waiting outside. 'We are not going in that truck,' he said angrily, to which Rabuka told a policeman, Dou raici koya na Turaga ni Ovisa sa lako oqori. 'Look out for that inspector. Keep him covered.' Sensing trouble, Dr Bavadra politely asked his colleagues to obey the orders to avoid bloodshed. The soldiers clearly meant business. Reddy was taken completely by surprise like everyone else as he turned to watch the unfolding commotion. Perhaps a movie was being filmed, he thought to himself. That same thought had also occurred to the Commerce and Trade Minister, Navin Maharaj. But soon the reality dawned on him. What had been threatened the previous three weeks or so had finally come to pass. As a colleague, probably Tupeni Baba, on his way out of the chamber, opened Erskine May's Parliamentary Practice to see if it mentioned the word coup — it did not - Reddy simply remarked: 'This is nothing but the conquest of one community by another.' As he was being marched out, he looked towards the Grand Pacific Hotel and the sea and the craggy Serua mountains beyond for what he thought might be the last time. Assassination was very much on his mind.

Shortly afterwards, the waiting military trucks drove away, taking the hostages to the Royal Fiji Military Barracks at Nabua, on the outskirts of Suva, where they were promptly put in the Guard House, which was filthy, full of foul smell, and surrounded by fully armed soldiers. They all sat on the floor except Dr Bavadra for whom a chair was brought. The whole atmosphere was gloomy, Reddy recalled, the sense of humiliation great. They waited in the cell, anxious, worried, cut off from the outside, unable to communicate even with their families. There were no mobile phones then, no internet, and no easy way to communicate vital information. At 
around 11:15 that evening, the deposed parliamentarians were driven to the Prime Minister's residence at Vieuto after Adi Kuini Bavadra had 'accepted' Rabuka's polite request 'to the lady of the house' for possible accommodation for the detainees. 'For your information, I can accommodate the Prime Minister and all the rest of them,' Adi Kuini said. Such politeness and observance of cultural protocol, such respectful deference, even at a time like this. The Coalition parliamentarians remained at Vieuto for two nights as people in their hundreds gathered around Battery Hill keeping a vigil behind rolled barbed wires guarded by balaclava-wearing soldiers.

Inside, the parliamentarians talked anxiously among themselves, pondered their fate and took turns praying. How the Koran, the Bhagvada Gita and the Ramayana were smuggled into the Prime Minister's residence surrounded by so much tight security remained a mystery to Reddy. At first, all the parliamentarians were kept together. On the second night, soldiers arrived with orders to take the deposed Deputy Prime Minister Harish Sharma and Foreign Minister Krishna Datt away 'to a better place than this, which sent speculations wild' invoking the last rites and prayers, Reddy recalled later to some guilty laughter from those who had supported the coup. Bavadra told the two to do what the soldiers ordered. When Harish Sharma asked Reddy for his view, Reddy overruled Bavadra, saying with 'some heat and conviction,' as Harish recalled, that he would not countenance the parliamentary team being forcibly separated. Either they would all go together or they would all stay where they were.

Reddy's famous short fuse erupted when the soldiers came again later, Sharma recalls. 'You want my blood, isn't it,' he said. 'You take me. Leave these people alone.' 'No, sir, we can't do that, sir,' the soldier replied. Noor Dean offered himself to go in place of the two, to sacrifice his life if that was what was needed, later loudly shouting 'Allahu Akbar,' 'God is Great,' as he was thrown roughly into the back of the military truck. Reddy admired Dean's courage; many of his other colleagues were made of softer stuff. Bavadra came around to accepting Reddy's view. 'We all go or we don't go at all,' he said. At Reddy's suggestion and led by Navin Patel, ${ }^{6}$ the politi- 
cians then went into prolonged hymn singing (Mahatma Gandhi's favorite Raghu Pati Raghav Raja Ram, Pati Tapaavan Sita Ram) and prayer session, some praying furiously for the first time in their lives, hoping to put off the soldiers for a while longer. 'We kept this going till very late at night, almost till midnight,' recalled Reddy, while the soldiers waited outside. ' $M y$ officer is very impressed with your singing,' a soldier said respectfully. ${ }^{8}$ It was probably Reddy's tenor voice, Kelemedi Bulewa, the SVT Attorney General, would remark jocularly later.

The vigil ended early the next morning when a truck load of soldiers arrived to take the Indian members to Borron House in Samabula, a rambling mansion of a crusty former European plantation owner where, legend has it, it was decreed that no Indians were ever to be welcomed, except as servants. That was the way things were in the days of colonial rule and planter power. The Borrons had been the employers of Indian indentured labour on freehold island of Mago. Now the descendants of indentured labourers were going to occupy the mansion, albeit as captives. There was resistance as the parliamentarians lay on the floor holding hands, fighting back the enforced separation of the two ethnic groups. 'It was a very touching moment in our lives,' an emotional Reddy recalled, 'Fijians holding Indians, Indians holding Fijians and there were two or three General Electors.' The separation, for Reddy, symbolized the 'tearing apart of Fiji.' Reddy snapped at the soldiers. 'Why are you doing this? You are brave men, you have rifles, why don't you shoot us?' Again, the soldiers were polite and deferential. 'No, sir, we cannot do that, sir.' They were behaving as if they knew that what they were doing was dishonourable, but the deed had to be done on orders from the top. The detained Indo-Fijian members remained at Borron House until they were released after a further two days of captivity. They did not know it then, but the rupture that had taken place at Vieuto would take its toll in the decades ahead. The lights were going out all over Fiji, and they would not be lit again for a long time.

The symbolism of separation would remain with Jai Ram Reddy for a very long time, a rare, cherished moment of ethnic unity being torn 
asunder by the power of guns at the behest of people pursuing their own private agendas. Reddy remembers vividly the heart-rending scene of Adi Kuini Bavadra weeping inconsolably as the Indo-Fijian members were being driven away from Vieuto. He recalls a heated argument with one of the parliamentarians — probably Krishna Datt — about mounting a hunger strike; the Reserve Bank Governor Savenaca Siwatibau visiting Reddy's residence to console Chandra and to generally offer assistance, if it was needed; and, movingly, his Fijian secretary in the Attorney General's chambers quietly packing his private papers in his briefcase and sending them to his home. Such loyalty at such a time touched Reddy deeply. He had always had excellent relations with his staff. In the Attorney General's office, the staff appreciated the 'courtesy and respect with which they were treated,' Ratu Joni Madraiwiwi recalled. Reddy never spoke in Hindi to third parties in the presence of Fijian staff. 'A minor detail perhaps,' noted Ratu Joni, 'but one which struck those concerned quite profoundly.' And there were some devoted friends and supporters from the west planning the safest way to get Reddy back to his home in Lautoka: by crane, one of them suggested in all seriousness! Most of all, he recalls pondering the 'humiliation' and 'debilitation' that incarceration can cause. As prosecutor, he had sent hundreds of people to jail over many years, but this was the first time he realized what the loss of freedom and dignity actually meant for human beings languishing behind bars: the utter powerlessness, the helplessness, and the impotent rage.

The news of the 'coop,' as coup was invariably pronounced in the early days, spread like wild sugar cane fire. Wooden shutters went up in the city, the supermarkets were clogged with people hurriedly buying emergency supplies, and overflowing buses screeched out of town. Government offices emptied, and parents rushed to schools to take their children home. Commandeered government four wheel drives appeared on the streets with rifle-carrying soldiers in them and balaclava-clad sharp shooters atop strategic buildings and at key installations. Among those I saw in military uniform was Ratu Finau Mara, the Alliance Prime Minister's son. He was 
in the lobby of the parliamentary chamber when the soldiers arrived. He was later joined outside parliament by Captain Isikeli Mataitoga. Anxious crowds chanting pro-democracy slogans and carrying anti-coup placards gathered behind rolls of barbed wire at Vieuto and Borron House to catch a glimpse of their leaders incarcerated inside and to comfort each other amidst the swirling confusion. In the west, shops and schools closed, and supermarkets and hotels ran out of smaller currency for changing bigger denominations. Capital was fleeing the country. ${ }^{9}$

At around 11 am, Radio Fiji finally announced the news of the military takeover. Colonel Rabuka, it said, had gone to Government House to see the Governor General and to seek recognition of the military action and the overthrow of the Bavadra government. A caretaker government was to be named shortly, and the public was urged to 'remain calm and continue with their daily work.' The Fijian people especially were asked not take advantage of the volatile situation in the country. As dusk settled over a cowering, shaken city, the reality finally hit most people that something untoward, something huge, had taken place. Adi Kuini Bavadra spoke for many when she said, 'This is just not Fiji. It is another banana republic. Democracy is dead, and it is very unfortunate.' Jeff Penneberthy, of Time magazine, wrote: 'Another colonel, another coup, another small country with its constitution and the rule of law usurped at the point of a gun. The difference is that no one had imagined it happening in this arcadian region and in a place that had become a model of democracy for its emerging region. ${ }^{10}$

Perhaps more than anything else, the coup destroyed the sense of innocence with which the people of Fiji had approached public affairs until then. Despite all the tensions and aggravations that came with the characteristically red-hot election campaigns, a military takeover of government was not on the mental radar of most people. Coups always happened elsewhere, in Africa and Latin America and other such ill-fated places. From 1987, they would occupy a permanent place at the back of the minds of most Fiji citizens. A coup culture was born. 


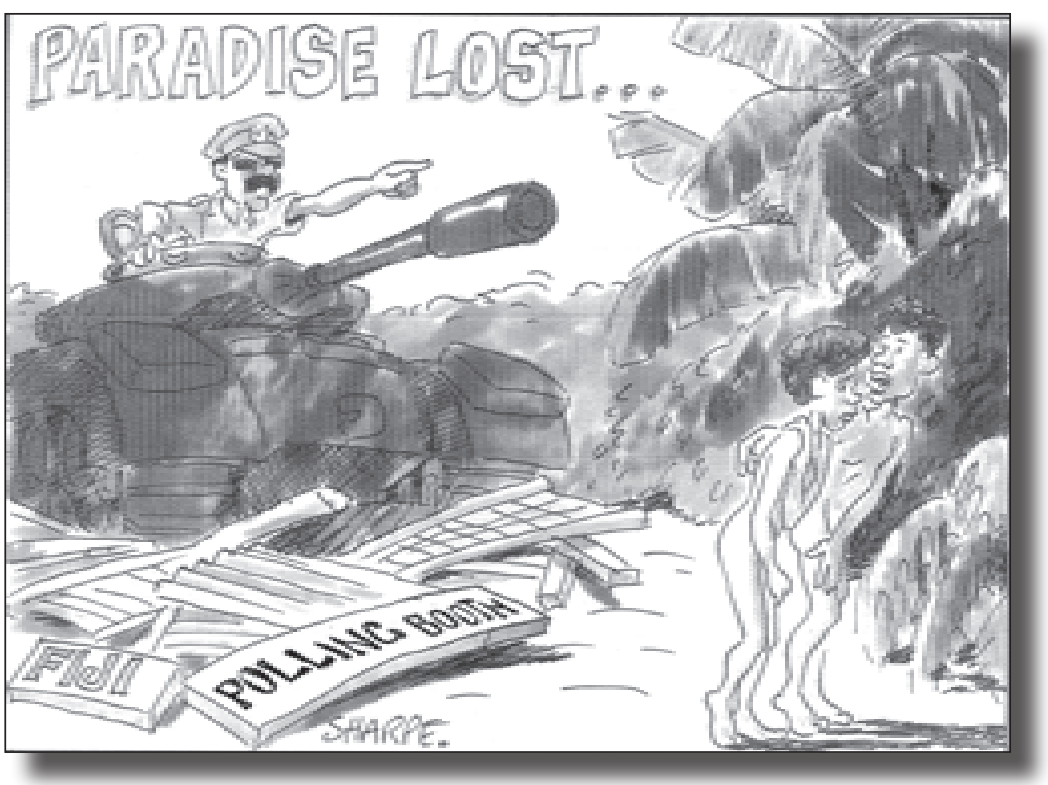

Two views of the coup reproduced by permission. Courtesy of Mr Ian Sharpe and Mr Geoff Pryor.

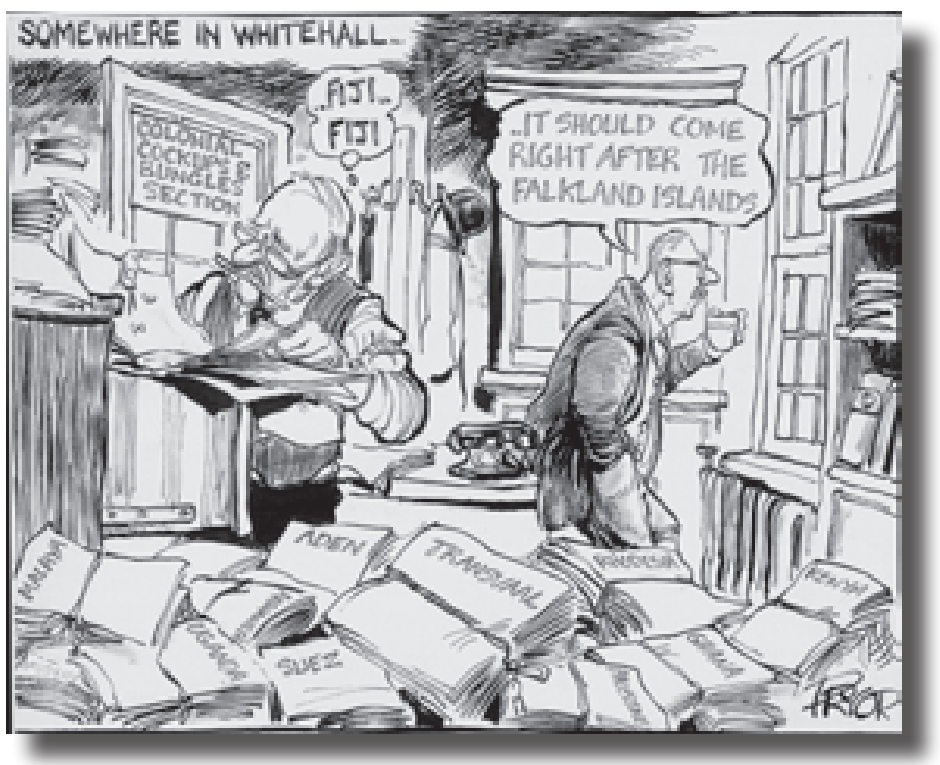


THE ROAD TO MAY 14

As soon as the results of the elections became known, Dr Bavadra proclaimed himself ready and able to form the new government. Coalition parliamentarian Navin Maharaj's factory at Vatuwaqa, an industrial suburb of Suva, became the impromptu Coalition headquarters where elected members gathered for briefings and to elect the new ministers. Dr Bavadra rang Reddy and pleaded with him to join the new government as its Attorney General. Reddy hesitated. Having made the break in 1984, he thought he had left national politics for good. He was not interested in pursuing a parliamentary career again although his critics alleged, as they still do, that he had actually engineered the invitation and accepted it with alacrity when it came. That was someone's figment of imagination, but the pressure on him was enormous, and it could not be ignored. 'You helped put the Coalition together, and now you must go in and make it work,' was how one supporter put it to Reddy. ${ }^{11}$ It was then that Reddy realized that he had no choice but to join the new administration. The news of Reddy's acceptance was received with much relief by the Indo-Fijian community, for he was one truly recognized and experienced political leader in the new government they knew and could trust. Harish Sharma was another. Reddy's induction into the new Cabinet angered the Alliance. 'What made the Alliance camp irate,' wrote Nemani Delaibatiki, 'was that Mr Reddy apparently had gone into political inactivity [but] like a master tactician he worked his way back and became one of the powerful key people behind Prime Minister Timoci Bavadra. ${ }^{\prime 2}$ For that reason, Reddy would become the chief target of Fijian protest movements, the principal focus of their wrath and retribution. Reddy was the man the Fijian nationalists loved to hate more than any other leader.

Thoughtful people from across the political divide were happy that Reddy was in the government to contribute a calming presence in it. In the folder he was carrying on the day of the coup were many letters of congratulations he had received from a wide cross-section of the community. Haji Mohammed Hanif wrote: 'I am sure that with your appointment, the 
people of our nation can be assured of justice during your term.' Sir Robert Munro, a leading Suva lawyer and sometime President of the Senate, wrote: 'The profession and the public will expect much of you after so many disastrous years and I, and my partners, are confident that you will clean the Augean stable.' Former Alliance Finance Minister Wesley Barrett said 'in all sincerity' that the 'Nation was fortunate that you have accepted this post of grave responsibility at considerable financial sacrifice.' Fiji High Commissioner to New Zealand, Satyanand, said 'they could not have found a better person for the position.' Justice Sir Graham Speight, later President of the Fiji Court of Appeal, wrote to 'express my delight in hearing of your acceptance of the offices of Attorney General and Minister of Justice. The country is indeed fortunate in having a man of your calibre available in such a crucial role at such an important time in its history.' 'Our prayers will always be with you,' wrote the former Indian High Commissioner to Fiji, CP Ravindranathan. 'The tasks ahead are immense and liable to continue to test your political skills, but we know that you will face them with serenity — and succeed.' Moving words, but fate willed otherwise.

In the negotiations over the allocation of portfolios, NFP was led by Reddy, his law partner Bhupendra Patel, and campaign manager Dijendra Singh. But there was not much consultation within the party about power sharing arrangements in the new government being formed. The party hierarchs were on the outer. Harish Sharma, who was still officially the parliamentary leader of the NFP, recalls being 'told' by 'two outsiders' (Patel and Singh: outsiders in the sense that neither of them was in Parliament, or had even contested the election) that he would be 'offered' the position of Deputy Prime Minister. Even as a senior member of the NFP, he had been left out of the negotiations. He felt especially dismayed because the initial coalition talks between NFP and Labour had begun with him, he recalled, but his injured pride mattered little, he said without biterness. His party and his community were beginning a new and historic journey, and he was happy to be a part of a historic moment. ${ }^{13}$ When the final list of cabinet members was announced, Labour emerged the clear winner by a country mile. 
NFP-FLP COALITION CABINET

Portfolio

Name

Party

Prime Minister

T Bavadra

FLP

Home Affairs

T. Bavadra

FLP

Fijian Affairs

T. Bavadra

FLP

Education

T. Baba

FLP

Primary Industries

J Nacola

FLP

Labour

J Kalou

FLP

Land \& Mineral Resources

M. Volavola

FLP

Foreign Affairs

K. Datt

FLP

Finance \& Planning

M. Chaudhry

FLP

Trade \& Industry

N. Maharaj

FLP

Health \& Social Welfare

S. Nandan

FLP

Deputy PM \& Information

H. Sharma

NFP

Transport \& Communication

A. Bhamji

NFP

Attorney General \& Justice

JR Reddy

NFP

\section{Ministers of State}

Fijian Affairs

F. Ralogaivou

FLP

Works

C. Work

FLP

Rural Dev \& Housing

T. Sukunaivalu

NFP 


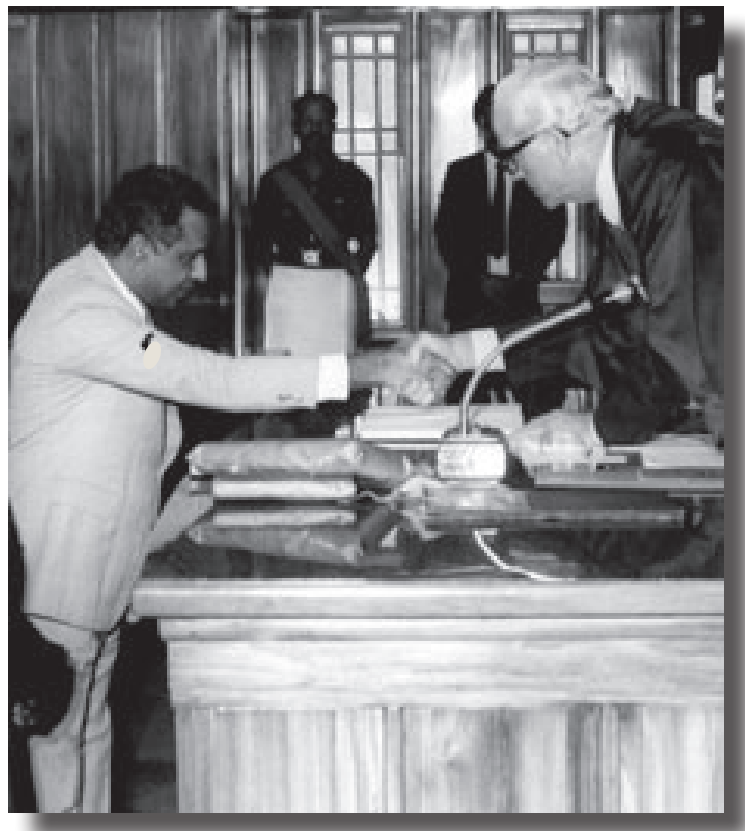

Being sworn in as Attorney General.

Folder containing congratulatory messages on Reddy's appointment as Attorney General.

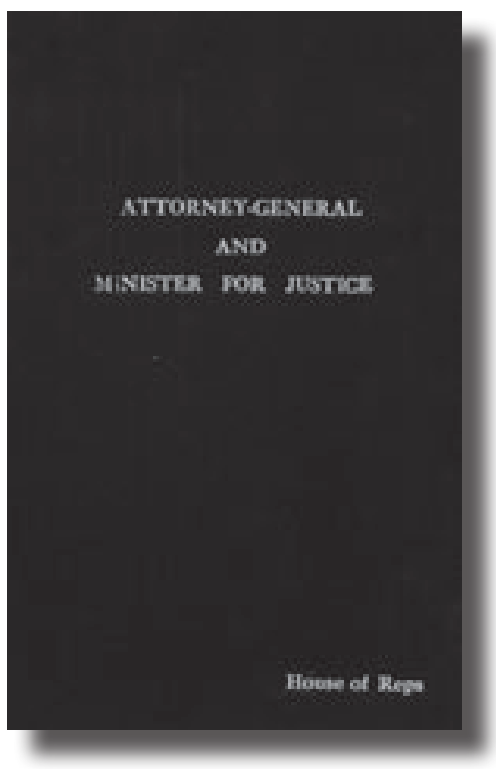


The NFP's under-representation in the cabinet is evident, but there were other considerations which carried more weight. Racial balance was one of them. For the government to be acceptable to Fijians, everyone including Reddy realized, the cabinet had to be racially balanced, with Fijian members occupying a suitable number of senior positions. And the best Fijians were in Labour. The most experienced Fijian parliamentarian of them all, though, and one of the most loyal and longest serving of the NFP members, indeed its vice president, Temo Sukunaivalu, was given only a junior portfolio. Labour would not concede the Fijian constituency to the NFP at any cost, and NFP did not insist. It will be recalled, for instance, that the NFP Vice President Koresi Matatolu had to be sacrificed to accommodate Dr Bavadra. For Reddy, whether the Indo-Fijian members of government were Labour or NFP did not really matter much. On questions of fundamental importance to the Indo-Fijian community, their interests were identical. It was crucial to make the Coalition work, and if the interests of the party had to be subordinated to the larger interests of the community and the nation, that sacrifice had to be made for the greater good; and he would do so gladly. But his vision was not always shared by the Labour members for many of whom the interests of their party were paramount. Mahendra Chaudhry's game plan, as he said over and over again, was to 'finish NFP off.' Some in the NFP quietly questioned the lop-sided nature of the Coalition government. Former Alliance minister James Shankar Singh was an eminently suitable cabinet material, it was said, and there were others equally qualified who were overlooked. But none dared to raise their dissent in public. What Reddy said, went.

'How is the government doing, Mr Reddy,' Jag Nadan, a party supporter, asked the NFP leader at a private gathering in Suva soon after it was sworn in. 'If we last a month, we will survive,' Reddy replied. He probably had in mind both the internal cohesion of the government as well as threats from outside. From the balcony of the Attorney General's chambers, he saw the ominous storm clouds gathering on the horizon as protest marches were orchestrated around the country. Ratu Joni Madraiwiwi, then a young law- 
yer in the Attorney General's office, detected in Reddy's mood at the time not a spirit of quiet achievement, but a deep sense of foreboding. In cabinet, Reddy urged caution and prudence, to make haste slowly. But Labour members, who were now clearly calling the shots, had other ideas. They had the 'mandate' of the people to govern with policies they had promised, and the sooner this was done the better. There was an air of 'raring to go' in the Labour camp. An early impression of purposefulness and direction had to be made quickly. This was not the last time that Labour would vigorously invoke the mantra of mandate, ultimately to its detriment. The mandate of Parliament was one among many mandates in the country: the Native Land Trust Board had its mandate, as had the Great Council of Chiefs, and the military. Negotiating one mandate among many required true statesmanship.

The government announced a number of small measures immediately, such as the removal of hospital charges, free bus service to pensioners and ex-servicemen, and cancellation of customs duty from all staple food items. Tupeni Baba, among others, talked about the need quickly to investigate past 'corrupt' practices of the Alliance government and to expose them to get the people behind the new government. The use and alleged abuse of the Prime Minister's Hurricane Relief Fund came in for special mention, as well as the controversy surrounding the leasing out to the Education Department of Mara family's property, the Marella House, causing great irritation, and concern, among Alliance members. 'They should have been preparing to govern, not digging up dirt on others,' was how one Alliance party member put it to me. Every issue of public policy was elevated to the level of principle, to be defended with blood, at all cost and against all odds. Power can have that effect on some people, especially those who acquire it for the first time after generations in the wilderness.

The new government's enthusiasm was understandable. This was the first time ever in Fijian history that there had been a change of government. It was the first time, too, that a genuinely multiracial government was in place in which Indo-Fijians had a fair share of power. And the Coalition 
proved adept at playing the game Alliance had played all those years it was in power: the game of patronage. When it came to selecting the Speaker of the House, it chose Ratu William Toganivalu, a senior member of the Alliance Party perennially in financial need and matanivanua, traditional herald, to Roko Tui Bau. Toganivalu's acceptance stunned the Alliance. Only at the last minute was Ratu Willie (as he was affectionately known) 'persuaded' by his financier, Jim Ah Koy, not to accept the nomination, or he would have to face the consequences of his action. Ratu Willie, indebted to Ah Koy, had no option but to decline. ${ }^{14}$ Ah Koy was the financial advisor to many Alliance leaders, including Ratu Mara. But not Militoni Leweniqila, the big, life-loving former Alliance minister from Macuata, and a regular habitué of the Union Club in Suva, who accepted the offer after being persuaded by his close friend Maan Singh, former Suva Mayor and a fellow poker player. Militoni then proceeded promptly to accuse his party of petulant behaviour since their loss, for 'displaying the law of the jungle. ${ }^{35}$ Fijians gravitate to power very quickly, an astute observer of the Fijian scene once told me. Abstract principles matter little to them, and loyalty is always contingent, not absolute or permanent. Pragmatism is what they are all about. That, after all, was how things were done in pre-colonial times. It was feared other notable Alliance establishmentarians might similarly be enticed to lend their support to the new government in return for perks and privileges of office or overseas diplomatic appointments. The urgency to stop the potential slippage only intensified with time.

Opposition to the Coalition government had begun almost as soon as its victory was announced. The first signs emerged from among the ranks of the defeated Alliance politicians. A meeting called ostensibly to analyze the reasons for the Alliance's failure in the elections was held in Raiwaqa, one of the poorer, predominantly Fijian suburbs of Suva. It was attended by Filipe Bole, a former senior civil servant and minister, Qoriniasi Bale, former Attorney General, Ratu Finau Mara, the former Prime Minister's eldest son, Taniela Veitata, Alliance parliamentarian and rampaging trade unionist, and many other lesser figures of nationalist bent. Even before the 
full Coalition government had been sworn in, the eight hundred-strong meeting resolved to petition the Governor General to change the constitution in favor of a permanent Fijian-dominated one. To these Fijians, even very highly educated ones, the idea of a government not headed by an 'acceptable' Fijian from the ranks of the Fijian establishment, and one committed to genuine multiracialism and power sharing, was an anathema. Feeding upon, and fostering, latent ethnic prejudices and fears of the Fijian people caught up in a changing environment they did not understand, the meeting sent out a powerful signal of developing opposition which was picked up by others around the country hostile to the Coalition government. Bole and Bale, two highly educated professionals, couldn't possibly be wrong. Ordinary Fijian people looked up to them for leadership and guidance, especially in moments of crisis such as the one now unfolding.

In Tavua, on the other side of Viti Levu, the Tui Tavua, Ratu Ovini Bokini, a relative of Bole's and a staunch supporter of the Fijian Association (as he had to be by virtue of his traditional position), instructed his people to erect a road block on the King's Highway in protest against the new government. To emphasize his point, he asked them to place forty-four gallon drums, wooden planks and shrubbery on the road right in front of the local police station. Placards displayed the message: 'Labour Government is Lowest in the World,' 'Change the Government,' 'We Hate Coalition, We Don't Need it,' 'Change It, Change It.. ${ }^{16}$ The local police chief, in an act which smacked of collusion with the protesters, refused to apprehend the offenders and, instead led a team of officers to the chiefly bure to offer a sevusevu, traditional offering, to Ratu Ovini to persuade his supporters to disband. The police chief was later reprimanded for dereliction of duty, but by then Bokini had made his point: it was he, and not the new government in Suva, who wielded real power where and when it mattered. The Fiji Times wrote: 'We find it disturbing that such illegal activity can take place under the noses of police officers, The so-called demonstrators' lack of respect for the guardians of the law is disconcerting. ${ }^{, 17}$ It was, in truth, more than disconcerting; it was frightening. 
All this was just the beginning. The news from Tavua and of similar incidents elsewhere emboldened others contemplating similar acts of protest. On 21 April, at Viseisei, Dr Bavadra's own village, two thousand Fijians gathered to share views and consider further plans for action against the Coalition government. ${ }^{18}$ Among those present at the meeting were many prominent Fijians and Alliance members, including Tui Vuda, Ratu Josaia Tavaiqia, David Pickering, Aporosa Rakoto, Jona Qio, Jone Veisamasama, Inoke Tabua and Jone Koroitamana. The chief organizer of the meeting was Apisai Tora, a former NFP member of Parliament, and a longtime champion of the interests and aspirations of western Fijians, of whom, ironically, Dr Bavadra was one himself. Tora was also a Fijian nationalist who had petitioned the Colonial Office in the 1960 s to recognize the principle of Fijian paramountcy. He had cabled Ratu Mara to walk out of the constitutional conference in 1965 if the 'Colonial Office wallahs' insisted on the introduction of common roll. Then in 1969, he joined the National Federation Party and later the Alliance. Before his political career was over, he would form several parties (Party of National Unity, All National Congress, Bai Kai Viti, among others) to advance this cause or that, but with himself squarely at the centre of things. He was willing to serve under Koya, wrote four residents of Nailuva, Suva, but was 'now agitating against a Fijian Prime Minister who is supported by a larger percentage of Fijian votes than NFP ever had.' 'Where were his concerns then,' they asked. 'Why did he not join Mr Butadroka and ask that the constitution be changed?' 19 Tora was as complex and contradictory a character as there ever was in Fijian politics. His only consistency, as he would say of his opponents, was his inconsistency. At the Viseisei meeting, he provided the ideological and political justification for ousting the Coalition government.

Tora claimed the Coalition victory had breached a sacred principle of Fijian politics. That is, while Fiji was to be home to various communities, there was a 'clear understanding that the interests of the indigenous Fijians would be paramount in Fiji.' That, he claimed, was enshrined in the Deed 
of Cession. Tora then cited the 1933 Great Council of Chiefs resolution that the immigrant Indian population should neither directly or directly have any part in the control of the direction of matters affecting the interests of the Fijian race.' Tora said that Siddiq Koya, on behalf of the Indo-Fijian community, had accepted a political settlement at Independence which recognized the earlier understandings of how things were to be done in Fiji. That is, he had tacitly accepted the principle of Fijian paramountcy. Jai Ram Reddy, Tora continued, had disregarded 'the constitutional understanding' by seeking to defeat the Alliance Party in 1982. The 'constitutional understanding' was a figment of Tora's imagination. Dr Bavadra was merely the 'figurehead' of 'Jai Ram Reddy's party.' For Tora, Reddy 'was the real Prime Minister and Bavadra [was] his shield.' 'See how quickly Reddy was put in the Bavadra's cabinet.' To many nationalist Fijians, Reddy's name was like a red rag to an enraged bull. 'Our independence is shattered,' Tora lamented. 'Upon us is imposed a new colonialism, not from outside but from within our own country by those who arrived here with no rights and were given full rights by us, the taukei.'

A petition was signed by fourteen leading chiefs from western Viti Levu expressing no confidence in the Coalition government and calling for change so that Fijians 'must always control the government to safeguard their special status and rights.' Democracy should be abolished 'if it is to become the vehicle for eroding the taukei's entrenched position in Fiji's political structure. ${ }^{20}$ 'I cannot imagine us listening to government leaders who are not chiefs,' said Bulou Eta Vosailagi from the chiefly village of Nakuruvakarua in Sigatoka. 'I ask the chiefs here, and all of us, to support, to bring back the control of our government to the Fijian chiefs.' They would march and let their views be known whether they were given the permit to protest or not. With the protest movement gaining momentum rapidly, the disparate groups with divergent agendas but a common goal came under the overarching umbrella organization called the 'Taukei Movement.' The name was simple but catchy. The goal was to derail the 'Indian-dominated' Coalition government. 
Encouraged by their efforts in the west, the Taukei Movement staged a massive and menacing three-thousand strong march through Suva on 24 April, beginning at Suva Market and ending at Government House. Standing outside the old Suva Town Hall, I felt a strange sensation of fear of a kind I had never felt before. I had never imagined that Fiji could become like this. I had never seen anything like it before, people bussed in their hundreds from the heartland of southeastern Viti Levu, pure Butadroka country, outwardly cheerful and restrained but boiling inside. A slight provocation, and the place could have exploded, with what consequences it was simply too painful to contemplate. To see some people I knew among the protesters, educated middle class, outwardly multiracial in outlook, compounded my distress. The placards said it all: 'Fiji for Fijians,' 'Ka Idia Go Back,' 'It is Time to Fight for Our Rights,' 'River of No Return for Fijians,' 'Noqu Kalou, Noqu Vanua,' (Our God, Our Land),' 'Bavadra the Boat, Reddy the Captain,' 'Reddy the Gun, Bavadra the Bullet,' 'Jai Ram Reddy, You Don't Belong Here.' ${ }^{21}$. The last time Fiji had witnessed such a scene was in the aftermath of the 1968 by-elections when the Federation Party had returned to the Legislative Council with an increased majority.

While the Coalition government watched the worrying unfolding events with outward calm, the nationalist protestors were busy drawing up plans to reduce the country to chaos. ${ }^{22}$ These included burning cane fields in the west at the rate of six per week, blowing up bridges and burning down shops in Suva, torching Nausori and killing enough Indians to precipitate a state of emergency. What if their acts led to violence, Australian journalist Marian Wilkinson asked Tora. 'If that is God's will, so be it,' he replied chillingly. ${ }^{23}$ Reddy's law firm was firebombed as part of the destabilizing plan, which led a visibly distressed Tui Vuda, Ratu Josaia Tavaiqia, who knew and liked and admired Reddy, to completely distance himself from the Taukei Movement. Senator Jona Qio was charged with arson and Apisai Tora was charged for breaching the Public Order Act for inciting racial ill hatred. Butadroka had been sent to jail under the Act a few years earlier. But no protest marches were banned because of the fear that a ban 
would play straight into the hands of the nationalists: Fijians being silenced in their own country. There was also confidence, misplaced as it turned out to be, among some in the government that the protests would eventually run out of steam.

To the claims of the nationalists that the Fijian people had lost everything, that their cherished rights were now in danger, Dr Bavadra pleaded for calm and introspection and a chance for the Coalition to prove its mettle. 'It is unthinkable that we would sacrifice the welfare of our own people, so I am truly saddened by the fact that some of our own people are suggesting that I would allow my government to put the welfare of Fijians at risk.' He continued: 'Let us not yield to the designs of a disgruntled few. Let us not sacrifice the future of our beloved children to the greed of a small minority. Let us not tarnish the image of tolerance and goodwill for which Fiji is renowned. Instead, let us stand firm in the face of adversity.' 'Where,' Dr Bavadra asked, was 'justice and reason in trying to destabilize and remove a government as soon as it has been elected? Is the government to be denied the opportunity to prove itself? Is the government to be stopped from proving its commitment to the people? Will you judge the government before we have even had the chance to perform? ${ }^{24}$

The Governor General, Ratu Sir Penaia Ganilau, also issued a similar message to the 'chiefs and people of Fiji' to uphold the rule of law. 'Nothing good,' he said, could 'come out of unlawful acts or actions that are designed to destabilize the Coalition government.' The unlawful marches would only prevent the government to 'show their leadership potential,' 'disrupt the progress and achievement of the Alliance government of the last sixteen years,' and 'forever change Fiji's image and relationships at regional and international levels. ${ }^{25}$ Former Governor General and Vunivalu of Bau, Ratu Sir George Cakobau, similarly urged everyone to respect the 'peoples' choice of a new government.' The only other person of consequence on the Fijian scene, Ratu Sir Kamisese Mara, maintained what the Fiji Times called a 'conspicuous silence. ${ }^{26}$ And the Alliance party, too: 'Apart from the briefest of statements declaring that it had nothing to do with the anti- 
Government foment, the Alliance has remained extremely quiet.' Maan Singh, President of the Suva branch of the Indian Alliance, expressed the frustration of many of his community in his party. 'All along the Alliance has propagated tolerance, harmony, peace, stability and security. 'It's good for all. Now what has happened to all that?' Ratu Mara, he said, should have shown some respect to Indian members of the Alliance party, which of late he hadn't, understandably dismayed about their poor pulling power in the Indo-Fijian community. ${ }^{27}$

Ratu Mara's silence was predictable. He had maintained reticence on similar occasions in the past. In 1968, for instance, when the country teetered on the brink of racial riots, he had retreated to Lau where he remained incommunicado for a while. In 1982, he had abstained on the racially inflammatory resolutions passed by the Great Council of Chiefs at Bau. Mara had conceded defeat in a properly constitutional manner, but there was no doubt in anyone's mind that his rejection at the polls had injured his pride and hurt him deeply. The sense of invincibility and indispensability to the nation he had led for so long was shattered. Those who had rejected him should now pay the price for their 'foolhardiness', he probably felt. That certainly was the Indian High Commissioner TP Sreenivasan's impression who thought Mara was the 'bitterest enemy of the Bavadra government' because 'he saw himself as the rightful owner of the Fijian throne. ${ }^{28}$ Beyond that, Mara was probably just as much in the dark as the rest of the country about what all the protests might lead to. In those circumstances, he probably thought it wise to keep his counsel to himself, keep his powder dry, and his options open. A chief must be where his or her people are, he often said. He had already asked his people to support the new government. 'I couldn't see what else I could say further than that. Do I have to repeat it ad nauseum? ${ }^{29}$

Away from the public eye, at Savura Creek, Wailoku, Lt Col. Sitiveni Rabuka began training a handful of trusted soldiers for a military coup without actually divulging his true intentions to them until the last minute. Among those who knew of the plans was Isireli Dugu, who led the masked 
commandos into Parliament on 14 May. Another member of the close knit circle was Captain Matai Kabara who had returned from training in the United States with a plan, it was speculated, on how to stage a coup. Rabuka portrayed himself as a lone wolf, but he was in fact part of a larger network, according to Ratu Inoke Kubuabola, secretary of the South Pacific Bible Society and an ardent nationalist, who said that 'we asked Rabuka to prepare that [military] side and when the time [comes], when we reach a stage when he must step in, he must be ready to step in.' The decision to execute the coup was 'taken in my office at the Bible Society with Rabuka. ${ }^{30}$ The original plan, according to Kubuabola, had been to use a roll-on, roll-off ship at Suva Harbour to transport the detained government members to the remote island of Makogai in the Lomaiviti Sea which had once housed Fiji's only leprosy hospital. The plan had to be revised and the coup executed a day earlier because parliament was not sitting on the designated day. So the detained parliamentarians were taken first to the Queen Elizabeth Barracks, then Vieuto and finally Borron House. Apparently a few other people were in the know, including Militoni Leweniqila, the new Speaker of the House, who recalled telling Rabuka that if you are going to successfully execute a coup, you may have to take some lives because no one believes a coup is possible in Fiji. ${ }^{31}$ No one on the government side seemed to have any inkling of what was afoot although it was rumoured at the time that Police Commissioner PU Raman had conveyed an intelligence report on the impending trouble to some in the government.

Rabuka justified his military coup on a number of grounds, none of which now hold water; they did not do so even then. He cited law and order as an important reason. ${ }^{32}$ He had acted in the national interest to prevent madness and mayhem planned by the Taukei Movement. But duty, surely, demanded that he assist the security forces in apprehending the would-be arsonists instead of joining their ranks and becoming their leader. The key coup supporters, including Inoke Kubuabola, Tomasi Raikivi, Viliame Gonelevu, Apisai Tora, Taniela Veitata, and Filipe Bole, became his closest advisers and members of his Council of State. This was a carefully planned, 
well orchestrated coup. Neither was Rabuka's assertion that Fijian interests and institutions were imperiled by the election of the Coalition government. No government, not even a Fijian-dominated one, could touch any legislation affecting Fijian interests without the consent of the nominees in the Senate of the Great Council of Chiefs. His excuses were just that: excuses, and they kept changing as the context and his mood changed.

At the time of the coup, Rabuka portrayed himself as simply a selfless soldier acting alone to save his people from the evil designs of the Coalition government. He even claimed divine inspiration for his plans, as illegal usurpers of power usually do. The tee-shirts proclaimed: 'Steve: The Hand of God,' 'Fiji: God is With Us.' Rabuka was a handsome young man with a massive handlebar moustache and a strong voice, confident in his bearing, convinced of his mission as the messiah of his people and determined to succeed. He reveled in the glory and attention that came his way, untroubled by doubts about the genie his coup had unleashed. In the mid-1990s, as things began to unravel and his leadership was challenged, he invoked the Nuremberg principle of defense: that he had obeyed orders to do what he did. He once told me that he would one day like to write a book with such a title as 'The Kleenax Man,' or 'The Fall Guy' for the manner in which he was used and discarded by some Fijian chiefs who had their own private political ambitions. ${ }^{33}$ Specifically, he implicated Ratu Mara in the coup machinations.

Ratu Mara always maintained his innocence, saying that he joined the coup administration purely out of the noblest of motives. His house was on fire, and he could not stand idly by and see it burnt down, which led some to quip — perhaps it was Judge Kishore Govind — that in that event, he should have joined the firefighters, not the arsonists. Jai Ram Reddy and, indeed, most people in Fiji are convinced that a person of Ratu Mara's stature, experience and connections could not but have known what was afoot. Many people would probably see a grain of truth in Indian High Commissioner Sreenivasan's assertion that Mara had to be in the loop 'because I knew that nothing important could happen in Fiji without his blessings. ${ }^{34}$ I have 
seen sworn statements from Fijians close to the action expressly stating that people were sent to inform Ratu Mara about what was coming. ${ }^{35}$ However, it was not so much about what he knew or did not know beforehand that is important in the end. It was what he actually did at the time that matters. And the simple truth is that he did very little in defense of democracy at the moment of its greatest danger. It is in that regard that he failed as a national leader. Dr Martin Luther King's words are apposite: 'The ultimate measure of a man is not where he stands in moments of comfort, but where he stands at times of challenge and controversy.' Whatever his motivations, Mara's joining the coup cabinet, Time Magazine said, 'lent the new regime weight and substance, if not legitimacy, giving the 'new civilian regime its best chance of gaining international recognition. ${ }^{36}$

The other chief upon whom suspicion focused was the Governor General, Ratu Sir Penaia Ganilau, Rabuka's own paramount chief and patron. ${ }^{37}$ Again, there is no direct evidence linking him to the coup plotters, and some have even defended his innocence, ${ }^{38}$ but proclamations of his innocence must be treated with skepticism. Daryl Tarte makes the persuasive observation that Ratu Penaia was torn. 'Throughout his career he had expressed concern about the diminishing influence of Fijians in their own land, while at the same time upholding the principles of equal opportunity for all. His instinct for the survival and domination of Fijians was a powerful force that could not be ignored. ${ }^{39}$ Whether that emotion was strong enough for him to lean in Rabuka's direction remains the unanswered question. It probably was. They were all implicated by degrees. It was guilt by association, Reddy believes. None of them wanted power to be exercised by anyone else except by the Fijians, preferably high chiefs.

\section{D-DAY AND WEEK AFTER}

At Borron House, the Coalition members were cut off from the world. There was both frustration and fear. ${ }^{40} \mathrm{~A}$ hunger strike was begun but soon aborted. Fiji was not India under the British rule, someone said, where civilized protocols were observed even in the gravest of circumstances. Here, no 
one would care if they died. It was not for no reason that the islands were once known as the 'Cannibal Isles.' Speaker Militoni Leweniqila tried to lighten the mood of the captives with a couple of bottles of whisky and tall tales, but despair and desperation filled the general atmosphere. On 19 May, all the detained Indo-Fijian Parliamentarians wrote a signed handwritten letter to the Governor General:

The Indian members of the Coalition have been incarcerated at Borron House since the early hours of Sunday, 17th May, 1987. We were removed here forcibly and against the wishes of both ourselves and our non-Indian colleagues by the military. As of 18th of May, visits by our wives have been discontinued. We have no way of communicating with the outside world and do not know of our present position and future.

It has come to our attention through news broadcast that you have sworn in the military commander who assumed power by the use of force and in flagrant violation of the country's constitution. We have learnt with shock that you have sworn in the Military Commander as the chairman of the Council of Ministers, the remaining members of which we understand will be sworn in later today. We have also learnt with alarm that it is proposed to put in place a new constitution which will deprive the Indian community of their rights enshrined in the present constitution which was negotiated and agreed upon in good faith at the London conference.

The constitution is a grant from Her Majesty to all the people of Fiji. It is unprecedented that those rights are now being taken away as a result of unilateral decision of those who assumed power illegally. Your Excellency is aware that not a single bona fide Indian leader is free to advise or lead his people. This whole exercise borders on deceit and treachery. We, the Indians members, lodge the strongest protest to you against this treatment of a whole community. 
Surely, we are entitled to expect a little more and we would like to know as a matter of urgency our position and the future course you propose as Her Majesty's representative in this country. Our particular concern at this point is the question of release and the timing so that we may be with our families and our people in the hour of their greatest need. It seems that the others that we trusted and relied upon have deserted them.

As we see it, we were separated from our non-Indian colleagues deliberately as part of an orchestrated anti-Indian campaign by the military ruler and those who are behind him. We are equally concerned for Dr Bavadra and our other colleagues presently held at Vieuto.

In the name of humanity, can we have an answer from you please?

Whether the Governor General ever saw the letter is not known. He was himself caught in a swirling pool of confusion. Soon after taking over Parliament, Rabuka went up to Government House to personally inform Ratu Penaia of the momentous event which had just taken place. He pleaded with him to 'please distance yourself to see what it is we as your subjects can do to take over leadership of this land and the Fijian people until such time as we think that you should be invited to resume your leadership to a position which is rightfully yours and which was bestowed upon you by our Father and God Almighty.41 Rabuka spoke feelingly and respectfully as Ganilau was his traditional chief and the two had been 'very, very close together' for some time. Ratu Penaia responded only with mild rebuke rather than consternation, as the occasion demanded. 'What have you done?' he asked. 'You mean I have no job?' He added, 'Couldn't you have given them [the Coalition] time to carry out their policies? Perhaps they would have shown us in a few months time they were incapable of running the country anyway?' And 'Have you thought of what you are going to do next?'“Good luck,' the Governor General is reported to have said to Rabuka. 'I hope you know what you are doing. ${ }^{32}$ 
Rabuka then returned to Government Buildings to meet with the members of the diplomatic corps at 2 in the afternoon. ${ }^{43}$ Flanked by former Alliance ministers Ahmed Ali and Peter Stinson, he announced that the 1970 constitution had been abrogated, the three most senior police officers sacked (Police Commissioner PU Raman, his deputy, Mosese Tuisawau, and Assistant Commissioner Chandra Deo Sharma), and Fiji Military Forces Commander Ratu Epeli Nailatikau, who was away in Australia on an official visit, and Lt Col. Jim Sanday, the Chief of Staff, suspended. Sanday left Fiji for good soon afterwards and refused many offers over the years to rejoin the military. Indeed, he flatly contradicted the reasons Rabuka publicly gave for the coup. ${ }^{44}$ Ratu Epeli, ever adaptable and with a well known taste for the good life, managed to keep himself gainfully employed as a diplomat and a politician (and as a minister in the military interim administration after the 2006 coup). In May 2009, he accepted an invitation from the military to become the Vice President of Fiji, and in October, was appointed President. Such are the politics of survival in Fiji.

The news of the composition of the new interim administration came early on the morning of 15 May. Rabuka was the only military representative on the Council of Ministers. The rest were members of the Taukei Movement and the former Alliance government. They included Ratu William Toganivalu, Ratu Josaia Tavaiqia, Peter Stinson, Dr Ahmed Ali, Dr Apenisa Kurusiqila, Narsi Raniga, Filipe Bole, Viliame Gonelevu, Timoci Vesikula, Kelemedi Bulewa, Rev. Tomasi Raikivi, Adi Litia Cakobau and Jone Veisamasama, the secretary of the Alliance Party. The most surprising inclusion was Ratu Sir Kamisese Mara. 'I accept,' is what Mara told Rabuka when offered a position. 'I nearly hit the roof as I jumped and cheered,' Rabuka recalled. Well he might: with Mara on board, Rabuka had won the first round. For his part, Ratu Mara said, 'I have no authority to talk to him. I was called to come and help. He was the man in-charge. I came in and took my place among others. ${ }^{45}$ Perhaps. The presence of such a strong Alliance contingent in the Council reinforced the rapidly deepening suspicion of the party's collusion with the coup makers. The broad smiles, victory 
signs and clenched fists punching the air showed the enthusiasm of those who had joined in. An Australian television program reported that Ahmed Ali had 'made it clear that the Alliance Party was unofficially backing the Taki [Taukei] Movement and that the Alliance would not be in opposition for too much longer. ${ }^{36}$ 'The Crown sits uneasily on Bavadra's head,' is what he said to me at the time. Reddy was in no doubt that 'the real cause of the coup lay in the ambitions of those who had lost power in 1987 and were determined to get it back. They were engineered to regain political control.'

Ratu Sir Penaia Ganilau was goaded into a different direction, despite advice from Sir John Falvey and Isikeli Mataitoga, later a High Court judge and diplomat, that he was no longer the Governor General but was now acting in his capacity simply as a high chief of Cakaudrove. For these two - Mataitoga would later be sworn in as a captain in the army and appear in public in military uniform with a pistol by his side - had accepted the coup as a done deed and an accomplished fact against which it was futile to protest. Ratu Penaia may have emotionally sympathized with the aims of the coup, and probably did too, but he heeded firm advice from the Queen not to recognize the military regime, by the international opinion which overwhelmingly condemned the military take over, especially from the leaders of the Commonwealth, and locally by the high court judges, led by the Chief Justice, Sir Timoci Tuivaga. At 2 pm, Tuivaga, through magistrate Howard Morrison, a former member of the elite SAS, secretly sent the Governor General an unsolicited letter signed by himself and seven other judges which said that the 'purported suspension of the constitution by the military was 'illegal and invalid,' as was the purported suspension of the judiciary, that the constitution 'remains in force unchanged,' that the judges assured the Governor General 'of our undivided and complete loyalty and of our readiness to continue to exercise our duties in accordance with the law of Fiji and our oath of office, and the judges' declaration was endorsed by other judges of the Court of Appeal and the Supreme Court who were not physically present in Suva to sign the letter. ${ }^{47}$ It was a declaration of great courage and integrity at a moment of grave crisis. 
Official Residence of the Chief Justice, 228 Rata Sukana Road, Suva,

17 th May, 1987.

His Excellency Ratu Sir Penaia Gasilau, GCMG, KCVO, DSO, ED, Governor-Genera1, Government House, SUVA.

Your Excellency,

We, Her Majesty's Judges of Fiji whose names appear belew declare to Your Excelleney

(1) That the purported suspension of the Constitution of Fiji by the military regime which has assumed de facto power is illegal and invalid.

(2) That the purported suspension of the Judiciary by the said regine is also illegal and invalid.

(3) That the Constitution of Fiji established by Her Majesty in council by the Fiji Independence Order 1970 remains in force unchanged.

(4) That we assure Your Excellency of our undivided and coaplete loyalty and of our readiness to. continue to exercise our duties in accordance with the law of Fiji and our oaths of office.

(5) This declaration is supported by the Judges who are not present at the signing hereof nasely, Sir Grahan Speight, Vice President of the Court of Appeal, Sir Clinton Roper and Sir Barry o'Regan, Justices of the Court of Appeal and Mr. Justice Dyke of the Suprene Court.

GOD SAVE THE QUEEN

Dated at Sura this 17th day of May 1987

This page and facing page: Judges rallying against the coup. Courtesy of Sir Timoci Tuivaga. 
sicned by<smiles>C=CC1CCCC1CC</smiles>

(Sir Tineei eluifuretu Tulvaga) Chief Juatice and Preaident of the Fiji Ceurt of Appesil.

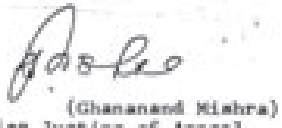

Senier Juatice of Apoeal

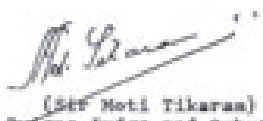

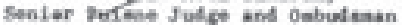

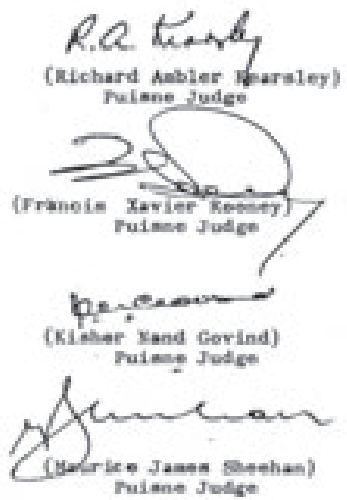


The judge's intervention stiffened the Governor General's resolve to stand by the constitution. In the early hours of Friday morning, FM 96, then the country's only commercial station, played the full tape of his message, which had been broadcast in a truncated form at six the previous evening. Proclaiming himself deeply disturbed by the 'unlawful seizure of members of my government,' a situation 'which must not be allowed to continue,' Ratu Sir Penaia declared a state of emergency and assumed executive authority vested in him by the constitution. The constitution had not been abrogated, he said, 'and all officers duly appointed as such remain in office.' He urged everyone, especially the members of the Royal Fiji Military Forces, to 'return to their lawful allegiance in accordance with the oath of office and their duty of obedience without delay.' He said that 'In the temporary absence of the Ministers of the Crown I have assumed that authority. ${ }^{48}$ These were brave words from a besieged Head of State, but not destined to last long. Upon returning from Taveuni on Sunday evening on 17 May, where he had gone to attend the funeral of a relative, Ratu Penaia inexplicably swore in Rabuka as the head of government, just two days after he had castigated him as the unlawful usurper of his, the Governor General's, constitutional authority.

Why he changed his mind it is not known. Most probably, he had heeded the advice of his people from Cakaudrove, where he was the Tui Cakau-elect, the paramount chief of the province and of Sitiveni Rabuka himself, that Rabuka had done what most Fijians wanted done anyway, that he was not a treasonous criminal but a great Fijian hero.

Rabuka's newly legitimized role did not last long. No sooner had he left Government House than the Chief Justice, after numerous failed attempts, was able to get an audience with the Governor General at 7:45 that evening. He presented him with a four-point plan. The plan advised the Governor General to dissolve the Parliament and call for fresh elections; proclaim himself the Executive Authority under Section 72 of the constitution; appoint a bi-partisan Council of Advisors to help him run the country in the interim period, and set up a Royal Commission of Enquiry to 'inquire 
into the efficacy and general acceptance of the 1970 Constitution and to suggest such modification as may meet the expectations and assuage the fears of the people of Fiji.' Meanwhile, the Governor General could exercise the prerogative of mercy to pardon all those 'implicated in the illegal seizure of power' as 'no purpose will be served by vindictiveness which might hinder the complete restoration of legitimacy.' This was sanguine advice under the most difficult of circumstances, but defective in strictly constitutional terms. The Prerogative of Mercy could only be exercised after the due process of law had been allowed to take it course.

Equally problematic was the dissolution of Parliament without the consent of the duly elected Prime Minister. Jai Ram Reddy would later help Dr Bavadra mount a Supreme Court case challenging the constitutionality of the Governor General's action. ${ }^{49}$ Perhaps reminded of the important legal and constitutional issues at stake, late on Monday afternoon (18 May), Ratu Penaia informed the nation that it was 'impossible for him to recognize the regime.' The following day, he refused to swear in Rabuka's ministers when they arrived at Government House in their Sunday best. Rabuka was dejected. 'The penalty for treason in all Commonwealth countries is death,' he said in a statement read on Radio Fiji,' 'and if this is to be my destiny, then I will accept it.' At 4 O'clock, the Governor General announced the plan the judges had advised him to follow. Later that evening, all the detained Coalition parliamentarians were released. 'I think there was considerable courage displayed by the Governor General,' said New Zealand Prime Minister David Lange. 'He was simply not supported by Ratu Mara. ${ }^{50}$ That was a fairly widely held view internationally. For his part, Ratu Mara would never forgive Lange, or Bob Hawke, his Australian counterpart, for their openly biting, sneering criticism of the Alliance leader and his 'conspicuous silence,' not too subtly doubting his proclamations of innocence and hinting at his complicity in the whole affair.

The release of the detained parliamentarians brought huge relief to the country knowing that they were not subjected to physical assault and abuse. The following day, 20 May, as news spread of Dr Bavadra addressing 
a rally at Albert Park spread, large crowds began to gather in the city. By mid-day about a thousand Indo-Fijians had assembled at the Park. Many had come in hired buses from various parts of Viti Levu, some, as I was to discover, armed with sharpened cane knives hidden in the boots of cars in case any harm came to their leaders. Their loyalty and determination was both impressive and distressing. But what was seen by one group, the Coalition supporters, as a quiet celebration of peaceful end of a crisis, was seen by another, supporters of the Taukei Movement, as a provocation. About a hundred hired Fijian youth employed at the Suva docks, Veitata's stronghold, marched through Victoria Parade, Suva's main street, determined to break up the meeting. Armed with sticks, stones, cement bricks and iron bars plucked from parked Suva City repair trucks, they went on a rampage, smashing car windows, and chasing and beating any and every Indo-Fijian they could find, the images of rampant violence caught on tape and broadcast around the world.

At the edge of Albert Park, fierce fighting broke out briefly between the two camps before a timely arrival of a truck full of soldiers stopped the violence from escalating. One soldier who formed a barrier between the rampaging mob and the Albert Park crowd was Captain Filipo Tarakinikini, who would rise to fame during George Speight's attempted coup in 2000. ${ }^{51}$ The Fijian youth then retreated towards the market, taunting and offering to fight their opponents in the virtually deserted, cowering, streets of Suva, throwing stones and other objects at offices and shops safe behind wooden hurricane shutters. The injured Indo-Fijians were treated at the Suva hospital, while frightened residents in the neighborhoods of the city formed groups to protect their family and homes. There were some isolated incidents of looting and stone-throwing in other parts of Viti Levu, especially Nausori, but the worst had passed. The coup supporters had vented their frustration and taken their revenge, and their hapless victims were left to nurse their wounds and ponder their unsettled future. All that survives of that frightening incident now are the grainy images captured on Australian television tapes of people being punched and fleeing, a permanent reminder 


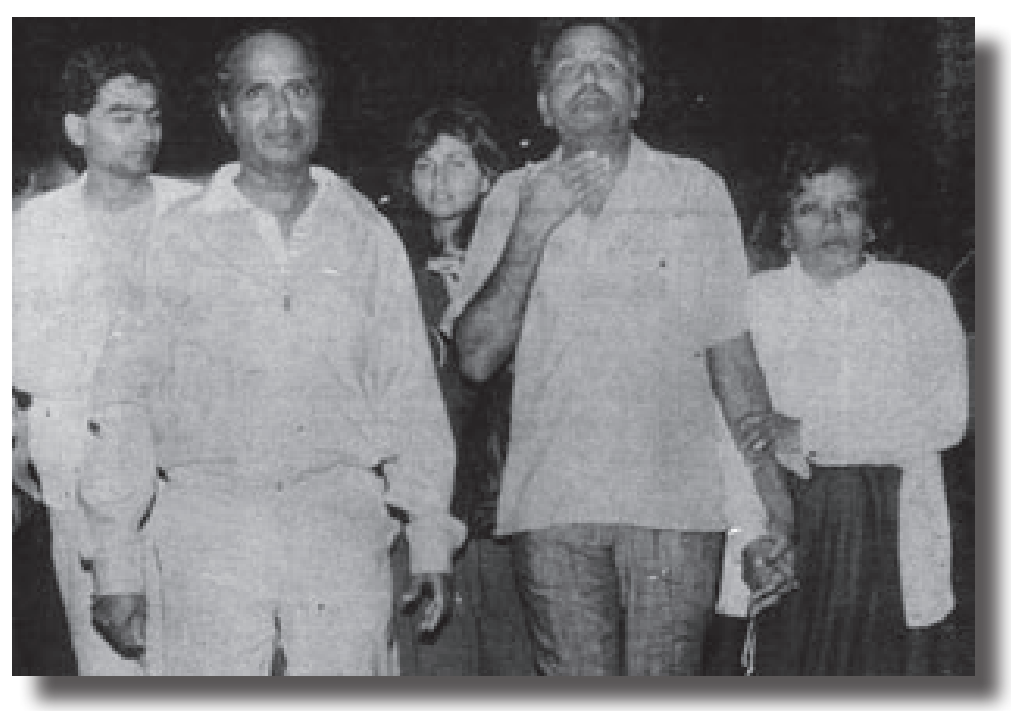

Released from captivity, with wife Chandra, daughter Helen, an unidentified person, and brother-in-law Dr Krishna Nair in front. Photo courtesy of Fiji Times.

of how ugly things had turned in Suva and how volatile and potentially dangerous the situation really was. Anything could have happened.

At the other end of town, at the Suva Civic Centre, a Great Council of Chiefs meeting had been convened by Ratu Sir Penaia. As a distinguished soldier of the Malaya campaign, a conservative high chief in the Sukuna tradition of 'responsible authoritarianism' with an 'unambiguous lack of compromise towards any proposals deemed likely to weaken Fijian rights and institutions, ${ }^{, 52}$ his public opposition to the coup and the military generally went against the grain of his inner feelings. Ratu Penaia was emotionally close to Rabuka, and his own sons were officers in the Fiji military. To test his judgment and to seek advice from circles beyond the judiciary, he convened a meeting of the body he trusted most and of which he had long been the head: the Great Council of Chiefs. ${ }^{53}$ The chiefs gathered at the Suva Civic Centre on Tuesday, surrounded by hundreds of specially bussed-in, hymn-singing Fijian men and women beseeching them to support Rabuka. 
Tears flowed freely along with copious amounts of yaqona in what resembled a carnival atmosphere at Sukuna Park across the street, cheerful and celebratory, people sitting on the lawn, clapping and singing. Inside the Centre, the discussions were tense and emotional. Chiefs with liberal views who were considered sympathetic to the deposed government and to the cause of democracy, such as Bau chief Ratu Joni Madraiwiwi, were excluded from the meeting. Speaker after speaker rose to support Colonel Rabuka and the spirit and intent of the coup, and for a greater role for themselves in any future constitutional arrangement. For most at the meeting, the issue was not that the 1970 Constitution should be overthrown; it was whether, in the event of some unforeseen legal obstacles, they should go the full distance and, if it came to it, sever Fiji's links with the Crown altogether. By the time the Great Council of Chiefs concluded its meeting on Friday (21 May), there was unanimous support for the coup and for Rabuka personally. The republic option was postponed for the moment, but the chiefs wanted a hand in deciding the composition of the Governor General's proposed Council of Advisors. The military, the chiefs resolved, should be asked to re-examine the 1970 Constitution 'with a view to changing, abolishing or abrogating it in the quickest possible time and to ensure that Fijians were guaranteed the political government at all time.'

Rabuka was elated with the solid support the chiefs had given him. A transformed man now, his spirits soaring, he smiled broadly from the balcony of the Suva Civic Centre with a watchful Mara standing behind him as the Royal Fiji Military Force Band played 'I Did It My Way,' 'Onward Christian Soldiers,' and 'Bridge Over Troubled Waters.' Both his clenched fists raised in victory, he told the applauding Fijians sitting across the lawn below, Sa noda na qaqa, the victory is ours, the same words Ratu Mara had used in his message to the Fijian people at the conclusion of the 1965 constitutional conference. With the chiefs firmly behind him, Rabuka vowed 'not to agree to anything that will destroy the aim of the coup.' He was the man at the helm again. Ratu Penaia, too, was overwhelmed by the support the chiefs had given to the coup, and accordingly changed his course 
SURPORT THE G-O

The Preas and the Radio are no longer free. But we expreas our reapect and appreciation for the Inapiring atand of the Governor-General, Ratu S1r Penale Ganilau. He bas oourageoualy atated that he 1 s atill the rightful Head of Government and he doea not aupport the allitery take-over.

Ho 1a under arreat and is no longer able to apeak to the Sation. This undigniflad defention of ach a highly-placed and reapeoted leader is an lhault to the tradition of this land.

We appeal that Ratu Sir Penaia be given a full and free opportun1ty to addreas the nation.

Brothera and alatera, let wa be warned, now that freedoa has been ourtailed, that this regine will wae any teeties to Inat111 fear anongat wa.

Let ua not apread. runours that ineite violence or oonvey cear. Te can deo1de that we w111 not be governed by tear. So long as we reaolutely stiok to MOH-VIOLESCE and our actiona are just, we should not bold back.

If we w111 not act, bow can we expeot othera to do so? If we take one anall atep in courage, perhapa we will diacover greater gourage. Immedistely you could make coplea of this and begin pasaing thea around.

Each one, tell one.

Paint algma and prepare posters aeylng $t$ ' TB SUPPORT 0 - 0 ' 'LEZ G-G SPEAK' 'PREE OUR G-G' OF 'PEOPLE O? PLJI RESIS? THE AILITARY REOME'.

WUY COD BLESS PIJI

An anti-coup leaflet on the streets of Suva, 16 May 1987. 
in their favor. Invited to address the chiefs' meeting on Thursday, he was booed by some more ardent supporters of the coup, which in itself was an unprecedented gesture of insult to a high chief, punishable by death in ancient times. Ratu Penaia tried to explain his complex constitutional role as the head of state which required him, whatever his own private feelings on any matter might be, to be faithful to his oath of office to uphold the constitution and remain above partisan politics. His stand left many chiefs at the meeting frustrated, and they later dispatched Mara and Rabuka to plead with him to be more sympathetic to their interests and concerns. The Governor General was persuaded.

He returned the next day to the Civic Centre. There had been a misunderstanding between himself and the chiefs 'in the true meaning and implications of the message contained in my address to you,' he said, adding that 'we are all aiming at the same result, generally, but that we are considering different methods of achieving this. ${ }^{54} \mathrm{He}$ went on: 'Let there be no doubt in anyone's mind, therefore, that as a native Fijian and as one who is blessed with Fijian chiefly status, the interests of my people, the indigenous Fijians, are those which I hold and shall always hold dear and close to my heart.' He assured the chiefs that he would place 'great weight' on their advice and promised that the views 'expressed in this meeting on the need not to ignore or undermine the best interests of the native Fijians shall always be paramount in my mind.' This was a commitment and pledge which he would try to honor and accommodate, while simultaneously keeping his oath of office and his loyalty to the Crown.

Just how far the Governor General was prepared to go to accommodate the chiefs' demands became clear when he announced his plan to restore Fiji to normalcy, a plan which, he hastened to add, 'has been discussed with and found acceptable to the military regime and its leader, Colonel Rabuka.' The announcement of his 18-member Council of Advisors demonstrated the influence of the Great Council of Chiefs and the Alliance party. Of the three Indo-Fijians, Harish Sharma, the deposed Deputy Prime Minister, and Mustapha, former president of the influential and overwhelmingly 


\begin{tabular}{lll} 
GOVERNOR GENERAL'S COUNCIL OF ADVISORS \\
Name & Affiliation & Ethnicity \\
\hline Sitiveni Rabuka & Military & Fijian \\
Alipate Qetaki & Taukei Movement & Fijian \\
Ratu Sir Kamisese Mara & Alliance & Fijian \\
Ratu J Tavaiqia & Alliance & Fijian \\
Livai Nasilivata & Alliance & Fijian \\
Jone Veisamasama & Alliance & Fijian \\
Apenisa Kurusiqila & Alliance & Fijian \\
Viliame Gonelevu & Taukei Movement & Fijian \\
Filipe Bole & Alliance & Fijian \\
Josua Toganivalu & Alliance & Fijian \\
Jo Cavalevu & Civil Servant & Fijian \\
Savenaca Siwatibau & Civil Servant & Fijian \\
Dr Timoci Bavadra & Coalition & Fijian \\
Harish Sharma & Coalition & Indo-Fijian \\
Daniel Mustapha & Independent & Indo-Fijian \\
Mumtaz Ali & Independent & Indo-Fijian \\
Paul Manueli & Independent & Rotuman \\
& & \\
\end{tabular}

indigenous Fijian Methodist Church, refused to serve while Mumtaz Ali let his membership lapse quietly. Dr Bavadra refused as well, saying that 'there was virtually no consultation with me, as Prime Minister of Fiji, as to the composition or formation of the Council of Advisors.' Also, when the announcement was made, it was specified that the agreement was between the Governor General, Rabuka and Ratu Mara. 'The head, or the Prime Minister of the country, was virtually ignored. I cannot see my way through to participate in a Council of Advisors that was formed undemocratically and unconstitutionally. ${ }^{55}$ 
Dr Bavadra must by now have realized that Ratu Penaia was not the neutral and impartial leader he had imagined him at first to be. That certainly was the gradually forming opinion overseas. Bavadra started to distance himself from the Governor General's plans and began seeking alternative ways of restoring his deposed government back into power, which was by then fast becoming an evanescent dream. With the announcement of the Council of Advisors came to an end the first phase of the crisis. The brief tussle for power between Colonel Rabuka and the Taukei Movement, on the one hand, and the Governor General and the deposed Coalition government, on the other, had been resolved in favor of the former. Reddy, too, was disappointed. 'When the Governor General took over the reins after the coup, there was some hope in the little flickering light. But when he announced the advisory council after dissolving Parliament, the light was extinguished,' he said. 'How can we serve on a committee [the Falvey Committee: see below] which is bent on giving almost entire rights for the Fijians to rule this country? What happens to the political rights of the Indians and other races? ${ }^{56}$

On 1 June, Ratu Penaia traveled to the west to see and assess for himself the mood of the country, particularly of the Indo-Fijian community with whom, up to that point, contact had been virtually non-existent. He would have seen, as he travelled through the dispirited cane country beginning around Sigatoka, people going about their daily lives in resignation, deeply concerned about the unfolding events, disturbed about their marginalization and anxious about their future. At the Governor's Bure in Lautoka, the Governor General had a one-on-one meeting with Jai Ram Reddy. At the meeting, at which Isikeli Mataitoga and Inoke Tabualevu, a senior civil servant, were present, Ganilau impressed on Reddy the importance of keeping the economy going. 'Give him a scotch,' he ordered, and then asked Reddy why the Indo-Fijian cane growers were boycotting the cane harvest. Could he not make them see reason? Reddy responded: 'Fijians have taken what they wanted by force. Why can't Indians peacefully protest what has happened to them?' Reddy conveyed to Ratu Penaia the deep sense of hurt 
in the Indo-Fijian community, their sense of despair and disillusionment. He wanted the soldiers to stop threatening and intimidating innocent civilians. Above all, he sought an opportunity to hold public meetings, to talk to his people, to gauge their feelings, to tell them of his plans about their future. Ratu Penaia agreed to relax the Public Emergency Regulation then in force. Reddy also remembers telling Ratu Penaia 'how disappointed he was in the former Prime Minister [Mara].' Ganilau did not respond. No doubt, he had heard many others saying the same thing. By the end of the meeting, recalls Peter Thomson, the Governor General's Permanent Secretary, who was also present at the meeting, 'there was a genuine sense of desire to help each other,' with Reddy telling Ganilau: 'You and I always got along well when we were in Parliament. ${ }^{, 57}$ That was then.

With things simmering in Fiji, it was decided to send senior Coalition leaders to key countries to brief them on the events in Fiji and to seek their support for the restoration of democracy. One of the truly remarkable developments following the military takeover was the overnight sprouting of pro-democracy movements in all the major cities with sizeable Fijian and Indo-Fijian communities in Australia, New Zealand, the United Kingdom, Canada and the United States. They held political rallies, lobbied their members of Parliament, wrote angry letters to the newspapers, appeared on radio and television, collected funds. They were also keen to hear the story from the 'horse's mouth.'

Jai Ram Reddy, Dr Timoci Bavadra and Joeli Kalou were sent to London to seek an audience with the Queen. 'She is my Queen, she is the Queen of Fiji,' Dr Bavadra said. 'She is bound at least to listen to me,' Bavadra told reporters. ${ }^{58}$ Unfortunately, Her Majesty was under no such obligation. The Governor General was still in office and he had initiated a (tortuous) process of getting the country back to constitutional normalcy. He would remain the sole channel of communication with the Palace for the time being. But the Bavadra group did manage to have four audiences with the Queen's Principal Private Secretary, Sir Michael Heseltine, at Kensington Palace. What transpired in those meetings remains confidential, but there 
can be little doubt that the true motives of the coup would have been conveyed to him. Sir Michael, it was reported in the press, asked the group to return to Fiji and work with the Governor General. Joeli Kalou reportedly could not contain his frustration at the Palace's seeming vaccillation. 'What's the point of talking to him? He is the one who initiated the coup.' The Governor General's alleged complicity in the crisis was a matter of wide public speculation. The group also saw Sir Sridath Ramphal, the Secretary General of the Commonwealth, and briefed him on the situation in Fiji. Ramphal, for his part, though, saw Bavadra as a man who had won the last elections, but was no longer the Prime Minister of Fiji.

While in London, the group met with the members of Movement for Democracy. Kenneth Bain, once the Secretary of Social Services to AD Patel, and later a staff of the Commonwealth Secretariat, wrote about one such meeting. Reddy impressed him: 'There was Jai Ram Reddy, Attorney General and nominated by the new Prime Minister as a member of the Senate on 12 April. He was a quietly impressive, somewhat aloof, man - calm, lucid and persuasive. He spent much of the time listening and drafting: but there were moments when he would allow himself the indulgence of a barely perceptible smile. ${ }^{59}$ (The contrast Bain drew with Tupeni Baba was interesting: his 'engaging impetuosity' and his own estimation that he could be 'mesmerizing').

On his way to London, Reddy and his law partner Bhupendra Patel, who had accompanied him as well, met with Natwar Singh, the Indian Minister for External Affairs, who had flown to Bombay to meet with them. In Bombay, Reddy and Patel also met with former Indian High Commissioner to Fiji, AP Venkateswaran, who had taken a keen interest in recent developments in Fiji. On their way back, they briefly met Prime Minister Rajiv Gandhi in New Delhi. Reddy was defiant and determined to restore democracy. 'We will have rallies, civil disobedience - everything to oppose the army rule,' he told the Indians. ${ }^{60}$ 'I am prepared to do anything peacefully. And we will accept nothing short of the restoration of the government that was overthrown.' He was also asked about the 
outlandish (and soon discredited) view propagated by the hyperactive Fiji exile and Hawaii-based conspiracy theoristJames Anthony that the coup was engineered by the Americans worried about the slippage of their power and prestige in the region. 'I am convinced it was planned from within,' Reddy said. 'There was no question of our government undermining the interests of the Americans. In fact, we had made it clear that we will have no truck with the Soviets.' Similar assurances were given and views expressed by others touring the world, although Krishna Datt's fearinducing claims of massive rapes of women, of imminent rifts within the military and of rampant beatings and harassment by soldiers seemed, in the absence of credible, verifiable, evidence, to be stretched. Krishna, my high school history teacher, has a theatrical side to him. The overseas trips had given the Coalition the opportunity to air their views and connect with their supporters, but the leaders, certainly Reddy, also returned firmly believing that the true battle would have to be won in Fiji, not overseas. The situation was summed up best by Melbourne Herald: 'In the world capitals the deposed Prime Minister managed to muster some obligatory tut-tut ting, but that was about all. His disappointing reception in countries which publicly make so much of their support for democratic institutions has taught them much about realpolitik. ${ }^{61}$

Except in Suva, by early July life was beginning to return to normal, or as normal as it could be hoped for in the circumstances. Reddy toured the country around that time and gave speeches to massive rallies of Coalition supporters. He was the one leader they all Indo-Fijians wanted to hear. At these meetings, Reddy informed the people of their overseas visits and plans they had to return Fiji to constitutional democracy. There were two themes in particular he emphasized in his rallies. One was the importance of having political rights. Rabuka said that Indo-Fijians could stay in Fiji and make all the money they wanted, own the best buildings and drive the best cars, but should accept curtailment of their political rights in favor of the indigenous community. Reddy told a thousand-strong meeting in Rakiraki that 'to remove the political rights of the Indians would mean 
turning them into economic slaves,' adding: 'Once your political rights are gone, what guarantee have you that your stay here is safe. We should not live in fear. Living in fear is like suffering for death. ${ }^{62}$ A message of hope, to stand up for your rights, mattered hugely at a time of almost total darkness and despair.

And the second theme he continuously emphasized was for the Indo-Fijian community not to lose hope or confidence or accept the narrative about their role in Fijian history written by the Fijian nationalists and their European sympathizers. At an equally well-attended meeting in Labasa a week earlier, Reddy had told the gathering, 'People wanting to change the constitution ought to understand the cause of the Indians and how they had worked under difficult conditions to shape Fiji to what it is today.' To those who pushed for accommodation in the name of 'facing reality,' Reddy retorted, 'If we let the present situation remain, then our children will return to girmit life.' 63 'Hum log aap ke sun ke ghar men diya ek baar phir jalaya,' a man said to Reddy. We have lit lights again in our homes after listening to you. I have listened to some of the tapes of these and other meetings. The speeches are passionate and rousing, sometimes leading to the thought: 'We should not accept what is being done to us lying down.' The thought of turning away from the path of peace crosses your mind momentarily, of drawing a line in the sand and saying: 'This far and no further, no matter what the price.' Reddy's speeches have that kind of effect. I get the distinct sense of a volcanic rage in Reddy as I listen to his words, of a proud man from a proud warrior tradition, powerless to protect his people at a time of the gravest crisis in their lives, and unable to stem the tide of daily humiliation visited upon them for no fault of their own. I meet people even today who recall vividly the emotional power and intensity of one of Jai Ram Reddy's greatest speeches delivered, now probably lost to posterity, to a packed Govind Park Stadium at Ba on Diwali night in 1988. A tamer English translation is at the end of this chapter. 


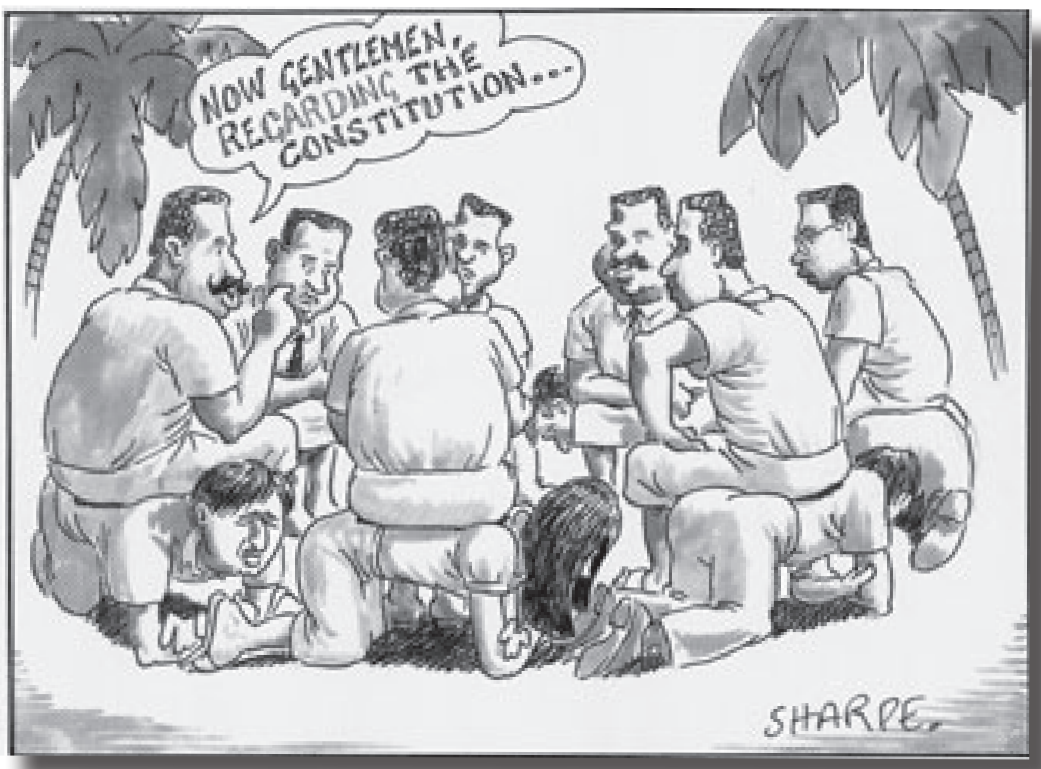

Lopsided post-coupconstitutionaldiscussions. Cartoon reproduced with the permission of Ian Sharpe.

\section{FALVEY AND HIS STILL-BORN REPORT}

Two weeks after announcing his 'compromise' plan, Ratu Sir Penaia Ganilau unveiled his detailed proposal to return Fiji to constitutional normalcy. It involved a four-stage process. The first step would be the appointment of a Constitutional Review Commission. The Commission would comprise four representatives each from the Coalition, the Alliance, the Great Council of Chiefs and the Governor General himself. The second stage would involve the Commission holding a series of public hearings throughout the country to gauge public opinion on how best to achieve that goal and then prepare a report on the "ways and means of strengthening the political rights of the indigenous Fijians. The third stage would involve the formation of a Council of National Reconciliation which would 'arrive at a consensus to agree on the proposed changes to the constitution and to agree on a Covenant of 
National Reconciliation.' If consensus was reached at that stage, as Ratu Penaia hoped, the recommendations of the Commission would be enacted in accordance with the amendment provisions of the 1970 Constitution. The last step would be an uncontested election for the House of Representatives which would approve the unanimously recommended changes in accordance with the formula for national reconciliation. The final outcome, the Governor General hoped, would be an amended constitution embodying changes which would satisfy the Fijian demand for political paramountcy. The Parliament would then be dissolved, and fresh elections called under the new constitution.

The Governor General's 'path back to normalcy' received predictable responses from various quarters. Rabuka was happy. 'I have seen the plans and I believe they can achieve the objectives I set out to achieve for the Fijians and the people of Fiji. I think the GG and my committee that had set out to review the constitution have the same objective but the method of achieving the objective are different,' echoing the Governor General's own words at the meeting of the Great Council of Chiefs. Reddy said the Coalition would refuse to participate in the Commission's proceedings. ${ }^{64}$ 'They can have the wedding, if they want, but the bridegroom would not be there,' he said in Hindi. Dr Bavadra outlined the obvious flaws. His party which had won the elections, and thus enjoyed the mandate of the people would be in a minority on the Commission dominated by representatives of other groups, including the Alliance Party and the Great Council of Chiefs, both of which had a 'community of purpose' in supporting changes to the constitution. He noted, too, that the Governor General had assumed, without testing the public opinion through a referendum, for example, that the constitution needed to be changed. If any changes were to be contemplated, it should be done by a Royal Commission comprising eminent jurists from outside Fiji.

Bavadra and Reddy were not the only people casting doubts on the wisdom of the Governor General's proposed plan of action. The Australian newspaper, which had until then urged caution and support for the Governor 
General, denounced the plans as a triumph of 'Melanesian chauvinism and exclusivism.' It wrote:

Implicit in Ratu Sir Penaia Ganilau's announcement of a socalled 'path back to democracy' is a deplorable admission that Fiji, under its present administration, has now definitely withdrawn from the international community of democratic nations and placed itself in the same camp as those like South Africa where considerations of race and ethnicity are judged to be more important than fundamental civil and political rights. An uncontested election would simply rubber stamp constitutional changes designed to ensure native Fijian hegemony over the Indians and other non-Fijian majority. In this way, the objectives of Colonel Sitiveni Rabuka and his fellow ethnic nationalists would be effectively fulfilled, with the added bonus of having been achieved through a vote in Parliament, the only institution that is empowered to change the constitution. ${ }^{65}$

The New Zealand Herald called the Governor General's proposals a 'face-saving charade of consultation. ${ }^{66}$ Even the United States, which had maintained a noticeably low profile on Fiji, stated that the 'creation of any system in Fiji which did not respect and protect the rights of all of Fiji's people, regardless of its label, should not expect support from us. ${ }^{67}$

In late June, Ratu Sir Penaia appointed a Constitutional Review Committee chaired by Sir John Falvey, the former Alliance Attorney General and a close confidante of the Fijian establishment for over three decades. The Coalition would be represented by Jai Ram Reddy, Tupeni Baba, Ratu Mosese Tuisawau and Krishna Datt. The Alliance was represented by Tomasi Vakatora, Filipe Bole, Apisai Tora and David Pickering, Tora being the founder member of the Taukei Movement. Adi Litia Cakobau, Aporosa Rakoto, Sitiveni Rabuka and Ro Jone Mataitini represented the Great Council of Chiefs and Dr MS Sahu Khan, Kantilal Parshottam, Atfoa Varea and Isikeli Mataitoga, all lawyers, represented the Governor General. The Terms of Reference of the Committee required it 
To review the constitution of Fiji with the view to proposing to the Governor-General amendments which will strengthen the representation of indigenous Fijians and in so doing bear in mind the best interests of other peoples in Fiji; to call upon and hear the views of the public of Fiji on this subject; to begin hearings on 6th July, 1987, and to deliver to the Governor General the findings and recommendations of the Committee by 31 July, 1987.

The urgency and the intent are evident in setting up the Committee and in the scope of its work. Reddy and his colleagues on the Committee boycotted its proceedings for the first week because they objected to the restrictive Terms of Reference which were loaded to accomplish one goal: the entrenchment of Fijian political control. The Fijian nationalists were equally adamant against any concession, with Filipe Bole, Inoke Kubuabola and Taniela Veitata telling Ratu Penaia on 3 July: sa vakarau na dogo, meaning that they were ready to make clubs from the mangrove trees to use violence against their opponents. ${ }^{68}$ The Coalition was unmoved. Reddy proposed an alternative Terms of Reference. The Governor General acceded to his request, with the result that the final Terms of Reference of the Constitutional Review Committee read: 'To review the constitution of Fiji with the view to proposing to the Governor-General any amendments which will guarantee indigenous Fijian political interests with full regard to the interests of other people in Fiji.' 'The [original] terms infer, without doubt,' editorialized the Fiji Times, 'that whatever happens, the Fijians will be given complete political dominance over the non-Fijian majority of the population.' It quoted a letter Dr Bavadra had written to the Governor General on 29 June: 'To effectively disenfranchise people born in Fiji for no reason other than their ethnicity will not make for the long term peace and stability of Fiji. On the contrary, it will be sowing the seeds of resentment, disharmony and even confrontation. The world is full of examples of such cases. Is this not the very kind of discrimination the Commonwealth says it is fighting against the South African regime?' ${ }^{29}$ Cogent arguments, but the minds in powerful circles had been made up already. 
There were some calls for the Coalition to boycott the proceedings of the Review Committee altogether because, given its composition, the outcome was a foregone conclusion. Why taint yourself by participating in a flawed, farcical process designed to produce a predetermined outcome that would be detrimental to the cause of democracy? Reddy disagreed. Participation did not mean concurrence. He was aware that there was tremendous pressure on the Coalition from its supporters both at home and abroad to participate. A boycott would most likely bring adverse consequence which the Coalition could ill-afford. Reddy was determined to take the opportunity of the hearings to put his case before the people of Fiji and the international community. Reddy also reasoned that the expected public submissions from across the country and from people from all walks of life could become an important platform to educate the people about the protection in the 1970 Constitution of the rights of indigenous Fijians which could, conceivably, undermine the propaganda of the Taukei Movement and other nationalist Fijians. Participation would buy the Coalition valuable time to consolidate its position and put pressure on the Governor General to extract further concessions from the coup supporters. And finally, as the visits to foreign capitals had shown, sympathy did not always translate into tangible support. The battle would have to be fought in Fiji. Five years later, Reddy would face a similar dilemma and he would, once again, make a similar decision.

The Review Committee began its work in mid-July, traveling to the country's four major towns and receiving some eight hundred submissions from individuals, social and religious groups, cultural organizations and political parties. The whole atmosphere was eerie, Reddy recalled, a 'terrible experience' made even more ominous with Rabuka turning up armed with pistol visibly on display. The overwhelming majority of the Indo-Fijian community opposed any alterations to the 1970 Constitution without a full national debate. The only notable exception was the Fiji Muslim League, or rather a Suva-oriented branch influenced by Ahmed Ali, which told the Review Committee that it endorsed the changes wanted by the chiefs of Fiji because Fiji was first and foremost a Fijian country where Fijian 
values should prevail, just as Jewish culture prevailed in Israel and Indian culture in India. 'We see this demand as a rightful desire to have stamped on Fiji the mark of the indigenous people.' This was pure Ali prose. The submission argued that the 1970 Constitution had 'disinherited' Muslims; that it was 'wrong and unjust' to describe Muslims as Indians, and that the deposed Coalition government would not care for their interests. 'If the Fijian community which is 46 per cent of the population is rightly concerned about its future, then a mere 9 per cent has even greater reason to desire safeguards.. ${ }^{70}$ The League wanted a certain number of separate seats reserved for the Muslims in return for endorsing Fijian political control. The demand for separate representation was not new, but its timing and the context in which it was made seemed inappropriate. The demand was not endorsed universally across the Muslim community. Many were actually distressed by the submission, and questioned the Muslim League's right to make such a representation on their behalf without prior consultation. ${ }^{71}$

The Methodist Church, long the bastion of Fijian establishment, recommended increasing the number of Fijian seats in the House from twenty two to thirty, while retaining the existing twenty two and eight respectively for Indo-Fijians and General Electors. It similarly wanted Fijian representation strengthened in the Senate. Details and emphases varied, but on the whole most Fijian provinces wanted Fijian political control of Parliament strengthened and certain positions reserved for the indigenous community exclusively, especially that of the Prime Minister and the Governor General. The Church also wanted Fiji to be declared a Christian state. The most extreme suggestion came from the Ba Provincial Council which has the largest number of Indo-Fijians in it and where many Fijians benefited from the rents paid by Indo-Fijian tenants. It proposed that Fiji be declared a republic with a fifty-two seat Parliament of which fifty should be reserved for Fijians and the remaining two allocated to Rotumans. The Indo-Fijian community would have no representatives of it own in Parliament at all. One must assume that the Council was not really serious in making this recommendation; if it was, the suggestion was simply ludicrous. 
By the time the Great Council of Chiefs met in Suva in late July, the real question was not whether the Council would endorse the general sentiment expressed in the various Fijian submissions: that was a foregone conclusion. The real question was whether it would go the full distance and recommend terminating the link with the Crown altogether. In the meeting, intense and heated debate took place between those who wanted Fiji declared a republic and those who preferred maintaining the status quo. Opening the meeting, Ratu Penaia exhorted the chiefs to come out with a 'chiefly system of government that would protect individual rights and freedoms,' warning that 'individual freedom and liberty are not [to be] used or manipulated to interfere with Fijian traditional customary rights and responsibilities. ${ }^{72}$ The chiefs agreed. Dr Bavadra attended the meeting and was given a reluctant but polite hearing. His colleague, Tupeni Baba, was not so lucky. He was assaulted as he left a session.

After several days of deliberation, the Council of Chiefs' Constitutional Committee, headed by Ratu Mara and Sitiveni Rabuka, issued a lengthy document. It demanded that Fiji be founded upon Christian principles and traditional Fijian values, with particular regard to Fijian rights and aspirations. This represented a marked departure from the letter and spirit of the 1970 Constitution. The Council stated that the constitution should expressly incorporate provisions regarding preferential treatment and special affirmative action for Fijians to enhance their participation in public offices, statutory bodies and even in the private sector. This, unofficially, had been the thrust of the Alliance government policies for many years, but they were now to be enacted into law. The bi-cameral legislature, the Council recommended, should be replaced with a single chamber of seventy one seats, to be allocated as follows: forty for Fijians (twenty eight nominated by the Provincial Councils through consensus rather than direct election), eight nominated by the Great Council of Chiefs (that is, the Senate representatives transferred to the Lower House) and four nominated by the Prime Minister. The number of Indo-Fijians at 22 and General Electors at 8 would remain unchanged. Four of the twenty two Indian seats should be reserved 
for Muslims. All national, non-communal seats were to be abolished and replaced by communal ones.

Certain offices, moreover, were to be reserved exclusively for Fijians. These included the office of the Prime Minister who 'can command the respect of the Fijian members of the House' and not all its members as is the case in the Westminster system. Only Fijians would occupy the ministries of Fijian Affairs, Agriculture, Home Affairs, Finance and Industry. The Commander of the Fiji Military Forces, the chairman of the Public Service Commission and the Secretary to Cabinet were always to be Fijian. The Governor General would be appointed on the advice of the Great Council of Chiefs and empowered, in addition to exercising the Prerogative of Mercy, to 'grant general immunity from criminal prosecution and related civil litigation in very special circumstances.' This was clearly intended to cover all those who had been implicated in the coup in various ways. Further, the Council wanted to curtail the Crown's privileges of eminent domain enshrined in the 1970 Constitution. Fijians should be given the ownership of all underground water, un-extracted minerals, including petroleum, geothermal heat and energy, foreshores, including mangrove swamps and lagoons, reefs and sandbanks, fishing rights, riverbeds, and traditional intellectual property rights, paleontological and archaeological excavations.

This is as extensive and overarching a list as it is possible to imagine. The endorsement of the proposal from Rabuka was to be expected. Ratu Mara's support, however, left many heads shaking in bewilderment: this from a leader who had championed the cause of multiracialism? But his stance was not altogether surprising. As a chief, he wanted to be where his people were. Protocol outweighed principles. 'I am in total agreement with the concept that the constitution should be changed to guarantee Fijians' continued leadership at all times,' Ratu Mara told the Lau Provincial Council. He knew in his heart that changing the constitution to allow Fijian leadership 'will not be fruitful, effective and meaningful if we Fijians cannot shoulder those responsibilities to support our leadership. ${ }^{73}$ Still, publicly, his nationalist credentials were visibly on display. 
The Great Council of Chiefs proposals were similar in substance, if not in tone, to the Taukei Movement's submission. Both wanted Fijian paramountcy in the affairs of Fiji, and both rejected the notion of equal constitutional rights for other groups. They differed only in their methods. While the Taukei extremists were forthright in their true feelings, the GCC preferred to maintain the impression of Fiji as a functioning multiracial democracy and give the appearance of reasonableness, while rejecting the principle of political equality. This criticism of the GCC could perhaps be softened by the view that the chiefs were merely reflecting the views of their people, not trying to stifle them, and that without their intervention things could have taken a much worse turn, that they were exercising a calming influence, providing an alternative avenue for the Fijians to air their concerns and grievances. Perhaps.

In its submission, the Coalition refused to entertain any change to the 1970 constitution in the prevailing circumstances. Said Dr Bavadra:

The Coalition maintains that the present system of political representation is just, fair and equitable. The system has withstood the test of time and has become accepted by the majority of the citizens of this country. It protects the special interests of the indigenous Fijians through special provisions of power of veto by nominees of the Great Council of Chiefs. To devise changes to the existing constitution on the basis of the preponderance of any particular race must in the end be harmful to race relations as it would enhance polarization of our communities along racial lines. It will also disturb the balance of power in the current constitution. This could lead to loss of confidence in the long term stability of the country which would translate into serious economic results, similar to what has been evidenced since the coup. ${ }^{74}$

Given the widely divergent submissions presented to the Constitutional Review Committee (with its slanted mandate and composition in the first place), no one expected a united report or a common understanding of the best way forward for Fiji. And a divided report was the final, predictable 
result. The majority report, supported by the Great Council of Chiefs and Alliance nominees, accepted many of the most important recommendations made by the chiefs. It endorsed, for example, the concept of a single chamber Parliament, to be elected entirely from communal rolls. It agreed that the Governor General should always be a Fijian, and a high chief nominated by the Great Council of Chiefs and formally appointed by the Queen. The positions of Prime Minister, and ministers of Home Affairs, Foreign Affairs, Fijian Affairs, Finance and Industries must be reserved for the indigenous community. Fijian customary law should be recognized in the new constitution along with Fijian ownership of the foreshores, river beds and other things demanded by the chiefs and the Taukei Movement.

The minority report, masterminded by Jai Ram Reddy, rejected the whole thrust of the majority recommendations. It found its proposals 'repugnant on the grounds that they will further segregate the various races.' Integration, not segregation, was the way forward. 'Any constitution for Fiji must recognize the existence of major races in this country and should provide for means to allow integration between the races. We are opposed to any change which discriminates on the basis of race, colour and creed.' Where, it was asked, was fairness in the majority report when Indo-Fijians at 49 per cent of the national population were allocated only twenty seats while indigenous Fijians, at 47 per cent of the population were given forty seats and General Electors at 5 per cent of the population, eight seats? Since General Electors from communal seats invariably sided with the Fijians, this would mean further entrenchment of the indigenous community.

The intent of the majority report, the Coalition correctly pointed out, was the ultimate subjugation of the Indo-Fijian community. The removal of cross-voting seats which provided some opportunity for cross-ethnic voting would entrench communalism in the political system whose pernicious effects, once entrenched, would be difficult to remove. The removal of the national seats would 'result in extreme communalism and racial prejudice,' 'reinforcing 'socio-economic and cultural disparities.' It added accurately that 'the inter-dependence and common needs and aspirations of our people 
will be artificially divided by entrenched political communalism. Race will be exploited at the expense of national unity.' A democratic society worth its name should allow for the theoretical possibility of a change of government. The majority report was a recipe for Fijian ethnocracy. 'An outright majority of Parliamentary seats constitutionally guaranteed to a single race is not only discriminatory but it also means that a party, however corrupt, inefficient or oppressive, can remain perpetually in power through this built-in advantage. This is a most dangerous situation for any country and therefore the most compelling argument against granting extra seats on purely racial grounds.' On the Fijian absence in the commercial and business sector, Reddy and his team pointed out, the fault lay not with the constitution but rather with the formulation and implementation of policies by the Alliance government in power for the last 17 years.

On the question of separate Muslim representation, on which the majority report had been unable to reach a consensus, Reddy noted that many Muslims across the country had not asked for a separate seat at all, preferring to maintain the status quo. Nor, strangely enough, had the Fiji Muslim League appeared before the Constitutional Review Committee to present its case. On what basis, then, could a recommendation for separate seats be made? Reddy and his team rested their case on the arguments against separate representation advanced by the 'Street Commission' in 1975. They had argued then that separate representation 'would go further in fragmenting and confusing the electoral system than even those other proposals for giving separate representation to small racial groups which we have rejected. These proposals are based not on race, difficult as that may at times be to identify, but on the much less specific grounds of religious belief. Moreover, if accepted, they would open the door for further religious groups to claim separate representation.' The proposal by the majority of the constitutional Review Committee to give four of the 22 Indian seats to Muslims 'is viewed by us as an attempt to divide the Fiji Indians on religious lines.'

The assumptions and understandings which underpinned the majority report's recommendations to the Governor General had not been 
properly thought through. There was no way the international community would ever sanction its racially discriminatory provisions clearly in blatant breach of human and civil rights conventions to which Fiji was a signatory. If anything, they would have the ultimate effect of keeping Fiji on the pariah list for much longer. Nor, common sense should have told them, could the expectation of permanent Fijian political unity ever be realized, and that, as Oxford University's David Butler had told Ratu Mara in 1970, would be the precondition for Fijian political control. The Constitutional Review Committee, then, did not produce the miraculous compromise solution the Governor General had expected. It had, instead, produced an impossible impasse and an even more polarized atmosphere. It was clear that more sympathetic and genuine appreciation of the Coalition's position would be needed to achieve a measure of reconciliation to break the impasse. The Committee's report was a still-born child whose body had to be buried hurriedly, but the views expressed during the hearings across the country would be echoed a few years later, with the same leaders at the helm.

\section{TO SEPTEMBER 27 AND BEYOND}

The weeks and months following the May coup were a time of great confusion, anxiety, tension and violence in Fiji. As time went on, protagonists on both sides of the political divide mobilized their forces, and attitudes hardened, making dialogue between opposing camps impossible. For a month after the coup, the country was under Public Emergency Regulation. Anyone deemed by the military to be 'acting in a manner prejudicial to public safety or the preservation of the peace' could be detained for up to forty eight hours without trial, and in exceptional circumstances, for up to seven days. ${ }^{75}$ The security forces could enter and search any property they chose to, curtail the right of assembly, impose curfew, close off roads, and control the movement of people. They could enter and search buildings where they had 'reason to believe that a meeting of three or more persons is to be held or is being held and may remain in such building for the purpose of ascertaining whether or not the provision of the law are being observed.' 
A permit was required to hold meetings, whether it was funeral procession or a wedding celebration. As emergency regulations go, there was nothing exceptional about those proclaimed by the Governor General. But it was their selective application against the supporters of the Coalition, mostly Indo-Fijians and a handful of Fijians, which wreaked havoc. Daily, people were picked up from their offices or off the streets and taken for questioning at the police stations. Hundreds of houses throughout the country were searched at all hours by the security forces, acting on their own initiative or upon tips provided by others perhaps keen to settle old scores. No one was ever charged, but that may not have been the intention in the first place. The intention may simply have been to intimidate people into silence and self-censorship. ${ }^{76}$

The size of the army was increased from 2500 to 6000. The Nasinu Approved Boys School was closed down to train the new entrants. The military was a constant presence at key installations throughout the country. Certain areas received special attention, such as the Baulevu Indian settlement fringed by Fijian koros loyal to the Taukei Movement leader Ratu Meli Vesikula, and suspected of habouring 'seditious' elements intent upon fomenting resistance to the regime. The military confiscated all licensed guns from Indo-Fijians to eliminate even the remotest possibility of armed resistance. Disarmed and disheartened, people chose the path of passive resistance. Even the diplomatic corps became the target of the military's exuberance, as diplomats were body-searched and their cars fired upon. Shops opened for business irregularly, many schools closed, public transport was disrupted and work in government offices ground to a virtual halt as the coup supporters celebrated their success and its victims nursed their wounded pride and pondered their worsening predicament. The tourism industry slumped as hotel occupancy rates dropped to around 20 per cent and foreign tourists chose 'safer destinations.' Perhaps the excesses were best captured by the detention of some MH shop assistants who had supposedly 'insulted' the wife of the Commissioner of Police by not packing her grocery in big enough paper bags as befitting her status! 
With the urban areas paralyzed, and the cane harvesting season about to start, attention shifted to the Indo-Fijian cane farmers of Fiji. With the tourist industry down, with all major hotels reporting an occupancy rate of 20 per cent or less, and foreign reserves falling to alarmingly low levels, the economy badly needed the sugar dollar to keep it afloat. The military regime therefore wanted an early harvest of cane. The cane growers, though, had other intentions. Strong supporters of the Coalition, they were understandably reluctant to bail out a regime which had ousted 'their' duly elected government. They threatened to boycott harvest if the military was not removed from the cane areas, and they did not receive immediate payment of some of the previous year's outstanding balance and a guaranteed payment in fixed installments of the year's forecast price of $\$ 23.50$ per tonne. ${ }^{77}$ Ratu Penaia thundered that any "unlawful activities by extremists will be dealt with by the full force of the law, great vigilance will be exercised to see that all such activities are curtailed.' Fiji, he said, 'will not allow itself to be held ransom by reckless minorities.' ${ }^{78}$ The Governor General's choice of words was revealing. The farmers were now seen as 'extremists,' and 'reckless minorities.' The farmers, veterans of strikes against the old formidable enemy, the Colonial Sugar Refining Company, knew better and held most of their ground. The Governor General soon realized the folly of flexing his muscle and pushing the farmers to the brink. In the end, he conceded most of their demands, and farmers began harvesting in late June, saving Fiji from almost certain economic ruin.

Just as the opponents of the coup were committed to turning the clock back and to restoring Fiji to parliamentary democracy, so were the members of the Taukei Movement committed to preventing this from occurring. First, there was Colonel Rabuka himself. The army, he said, would remain an integral part of the Fiji political scene, irrespective of the political system which was eventually devised. He sent a team, led by Ratu Sir Kamisese Mara, Advisor on Foreign Affairs, on a tour of ASEAN countries to buy, among other things, arms for the military. His aim was clear: 'If we can't achieve agreement through democratic means we would 
have to struggle for Fiji we want. I am talking about armed struggle. We may well have to go through a period of revolution in this country. ${ }^{79}$ Many in the provinces agreed, and traveled to the Queen Elizabeth Barracks in Nabua to pay their respects and to provide food for the soldiers. The most emotional and symbolically important of these visits was by the paramount chief of Burebasaga, Tui Dreketi Adi Lady Lala Mara, the wife of the Alliance leader, who visited the Barracks in late July to present a necklace of tabua (whale's tooth) to Rabuka saying, according to some reports, that the Colonel had achieved in seventeen minutes what the Alliance party had not been able to achieve in seventeen years: Fijian supremacy in the political governance of the country.

Ratu Meli Vesikula, a former Fijian soldier in the British army and now a leader of the Taukei Movement, wrote to the newspapers, telling people to 'watch out.' Ratu Meli would be active again, after the military coup of 2006, but this time on the side of democracy,. Unless their goals were realized, he said, 'we, the Fijian people, will have only one option left open to us and that is to pick up our clubs, old and new, and protect our interests and supremacy with all our might. This is not an idle threat: it is a promise. ${ }^{80}$ The Kaitani, or foreigners, must either learn to accept their subordinate place in Fiji or leave. There could be no accommodation and no compromise. As he put it, 'consensus will never be reached between Indians and Fijians,' nor, he might have added, allowed to be reached as long as people like him were around. The nationalist protests took several forms, but the one which received great notoriety was the incident in a park across the street from Government Buildings. ${ }^{81}$ Taukei Movement supporters in full traditional battle regalia (grass skirt, faces painted black) carrying spears and war clubs in front of a heated lovo, underground oven, threatened to kill and cook Coalition leaders if they proceeded to challenge the Governor General's action in dissolving Parliament. Perhaps the threat was issued to coerce the Coalition's acquiescence, but it was frightening nonetheless. 'We are at the end of our tethers and this is not for show' fumed a militant Vesikula, 'we will put people in the lovo if our high chief ever reaches court.' 
The lighted lovo was a terrifying symbol of the nationalists' anger and a savage reminder of the fate of chiefs' opponents in ancient times.

The threats of violence were not empty as Richard Naidu, Dr Bavadra's media spokesman, found out. He was chased and beaten with clubs and later deported from Fiji. In mid-September, Suva became the target of a coordinated campaign of arson and violence. Shops in central parts of the city were torched with petrol bombs and looted in smashand-grab raids, and Fiji's only medical laboratory, belonging to a known Coalition supporter (Dr Karam Singh), was razed to the ground. People on the streets were assaulted and robbed randomly. Further violence was prevented only after the army erected roadblocks and installed checkpoints at strategic points in the city. In their final gesture of protest, on 23 September, the leading Taukei Movement supporters engineered a massive release of prisoners from the Naboro prison some fifteen miles out of Suva. Over one hundred prisoners were on the loose, demanding not improvement in the prisons, but wanting to meet the Governor General to express their dissatisfaction over the political situation in the country. With the security officers as their guards, the prisoners marched through Victoria Parade, Suva's main thoroughfare, to Government House. After presenting their petition and having breakfast there, they returned to the prison. The Fiji Sun editorialized:

The fact that criminals were permitted to march unmolested through the streets of the capital to the home of Her Majesty the Queen's representative in Fiji, constitutes not only a grave insult to Her Majesty, the Governor General himself, and the people of this country, but also raises the question: Was the Governor General under duress to receive the criminal rabble? Figuratively speaking, was there a gun at his head? Is he now a free agent and, more importantly, who so misguidedly advised him to even listen to law breakers masquerading under the pretext of demonstrating their dubious allegiance to a High Chief? ${ }^{82}$

This was an interesting question, but soon moot. On 25 September, Sitiveni Rabuka launched his second coup. 


\section{A CHARTER FOR MAYHEM ${ }^{83}$}

A special meeting was held on Monday evening and these were the plans drawn up (Taukei Movement). Taukei Movement leaders and prominent members took part. Release the prisoners but first of all lighting the complex, medium and minimum, on fire. Get whatever tools available from prison storeroom to fight and attack with. To be done on Tuesday night 22.9.87 after tea.

1. The earlier the better to enable one group of prisoners to escape inland and hide or try making their way to the Suva area. One group of prisoners to protest to Governor General. Wait until dawn. Show themselves to security forces. Their demand must be met or else. Prison officers supporting the Taukei Movement to release them. Let them march to Governor General and also see Rabuka.

2. Night raids and attacks to begin at night on Wednesday 23.9.87 (mass killing) target Indian community and Bavadra supporters. Prisoners to be supported by gangs at Raiwai, Delainivesi, Samabula, Kinoya and Naboro. Must be as combined effort. Names mentioned Bavadra, Kalou, Navuso, Tavai, Naidu, Siwatibau (Reserve Bank) main targets.

3. The talks held in Deuba to carry on and to approve everything about a caretaker government but when this caretaker government comes into operation sometime next week, more riots and unrest should take place to enable another coup to take place. Excuse is that this caretaker government cannot control the whole situation. Soldiers not to protect Indians and Bavadra supporters. No help to be given. Four hours only to be given for the short ruling of the caretaker government.

4. 29.9.87: Make another lovo and protest to the Governor General over court case. If Bavadra wins, club him and his supporters and put them into the lovo. 
5. This weekend more trouble to take place.

6. 2000 people from Cakaudrove, Bua, Macuata (CBM) to come to Suva to be present during the court case on 29.9.87. They prepare the lovo to put the Coalition supporters in.

7. Another coup to take place-overthrow the Governor General, shoot Bavadra, Epeli Nailatikau and Coalition supporters.

9. Fiji to be under military regime until 10.10 .87 when the country will be declared a republic.

10. All seats to be Fijian, other races not to be given power and decision making.

11. Indian schools next target of attacks. Observation and stories from the security forces heard soldiers helping terrorists, also have been helping throw petrol bombs at buildings although pretending to protect public (Friday incident also Saturday night 12.9.87).

12. Soldiers and Taukei Movement working hand in hand. There is evidence — overhead a police officer saying let them do it, Friday's riot.

13. Not all soldiers, Westerners and other supporters in the army are merely carrying out orders but may revolt if they are forced to shoot their own relatives and kai vata. These soldiers and policemen are just working for their bread and butter. Inside there is a bitter feeling against Rabuka.

14. Everything happening now is being backed by the Taukei Movement leaders who have encouraged youths and ex-criminals. There is evidence that some soldiers and policemen already knew before what would happen on Saturday night 12.9.87 and Friday 18.9.87. On Sunday evening 7:30 pm 20.9.87 Rabuka went to the Central Police Station cell and had a private audience with five to eight members of those who were to appear in court on Monday 
morning 21.9 .87 (arsonists). He took cigarettes and gave it to them. He had a secret discussion with them. Only him alone, no other member of the security forces was to be with them. He ordered that the arsonists be released for a few hours that evening. He apparently entertained them and briefed them. Please, I hope you won't reveal my identity. We pity Bavadra, Navuso, Nailatikau, etc. We are trying to help them. Please take care.

\section{DEUBA ACCORD: 'BRITISH SOLUTION TO A FIJIAN PROBLEM'84}

The second coup came at a particularly inopportune time. With the Constitution Review Committee issuing a divided report, the Governor General realized the need for a fresh start. Learning from his errors of judgment over the past few months, he promised a new caretaker government which would be 'more representative and balanced,' and 'command the necessary public confidence.' It would consist of members of the dissolved Parliament, the senate as well as his Council of Advisors, and would run the country while a more permanent solution was being sought. To this end, he initiated a series of private meetings between the principal players. The negotiations, 'protracted and held over many days,' Reddy recalled, 'resulting in intense negotiations and discussions, ${ }^{85}$ took place at a Deuba resort, about forty five kilometers west of Suva, after an earlier meeting at the Hyatt near Sigatoka. The Coalition negotiating team included Jai Ram Reddy, Dr Bavadra, Mahendra Chaudhry and Krishna Datt, and the Alliance team of Tomasi Vakatoa, Ahmed Ali and Filipe Bole was led by Ratu Mara.

Reddy's leadership of the Coalition in the talks was questioned by the Alliance team. He should not be part of any future interim arrangement, the Alliance insisted, because he was not an elected member of the deposed Parliament. When Ganilau looked at him, Reddy reminded the Governor 
General of his own position in 1972. Having lost that election to NFP's Atunaisa Maitoga, Ganilau had been appointed to the Senate and then inducted into the Alliance cabinet. And Reddy reminded the meeting that under the 'Doctrine of Necessity,' only those parts of the constitution which had been rendered inoperable by reason of the revolution would be set aside while the other provisions of the constitution remained intact. When the Governor General's constitutional advisor, Professor Keith Patchett, agreed with Reddy's interpretation, Ganilau overruled the Alliance, and Reddy remained in contention for a possible future role in an interim administration. Another contentious issue was the Coalition's court case against the Governor General's dissolution of Parliament. Ratu Mara was incensed. 'We are also aggrieved that we are meeting here when there is a court case hanging over your head. This case is resented by Fijians. It will be pointless to go on discussing if the court case intervenes and our talks are useless.' Reddy responded: 'It is common knowledge that any aggrieved party is entitled to go to the courts. It is a lawful action. We have not sued the person; it is the office. You [Ganilau] are not even named in the action. It is 'Bavadra vs the Attorney-General.' It is too early to ask us to withdraw the case now. We don't have the army, we only have the courts. ${ }^{\prime 86}$ Fortunately, emotions subsided after Tomasi Vakatora spoke some soothing words and negotiations began.

The Deuba Accord, as it came to be known, agreed that a bi-partisan caretaker government would be formed to 'guide the country to a solution of Fiji's constitutional problems, re-establish Fiji's respect for law and order, and put the economy on a firm footing.' The new Council of State, to be chaired by the Governor General himself, would consist of twenty ministers, with an equal number from each of the parties, sharing power on an equal basis. Of the twenty members, six - three each from the two main parties - would form a new Constitutional Review Committee, under the chairmanship of an eminent expert from overseas. The enquiry, it was hoped, would find a permanent constitutional solution to the problems of Fiji. Its Terms of Reference required the committee to 'recommend arrangements 
for the early return to full Parliamentary democracy,' 'take full account of the aspirations of the indigenous Fijians for the betterment of their constitutional, economic and social interests,' and 'provide a framework for a multi-racial society in which the rights and interests of all the communities are safeguarded, thereby laying a foundation for just and harmonious relations between all communities.' To that end, the enquiry would 'give due regard to the aspirations and concerns expressed throughout the report of the Constitutional Review Committee, and to take proper account of all recommendations made therein,' and to examine whether any other form of constitutional arrangement is better suited to meet the present and future needs of Fiji than the Westminster model and, in particular, to consider the extent to which some form of power sharing might be given effect.'

This was an impressive breakthrough, especially the possibility of some form of power sharing, at a time when the nationalists were demanding total Fijian control of political power. To re-visit all, and not only the majority recommendations of the Falvey report with an open mind, was also a sensible concession. Unbeknownst to many at the time, the Coalition had flown in the eminent constitutional lawyer Yash Ghai to be on the standby at Deuba just in case his input was needed. Too much was at stake to take any chances. Reddy was later repeatedly attacked by his opponents for fleeing Fiji at the 'height of the coup,' but as he said in his defense, he was in Fiji throughout the most serious period of the crisis, very much at the centre of the unfolding events, as part of the Falvey enquiry and as a participant at Deuba. There was a small, formal celebration among the participants after the Accord was signed at Government House. A press photo captured Ratu Mara, Ratu Penaia and Dr Bavadra cutting a celebratory cake. Others, including Reddy, were heading back to the west for similar celebrations there.

But before the ink had dried on the document, Rabuka executed his second coup. Rabuka was not a party to the meeting that formulated the Deuba Accord. Ratu Mara suggested that he might be included in the negotiations, but reported Sir Len Usher, the idea was rejected by the Coalition 
'influenced primarily by Mr Jai Ram Reddy. ${ }^{97}$ This was 'a major tragedy,' Usher went on, 'because such subsequent happenings as the declaration of a republic, the Governor General's resignation, the removal of the Queen's unifying influence and the loss of Fiji's membership of The Commonwealth' could possibly have been avoided. Usher also suggested in his letter that 'when the [Deuba] meeting ended, there was considerable support within the Coalition for the principle of a Fijian majority in Parliament.' This, he said, was 'an important factor in the achievement of the goodwill' to which Dr Bavadra had referred in an earlier letter. Overall, in Usher's view, the reasons for the failure lay squarely at Reddy's door.

Reddy responded to Usher's letter with a letter of his own. ${ }^{88} \mathrm{He}$ was scathing. 'As a former editor of the Fiji Times,' he wrote, 'Sir Leonard should know that, in attempting to distil the facts of any story, one needs to talk to both sides. It is of little use to 'question a number of people present' at the meeting of September 23 and October 5, if they are all from the same party.' None of the Coalition delegation was interviewed. If Ratu Mara had indeed suggested that Rabuka be a party to the talks, he had not done so in the presence of the Coalition. 'The subject was never raised with us,' Reddy said. Nor did it need to be. Ratu Sir Penaia had already told the assembled delegates at Deuba on 22 September that he had talked to Rabuka and had 'his full assurance that the political consensus which is the goal of the current talks will have his full support. ${ }^{89}$ The substantial agreement, to which Usher had referred, only covered the formation of a joint administration and the terms of reference for a constitutional review. There was 'no general understanding' that there was 'considerable support within the Coalition for the principle of Fijian paramountcy.' That would have been inconsistent with the Coalition position. 'We have agreed to full constitutional review,' Reddy argued, 'but that did not mean unfair representation for any ethnic group.' Usher had said this 'understanding' was not spelt out in the statement issued at the end of the September 23 meeting. 'It was not spelt out,' Reddy rebutted, for a very good reason. 'No such understanding existed.' 
Four days after the second coup, Rabuka declared Fiji a de facto republic, but still hoping that the Coalition would accede to his demands. When that possibility faded, he finally severed Fiji's link with the British monarchy at midnight on 7 October. Rabuka told an Indian journalist that once 'the caretaker government came into being, they would have imposed watch-dogs on the military, watered down the military and restricted its capacity to stage another coup. We thought that if the caretaker government would carry on long enough, they would forget the real issue which was to change the constitution, ensuring the paramountcy of Fijian interests. ${ }^{, 90}$ That irrevocable step was taken after a meeting failed to resolve an impasse that had developed after the Deuba Accord had been signed. Rabuka had agreed to abide by the consensus of the meeting, but when he saw the terms of the agreement reached, he rejected the Accord. When Dr Bavadra came out of hiding after the second coup, he was taken straight to the Government House to meet Ganilau and Mara. At that meeting, Rabuka presented his minimum demands, which Mara agreed to and so, too, apparently did Bavadra. But before he could give that commitment, he wanted to consult his other colleagues. A meeting was arranged in Lautoka to see if a way could be found to meet Rabuka's minimum demands. Reddy erupted at Bavadra's willingness to hold the meeting in the first place. 'They don't honour their agreements,' he said, referring to the Deuba Accord. 'Why should we meet with them?' But he was persuaded to relent. Bavadra had given the commitment, and no one wanted to embarrass the leader.

At the Lautoka meeting on October 5, Rabuka presented his five minimum demands. These were: thirty seven Fijians in a sixty seven-seat House of Representatives; a Fijian Governor General and his deputy to be appointed by the Queen on the advice of the Great Council of Chiefs; a Fijian Prime Minister; mandatory review of the constitution every ten years; and the imposition of the 'Sunday Ban.' The only demand that Rabuka said was open to negotiation was the Sunday Ban; the rest were to stay untouched. After Rabuka had finished speaking, eyes focused on Bavadra. Feeling already chastised by Reddy for willing to attend the meeting in 
the first place, Bavadra reiterated the Coalition's unwavering support for the Deuba Accord. 'But that is not what you said at Government House,' Ratu Mara replied angrily. Bavadra was put on the spot, embarrassed. Mara himself was willing to accept Rabuka's demands if that would return the country to the Governor General's rule. As Vakatora recalled, the Alliance thought 'there was nothing at all in the demands that could be objectionable.' Therefore, they 'decided to go along in the national interest and to assist the Governor General in his efforts to return our country to normalcy as quickly as possible.' In the Alliance view, according to Vakatora, it was the Coalition leaders who 'were so blinded by their obsession that they completely forgot the reality of the situation. '91 'What do you say, Jai Ram,' Ganilau asked. Reddy had gone to the Lautoka meeting thinking that there might an opportunity for an inter-party dialogue, but he was now being presented with what clearly was a done deal between the military and the Alliance. 'We are prisoners,' Reddy replied. 'We have just come out of hiding. What mandate do we have to agree to these demands?' 'Sometimes, leaders have to take the plunge,' Ganilau replied. 'This is one plunge we cannot take,' Reddy responded. 'No, it is important,' Ratu Penaia said. 'Well, if this is the way constitutions are made, under duress, then you might as well take us outside, line us up and shoot us,' Reddy said in a matter of fact way. 'What good is assent or consent in these circumstances? We haven't consulted our people. ${ }^{92}$ The meeting broke up at that point.

\section{SEPTEMBER COUP}

The September coup was a much more carefully controlled and precisely executed affair than the May coup. Rabuka announced the second takeover at 4:50 in the afternoon on Friday, slapped an immediate curfew, enforced an immediate ban on foreign travel by selected Fiji citizens, and cut off all international communication. In the next two days, Coalition members and their supporters, judges, journalists and others who had for one reason or another incurred the wrath of the Fijian nationalists in the coup camp were, arrested, detained or sent to Naboro prison, and a few chosen targets 
were beaten and otherwise harassed. Soldiers scoured the west for prominent Coalition leaders, especially Jai Ram Reddy, the bete noir of the Taukei Movement, and Mahendra Chaudhry.

Both men sought refuge for several days at the homes of close friends in Ba and Lautoka, with Reddy on one occasion hiding under a verandah for three hours to escape arrest. I have no doubt that had he been caught, Reddy would have been killed, or at the very least, severely injured, so intense was the nationalists' hatred of him, so passionate their belief that he was the one man who had been the cause of the Coalition victory and, therefore, of the present troubles in the country. Reddy recalls the humiliating episode with a palpable sense of hurt, especially the dismissive and ridiculing comments by his opponents in the Indo-Fijian community that he had done so little for them when it really mattered. 'In this country, Mr Reddy, you take what we give you. No more,' a soldier had told him menacingly in Nadi, as Reddy was on his way for a social visit with former NFP parliamentarian HM Lodhia. 'Haven't you had enough,' the soldiers said on another occasion, repeating the words Ratu Mara had spoken. It all seemed to him to be a part of an orchestrated campaign of fear and intimidation. But Reddy was determined not to give in. 'There is no way we will agree,' he said. 'Any leader who bows down to threats is not a leader. Those who want to declare Fiji a republic should go ahead. What difference will it make if they decide to go for a republic? The situation will be like a pregnant woman who has to give birth sooner or later. ${ }^{93}$

Following the September coup, Fiji was plunged into the darkest period in its modern history, remembered today as a time of wanton disregard for human rights and rampant racial extremism. ${ }^{94}$ All Coalition members and supporters were fair target for abuse and harassment. Leading dissidents as well as professionals were barred from leaving the country. Reddy was on the banned list until December. Senior Indo-Fijian civil servants, suspected of harbouring pro-Coalition sympathy, were detained and subsequently 'retired.' In Ba, Labasa, Nausori and Lautoka, their fellow travelers suffered more humiliating treatment. The more prominent were 
tortured by the military to extract information about the supposed subterranean activities of the Coalition and the whereabouts of their leaders. The torture techniques reportedly included caning, beating, the threat of rape and water and sewerage immersion. A series of decrees sought to curtail personal freedom of the people. The Sunday Observance Decree banned all recreational and religious activities except for those who went to church. The Fundamental Freedoms Decree outlawed all political activity deemed detrimental to the military and its administration. Soldiers were given order to 'shoot to kill' if necessary 'while making a lawful arrest or preventing escape, to suppress a riot, or to prevent a criminal offence.' The Fiji Service Commission and Public Service Amendment Decree required fifty percent of all positions at all levels of the civil service to be allocated to Fijians and to Rotumans. The Public Commission could dismiss anyone on the grounds of 'public interest.' And so it went.

Still, things did not quite go the way Rabuka and his advisors had hoped. The economy was deteriorating rapidly. The rising cost of living, the increasing inflation rate, the compulsory 25 per cent salary cuts for civil servants at a time when the Fijian dollar had already been devalued by 35 per cent, all took a heavy toll. Local and foreign investor confidence had vanished and the tourism industry was in a slump and unlikely to recover anytime soon. And the prospects on the horizon did not look any brighter. Ratu Mara correctly surmised that unless urgent corrective action was taken, Fiji was heading towards bankruptcy. The international condemnation of the September coup was strong and unrelenting. In May, there was a great deal of confusion, and in some quarters the reaction was muted because of Ratu Mara's presence in the coup cabinet. But his absence from the September cabinet caused the second coup to be perceived not as an indigenous struggle but as a play for power by a bunch of extremist men. 'This is an act of intervention against a political process that was succeeding, not one that was failing,' said Sridath Ramphal, the Commonwealth Secretary General. And reports of gross abuse of human rights exposed a very ugly and disconcerting face of military rule in Fiji. The Commonwealth Heads 
of Government Meeting (CHOGM) in Vancouver decided, upon Sir Vijay R Singh's strong representation, to temporarily suspend Fiji's membership of the Commonwealth.

The writing was on the wall for the military administration headed by Rabuka (which contained an unlikely assortment of nationalists and opportunists such as Sakeasi Butadroka, Apisai Tora, and Inoke Kubuabola, Timoci Vesikula and Filipe Bole). Trying to distance himself from his more inexperienced, squabbling colleagues, Tora organized a petition to bring Ratu Mara back as leader, realizing that without a firm hand at the helm, the military government was heading towards certain doom. Mara's experience and international connections were sorely needed. 'There was a message coming through from many overseas governments,' Tora recalled, that 'put Ratu Mara back and recognition and aid will flow. ${ }^{\prime 95}$ Rabuka really had no choice but to oblige, though not before many of his preconditions were met. These included, among others, that no member of the Coalition should be part of the interim administration, that at least two senior officers other than Rabuka would be appointed to the new cabinet, and that the draft constitution prepared by the military would be accepted and any future amendments made to it be done in consultation with the military's own legal officers.

With the details out of the way, Rabuka formally approached Ratu Sir Penaia Ganilau to accept the presidency of the new Republic of Fiji. At a significant ceremony on 5 December 1987, with the traditional warriors of the chiefly houses of Kaba, Rewa and Tovata in traditional battle dress standing behind him, Rabuka asked for forgiveness from his paramount chief for any unintended transgressions of cultural protocol. He disclaimed any personal political ambitions for himself; he was merely doing what his people wanted: that is, to give them the political control of the land. 'What we were doing, we are doing, is because we love the land, the chiefly way of life of the Fijian people. 96 'We will be prepared to support and hear your call and heed your wishes in your time of leadership. I have pledged the support of your officers and your warriors who have come to handover lead- 
ership to you today,' Rabuka said. Ganilau acknowledged the significance of the occasion and said, 'Firm is our relationship, firm is the string that binds all Fijians together. Let us all shoulder one club for all time.' The next day, he told the nation that he had accepted the position of President and assured the Fijian people that the 'future protection of the indigenous Fijian interests is in safe hands.' Ratu Mara returned to his accustomed role as Prime Minister 'with honour and pride.'

On the other side of the island, Jai Ram Reddy and his colleagues had been in a limbo since the September coup, marginal to the developments taking place in Suva. It was a painful period of political impotence and great humiliation. A year after the coup, a three-member Australian Labor Party delegation, led by former Fiji-born South Australian premier Don Dunstan, visited Fiji on a fact finding tour of Fiji. Their report portrayed a stark picture of the present and future of the Indo-Fijian community. Its report noted that the response of the Indo-Fijian community was:

one of utter depression, a feeling that there was no longer any future for them in Fiji and a belief that the current administration would never afford them political rights in the future. Reference has already been to the purge of Indians in the senior ranks of the civil service. It is not surprising that private sector establishments, including foreign employers, have begun to discriminate against Indians in recruitment policy in order to make their presence acceptable to the current administration. In the last year there has been an exodus of Indian professionals from Fiji, including one hundred of the two hundred and seventy doctors working in Fiji in May 1987 and seventy of the one hundred and forty lawyers practicing in the country at that time. Over two hundred qualified teachers have resigned since May 1987 from secondary schools and five hundred teachers have resigned or retired at the primary level (in comparison with the one hundred and fifty who would leave the primary teaching service each year in normal circumstances). The most despairing reaction came from 
the sugar cane farmers who generally do not have the means to leave the country. The leases under which they occupy their farms are scheduled to expire between the years 1997 and 2000 and they are concerned that the leases will either not be renewed or that rentals will be set at a level that reduces them to subsistence or that they would become mere share-croppers. Already rentals have been significantly increased from pre-14 May 1987 levels, in many cases by 500 per cent. A purge of Indians has also taken place at senior levels in the police force. It would appear inevitable in the long term that the police force will, like the army, retain very few, if any Indians. It is evident that since 14 May, 1987, the police have on many occasions been indifferent to appeals for protection from members of the Indian community that have previously been acted upon. The result of these developments is that the Indian community has lost confidence in the police force and is generally reluctant to seek their assistance. ${ }^{97}$

The inevitable result was 'an increase in the physical and psychological pressures ... and their victimization by other sections of the community.' How to lead his people out of this dire situation would be one of the most challenging tasks to face Jai Ram Reddy and other leaders of the IndoFijian community. Still, they had stood their ground and refused to acquiesce against the most terrible of odds. For Rabuka and his men, this was a victory of sorts, though in the end it proved to be pyrrhic. For Reddy it meant having to start all over again.

It was not easy. The months since May had been for Jai Ram Reddy the most difficult time in his life. Things had turned especially bad since September. Chaos and confusion reigned. The economy had ground to a halt, and there was little work at office. Chandra and the children were in New Zealand and Reddy was staying at his father's place at Naviyago. People were shunning him on the streets, apparently fearful of their safety if seen publicly in his company. Reddy was depressed and very unsettled and, 
partly as a result, drank excessively to kill boredom and pass time. It was then that he wrote to Isikeli Mataitoga, who was at the time in the Solicitor General's office, 'from one lawyer to another,' as he puts it, to lift the travel ban imposed on him so that he could visit his family in New Zealand. He was no threat to the state; whatever he had done he had done publicly and openly; and he wasn't fleeing the country. His request was approved immediately. Reddy flew to New Zealand for Christmas and returned four weeks later, back in the cauldron of local politics.

1987 taught an important lesson, Reddy later recalled, and he learned it well. 'There is no future if any community tries to pull its weight in an exclusive fashion to create an environment in which it sees itself as dominant in Government,' he said. 'What we need is to form a partnership. That is probably the most important thing.' This issue had not been considered seriously enough in the years before the coup 'because we all underestimated the depth of feelings that existed, particularly within the indigenous Fijian community.' Everyone got carried away with elections, democracy and a constitution which allowed for governments to be voted in and voted out. 'But we never really understood the human dimension, until raw emotions erupted post-coup.' There was a great deal of hurt and humiliation, 'but they should not be dwelt upon in a disproportionate way so that it becomes a hindrance to the future healing process. ${ }^{98}$ 


\section{INTERLUDE}

\section{DEUBA ACCORD}

\section{Summary of Agreement Relating to the Formation of a Council of State of Fiji}

\section{AIMS}

To guide the country to a solution to Fiji's constitutional problems

To re-establish Fiji's respect for law and order

To put the Fiji economy back upon a firm footing

\section{LEADERSHIP}

His Excellency the Governor-General, who, in law, is exercising the executive authority for Fiji will have overall direction of the Government and will be chairman of the Council of State

\section{APPOINTMENT OF MEMBERS}

a. His Excellency the Governor-General will formally appoint the members of the Council of State;

b. the choice of the 11 members to be appointed from each party will be made by that party alone;

c. the members will be chosen from the elected members of the last Parliament and in addition the Governor-General will be free to accept the nomination by either party of a Senator to be a member of the Council of State.

\section{BI-PARTISANSHIP}

The Council of State will be bi-partisan by virtue of having equal numbers of members from the two principal political parties and of sharing equally the portfolios (see further item 9). 


\section{CHANGES IN MEMBERSHIP}

Will be determined by the Governor-General but will reflect the same bi-partisanship principle set out in 4, and will follow the same processes for appointment set out in 3 .

\section{SIZE}

The Council of State will comprise the Governor-General, who will be the Chairman, and 11 persons nominated by each of the principal political parties. (Subject to item 12 in respect of the Law Officer).

\section{EXTERNAL MEMBERSHIP}

There will be no members of the Council of State who are not Members of the dissolved Parliament. (see further item 12 in respect of the Law Officer).

\section{ASSIGNMENT OF PORTFOLIOS}

a. His Excellency will retain the portfolio of Home Affairs;

b. the actual allocation of portfolios will be made by His Excellency the Governor-General after due consultation with the Heads of the respective political parties.

c. the more important portfolios will be shared equally between the parties. The subject areas of these portfolios are:

* Finance \& Economic Planning * Fijian Affairs

* Foreign Affairs \& Civil Aviation * Education

* Lands, Mineral Resources \& Energy * Primary Industries

* Works, Communications \& Transport * Health \& Social Welfare

d. There will be six Councilors of State without Portfolio who will be members of the Constitution Inquiry. 


\section{RESPONSIBILITIES OF MEMBERS}

Members of the Council of State to whom portfolios are assigned will have conferred upon them the same executive responsibilities as Ministers under the present arrangements. They will therefore be heads of the Ministries and Government Departments to which their portfolios relate.

\section{DEPUTY CHAIRMAN}

In the event the Governor-General is absent from Fiji or is otherwise unable to perform the functions of Chairman of the Council, he will designate a person as Deputy Chairman to perform those functions after due consultation with the leaders of the two political parties.

\section{PROCEDURES}

The usual Cabinet procedures and practices will be followed by the Council of State.

\section{LAW OFFICER}

There will be a legally qualified Law Officer appointed by the Governor-General who will be principal legal advisor to the Council. The Governor-General will endeavour to find a suitably qualified and knowledgeable citizen of Fiji but, if he is unable to find such a person, he will be entitled to look for such an appointee from outside Fiji. If a Fiji citizen is appointed the Governor-General may appoint him to be a full member of the Council. Otherwise the officer would not be a member of the Council but would participate fully in the work of the Council.

\section{LEGISLATIVE RESPONSIBILITIES}

Power will be conferred upon the Governor-General, acting on the advice of the Council of State, to make ordinances for limited purposes, which would include questions of supply and appro- 
priation and security; namely matters meeting the requirement of necessity. When the legislative requirements of the Council are better understood, it will be open to the Council of State to look at the question of whether the dissolved Parliament should be reinstated, perhaps with circumscribed powers, to act as the legislative arm of the Council.

\section{CREATION OF COUNCIL OF STATE}

The Council of State of Fiji will be created by proclamation made by His Excellency the Governor-General. The members of the Council will be known as Councillor of State for the subject of their portfolio or Councillor of State without portfolio.

\section{Summary of Agreement Relating to Constitutional Review}

1. A primary responsibility of the Council of State will be to oversee the process of Constitutional Review.

2. For this purpose a Constitution Inquiry will be established comprising Councilors of State without Portfolio and an independent Chairman from overseas.

3. The Governor-General will decide the exact format of the Inquiry and in particular whether it should be established under the Commission of Inquiry Act.

4. The Terms of Reference of Inquiry will be:

To make proposals for a permanent constitutional solution acceptable to the people of Fiji, and in particular -

i. to recommend arrangements for the early return to full Parliamentary democracy; 
ii. to take full account of the aspirations of the indigenous Fijians for the betterment of their constitutional, economic and social interests;

iii. to provide a framework for a multiracial society of all the communities in which the rights and interests of all the communities are safeguarded, thereby laying a foundation for just and harmonious relations between all communities.

To these ends,

a. to give due regard to the aspirations and concerns expressed throughout the Report of the Constitution Review Committee and to take proper account of all the recommendations therein;

b. to examine whether any other form of constitutional arrangement is better suited to meet the present and future needs of Fiji than the Westminster model, and in particular to consider the extent to which some form of power sharing might be given effect.

5. The mechanism for effecting changes to the constitution will be determined by the Council of State on the recommendation of the Constitution Inquiry under item 4 of the Terms of Reference and is likely to be one of the following three alternatives:

a. the recall of the dissolved Parliament for the purpose of enacting the changes in accordance with the special procedures laid down in Section 67 of the Constitution;

b. the creation by Proclamation of a Constituent Assembly, the members of which would be elected in accordance with any new electoral procedures proposed for inclusion in the new constitution; 
c. the implementation of the changes by Proclamation after those changes have been presented to the country in a referendum and have received the approval of a substantial proportion of the electorate of Fiji.

\section{PROVISIONAL LIST OF PORTFOLIOS}

- Finance and Economic Planning

- Foreign Affairs and Civil Aviation

- Fijian Affairs

- Education, Youth and Sport

- Health and Social Welfare

- Primary Industries (Agriculture, Fisheries and Forests)

- Public Service

- Works and Transport

- Communications

- Lands, Energy and Mineral Resources

- Housing and Urban Affairs

- Information

- Labour and Immigration

- Trade, Industry and Tourism

- Rural Development, Rehabilitation and Relief

- Co-operatives and Consumer Affairs

+6 Councillors without Portfolio

* Home Affairs (retained by Governor-General). 


\section{INTERLUDE}

\section{DIWALI ADDRESS, BA 1988 \\ (Translated from Hindi by Radio Fiji)}

Today is Diwali. Signs and celebrations of this festival are to be found in the pages of Indian history from time immemorial. In fact, how and when this festival started is not fully known. However, despite differing views of its origin, it is widely celebrated. The basic principles that this festival establishes and teaches are vital in everyone's life. This evening many of our homes will be lit with large and small lights and 'diyas.' The poor and the rich will all join in the celebration. It's a festival which signifies that wherever there is light, darkness disappears. It is symbolic of 'truth overcoming falsehood.'

Dear Brothers and Sisters, remember that it's not only the outer darkness that needs to be conquered; there are dark spots and dark areas in our own hearts and in the society that need to be dispelled for happy and peaceful living. This evening we have gathered here to reflect on some of these things. We should regard it as our duty and should firmly pledge that as the 'diyas' spread their light over darkness so we too should cleanse our hearts and eradicate the ills of the society for progress and better living. Fear, despair and despondency are the root [causes] of destruction of any society. Many of us are suffering from these at the moment. Let us pledge to conquer these as 'light conquers darkness.'

One of the fundamental lessons we learn from Diwali is that in time of difficulty and external tragedies, visible or invisible, one must not lose one's sense of balance, hope, courage and determination. As light conquers darkness, you too will find the rays of light dispelling your doubts and despairs and make you more firm and resolute to realize your aspirations. 
Dear Brothers and Sisters, it is estimated that the first Diwali was celebrated in Fiji about 108 years ago. It is important to reflect and ask ourselves who those people were who first celebrated the Diwali, where did they come from and why did they come? Many people will give many views about the coming of the Indians to Fiji and some will give distorted views largely based on their imagination. But history is a product of research supported by documented facts.

On this auspicious Diwali I consider it appropriate to remind ourselves and the world about when, how and why the Indians came to Fiji. Indians did not come to cause trouble or confiscate anyone's land, nor did they come here as colonizers, to subjugate any group of people or to exploit or deprive anyone of their rights. The reality is, Brothers and Sisters, that the Indians did not come here by choice. They were brought here under the indenture system, which was a form of slavery. Despite the hardship they suffered, they accepted the challenge and served their cause honorably and heroically. With their hard work and labour, they survived and prospered.

Now we are told we are an immigrant race: that we have no rights. In fact in the formation of the new draft legislation [constitution] we are treated as non-entities. This new constitution which is to replace the 1970 Constitution deprives us of the fundamental right of citizenship in this country. We are asked to accept this new constitution even though we are not considered worthy of being mentioned in the preamble.

Today we are told that the new constitution is based on reality and these Indians must accept it. I wish to question as to what this reality is. Does this reality mean that we forget our 108 years of history? Or is it that we should forego all our rights and ac- 
cept the denials of human dignity and sign forever to be third class citizens of this country? Remember, we are not only asked to unconditionally accept the new constitution for ourselves but also for and on behalf of our future generations. What a reality! Brothers and Sisters, there is only one reality that I know of and it is that in the eyes of God we are all EQUAL. History tells us that from the dawn of civilization, human beings have always cherished their freedom and have fought for their rights. In the darkest of these days they did not lose their courage, hope or aspirations and persistently struggled to preserve and guard their honour, freedom and dignity.

If we look at our own 108 years of history in this country and reflect on how we came here as semi-slaves until we were emancipated, at no stage will you find that we did not have to struggle for our freedom and rightful existence. During the course of these 108 years at no stage were we ever classed as third class citizens. It is only today that we are ordered to accept this and ask no questions. The reality is this, dear Brothers and Sisters, that until our last breath we must not deviate from the truth and we must not to give up our fight for freedom and rightful existence. It is said today that Indians must unconditionally accept the new constitution. It is like being asked to dig one's own grave to bury oneself.

I will be greatly shocked and surprised if anyone accepted this new constitution as just and fair unless that person was blind or had not seen or read it, was compelled to accept under duress. Let me remind you, dear Brothers and Sisters, that your acceptance of this new constitution will be the acceptance of the denial of your fundamental rights. You will be bound by it and shall always remain as third class citizens of this country. 
There is another rather strange thing about the exponents of the new constitution and it is that when they abrogated the old (1970) Constitution no one asked us whether it should be destroyed and replaced with a new one. Furthermore, when the constitutionally and democratically elected government was ruthlessly overthrown by the army at gunpoint, no one consulted us prior to the overthrow of the government. During the last 18 months, whatever they wanted to take away from us they have taken. We could not do anything and remained quiet. Then why all of a sudden is there a change of heart - why are we being asked to submit to the new constitution with our own free will and accept it in totality?

In the last 18 months the communication has been at gunpoint, and in most cases we have been subjected to threats and force. But now we are being asked to accept the new constitution voluntarily. Why? There must be a hidden motive and reason for such a move on the part of the government.

There is one obvious reason and it is that all countries of the world, where there is a democracy and people have freedom, justice and above all have equal rights in all spheres of life, have disapproved of and condemned the new constitution propounded by the present government. New Zealand, India, America and Australia, to name a few, have all voiced their disapproval of this new constitution as it stands in its present form. We are being asked to accept the constitution to demonstrate to the world that the people of Fiji are voluntarily favouring it and therefore it is in the interest of all those who are accepting it. Friends, please don't be fooled and misled by these ulterior motives.

This evening, the 'diyas' are glowing outside and the darkness is being dispelled by the light. I say to you that like the lights of the 'diya,' let the light shine in your hearts, sharpen your wis- 
dom and vision and expose the deception so subtly hidden in the 'request' of the government for our voluntary acceptance of this new constitution. My request to you is that when this evening you light your 'diyas' make a pledge and with courage and conviction say 'No' to the new constitution. You know that the constitution is neither just nor fair nor would it be in your interest or in the interest of the future generations.

Brothers and Sisters, we know that our powers have been restricted and are still limited. But we know that no power can compel us to do what we do not wish to do. Remember that it is not a struggle for power; our defiance is fundamentally based on the irrational compulsion by the government and its encroachment on your freedom of choice and free will. But we are not so timid and ignorant that we cannot help ourselves. We must not forget that unless we help ourselves no one will help us.

Brothers and Sisters, I realize that tonight I have said more on the new constitution and rather less on 'Diwali.' I have done so purposely and you will agree with me that it is not the only 'Diwali' that you and I will celebrate. On this occasion we are also concerned for the future of our generations to come. What a 'Diwali it is going to be if we pretend and fool ourselves that our future is bright. It is not a time to be complacent. We will be deceiving ourselves and living in a fool's paradise. Arise, sharpen your wits and with Diwali rekindle the flame of your wisdom. Learn from the past and strengthen your future from the experience of the present.

Brothers and Sisters, I pray that this 'Diwali' may bring you health and happiness and give you solace and peace. May you have the strength, courage, and wisdom so that you may act with responsibility and be able to discuss and distinguish reality from unreality, and truth from lies.

May God Bless You 


\section{NOTES}

1. Hansard, 14 May 1987.

2. In Fijian custom, Leweniqila recalled, uncle and nephew seldom talk to each other. See Islands Business, May 1988: 16 for Lewniqila's reflections.

3. His surprise is surprising because two weeks before the coup, Leweniqila recalled having discussed the possible effects of a military coup on Fiji with Sitiveni Rabuka. See Islands Business, May 1988: 16.

4. See Satendra Nandan, Requiem for a Rainbow (Canberra: Pacific Indian Publications, 2001), 34. Strangely, Nandan does not name Reddy, though he adds: 'As usual, few minutes after the coup, the man had gone to the heart of the matter.' Reddy's recollection is also in Roger Vaughn, 'The Two Worlds of Fiji,' National Geographic, 188 (4), Oct. 1995, 118.

5. Fiji Times, 21 May, 1987.

6. Reddy had a lot of respect for Navin's courage. He was, like AD Patel, a Charotari Patel, people of steel feared and respected throughout Gujarat.

7. Hansard, 8 July 1993.

8. Reddy's recollection is in Hansard, 8 July, 1993.

9. Fiji Times, 21 May 1987.

10. Time, I June 1987. The magazine cover had a photograph of Sitiveni Rabuka on it.

11. See also Daily Post, 18 May 1999 about Reddy's critical role in the formation of the Coalition.

12. Fiji Sun, 10 May 1987.

13. I draw on my conversation with Mr Sharma over many years.

14. Fiji Times, 8 Apr. 1987.

15. Fiji Times, 9 May 1987.

16. Fiji Sun, 21 Apr. 1987.

17. Fiji Times, 21 Apr. 1987. 
18. Fiji Sun, 22 Apr. has extensive coverage.

19. Letter by Ram Naidu, Sultan Ali, Eshad Ali, Sada Sivam, Fiji Times, 11 May 1987.

20. Fiji Sun, 22 April, 1987 has an extensive coverage of the event.

21. Fiji Sun, 24 Apr. 1987

22. See Fiji Sun 19 July for Veitata's plans.

23. See Karen Magnall's story in Sunday Star, 15 May 1988.

24. Fiji Times, 25 Apr. 1987.

25. Fiji Times, 23 Apr. 1987.

26. Fiji Times, 25 Apr. 1987.

27. Fiji Sun, 24 Apr 1987.

28. Rediff.com, 14 Feb. 2005.

29. Fiji Sun, 28 May 1987.

30. From an extensive interview Kubuabola gave to Islands Business, May 1988, 18.

31. Ibid.

32. See Eddie Dean and Stan Ritova, No Other Way (Sydney: Doubleday, 1988).

33. For more discussion, see John Sharpham, Rabuka of Fiji: The authorised biography of Major-General Sitiveni Rabuka (Rockhampton: Central Queensland University Press, 2000).

34. Rediff.com, 14 Feb. 2005.

35. Ratu Meli Vesikula made similar claims in his interviews with the media in Australia. I have a transcript in my possession.

36. Time Magazine (Australian edn), 25 May 1987. See also Islands Business, June 1987: 'What dismayed many of the bewildered and bemused people of Fiji was the speed with which the Prime Minister for 16 years, Ratu Sir Kamisese Mara, agreed to accept Rabuka's invitation to join his Council of Ministers.'

37. An account of Ganilau's life is in Daryl Tarte, Turaga: The Life and Times and Chiefly Authority of Ratu Sir Penaia Ganilau (Suva: Fiji Times, 1993). 
38. Among them Lt Col. Jim Sanday who, to his great credit, resigned from the Fiji military when the coup took place and left Fiji for good.

39. Turaga, 174.

40. For a general account, see also Michael C Howard, 'Fiji After the First Coup,' South Pacific Forum 4: 2 (Apr 1988), 190-208.

41. Rabuka recalled these words when he handed power over to Ganilau on 5 Dec. 1987. Quote is from a transcript in my possession.

42. For more, see Dean and Ritova, No Other Way

43. Fiji Times, 15 May 1987

44. 'Sanday: 'Truths' Rabuka left out,' Islands Business, Mar 1988.

45. Ibid.

46. ABC Four Corners Program broadcast on 18 May 1987. Marian Wilkinson was the chief reporter for the programme.

47. A copy of the letter was given to me by Sir Timoci Tuivaga in June 1987.

48. Fiji Times, 15 May 1987.

49. See FM Brookfield, 'The Fiji Revolution of 1987,' New Zealand Law Journal, July 1988, 253.

50. Fiji Times, 15 May 1987.

51. Fiji Sun, 21 May 1987.

52. Rod Alley, 'The Development of Political Parties in Fiji,' (unpublished PhD thesis, Victoria University of Wellington, 1973), 64.

53. Fiji Times, 22 May 1987.

54. Fiji Sun, 23 May 1987.

55. Quoted in Time Australia, 1 June 1987, 17.

56. Fiji Sun, 6 July 1987

57. Peter Thomson, Kava in the Blood, 127.

58. Fiji Times, 9 June 1987.

59. Kenneth Bain, Treason at 10: Fiji at the Crossroads (London: Hodder and 
Stoughton, 1989), 87.

60. Fiji Sun, 17 June 1987.

61. Melbourne Herald, 25 June 1987.

62. Fiji Sun, 13 July 1987.

63. Fiji Sun, 2 July 1987.

64. Fiji Times, 13 June 1987.

65. Editorial, 15 June 1987.

66. New Zealand Herald editorial, 25 June 1987

67. US Embassy statement is printed in Fiji Times, 21 June 1987.

68. According to Peter Thomson, Kava in the Blood, 129.

69. 'Terms of Contention,' Fiji Times, 4 July 1987.

70. Brief excerpts of the League's submission appeared in the Fiji Times, 6 June 1987.

71. See 'Muslim League Talks Blocked,' Fiji Times, 10 Aug. 1987; also 'Muslims in Crossfire,' in Pacific Islands Monthly, Sept. 1987, 24.

72. Fiji Times, 21 July 1987.

73. Fiji Times, 18 June 1987.

74. Quote is from a transcript in my possession.

75. Public Emergency Regulation was published in Royal Fiji Gazette, 114: 37, 18 May 1987.

76. See Fiji Times editorial of 29 June titled 'Detainees Rights.'

77. The sugar cane growers proposal, drafted by Sir Vijay R Singh, chief executive of the Sugar Cane Growers Council, is in Fiji Sun, 1 July 1987.

78. The Governor General's speech over Radio Fiji is printed in Fiji Times, 19 June 1987.

79. Interview with Bruce Stannard, published in Bulletin magazine, 13 Oct. 1987, 20.

80. Fiji Sun 12 Sept. 1987.

81. Details are Fiji Sun, 5 Sept. 1987. 
82. Fiji Sun, 24 Sept. 1987.

83. From a handwritten note by a senior soldier, 21 Sept. 1987. It was later published by the Fiji Independent News Service ( no. 2, Oct. 1987).

84. See Tarte, Turaga, 183

85. Hansard, 22 Sept. 1993.

86. As recalled by Peter Thomson, Kava in the Blood, 162-63.

87. Letter in Fiji Times, 17 Dec. 1987.

88. Fiji Times, 18 December 1987.

89. See also Daryl Tarte, Turaga, 182-83

90. The Indian journalist was Saed Naqvi. See his 'Marooned at Home: A demoralised (Fiji) Indian community,' India Today 30 Nov. 1987.

91. Vakatora, From the Mangrove Swamps, 80.

92. Reddy's heated remarks gave Mara and Ganilau the worst dressing down he had ever seen chiefs get, according to Apisai Tora. Letter to author 17 May 2010.

93. From an undated newspaper clipping in the Reddy papers.

94. One only has to read the reports published in the Sydney-based Fiji Independent News Service to get a sense of what was going on in the country soon after the second coup.

95. Islands Business, May 1988, 15.

96. The words are from a translated script of the words spoken at the ceremony. The quotes are from my copy.

97. The report does not seem to have been formally published. I have a copy of the 19 page report. The other members of the ALP team were Ray Hogan, Victorian secretary of the Miscellaneous Workers Union, and Michael Saxton, a Sydney lawyer and chairman of the NSW ALP's Foreign Affairs Committee. See also Satendra Prasad (ed.), Coup and Crisis: Fiji A Year Later (Melbourne: Arena Publications, 1988) for a similar assessment by several writers.

98. Review Magazine, June 1997, 16-17. 


\section{CHAPTER 6: TRANSITION}

The old order changeth, yields place to new

And God fulfils himself in many ways

Lest one good custom corrupt another

Alfred Lord Tennyson

12 May 1987 was Jai Ram Reddy's 50th birthday. It had been an eventful half century for the lad from rural Lautoka, handed the short straw like so many of his time and place, and growing up in the long, lingering shadow cast by the events of World War II: the dislocation of the farming community in western Viti Levu caused by the war-time work, the effects of the crippling strikes in the sugar industry, and the deteriorating race relations resulting from the varying degrees of enthusiasm with which the different communities had approached the war effort. After an indifferent high school record, Reddy had acquired a New Zealand law degree, later emerging as the leading criminal barrister of his generation. His early political career had been spent almost entirely in the labyrinth of Indo-Fijian politics as a fire-fighter, a peace-maker and a bridge-builder, although he was of course not viewed that way by those who were on the other side of the political divide for whom he was the very epicentre of the political turbulence that racked his people and his party. After 1977, Reddy emerged on the centre stage as the dominant leader of the Indo-Fijian community and its representative to the outside world.

In December 1983 Reddy had walked out of parliament after an altercation with the Speaker of the House, hoping that would be the end of his parliamentary career. The elections of 1987 brought him back on to the political stage as the principal architect of the Coalition which finally 
dislodged the Alliance from power after an uninterrupted reign of twenty one years, and as its leading campaigner even though he himself was not a candidate. He was often in the eye of the storm after the coups, the target of attacks by the Fijian nationalists who thought him the real power behind the Bavadra throne, sitting on various commissions struggling to get Fiji back onto the road of parliamentary democracy, counselling caution and moderation in political dialogue, giving hope to his people demoralized by the display of destructive indigenous ethno-nationalism and rampant religious fanaticism. The coups marked the end of the first, largely unproductive phase of Jai Ram Reddy's career. A more productive one was about to unfold, transforming in the process a communal politician into a respected elder statesman.

1987 was also a cataclysmic year for Fiji. It ended an era in modern Fijian history and ushered another whose future and fate it is yet too early to tell. But of its seminal, life-changing impact on the politics, society and economy of Fiji there can be no doubt. It was, by any measure, a watershed year etched forever in the collective memory of the nation, the most transforming moment in its 20th-century history. The bayonet abruptly overturned the verdict of the ballot box. The rule of law was rudely ruptured. Political turmoil engulfed the country. Race relations were frayed and racial discrimination entrenched in public policy as never before. Indo-Fijian tenants were threatened with the non-renewal of their leases for no other reason than for voting for a political party not supported by the landowners. Poverty deepened and mushrooming squatter settlements became a permanent feature of areas surrounding major urban centres. There was, after all this, justifiable ground for grief and despair and anger but instead Jai Ram Reddy chose reconciliation and healing as his preferred path forward so that his people could live a life of dignity and peace in a land where they had so few rights and such limited opportunities. After the coups, Reddy seriously began to question the assumptions and political arrangements of the early independence era. These, he realized, had proved disastrous for Fiji and had to be discarded in favour of something else that nurtured 
consensus, not confrontation and that promoted national unity rather than ethnic division. His focus shifted from acquiring power through the ballot box to sharing it in a just and equitable way with the other communities.

The coups hastened the departure from the national scene of the paramount Fijian chiefs who had for long dominated the affairs of their people and of the nation at large. The four great chiefs of their time, Ratu Sir George Cakobau, Ratu Sir Edward Cakobau, Ratu Sir Penaia Ganilau and, of course, Ratu Sir Kamisese Mara, were tutored by the United Kingdom for national leadership, to take charge when the independence train took off in the early 1960s. The first two went early, but Ganilau and Mara were fated to live through the traumatic transition effected by the coups and variously touched by the many controversies generated by them. By then they were not the same influential, awe-inspiring figures they had once been, their life's work being undone before their eyes, their overarching influence unobtrusively on the wane. The May 1987 coup was ostensibly carried out in the name of the Fijian people, to preserve the central tenets of traditional Fijian society from erosion by the forces of modernity, but its cumulative effect ironically was to achieve quite the opposite: to undermine the ideology and structure of chiefly leadership. It also opened up deep fissures within indigenous Fijian society which had been carefully hidden from the public view by the policies and artifices of the colonial administration and the overarching influence of chiefly leadership. Fijian political fragmentation, which would have appeared unthinkable in the 1970s, became a troubling, persistent reality in the 1990 s, and it is unlikely ever now to disappear.

Rabuka's public attitude towards chiefs, once dutiful and reverential, changed over time. He publicly clashed with Ratu Mara who, in turn, sought to undermine the young 'upstart,' to use his words, by encouraging the formation of rival political parties, most notably the Fijian Association Party. Rabuka's defeat in 1999 was attributable in part at least to Mara's continuing, subtle behind-the-scenes influence. Nonetheless, Rabuka remained the preeminent Fijian leader in the 1990s. His presence at the helm was significant for the political developments that unfolded and defined 
the decade, not the least because Jai Ram Reddy could work fruitfully with Rabuka better than he ever could with Mara. At the time of the coup in 1987, though, Rabuka was a fire-breathing nationalist, a religious fundamentalist determined, he said, to convert the 'heathens' to his faith. In the early 1990s, he was still erratic, making contradictory statements, still courting the nationalist fringe perhaps as a survival strategy. But from the mid-1990s he changed and became a committed multiracialist. A part of the reason was the endless informal conversations Rabuka had with Reddy. There was a developing mutual trust between the two men. Rabuka 'trusted' Reddy in a way he did not trust Mahendra Chaudhry, even though the Labour leader had helped launch his political career in 1992. Reddy saw the possibility of change in Rabuka and sought to work with him. Mara was Olympian, a seasoned politician who could never quite fathom Reddy and who, for all his proclaimed commitment to democracy, believed deep inside him that Fijians, and especially chiefs, should take the lead in running the country. Rabuka hindered his dynastic ambitions.

Jai Ram Reddy entered politics when the Indo-Fijian community was nearly half the national population. It was, in the early days of independence, a moderately prosperous and settled community. The future of the sugar industry looked bright; rural schools were full and run well, and school leavers were able to find public sector jobs of varying degrees of attractiveness and financial satisfaction. By the late 1960s and early 1970s, as Canada opened up its immigration policy under the progressive Liberal Prime Minister Pierre Trudeau, some were beginning to emigrate or were contemplating it, though for most that prospect seemed remote on the horizon. But politically, the Indo-Fijian community was marginalized. The leaders of the National Federation Party had been in the vanguard of the independence movement, but their people were not fated to enjoy its fruits as equal partners in government because of a race-based electoral system that manifestly disadvantaged them, consigning them to a permanent place on the Opposition benches. By the time Reddy departed the political arena, the Indo-Fijian community had been reduced to a sizeable 
but diminishing minority of the total population, with attendant political consequences.

Fear of 'Indian dominance' lay very near the surface of Fijian political thinking in the 1970s and 1980s, that Fijian people would be dispossessed of their fundamental birthright, especially their rights to land, if Indo-Fijians, with their superior numbers and inherent cunning, were ever allowed to assume the reins of power. 'Blood will flow' was a commonplace phrase in the immediate post-independence years uttered ominously by Ratu Mara himself, meaning Indian blood would flow if Fijian land and leadership were ever threatened. A system of racial representation in parliament ensured that politics was racially organized. It was so from the beginning. The National Federation Party was based in the Indo-Fijian community and the Alliance in the Fijian and General Elector. Both paid obligatory lip service to the principles of multiracialism, but the underlying truth of racial compartmentalization was never quite hidden from view. In this scheme of things, appealing for political support from members of other communities was seen not as an opportunity to increase the space of genuine multiracial politics, but rather as an attempt to divide the people, which worsened relations at election time. Elections in truth became racial censuses, racial contests. Victory had to be obtained at any cost, for the very survival of a particular 'race' depended on the outcome, the politicians told the people. Politics was a deadly zero-sum, winner-take-all game, which left little space for consensus and compromise.

This was the world of politics that Reddy inherited and which he inhabited for the first part of his career. But soon he despaired at the futility of it all. With the grossly inflated numbers of General Voters in parliament, Reddy realized that Fijians would always remain in power and that his people would be consigned to the political wilderness forever. Preoccupation with race was detrimental not only for his own community but for the country as a whole. Power sharing, he was beginning to feel, was far better than openly competing for it in the traditional Westminster style. He accepted that, at least for the foreseeable future, political activity in Fiji would 
be organized along racial lines. Rather than fight that truth, it was better to acknowledge it and devise a political arrangement that would facilitate genuine power sharing between the two major communities. Reddy had experience to go by. 'The communal pools are extremely strong,' he said in 1992, and multiracialism through open competition for power was 'a bit premature for Fiji' for the foreseeable future where race would continue to play an important role in forming perceptions. ${ }^{1}$ Instead of denying it, Reddy argued, it was best 'to accept it because neither party [Alliance nor the NFP] has been very successful in attracting support from the other community over the years.' Any effort to gather support from another group fostered suspicion and hostility about divide and rule. 'Let us accept that we must co-exist and work together and work with each other.'2

The concept of power sharing that Reddy had been advocating for nearly a decade by the 1990s, had been around in continental Europe for decades, its principal theorist being the Dutch-born political scientist, Arend Lijphart. ${ }^{3}$ Consociationalism, which was the name given to the power-sharing arrangement, rests on some fundamental pillars. It involves guaranteed representation of recognized communities in parliament and state apparatus on the principle of proportionality, respect for the 'segmental autonomy' of the different groups in the management of their internal affairs, 'mutual veto' over matters of importance to the different communities and a 'grand coalition' where elites of the different communities cooperate for the harmonious functioning of society. Political stability is thus achieved through a formally recognized and mutually respected system of structured power sharing. The fear of dominance of one group over another is reduced, if not eliminated. And this was what Reddy wanted for Fiji. 'We are not seeking dominance,' he said as early as 1993. 'All we are seeking is a fair chance. We are seeking fairness, equity and justice which are recognized human right. ${ }^{4}$ So, from open to structured competition for power was one important change in Reddy's out look.

There was another: the tone and tenor of Indo-Fijian political discourse. For a very long time, Indo-Fijian politics was suffused with a large 
dose of grievance and flourished on a confrontational style of politics. This was understandable in the circumstances. In many sectors of life — in the allocation of tertiary scholarships and employment in the public service, for instance - Indo-Fijians were systematically discriminated against purely on the grounds of ethnicity, and their leaders were obliged to raise their concerns in public, even at the expense of incurring the wrath of the government. But this is more or less all they did: talk; and they received a predictable response from the government: closing of rank along racial lines. Every issue of public policy in time came to be viewed through the prism of race. There was little opportunity, and even less political incentive, to see problems from the other side of the divide. In this environment, leaders often talked at each other rather than to each other, often through the media. Race, Ratu Mara often said, was a fact of life in Fiji. It was also becoming a way of life.

By the early 1990s, Reddy was moving decisively away from the old style of politics. This is evident, for instance, in his address to the NFP convention in Suva in 1994. There, Reddy talked about the various problems facing Fiji, including unemployment, crime, poor health care, declining social welfare. His approach was inclusive and far-sighted: 'These are not communal or racial issues,' he said. 'I am just as concerned with Fijian poverty as I am with Indian poverty. My desire for better health care is not limited to the Indian community. Hunger and disease make no racial distinctions: they affect us all in the same way. Our need for a robust and successful economy bringing prosperity to every citizen, likewise, offers us a common purpose.' It was the same message he gave in an address to the Fiji Principals Association in 1994. 'There can be no dissent from the aim of increasing indigenous Fijian participation in education and enhancing the performance of Fijian students. We must all share in the concern about the results coming from some Fijian schools. The trend cannot be ignored. We will never succeed in shaping a model of multiracial society if the curriculum, the facilities and the teaching environment are not responsive to the particular needs of the indigenous community.' 
The search for a common, uniting purpose, the common space, would be Reddy's major preoccupation throughout the 1990s. He told the 1994 NFP convention that there should be 'no place in our thinking for what might be called a zero-sum game, in which one community must lose for the other to gain.' It was the same message Reddy delivered to the General Voters Party. 'I am not interested in the tired old rhetoric of racial politics,' he said. 'I am weary of pointless bickering, ugly innuendoes and raking over old coal.' There were challenges ahead which would not be met by 'perpetuating the recriminations and narrow racial perceptions of the past.' He asked people to be open-minded and accommodating. Speaking on multiracialism at the NFP's 1997 convention, he said that the concept to him was 'an attitude, a state of the mind.' He continued: 'Multiracialism to me means sensitivity to and understanding of other people's feelings and needs,' 'a capacity to understand and care about others who may be different from me,' 'a willingness to be accommodative,' 'and the ability to appreciate and rejoice in other people's cultures and accomplishments.' Such talk would have been rare in the 1970s and 1980s.

By the 1990s, Reddy's early impatience and a preoccupation with a speedy resolution of problems were gone, as he realized that he was embarked on a massive project of social and political reform and reengagement which might conceivably go even beyond his own life time. What was important for him was to make a start in the right direction, and not worry about the final destination of a long and difficult journey ahead. He began to take a long-term view of things, while his opponents focused squarely on things here and now. Reddy would say, for instance, that the 1997 Constitution, with its novel power sharing idea at the centre of it, should be given time, perhaps even at the expense of party political activity for some years, to prove its potential. He asked questions that transcended the narrow confines of communal politics. 'Unless we have a clear sense of who we are,' he told a Fijian Association Party function in May 1996, 'we cannot proceed to determine the place we want Fiji to be, we can't expect to find our niche among nations.' Valuable time was being wasted. 'We seem to be 
struggling in the torrent of history, unable or unwilling to chart a course that will take us safely through to nationhood. And if we lack a clear vision of what we want for ourselves as a people — all of us - how can we hope to define ourselves as a nation or plot a future for our children. Not only do we seem unsure of precisely how we are to set out on this mission, we sometimes appear unable to accurately identify our destination.'

This enlarging, encompassing, approach was an important part of Reddy's political repertoire in 1990s. He was now focused on the process of bringing about change, not some clearly identifiable end result. 'What we are saying,' Reddy remarked in 1992, 'is that we will try our best by the most honest and practical way we know' to bring about change. '[The] rest I would leave to Providence.' The contrast with Labour's more agitational, outcome-oriented style of politics could not be greater. Reddy agreed with Rabuka who had likened a nation to a family. 'Like all families, we have our disagreements, our sibling rivalries, if you like,' he said. 'But don't we also have a real sense of the intrinsic virtue of unity and togetherness? Don't we have a sense of what we can achieve if we realize that we are interdependent, that we all need each other?' To be sure, members of a family had varying interests and worries. Nonetheless, 'we share a common love for our home, for the land that gave us birth, and in whose service we are now called to find common cause and unity.' Reddy said in October 1995: 'The coup did many bad things, but it made both Fijians and Indians realize that coexistence is not enough. The two races must become one nationality. It's time. ${ }^{5}$

The early years of Reddy's career were spent almost entirely in the world of Indo-Fijian politics. Both the community and the party were bitterly divided as became painfully clear in the 1977 elections. The leadership ambitions of NFP's political leaders hobbled the party and virtually destroyed its prospects as a government-in-waiting. Reddy, as a newcomer and as a person with a clean image, was called upon to mend fences, build bridges, to put out the intra-party fires. An enormous amount of his energy went into healing the wounds within his own party. To his credit, 
he succeeded in rebuilding a shattered political organization into an effective fighting machine by the early 1980s, enough, as we have seen, to come within two seats of capturing power in the 1982 general elections. But the overwhelming impression of the early years is of incessant fighting over small things that in the larger perspective did not matter. Essentially, the NFP was a party of the Indo-Fijian community with a small sprinkling of non-Indian support. Reddy realized that things had to change if the party was to make a serious bid for national power. It would have to reach beyond the Indo-Fijian community for support. To that end, he attempted a coalition with the Western United Front. In line with his developing philosophy of consociationalism, he would seek partnership with a representative Fijian party as he would with the SVT in the late 1990s.

Reddy also brought a degree of professionalism to the proceedings of the National Federation Party beyond his role as the repairer of damage: The NFP conventions of the 1970s appear to have been occasions beset with intrigue and machination, concerned to ensure the election of 'right' people as office bearers. Speeches were made, but no archival record survives of them. The convention brochures are perfunctory, containing messages from branch presidents and other worthies, snippets from public speeches, advertisements from companies supporting the party. Under Reddy's leadership, I have no doubt there was plotting and campaigning going on behind the scenes, but this was not the main feature of the event. As two speeches (of the Cuvu and the Ba conventions) included in this book show, the Party Leader's address was the main event of the day. The speeches are, by any yardstick, remarkable documents of power and persuasion. Reddy raises substantial issues; he talks to the people, not at them. He invites reflection and feedback. There is a seriousness of purpose in the speeches that is refreshing and stimulating. Reddy appears to be using the occasion to reach out to a larger constituency beyond his party. And this would be the hallmark of all NFP conventions throughout the 1990s, with one added feature: the engagement of a keynote speaker, who was not usually a member of the party, but who was expected to raise pertinent issues for discus- 
sion and reflection. Among those who addressed the NFP convention in the 1990s was (the now disgraced) Justice of the Federal Court of Australia and former Human Rights Commissioner, Justice Marcus Einfeld. I spoke at the convention in 1993.

Beyond politics, Reddy began to engage more broadly with other communities. 1987 was perhaps the first occasion that Reddy appeared on the political scene not simply as an Indian leader, but as a national figure. Non-Indians for the first time saw him as a speaker and a campaigner, and were impressed by what they saw. In the 1990s, as his stature grew, he gave talks and addresses to non-Indian audiences: to the General Voters Party, the Fijian Association Party, to the Queen Victoria School, to multiracial business communities and non-government organizations. He was deliberately reaching out, sharing his vision with a wider community which had hitherto remained inaccessible to him and to most Indo-Fijian leaders. Reddy realized that to break the ice, he would have to make the first move, and he did. On all these occasions, he talked about the broader national interest, the need for national unity and cohesion, the necessity to move away from a preoccupation with race. He told St Joseph Secondary School in Suva: 'The path you follow, the steps you climb, the dream you dream, is yours. How we want the future to be is up to us. If we dream that dream, we can have it. It is just a matter of working towards it.' He told the QVS students: 'You belong to a proud race of people. You have much to be proud of. While you must be firmly rooted in your own culture, language and traditions, you must also recognize you have nothing to lose, to gain much, by learning of, and about, the language and culture and ways of life of other communities around you.' The last time an Indian leader had addressed QVS was AD Patel in 1968. And giving the concluding address to mark the 'Year of the Indigenous People,' celebrations, Reddy spoke warmly of the 'folklore, the songs and dance, the art and artefacts of the Fijian people,' their 'wonderful seafaring skills, the awe-inspiring ocean-going canoes,' 'their well-organized, self-contained and resilient society built in harmony with their environment,' and embraced these as 'part of my own heritage. 
The full speech is reproduced later in this book. The culmination of these efforts was, of course, Reddy's history-defining address to the Great Council of Chiefs in 1997.

By the late 1980s and early 1990s, Reddy was in complete command of his party, its universally accepted leader, in the same way that AD Patel had been in the 1960s. There were no hints of dissension, which was a far cry from the days of the 1970s and the early 1980s. All the old warriors were gone. Karam Ramrakha had migrated to Australia in the early 1980s, from where he wrote the occasional article about local politics, but made no other intervention. Siddiq Koya, denied a seat in the 1987 general elections, was out of politics and in the twilight of his public life. Mrs Irene Jai Narayan had self-destructed. She had joined the Alliance and after 1987, even more incredibly, Sitiveni Rabuka's military government. After that involvement, there was no coming back for her; her bridges to her former party and to her community, were burnt for good. Vijay Parmanandam and Shardha Nand and Sir Vijay R Singh, among the prominent players in the earlier days, and other manufacturers of intrigue and instability and insurrection, were all gone or in retirement. Reddy was now in complete control of a new team. Their loyalty was assured.

For all his time in parliament, Jai Ram Reddy was the parliamentary leader of the National Federation Party as well as the Leader of the Opposition. The office of the Leader of the Opposition is unique to the Westminster system of government. The office is traditionally held by the leader of the largest parliamentary party not in government, who is also seen as the alternative Prime Minister. Reddy holds the unenviable record of being the longest serving Leader of the Opposition in Fiji's parliamentary history. The job, if conscientiously done, is taxing and inordinately time consuming. It demands a mastery of parliamentary and committee procedures. It requires providing cohesion and leadership to the Opposition team, a careful and searching scrutiny of government initiatives and policies, and an alternative vision to the electorate. More, it requires a competence to speak on a mind-boggling array of often mundane subjects — with persuasion 
and eloquence, if you are to make any impression on the government, or anyone else — as this typical list for the period August-December 1978 would suggest, when Reddy spoke at varying lengths on: Bill on Edible Oil, the Civil Service, Debt Servicing Budget Deficit, Nadi Airport Tender Situation Operating Expenditure, Flour Mills of Fiji Company Tax, Taxation, Sugar Industry Board, Third Party Insurance, Customs and Tariff Bill, Fiji National Provident Fund Amendment Bill, Guarantee of Loan to Fiji Electricity Authority, High Drainage Rates, Parliamentary Salaries Review Committee, Petroleum Exploration and Exploitation Bill, Business Fee for Medical Practitioners, Commission of Enquiry to Review all Reports of Treatment of Offenders, Ombudsman Report on Alleged Brutalities, Report on Motor Vehicle Insurance, Traffic Amendment Legislation, Supplementary Appropriations Bill, Unit Trust Amendment Bill

If you add to this list the literally hundreds of speeches the Leader of the Opposition is expected as guest speaker to give on public occasions outside parliament, and the countless articles he has to write for the annual school magazines and brochures of community organizations, you begin to appreciate the sheer enormity and tedium of the task. Some contributions are, of course, more important than others, and perhaps few as eagerly anticipated as the Opposition's Budget Reply when the government's program of expenditure for the following year is presented for parliamentary approval. Reddy gave the annual Reply throughout the early-mid 1990s, when the responsibility was assumed by the economist Wadan Narsey, to Reddy's enormous relief. Each Reply is a small monograph really, carefully thought out and accessibly written. The degree of professionalism that went into its preparation is impressive.

In the 1970s and 1980s, as the Leader of the Opposition, Reddy had raised issues about discrimination against Indo-Fijians in the civil service, and about education or the reservation of Crown land. But these were seen by many Fijians as simply 'Indian' issues, and treated accordingly: disregarded. It must have been soul-destroying for the Opposition benches to be repeatedly dismissed by the government of the day no mat- 
ter how genuine or serious their grievances. The frustration caused by this may have contributed to Reddy's decision to leave parliament in 1983. By the 1990s, when Reddy was in the second phase of his parliamentary career, while many similar issues were raised, the tone and tenor of the discourse changed, which brought more receptiveness from the other side of the House. It helped that Sitiveni Rabuka, not Ratu Mara, was at the helm of the government. Mara could be cold and curt, as was his wont when challenged, while Rabuka was courteous and collegial and open to persuasion. By the 1990 s, Reddy had a commanding presence in the House as its elder statesman. When he spoke, people listened. There was his spellbinding oratory of which people spoke, his careful marshalling of the evidence to make a compelling case. He put his forensic advocacy skills as a barrister to effective use. People crossed swords with him at their peril. Once when Semesa Sikivou interjected to say that Reddy was an exception to his own rule, Reddy responded: 'You are an exception to every rule I know.' When Sakeasi Butadroka peppered parliament with his trademark racially provocative remarks, Reddy said: 'I cannot help thinking that the Honourable Member sometimes, or most of the time, has his head in neutral and allows his tongue to idle off.' And when Labour's Vinod Maharaj asked for ninety-nine year agricultural leases, Reddy shot back, 'Is native land your father's private property?' Tumhaar baap ke zameen hai? This was the only time in Fiji's recent parliamentary history when a free-flowing (and predictably acrimonious) debate was conducted in Hindustani. But there were lighter moments as well. Once Reddy used the word 'albeit' in the course of his speech, which to a somnolent Dan Costello sounded like 'bullshit,' whereupon he promptly asked for the Speaker's ruling on the use of unparliamentary language by the Leader of the Opposition! When KN Rao, speaking on the Fiji National Provident Fund, ponderously asked, 'What will be my position when I am dead,' someone remarked to much mirth: 'Horizontal.' And once, when a speaker, getting carried away, said that Fiji could become a Utopia, someone whispered 'More like Ethiopia.' 
Jai Ram Reddy played the leading role in exposing two of the worst scandals in Fiji's postcolonial history, one which led eventually to the toppling of the first Rabuka government, and the other which took Fiji to the brink of bankruptcy. The first was what came to be known as the Tony Stephens affair. Stephens was a conman who had been detained by the security forces in 1988 for allegedly importing pen pistols into Fiji. Discharged, he sued the government for $\$ \mathrm{~F} 30$ million in damages, but agreed to settle for a mere $\$ \mathrm{~F} 10$ million. Under a deed of settlement surreptitiously signed by the Attorney General, Apaitia Seru, Stephens was to be paid $\$ F 980,000$ in cash in an out-of-court settlement. For the remaining amount, the government agreed to pay off two mortgages under Stephens' name with the Home Finance Company and the National Bank of Fiji; settle claims with the ANZ for a guarantee to Stephens and dismiss a bankruptcy case against him; transfer a plantation in Taveuni under mortgage control of the National Bank of Fiji; and settle all matters relating to three land titles owned by Stephens' family. The deed was astonishingly exempt from income tax, land tax and value-added tax. Fortunately, before the deed could be executed, Reddy exposed the scandal in parliament as an example of 'gross corruption,' 'gross incompetence,' and 'an 'attempt to swindle the government.'

Jai Ram Reddy pressed for a binding judicial enquiry, but the government settled on an ordinary commission of inquiry, headed by retired high court judge, Sir Ronald Kermode. In a damning report, Kermode concluded that 'the Prime Minister's actions as regard the events leading up to the execution of the Deed were not only improper but prima facie illegal.' The government sought to dismiss the report, which led Reddy to remark: 'If we treat Commissioners like this it would not surprise me if no judge worth half a grain of salt would undertake an enquiry of this nature. ${ }^{7}$ The proper place to test the findings of the report, Reddy argued was in a court of law. The whole saga tarnished the government's reputation for probity. Rabuka's moral authority as the leader of government was compromised, and it emboldened his critics within his party to move against him, which they did two years later. 
The other major scandal which Reddy exposed in parliament involved the National Bank of Fiji. On 15 June, 1995, Finance Minister Berenado Vunibobo announced that the government-owned commercial back had accumulated a debt of around $\$ F 220$ million, or about eight percent of Fiji’s GDP, leading ultimately to its collapse. ${ }^{8}$ How did this come about? Reddy had been concerned for sometime about rumours surrounding the Bank's financial status, and raised questions about its integrity, internal corruption, alleged kickbacks and unsecured loans. The Bank, he told parliament, 'never followed prudent banking practices, its directors never carried out the task that was assigned to them; the management broke every rule in the book on [its] lending services.' 9 'There is even talk of NBF being insolvent,' he continued, asking whether it was 'not time we probed a little more deeply into the affairs of the Bank.' He was convinced that 'there is more than just carelessness in NBF.' He talked of corrupt transactions and negligence, pointing to irregular securities on loans, lack of insurance cover on properties mortgaged to the Bank, irregular or no loan repayment, defaulting clients, and poor or no recovery strategy. ${ }^{10}$ Reddy attacked the Minister of Finance Paul Manueli for not accepting 'the responsibility for the mess that has been created,' and pressed for an independent and comprehensive enquiry into the Bank's affairs.

When the government invoked the confidentiality principle to block any enquiry, Reddy responded that 'the doctrine of confidentiality does not extend to fraudulent actions or those actions which constitute gross and serious abuse of office.' It was a fine point, but the government was not listening. Instead, it clamped down on the media for exposing the scandal. 'They do not want you to know about the abuse of public office and public corruption and the growing cancer of corruption across our land,' Reddy said. 'They don't want the free flow of information which citizens need to make informed decisions. They only want you to know what they think you should know. ${ }^{\text {"1 }}$ In 1996, under enormous public pressure, the government introduced the NBF Restructuring Bill to clean up the debris left behind by the debacle. Reddy had played a seminal role, in parliament and outside, 
in raising public awareness of the issue. Some in government thought this was an 'Indian' attempt to malign a 'Fijian' government institution, among them Sitiveni Rabuka who portrayed 'the attack on the National Bank of Fiji [as] orchestrated against Fijian businessmen and companies, ${ }^{12}$ but the charge carried no weight. As a Fiji Times editorial said forthrightly: 'Let us get some things straight. There is no foreign plot. The media is not trying to topple the government. Criticism of the NBF debacle has nothing to do with race.'13 The NBF, Sir Vijay R Singh quipped, should have been in the business of lending money, not giving it away. ${ }^{14}$ Reddy's national stature as a leader of conscience and commitment remained intact.

It is a truism in the Westminster system of government that all too often, governments propose and oppositions oppose. The adversarial system of politics allows little space for concession, dialogue and negotiation, which could be construed as signs of weakness. So, governments often carry on 'right, wrong, or indifferent.' 'Unless we can devise a format in which intelligent and meaningful discussion can take place,' Reddy said in December 1983, 'within the scope of which intelligent and meaningful changes can be brought about, there is really very little scope for a constructive or meaningful debate. ${ }^{15}$ In this respect, the 1970s and the 1980s were wasted years because the Alliance was intent on governing on its own, rarely ever taking the Opposition into confidence. Jai Ram Reddy had more luck in the 1990s. By then, he was the senior member of the House whose views commanded respect and attention, if not universal acceptance. On one occasion, his eloquence and persuasive powers won over several ministers, leading them to vote for an Opposition motion against their own government! The motion moved by Reddy condemned the resumption of nuclear testing in the Pacific by the French. ${ }^{16}$ The French decision, Reddy said, 'displays an arrogant and blatant disregard for the views of the sovereign nations of the Pacific Region, and denies its people of various ethnic origins and groups their basic human rights to continue enjoying a healthy and wholesome environment, completely free form radiation and other nuclear testing consequences and dangers.' The Pacific, Reddy said, 'is not a laboratory for 
testing nuclear bombs; it is our home. There is no guarantee for the safety of nuclear testing, and, therefore, Fiji should not accept the assumption that these tests are safe. If the tests were safe, they should be carried out in France, and not at Mururoa or anywhere else in the Pacific region.'

Sitiveni Rabuka, caught off-guard, endorsed the spirit of Reddy's motion, but moved an amendment which condemned 'the development of nuclear technology for war-like devices and arsenal developments, and their testing whether they be atmospheric or subterranean, regardless of geographical locations of test sites,' urging 'nuclear-armed powers to proceed with the dismantling of nuclear war heads and other weapons of mass destruction.' Finance Minister Berenado Vunibobo urged a soft approach because, he said, Fiji's sugar export to the European Union might be placed in jeopardy if France took umbrage at Fiji's anti-nuclear stance. And the sovereignty argument was raised as well. Reddy replied with cool precision and devastating logic. 'I find the sugar argument the most spurious of all. It can be put as being the most ridiculous. If the Honourable Minister of Finance [Vunibobo] had to choose between contaminating Fiji with nuclear waste or nuclear pollution and not selling sugar, what would you choose? Is that not the bottom end of the argument?' As for the sovereignty argument, Reddy responded that his motion was not against France or the French; it was against nuclear testing in the Pacific. Sovereignty was never an absolute concept anyway because 'there are a host of things that countries are not allowed to do because they offend international law, international conventions and, above all, decency and humanity that we should learn to bear towards each other.'

Regarding the economic argument, Reddy said that the 'Europeans are very much economically inter-dependent but that did not stop European leaders from telling the French that what they were doing in the Pacific was not right.' Rabuka's amendment 'unnecessarily dilutes this debate,' Reddy argued. 'It takes the focus away from the issue that we are trying to address.' Two ministers, Leo Smith and Taufa Vakatale, agreed with Reddy and voted for his motion, thereby forfeiting their place in cabinet, 
Taufa Vakatale in conversation with Reddy in Parliament

House at the time of the debate. Azam

Khalil is in the

foreground. Photo courtesy of Fiji Times.

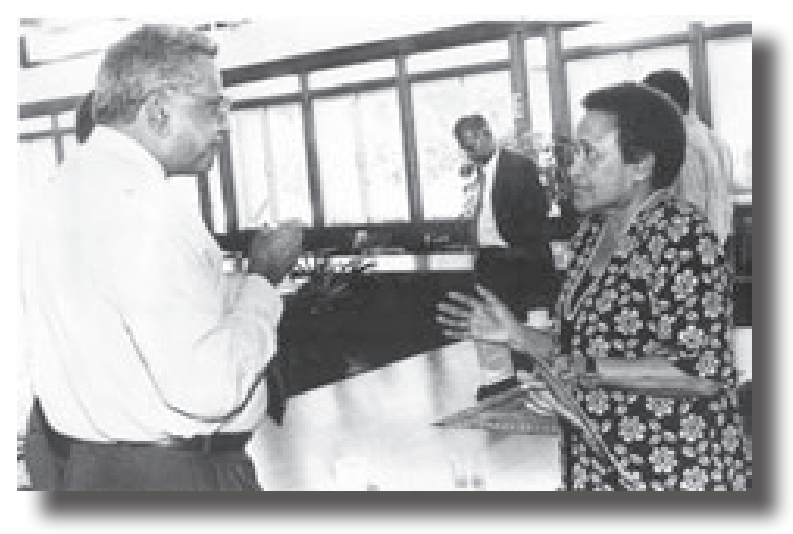

while another, Isimeli Bose, abstained. 'I have to give it to him,' said Etuate Tavai of Reddy's performance. 'The politician that he is and the lawyer that he is, it was very convincing. He said this motion is not against the government, this motion is not against France. It is against nuclear testing in the South Pacific. And I am sure he must have convinced some of the members. ${ }^{37}$ In truth, Reddy had most of the country behind him, including many prominent Church leaders who had petitioned him to take the cause up in parliament.

Just when things were looking to settle down for Reddy, there emerged a very tenacious Mahendra Chaudhry, leader of the Fiji Labour Party, who had begun stalking him for the leadership of the Indo-Fijian community sine the early 1990s. Reddy informed his party colleagues of his desire eventually to hand over the reins of leadership to Chaudhry, whom he saw as his natural successor as the leader of the Indo-Fijian community, to the dismay of some in his own party who had their own private aspirations. But Chaudhry was impatient. He was keen to get to the top quickly. Reddy's political demise was, therefore, imperative for his ascendancy. For Reddy, it was like falling from the frying pan of his colleagues' leadership ambitions of the 1970s, into the fire of Chaudhry's determined quest for political dominance, and that too at a time when fundamental problems, such as the constitution and ALTA, were still to be resolved. The manufactured 
differences were really paltry and inconsequential in the long term, but they took their toll at the time. 'Can you imagine any situation more depraved than the one we are in now?' Reddy asked in 1993. 'We have been denied everything; all our rights were taken away. What was 1987 but a virtual conquest! Our political rights were taken away, the government we helped get elected taken away, our constitution was taken away, and many senior civil servants were removed at gun point. And what are we doing now? We are busy undoing each other. It is an embarrassing situation to be in. I have to admit with some shame to people overseas that this is the situation. ${ }^{18}$ Soot na kapaas, kolia me lattha latthi, as AD Patel used to say in the 1960s: the weavers [Indians] had neither thread nor cotton, and yet they were breaking each other's heads over it: fighting futile battles for no larger purpose at all.

For Reddy, the one paramount concern throughout the 1990s was the preservation of the unity of the Indo-Fijian community. He had experienced at first hand the deep hurt and lingering animosity intra-communal conflicts unleashed which took decades to heal. If April 1977 elections were a 'wake-up' call for Ratu Mara to mend fences with his Fijian constituency, the September elections of that year performed a similar role for Reddy. Throughout the 1990s, despite his often bitter battles, Reddy sought to maintain dialogue with Labour, despite Chaudhry's oft-repeated intention to 'finish NFP off.' In 1992, after initially supporting Reddy for the Leader of the Opposition, Chaudhry sought the support of four Fijian nationalists to have himself appointed to that position, but Reddy continued working with him. In 1995, for instance, he agreed to make a joint submission with Labour to the Constitution Review Commission when he could easily have gone alone. That same year, when a group of disgruntled NFP supporters, essentially Reddy's supporters, formed a new 'Janata Party' to contest a byelection against Labour's Gaffar Ahmed, Reddy actually campaigned for Labour when, given the circumstances, he might have been expected at the very least to remain prudently neutral. Privately, some battle-eager party supporters chafed at Reddy's strategy, raring to take the fight to the Labour leader, to meet him on his own terms and on his own turf, but none dared 
to confront him publicly because Reddy was doing the right thing for the community, if not strictly in the narrow interests of his party.

The community which Reddy was leading in the 1990s was not the same as the one in the early 1970s when he entered politics. It had undergone a fundamental transformation caused by changes in travel and technology. Many people were moving away from villages and settlements to urban and peri-urban areas, both out of choice (because jobs could be had there) and by necessity (because agricultural leases were not being renewed). For these people, desperate and displaced, living in precarious circumstances in mushrooming squatter settlements, 'bread and butter' issues were all that mattered. They were therefore a natural constituency for Labour. And many in large numbers were emigrating to Australia, New Zealand and North America, people of talent and skill and commitment to the party (such as Girdhar (Gary) Raniga, Chandu Lodhia, Ahmed Bhamji, members of the professional and middle classes who had once formed a solid base for the National Federation Party. Even those who remained in Fiji saw no future in the country for themselves and their families and dreamed of leaving one day. Getting into politics was the last thing on their minds. Interestingly, many Indo-Fijians living overseas became vocal Labour supporters for a whole variety of reasons ranging from revenge for past injustices against them, to vague ideological commitment to the labour movement. They raised funds and even campaigned for Labour. It was not an insignificant factor in Labour's victory in Fiji.

By the 1990s, the culture of political campaigning in Fiji had changed. In the 1970s and the 1980s, big rallies full of rousing speeches were the order of the day. Political rallies were serious business as well as serious theatre, a valuable source of 'infotainment.' It was through this route that Reddy had entered the political arena. But by the late 1990s, not large rallies, but small 'pocket meetings' had become the norm of electioneering. What was said in these small gatherings, what message was sent out, what ideas planted in peoples' heads, no one outside the small circle knew, and there was no way of checking. But the new technique was effective. Labour was better 
at playing this game than the NFP, with their extensive network reaching the grassroots. New entertainment had arrived in the form of videos and television. For the younger generation, large political rallies, never a part of their immediate personal experience anyway, had little appeal. The television gave them all they thought they needed to know about what was happening in the country. And the people, too, had changed, demanding immediate satisfaction and resolution of their daily problems, and leaders who would keep in constant touch with them and respond to their concerns and needs. Reddy's long term vision for his people and for the country were not falling on receptive ears.

Reddy's opponents accused him of 'lacking a strategy' for the IndoFijian community. Reddy had his eye on the larger picture for his community and the country. Krishna Datt dramatized the issue this way. He told a rally in Ba in 1994 that politics was a bit like fishing. You drop your anchor here, and if there are no bites, you move to another place; you keep moving until you catch something. The problem with Jai Ram Reddy, he said, was that he was simply sitting with his anchor in one place. (To which an old man sitting at the back of the crowd said: 'Son, what would you know about anchors; you have none yourself!'). Reddy abhorred Labour's tactics of boycotts, strikes and confrontational politics. They had been counter-productive, he had learned from personal experience; and the people who suffered most were not well-heeled trade union leaders but ordinary workers and farmers. 'In the context of multiracial societies, demands don't work,' Reddy said. 'We have to work slowly through consensus building exercise where we are able to identify areas of agreement and narrow down areas of disagreement and work around areas of disagreement to find compromise solutions. ${ }^{39}$

Any confrontation with Fijians would hurt his own people more than anyone else. 'We will have to stop, as a matter of priority, inciting the ordinary people of this country,' Reddy argued. 'We will have to stop all forms of grandstanding and dramatics. We will have to show by our utterances and conduct that we have sincerity of purpose and, above all, we must resolve to 
find the solutions to our problems, however intractable these problems may seem to us. ${ }^{20}$ So Reddy, his mind set on the fundamentals, worked not to a pre-determined plan of action but instead entered into discussions with an open mind with a view to exploring possible common ground. Reddy took nothing for granted. Throughout the early 1990s, Sitiveni Rabuka ducked and manoeuvred, supporting the constitutional review process in one breath and asserting Fijian nationalist dogmas in another. He was, it is not too harsh to say, a bundle of contradictions, unpredictable. But Reddy persisted with him. Indeed, Rabuka came to be a part of Jai Ram Reddy's luck. Without him at the helm of Fijian leadership in the 1990s, Reddy is certain that the progress of the kind that took place may not have been possible or perhaps prolonged.

But it was not without cost, as we know. In the 1999 general elections, both Sitiveni Rabuka and Jai Ram Reddy would be punished by the electorate. As we shall see, neither Reddy nor Rabuka would have any regrets about the path of reconciliation and moderation and power-sharing they had chalked together. Both men had made the impossible possible. Rabuka, the coup maker, had emerged as a constitutionalist. And Jai Ram Reddy, the communal leader from the cane belts of Fiji, had emerged as a respected statesman admired more by members of other communities than by his own people. He spoke forthrightly about the problem of communication in multi-ethnic societies as he saw them. 'In our own lives, as we grow older and reflect upon the years,' he said in 1996, 'if we are honest with ourselves, we all know that there were roads that we took that perhaps we should not have taken; and the roads we should have taken, but did not.' That was hindsight. 'But I believe one of the greatest difficulties of interacting, particularly at the political level, is the difficulties that arise due to our lack of knowledge of each other. I think in the course of our lives, we pick up many stereotypes, prejudices and preconceptions, which upon reflection, after the benefit of better interaction and better knowledge and understanding of others, you are compelled to admit are not really correct. ${ }^{21}$ He spoke about the pernicious legacies of colonial rule 
in Fiji and urged its leaders to meet the challenges bequeathed by it. It was a remarkable transformation in a leader who had grown up in the cane belts of Fiji, and formed by its needs and aspirations but who was nevertheless able to transcend it to embrace a larger vision for his people and his country.

Some of the transformation is captured in the words he spoke in 1994, the speech remembered across the years as the 'Suva Declaration':

Let us declare that we believe in a Fiji which offers fair and equal rights to all her people. Let us declare on behalf of the dignity of the individual, and in the individual's right to freedom of speech, expression, conscience and religion. Let us declare that, though we oppose the 1990 Constitution, we stand prepared to join in reshaping it into a document which reflects the unique circumstances history has bequeathed to us. Let us declare ourselves not only representatives of the Indian community, but seekers of equality for all. Let us declare that we are enemies of none, and dedicate ourselves to unity with the indigenous people of this land in securing their future and ours. Let us declare our love for Fiji and our desire for a common and united future for the generations which will follow. And, most of all, we declare our willingness to toil side by side in equal partnership with all of Fiji's communities, so that their children and ours may live together in peace. 

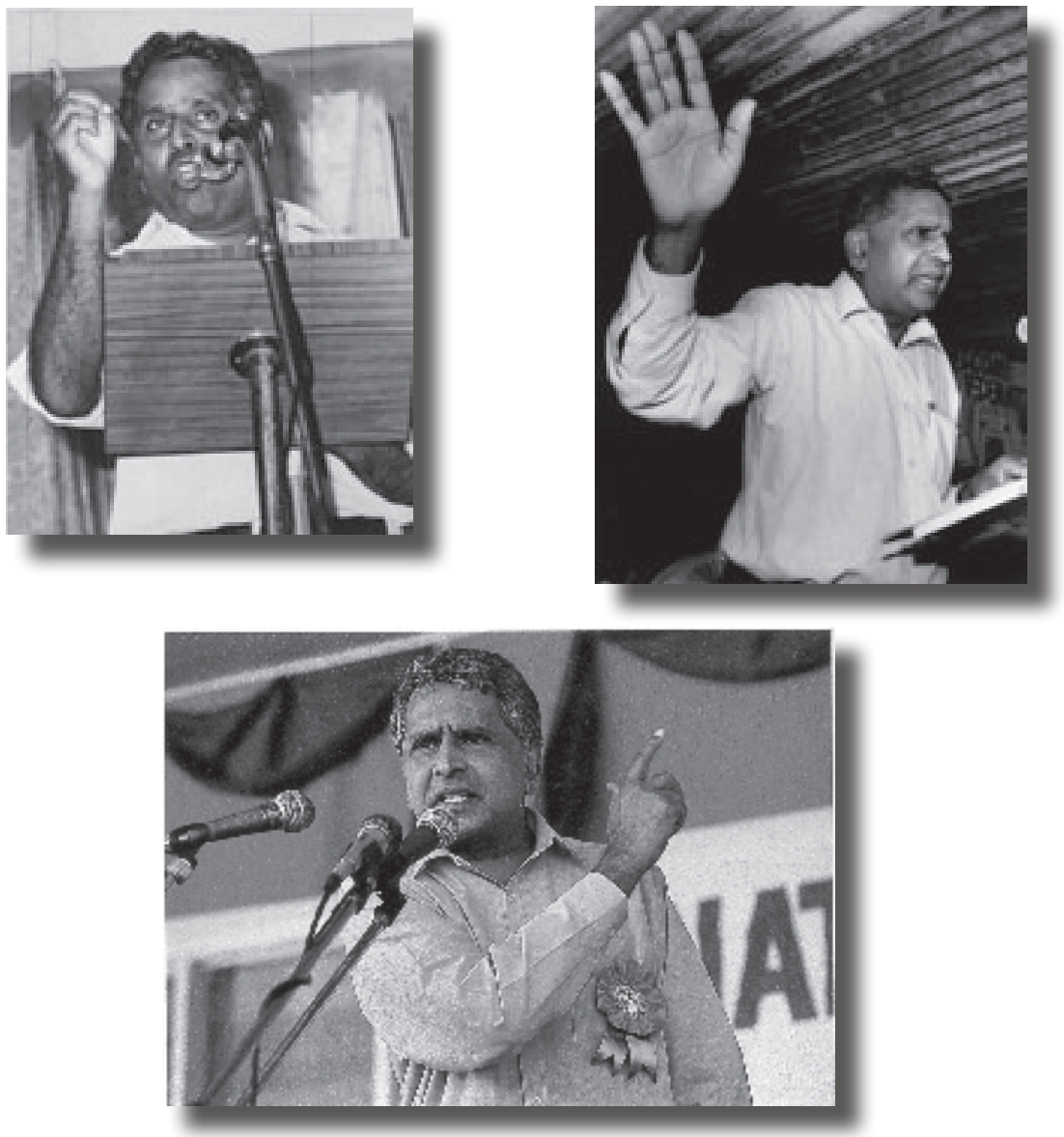

Campaign speech-making, 1970s to 1990s. Courtesy of Fiji Times and National Geographic.

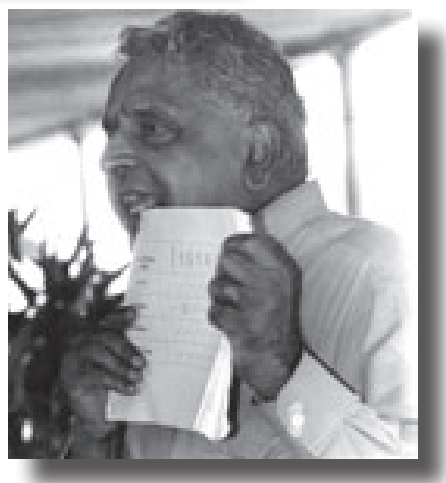




\section{INTERLUDE}

\section{'FIJI'S PLACE IN THE MODERN WORLD': JAI RAM REDDY'S ADDRESS TO THE FIJIAN ASSOCIATION PARTY, MAY 3, 1996}

I have been asked this evening to reflect on Fiji's place in the modern world. And so I shall, in due course. I believe, however, that before I can do that, there are some fundamental questions which need to be considered if we are to place this subject in its proper perspective. I also must observe that this is a hugely demanding topic to speak on at an occasion such as this. I trust you'll agree that without presenting a thousand word thesis it's not going to be possible to discuss all the factors that contribute to making Fiji what it is, and what we would like it to be. I'm happy to try, but I hope you'll forgive me if I don't solve all our problems in the next 15 minutes or so! I wish to start by submitting that, unless we first have some clear sense of who we are, we cannot proceed to determine the place we wish to occupy in the modern world. Until we decide what sort of place we want Fiji to be, we can't expect to find our niche among nations.

Ladies and Gentlemen, I have previously referred to our generation of Fiji citizens as the 'Lost Generation.' It is my conviction — and I think many would agree — that we have lost our way. We do not have a clear sense of national identity, of where we are going, a perception of ourselves as citizens of this country or of our destiny together. We seem to be struggling in the torrent of history, unable or unwilling to chart a course that will carry us safely through to full nationhood.

And if we lack a clear vision of what we want for ourselves as a people - all of us - how can we hope to define ourselves as a nation, or plot a future for our children? Not only do we seem unsure of precisely 
how we are to set out on this mission, we sometimes appear unable to accurately identify our destination.

So having made these points by way of introduction I will now offer some broad ideas about this matter of 'place,' and generate, I hope, constructive public debate about it.

Having stated my belief about our lack of a unified vision, I must also say I firmly believe there are in fact many things on which we agree. And I here refer specifically to what we want - and what we don't want - our homeland to become.

In recent days, we have watched as the horror of war plunged Lebanon back into the abyss. We have seen innocent people die. We have seen lives lost or torn apart, all in the name of divisions and causes not totally different from many of our own. After all, the various factions in that tortured land, and its neighbours, all believe they are fighting for the rights and aspirations of their respective peoples, religions and ideologies. Each has fears of being submerged by the other, of losing identity, or land, or way of life. From our safe vantage point in the Pacific, we have watched as young men and women hurl themselves and others to needless death for those causes. We have watched as our Fiji soldiers sought to bring comfort and refuge to the innocent victims of the fighting. Who among us has not felt the pride of watching our countrymen's brave efforts to bring peace to Lebanon? Who among us has not been touched by the sight of hardened veterans weeping for the dead of Qana? And who among us has not whispered a quiet prayer of thanks that our own land has never known the torment of the Middle East. Nor have we seen the fratricide of Northern Ireland, or the civil war that has ripped asunder so many nations and communities.

And in Lebanon, and our role there, we have an example both of our place in the world, and of our agreement on what Fiji is not: while our peacekeepers carry the standard of one of Fiji's most honourable 
contributions to the modern world, we at home are united in our belief that this country is not like the land in which they serve. We are not a people of violence, a community which has allowed its fears and insecurities to boil over into hatred against our neighbours.

What, then, do we want Fiji to become? Each of us would doubtless have a slightly different picture of the future we would like to create. But I suspect, for the most part, our differences in this area are in the detail, rather than in substance.

I think we can all agree that we want a harmonious, law-abiding, economically-successful island nation — retaining the special cultural elements which make our communities what they are. We want the rights and aspirations of all our communities secured and upheld. We would like to see our unique ethnic identities existing within a social and political system that provides for a national identity and encourages loyalty to the country, and that adheres to international standards and charters on personal freedom and human rights. I should add here that if we are to take our rightful place in the world we must also begin to urgently address the emerging cancer of corruption and nepotism. We must demonstrate that our society practices certain principles and precepts, especially in relation to accountability and integrity of those who hold public office.

I believe all right thinking people must view with trepidation recent developments which show that some of our values are becoming warped, that what should be considered by any reasonable standard as unacceptable is apparently being tolerated. We need to move decisively to stop this rot in the system before it eats right into the heart of our nation. We have, I think, agreed that we want a nation retaining its traditions but accepting and embracing the modern economic order. We aspire to be a country that provides enough economic growth to provide work for up to thirteen thousand school leavers a year. We dream of a caring 
Fiji in which people are prepared to help each other, a nation of good neighbours and strong families. We want to play a leading and helpful role in the region and in the wider international community.

The question before us is: how do we get there? How do we turn this dream into fact? Indeed, can we do it?

If I can address my second question first, I wish to say that I believe the answer is Yes, we can. I remain convinced that there are enough people in Fiji, of all races and political persuasions, who understand and realize that there is more to be gained for everybody if we put our minds and talents together to deal with the real problems that confront us. I am heartened there are more people publicly expressing these sentiments today than there were five or six years ago. This represents real progress, changing attitudes to the issues which challenge us. If you study the record, I think you will find that most of us see things a little differently than we did a few years ago. One of the benefits of adversity is that it forces us to look hard at our beliefs, convictions and prejudices, and reassess them in the light of new insights.

I am reminded here of an anecdote about Mahatma Gandhi. Never a man to be reticent about his beliefs, he often confused his closest friends by apparently contradicting something he had previously said. The story goes that one day, frustrated by one if his statements, one of his confidantes burst out: 'But, Bapu, just yesterday you said the opposite!' 'Ah, yes,' replied the Mahatma, 'but I have learned something since yesterday.'

There is a message there that we would all do well to take to heart. Certainly, we have strong convictions. But not all of them need to be carved in stone. They are based on our experience and knowledge at any given point in time. As we live, we learn, and as we learn we can change. Certainly, we in Fiji know more today about the concerns of our brothers and sisters of other ethnic group than we did ten years ago. And, as I have said, many of us have adjusted our approach to the future 
accordingly. We are not less committed to certain fundamental beliefs. But, through a greater understanding of each others' fears and needs, we stand a better chance of finding mutually-acceptable solutions to our problems. This sort of thinking which, as I have said, I see reflected increasingly in the public statements of political and community leaders, gives me the confidence to continue with the process of consensus and dialogue to which I have committed myself.

Which brings me back to the first of the two questions I posed a moment ago: how do we reach the goals to which we aspire as a nation? I don't want to make a partisan political speech, but no discussion of our national place in the world, and our sense of our individual places within a nation, can ignore some of the pressing questions which have to be answered. And, yes, I am thinking here of such things as the Constitution and ALTA. But rather than repeating everyone's stated positions, I would like to consider our overall approach to nation building. I want us all to bear in mind also that we are developing a nation here. This requires careful thought, discussion and debate. Many are agreed that the system of political representation and government we have at present is far from ideal. To the Indians of Fiji it is simply unjust - a formula for unhappiness and alienation. We feel excluded, deprived and marginalized - and that is why we are looking for a better way of governance, a way that will bring us together as a nation. Gatherings of goodwill like this are vital in this process. In that spirit, then, let me give you some personal reflections on our current efforts towards a political prescription unique to our circumstances in Fiji.

Let us start with this concept of Government of National Unity - the familiar GNU. While this idea has had its ups and downs as political flavour of the month, and may very likely not in fact work in the forms that have been suggested, it has served a very useful purpose in stimulating discussion and thought. With so many divergent views on the political 
approach for Fiji, how do we form a government that really combines all of them? Does the current constitution lend itself to such a GNU? Probably not. Frankly, it's just so controversial that it would be likely to work against the very unity we are trying to achieve. To establish such a government and have it fall apart a few months later would do more harm than good.

But although a GNU might not be feasible right now, this does not mean our political parties must always be deadly enemies. The Opposition need not automatically oppose everything the Government does, any more than the Government must always consider itself to be right and enforce its strength of numbers to get its way. Surely it is more sensible to try and co-operate, to look for consensus rather than confrontation. Why not adopt a 'Fiji Way' of governance? We could then co-operate in that spirit to develop a framework which institutionalizes a model of administration uniquely ours. What I am saying, I suppose, is that, rather than trying to impose a Government of National Unity over a constitution which itself is an obstacle to unity, why not work together towards unity, and develop from this a constitution which reinforces it?

In recent times, we have seen exactly this sort of formula succeed, not just in rhetoric, but in reality. The Serious Fraud Bill, a major piece of legislation, serves as a dramatic example. Although the government may well have been able to enforce its majority and pass the legislation, it was decided to refer it to a multi-party select committee. The Indians on this occasion were thus admitted to the provinces of power usually denied to them. Although outnumbered, the Opposition made a very real and substantial contribution to this committee, which considered the view of a wide range of people. At the end of the day, it was decided by consensus not to proceed with the Bill. I stress 'by consensus,' because that is the point here. By adopting this method, we were able to bring 
what were initially two widely different positions together and agree on a mutually acceptable course of action. We have now begun a similar process for the Public Enterprise Bill.

Am I attaching too much importance to this at a time when the Indian position is so precarious? Is this grasping at straws? I don't think so. They are positive signs of what is possible. Certainly they might be small steps, but they are important steps. And, like Gandhi, we are learning something each day. Most of all, we are learning, as leaders, that we can come together, that we can find common ground. We are learning that we don't have to fear, hate or distrust one another. We are learning that there is another way. What we must constantly seek is the courage to take that way, and not fall into the cycle of confrontation that leads inexorably to disaster.

Leadership, Ladies and Gentlemen, is about averting disaster, not creating the conditions in which it thrives.

And creating an environment conducive to unity can be a slow process. There is no overnight solution. We must possess ourselves of patience and remain firmly persuaded that the only sensible way to proceed is through sincere discussion, negotiation, and compromise. We must recognize that truth, and be united in our determination to face it together. Without these things, there can be no place for us in the modern world - or at least not a place we would wish to occupy.

I would like to finish by returning to our central theme. It seems to me that our greatest contribution to the international community would be to follow our path of self-discovery — our national learning curve, if you like — to its most positive conclusion. If we can remain steadfast in our refusal to make the mistakes of so many other countries, if we removed the present injustices and find acceptable joint solutions for Fiji's problems, we will be able to offer the world a better way. We can do this if we allow ourselves. We can do it. 
Most of all, Ladies and Gentlemen, let us bring our lost generation in from the cold. We need to end our wanderings in search of something we cannot yet see and join hands to go forward together, no longer lost but with a clear gaze towards the road of unity. It may be long and it may be difficult but it is the right course for us, the only one.

Only when we are marching surely in this direction can the children of the lost generation come home. Only then will we, their parents, be able to look them in the eye, knowing that we have served them well, and with wisdom, in making this nation. Only then will Fiji truly be able to take her place in the modern world - a place distinguished by pride in distinctive cultures and peoples and a great and loyal love for these islands and the one destiny that we can — that we must — create together.

REFLECTIONS, 1987-1997:

AN INTERVIEW WITH JAI RAM REDDY 22

Q: How do you see the coups and what has happened in the last 10 years since $1987 ?$

A: My appointment as Attorney General by Dr (Timoci) Bavadra (Labour leader and Prime Minister in 1987) seemed to create resentment, particularly among those who had lost power and felt threatened by the changes. But I am not embittered. My approach is to learn from it, look to the future, and see how we might reshape the affairs of Fiji. There are many things about the coup that people do not understand. One of the most stark things was how the coup victims gave in so easily. That is why it was such a bloodless coup. If they had resisted, a good deal of blood would have been spilt. I do not believe anyone has gained from the coups, neither the indigenous Fijians nor the Indians. We have 
gone backwards. Any objective observer would have to agree the coups were unnecessary. No rights of the indigenous people were being threatened. The true reason is that those who lost power just could not stomach it. They were engineered to regain political control. But maybe things did not go the way even they intended. So, in a sense, they too were losers. I am not forgetting the coups and the hardships and humiliation that we suffered individually and collectively, but they should not be dwelt upon in a disproportionate way so that it becomes a hindrance to the future healing process.

Q: Were pre-coup race relations a façade?

A: Certainly. There was more rhetoric than action. Also, tokenism was the order of the day which is why Indians felt a strong sense of alienation from independence to 1987. Under the old cross-voting system, there were token Indians in government. That is why I am opposed to cross-voting. It is worse than communal voting.

Q: Do you think 1987 has given us a chance to sort these issues out by bringing them to a head?

A: Somebody said that the Fijian leaders accepted the 1970 Constitution because they were told that they would never lose power under it if they remained united. ${ }^{23}$ If the reality was that the 1970 Constitution was supposed to ensure that the Alliance Party remained in government all the time, yes, I am glad that 1987 happened. Because that myth was exposed. And those who were paying lip service to democracy were found wanting. At least now, people are facing up to the truth. No constitution will [can] keep [a] people in power [permanently].

Q: What, since 1987, disturbs you most in our society?

A: The level of violent crime. I can understand someone stealing because he does not have money to buy food. But the violence? It almost seems like there is something else that is bugging the 
criminals. I wonder if it has something to do with the forces that the coups unleashed - a license of sorts that means it was all right to be violent to get what you want. This was not there before the coups. Add to this the corresponding collapse of morality in the public service, the level of corruption and all the shortcuts that people take, the things that went on in the National Bank of Fiji and the Housing Authority. I cannot see anyone arguing that this has nothing to do with the coups.

Q: Does this have the potential to undermine any of the gains that might be made?

A: Definitely. My hope is that with an improved constitution and more representative government, some of these issues can be tackled vigorously and effectively. Probably the most valuable thing that could come out of this would be a re-establishment of a sense of confidence. However, there are so many ifs and buts.

Q: What are some of the lessons that you are mindful of as you help in reshaping the future of Fiji?

A: There is no future if any community tries to pull its weight in an exclusive fashion to create an environment in which it sees itself as dominant in government. What we need is to form a partnership. That is probably the most important thing. This was not addressed seriously enough in the years before the coup, because we all underestimated the depth of feelings that existed, particularly within the indigenous Fijian community. We all got carried away by elections, democracy and by a constitution which allowed for governments to be voted in and voted out. But we never really understood the human dimension, until raw emotions erupted post-coup.

Q: Was it an inability to perceive the feelings at the grassroots level?

A: Maybe a lot of leaders did perceive [it]. When the NFP won in 1977, I did raise the concern whether an Indian government 
might be acceptable to Fijians. I articulated it in another way and people came down on me like a ton of bricks. Ten years later, what I had said actually happened.

Q: Do you think the leaders at the time did enough?

Yes, sure. Because they were making judgments in 1985, '86 and '87. Not June 1987 or 1990. Everybody is wise after the event. The Coalition was conscious of this which is why they did not want a government which was visibly Indian although it drew it support mainly from the Indian community. So it readily embraced a Fijian leader and accepted that at least half of the cabinet should be Fijians. But on hindsight, it appears that was not enough.

Q" That is at the political level. Was enough done on the social front to develop multiracialism?

A: Social initiatives should be taken by the people. Political leaders cannot take all the initiatives. They can show the way. But every Indian should ask how many Fijian friends do they have? You might argue that these things should have been foreseen by every school teacher, every court clerk, every bank officer and every farmer. I am at the tail-end of my career. I can speak freely. Unless the Indian people honestly confront these questions, we will always have problems. Indians were confronted by an overwhelming show of force during the coups, and they had no answer. They still have not found that answer. That is why you hear everyday that when people break into their homes, they do nothing. They say, 'take everything but leave me alone.' We can have the most perfect constitution in the world but it will not be able to help them when their homes are invaded. The coups and the current political arrangements have given the two sides totally wrong messages. The message to the Fijians is they can 
do as they like and the Indian feels that because he is intended to be the victim, he sees this violence against him as a kind of a logical extension of his status in society. The ordinary Fijian feels that the Indian is fair game. It is okay to rob him or beat him up. The aggressor probably does not see it any other way. And the first base towards changing that is the constitutional review. The supreme law of the land currently makes discrimination against an Indian legitimate. When his status under the constitution is changed, only then will this be changed. That is why I emphasize the need to reform the constitution. Even the land problem cannot be solved until that is solved because everything is a logical extension of that.

Q: Is migration an indication of the attitude in the Indian community?

A: Well, take the leadership, for example. It is very hard to get anybody interested [in politics]. Those who have talent are either migrating or are so absorbed in their personal lives, in their professions or as academics. There may come a time when we as a community will have no effective spokesmen. We had to literally beg people in 1992 to be candidates, yet some are now being criticized because they hold permanent residence overseas. But if people who have the ability are not willing to serve, what is the leadership supposed to do?

Q: How is this going to be resolved?

A: I will be 60 next month [May]. My hope is that with a better constitution, more young people will see a career in politics. Part of the problem in 1992 may have been disillusionment with the 1990 Constitution. But that constitution has to be changed and somebody has to work for it. Politics is not about coming in when things are good. 
Q: Do you think the current review process will eventually give form to the country's true identity?

A: I think so. People are a lot more realistic. The Indians are a lot more realistic. And why not? What really is taking place is a search for accommodation between the three major groups that will give the sense of security that we all want. But which is also honest, not some bluff about democracy, multiracialism, etc. This is why I desperately hope that some sort of power-sharing formula can be worked out so people are forced to work together.

Q: What is your vision for Fiji in the next decade?

A: I would like to see that the next general elections are fought not on an Indians versus Fijian basis, or vice versa, but through a type of national front where a number of political parties are in partnership and forming a kind of government of national unity that is in place for at least 10 years. That can be a period of consolidation, rebuilding of genuine multiracialism, accommodation by the communities and a period of economic growth and prosperity. If Fiji can have a 10 -year period of harmony and stability, then the foundations will be laid for long-term prosperity. 


\section{7-1997: AN ERA OF TURBULENCE 24}

1987

Apr 11: Final election results come out, confirming NFP-FLP Coalition victory, 28-24 seats.

Apr 13: Coalition leader Dr Timoci Bavadra is sworn in as Fiji's second Prime Minister by Governor General Ratu Sir Penaia Ganilau.

Apr 19: Tavua villages erect road blocks in protest against the new government.

Apr 21: About 3000 protesting Fijians meet at Veseisei village, Lautoka, calling for cancellation of leases to Indo-Fijians and the entrenchment of Fijian political control.

Apr 24: At 10 am, 5000 Fijian protesters, led by Taukei Movement leaders Taniela Veitata, Rev Tomasi Raikivi, Viliame Gonelvu and Ratu Inoke Kubuabola, march through Suva to demand Fijian political paramountcy and to ask the Governor General to sack the new government.

Apr 25: Taukei Movement leader Apisai Tora and Tui Vuda Ratu Josaia Tavaiqia lead a protest march through Lautoka.

May 2: Petrol bombs damage Jai Ram Reddy's Lautoka law firm office.

May 8: Parliament opens. Alliance member Militoni Leweniqila sworn in as Speaker of the House of Representatives.

May 14: Lieutenant Colonel Sitiveni Rabuka takes over parliament in a military coup. Government members arrested and detained. The constitution is suspended. Rabuka appoints himself Commander-in-Chief, and appoints a 15 -member Council made up of Alliance and Taukei Movement leaders.

Ma 15: Governor General assumes executive authority, and issues a media statement deploring the coup. 
May 19: Sitiveni Rabuka is sworn in as head of the military government and granted immunity by Governor General Ratu Sir Penaia Ganilau.

May 20: Riots break out at Albert Park as Coalition supporters are attacked with rocks and sticks. Violence spreads to Nausori, Delainivesi, Naosle and Raiwaqa.

May 22: Council of Advisors, consisting of the Alliance Party and the military, is sworn in by the Governor General.

July 6: A Constitution Review Committee, chaired by Sir John Falvey, begins public hearings on the 1970 Constitution, and issues a divided report.

Sept 23: Party talks, initiated by Ratu Sir Penaia Ganilau, lead to the Deuba Accord in which the Coalition and the Alliance agree to participate equally in a caretaker administration chaired by Ganilau; Taukei Movement outrage and violence.

Sept 25: At 4pm Rabuka stages a second coup, citing dissatisfaction with the terms of the Deuba Accord.

Oct 1: Rabuka issues two decrees formally abrogating the 1970 Constitution and sacking the Governor General.

Oct 6: At midnight, Rabuka formally declares Fiji a Republic, temporarily severing Fiji's membership of the Commonwealth

Nov 4: Sunday Observance Decree is promulgated banning recreational and trading activities on Sunday.

Dec 5: Rabuka dismisses the military administration and announces a 25-member mostly Alliance cabinet headed by Ratu Sir Kamisese Mara, appointed by a newly installed President, Ratu Sir Penaia Ganilau. 
1988

Apr 11: Discovery of a large quantity of arms in Sydney, some of which was smuggled into Fiji.

1989

Sept 23: The Manueli Committee issues its report on the future Constitution of Fiji, recommending Fijian dominance in parliament and elections from exclusively racial electoral rolls.

Nov 3: Dr Timoci Bavadra, 55, passes away at Lautoka Hospital, succumbing to the cancer of the spine.

1990

July 25: President Ratu Sir Penaia Ganilau decrees a new constitution based on the Manueli Report.

1991

July 11: Sitiveni Rabuka resigns from the military under pressure and accepts the post of co-deputy Prime Minister in the Ratu Mara-led interim administration.

July 27: The NFP decides at its national convention to participate in the forthcoming general elections to be held under the 1990 Constitution.

1992

May 30: The Great Council of Chiefs-sponsored Soqosoqo ni Vakavulewa ni Taukei (SVT) led by Sitiveni Rabuka wins 30 of the 37 Fijian seats. NFP wins 14 of the Indian communal seats and Labour 13.

Dec 4: Prime Minister Sitiveni Rabuka proposes a Government of National Unity.

1993

Sept 14: The Terms of Reference for the review of the 1990 Constitution is passed by parliament. 
Nov 30: The Government Budget falls with 8 Government backbenchers voting against it, paving the way for fresh elections.

\section{4}

Jan 15: A new Fijian Association Party is launched with Josefa Kamikamica as leader

Feb 28: SVT wins the February elections, capturing 31 seats to Fijian Association's 5. NFP wins 20 of the 27 Indian communal seats to Labour's 7.

June 24: A Joint Parliamentary Select Committee on Constitution Review is established.

\section{5}

Mar 15: President Ratu Sir Kamisese Mara appoints a Constitution Review Commission chaired by Sir Paul Reeves, with Tomasi Vakatora and Dr Brij Lal as its two other members.

Oct 27: Sunday Observance Decree is repealed in parliament.

\section{6}

Sept 6: The Fiji Constitution Review Commission hands its report to President Mara at Government House, recommending a gradual but decisive move away from race-based politics.

\section{7}

May 14: The Constitution Amendment Bill unanimously passes both Houses of Parliament.

Oct 1: Fiji officially re-joins the Commonwealth. 


\section{TRANSITION}

\section{NOTES}

1. Hansard, 24 July 1992.

2. The Weekender, 30 Apr. 1993.

3. See particularly his Democracy in Plural societies: A Comparative Exploration New Haven: Yale University Press, 1977), and 'Constitutional Design for Divided Societies,' Journal of Democracy (2004), 15: 2, 96-109.

4. Review magazine, Mar 1993: 13. See also Pacific Islands Monthly, Sept. 1997, $23-24$.

5. Quote from National Geographic vol. 188: 4 (Oct 1995), 134.

6. Quote from reports in Fiji Times, 1 Oct. 1992.

7. Fiji Times, 22 Oct. 1993.

8. For the NBF saga, I draw at length on Roman Grynberg, Doug Munro and Michael White, Crisis: Collapse of the National Bank of Fiji (Adelaide: Crawford House Publishing, 2002).

9. Hansard, 28 Mar. 1996.

10. There is an extensive coverage in The Review Magazine, Nov. 1995.

11. Reddy's fight for a free press was longstanding. He told parliament in 1982 (8 Dec): 'A free press is absolutely vital for the survival of democracy, for the maintenance of decency in public life and for the purposes of projecting the wider public interest. I would be the last person to advocate any form of control of the press. I think the control has to be self-imposed.'

12. Daily Post, 19 Aug. 1995. Filipe Bole was another minister who raised the race issue.

13. Fiji Times, 12 Dec. 1995.

14. Daily Post, 19 Aug. 1995.

15. Hansard, December 1983.

16. Hansard, 27 July 1995.

17. Review Magazine, Aug. 1995, 20. 


\section{IN THE EYE OF THE STORM}

18. Review Magazine, Feb/Mar, 1993: 18.

19. Weekender, 30 Apr. 1993.

20. Weekender, 16 July 1993.

21. Hansard, 28 Mar. 1996.

22. The interview is from The Review, June 1997, 16-17. The magazine is now dead, but my thanks for using the interview are hereby expressed.

23. It was David Butler, of Nuffield College, Oxford, who Ratu Mara had consulted during the independence negotiations.

24. This tabulation is drawn from The Review magazine (May 1997), 25, and Sanjay Ramesh, 'Chronology of Fiji Events, 1987-1997,' in Brij V Lal et al. (eds), 1987: Fiji Twenty Years On (Lautoka: Fiji Institute of Applied Studies, 2008), 205-215. 


\title{
CHAPTER 7: BACK FROM THE BRINK
}

\author{
After such knowledge, what forgiveness? Think now \\ History has many cunning passages, contrived corridors \\ And issues, deceives with whispering ambition, Guides us by vanities \\ TS Eliot
}

'W

e see a new order of hope, of peace, reconciliation, and progress in which the fundamental rights and freedoms of all citizens are guaranteed,' President Ratu Sir Penaia Ganilau said, promulgating the 1990 Constitution. 'We seek understanding, trust and tolerance.' The new constitution was not based on 'some revolutionary and radical proposition,' he continued; it simply provided 'for a continuation, and an enlargement, of an idea which has become an established part of our power-sharing arrangements.' By this, Ratu Penaia meant the entrenchment of the principle of Fijian political paramountcy. This was necessary, he continued, to protect the Fijian identity, culture and way of life which were under severe threat. Justifying the enhanced role of the chiefs in the new constitution, he said: 'The chiefs are a force for moderation, balance and fair play [who have] done much to bring Fiji into the modern world and to spur on our economic progress.' Ratu Penaia assured the Indo-Fijians that it was never the intention of the Fijian leaders to disenfranchise anyone, for 'to have taken such a course would not only have been an affront to accepted principles of human conduct, it would also have been contrary to the cultural values of respect, tolerance, mutual caring and Christian love that the Fijians hold dear.' 'The time has now come,' he continued 'to lay to rest the ghosts of the girmit experience, to put aside the sense of grievance of the past. Be positive about Fiji. Have faith in it as a nation with a bright and shining future.' 
A bright and shining future was the last thing the Indo-Fijian community saw for itself in Fiji. For Jai Ram Reddy and other leaders, the new constitution would not lay to rest but instead resurrect the ghost of the girmit experience. Reddy was emphatic about the deep flaws of the constitution:

\begin{abstract}
The constitution is an imposed document. We had no hand in its making. It is an unjust document. It seeks to and discriminates against citizens of Indian origin in this country. It monopolizes political power in the hands of one community to the total exclusion of another. It is a backward looking document which negates the multi-racial character of Fiji. It rides roughshod over fundamental constitutional values, and violates many international instruments of human rights. ${ }^{2}$
\end{abstract}

And it was to the rejection of the constitution and its replacement by a fairer one that Reddy would devote a large part of his energies during his last decade in politics. Indeed, it would be his principal political obsession in the 1990s. Without political rights, a people were nothing more than slaves, he would say over and over again to those who wanted the constitution to be left alone to concentrate on improving their economic position. The cause of human dignity and freedom demanded an unqualified repudiation of a document which had effectively rendered his people second class citizens. The task would not be easy, for emotions were inflamed, attitudes entrenched, and lines firmly drawn in the sand. But Reddy was not deterred. Bit by small bit, he chipped away at the walls of prejudice and suspicion between the two main communities to create an atmosphere for rational dialogue and discussion. Success, however, came at a huge price. His preferred path for dialogue differed from that proposed by his party's Coalition partner, the Fiji Labour Party. Unable to reconcile their differences, the two parted company for good. This meant that throughout the 1990s, Reddy would be battling both his Fijian opponents as well as his former coalition partners over issues which now seem so inconsequential. 


\section{TOWARDS THE 1990 CONSTITUTION}

Two problems faced the military-backed interim administration when it assumed power in December 1987. One was the formulation of a constitution which would address the concerns and aspirations of the indigenous Fijians, and the other was resuscitating an economy teetering on the brink of collapse from shattered investor confidence, the haemorrhaging of skilled personnel from the public sector, the flight of capital, the interruptions in cane harvest and a severe downturn in the tourism industry. ${ }^{3}$ To address these problems, the interim administration initiated policies which promised a new direction for Fiji. It explored commercial and trading links with ASEAN countries as part of its 'Look North' policy in part to lessen dependence on Fiji's traditional trading partners which had strongly condemned the coups. It also began de-regulating the economy and eliminating import-substitution policies. A tax free zone was started which gave companies exporting more than 90 per cent of their products thirteen year tax holidays and exemption from customs duties on imported equipments and production materials.

The chief beneficiary of this initiative was the garment industry. ${ }^{4}$ For these and other industries to flourish, stringent regulations were needed. In 1991, the interim administration enacted a series of repressive labour laws intended to emasculate the trade unions, the backbone of the Fiji Labour Party, but publicly justified in the name of improving the country's international competitiveness and internal economic flexibility. The new decrees enabled the prosecution of trade unions for damages arising from 'unlawful' trade disputes; introduced company-based unions, amended the Trade Disputes Act to include other forms of industrial actions, such as go-slow, work-to-rule, and the withdrawal of goodwill; and provided for the use of postal or workplace ballots for the election of union officials. ${ }^{5}$ Tensions continued to simmer in the cane belt over the uncertainty of obtaining the full forecast price of cane, but there was mercifully no full-scale confrontation between the growers, the Fiji Sugar Corporation and the government. A tenuous truce characterized industrial relations throughout the 1990s. 
It was the government's proposals for the formulation of the new constitution that the nation and the international community watched carefully. In October 1988, nearly a year after assuming office, the interim administration appointed an 18-person Fiji Constitution Inquiry and Advisory Committee (FCIAC), chaired by retired Colonel Paul Manueli, Fiji's first local commander of the military forces. There was no representation of the Coalition on the Committee, nor were any other parties represented. The Committee was thus theoretically neutral, but it lacked credibility. Its Indo-Fijian members included RH Bechan, Tamessar Bhim, Hafiz Khan, Shardha Nand, GP Shankar and Uday Singh, all non-Coalition people, some of whom (Nand and Singh) had contested elections against the Coalition in the past. ${ }^{6}$ Though successful in their various chosen professions - agriculture, law, commerce and public service - they lacked a credible political profile among their own people. Nothing much though was expected from them. If they were able to orchestrate a progressive outcome, they would be praised, and if they failed, they would be condemned and ostracized.

The Committee was not starting from scratch. The Cabinet had prepared a draft constitution which it wanted subjected to further public scrutiny and tested for its broad acceptability, 'having regard in particular to the failure of the 1970 Constitution to provide adequate and full protection of the rights, interests and concerns of the indigenous Fijian people, and having regard to all the circumstances prevailing in Fiji.' ${ }^{7}$ These patently loaded Terms of Reference for the Committee are clear. It was accepted, for instance, that the 1970 Constitution had failed to meet Fijian aspirations, begging the question how that determination was arrived at and by whom. Further, the Committee had to be bear in mind the 'prevailing circumstances' as it conducted its enquiry. The coup leaders were described as 'members of the security forces who had assisted in the change of government in 1987'. How were concepts such as 'rights,' 'interests,' and 'concerns' to be understood? Did the indigenous people have a 'right' to political dominance solely on the grounds of ethnicity? And would increased 
numbers by themselves guarantee Fijian political dominance? How would power be distributed within Fijian society? Questions such as these would be asked by many in the years ahead, exposing the fallacy that underpinned the thinking of those who prepared the draft constitution and the Terms of Reference for the Manueli Committee.

Fundamentally, the Cabinet Draft differed little in spirit and content from the Great Council of Chiefs' submission to the Falvey Committee in 1987. The draft proposed, among other things, to create a Fijian-dominated parliament of seventy one seats with twenty eight elected Fijians, twenty two Indians, eight General Electors and one Rotuman, with a further eight Fijians to be nominated by the Great Council of Chiefs and four by the Prime Minister, all of whom would have the same privileges as the elected members of the House; to give power to an executive committee of the Great Council of Chiefs to nominate the President, who, in turn, would appoint the Prime Minister; to place all the most important ministries as well as the chairs of the powerful statutory bodies (police, public service, and legal commissions) in indigenous Fijian hands; to install the commander of the Fiji Military Forces as a permanent member of the cabinet; to conduct all parliamentary elections on strictly communal franchise; and not least, to "promote and safeguard the interests and aspirations of the Fijian and Rotuman people and in particular to promote and maintain their cultures and traditions and their social, educational and economic well-being' through special government-directed programs of positive discrimination.

The Manueli Committee received many oral and written submissions and characterized Fijian and Indo-Fijian submissions this way. By and large, it concluded, 'the majority of submissions from the Fijian community were conclusive in their view that they were the indigenous people of the country, and as such, their aspirations and special position should be formally recognized in the country's political and administrative structures.' To this end, they 'should be given political control through a parliamentary majority in the new Fiji Constitution. ${ }^{8}$ In addition, Fijians 'contended that special arrangements should be made in the public service to ensure the fair 
distribution of civil service positions in their favour and to give them control over a substantial degree of decision-making.' Christianity, which held a special place in the life of the Fijian community for more than a century, should be recognized as the state religion and the Sabbath observed strictly by everyone, including non-Christians. Many were relieved that the coup had 'nipped in the bud' the threat to Fijian culture and identity, for which they were grateful. As Fijians saw it, their demand for political control was sensible and 'in the interest of political stability and peace.' Fijians differed to some extent on the degree of political control that should be given to the indigenous community, but there was no disagreement on the principle.

The Indo-Fijian community, on the other hand, the Manueli Committee report concluded, 'was generally united in their view that the fear expressed by the Fijians that they would be dominated by them was groundless,' and that the coup was nothing more than an attempt by the Alliance party to regain power it had lost at the elections. ${ }^{9}$ They acknowledged the Fijian predicament in the modern economic sector, but this, the Indo-Fijian leaders argued, was not the result of flaws in the constitution but the direct outcome of 'development policies implemented by the predominantly Fijian-dominated Government that held political power continuously during the first seventeen years of independence.' The problems of the Fijian people would be resolved not through contrived political control but 'in raising their level of motivation, individual attitudes and dedication to improvement in their education, commercial entrepreneurship and in engaging themselves in productive activities. Political representation should be based not on principles of apartheid but on 'democratic principles of liberty, personal freedom and equality. There should be a strict separation of religion and state, and the Sunday Observance Decree, which was an imposition on their personal freedom and liberty should be scrapped. Muslims predictably pleaded for separate representation, ${ }^{10}$ while the various minority communities generally supported Fijian aspirations and demands for reasons of 'blood ties,' but asked for varying degrees of separate representation for themselves as well. 
The NFP-FLP Coalition presented its submission to the Manueli Committee on 6 January 1989. ${ }^{11}$ It was a long and thoughtful document. The Coalition was helped by the eminent constitutional lawyer, the Kenyan-born, Harvard and Oxford-educated Professor Yash Ghai, then at the University of Hong Kong. Ghai had been a constitutional advisor to several Pacific islands (Papua New Guinea, Solomon Islands and Vanuatu) during their transition to independence and had been taking a keen interest in Fiji's recent constitutional history. The NFP raised funds to engage him, and he would remain their principal constitutional advisor for the next decade. Ghai consulted widely and especially with Jai Ram Reddy as the Coalition's principal point man on the constitution and, through him, the main political and business leaders in the Indo-Fijian community such as Hari Punja, YP Reddy, Vinod Patel and others, as well as leaders of the Labour Party. In the final stages of writing the submission, Reddy flew to Sydney for a long weekend for the preparation of the final draft.

The Coalition submission stressed the 'restoration of national unity and racial harmony' as the most urgent priority for the nation. 'Without that, our social and economic goals cannot be met. Neither national unity nor economic and social development can be achieved by a government which does not enjoy the confidence and the respect of the people. The legitimacy of a government can, in turn, only be secured through democracy.' The Draft Constitution was, in its view, 'authoritarian, undemocratic, militaristic, racist and feudalistic,' and it provided a detailed and devastating critique of the document. Why should Indo-Fijians comprising nearly 50 per cent of the population have only twenty two of the proposed seventy one seats in the House of Representatives? What purpose would be served by entrenching a purely communal system of voting in a multi-ethnic society like Fiji? Why should key positions of the state be reserved for one ethnic group only? What was the point of depriving the Council of Chiefs of commoner (administrative and parliamentary) members? Why the disproportionate allocation of Fijian seats to rural constituencies when more than a third of the indigenous community was living in urban and peri- 
urban areas? How could 'economic development take place in conditions of discrimination and insecurity' and 'lasting progress or peace come from the subordination of one race to another?' As an exercise in cogent and accessible exposition of complex constitutional issues, the submission is a masterpiece and well worth reading even now.

Following this detailed critique of the Draft Constitution, the NFP-FLP Coalition made its own proposals for a new constitution for Fiji. The constitution, it said, 'should be based on principles and practices of parliamentary democracy. It should be as participatory as possible.' And second, it should embrace the principle of multi-racialism, 'a partnership of communities.' Just and fair power sharing between the main communities should lie at the very heart of the new constitution. The President should be elected by members of the House of Representatives using the Alternative Vote, but executive power should be vested not in the President, who should continue to perform a largely ceremonial role, but in the Cabinet unless in exceptional circumstances of emergency. The House of Representatives itself should consist of sixty two members, all of whom would be elected, and none nominated. These seats would be allocated as follows: twelve communal seats each for Fijians and Indo-Fijians and three for General Electors, and fifteen national seats each for the two major communities and five for the General Electors. The increase in the national seats would 'remove a weakness in the [1970] Constitution shifting the communal bias of the system towards multi-racial cooperation.' There were many other similar proposals designed to create the framework of a transparent and fair system of government and to remove, as far as possible, all vestiges of racial discrimination in the public sector.

It would be too much to suppose that the NFP-FLP Coalition had high hopes that its proposals would receive a fair hearing in the Manueli Committee. But perhaps they realized the impediments and hoped to articulate an alternative vision for the people to ponder. In the end, the submission fell on deaf ears. Nothing it proposed was taken on board. Instead, there was a complete endorsement of the Fijian view. Because the 
constitution which developed from the Manueli Committee report would become such a controversial document, it is helpful to outline briefly its main features. The constitution provided that the President would be appointed by the Great Council of Chiefs for five years, would serve at the chiefs' pleasure and would be accountable for his actions to them and to no one else. He would be more than simply a figurehead. He was empowered to suspend the Constitution and the civil liberties of individuals to deal with any act that excited 'disaffection against the President or the Government' or others he deemed 'prejudicial to the security of Fiji.' It was assumed that the Presidency would be rotated among the three confederacies of Tovata, Kubuna and Burebasaga and that the President would always be a person of chiefly background.

The Senate was not abolished, as recommended by both the Great Council of Chiefs and Coalition itself in favour of a unicameral legislature. It would comprise thirty four members of whom twenty four would be Fijians appointed by the Great Council of Chiefs, one Rotuman appointed by the Council of Rotuma and nine 'Others' appointed by the President. The prerogative of the Prime Minister and the Leader of the Opposition to nominate members to the upper house, present in the 1970 Constitution, was abolished. In appointing the nine members, the President would be required to 'take into consideration the special interests of the minority communities.' These would include Europeans, Part-Europeans, Chinese and Pacific Islanders besides Indo-Fijians who would, by virtue of their reduced numbers, be rendered voiceless in the proceedings of the Senate. Their complete subordination was a cruel example of blatant racial discrimination against the combined majority community of Fiji. The Great Council of Chiefs would retain the power of veto over all legislation that affected Fijian interests and institutions including the Fijian Affairs Act, the Fijian Development Fund Act, the Native Land Act, the Native Land Trust Act, the Rotuma Act, the Rotuman Land Act, the Banaban Land Act and the Banaban Settlement Act. Fijian dominance in the upper house was complete. 
In the composition of the House of Representatives, there was an even more marked departure from the 1970 Constitution. The new House would comprise 70 members (instead of the previous fifty two) of whom thirty seven (48 per cent of the population) would be reserved for Fijians, twenty seven (46 per cent of the population) for Indo-Fijians, five for General Electors and one for Rotuma (which now had a member each in both the houses of parliament). The principle of parity between the two major communities was discarded. All cross-voting was abolished, thereby eliminating an even limited incentive to work towards cross-ethnic politics which the 1970 Constitution had provided for in a restricted kind of way through the national seats. The constitution entrenched complete electoral apartheid. 'Separate and Unequal' was the doctrine that underpinned the foundations of the new political order. But there was discrimination in the distribution of seats among the Fijian provinces themselves. Of the thirty seven members of the House of Representatives, thirty two would be elected from the fourteen Fijian provinces and the remaining five from urban constituencies. Ba, the largest Fijian province with a population (1986 census) of 55,000 had only three seats, the same as Lau, with a population of 14,000; and Rewa, with 48,000 would have two seats, the same as Kadavu with a population of 9,600. According to the 1986 census, 107, 780 or nearly a third of the indigenous Fijian population lived in urban areas, but they had only five of the thirty seven seats. The constitution had many other discriminatory features as well, symbolized powerfully in the provision that only an indigenous Fijian could become Prime Minister of Fiji.

The 1990 Constitution was a 'perverse' document, Jai Ram Reddy said often, pernicious in its various racially discriminatory provisions that even its architects acknowledged at the time. But this is what most Fijians wanted. Fijian leaders who knew very well that the assumptions which underpinned the constitution would not and could not work, remained silent. The Manueli Committee and the Cabinet's Draft Constitution had misdiagnosed the problem and prescribed the wrong medication that instead of curing the sickness only served to aggravate it. The deep contradictions 
which lay at the heart of the new constitution would become clear soon after its promulgation. But while it gave the Fijian people the illusion of power and control and comparative advantage over other communities, it also underlined and entrenched a subordinate role in Fiji for the Indo-Fijian community. Like children, the Indo-Fijians would be seen but not heard, at least not heard in the important councils of state. As Reddy put it, 'The only role of the Indian and other communities under the constitution is to work and pay taxes to the government to fill its coffers without having any say in the distribution of the government revenue. We have been strangled with the aid of those six stooges (Indo-Fijians on the Manueli Committee) who signed the document before it was promulgated and now the community is barely conscious. ${ }^{\prime 2}$ Rejection of the 1990 Constitution became Jai Ram Reddy's principal political concern in the decade following. But amidst all the gloom, there was one glimmer of hope. There was a provision in the constitution itself for a review within seven years of promulgation and the new parliament and the elected representatives of all the communities would play a key role in that process.

\section{DEATH OF A LEADER AND A DREAM}

On 3 November 1989, Dr Timoci Bavadra died from spinal cancer. He was only fifty five. Bavadra's death grieved the nation, including his political opponents, as the passing away of some other national leaders did not. $\mathrm{He}$ was essentially an unassuming man, gentle and humane, who had been swept by the tide of history to lead the Fiji Labour Party of which he was the founding president. He was that rare Fijian leader, possibly the only one ever, to whom most Indo-Fijians were genuinely drawn by a bond of affection. Ratu Mara, they felt, wanted their support to remain in power, but Bavadra gave the impression of being caring and compassionate, of not being personally ambitious for office. To many, he was simply 'Doc.' Everyone accepted him as the undisputed leader of the Coalition, even those who doubted his political savvy. He was the glue, the moral force, which kept the Coalition together, an indispensible condition for its success. As Reddy re- 
marked, Dr Bavadra 'was his own man; he was intelligent, compassionate; he meant well and he always acted in the interest of all the people of Fiji, and who was followed 'because we trusted him, we liked him and because he was a good leader.'13

With Dr Bavadra's death ended the dream of a united NFP-FLP Coalition. Bavadra's wife, Adi Kuini, succeeded him, and led the coalition until 1991 when she resigned from the Fiji Labour Party to form her own Fijian Association Party (after a brief period with the All National Congress). She lacked her husband's stature and affection among the people, although those who knew her, as I did, never doubted her moral courage and her commitment to the cause of multiracialism. She was a brave and principled leader in her own right. Bavadra's death brought to the fore of the Labour Party Assistant General Secretary, Mahendra Pal Chaudhry who, until then, had none of Jai Ram Reddy's national profile or standing. Born in the western sugar district of Tavua, he attended the Sri Vivekananda High in Nadi. Upon completing high school, Chaudhry joined the Audit department and rose through the ranks to become Senior Auditor before leaving the public service to lead the Fiji Public Service Association. There he acquired a well-deserved reputation as a tough negotiator and uncompromising advocate of his members' rights.

Chaudhry's ascendancy changed the dynamics of politics within the Labour Party. Whereas Bavadra had been gentle and accommodating and not personally ambitious for rule or control, Chaudhry was the complete opposite. He knew power and understood the exercise of it. With unerring instinct and considerable skill, he began to assert his authority over the party machinery. Dissent was suppressed in the name of party discipline, and even the most senior members of the party risked sacking for questioning the judgment of the party leader. Many genuinely idealistic members who believed in the cause of the labour movement in the broader ideological sense and had joined the party for that reason, found Chaudhry's increasing authoritarianism troubling. Over time, for one reason or another, nearly all of them left the party, carrying varying degrees of disillusionment with the 
way things were run in the party and Chaudhry's leadership of it.

Some left politics altogether, while others joined the National Federation Party, saying they were attracted to it by Reddy's moderate approach and inclusive vision, even while muttering privately about NFP's 'communal' base and orientation. The vacuum left by their departure would be filled by non-threatening members loyal to, and dependent on, Chaudhry for their own position and political survival. Their loyalty to the leader was complete and unwavering. The contrast with Reddy could not be greater for, as the 1990s proceeded, he gathered around him arguably the best talent the NFP had ever had, people of genuine ability and skill who were among the best in the country: economists, trade union leaders, businessmen, and professionals in various fields. Conversely, the Labour leader surrounded himself with a generally undistinguished group who were no match for their NFP counterparts. Chaudhry was not content only to be the leader of the Fiji Labour Party. He was determined to become the undisputed leader of the Indo-Fijian community as well. He had accepted Bavadra as his superior in a way he never accepted Jai Ram Reddy. He was committed to NFP's destruction, using whatever means he had at his disposal. In this mission, Chaudhry was single-minded and relentless. Reddy's mistake was not to grasp the true nature and purpose of Chaudhry's mission early enough, preoccupied throughout the 1990s, as he was, with the larger changes and challenges facing his community and the nation. For that, he and his party would pay a terrible price. It took Chaudhry a full decade to realize his goal of toppling Reddy and assuming the mantle of Indo-Fijian leadership, but his great tragedy was that he was not fated to enjoy his spot in the sun for too long. Livy's words are apt: 'You know how to conquer Hannibal, but you know not how to utilize victory.'

The first fracture in the NFP-FLP Coalition occurred over the 1990 constitution, but not before some preliminary explorations about a merger had taken place. The proposal came from the Labour Party. ${ }^{14}$ Labour reminded the NFP of its apparent commitment to a merger in the late 1980s, which the party completely disavowed. No approaches were made to Reddy 
who was the de facto leader of the National Federation Party. The NFP rejected the merger option in the interests of political survival too. The Coalition arrangement had worked well, said Reddy, and should continue. 'We can speak without treading on each other's toes. In a merged party, I would be very unhappy if the party agreed to nationalization. Then we would project an image of division.' The NFP, he said, represented a broad cross-section of the Indo-Fijian community, and it had served the people well over a very long period of time. He then asked the obvious question. 'I am more and more intrigued, as time progresses, about the real motives behind this move. Is it unity or is it because the NFP has become too much of a nuisance for the Labour Party?'15

But some within the Labour party itself were opposed to the idea of a merger. Among them was the party Vice President Simione Durutalo who argued that any closer association with the NFP would play straight into the hands of the Fijian nationalists. A merger would 'lock everybody back into pre-1987 voting patterns with people voting on racial lines rather than for parties' by raising the spectre of Indian domination. He went on to argue that it would be far better for Labour to prepare its groundwork and position itself for victory in the 1996 general elections than attempt to win through a merger in 1992. 'Then, if the military comes in, we will have the people's support.' The only way forward in Fiji politics, argued Durutalo, was to 'democratize Fijian society. ${ }^{16}$ Durutalo's was a voice in the wilderness, although the merger option died a quiet death when the NFP rejected it out of hand. It was a non-starter from the beginning anyway.

\section{TO PARTICIPATE OR NOT TO PARTICIPATE}

Both Labour and the NFP condemned the lopsided 1990 Constitution and demanded its rejection. But they differed on whether they should participate in the general elections to be held under it. Opinion was widely canvassed. Jai Ram Reddy, Mahendra Chaudhry and Navin Maharaj visited India and raised the issue with Atal Behari Vajpayee, who later became Prime Minister of India. His advice was to contest the elections and try to change 
the constitution from within, which is what the Congress Party had done once in the 1930s, rejecting the 1935 Constitution but participating in the provincial elections to keep a foot in the door. 'Staying out will not help your cause,' both Vajpayee and Bhartiye Janata Party President LK Advani told the Indo-Fijian leaders. 'You don't have to convince me,' Reddy replied. 'You have to convince him [Chaudhry].' Ramsay Clarke, Attorney General in Lyndon B Johnson's administration, whom Reddy met privately in New York, offered similar advice. He told Reddy how in Guyana Cheddi Jagan had initially boycotted parliament but, realizing his error of judgment, had returned to participate in its proceedings. Reddy told a meeting in Moto, Ba, that every minister or senior official he had met from Australia, New Zealand, Britain and the United States had 'advised us that while they would provide moral support, they could not directly intervene as it was Fiji's own internal problem to be solved by the people. ${ }^{17}$ The advice of the Coalition's legal advisor, Professor Yash Ghai, was the same: one could participate in the elections under the flawed constitution and use the opportunity to protest against it, expose its flaws and educate the public about it. He advised:

It is possible to attack a constitution and yet take part in the elections. But it is absolutely essential that the terms on which a party takes part is made clear so that it [not taking part] are not interpreted as an endorsement of the constitution. A party may wish to take part in the elections with a view to changing the constitution, or making the political system under it difficult to operate, or not letting its rivals dominate parliament and government. So while there may be a strong moral case for a boycott, it may occasionally make sense to take part in elections while simultaneously attacking the constitution. The important question was not boycott, but whether to endorse the constitution. ${ }^{18}$

Reddy was reassured by such advice, but he instinctively knew from the very outset that boycotting was no option. 'Boycott is a negative sentiment,' he said, 'and little good comes out of negative reactions.' ${ }^{19}$ The Labour lead- 
ers were 'by nature negative and their language is boycott, strike, disrupt, destroy and wreck. They want to destroy everything in sight. ${ }^{20}$ 'If you get elected and do nothing,' he said, 'then you are accepting it [the constitution]. If at every opportunity, you raise your voice, and if need be walk out of the House, that is not accepting the constitution. ${ }^{21}$ He had his party's history on his side. The NFP rejected the 1965 Constitution completely yet agreed under protest to take part in the 1966 elections under it. When it was unsuccessful in having it amended to make it more democratic, it boycotted the Legislative Council, but not before demonstrating the constitution's obvious biases and flaws. And Reddy knew his community well enough to know that there would always be opportunists who would participate in the name of the Indo-Fijian community, even if they represented no one but themselves, all the while parading themselves to the world as democratically elected representatives of their people in parliament. Even Fijian leaders such as Ratu Sir Kamisese Mara and Ratu William Toganivalu urged dialogue, as did the business community, which wanted stability. 'Many times I told Mr Chaudhry,' Reddy said, 'that if he wanted to be a leader, he should not indulge in class wars, which separated growers, workers and businessmen. But he was always bent on orchestrating strikes and boycotts, and always criticized the business community. ${ }^{22}$

The Fiji Labour Party disagreed. Going on the offensive, and referring to Reddy's anti-boycott stance, Chaudhry attacked the NFP leader for not 'respecting the rights of workers, the farmer, and the poor.' 'In fact,' he said, Reddy showed 'contempt for them. It is about time that he understood that boycotts and strikes are legitimate and lawful actions used by the working class to protect themselves against exploitation and oppression. ${ }^{23}$ How could they participate in an election under a constitution they had all roundly condemned as racist, authoritarian, undemocratic and feudalistic? To do so would accord legitimacy to that flawed document and undermine the party's credibility internationally. The FLP told the visiting Australian Foreign Minister Gareth Evans in February 1992 that 'we do not wish to be a party to an election that will not return 
Fiji to genuine democracy but instead entrench an authoritarian racist government similar to that in South Africa.'

International pressure, Labour believed, and nothing else, would force the government to the negotiating table. Said Navin Maharaj, its Secretary General: 'Nothing can be done by going into parliament and success can only come through international pressure, and that is what we intend to do. ${ }^{24}$ In any case, he added, 'People are not really interested in elections. There is quite a lot of apathy among the general public. The public wouldn't give a damn whether there is an election or not. ${ }^{25}$ 'Rabuka has explicitly told us that the constitution cannot be changed and likewise the Soqosoqo Vakavulewa ni Taukei has not given any assurance of any change,' said Mahendra Chaudhry. 'Do you think the coup-plotters carried out so many atrocities for the last five years just to change the constitution?'26 At a meeting in Tavua in May 1992, Chaudhry accused Reddy of falling into an elaborate trap laid by the Fijian leaders to remain in power. The final stage of their master plan, he said, 'is the 1992 general elections.' 'If we sit in parliament,' he continued, 'they will sing to the world that everything is normal in Fiji and that the government would solve the grievances of the Indian community through the parliamentary process. ${ }^{27}$

Reddy rejected the charge, accusing Chaudhry of being a "power hungry politician playing a game with an unsuspecting Indian community. He always wants to be the man at the top and that is the game he is playing. ${ }^{28}$ 'By boycotting elections and staying out of parliament, the Indian community will aggravate its grievances...Labour is harping about international focus and pressure. Where will they get pressure from? From the International Confederation of Trade Unions? It is absolute facts not fantasies that the international community recognizes the government of the day.' ${ }^{29}$ He said repeatedly that the 1990 Constitution was 'abhorrent and something no political party with a sense of propriety can accept.' Still, 'as a matter of practical politics, the chances of getting it improved are better by participation rather than by staying out. ${ }^{30}$ In this stance, Reddy received the full support of Siddiq Koya, whom Labour had opportunistically lauded 
over the NFP leader. 'My views are completely against the Labour Party,' he said. ${ }^{31}$ 'Their decision [not to participate in the elections] is not in the best interests of this country.' 'Negotiation with those in power is the only way change could be brought about to the constitution,' Koya said, 'bearing in mind that talks should be done on the home front.'

In another meeting, Reddy warned about the strategy of wrecking the economy to put pressure on the government to address the grievances of the Indo-Fijian community. He concluded it would be counterproductive. It would only 'lead to a point of no return where there would be no atmosphere for dialogue. ${ }^{32}$ The 'debate on whether the constitution can be changed from within or outside of parliament is an academic one,' Reddy argued. 'The truth is that the only worthwhile constitution will be agreed upon by all the communities and that will not be possible unless we talk. That is vital and there is no other way to proceed. ${ }^{33}$ But Labour was undeterred. In pocket meetings in Penang, Vaileka, Ellington, Barotu, Madhuvani and Vunikavikaloa, Navin Maharaj, Tupeni Baba, Mahendra Chaudhry, Samresan Pillay, and RS Goundar, formerly a president of the NFP, told their supporters not to vote in the elections. ${ }^{34}$ "Any Indian leader, who is seeking a permanent solution to the problems they face in Fiji will never in his right mind advise Indians to participate in the forthcoming elections under the 1990 Constitution, 35 they said. But as we shall see, not only would Chaudhry contest the elections under that 1990 Constitution, he would support the government formed under it! The whole boycott strategy was both short-sighted and short-lived and in the end jettisoned without regret.

The boycott option was not widely shared within the Labour party. As mentioned, among its more vocal critics were intellectuals like Simione Durutalo, of the University of the South Pacific. It would make more sense for leaders to be inside parliament than outside, he said. 'Even an authoritarian parliament is better than no parliament. ${ }^{36}$ The boycott strategy would, furthermore, deprive Fijians who wanted to vote for Labour and were opposed to other parties. He questioned Labour's strategy to constantly 'harp' on the racist nature of the constitution. That it was racist was undeniable, 
but most ordinary Fijians did not have a sufficient appreciation of this fact. It was important to try and educate the Fijians about the constitution. 'An indigenous Fijian-oriented strategy for Labour is the best way to defend Indo-Fijian interests and aspirations in Fiji.' And this strategy, he argued, 'points towards electoral participation rather than boycott strategy.' The boycott decision 'shows how insensitive the party is when it comes to the interests of the Fijian people. They have failed to notice that while the boycott stand would be ideal for the party's Fiji Indian electorate, it is not so for their Fijian counterparts. ${ }^{37}$ Durutalo questioned the way decisions were made in the party. The fatal weakness of the Fiji Labour Party, he said, 'has been the installation of puppet leaders who are used as mere mouthpieces by powerful political personalities pulling strings behind the scenes.' The 'three musketeers' he had in his sight were Mahendra Chaudhry, Navin Maharaj and Tupeni Baba. The token leader Durutalo had in mind was Jokapeci Koroi. ${ }^{38}$ Chaudhry accused Durutalo of opportunism, of having suddenly changed his mind when he had in fact supported the boycott option until August 1991. ${ }^{39}$

The truth was that Durutalo's position was widely shared by many other members. Durutalo resigned from the party along with another prominent founding member, Michael Columbus, president of the Fiji Trade Union Congress, who called the boycott position a 'sham' and pointed out the ironic situation of him asking for dialogue with the government under the existing constitution and then boycotting elections held under it. ${ }^{40}$ In March 1992, Adi Kuini Bavadra said that 'there are really no grounds left for a boycott and the only realistic and practical option is for participation. ${ }^{31}$ A month earlier, Jone Dakuvula had resigned from Labour over 'fundamental disagreement' with the boycott decision of the party. Durutalo's parting shot at his former party was that its coalition with the National Federation Party had been an 'unmitigated disaster.' It was, he said, 'a classic case of political expediency by those in a hurry to get to power at any cost. The political product was a top heavy Coalition government with solid Fiji Indian backing but a very fragile Fijian base. ${ }^{42}$ 
The departure from the Labour ranks of some of its well known members was depressing. The exodus of the founding members, Reddy said, was due to the 'stubbornness of one man, who thinks he knows everything, does not need to consult anybody and tells people that all Indian leaders till now have not done anything for the community. One man's ego is destroying the community. ${ }^{43}$

By late April, FLP's boycott strategy was in complete disarray, criticized both from within and from without. On 30 April, FLP wrote to the NFP proposing that it would not contest the elections if the NFP undertook to abide by certain 'conditions.' In hindsight, the conditions are so unbelievable, so brazenly outrageous, as to lead to the thought that perhaps they were intentionally designed for rejection so that Labour could then find an excuse to contest the elections. ${ }^{44}$ Labour wanted NFP, upon election, to seek an assurance from the government to immediately address all issues of concern to the Coalition, the foremost of which would be the review of the constitution. This assurance, FLP demanded, should be sought outside parliament and steps to be taken to redress the grievances established. If the government refused, the NFP would not enter parliament, but if the government agreed, then the NFP would enter parliament and participate in deliberations 'only to the extent at first of giving effect to redressing those grievances.' Further, the NFP would have to undertake to 'consult with and obtain agreement of the Fiji Labour Party at all stages of the negotiations.' How Labour expected an independent, self-respecting party to give in to such a set of demands only its leaders knew. The NFP expectedly replied that it saw no merit at all in Labour's views and could not possibly accept the terms and conditions 'without sacrificing for all time the NFP's reputation and integrity.' 'The real effect of presenting demands of the kind that Mr Chaudhry is suggesting,' Reddy said, 'will simply put other peoples' back up against the Indians and will not lead to any sensible solution to the present crisis. ${ }^{45}$ RD Patel, one of the founding members of the NFP, likened Labour's behaviour to that of a seven year cheeky child making demands on a thirty year old adult. 
Unable to move the NFP, Labour rescinded its boycott decision and announced that it would fight the election, but, strangely enough, not enter parliament! How did Labour explain its position? Said Navin Maharaj: 'It was only a change in strategy: from boycott of election to boycott of parliament.' Why? 'The change came about because the NFP has no clear picture. ${ }^{46}$ The Coalition was dead. It was a sad end to an arrangement which had begun with so much promise less than a decade ago. On 4 May, Reddy was elected leader of the NFP to take the party into the general elections. In a letter to Chaudhry, he wrote: 'The NFP strongly feels that your eleventh hour decision to field candidates after maintaining for months that you had strong grassroots support for your position is untenable, just as is your decision to field candidates who have already broken written pledges given to people.' Reddy was referring to people who had pledged not to stand against the NFP if they were unsuccessful in getting a party ticket to stand, but who were now standing either for Labour or the recently launched Fiji Indian Congress, and others who had given no pledges but had unsuccessfully applied for a NFP ticket. Among those now contesting the elections, who had applied for NFP ticket, were Lekh Ram Vayeshnoi, Rameshwar Prasad, and Pradhuman Raniga (all successful as Labour candidates). In Indo-Fijian politics, loyalties are tenuous, and commitment to principles even more so. Pet Puja, looking after yourself first, is what the game is often all about. Reddy continued:

The NFP has not made a decision to enter Parliament unconditionally after the general elections. That issue has to be addressed once the elections are held and the identity of the Government is established. A decision would have to be taken then, after due negotiations on critical issues affecting the Indian community are held with those in power. The decision will depend on the result of those negotiations and is a matter exclusively for the National Federation Party. You seem to fail to understand that no political party wishing to retain any credibility with the public can allow itself to be placed in a position where it appears 
to be under the control of another political party, and that too a rival one on critical issues. Furthermore, the NFP does not share your view that entering Parliament, even under protest, will amount to legitimizing the constitution. If that is legitimizing the constitution, then participation by the Fiji Labour Party in the electoral process must do the same. The NFP has made it repeatedly clear that it rejects the constitution. The NFP is fully committed to bring about changes to the constitution. Where we differ is on the method. ${ }^{47}$

The campaign that followed was hard and bitter. It was a head-tohead battle between Reddy and Chaudhry. The key question became: who could be trusted to be the leader of the Indo-Fijian community? Reddy's longer political record provided the necessary grist for Labour's campaign mill. ALTA was depicted as a sell-out of the Indo-Fijian farming community, in whose passage Reddy was said to have had a big hand. To Muslim audiences, Reddy was portrayed as the man who had prevented Siddiq Koya from becoming Prime Minister. His radio address after the April 1977 general elections was dredged up as an example of a leader who was afraid to lead. Reddy's call for a consociationalist government of national unity 'based on a formula of power-sharing which would ensure that every community is represented at the decision making level ${ }^{34}$ was ridiculed by Labour as an arrangement which would 'both implicitly and explicitly give credence and legitimacy to the decreed constitution' and reduce the NFP to a 'subservient position' depending on the mercy of the Fijian side in parliament. ${ }^{39}$ And so it went.

Chaudhry knew, or should have known, what the truth was (as I have shown in earlier chapters), but truth is usually the first casualty in an election campaign. Chaudhry claimed in a meeting in Tavua in May that Reddy had 'left Indians in Fiji to fend for themselves during the most difficult period in this country's history.' Reddy, he said, was like leaders who 'surface during elections and desert people in crisis.'50 'Run Away Reddy' was a common phrase heard at Labour rallies. But it was also a blatant 
lie, one among a long series of lies, half-lies and gross distortions. Reddy was in Fiji throughout 1987. He could not have left the country because he was blacklisted and banned from travelling until December of that year. He had, as we have already seen, been instrumental in the Deuba Accord negotiations. He had instigated a court case against the Governor General for illegal dissolution of parliament. He had been on the Falvey Committee, travelling around the country receiving submissions. He had written the minority report. He had left for New Zealand briefly during the Christmas break and before the arms seizure in June 1988, a full year after the first coup, and remained there for two and half or so months afterwards on the advice of friends 'who pleaded with me to stay out of the country fearing for my safety.' There was good cause for concern. Reddy was still the man the Fijian nationalists fingered as the chief architect of the Alliance defeat. And there was nothing much to do in Fiji anyway, with the military government firmly in place and repressive decrees banning free speech. Jagnnath Sami recalls people hurriedly crossing the streets to avoid meeting Reddy, fearing that even the slightest hint of acquaintance with the NFP leader might lead to a visit by the security forces.

Knowing what the truth was but still making a patently false allegation was something Reddy could not comprehend. 'There are very serious doubts about his suitability to lead the country,' was all he managed to say about Chaudhry. Of all the false allegations made against Reddy, the one about him deserting his people in their hour of need hurt him most deeply, and of which he is to this day unforgiving. But Reddy's 'supposed absence' at the 'height of the crisis' caught on among the Indo-Fijian electorate who had no way of verifying the truth of the allegation, but were willing nonetheless to believe the worst about their opponents. Vinod Chand Maharaj of Lautoka, a Labour candidate, told pocket meetings that Reddy had left the country disguised as a woman! Chaudhry, by contrast, was the man of the moment. Wrote Arvind Pillay of Namousau Ba (if he was the real letter writer): 'It is not for Mr Reddy or anyone else today to denigrate the leadership of a man who stood by the oppressed and downtrodden, raising 
his voice fearlessly for their rights, putting his family, his property and his person to considerable risk. ${ }^{51}$ Of Chaudhry's courage there was no doubt. Even his strongest opponents would concede that. But how could Chaudhry and his colleagues tell tall tales about Reddy knowing the real truth remains beyond easy comprehension and explanation as well.

\section{CONFUSION IN THE FIJIAN CAMP}

While the Indo-Fijian community was racked with division and disunity, things were not much better on the Fijian side either. Divisions in it would have a large bearing on post-election developments. When the constitution was formally promulgated in July 1990, the Great Council of Chiefs launched a new political party, the Soqosoqo ni Vakavulewa ni Taukei (SVT) that, it hoped, would unite the Fijian people under one umbrella in the manner of the old Fijian Administration system. This united Fijian party, the chiefs hoped, would lead the Fijian people to electoral victory and thus fulfil one of the aims of the coup. The reality turned out to be entirely different. Even as the party was being formed, some Fijian leaders questioned the wisdom of the Great Council of Chiefs sponsoring a single political party for all Fijians when it would have been prudent for it remain above the fray of electoral politics. What would happen to the dignity of the Council, the pinnacle of Fijian society, if its party failed to win, asked Apisai Tora, who then went on to form a separate party of his own! $!^{52}$

But views such as this went unheeded, planting the seeds for further problems. The first of these emerged over the election of the president of the SVT. Many Fijians wanted a non-political chief, chosen through consensus, to lead the party and thus provide it with a semblance of traditional authority. Once again, and to no one's surprise, the reality turned out to be different. There were three contenders for the position: Ratu William Toganivalu, a former Alliance minister, Ro Lady Lala Mara, Tui Dreketi, paramount chief of the Burebasaga confederacy and wife of Ratu Mara, and Sitiveni Rabuka. To the surprise of many and the consternation of some, Rabuka beat the chiefs, winning nine 
of the nineteen SVT management committee's votes, to Lady Mara's six and Toganivalu's four. Rabuka's ascendancy troubled many Fijians, including some of his former (but now disenchanted) supporters who had expected him to fade away from the public scene after executing the coup. Rabuka's sharp criticisms of Ratu Mara and his administration troubled many, as did his ambition to become Prime Minister. Said Sakeasi Butadroka: 'If the SVT delegates can put a commoner before a chief, then I don't understand why the Great Council of Chiefs is backing the SVT.' He went on: 'I don't know why a chiefs-backed party can do such a thing, putting a chief — in this case the highest ranking chief, Ro Lady Lala - before a selection panel. ${ }^{53}$ It was a good question to which there were no clear cut answers.

Rabuka began making pronouncements which resembled the criticisms that Bavadra had been making in the 1980s. He wondered whether it was appropriate for chiefs to involve themselves in politics. The proper role for them was at the village level, because when it came to politics, 'the chiefs do not have the mandate of the people. ${ }^{54}$ Underscoring the point, he added that 'there are a lot of capable commoners who can play a very, very important role in Fiji of the next decade. ${ }^{.55}$ Implicitly, he counted himself among them. Rabuka also noted that the 'dominance of customary chiefs in government is coming to an end,' with meritocracy replacing aristocracy. None too subtly, he was invoking the Melanesian model of 'achieved leadership' to the Polynesian model of 'ascribed leadership.' He compared his paramount chiefs — he had Mara in mind — to the towering banyan tree 'where you don't see anything growing,' and he suggested that they step aside. ${ }^{56}$ No one was indispensable, he added, and 'those defeated in elections should take it in their political stride and accept defeat and move out gracefully. ${ }^{57}$

Ratu Mara, the unmistakable target of Rabuka's barb, was among those disturbed by Rabuka's strident ascendancy. He thought Rabuka an 'angry young man,' a naïve soldier, erratic, 'speaking off the cuff in any instigation. ${ }^{58}$ The SVT under Rabuka was a 'debacle,' 'an organization in 
disarray,' Mara reportedly told his political intimates. ${ }^{59}$ Rabuka retaliated by calling Mara 'a ruthless politician who has been allowed to get away with a lot. Maybe it's because of the Fijian culture that he is a big chief and because he was groomed well by the colonial government. ${ }^{60}$ The bad blood between the two strong-willed men was becoming public knowledge, with accusations and counter-accusations flying freely through the media about motives and machinations. Early in 1992, Mara encouraged the formation of a 'Diner's Club' through which he proposed to share his political experience with a select number of prominent and aspiring Fijian leaders. Rabuka was not among them. Mara went further and backed Josefata Kamikamica, former long time head of the Native Land Trust Board and the interim Finance Minister, as his preferred successor. With that, the rupture between Mara and Rabuka was complete. ${ }^{61}$

Tensions within the SVT erupted when candidates were being selected for the 1992 elections. In province after province, aspirants questioned the selection procedures, threatened to stand as independents, and sometimes formed their own political parties even as they pledged undying loyalty to their chiefs. On the eve of the elections, Fijians seemed more hopelessly divided than ever before. The triumphant post-coup Fijian nationalism and the assumptions which underpinned the formation of the SVT were in imminent danger of derailment. The coup had removed the threat of Indian dominance, and thus opened up more space for democratic debate among indigenous Fijians. As a Fiji Times editorial put it, 'the Fijians are now facing so many issues that challenge the very fabric of traditional and customary life. Things they thought were sacred have become political topics, publicly debated, scrutinized and ridiculed.' 'Now' the editorial continued, 'the threat is coming from their own communities where the politics of numbers are changing loyalties and alliances. For the first time in modern history, the Fijian community is in danger of fragmentation; democracy is taking its toll. The chiefs are losing their mana and politicians enjoy increasing influence. ${ }^{62}$ 


\section{THE RACE FOR PRIME MINISTER}

Polling lasted a week, from 23 May to 30 June. The SVT won thirty of the thirty seven Fijian seats, with the remaining seven going to the Fijian Nationalist Party (three), Soqosoqo ni Taukei ni Vanua (two), and independents (two). The SVT had done well, but it still did not have the numbers to form government. The election results among Indo-Fijians surprised most people. Expected to win all the twenty seven seats comfortably, the NFP won only fourteen, capturing 50 per cent of the Indo-Fijian votes cast $(114,005)$ while Labour won marginally fewer: thirteen seats. Reddy (2,405 votes) won over Labour's largely unknown candidate Kesho Ram Sharma (1,640 votes), but among its big losses were party president Balwant Singh Rakkha and former party leader Harish Sharma. There was an interesting irony in the Indo-Fijian voting pattern. Labour, with an essentially urban base, won easily in the sugar cane belt, failing to win only one rural seat, the one contested by Reddy, while the National Federation Party, founded in the cane belt of western Viti Levu, captured the votes of the urban Indo-Fijian electorate. NFP's urban success owed in part to the fact that it was better-funded, fielded better candidates and was able to benefit from bitter divisions within the ranks of the trade union movement. Some of Chaudhry's harshest critics, such as the former Secretary General of the Fiji Trade Union Congress, James Raman, were successful NFP candidates. And it might also have been the case that the urban voters read the newspapers and so better understood the issues the two parties presented to them.

Labour's rural success was due largely to the National Farmers Union, with some in the media proclaiming Chaudhry to be 'undisputed leader' of the cane farming community. ${ }^{63}$ The idea of such a farmers' union had in fact been first mooted by Reddy in 1976. He had in mind a non-political farmers' trade union which could, like other trade unions, look after the interests of its members. NFU was launched in Labasa in the late 1970s, with NFP's support and Chaudhry quickly apprehended the political sig- 
nificance of the organization for his purposes. Accordingly, he devoted his considerable energies to enlarging and strengthening its base as its General Secretary. Reddy accused Chaudhry of politicizing the NFU and of using its infrastructure and apparatus for Labour's election purposes. ${ }^{64}$ Chaudhry implausibly denied the charge, but retorted that it was the human right of every farmer to participate in politics. NFU's chairman, Sharda Nand, resigned from the organization in disgust at the manner in which the NFU machinery was 'fully utilized [by Labour] during the elections. ${ }^{65}$ The NFP resolved to reclaim its presence in the farming community and delegated Ali Hussain, formerly of the Fiji Sugar Corporation Research Centre, and Lakshman Maharaj, former FSC executive, for that task. They would achieve some success, but a politicized, Labour-controlled NFU, with Chaudhry at its head, would become and remain an important feature of the Indo-Fijian political landscape for the rest of the decade and beyond. Reddy had emerged victorious, but only just. 'This is a no-win situation,' he told his party members. 'The society is fallen. Don't think you have won. ${ }^{66}$ The very thing he had worked so hard to avoid, division in the Indo-Fijian community, had returned to haunt his people once again. He had spent much of his time and energy in the 1970s dealing with the rifts and ruptures within his own party; now he was facing the same problems with Labour.

The race for Prime Minister started even before results were known, as leading candidates, Rabuka and Kamikamica, began to campaign for support among opposition parties. This was unusual. Rabuka was the elected president of the party; he had led it in the election campaign and, having the largest number of seats in parliament, should have been the automatic choice for prime minister. But SVT met on 31 May to elect a leader, who would be its candidate for prime minister. At this meeting, Rabuka reportedly won eighteen votes, Kamikamica two, Filipe Bole four and Ratu William Toganivalu three. Claiming he had the support of forty two members, Rabuka went up to Government House to be sworn in, but President Ganilau told him to produce the signatures of all those 
who supported him before 10 am the next day. The president, emotionally close to Rabuka, was aware of the split in the SVT and was also mindful of Mara's preference. Equally, he was cognizant of the constitutional requirement to appoint as Prime Minister the Fijian best able to command the majority support of all members of the House of Representatives.

Obtaining the signatures was not as easy as Rabuka might have supposed, for by the time he returned from Government House new tensions had risen. Some Fijian members who had supported him initially opposed any formal association with the Fijian Nationalists who had joined hands with Rabuka, and threatened to support his opponent. The support of the Indo-Fijian parties thus became crucial. In fact, as the results were being counted, Rabuka sent Koresi Matatolu, now of the SVT but once a vice president of the NFP, to ask Jai Ram Reddy for his support. Reddy refused point blank on principle. 'How can we support such a person who snatched our rights away and subjected us to harassment,' he asked, this man who had hounded his people and brought about so much misery to the country ${ }^{67}$ He considered Kamikamica a safer bet as he had verbally assured the NFP during the campaign of his willingness to initiate an immediate dialogue on the constitution. And he was, of course, untainted by the coups. By some accounts, Kamikamica had secured the support of thirty parliamentarians (ten SVT, one Rotuman, five General Voters Party and fourteen from the NFP), while Rabuka was supported by twenty SVT, five Nationalists and one Independent. Faced with this crisis, Rabuka's emissaries contacted the Fiji Labour Party in the early hours of 2 June.

Chaudhry reacted differently to Rabuka's overtures. With an unexpected thirteen seats in parliament, the party which had maintained its boycott stance until the last minute, now saw itself as a key player on the political scene, the tail which might finally wag the dog. Labour agreed to support Rabuka for the top position in return for an undertaking to address several of its key concerns. They wrote to Rabuka on 2 June. Their letter and Rabuka's response are reproduced below. 
2 June 1992 (CONFIDENTIAL) ${ }^{68}$

MAJOR GENERAL SITIVENI RABUKA

(Hand Delivered)

The Fiji Labour Party has agreed to lend support to you for the position of Prime Minister on the basis that our party would be given firm assurance on the following issues in writing:

\section{A. CONSTITUTION}

The new government would immediately initiate a process of review and change of the 1990 Constitution by a jointly appointed team that would take into regard the objections that have been expressed by the Fiji Labour Party on behalf of the Indian community, urban Fijians and Western Fijians, and take immediate measures to address such objections.

Such a process to be initiated as soon as parliament convenes.

\section{B. LABOUR REFORM DECREES}

That the new government would urgently seek to have the labour decrees revoked to take account of the objections by the trade union movement in Fiji.

\section{VAT (Value-Added Tax)}

That the new government would urgently scrap VAT as a matter of priority. D. LAND

That the new government would convene a machinery to facilitate discussions on the issue of land, particularly relating to the extension of ALTA (Agricultural Landlord and Tenant Act).

That as soon as the parliament convenes, such a machinery be deliberated upon.

The Fiji Labour Party is awaiting your urgent and serious consideration of our request.

Yours sincerely

Jokapeci Koroi (Mrs) (President) 
Rabuka replied instantly.

MRS JOKAPECI KOROI PRESIDENT

FIJI LABOUR PARTY SUVA

Dear Mrs Koroi

I acknowledge your proposals outlined in your letter and agree to take action on all the issues, namely the Constitution, VAT, labour reforms and land tenure on the basis suggested in your letter.

I agree to hold discussions on the above issue in order to finalize the machinery to progress the matters further.

Yours faithfully

S.L. Rabuka (Major) General, President

Interestingly, the Fiji Labour Party also obtained an undertaking from the Fijian Nationalist Party and the Soqosoqo ni Taukei ni Vanua, which, according to some sources, had been instrumental in initiating dialogue between Rabuka and Labour. These two parties' five parliamentarians (Butadroka, Gavidi, Lepani Tonitonivanua, Ratu Mosese Varasikete Tuisawau and Mosese Tuisawau) and the nationalist-minded independent, Kolinio Qiqiwaqa, wrote to the Labour Party: 'We give you our assurance that should the President accept his nomination we will support your conditions as set out by the new Prime Minister.' This offer hardly seems genuine or trustworthy. Why would Butadroka, of all people, endorse a review of the constitution which enshrined the principle of Fijian political paramountcy he had championed all his political life? Or resolution of the land issue in favour of the Indo-Fijian tenants when he had long agitated for the non-renewal of leases to them unless they agreed with the principle of Fijian political paramountcy?

Not everyone in the Labour hierarchy supported the deal with Rabuka. Among those who voiced doubts was Tupeni Baba, who predicted turmoil 
if Rabuka was elected Prime Minister. 'Rabuka's approach at the expense of others will bring instability to Fiji with his unpredictable utterances and demands,' he said. ${ }^{69}$ Kamikamica, he thought, would command greater and more solid support among the parliamentarians. But it was Mahendra Chaudhry's words which carried weight and carried the day. He said that he had noticed a change in Rabuka. 'I won't say he is the same man who marched his soldiers into parliament on the 14th of May 1987. Certainly, he has been mellowing in his attitudes and we hope to see more of this in the future.' Chaudhry did not think Rabuka would renege on his word. 'I believe that Mr Rabuka is sincere. We cannot have goodwill if there is an air of distrust and suspicion. ${ }^{70}$ He believed Rabuka when he said that he had been 'used' by some chiefs to execute the coups. 'We hope the influence of these chiefs in Fiji politics won't be there for very long. ${ }^{.71}$ Among those chiefs was Ratu Mara, but by 1999, the same chief would become a friend whose influence, Chaudhry hoped, would last long into the future. Kamikamica, Rabuka's rival, and one who enjoyed the support of the NFP, was for Chaudhry a rightwing leader who had imposed anti-worker decrees when he was interim Finance Minister. This it would appear was a greater evil than carrying out the coup.

Reddy decried Chaudhry's new manoeuvrings and allegiances. 'At this crucial time,' he said, 'there is a need to heal the wounds and work together to map our common strategies to oppose and seek changes to the 1990 Constitution ... If we all want to unite, then this game of one upmanship must stop.' Before making the deal with Rabuka, Reddy said, 'they could at least have consulted us on some vital issues.' Reddy did not think much of the assurances Rabuka had given to the Labour Party. 'These assurances were given for a limited purpose, that is to secure the numbers [for Rabuka] to become the Prime Minister. I think the big question now is how serious is the intention to deliver on these promises. ${ }^{172}$ The answer, which Labour discovered soon enough, was: not very serious at all. Jone Dakuvula, SVT spokesman, said in early June that 'at no stage did the Prime Minister make an agreement with the Labour parliamentarians that he would fulfil 
the four conditions they had demanded. There is no such agreement. ..The response we sent them was that the Prime Minister is willing to discuss these matters they raised. That's all. While we value the support they gave us, there was no agreement that we would get their support in return for the conditions they said they wanted. ${ }^{73}$

Seasoned observers thought Labour's demands potentially counterproductive. Simione Durutalo thought Labour's support for Rabuka was a mistake, while Ratu Mara said that an 'immediate review of the constitution is not good.' If the SVT tried 'to tackle the issues as the Labour Party demands, then it is a foregone conclusion it will fail. You want people to be even-tempered when they look at things ${ }^{74}$ But for Labour, the deal had served its purpose. It provided them the justification they needed to enter parliament just as they said they would: by seeking assurances for a review of the constitution from outside and entering it only when an undertaking was given. It is beyond belief that Labour had any realistic expectation of getting their grievances redressed anytime soon. Reddy was not at all surprised when Rabuka wavered on the deal soon after agreeing to it. At a meeting at Adam's Triangle in Ba in June, he said: 'Nobody is surprised by Rabuka's denial of an agreement. After all, who can trust him when he overthrew a lawfully elected government? ${ }^{25}$

Soon after striking the deal with Rabuka, Chaudhry travelled to Reddy's Teidamu retreat - 'came running to my farm, this man who fought me bitterly in that election, and accused me of selling out Indians' as Reddy recalled ${ }^{76}$ — where he met Reddy and his law partner, Bhupendra Patel. They talked for more than an hour during which Chaudhry gave Reddy a copy of his so-called agreement with Rabuka. He asked Reddy to accept the position of Leader of the Opposition. When Reddy asked why he should do this when he could not be the alternative Prime Minister, Chaudhry said, 'No it is very important for our international contacts that you should become the Leader of the Opposition. ${ }^{77}$ But soon after the meeting, Chaudhry sensed an opportunity for himself to ascend to that office when the Fijian Nationalists threw their support behind Labour, 
giving them a total of nineteen Opposition seats in parliament. This the nationalists did after they failed to get NFP to support Ratu Osea Gavidi for the position of Opposition leader. Butadroka also backed Labour because it had supported the removal of the $\$ 1000$ nomination fee for the general elections. ${ }^{78}$

Labour then wrote to the President to appoint Chaudhry the Leader of the Opposition. Ratu Penaia rang Reddy. 'Jai Ram, I have received a letter signed by Sakeasi Butadroka and Mahendra Chaudhry mentioning there has been a mistake; they have the numbers, you should be removed, and Mahendra Chaudhry [should replace you.] $]^{79}$ Ratu Penaia, who recalled this request with some puzzled amusement, asked Reddy: 'What's wrong with the Labour Party? How can they support Butadroka?' It was a fair question. Ganilau refused Labour's request because to accede to it would have breached the constitution which (section 97) provided that 'whenever the President has occasion to appoint a Leader of the Opposition, he shall appoint - if there is an opposition party whose numerical strength in the House of Representatives is greater than the strength of any other opposition party - the member of the House who is the leader in the House of that party.' The Nationalists and Labour did not constitute a 'single' party, which the NFP did. There was no provision in the constitution for a Leader of the Opposition from a coalition of Opposition parties, advised parliamentary counsel Alipate Qetaki. ${ }^{80}$

Reddy accepted his appointment as the Leader of the Opposition 'with a heavy heart,' noting the obvious fact that under the constitution no IndoFijian, or any other non-Fijian, could aspire to become prime minister. 'I find this fact deeply distressing, not for my sake but for the sake of Fiji and the entire Indian community. ${ }^{91}$ All the important consultative provisions of the 1970 Constitution were gone. Now, consultation with the Leader of the Opposition in the appointment of the Chief Justice, the chairperson of the Public Service Commission, the Police Services Commission, the Boundaries Commission and the Electoral Commission were removed. The position of the Opposition Leader had been reduced to 'bare minimum,' 
Reddy noted, but he nonetheless hoped to use the House of Representative and the Opposition Leader's office to air the views and concerns of his people. This he did with great dignity and remarkable success. He met with less success in healing the wounds within in his community.

\section{THE ROCKY ROAD TO RECOVERY}

In late June, Reddy met Rabuka and talked to him about his serious concerns over the constitution and its unsuitability for Fiji. Rabuka conceded that the constitution had shortcomings. Reddy entered parliament on Rabuka's undertaking to engage in dialogue and discussion. Indeed, he promised to put out a paper for discussion on the constitution for the September session of parliament. Rabuka expressed his admiration for Reddy. 'I think he is taking a very mature attitude in his concerns because I had talks with him in 1988, and the views he expressed then are still the same views he is expressing now. His main concern is the welfare of the Indian community. Whatever the racial breakdown of Parliament, his main concern is the Indians, not just the number of seats.' ${ }^{82}$ Reddy also extended his hand of cooperation to the Fiji Labour Party, notwithstanding their vitriolic attacks on him during the campaign. 'At this crucial time, there is need to heal the wounds and work together to map out common strategies to oppose and seek changes to the 1990 Constitution,' he said. ${ }^{83}$ 'Finger pointing, hurling accusations and squabbling will not lead us anywhere but only succeed in further fragmenting the community. My advice to the people is: Let's unite, forget our differences and demonstrate the solidarity of the Indian community in these trying times.' Chaudhry himself had approached Reddy soon after the elections (before writing to the President to be appointed the Leader of the Opposition) for the two leaders to cooperate on issues affecting the Indo-Fijian community, especially on the issue of the constitution. ${ }^{84}$

Rabuka initiated the preparatory work towards setting up a Constitution Review Commission, but he was hampered by difficulties in running the government. His immediate priority was to consolidate his 
support in the party and in the by now fractured Fijian community. To this end, he tried to co-opt potential opponents who had lost in the elections. Many were rewarded with seats in the Senate, diplomatic jobs or positions with statutory bodies. In cabinet and other appointments, he observed the principle of provincial balance. The logic of the electoral system demanded that each province be represented in the higher echelons of government. Indeed, when some members were dismissed or demoted for non-performance or other similar reasons, they attacked the prime minister. Viliame Saulekaleka called Rabuka anti-Lauan. Ilai Kuli, the mercurial sacked Minister for Posts and Telecommunications, treated his dismissal as a betrayal of the people of Naitasiri. Bua threatened to block the opening of the $\$ 10$ million Nabouwalu Hospital if its representative in cabinet, Koresi Matatolu, was removed. Rabuka may have had his mandate, but he had to work with a team whose loyalties were divided and contingent, and who had mandates of their own. In this scheme of things, the interests of the Indo-Fijian community featured nowhere.

In the first few months in office, Rabuka announced a number of pro-Fijian policies. His government said, for instance, that it would continue to support the special Fijian education initiatives. It proposed several measures to propel more Fijians into the commercial sector where they were conspicuous by their absence. These included a small business agency to advise and train Fijians, providing loans to provincial councils to increase their shares in Fijian Holdings Limited, giving that investment company priority in buying shares from privatized government enterprises, and proposing income-tax exemption for Fijian-owned businesses for up to twenty years. It also set aside funds worth $\$ 2$ million to provide interest-free loans payable over thirty years to certain mataqali to buy back freehold land on the market. Late in 1993, the government announced the transfer of the administration of all Crown Schedule A and B lands from the Department of Land to the Native Land Trust Board, with the view eventually to converting them to native title (which would take place under the Qarase government a decade later). 
Many of the pro-Fijian policies were cautiously supported both by Labour and the NFP. At the same time, they also raised questions about the discrimination against Indo-Fijians in the civil service, with Chaudhry pointing out that the principle of balance had been ignored. Of the 9597 civil servants in 1992, 5,897 (61 per cent) were ethnic Fijians and 3186 (33 per cent) were Indo-Fijians. On the boards of statutory organizations, the absence of Indo-Fijians was even more glaring. For instance, there was not a single Indo-Fijian on the boards of the Reserve Bank of Fiji, the Fiji Broadcasting Commission or, most incredibly, the Fiji Sugar Commission. Reddy pleaded with the government for fairness and equity, but the government had no political incentive to address the concerns of the non-Fijians. It was in the early years of the Rabuka administration that the culture of corruption grew in the public service as people were appointed and promoted not on the basis of competence and meritocracy but on the principle of patronage and ethnicity. For that Fiji would pay a terrible price later.

With time, Indo-Fijian disenchantment grew, but Rabuka was, or appeared to be, indifferent. He had his own internal concerns to attend to. The worst fears of Indo-Fijian leaders were coming to pass. Their people were feeling alienated and discriminated against with few remedies for redress at their disposal. No one felt more betrayed than Labour, whose support had made Rabuka Prime Minister. Rabuka effectively ignored the conditions of that support. The ten per cent value-added tax on most goods and services was retained as part of the government's tax reform package. The labour reform legislation, whose ultimate effect was to cripple the trade union movement, was not enforced though it remained on the books. And though there was some talk, there was no action on the pressing expiry of the Agricultural Landlord and Tenant Act. On the review of the constitution, Rabuka said, perhaps only half seriously, that to 'review means to look at what has been done. It does not mean that we have committed ourselves to making any changes or abolitions. ${ }^{85}$ In fact, the government had committed itself to a review within five years, but did not regard it as a matter of urgency. 
Then, suddenly in December 1992, Rabuka mooted the idea of a government of national unity. The proposal caught everyone by surprise. Perhaps it was a survival strategy, with his standing in his party shaky. He told the nation:

[W] hat I and those who support my idea envisage is a style of government that brings the communities together, that enables all ethnic groups to cooperate jointly in the affairs of the government and the work of the legislature. I want leaders of Fijian, Indian and General Voters to define the middle ground, the political centre, where they can pool their wisdom and their abilities in the national interest. I want to see them united in pursuit of defined national objectives - objectives that serve the interests and welfare of us all, Fijians, Indians and General Voters. In my vision of what I consider to be the ultimate good of the country, I see very clearly that it is in all our interest to develop a social and political partnership that transcends suspicion and distrust, that elevates us as a nation and gives us a combined sense of common destiny and purpose. ${ }^{86}$

The statement was hailed as a major policy declaration by the government though, in truth, it was much the same as what Rabuka had said in 1990 about abandoning 'extremities' and looking for 'points of convergence. ${ }^{87}$ Rabuka talked about inclusiveness and partnership, but his proposed national unity government would have eighteen members, twelve from the SVT, two each from NFP and Labour, and one each from the Nationalists and the General Voters Party. The proposal predictably received a mixed response. The SVT caucus complained of being kept in the dark. The Taukei Movement urged all Fijian members of parliament to 'completely reject and throw out of the window with precipated [sic] haste the devilish concept of government of national unity. ${ }^{88}$ They postponed threatened protest marches only after Rabuka assured them that promoting national unity should never be misinterpreted or misconstrued by anyone to mean that he and his government were giving away the special position 
conferred on the Fijians and Rotumans as the 'host' communities under the 1990 Constitution. ${ }^{89}$ Simione Durutalo thought the whole unity proposal was an attempt by Rabuka to 'repackage his 1987 image of an anti-Indian.' 'If the idea is accepted,' Durutalo said, 'it will be a big score for his prime ministership. If the idea is rejected, he will turn around and tell the Indian leaders he tried his best but the GCC blocked him. ${ }^{90}$ Reddy was also sceptical. There had to be some consensus on the basic principles before the proposal could be discussed further, he said. 'I am not going to nominate numbers,' he said, 'but at the end of the day in a government of national unity, Indians should be fairly represented. We should have a figure that bears some resemblance to their numbers, contribution and work, and not just a token number. ${ }^{91}$ But a government of national unity was not Reddy's main concern. He said:

Let me emphasize that our priority is not a government of national unity, our priority is the review of the constitution and I am absolutely convinced in my view that has to precede anything else. Because the potential gulf between us and Government on the future of the constitution could be so enormous that it would be utterly unrealistic for the Opposition to get locked into the government of national unity issue until such time we are able to narrow down those differences. I think my own gut feeling is that the government of national unity or any kind of unity would have to come after a constitution is in place which facilitates that kind of government. I don't think any meaningful dialogue can take place and any solution can be formed if there is an air of instability in the country. ${ }^{92}$

Rabuka then did what he should have done in the first place: he presented his proposal to the Great Council of Chiefs, adding that the proposal was not of "paramount importance. ${ }^{93}$ In the Council, many chiefs, including Ratu Mara, questioned the prospects for a government of national unity under the provisions of the 1990 Constitution. How could you have, in the same document, the principle of Fijian political control enshrined on the 
one hand, and the principle of democratic government and equitable power sharing on the other? As usually happened in these situations, the Council of Chiefs decided on more grassroots consultations, and sent the proposals to various Provincial Councils. And there they languished in the wilderness, never to be raised again. By then, Labour had had enough of Rabuka's meandering tactics. In July 1993, they walked out of parliament in protest against his procrastination and prevarication.

Behind the scenes, however, the government had been quietly preparing the ground work for the review of the 1990 Constitution. A month after being sworn in, the first paper on the constitution was prepared, and by September 13, the full cabinet had met eleven times to consider the review of the constitution. A cabinet subcommittee, with Deputy Prime Minister Filipe Bole as its chair, was set up to shepherd the review process through its initial stages. On 23 June, the President informed the parliament of the existence of the subcommittee to which Opposition members would be invited. On 9 June, Rabuka invited Reddy for the first informal meeting about the review process, the decision having already been made on 12 January 1993 to involve the Opposition in the discussions. Later four others were invited to join: James Raman, Maan Singh, Narayan Singh Arjun and Mosese Tuisawau.

Many more such meetings would take place where doubts and feelings would be expressed in the privacy of informal conversations as things progressed slowly. The main purpose of the Cabinet sub-committee was to develop consensus about a set of fundamental principles which should provide the underpinnings of the new constitution, prepare a draft Terms of Reference for an independent commission to review the constitution, and to look at substantive aspects of the document, and not only selected aspects of it, in line with the consensus principles. ${ }^{94}$ The discussion would be informal, face-to-face and frank, without an eye to the electorate or the next day's headline. It would provide an opportunity to hear the views of the other side so that the vast gulf between the two sides could be narrowed. There would not be a formal report at the end of the proceedings. 'It is not a forum at 
which decisions can or will be imposed on anyone,' Reddy said. 'It is easier,' he continued, 'to establish among sensible and responsible leaders who, in confidential discussions, can express their anxieties and acknowledge those of other communities and make suitable compromises [than] through wide public debates, where the pace is set by extremists on all side of the argument. ${ }^{95}$ That, after all, was how the 1970 Constitution was negotiated and, more recently, the Deuba Accord.

The discussions, though amicable, were not easy. There was, Reddy recalled, 'great intensity of feelings on both sides.' Questions of right and wrong — and who was wronged — were not easy to resolve. A certain generosity of mind and heart is required to break the impasse. '[O]ften in these things, it is not a question of whether I am right or wrong or whether the other side is right. It is often a question of being able to understand and appreciate the feelings that lie behind the positions that we take up. What is my right may be my opponents' wrongs and that which I perceive is right, correct and justifiable, may not be so perceived by my opponents, who equally and fervently believe that their own position is right. ${ }^{96}$ The important thing was to 'break down the fears that are at the back of these intense feelings.' It was with that frame of mind that Reddy accepted Rabuka's invitation to join the expanded Cabinet sub-committee on the constitution. Several informal meetings took place, all with one common theme: 'to try to create an environment in the country, to try and unite the people of this country so that we can all move forward in our endeavour to resolve the many problems and grievances that we have.' Time and patience would be required in abundance. It was not what the elected members of parliament thought or did about the review that would matter in the end; 'the success of failure will depend upon how well that constitution is received by the people of Fiji.'

On 14 September 1993, Sitiveni Rabuka moved, and Jai Ram Reddy seconded, a motion to review the 1990 Constitution. ${ }^{97}$ It was a milestone achievement, the first successful one of its kind since the Deuba Accord of September 1987, voluntarily arrived at by the major political leaders of 
all the communities in Fiji. The motion asked for an endorsement of the appointment of a commission to review the constitution 'with a view to promoting racial harmony and national unity and the economic and social advancement of all communities, and bearing in mind internationally recognized principles and standards of individual and group rights.' To that end, the Commission would:

Take into account that the constitution shall guarantee full protection and promotion of the rights, interests and concerns of the indigenous Fijian and Rotuman people

Scrutinize and consider the extent to which the Constitution of Fiji meets the present and future constitutional needs of the people of Fiji, having full regard for the rights, interests and concerns of all ethnic groups of people in Fiji

Facilitate the widest possible debate throughout Fiji on the terms of the constitution of Fiji and to inquire into and ascertain the variety of views and opinions that may exist in Fiji as to how the provisions of the Fiji constitution can be improved upon in the context of Fiji's needs as a multi-ethnic and multi-cultural society Report fully on all the above and, in particular, to recommend constitutional arrangements likely to achieve the objectives of the Constitutional Review as set out above.

Reddy refused to take credit for this achievement, but that his sensible and moderate approach, his sensitivity to the feelings and concerns of other communities, his willingness patiently to listen to contrary views and to compromise in the greater national interest, contributed enormously to the formulation of the Terms of Reference in large measure is beyond doubt.

But the scope of the Terms of Reference was not enough to satisfy Labour leader, Mahendra Chaudhry, who ended his boycott and returned to parliament in September to participate in the debate on Rabuka's motion, saying that the Terms of Reference were inadequate and restrictive, and that Jai Ram Reddy had, yet again, sold out the interests of the Indo-Fijian 
community. Chaudhry returned to parliament armed with an amendment to the motion. Most non-Labour parliamentarians were sceptical about Labour's real reasons for returning to parliament. Many thought it was really an excuse to get back on to the constitutional train now that it had started to leave, otherwise they risked being irrelevant to the process. The boycott was serving no useful purpose. ${ }^{98}$ Chaudhry raised several objections. He said that the expanded Cabinet sub-committee was not the appropriate place to formulate the Terms of Reference. That should have been the responsibility of the Joint Parliamentary Select Committee whose appointment had been foreshadowed in the President's address to parliament. He was particularly perturbed that the Joint Committee would begin its work after the Review Commission had submitted its report.

It was practical considerations rather than any devious motive which had led the sub-committee to take that path. Filipe Bole explained that there were many issues in the review exercise where there was little likelihood of meeting of minds, and if the Joint Parliamentary Select Committee were to be appointed at the beginning of the process, that would unduly delay the appointment of the Commission. Citizens would be making their submissions directly to the Commission, and the main task of the Committee would be to assist parliament in considering the report of the Review Commission. For Reddy, whether it was the expanded Cabinet subcommittee or the Joint Parliamentary Select Committee which drafted the Terms of Reference was irrelevant. The main point was reaching consensus on the scope and framework of the review exercise.

Chaudhry thought it could be counterproductive to facilitate a wide debate on the terms of the constitution because 'an overwhelming body of opinion has already been established on the matter.' Such an exercise would be time consuming and, worse, give extremist elements a platform to try and derail the process of review. And he made several other suggestions to make the Terms of Reference more specific, such as the appointment of 'independent' and 'suitably qualified' people to be on the Commission, a requirement to 'establish a democratic system of political representation,' that 


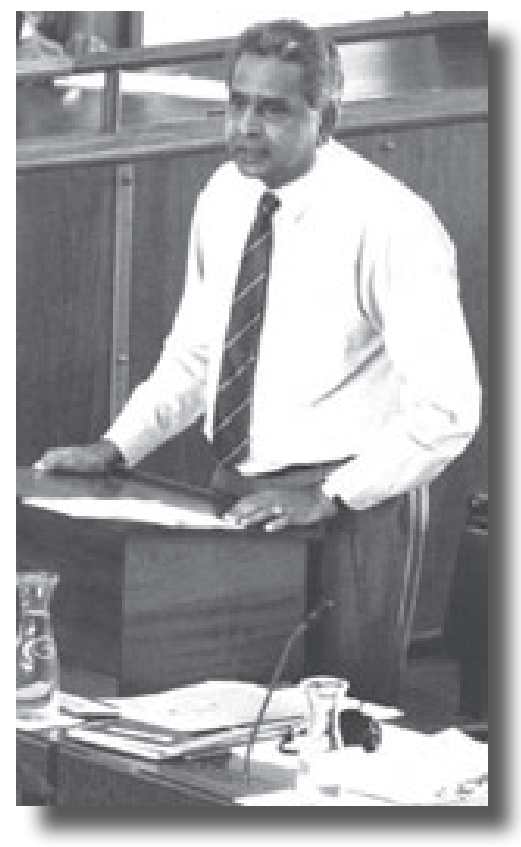

the interests of indigenous Fijians and Rotumans should be protected 'without sacrificing the rights, interests and concerns of all other people in Fiji, that the Commission be asked to report within twelve months, and so it went. Reddy accused Chaudhry of nit-picking by selecting for omission or deletion lines from the Terms of Reference. He asked him to read the document in its entirety before forming a judgment about it. 'You look at that document from one corner to the other, put it aside and say, what does this document mean? That is how documents of a legal nature, or any nature, are interpreted and should be interpreted.' In any case, it was not for the parliament to interpret the Terms of Reference. That, in the ultimate analysis, Reddy said, would be the task of the Commission itself, which is how things in fact turned out.

Looking back at the debate from a decade later, the controversy surrounding the drafting of the Terms of Reference and the appointment of the 'Commission to Review the Constitution,' seems so trivial. It is difficult to escape the conclusion that it was manufactured for political purposes, little else, although in defense of Chaudhry, his supporters argued that in the context of uncertainty at the time, his suspicions were justified. In the event, none of the issues that Chaudhry raised ever became a hindrance to the work of the Commission. Hindsight entirely vindicates the enormous value and significance of Reddy's consensus-building approach. What was not known to the public at the time was the amount of work and intense consultations which Reddy had undertaken, or initiated, with some of the world's finest legal minds with constitutional expertise. ${ }^{99}$ Nothing was left 
Facing page and this page: 'Man of the House': Jai Ram

Reddy in Parliament. He was its most eloquent speaker. Photo courtesy of Fiji Times.

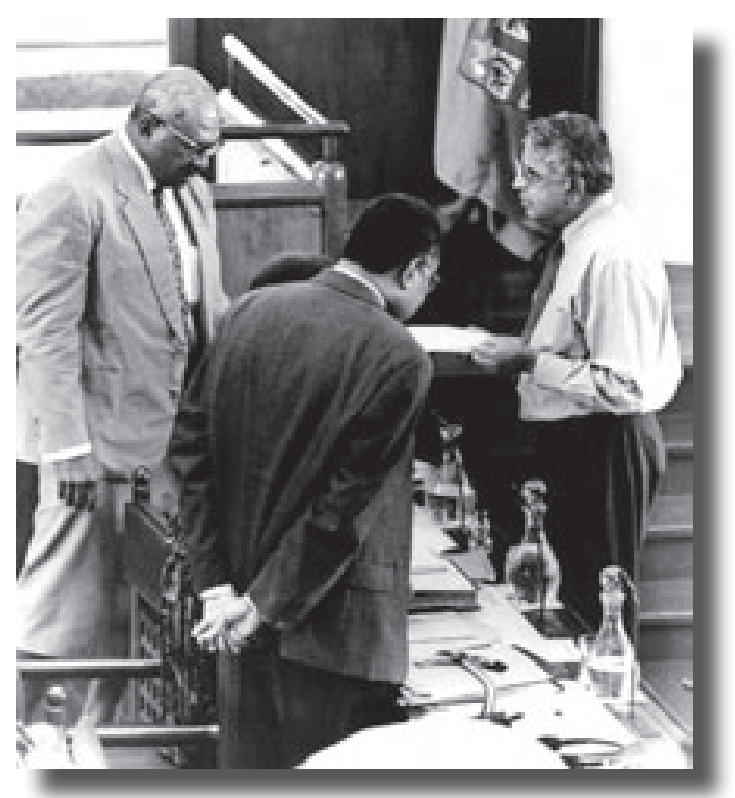

to chance. Nothing ever was. 'When you talk about political rights', he said, 'you are talking about generations unborn and people make great sacrifices to ensure those rights are enjoyed.' ${ }^{\prime 00}$

\section{DÉJÀ VU}

Impressive though this achievement was, any expectation of an early start on the review exercise was short-lived, being overshadowed by scandals enveloping the government and sapping its energy, and distracting it from the important tasks at hand. Reddy watched the SVT implosion with deepening dismay, the party turning in upon itself in the manner NFP had done in the1970s. The Posts and Telecommunications Minister Ilai Kuli resigned, and Fijian Holdings faced allegations of insider trading. Similar allegations surrounded the awarding of a tender to upgrade the Nadi International Airport to a company, Minsons Limited, in which Rabuka had shares. The Ports Authority was rocked by reports of excess expenditure, irregularities in the sale of equipment, personal insurance discrepancies and 
misappropriation of funds. Questions were asked about the purchase of the Prime Minister's new residence (owned by Ratu Penaia Ganilau family's Qeleni Holdings) for $\$ 650,000$ when the government valuer had estimated its value at $\$ 465,000$. $^{101}$

These incidents collectively epitomized the general culture of corruption in public life which had 'reached alarming proportions,' made even worse by the 'lack of action taken by the authorities on some of the more serious misappropriation cases involving hundreds of thousands of dollars. ${ }^{102}$ But all this was not surprising. The coups of 1987 had infected public institutions with the virus of nepotism, mismanagement and corruption. Principles of accountability and transparency had disappeared. Politicians and civil servants demanded bribes openly; greasing the palm was quickly becoming an accepted way of life in Fiji. Jai Ram Reddy raised some of these issues in his budget speech in November 1993:

[W] hen a quarter of a million dollars go missing from our police force, when exhibits seized by police from suspects go missing from police stations, when stolen goods exhibited in a court of law disappear; when frauds and dubious political hangers-on can get into key positions in important public sector organizations, then it is time for the people of this country to sit up and think about the rot and it is time for this House to do something for this state of affairs.

But these allegations, serious as they were, paled into insignificance beside the so-called Stephens affair, which has already been mentioned. Sadly for Rabuka, the November 1993 budget provided his opponents an opportunity to take advantage of his miseries and topple him. The substance and direction of the budget was consistent with the government's broad philosophy of economic development, which included the deregulation of the economy and structural market and labour reforms to increase Fiji's international competitiveness, but the growing budget deficit of $\$ 105$ million or nearly five cent of the GDP posed problems for the economy, with the government itself calling it 'an unacceptable level of government 
spending.' For Reddy that was the heart of the problem. 'The government has been strong on rhetoric but weak on action,' he said. 'There is a yawning gap between what this government says and what it does, raising serious questions both about its competence and ability to manage the national economy.' He and others criticized the high level of expenditure and deficit, misguided expenditure priorities, and socially regressive aspects such as higher duties on basic consumer items. The overall picture of economic management was disturbing. Government expenditure had increased from $\$ 723$ million in 1992 to nearly $\$ 830$ million in the 1993 revised estimates and was projected to increase to $\$ 847$ million in 1994 ; the gross deficit had increased from $\$ 120$ million in 1992 to $\$ 184$ million in the revised estimate for 1993. Government expenditure as a percentage of GDP had increased from 35 per cent in 1992 to 38 per cent in 1993 and projected to increase to 37 per cent in 1994. And so it went, from bad to worse. ${ }^{103}$

Reddy's criticism was not surprising, coming from the Leader of the Opposition, even though he had to be careful not to push the government too far. But the criticism from the government's own backbenchers was unexpected. Kamikamica led the charge. He did not question the government's economic policy. He even encouraged the government to do more for Fijians and Rotumans in the educational and economic sectors. The thrust of his criticism was that the government lacked the fiscal discipline necessary to implement correct policies. At least Kamikamica was consistent. Ratu Finau Mara acknowledged that the Finance Minister had 'very little choice in this budget,' but he was instrumental in orchestrating the Fijian vote against it, though he himself was away in Australia at the time of the voting. Cabinet minister Ratu Viliame Dreunimisimisi was 'not convinced that the budget should be abandoned,' but six hours later he voted against it. Knowing that the twenty seven Indo-Fijian members of parliament would vote against the budget, Rabuka's opponents saw their chance to defeat the government. When the budget came up for the second reading on 29 November, it was unexpectedly put to the vote, to the surprise of many on the Opposition 
benches. To the government's consternation, six Fijian members and one General Voter (David Pickering) joined the Opposition parliamentarians to vote against the government. Miscalculation and misplaced trust had cost the government dearly. Rued Rabuka: 'I think my military officer mentality came into focus and led me to believe that once a directive is given, everybody would toe the line, which they did not. ${ }^{304}$ He trusted people, and thought with his heart. 'That is my nature. I feel for people and I feel for them whenever they are in need. ${ }^{305}$ That feeling was evidently not reciprocated by his own colleagues in the SVT.

The manner of the defeat was surprising. In normal parliamentary practice, the second reading is regarded as procedural. It is followed by the committee stage(in this case 30 November to 3 December), when the whole House would constitute itself as a committee and scrutinize the proposed legislation. At this time, members of parliament can propose changes and amendments or seek explanation of particular parts. The substantive vote on a bill then takes place. But in this case, the budget was defeated before it reached the committee stage. It seems certain that the Fijian dissidents had not planned in advance to bring about the downfall of the Rabuka government. Their plans materialized only as the debate proceeded and only when the position of the Indo-Fijian parliamentarians became clear. ${ }^{106}$ Rabuka told the Great Council of Chiefs on 15 December that there were 'other considerations that lay behind their determination to vote against their own government.' Indeed there were. As some Fijian dissidents told Manueli, the Finance Minister himself, 'they were going to challenge the budget not because they were opposed to it, but because they wanted to change the leadership.' ${ }^{107}$

Strangely, before even informing the SVT caucus of their decision, the dissident group had informed Ratu Mara, who had succeeded Ratu Penaia into Government House, of their intention so that 'he would have more time to prepare himself for the outcome of the voting. ${ }^{\text {'108 }}$ One commentator thought that going to Mara was 'highly improper constitutionally, politically and morally - particularly when they did not turn up at the caucus 
meeting which decided that they should all vote for the budget. They never made any representation to the Budget Review Committee. ${ }^{\prime 09}$ How the dissidents expected Mara to behave is unknown, but this is what the Fiji Labour Party wrote to him:

It is quite evident to us that the defeat of the 1994 budget had other quite compelling reasons than the unacceptability of the budget itself. Over a period of the last few months, the credibility of the Rabuka Government has been brought [in]to serious question. The government has been rocked by one scandal after another. However, Prime Minister Rabuka seems to have cared very little, if at all, about these matters and has carried on in the fashion of business as usual. These incidents have seriously eroded the confidence of the opposition members and a number of government members of parliament in Prime Minister Rabuka. We feel Prime Minister Rabuka no longer enjoys the confidence of a majority of members of parliament and should therefore be asked to tender his resignation, following which Your Excellency should appoint a new Prime Minister who has majority support. The new Prime Minister should then appoint his cabinet and carry on the task of governing Fiji. We, Sir, would urge you to explore the above suggestion should it be constitutionally possible for you to do so. ${ }^{110}$

Labour's motive was understandable: Rabuka had betrayed them, and they wanted him out. But whatever their intentions, the constitution gave the Prime Minister three options. Within three days of a crisis, he could advise the President to dissolve parliament and to call for fresh general elections. Second, he could tender his resignation and that of his government and allow the President to choose another (Fijian) member of the House as Prime Minister. Only if the Prime Minister failed to act within the stipulated three days could the President then pursue his own initiative. Rabuka acted promptly. At 7:30 on the night of the budget defeat, he advised Mara to prorogue the parliament from 19 January and to issue the writ for elections within thirty days. Reddy endorsed Rabuka's decision, which led Mara to 
say, probably with relief, 'Mr Reddy saved my day.' Labour used this comment to hitch Reddy to Rabuka, insinuating that Mara might have pursued other options had it not been for Reddy's contrary advice. When Labour persisted with this line of attack, Reddy wrote to Mara to correct what he called 'a gross misrepresentation' of his position. 'At no time did I say to you that I supported Mr Rabuka as the question did not arise.'111 All that Mara had done was to inform Reddy of FLP's letter. 'The NFP was not involved at all.' In truth, it was not Reddy but the constitution which saved the President's day, for any other decision on his part would not only have been unconstitutional, but would also have implicated him even deeper in the machinations of the anti-Rabuka faction in the government. Independent of Mara's decision, Reddy probably welcomed an early poll to capitalize on his party's strong showing in public opinion polls.

\section{ELECTIONS}

Trust and treachery became the two key issues in the campaign. Rabuka reminded the Fijians of the many pro-Fijian initiatives. He admitted that he still had a lot to learn, and he asked for forgiveness for his unintended errors of judgment and publicly advertised lapses in his personal life. His opponents had criticized his leadership, he said, 'but no leader could really be effective if from within the ranks of his or her team there were people who were not prepared to show their loyalty to the team leader and commitment to play their role as team members. Could such people be trusted to safeguard the future of the Fijian people? He may have erred, Rabuka admitted, but 'what I have never been, and what I will never do, is to be disloyal to the Fijian and Rotuman communities, and to give away what I had personally sacrificed myself to achieve in 1987' - and that is to secure and to safeguard the interests of the Fijian and Rotuman people. He expressed astonishment at the disloyalty of his colleagues who 'almost handed over power of effective control of the national Government of Fiji to other communities.' This was not the time to change course. Unity was of paramount importance. Loyalty was one virtue which Rabuka emphasized over and 


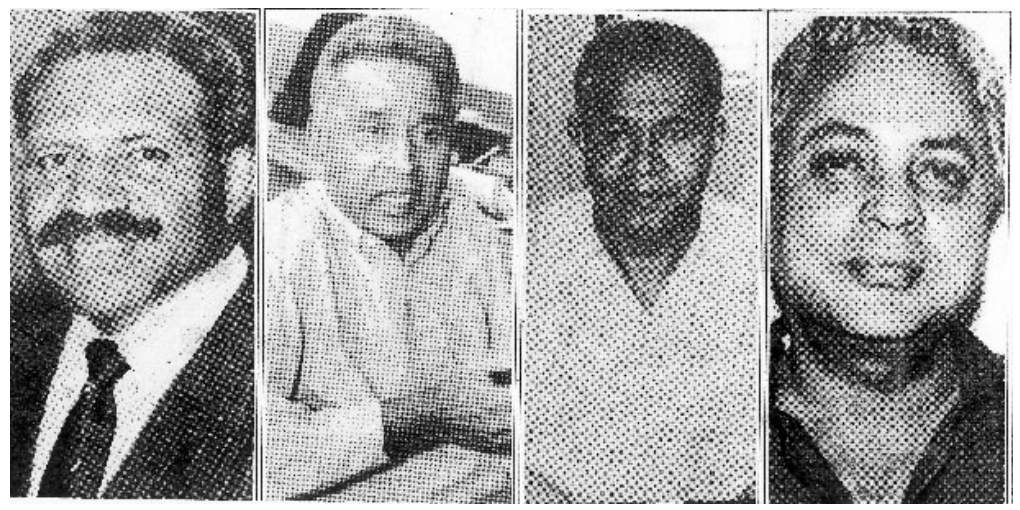

The principal players, from left: Sitiveni Rabuka, Reddy, Josefata Kamikamica, Mahendra Chaudhry. Courtesy of The Weekender.

over again. 'We must be unremitting in our loyalty to each other, to our chiefs, to this highest of all Fijian councils, the Bose Levu Vakaturaga'

Rabuka's chief rival for Fijian votes was Josefata Kamikamica, and on the campaign trail, he had one and only one issue that he raised with relentless persistence: that Rabuka was a leader unworthy of the Fijian people and of the country as a whole. Kamikamica said: 'The SVT leader, over the last 18 months, has followed a path full of broken promises, contradictory statements, reversal of policy, and dishonourable behaviour. Fijian and national unity cannot be achieved through cheap political point scoring just for the sake of rallying together, or for any other selfish vested interest.' ${ }^{112} \mathrm{He}$ pointed to Rabuka's involvement in the Stephens' scandal, his close identification with Fijian nationalist aspirations, and his administrative inexperience. 'Give another five years of this style of leadership and it will be very difficult for the country because the network of interests that feed upon each other in a situation like this will be very difficult to break. ${ }^{13}$ The Fijian Association Party, Kamikamica said, was not disrespectful to chiefs, pointing to a number of high chiefs among its ranks, including Ratu Apenisa Cakobau, son of the late Vunivalu and the first local Governor General, Ratu Sir George Cakobau, Ratu Wili Maivalili of Cakaudrove, and Ratu 
Aca Silatolu of Rewa. If elected, Kamikamica promised, he would try and restore Fiji's links with the British monarchy. Rabuka appealed to another tradition in Fijian society: cultural pride. 'The sooner we realize we are out, the better it will be for us rather than crying over spilt milk. We are a proud race. We won't go crawling back to the British and the Commonwealth.114 In this stance, he echoed the sentiments of many ordinary Fijians.

Among Indo-Fijians, the divisions were as deep, if not deeper, and the vitriol as pungent. With NFP and Labour, too, the key issue was the leadership of the community, the tussle made all the more intense given the closeness of the previous election results. Labour's last minute decision to contest the elections became an issue, dubbed by Reddy as a classic case of 'flip-flop' politics of inconsistency. ${ }^{115}$ Chaudhry, Reddy charged, had advised the voters not to register for the elections because of his party's boycott stance, but got himself registered. He had promised not to enter parliament, but then did. He said that the constitution could not be changed from the inside the parliament, but that precisely was what was happening now and Chaudhry was a part of the process. Chaudhry, Reddy continued, had said that no self-respecting Indo-Fijian leader could take oath under the 1990 Constitution, yet he took the oath under it when he entered parliament. Chaudhry had promised not to make any deals, but had made an agreement with Rabuka which was 'neither politically feasible nor legally enforceable ${ }^{\prime 16}$ Chaudhry had said that the Reddy would sell the rights and interests of the Indian community by participating in the flawed review process, but he himself was now a part of it. Chaudhry had promised to start a campaign of satyagraha, but had done a 'kerekere' with Rabuka. He had thereby done the 'Third Coup' against the Indian community by lending his support to Rabuka to become the prime minister. Value Added Tax got implemented, but Chaudhry remained in parliament

Reddy patiently explained the philosophical underpinnings of his approach and where things stood. He defended his decision to join the expanded Cabinet sub-committee. His primary goal was to seek a broad consensus on the constitution because imposed constitutions never worked. 
'Consensus can only emerge where there is effective and meaningful communication.' He had fought the 1992 elections to 'open up dialogue with the Fijian chiefs and their people, to help improve the overall political climate in this country so that we would all collectively look at our problems in a calm and dispassionate manner.' He did not set any preconditions about entering parliament. 'We went into parliament with open minds with the proviso that ultimately if our wishes for dialogue drew no positive response, then we will vacate our seats in parliament.' Reddy explained that he had supported Kamikamica over Rabuka because he, Kamikamica, had said on numerous occasions that there were legitimate grievances that the Indian community had about the 1990 Constitution. ${ }^{117}$ Progress was slow, Reddy conceded, but progress there was. There was, for instance, an emerging consensus in the country that a system of government which put one community in power to the total exclusion of another was not in the long term interests of the nation. The parliament had agreed to set up an independent commission to review the constitution, and that in itself was a major achievement. He had taken part in the setting up of the review process to 'put it to the test. It would be counterproductive to be obsessed with the result at this point in time.'

For Mahendra Chaudhry, Reddy's approach and his leadership of the Indo-Fijian community became the principal campaign theme as he sought, with varying degrees of success, to explain to a sceptical electorate his boycott strategies and its abandonment and his support for Rabuka. ${ }^{118}$ The 'Third Coup' claim was striking a cord with the electorate. But Reddy was his main target, not the least because his approval rating nationally was astounding: over eighty per cent. He ridiculed Reddy's approach to dialogue. 'The truth is that Jai Ram Reddy's policy of peaceful dialogue translates into a policy of selling out Indian interests bit by bit. He has done this systematically under the guise of dialogue ever since he began to play a leading role in NFP politics.'119 And he proceeded to catalogue a long list of Reddy's political sins, many of which should be familiar by now. Chaudhry accused Reddy of selling out Indian land interests over the ALTA in 1976 


\section{9 नेशनल फेडरेशन पार्टी तीसरा 'कू' किस ने किया? चौधरी से पूछो}

फीजी में तीन 'कू' हुए:

पहला और वूसरा 'के' रम्बूका ने किया

लीसरा 'क' चौ औरी और उनके लेबर पार्टी ने की, जब उन्होंने राम्बूका को पाँच साल के लिए प्रधान मन्त्री बनाया।

- वह रम्बून जो कौलिशन सरकार को पार्तिमेंट से बन्दूक के बल पर निकल फेंका -

- बह रम्बूका जो 1970 (१९७०) विधान को जबरदस्ती रह् कर दिया।

- वह रम्बल्ब जिसके कारण तमाम परिखार छित्तर-यितर हो गये। चौध्ररी ने रम्यूका को प्रधान मंत्री वनाकर हम हिन्दुस्तानियों पर पोर अन्याद्र किया।

क्या आप ऐसे नेता को चाहते हैं?

\section{सावधान !}

अपने भविष्य को ध्यान में रख्बते हुए तथा हिन्दुस्तानी कौम की भलाई के लिए ब्रपनी हिन्दुस्तानी पारीं 'एन. एक, पी.' को बोट दीजिए।

\section{NATIONAL FEDERATION PARTY}

Who did the Third Coup? Ask Chaudhry 
when he voted with the Alliance against the directives of his party leader. Reddy had sold out Indian interests in April 1977 when he informed the nation that there was no one Indian leader capable of becoming Prime Minister, effectively cheating Siddiq Koya of his right to the highest office. Reddy had 'abandoned' the Indian cause 'when he fled to safety in Auckland after the second coup.' Reddy had 'severed' Indian unity in 1991 when he 'abandoned' the coalition with Labour 'in order to serve the narrow interests of his big business supporters.' And he had sold out Indian interests in 1992 by agreeing to 'a very restricted Terms of Reference for a commission to review the 1990 Constitution.' For good measure, Chaudhry added: 'The list is hardly exhaustive.'

Claims and counter claims of treachery and betrayal, of cowardice and complicity, dominated the campaign. If he was indeed the wicked, unreliable leader that Chaudhry had portrayed him to be, Reddy asked, if all the allegations against him were true: that he had hobbled Koya's chance to become prime minister, that he had betrayed his people over the Agricultural Landlord and Tenant Act, then why did Chaudhry and other Labour leaders ask him in 1987 to form a coalition? How could they trust him with that responsibility? Why was he begged to join the Coalition government as its Attorney General? Why was he asked to accompany Dr Bavadra to London and to other capitals to plead the Coalition's case after the 1987 coup? ${ }^{120}$ But Chaudhry's allegations and charges were pure campaign talk designed to cause disaffection against Reddy in the Indo-Fijian community. The ALTA, over which Chaudhry had severely criticized Reddy would be one piece of legislation that the Labour leader would later do everything in his power to retain. And in 1995, he would make a joint submission on the review of the constitution with the same leader he had accused of selling out the interests of the Indian community (just as in 1999 Reddy would enter into an alliance with Rabuka against Chaudhry). Such are the realities of politics in Fiji.

The 1994 election was a clear triumph for the NFP, which won twenty of the twenty seven Indian seats, capturing 56 per cent of the 


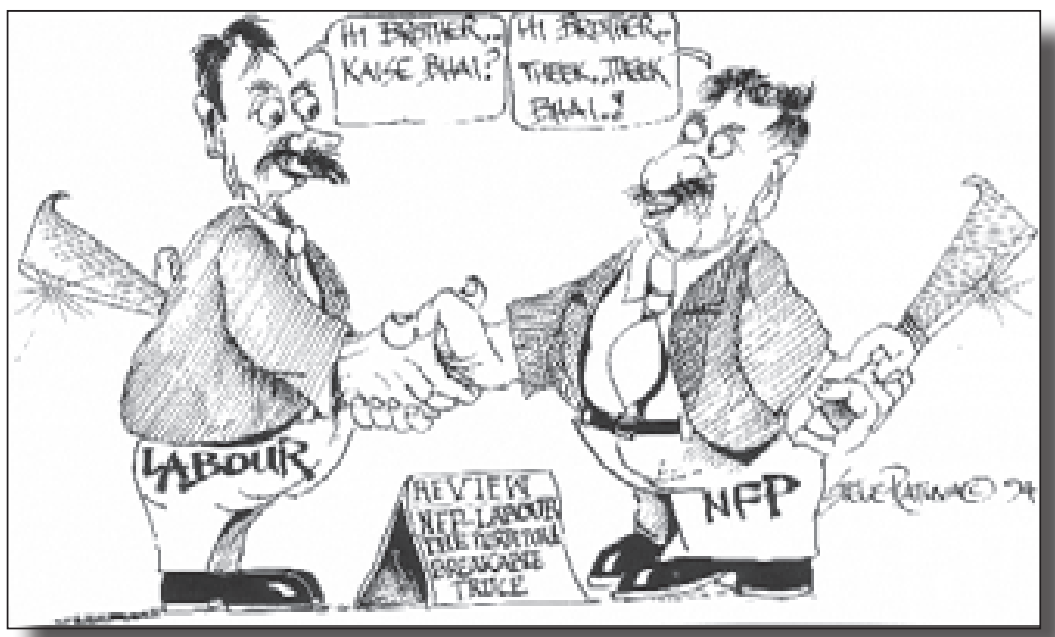

Keeping Your Knife Sharpened. Courtesy of The Review magazine

Indian communal votes, a slight increase over the 1992 percentage while Labour won seven seats and 44 per cent of the votes. The SVT had a similar emphatic victory. NFP made a clean sweep of all the Vanua Levu seats, which had gone to Labour in 1992, and the urban seats. It would be pleasant to conclude that Reddy's sensible, pragmatic approach helped his party. Reddy clearly was his party's trump card. Many responded to his quiet tenacity. But many local issues dear to the heart of one group or another played a role as well. Indo-Fijians had not renounced Chaudhry's style of confrontational politics; they had merely suspended it temporarily in favour of Reddy's consensus approach.

With the elections over, the parliament continued its interrupted work on the review of the constitution. On 24 June, 1994, Prime Minister Sitiveni Rabuka announced the appointment of a multi-ethnic Joint Parliamentary Select Committee to prepare for a review of the constitution comprising 55 per cent Fijian and General Voter members and 45 per cent representing the Indo-Fijian community. The purpose of the committee would be to recommend the size of the Constitution Review Commission, to facilitate its work 
Reddy at the ballot box.

Courtesy of The Review magazine

by providing it with all the necessary documents and information relevant to the task of the review, make recommendations concerning submissions made to the Commission, encourage the development of consensus among

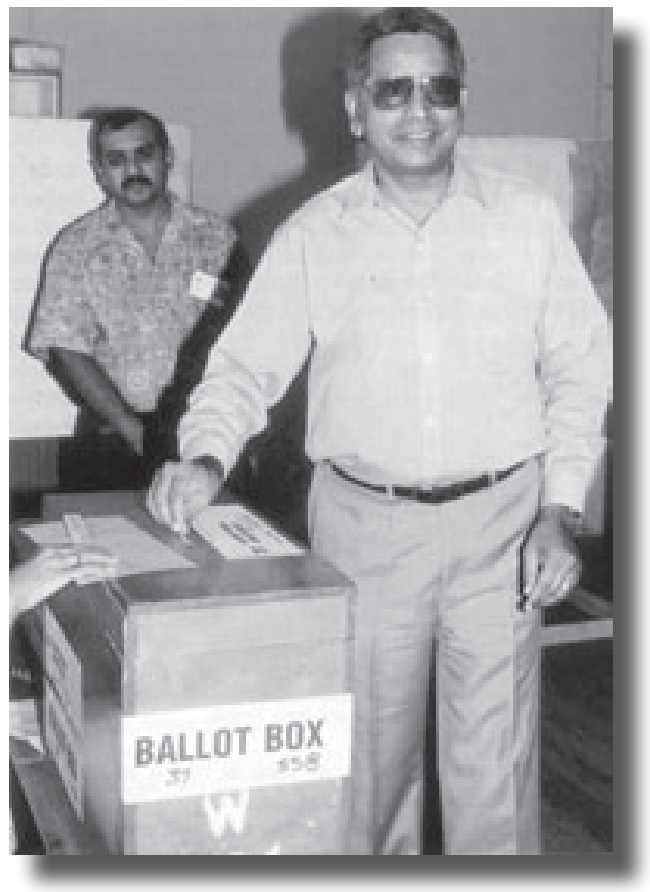
the political parties about a future constitution, and to facilitate the passage of the new constitution through the parliament.

Reddy welcomed Rabuka's initiative as 'an important step forward for this nation as a whole, as our quest for a constitution acceptable to all the communities whose home is Fiji, continues on course.' The journey has not been easy,' he said, 'and it will not be easy but patience, goodwill and good sense should see us through.' Fiji had a great future, Reddy continued, 'if only the leaders and the ordinary people of this country understand that that future can only be heard if we learn to cooperate with each other. Cooperation begins with the capacity to listen. Let us listen to what each one is saying. No difference is so intractable as to be insoluble given patience, goodwill, tolerance and a commitment to dialogue as opposed to confrontation.' To that task he would turn his attention for the next five years. 


\section{INTERLUDE}

\section{CONCLUDING ADDRESS TO THE YEAR OF THE INDIGENOUS PEOPLE, 1993}

I must say first of all how deeply moved I was by the invitation to be the chief guest at this occasion. This closing of the formal activities in Fiji to mark the international year of the world's indigenous people is a very real indicator that, at a time when many indigenous peoples are struggling simply to survive, Fijian culture is very much alive. Today's event is a spectacular and powerful celebration of things Fijian. It is therefore no small thing that the organizers of this grand event should see fit to invite the grandson of an Indian indentured labourer to be the chief guest. So I am personally honoured to have been invited, and I thank you not only for chance to say a few words tonight, but for the message that your invitation sends out to the people of Fiji, and to the world beyond our shores.

It is a simple fact that my presence here says more about the true nature of these islands than any mere words could express. History is unlikely to long recall the text of my speech tonight. But what the record will show is that, here in our country, the year of the indigenous people was closed by a non-indigenous citizen. And that is a remarkable reflection both of the tolerant and welcoming nature of taukei culture, and of the new Fiji we are building together.

It is yet another sign of the growing desire for national reconciliation and healing among all our peoples. Our difficulties are by no means over, and I think we are all acutely aware of the obstacles that lie in our path. Nevertheless, I believe we have made a start. We have begun dialogue and discussion among ourselves. We are talking to each other, rather than at each other. We must resolve in our hearts to keep our 
country united and peaceful for all our peoples, irrespective of their colour, creed, race or sex.

Ladies and Gentlemen, the past few centuries of human history have, sadly, been notable for the domination and exploitation of peoples in far too many nations. They have been centuries of conquest, of imperialism and colonialism. As humankind developed the ability to travel further and further afield, and fortune and power beckoned in newly accessible continents, peoples from many corners of the globe began to explore land which had previously been only vaguely imagined. Some came as conquerors, some as traders. Some came as migrants and others as missionaries. They came for gold and precious gems, for spices and cloth. Some fled persecution and others fled the law.

For those who were already inhabiting the lands to which these new arrivals came, their arrival often represented the beginning of the end for ways of life that had existed for many thousands of years. Whether by gunfire or alien diseases, by fire or by sword, indigenous populations often dwindled. The local culture and beliefs were eroded by religion and politics and strange new ideas. The survival of ancient traditions hung by a thread.

And now comes the year of the world's indigenous people - a milestone, I believe, in global awareness and recognition of the modern world's forgotten people: those whose cultures and languages and traditions have been denigrated or, worse, simply obliterated from the face of the earth; those who have been dispossessed of their lands and their livelihoods and now live on the fringes of their own countries; and those who have been otherwise marginalized by forces of change beyond their power to control. The world, sadly, is replete with the ruins of cultures which lie buried in the graveyards of history, victims of man's insatiable greed and lust for power. If this year helps to increase our sensitivity to the plight of these less fortunate of our brothers and sisters, then humankind will have made a giant step 
towards regaining its humanity. And all of us will be the richer for the experience.

Here in Fiji, different people may — and indeed probably already have - put different constructions on this year. Some will seize it to further the cause of their own racism, to attempt to demonstrate an aggressive cultural superiority, or to try to revive a paradise that never was - or that has now vanished beyond recall. They will use this event as a vehicle for their particular political interests and ideologies. For me, however, the year of the indigenous people raises a different set of issues, and evokes a different set of images. The event, for me, means not destructive divisiveness in our community, but the celebration of diversity, distinction and difference. It draws my thoughts to the mosaic of cultures which - like the colours of a Pacific rainbow - constitute this nation of ours.

More specifically, it invites me to reflect on the indigenous Fijian heritage of our country, which has so enriched us all. I think of the folklore, the songs and dances, the art and artefacts of our Fijian people. I think of their wonderful seafaring skills, the awe-inspiring ocean-going canoes which had few rivals in the entire Pacific. I think of the well-organised, self-contained and resilient society they built in harmony with their environment. I rejoice at their spirit of adventure, courage and bravery, and celebrate their artistic and technical achievements. I honour, too, their values of tolerance, compassion, caring and community.

Though this celebration is very much a Fijian occasion, I must tell you, Ladies and Gentlemen, that to me, all of these things I have spoken of are in truth as much a part of my own heritage, our own national heritage, as they are a part of the heritage of the indigenous Fijians.

But having said that, I fear we may have taken the accomplishments and achievements, the way of life and the traditions of the earliest Fijians, for granted. We have treated their legacy as mere curiosity pieces to be performed for tourists or, worse still, seen them as things to be stored in 
some dusty museum or on a library shelf. That attitude, where it exists, must be changed. The past is just too important to be left alone for the edification of scholars or the entertainment of tourists. I believe it in our vital national interest to pursue an active and generously-funded national heritage policy which will identify, renovate and preserve historic sites for present and future generations. I think it would be a wonderful and fitting monument to the year of the indigenous people if we could re-ignite in our nation some of the sense of wonder, adventure, courage and bravery that moved our Fijian forebears many centuries ago. It would be a tremendous and lasting achievement if this special year helps us to light the lamp of cultural renaissance and rebirth.

So I pledge my support tonight for a greater awareness of, and sensitivity to, our cultural heritage. But I do not advocate a blind faith in rigid and unchanging tradition. Culture, defined simply as the way of life of a people, is a constantly evolving thing, changing, adapting, rejecting, reforming — all in response to circumstances. In this sense it is a profoundly organic, living entity. In the modern world, it has to be so. The waves of change are breaking on our shores. We see this in the things we read, the images we see, the experiences of our daily lives. We are living in a global village of instant communication, and in a time in which astounding developments in technology, imagination and human ingenuity appear to know no bounds. We cannot separate ourselves from the larger world of which we are a part, and this poses a great problem for us. Culture, which makes us what we are, can sustain us. Yet, just as easily, if we are not careful, it can become a shell which smothers the life within. It would be a sad day indeed if we sacrifice, in the name of progress and modernization, all those values and traditions, diversity and differences, that give us identity, bring pleasure and meaning to our lives and enrich our existence. It would be equally sad day if we refuse to recognize the realities of the modern world and cling defiantly to a past that may no longer serve our present needs. How we reconcile these two 
positions will test the mettle of our leaders and people, and determine our very destiny.

Ladies and Gentlemen, I would again declare to you that what we are seeing today is proof that Fijian culture is in fact very much alive, vibrant and well. We have witnessed - and are shortly to see more - demonstrations of indigenous culture, both ancient and modern. I would suggest that the original settlers of these islands, all those centuries ago, would be proud of their descendants - just as those of us who arrived further down history's path are proud of the heritage that has been left for all of us, Fijian and non-Fijian alike. I would suggest also that it is our diversity of cultures, and the nature of their arrival on these islands, that has helped keep each one of them alive. My forebears came to Fiji as migrants, almost as slaves, not as conquerors. Others have come as settlers and traders, seeking — and finding — a place to call home. We have all learned much from the culture we celebrate this evening, and, hand-in-hand with Fiji's indigenous community, we are building a new society, which draws strength and hope from the great and good things in all our traditions.

Ladies and Gentlemen, I come back to the point I made at the beginning. We have gone through turbulent times, but the progress we have made through dialogue and discussion has taught us many lessons. If there is one truth we learned anew from this experience, it is this: in human affairs, there are no eternal hostilities, just eternal interests. And no interest is more paramount for ourselves, our country and our children than survival. But we must not simply stumble and grope from day to day. We must fix our vision firmly on that bright torch of genuine multiracialism, of deep and abiding respect for each other's cultures and traditions. We must again find pride in our nation as a beacon of hope to the rest of the world. That is our challenge and our opportunity.

I thank you again, from the bottom of my heart, for your invitation, and the opportunity to be a part of a very special day and a very special year. 
I look forward to the rest of the evening's programme and to a future in which we may have many such evenings, with all the promise and celebration they represent. I congratulate those who have worked so hard to make this event a success. I can assure you that you have the gratitude and support of a watching nation — a nation in which, thank God, our cultures and traditions, indigenous and non-indigenous, stand for tolerance, understanding and, above all, peace. Long may it remain so.

\section{GOVERNMENT OF NATIONAL UNITY AND THE POLITICS OF GRIEVANCE AN INTERVIEW WITH JAI RAM REDDY, 1993}

Q: Sitiveni Rabuka has his concept of Government of National Unity. Are there any similarities between your concept and what he has suggested?

A: This is the difficulty. The term Government of National Unity means different things to different people. The reaction to the concept is largely an emotional one. People like the idea of unity. It sounds, feels, good. But it is when you get into the details and mechanics that you find views are so divergent.

A GNU to me means two things: shared objectives and fair representation. We begin from a position where our views on some fundamental issues are very different. The Prime Minister has very fixed views on the constitution. I want a fair constitution that does justice to the Indian community. The Prime Minister also seems to have some very fixed views on ALTA [Agricultural Landlord and Tenant Act]. I would like to see Indian farmers given a fair go. They also need security so they can plan for the future.

Even before the GNU is put together, there will have to be some consensus on what we can or cannot do on these fundamental 
issues. You can't have two groups of people who have totally opposite views on these essential issues coming together to work because it is just not functional.

That is why I was at pains to tell the media, the people, and government representatives, what we need to do is not public posturing but start at base one and begin to talk around these problems to see if there is some shared objectives and perceptions.

The worst scenario from the Indian community's point of view is if a token number of Indians join a GNU without any shared policy objectives. As the Prime Minister himself said, I believe, to the Macuata Provincial Council: 'They will be an insignificant minority in cabinet; they may make demands on behalf of the Indian people but they will be outvoted and then they will be silenced. They can't complain.' Now, that sounds too much like absorb and destroy.

In the meantime, there is an Opposition which theoretically may be led by Butadroka [Nationalist leader Sakeasi]. So you have a Fijian Prime Minister and a Fijian Leader of the Opposition with equally firm program for Fijian welfare and you will have an Indian community which is sandwiched between these two and which has been effectively silenced. This is why I believe people should not get carried away with the concept. The success or failure will lie in the ability of the leadership to work themselves to a position where there are some shared perceptions.

Q: But now that Rabuka has stated his position clearly, do you still see the GNU becoming a reality?

A: If he has prescribed parameters within which this concept has to evolve, then I think the chances of this concept succeeding are very remote. That makes it very difficult. But if there is going 
to be an open mind and a real willingness to work out a position which is acceptable to everybody, then the concept is feasible.

Q: It has been said that a GNU stood a better chance under the 1970 Constitution.

A: It is probably fair comment because there was the ultimate fallback position for, say, the Indian party. If it didn't work, they could go back and still try and aspire for office by forming coalitions with Fijian parties, General Electors and so on. Under the present [1990] Constitution, if they go in and it doesn't work, I think the whole political situation will be muddied even more. But it is not impossible if the will is there to have GNU under this Constitution.

Q: This would depend on the Fijians compromising their current hard line stand?

A: I think so. I think there has to be flexibility. I don't think the Indian community is seeking to dominate anybody. All we are seeking is a fair chance. We're seeking fairness, equity and justice which are a recognized human right.

Q: The flexibility does not seem to be there.

A: I wouldn't say that. I think there is a certain amount of posturing. I wouldn't write off the concept. I wouldn't consider that the Prime Minister has taken some unalterable position. I think there will be flexibility and that will be my attitude to what he has said.

Q: The claim by the Alliance that their offer in 1980 to you had been rejected continues to come back to haunt you.

A: I am not sure that the Alliance is saying it. I think some of my political detractors in the Indian camp are saying it. I think the old Alliance people know the truth.

What happened in 1980 was very simple. But before I talk about 1980, let me talk about 1977. In the first general elections in April, there was a tie; the NFP won 26 seats and there were 26 against it 
(24 Alliance, two independents, Butadroka and Ratu Osea Gavidi). I made a public appeal that under the circumstances we should have a GNU or a Coalition. The Alliance rejected it on the basis that they could not coalesce with an Indian-dominated party.

Let no one forget that because three years later, all that happened was that I was given a paper by the then Prime Minister, Ratu Sir Kamisese Mara, which had been written not by him but by Dr Ahmed Ali, as a matter of interest. I said I would take a copy of the letter and return the original to him which is exactly what I did, with a covering letter thanking him. But the Prime Minister himself never raised the subject with me although it was raised by them at Alliance Council meetings and other public forums. So I did the same. I responded to their public statements at a public forum - the 1981 NFP national convention in Ba.

If people still care for the truth and if they pick up the paper and read it, they will see that far from rejecting the concept, I accepted it. I made the point then that I made at the beginning of the interview that a GNU will work only if there are shared perceptions, shared policies and shared objectives.

But the premise of the paper (by Dr Ali) was that there could be no compromises on policy, i.e., we were asked to embrace Alliance Party policies and call ourselves part of a national unity government. And nothing very much has changed. Isn't that what we are asked to do today? So what happens to the concerns and worries of the Indian people? Right now every Indian farmer is worried about ALTA, and his constitutional position. What happens to that? Do we just ignore that?

\section{Q: Were NFP \& Labour too quick to embrace the invitation from Rabuka?}

A: I don't agree. We embraced the need for dialogue - the idea that we should talk. That's all we have done and the talks are at a very exploratory stage. 
Q: Suppose you reach consensus on objectives, is the offer of just the two ministries acceptable?

A: No! I can't see how we can. It has to be based on some principle of fairness and equity. It has to be meaningful. I am not going to nominate numbers, but it has to be something which any independent outsider can look at and say, 'Well, that looks fair.' At the end of the day in a GNU, Indians should be fairly represented. We should have a figure which bears some resemblance to their numbers, contribution and work and not just a token number.

Q: One line of Fijian thinking seems to be that the Indians have their backs to the wall now. We're offering them two ministerial positions and a chance to be part of the government so they can take it or leave it. How do you see this view?

A: I don't think we will have anything to gain by taking it. We will be better off in Opposition. At least we will be able to articulate our fears and doubts and hopes. I think that will probably be a much better position to be in.

\section{Q: What will happen if you don't join the GNU?}

A: Nothing will happen. People must understand that there are these risks. If we can explain to the people why we have not gone in, assuming we have good reasons, but you can only go in if our interests are taken care of. We represent an interest and are not going to go into it just for the sake of it. The real danger is that if you go in, it will be very difficult to come out without creating more ripples; so it has to be looked at very carefully.

Q: If the GNU does not work, where does it leave the Constitutional review?

A: That is the unfortunate thing. We have now successfully shifted the focus from the Constitution to something else. In a sense, it is red herring. But the Prime Minister made a very definite commitment 
to the nation. Sure, he made it to the Labour Party as such but he became the Prime Minister by making those commitments; therefore, they are national commitments. His commitments were to review the Constitution to make it fairer to the Indians, to abolish VAT and to review the labour laws. He hasn't delivered on any of this, and the Labour Party seems to have forgotten conveniently these promises that they in turn made to their supporters as the excuse for going into parliament, having fought the elections on a platform that they would not go. Now there is the national unity bogey and all this I think has been unfortunate in terms of getting the Constitution right. Even the five-year framework does not worry me provided we can make a start on the Constitution. It's like him not having delivered on a half-a-dozen things but making half-a-dozen new promises.

\section{Q: What are the key things you would like to see looked at in a review?}

A: Representation is really the key area because on that depends the structure of government and the share of political power. The virtue of the 1970 Constitution, disregarding its many shortcomings, was that at the end of the day whichever community got into political power, could do so only if they secured enough support from the other communities. A government had to be responsive to the needs of all communities. Any future constitution which does not aim for that objective will fail. The notion that one community or the other alone should be able to be in government without the need for support from the other communities is quite abhorrent and will create serious division in society. Measures like positive discrimination should be looked at; we can achieve the same objectives but these can be so stated that it will be possible to include within the scope of those provisions the weaker people of all communities. In that area, some very positive statements have been made by the government, including the Prime Minister. 
Q: How do you see the ALTA review proceeding and what would you like to see put in place?

A: We have all accepted historically that there is no question of ownership. The land belongs to the mataqali and we, the tenant community, want to use it because without it we can't survive here. All our other constitutional rights become quite meaningless if we have no place to live in. So it is not just an issue between landlords and tenants, it is a national problem. How do you house an entire community that doesn't own land and finds itself in the position of [perpetual] tenancy? That has to be tackled as a national issue.

The landowners are perfectly entitled to expect reasonable returns because that's their asset. Indians expect a reasonable return on the investment they make. It is a matter of assessing what reasonable returns are and which must then be paid to them. We might even have a look at some form of state intervention in that sector. So many things get subsidized, why not rents, particularly given our very peculiar situation where the majority of one community is landless and tenants.

Q: So what do you see happening?

A: We'll wait and see. Government says it will do something. We have had very positive statements from the two DPMs and [from] some of the chiefs in areas where a large number of Indian tenants live. What can one do but hope that there will be dialogue and discussion between all the interested parties and we will find a solution which will be in the interest of the whole nation.

\section{Q: What about the worst case [scenario] and compensation?}

A: Compensation is no answer. If you systematically refuse to renew these leases, aren't you really saying to these people: get out of this place? It evokes images of 400 Palestinians banished to the NoMan's Land in Southern Lebanon. 
Q: Apart from the constitutional review and ALTA, what else does the NFP want for the Indians?

A: Fair employment opportunities which I don't believe they have in the public sector. We want the problems of the very poor Indians addressed: the destitutes, squatters, the unemployed; they are the worst victims and there should be a better understanding of the suffering of these people so that they are also included in the more disadvantaged groups. Beyond that we are not against helping Fijians wherever they are: education, business.

Q: What about the economic policies the government is looking at putting in place to help Fijians, including adopting some aspects of the Malaysian system?

A: Indians shouldn't just react blindly. A lot of those policies will also help the Indian people and help Fiji as a whole. I would have a very open mind about these measures. It will be a long term thing. There will be failures but there will be successes and in time there will be enough Fijians who will be able to stand on their own feet. There are already signs that many do reasonably well. It's not going to happen overnight. I don't think Indians should begrudge that.

There is a gap in the visible retail sector which will have to be addressed, although the notion that Indians control the economy is a totally false one. The basic inputs are not in the hands of the Indians — land, sea resources, forests, banking/insurance sector. Where we excel is where labour and persistence are the key factors. That mostly shows up in ins small shops because that really has become the one source of survival for us. So the picture that is often painted outside and here of serious distortion is a self-serving political ploy. That becomes the justification for discrimination against the Indians.

We have to look at the whole thing. It's a fight for equity and fairness. We don't begrudge you anything. We have never been given 
anything for nothing. Why treat us unfairly only because we are immigrant community?

Q: How can the Indians help to make the situation here different?

A: They must determine what they want. If they can put their heads together and decide that, they have to act in unison. Can you imagine any situation more depraved than the one we are in now? We have been denied everything: all our rights were taken away. What was 1987 but a virtual conquest! Our political rights were taken away, the government we helped elect was taken away, and many senior civil servants were removed at gunpoint. And what are we doing now?

We are busy undoing each other. It is an embarrassing situation to be in. I have to admit with some shame to people that this is the situation. The great battle Labour Party is waging for supremacy in the Indian community: what will it give the Indians? Will it give them back their constitutional rights, equity and fairness and respect?

\section{VISION 20/20: ADDRESS TO THE GENERAL VOTERS PARTY, 1994}

Prime Minister, the President and members of the Executive of the General Voters Party, Ladies and Gentlemen. I want to thank you for inviting me to address this gathering. Given that this function has been organized by a partner in the governing coalition, some might find it odd that the Leader of the Opposition should be the chief guest here. So I'd better state for the record that there is no truth to the rumours that I'm planning on crossing the floor — even after this most enjoyable lunch and those kind words of welcome from Matt Wilson!

I do want to make the point, however, that forums such as this are a very important part of nurturing a new political climate in Fiji - a 
climate which makes it possible for us to address our country's problems and challenges in a constructive and mutually supportive way.

Some of the events and pronouncements of the last few months tell us that history is beckoning — that this country stands at a historic crossroads. They tell me that now is the time for fresh and creative thinking, for innovation, for new ways of practising politics. The message I receive says we must break down the old barriers that separate this nation; we must do away with that failed style of politics which is based on destructive and confrontational urges, which seems to thrive on dispute, constant verbal warfare and on impatient and petulant insistence that only one kind of agenda is right for the country.

I am here because these gatherings were conceived in a spirit of goodwill and co $\neg$ operation by the representatives of the minority communities who play such an important role in Fiji. I am told the G.V.P. is very much interested in contributing to the creation of a political environment which will permit us to move closer to the attainment of national unity - and, by extension, to a resolution of some of our political and constitutional problems. So the N.F.P. has a common interest with the G.V.P in this respect, just as we have shared concerns with the S.V.T.

When I began to think about the topic of Fiji in 20/20, I focused very much on our current efforts to fashion a new system of politics as a foundation for the future.

As I look around me today, it strikes me that in many ways the people in this room are a reflection of the sort of Fiji we are trying to build. We have represented here people of many races, many religions, many cultures, and many political, economic and social points of view. Some of us (as I am sure the Prime Minister can confirm!) differ quite strongly on many issues. But we are able to gather in most cordial circumstances, to eat and drink together, to talk of matters of interest both great and small, and, finally, to sit back and listen to a guest speaker whose views 
we may not share. It is my belief that this is a microcosm of the kind of nation the current climate of unity and healing is aimed at creating. We may not always agree, but we can nevertheless respect each others' opinions and beliefs, and find compromises and common ground to allow us to resolve our major differences.

It would be idle to suggest that we do not have serious divisions in our country. Nor would anyone here be fooled if I was to say that these gaps between us will be magically bridged by the passage of time, or by wishful thinking. The task of building the new Fiji is without doubt a difficult one, and no one yet has all the answers.

Which, of course, brings me back to my subject. How we approach that task of seeking unity now — and how successful we are - will determine the reality of Fiji in the year 20/20. To stand before you in 1993 and offer you a vision of this land more than a quarter of a century from now is at best a challenge, and at worst simply foolhardy. But I will try. I will, at least for the next few minutes, try to be a visionary, a soothsayer, and a crystal ball gazer. In setting out on this little journey, I am reminded of the words of the British Prime Minister David Lloyd George, who once said that a politician is a person with whose politics you don't agree - if you agree with him, he is a statesman. So whether my vision matches yours will have some bearing on where you place me on that particular score-card! But I'll take the risk.

First of all, let's put 20/20 into perspective. Though it once seemed like the preserve of science-fiction writers, the 21st century is, quite literally, just around the corner. In 20/20, this nation will celebrate the 50th anniversary of its independence. Children born after 1970 will already have grandchildren — giving us three post-independence generations. Like many of you here today, I would hope to be sitting in my rocking chair, enjoying my twilight years and muttering perhaps about the shortcomings of the next generation of leaders - most of whom will have no 
memory of Fiji before independence. Of course, it is quite possible that some of us will be looking on from an altogether different dimension by then, but let's be optimistic!

When you consider the changes we have witnessed in the last quarter of this century, I doubt if we could even begin to predict the scientific and technological advancements that will come in the next twenty-five years. No doubt 1993 will seem as ancient and primitive then as 1893 does to us today. I could have a good deal of fun this afternoon speculating on the wonders of supersonic travel, robot labour and instant gratification. I could predict wonder computers and artificial intelligence, universal use of solar power, vacation flights to the moon and molecular transport. I could offer you a vision of a wonderful world, and of a Fiji transformed by technology into a futuristic paradise.

But all these things by themselves would in my view make for a hollow vision, a mere shell. For it is my assertion that, amazing as the future will be, it is not the scientists who will determine its shape. It is not what we become that is important, but who we become, collectively as the people of Fiji. It is, in a very real sense, not the body of the nation that counts, but its soul. And it is with this that I am concerned today.

Ladies and Gentlemen, I suggest to you that the vision of the soul of Fiji in 20/20 is a hazy image, not quite yet in focus - just like that so-called ghost in parliament. Compare this with our vision at independence in 1970 of Fiji in 1993. We had, or at least thought we had, a clear idea of who we were and where we were going. We were, after all, "the way the world should be." We were a symbol of hope for the world, a model for the Third World. We were going to go forward in peace and harmony, and everything would be bright and beautiful. So our vision then was very clear, but we became so entranced with it that we forgot some of the facts of life in a young, multi-racial nation. And reality, as we all now know, has a way of providing harsh reminders to those who ignore it. 
So we toddled through our infancy, happily burbling and laughing, quite confident that the future would be everything we imagined. As we neared our teenage years, we had a few stumbles, economic, social and political. But surely these were just bumps on the road of life, problems to be overcome and then forgotten. Then, of course, came adolescence and, like many a teenager before us, we lost our way. Uncertain of our identity, and with changes sweeping around us at dizzying speed, we crashed heavily into the stone wall of the adult world. Dazed and uncertain, we faced a future that, if we could see it at all, was an ugly and frightening thing. That, just six years after hitting that wall, we can have a vision of 20/20 at all is remarkable. That we can picture a united and prosperous nation is a tribute to the people of this country, and to their fundamental fairness, tolerance and desire for peace. The reality, Ladies and Gentlemen, is that despite the glowing picture I have just painted, Fiji in the first years of our nationhood was a tinder box. There was more than enough flammable material to build a fire that would engulf us all. And, during our darkest days, there were those of many political persuasions who had reason to pour petrol on the tinder box — and to throw lighted matches at it.

But it would not burn. Certainly there were sparks, and a few isolated flare-ups, but the larger fire — which could have become Fiji's funeral pyre - simply refused to stay alight. And, now that the matches have been put away, we have the opportunity to lock up the tinder box once and for all. We can never keep extremists of all persuasions from playing with fire, but we can certainly ensure that their efforts are dampened and extinguished.

Ladies and Gentlemen, the process of building the vision of 20/20, of resolving our national identity crisis and laying the foundation for a country that is truly home to us all has begun. As you know, I have spent a long time in public life, and I can tell you I have never known a period where so many people were so committed to the whole concept of 
national unity and identity. We are no longer simply paying lip service to unity - we have started on a very real journey towards the future.

I ask you to consider for a moment the cabinet sub-committee on the constitution. Few would have believed that such a body would have been formed this soon. Many still believe it is simply a front, a sham. Those of us taking part in its deliberations have been accused of being puppets who are simply perpetrating an unjust system. The people who espouse that position are exercising a fundamental right. In my opinion, however, they are wrong.

In this committee we have yet another indicator of the willingness of our major communities to sit down and begin the task of finding common ground. That is precisely what we are doing. It is significant that these are the first real face-to-face talks, on the great issues, that the leaders of our major communities have had since the ill-fated Deuba Accord of 1987. The committee is providing a forum in which leaders can put their case forward, emotions and all. Because they are being held privately, we can get straight to the heart of the matter, without fear of premature backlash or opposition that could kill any possible agreement before it is born. I am much encouraged by the progress we are making.

I have become convinced that there is nothing to be achieved by endless public wrangling and name-calling. Our history shows us that when we have achieved great agreements in this country it has been through initial private dialogue between leaders of our major communities, producing substantial agreements which can then be put to the people. The 1970 Constitutional conference is a classic example, as was A.L.T.O. in 1966 and A.L.T.A. in 1976.

And now, in 1993, with our errors - and we have all made them - behind us, my message is that the time for anger is past. The time for bitterness is past. The time for recrimination and blame is past. At hand is the time for men and women of goodwill to frankly confront the future. 
It is one of the great ironies of communal politics that although our supporters — and I refer to supporters of both sides of our racial and political divide — want their politicians to resolve the problems that face us, if they see leaders of our different communities drawing closer together and seeking to find solutions in a friendly and mutually trusting manner, they become very uncomfortable.

Racial politics bears down on us like a dead weight. In such a situation each community, preoccupied with itself and in competition with other groups, must, inevitably, be drawn beneath the surface and perish.

Ladies and Gentlemen, I am not interested in the tired old rhetoric of racial politics. I am weary of pointless bickering, ugly innuendo and the raking over of old coals. There are issues and challenges before us which are more important than who wins the next election, or whose skill as a debater or public speaker is the most persuasive. None of us — Indian, Fijian or General Voter — does his or her own community any service by perpetuating the recriminations and narrow racial perceptions of the past.

I said in parliament recently that there must come a time in the life of this nation when the many aspirations we talk about merge and become one: a mighty collective force that will help propel this country into the 21 st century, as a great country, a shining example to the world.

It is my belief that the moment has arrived. It is my great hope and prayer that from this moment will come not just the vision, but the actuality of 20/20. For, as I have noted, Fiji in that year will be, in large measure, the product of our success or failure in 1993. And we must construct our future on the unique strengths that history and chance have given us.

I have said before that the different communities which live in this island nation of ours each have unique talents and skills. Some have the knack for individual enterprise, while others excel in situations which require 
group endeavour. Some find satisfaction in the joys of communal life, while others are at home in a more individualistic setting. Some seek succour by invoking the past, while others seek fulfilment by looking towards the future. This diversity is not a disadvantage. Far from it. It is a great asset, a great foundation upon which we can build a truly unique and lasting structure. We need each other; as I have said before, there is no need to tear us apart.

To build such a structure, we need a political framework that fosters the development of common values that encourage fulfilment in a common culture rather than in separate existence. We need a system of government that is based on the consent of the governed, on principles of equality, justice and fair play, that recognizes, accepts and reflects the integrity, diversity and richness of the multi-ethnic, multi-religious and multi $\neg$ racial character of our nation. Any other system, that negates the values of tolerance and mutual respect that all our traditions hold dear, is, as history has regularly reminded humankind, doomed to failure.

The road to 20/20 will not be easy. But then, nothing of value in life ever is. I believe that with dialogue and discussion, goodwill and a willingness to sacrifice self-interest in the national interest, we can succeed. We have to succeed, Ladies and Gentlemen. We have no other alternative. And what of the leadership required to make success possible? Earlier this year, I quoted the words of the Sudanese scholar, Dr Murtada. Noting that the world is at a critical stage of transition, he goes on to say, and I quote:

It needs leadership which does not expect to arrive at any final solution. It needs leadership for a new struggle to develop standards of conduct for a better person, a better life, a better country and a better world. The struggle never ends. In George Hanser's words, 'Perhaps the moment of great freedom is found as we engage in the struggle to achieve it. The process of 
transformation to a just community needs a leadership which admires virtue more than strength. The world needs a generation of concerned leaders with new ideas and experience. This period of flux will change many things, and not necessarily in a way that supports the survival of leaders.

Ladies and Gentlemen, the leaders of 20/20 are already among us. They look for their cue from those of us who are nearer to the end of our careers than the beginning. To them, and to you, I offer a vision of 20/20 which sees this beloved country of ours united in its diversity, forged out of adversity and built on trust. I offer you a vision of Fiji of which historians will say that, in the midst of our tragedy, we found courage and wisdom, and foresight and determination, to lead the nation away from the precipice into a prosperous future.

I am no Martin Luther King, Ladies and Gentlemen. But, today, I, too, have a dream. I, too, have a dream that one day this great country of ours will rise up and live out its true meaning. And, yes, I have a dream that one day your grandchildren and mine will live together as one people in a country of many cultures, religions and ways of life.

This is my dream and my vision of Fiji in 20/20. And to those who doubt it can become reality, I would say: the only things that stand between us and that future of promise and hope are our own fears and insecurities. In the words of Franklin Roosevelt, the only thing we have to fear is fear itself. If we can put fear aside, and stand together, refusing to be swayed or moved from our path towards true unity, the peace and security we all yearn for can be achieved.

We live in an era of momentous change. The world over, old hatreds and divisions are being healed, and events which once seemed impossible are happening with incredible regularity. Consider these words from the current issue of Time magazine: 
The past few years have been an age of miracles. Unimaginable events, consummations devoutly wished for but never really expected, have succeeded one another as if the creator had whistled up a new world. The Berlin wall tumbles. The Soviet empire melts away. Nelson Mandela, free at last, begins to bring democracy to black South Africans. Now comes what must be considered one of the greatest miracles of all: the first acknowledgment by Israelis and Palestinians that they can share the land they both call home..

If all these great and seemingly intractable differences and divisions can be resolved and bridged, in the face of a history of terror, bloodshed, persecution and hatred, why should we, too, not find our peace and our prosperity? In a land where - despite our problems - tolerance and common sense have always found a way to prevail, do we not have a great advantage? If Yitzhak Rabin and Yasser Arafat can come together to shake hands at the white house, how much easier must it be for Jai Ram Reddy and Sitiveni Rabuka to find common cause?

So, like others before us, let us seize the day. Let us, like Brutus in Shakespeare's Julius Caesar, acknowledge that there is, in his words,

A tide in the affairs of men

Which, taken at the flood, leads on to fortune;

Omitted, all the voyage of their life is bound in shallows and miseries.

Ladies and Gentlemen, I can only hope that I may be allowed to see 20/20. I can only hope that my vision of this most wonderful of nations will fulfil its promise. I can only pray that we who have the moment at hand will find the courage, the strength and the determination to let the past be the past, and build a nation that will stand not just to 2020, but down through the centuries. 


\section{EULOGY FOR \\ RATU SIR PENAIA GANILAU, 1994}

I am burdened today. I carry a burden of sorrow shared by all of Fiji's Indian community. We have witnessed the quiet outpourings of grief from our Fijian brothers and sisters as they mourn the loss of a venerated high chief and national leader. We have seen the other communities expressing the depth of their sorrow.

The Indians of Fiji weep as well. We weep for the loss of a great and benevolent man who gave so much of himself to the country he loved. Even as death beckoned, his thoughts were of his homeland and the destiny for us all. Fiji, his dear Fiji, was with him to the last.

We loved and respected Ratu Sir Penaia Ganilau for his goodness, his gentleness and decency. We admired his abilities as a statesman and political leader. We revered him as the embodiment of chiefly authority and wisdom. We knew we could trust him — and that he was absolutely sincere when he told us he felt we, too, were part of Fiji. There was no suggestion from him that we were foreigners, who should not be here. Although Ratu Penaia was a Fijian chief he became truly a leader for all the people. His love and concern encircled everyone in these islands and helped to draw us onwards, however hesitantly and slowly, towards that complete state of nationhood he knew we must have.

In my own public life I had numerous dealings with Ratu Sir Penaia. Sometimes we had to speak from opposite sides of an issue. I would argue with all my powers of persuasion. He would listen, calmly and intently. Then he would ask a question or two and make a polite observation which told you how his mind was working. You knew then that the political divide between you remained, but, from his side, there was no hint of ill-feeling or rancour. Politics, for Ratu Penaia, was never personal. It was never a reason for enmity. He could disagree with you 
and still regard you as his friend. For me, his friendship was something I treasured. He was there, supporting me, in some of my darkest hours.

The Indian people remember with gratitude Ratu Penaia's courage and stoical adherence to what he saw as his duty when Fiji was in turmoil in 1987. For a long time it seemed he was the only bulwark propping up the sagging structure of the state. It appeared he was the only source of authority protecting us from evil, and dispensing reason, kindliness and compassion.

The memories of this period are painful and I do not wish to dwell on them. But I will declare to the nation today that for me, and the entire Indian community, it was then, that we began to fully appreciate the breadth of Ratu Sir Penaia's greatness and his humanity. He was in a most difficult position himself, torn between his traditional responsibilities and loyalties and the obligations of his office. The pressures he had to bear were enormous and the problems facing him were daunting. But he applied himself to them with courage and vision. He gave us leadership which provided grounds for hope; he showed us there was a way for this nation to become reconciled and whole. He helped the Fijians and the Indians to look at each other again and see that unity was possible if we thought of ourselves as citizens of one country with common loyalties.

In the Hindu tradition, we are judged by our karma — or the way in which we discharge our duties in life.

We have first of all a duty to ourselves, to be educated, to acquire skills, to develop our abilities to the fullest, to practice self-discipline and to learn the true meaning of wisdom. Then we must do our duty to those who are near and dear, our parents and family. And finally we have a duty to serve our people and our country 
Ratu Sir Penaia Ganilau performed all these responsibilities in an exemplary way, he served his God by service to his fellow human beings.

All the tears that fall today for Ratu Sir Penaia tell us about his life and what he meant to this country. And so we pay homage to him and we praise him, we elevate him to the pantheon of national leaders and heroes who served and sacrificed for Fiji and left their indelible imprint on our history.

It is my heartfelt desire that all of us now abide by the wishes of this illustrious figure and go forward, together, as a people united. I am sure he would smile from his new home in heaven if, one day, someone like me, the descendant of an immigrant indentured labourer, came to an occasion such as this, not as the leader of the Indians but as a representative of us all.

My own heart is full and the burden of sorrow remains heavy as I come to the final wrenching moments of farewell.

Goodbye, Sir, and thank you, thank you for everything. I turn to Rabindranath Tagore for the words I cannot find:

Peace, my heart, let the time for the parting be sweet.

Let it not be a death but completeness.

Let love melt into memory and pain into songs.

Let the flight through the sky end in the folding of the wings over the nest.

Let the last touch of your hands be gentle like the flower of the night.

Stand still, O beautiful end, for a moment, and say your last words in silence.

I bow to you and hold up my lamp to light you on your way. 


\section{NOTES}

1. Quote from the transcript of Ratu Sir Penaia Ganilau's address over radio.

2. Weekender, 30 Oct. 1993.

3. For an overview, see Andrew Eleck and Hall Hill, Fiji: Economic Reforms and Performance since 1987 (Canberra: ANU Trade and Development Seminar, 1991; also Mark Sturton and Andrew McGregor, Fiji: Economic Adjustment, 1987-1991 (Honolulu: Pacific Islands Development Program, 1991).

4. Although there was talk of a broader base to include timber processing for furniture and fittings, light manufacture of technical equipment and assembly plants, production of leather goods, none of which materialized to any significant degree.

5. For an overview see Claire Slatter, 'The Trade union movement Since the Coup [1987] in Satendra Prasad (ed.), Coup and Crisis: Fiji a year later (Melbourne: Arena Publications, 1989), 22-26.

6. Nand had been an NFP parliamentarian but contested the 1987 elections against the NFP-FLP Coalition.

7. All quotes come from the report of the Fiji Constitution Inquiry and Advisory Committee.

8. FCIAC: 9

9. FCIAC: $10-11$

10. Hafiz Khan would later become the President of the Fiji Muslim League.

11. This was published later by the Coalition's Sunrise Press as a pamphlet titled Fraud on the Nation.

12. Daily Post, 8 June 1992.

13. Hansard, 24 July 1992, 726.

14. Fiji Times, 18 Aug 1991.

15. Fiji Times, 21 Aug 1991, see also Islands Business, Jan. 1991, 25-26.

16. Fiji Times, 16 Aug. 1991. 
17. Daily Post, 19 May 1992.

18. Fiji Times, 7 May 1992.

19. Fiji Times, 3 Feb. 1992.

20. Daily Post, 11 May 1992.

21. Fiji Times, 28 Aug 1991.

22. Daily Post, 21 May 1992.

23. Daily Post, 25 May 1992.

24. Daily Post, 27 Apr. 1992.

25. Islands Business, Mar 1992.

26. Daily Post, 11 May 1992.

27. Daily Post, 11 May 1992.

28. Daily Post, 12 May 1992.

29. Daily Post, 14 May 1992.

30. Islands Business, Jan 1991, 25.

31. Fiji Times, 12 May 1992.

32. Daily Post, 21 May 1992.

33. Daily Post, 22 May 1992.

34. Daily Post, 7 Jan. 1992.

35. Daily Post, 4 Feb. 1992.

36. Daily Post, 5 Feb. 1992.

37. Fiji Times, 20 Jan. 1992.

38. Fiji Times, 5 Feb. 1992.

39. Fiji Times, 7 Feb. 1992.

40. Daily Post, 20 Jan. 1992.

41. Daily Post, 6 Mar. 1992.

42. Fiji Times, 5 Feb. 1992.

43. Daily Post, 14 May 1992.

44. Fiji Times, 2 May 1992. 
45. Daily Post, 6 May 1992.

46. Daily Post, 11 May 1992.

47. From NFP media release. In my possession.

48. Daily Post, 9 May 1992.

49. FLP statement, 11 May, 1992.

50. Daily Post, 12 May 1992.

51. Daily Post, 13 May 1992.

52. Fiji Times, 10 Oct. 1991.

53. Fiji Times, 4 Nov. 1991.

54. Quoted in Age, 7 Aug. 1991

55. Islands Business, July 1991.

56. Pacific Islands Monthly, Aug. 1991.

57. Fiji Times, 1 Nov. 1991.

58. Quoted in Matangi Tonga, Nov. 1991.

59. Washington Pacific Report, Mar. 1992, 5.

60. Daily Post, 11 Dec. 1991.

61. The Weekender, 23 July 1993.

62. Fiji Times, 21 Mar 1991.

63. Fiji Times, 1 June 1992.

64. Daily Post, 2 June 1992.

65. Daily Post, 9 June, 1992.

66. Fiji Times, 8 June 1992.

67. Fiji Times, 8 June 1992.

68. Copies of the correspondence were published in the local media.

69. Daily Post, 2 June 1992.

70. Fiji Times, 8 June 1992.

71. Daily Post, 3 June 1992.

72. Daily Post, 4 June 1992. 
73. Fiji Times, 4 June 1992.

74. Fiji Times, 17 June 1992.

75. Daily Post, 8 June 1992.

76. Hansard, 5 Mar 1998.

77. Hansard, 5 March 1998.

78. Daily Post, 24 June 1992.

79. Hansard, 5 March 1998.

80. Daily Post, 24 June 1992.

81. Daily Post, 20 June 1992.

82. Daily Post, 21 Aug. 1992

83. Daily Post, 8 June 1992.

84. Daily Post, 22 June 1992.

85. Pacific Report, 28 June 1993.

86. The Weekender, 21 May 1993

87. Pacific Islands Month, Aug. 1990.

88. Fiji Times, 22 Dec. 1992.

89. Fiji Times, 19 Feb. 1993.

90. Fiji Times, 5 Apr. 1993.

91. The Review, Mar. 1993.

92. Daily Post, 4 Mar. 1993.

93. Fiji Times, 18 Mar. 1993.

94. Weekender, 30 Oct. 1993.

95. Hansard, 22 Sept. 1993.

96. Fiji Times, 23 Sept. 1993.

97. What follows draws on the Hansard of the Sept. session.

98. Rabuka said the FLP's 'decision to withdraw its support for government was meaningless.' See Review Magazine, Sept. 1993, 122.

99. Among those whom Professor Yash Ghai consulted included Soli Sorabji, a 
former Solicitor General of India, and other legal luminaries. 100. Weekender, 25 June 1993.

101. See Richard Naidu, 'Three Years of Turmoil,' Review Magazine, Aug. 1995, 17. 102. Fiji Times, 21 Aug. 1993.

103. Jai Ram Reddy, Reply to the Budget, a copy in my possession.

104. Fiji Times, 3 Dec. 1993.

105. Fiji Times, 16 Oct. 1993.

106. The Review Magazine, Dec. 1993.

107. From a copy of his address to the Great Council of Chiefs, in my possession.

108. Fiji Times, 8 Dec. 1993.

109. Daily Post, 11 Dec. 1993.

110. Fiji Times, 9 Dec. 1993.

111. Fiji Times, 10 Dec. 1993.

112. Fiji Times, 21 Jan. 1994.

113. Review Magazine, Feb. 1994.

114. Review Magazine, Feb. 1994.

115. Daily Post, 4 Apr. 1994.

116. Fiji Times, 15 Dec. 1993.

117. Weekender, 30 Oct. 1993.

118. Daily Post, 3 Feb. 1994.

119. Daily Post, 3 Feb. 1994.

120. Daily Post, 7 Feb. 1994.

121. Address at Albert Park, 8 Oct. 1993.

122. Reproduced from The Review, February /March, 1993, 13-18; slightly truncated.

123. 31 Dec. 1993. 


\section{CHAPTER 8: NEW FOUNDATIONS}

Problems will always torment us, because all important problems are insoluble; that is why they are important. The good comes from the continuing struggle to try and solve them, not from the vain hope of their solution. Reinhold Niebuhr

The world will go on somehow, and more crises will follow. It will go on best, however, if among us there are men who have stood apart, who have refused to be anxious or too much concerned, who were cool and inquiring and had their eyes on a longer past and longer future. Walter Lippman

$\mathrm{F}$ or Jai Ram Reddy, a fair and just constitution was the absolute prerequisite to addressing the problems facing the people of Fiji. To that end, the review of the 1990 Constitution was a matter of the highest urgency for him. 'You can talk about the land problem, or the economic problems, or the law and order problems,' he said, but the 'truth is that solution to all these is dependent on the kind of constitution that is put in place and the kind of government that emerges from it. A government that has a captive vote bank confined within a single community will never be able to govern for the good of all. That is the bottom line.' Many in his party and community were sceptical about the possibility of a fair and comprehensive review of the constitution. 'What will you do if there is no change to the constitution?' people asked him. 'I am confident that good sense and goodwill [will] prevail and the review will be successful,' he replied, probably more in hope than with conviction or certainty at that stage. And he urged people to take a broader, non-communal, view of the review exercise. 'Please remember 
this,' he told the sceptics. 'The review is not simply a communal issue. This is not a matter of Fijians versus the Indians. There are thousands of people of all races - and varying political beliefs - who see the need for a just constitution and are prepared to work for it.' Certainly, his own party, the National Federation Party, had made a whole hearted commitment to the review process 'in good faith, and we intend to remain firmly on course and give it our best until the process is exhausted.'

From early 1995 to 1997 , the review of the 1990 Constitution was Reddy's foremost concern. He listened carefully to counsel from his most trusted advisors and colleagues. He reached out to people outside the traditional political arena, to academics and trade unionists, among others. $\mathrm{He}$ raised funds to have access to the best legal advice available, which came in the person of Professor Yash Ghai. He welcomed every opportunity to build bridges with leaders of other communities to allay their fears about his motivations. The diplomatic community was regularly briefed in case their assistance was needed when the crunch came. Luncheon gatherings were addressed along with party meetings, speeches given to mark national occasions (such as the 'Year of the Indigenous People.') Newspapers and news magazines carried long and comprehensive interviews about his views on this controversial subject or that. The old suspicion of 'the media,' the ditherings and deflections were a matter of the past as Reddy actively sought to communicate his vision for Fiji to a larger audience. There were costs though as well. Deep and draining engagement with the review process, in all its facets, also meant less time for Reddy to attend to the routine affairs of the party, less time with the party's grassroots supporters, listening to their concerns and problems that only regular visits and consultations could provide, and as he had so assiduously done in the early part of his career. These matters were left none too successfully to the party's parliamentary members and to the party's hierarchy. Reddy was a remote figure, getting remoter by the day as it seemed to some of the grassroots supporters. Labour, on the other hand, spent a great deal of its time nurturing its roots and reinvigorating its links, with what results we shall see in the next chapter. 


\section{SETTING UP THE CONSTITUTION REVIEW COMMISSION}

Once the Terms of Reference for the Commission to Review the 1990 Constitution were approved, Sitiveni Rabuka appointed Deputy Prime Minister, Filipe Bole, to take charge of the review exercise, canvassing ideas about the machinery for the process, the membership of the Commission and other related matters. The choice of Bole was interesting. He was close to Rabuka. He was a teacher at the Queen Victoria School when Rabuka was a student there. In 1987, Bole had been a key member of the nationalist Taukei Movement, which was instrumental in orchestrating the overthrow of the Bavadra government. He was at the forefront of the April protest march which had presented a seditious petition to the Governor General, Ratu Sir Penaia Ganilau. He had been a member of the Military Government between September and December in 1987, and then a member of the Ratu Mara-led Interim Administration. In 1993, he was a cabinet minister in the Rabuka government. Now a changed man, or so it appeared, he pushed the idea of genuine power sharing in a truly multi-ethnic government. ${ }^{2}$

The idea of a Government of National Unity had been mooted by Rabuka early in his first term, but Reddy, while welcoming the idea, had said that his first priority was the review of the constitution as any kind of genuine cooperation under the 1990 Constitution was simply not feasible. Rabuka had intended to use that document as a framework for his concept of a broad based government. Bole wrote that the 1990 Constitution was generally acceptable to the Fijian community as safeguarding their interests. It had given them the control of the executive, the parliament and the civil service; recognized the national role and importance of the Great Council of Chiefs; and had provided the necessary constitutional legitimacy for affirmative action for indigenous Fijians and Rotumans. Yet, despite all these 'achievements,' Bole recognized the 1990 Constitution ultimately to be a 'divisive' document, which did not promote 'national reconciliation, togetherness, and unity which are vital to the maintenance of political stability in Fiji.' Political stability, Bole realized, 'was ultimately the most important 
factor in attracting increased overseas capital investment in private sector development in Fiji.'

The 'only way to strengthen national unity is to consider arrangements that would induce in members of the Indian community, and in particular their political representatives, a much greater identification with, and participation in, national decision-making affecting their interests and welfare as well as those of the other communities,' said Bole. In any such arrangement of power sharing, however, Indo-Fijians would have a minority role because the 'government would keep fully intact all the safeguards and gains which the Fijian and Rotuman communities have secured under the 1990 Constitution.' Co-option and destruction might be one way of describing the approach mooted by Filipe Bole, but that would be too simplistic. The statement reflected a genuine concern that in fundamental ways, the 1990 Constitution was not working, even, or especially, for the indigenous Fijians. The children of the Fijian elite benefitted disproportionately from the affirmative action programs of the government. Disregarding the principles of meritocracy in the civil service had led to gross inefficiency and nepotism. Procedures of accountability and good governance were breaking down if they hadn't done so already.

In response to Filipe Bole's exploratory paper, Jai Ram Reddy presented his own 'theme paper' on 13 August 1993 in which he broadly outlined his thoughts on what kind of constitution would be most appropriate for Fiji. ${ }^{4}$ In his view, the five priority areas for Fiji — pillar principles, they were called - were the promotion of racial harmony and national unity, the restoration of full democracy, the social and economic development of all the people of Fiji; social justice and equal development of all regions and communities in Fiji (unlike the 1990 Constitution which favoured the indigenous community), and the respect and legitimacy for Fiji in the international community which had been eroded considerably since the 1987 coups and the decreed imposition of the 1990 Constitution. For Reddy, it was imperative to 'abandon the notion that one community can only benefit at the expense of another.' The zero-sum mentality had to be jettisoned 
for good. If multiracialism meant anything, it meant above all, 'the fair representation of all communities in the legislature and the government as well as in other public policy making and administrative institutions.' A political system which excludes one or more communities from a share in the government or in policy making is incompatible with multi-racialism,' he said, continuing:

The NFP is aware of the heavy responsibility which rests on the leaders of all communities to ensure that the constitution provides for genuine multiracialism. Our people have been fashioned for decades, both before and after independence, to think in terms of communal politics and rivalries, an attitude unfortunately reinforced by the coups and the 1990 Constitution. It is for the leaders of all the political parties to provide leadership and persuade their followers of the necessity and value of a national and multi-racial approach, rather than to yield to their prejudices and racist rhetoric. As we know from our own and foreign experiences, the cost of failure of wise leadership and statesmanship in ethnically divided societies can be horrendous and incalculable.

Several things become clear. There was an acknowledgement on the Fijian side, even if grudging, that the 1990 Constitution was not working, and that the Indo-Fijian community had to be involved in the processes and apparatuses of government. It was also clear from Reddy's statement that he had in mind a fundamental re-assessment of the political culture which had developed in Fiji over a long period of time, and the charting of a new course for the nation that was inclusive and representative. It is remarkable that Reddy was able to articulate this view to the very person who had carried out the coup.

The thawing of relations between Reddy and Rabuka, and improvement in race relations more generally, was a direct result of Reddy's sensitive and tactful approach. Unbeknownst to the public, it was encouraged in the mid-1990s, by players outside the political arena, who assumed a dispas- 
sionate and trusted role of genuine friends of all the people of Fiji. Among them, according to Reddy, was the American Ambassador Don Girvetz who privately nudged Rabuka to a more open-minded position and who arranged private meetings between the two leaders to air their concerns away from the glare of public scrutiny. In these meetings, Reddy recalls, he spoke with utter frankness about his deepest fears and doubts and what he thought were the best course of action for Fiji. Reverend Ilaitia Tuwere, the president of the Methodist Church, played a similar role. Later, as the report of the Commission was being considered by the Joint Parliamentary Select Committee, the Speaker of the House of Representatives, Dr Apenisa Kurusiqila, was to play an equally seminal role. It will be recalled that to start the review process, Rabuka appointed a Cabinet subcommittee which was subsequently expanded to include Jai Ram Reddy and Mahendra Chaudhry.

The three agreed that the review would be completed in time for the 1997 general elections to be held under a revised constitution. Further, the review would not be confined to the electoral provisions of the 1990 Constitution but would be broadly based, covering the entire document, including 'a consideration of the system of government considered most appropriate for Fiji.' This was a tacit acknowledgement of the general inappropriateness of the adversarial Westminster system of parliamentary democracy which Fiji had adopted since 1966. Further, they agreed that the new constitution would be 'autochthonous,' developed by people within the country, unlike the independence constitution which was negotiated by Fiji's political leaders in London. Finally, the cabinet subcommittee agreed to appoint a Joint Parliamentary Select Committee whose job it would be to recommend to cabinet the size and composition of the review commission and generally assist the commission in its work by, among other things, developing consensus about the content and character of the new constitution. The JPSC was multiracial, comprising 14 members appointed by the Government and 11 Opposition nominees. ${ }^{5}$ At first, no one had any idea about the appropriate size of the Commission. In November 1993, the 
Cabinet agreed on a eight-member body to be chaired by a person from overseas who possessed 'vast experience in multi-racial, multi-cultural environment,' preferably someone from Malaysia, three Fijians, two Indo-Fijians, one Rotuman and one General Voter, and assisted by two legal counsel, one local and one expatriate. ${ }^{6}$ Subsequently, for reasons unknown, the SVT proposed a eleven-member commission, made up of a chairman (Fijian), deputy chairman (Indo-Fijian), SVT nominees (two), and one nominee each representing the General Voters, NFP, Labour, Fijian Association, All National Congress, Rotuma and the State Services.

The proposal did not get far, with the patent under-representation of the Indo-Fijian community on the Commission. Reddy wrote to Rabuka on 3 May 1994: 'I personally see no value in our proceeding in this way, and unless the composition of the Commission reflects a fair principle of representation (as, for example, parity between the two major sides or one based on the votes of a party in the last general election), we shall withdraw from the present review.' There was another area of disagreement. The government insisted that the Commission consist of local people who represented major political parties or groups in parliament and who were familiar with local languages and customs. '[A]ny foreign participation would be confined to the role of expert consultants and advisors only,' because 'the exercise would only be meaningful if it was undertaken by people whose lives would be affected by changes that would be implemented and who had the relevant language and cultural understanding of the different sections of the Fiji multi-ethnic and multi-religious society.' Reddy differed. 'We agree that the majority of the members must be from Fiji, but we do not consider that the presence of outsiders, whose principal task would be to suggest alternative solutions and to offer compromises between different local positions, would detract from the home grown nature of our constitution.'

The government also proposed that the members of the Commission should be appointed by the major political parties represented in parliament, and not by other interest groups, such as, for instance, the Great Council of Chiefs, or the President, or the churches, because 'this would better 
facilitate communication with the Joint Parliamentary Select Committee and the public of Fiji as well as provide an impetus to the bi-partisan consensus building process that was vital to the exercise.' Reddy was strong on the consensus-building process and on the supremacy of the parliament in the formulation of the constitution. This was no small achievement in the circumstances as there were many Fijians who sought a greater role for indigenous institutions (the church and the chiefs, for instance). As one of them said to me, the church and the chiefly system were the only longlasting institutions in Fiji, able to survive political turmoil, and they should therefore have a dominant role in the review process if the constitution was to be an enduring one. ${ }^{7}$ The government envisaged the review to be a two-stage process. In the first phase, the Commission would prepare an interim report and submit it to parliament for consideration. Parliament's comments would then be incorporated by the Commission in the final report. The exercise was expected to take about two years. But things turned differently in the end. The government's proposal for an eleven-member Commission was quietly dropped as too unwieldy and expensive. Reddy felt it was better to have a smaller commission comprising representatives of the two main communities with an outside chairman. The ultimate responsibility for fashioning the constitution, he argued, would rest with the elected representatives of the people in parliament. And that, as we shall see, was how things turned out.

Also quietly dropped was the two-stage proposal as cumbersome and potentially fraught. Reddy rejected the idea outright. He wrote to Rabuka: 'The task of the Commission is difficult enough without the additional complication of periodic reports (and approvals?) The periodic reports may give rise to misunderstandings, even acrimony, and will slow down the process (already in danger of missing the constitutional deadline for review.)' 'Our view of the Commission,' Reddy continued, 'is that of an independent and professional body which makes in its own deliberate judgment recommendations on the best constitution for Fiji. Once it has done that, its recommendations will no doubt receive political scrutiny.' Reddy's view 
prevailed. For a while, the SVT insisted that the chairman should be an indigenous Fijian, but this was rejected outright by both NFP and Labour, even though the government had in mind the Chief Justice, Sir Timoci Tuivaga, who had privately expressed an interest in the job. ${ }^{8}$ Both NFP and Labour threatened to boycott parliament if the government refused to budge on the issue. Reddy was convinced that only a person of international standing and credibility would give the process the necessary legitimacy in the eyes of the people, and the international community. That was his 'insurance policy.'

An impasse developed. Kelemedi Bulewa, the Attorney General and a man of nationalist bent strongly linked to the Taukei Movement, was adamant that the chairman would have to be a local while the Opposition, as Harish Sharma put it, 'could not think of any one person in this country who could look at Fiji's problems dispassionately and impartially.' ${ }^{9}$ Reddy reminded Bulewa of Rabuka's undertaking at the very outset of the review process to have an outside chairman of the Commission. The situation had changed, Bulewa argued; all previous agreements were now to be re-visited. 'We have told Cabinet,' he said, that 'in fact we are going to re-look at the whole thing, not only the chairmanship, but the composition of the Commission itself. As far as we are concerned, we are keeping an open mind about the whole thing. We have demonstrated that in the process of our discussions and I do not know what we can do further than that.' Reddy replied bluntly that 'if the earlier agreement was not honoured by Government,' then he saw no need for a vote on the candidate as demanded by Bulewa, 'and Government should do the review on its own.' It was then suggested that two names should be forwarded to the President for him to choose one.

Reddy again objected. He pointed out that the President would appoint according to the advice of the Cabinet, and the Joint Parliamentary Committee was merely an advisory body to the Cabinet. If two names were put to the President, he would pick the name that the Cabinet would recommend, as provided for under the constitution. That was why it was 
important, Reddy argued, to ascertain whether the Government side would abide by the earlier agreement (with Rabuka) that the chair would come from outside. If that commitment was not honoured, then there was no point in continuing the review exercise. But if that issue were to be resolved, then Reddy would be happy to provide names for consideration. The JPSC agreed to collect a list of names for future consideration. And the Committee, at Inoke Kubuabola's suggestion, agreed that Reddy and Rabuka meet privately to sort out the niggling issues on the review process between the Government and the Opposition. The chair of the commission was the 'stumbling block,' but it was resolved when Rabuka said that he was 'morally obliged' to get the chair from overseas because he had given that undertaking to the late Ratu Sir Penaia Ganilau. ${ }^{10}$

A number of prominent individuals from across the world were identified as potential chairs of the commission. Reddy forwarded the names of Sir Telford George, a former Chief Justice of Tanzania and Bermuda and a member of the commission which had reviewed the constitution of Trinidad in 1974; Sir Robin Cooke, of the Supreme Court of New Zealand; Sir Graham Speight, a retired New Zealand judge and former President of the Fiji Court of Appeal, and Sir Paul Reeves, former Governor General and Anglican Archbishop of New Zealand. The names of Eddie Durie, Chief Judge of the Maori Land Court, and of Sir Ian Thompson, former senior Fiji colonial civil servant living in retirement in Scotland, ${ }^{11}$ were subsequently added to the list. Reddy initially leaned towards Durie, a distinguished judge and a Maori as well. The combination seemed right to him. Durie was versed in the law and as a Maori, also understood the aspirations and anxieties of the indigenous people of the Pacific. Durie was honoured, he told me, but was unavailable because of his all-consuming Maori Land Tribunal work.

Some Fijian members of the JPSC were wary of having a person from a legal or jurisprudential background to chair the commission, fearing that he or she might be too enamoured of constitutional niceties and legal principles and precedents to fully and sympathetically grasp the thoughts and 
feelings of the Fijian people (which might be in contravention of international principles). A constitution, the argument went, was more than simply a legal document. It was a moral compact among the citizens about their country and its future and, therefore, required a much more inclusive input into its formulation. Of course, the skills of legal counsel would be readily made available to the Commission. The JPSC eventually agreed informally that the chairman should not be a lawyer or a judge.

The final choice of chairman came down to Thompson and Reeves, and Filipe Bole flew to Scotland and New Zealand to interview both men. Reddy was not keen on Thompson even though he respected his long and distinguished record of service to Fiji, including to the sugar industry as the Sugar Tribunal. He felt Thompson was too close to the Fijian elite (he had fought alongside them during the Pacific War and served for long periods in the Fijian Administration), too integral a part of Fiji's colonial and early postcolonial past to bring detachment and objectivity to the task of chairing the review. ${ }^{12}$ Thompson would have brought with him an intimate knowledge of Fijian thought and feeling, but his impartiality and detachment were an issue. ${ }^{13}$ The JPSC unanimously recommended the appointment of Sir Paul Reeves. It was, in my view, an inspired choice. Reeves (b. Dec. 1932) was an indigenous Pacific Islander, proud of his cultural heritage and sensitive to the concerns and aspirations of the indigenous people of the Pacific Islands. He had spent time at the United Nations as an observer of the Anglican Consultative Council. He was a knight of the realm, which carried weight among a people respectful of authority and hierarchy. He had been the Governor General of New Zealand. And he was a former Anglican Archbishop and Primate of New Zealand as well. Reeves, then, had the gravitas appropriate for the job. He was also, as I later discovered, considerate, sensitive and inclusive, a good listener and a great consensus builder. He kept the Commission on an even keel and diffused many a potentially explosive situation during submission hearings with good humour and Christian grace. 
The government nominated Tomasi Vakatora (1926-2006) as its nominee on the Commission. Vakatora was an experienced civil servant, a former Alliance Minister, Speaker of the House, and sometime businessmen. ${ }^{14}$ He had served on the Falvey Committee in 1987 and was, in fact, one of the architects of the 1990 Constitution which he would be reviewing for its suitability to Fiji's multi-ethnic society. And the people of Fiji did not need to be reminded of his altercation with Reddy in December 1983 which, as we have already seen, led to Reddy's resignation from parliament. Vakatora's nationalist credentials as the victor over Sakeasi Butadroka were impeccable. Many in the NFP were genuinely disappointed with Vakatora's appointment, viewing this as a not too subtle SVT ploy to derail the entire review process. Even Vakatora's former friends in the Alliance party warned me about him. After all, they said, how could an architect of the hugely controversial and racially-lopsided 1990 Constitution recommend its replacement with a fairer one? 'He will be the final brick wall,' one of them said to me, with foreboding, beyond which nothing will penetrate. ${ }^{15}$ True to his nature, Reddy never once spoke to me about Vakatora. In the event, all the misgivings about him proved unfounded.

Vakatora was a tough and skilled negotiator with well developed debating skills which he put on full display; he was a Fijian proud of his heritage and history. But he was also, in the end, a fundamentally fair man. He had been an architect of the 1990 constitution, but he was also prepared to listen and to change his mind. He had his spats with other members of the commission; he was a man of explosive temper, but never once did the two of us exchange harsh words. For him, I was the representative of a large ethnic community to be accorded respect befitting such a representative. 'I was determined to have a cordial working relationship with him [Lal],' Vakatora wrote, 'based on mutual trust and understanding of each others' point of view.' He continued, 'When the Commission ended its work 15 months later, we had established a bond of friendship which would last forever. ${ }^{16}$ I felt the same about 'Tom.' 


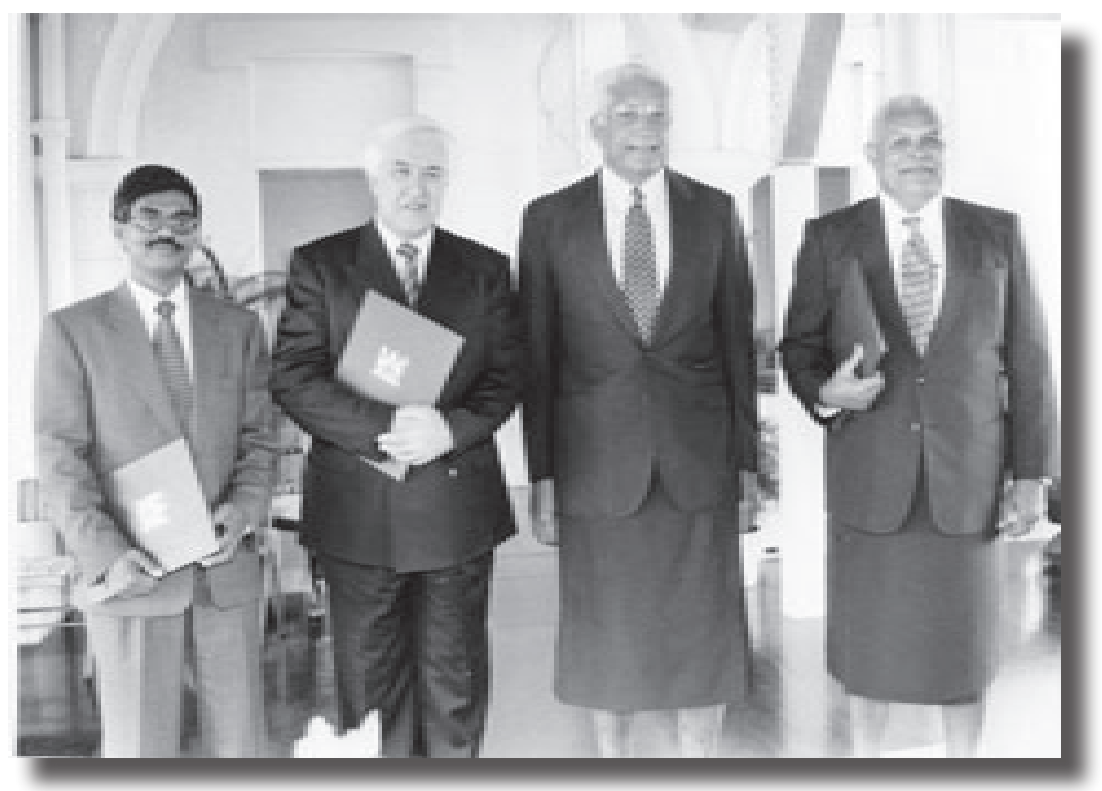

Fiji Constitution Review Commission with President Ratu Sir Kamisese Mara.

From left: Brij V. Lal, Sir Paul Reeves, Ratu Mara, Tomasi Vakatora. Courtesy of Fiji Times

Reddy proposed me as the Opposition's nominee on the Commission. I have never directly asked Reddy why he chose me above others who themselves had indicated availability, and attacked both me (and Reddy) bitterly for a long time afterwards. ${ }^{17}$ Reddy justified his choice to journalist Madhur Singh this way: 'We picked Brij Lal because we know from experience that he is totally committed to Fiji, even though he may live in Canberra. He knows the history of the Indian people here and their struggles and he is very sensitive to the aspirations of the Indian people. He has written so much about it that I would have thought that this would be pretty self evident thing. And I did not pick him. He is the unanimous choice of both the NFP and the Labour Party. We decided Dr Lal would be the best man for the job. ${ }^{18}$ I had met Reddy briefly a few times before the appointment 
and corresponded once or twice; I had given the keynote address to the 1993 National Federation Party annual convention in Nadi. He had read some of my writings and seemed to like what he had read. People he spoke to about me were generous in their comments about my ability but cautioned Reddy about my lack of political experience. 'Vakatora will eat him alive for breakfast,' one of them said. Reddy had a different approach in mind. 'Leave the politics to us,' he said to me at the beginning of the review process. 'Try and understand the fears and hopes of the Fijians. See if you can find some middle ground,' or words to that effect. I suppose he already knew where I stood on Indo-Fijian fears and concerns.

Still, it was a big decision for him. Much was riding on the review of the constitution, including his own political future. I came to know much later that Labour had in mind Don Dunstan, the late reformist Premier of South Australia with long Fiji connection (he was born there); but Reddy wanted someone from his own community, someone sufficiently dispassionate and detached from the local scene to represent it on the Commission. ${ }^{19} \mathrm{He}$ had the numbers in parliament and that sealed the matter for him. Once he had nominated me, Reddy scrupulously maintained his distance. He never once asked me about our work. I respected and admired his integrity and professional conduct. The Commission was assisted by its own legal counsels, Jon Apted and Alison Quentin-Baxter. Alison was the retired Executive Director of the New Zealand Law Reform Commission with experience of constitutional advising in the Marshalls and Niue. Alison was a great asset to the commission, with her tireless energy, meticulous preparation and impeccable professionalism and fair-mindedness. A harder working, more dedicated person I have never come across in my entire professional life. Apted was resourceful and intelligent, with sound understanding of the local scene. Walter Rigamoto, as Secretary, completed the make up of the commission. It did not occur to me then but it was a balanced commission: a Fijian, an Indo-Fijian, a General Voter and a Rotuman, with two expatriates! 


\section{REVIEWING THE CONSTITUTION}

The Terms of Reference for the Commission, an historic achievement of consensus and compromise that would have appeared impossible just a few years before, considering the bitterness generated by the coups, required the Commission to recommend constitutional arrangements to meet the present and future needs of the people of Fiji, and promote racial harmony, national unity and the economic and social advancement of all communities. These arrangements had to guarantee full protection and promotion of the rights, interests and concerns of the indigenous Fijian and Rotuman people, have full regard for the rights, interests and concerns of all ethnic groups and take into account internationally recognized principles and standards of individual and group rights. The Terms of Reference also required the Commission to 'facilitate the widest possible debate throughout Fiji on the terms of the constitution of Fiji and to inquire into and ascertain the variety of views and opinions that may exist in order to formulate provisions of a constitution that would meet the needs of a multi-ethnic and multi-cultural society.' The Terms of Reference were so wide-ranging that it prompted some cynics to wonder what they actually meant and whether they could be reconciled into a workable formula.

The provision regarding wide consultation troubled Reddy who told parliament that this 'widest possible consultation is unnecessary.'20 Mahendra Chaudhry agreed, adding that 'this was a concession we had to make.' Their hesitation was based on experience. They feared perhaps that a public enquiry would revive old hostilities, politicize the atmosphere and potentially derail the review process, embroiling it in endless 'consultations' with various levels of Fijian society until the review exercise went nowhere, except into the dust bin of history. Reddy felt that the inquiry would reveal nothing new because what the different communities wanted, or did not want, was already too well known to warrant re-visiting. The Commission could simply read the submissions given to previous enquiries. The Commission did not share this view. It was determined to make its 
own independent assessment, although it had access to papers submitted to, or prepared for, earlier enquiries. The Commission knew that its report would lack credibility without public input. The people of Fiji should be bound into the process for it was, after all, their constitution that was being reviewed. We expected to hear discordant, even disquieting voices from time to time; there would be public posturing and grandstanding; and some people might use the Commission hearings to push their own political agendas.

Some of our fears were realized as both Vakatora and I were attacked by people for one reason or another. That was the price to be paid for living in an open, democratic society. I recall one 'staged' confrontation vividly. Fijian nationalist leader Iliesa Duvuloco attacked me in Suva and gained much coverage on the television and in the newspapers. ${ }^{21} \mathrm{~A}$ few weeks later, when I met him in Tailevu, during the course of our Commission's visit there, he put his hands around my shoulders and said, 'Doc, I hope you did not mind my attacking you. I needed the publicity.' He was contesting a by-election in Tailevu and wanted to impress his voters that he could stand up to anyone, including a member of the Commission! From July to November 1995, the Commission travelled the country by boat, car and air, receiving over eight hundred oral and written submissions from individual citizens, community, religious, cultural and other interest groups, and all the major parties. The NFP encouraged its various branches and members around the country to make their own private submissions, but there was not a single Labour branch which appeared before the Commission in its own right, leaving the submission to its leader, Mahendra Chaudhry. Most of the submissions were made in public, and they were deeply moving in their sincerity and honesty.

Supplementing the submissions were research papers especially commissioned by us. ${ }^{22}$ One set of papers dealt with local issues such as the performance of the economy, education, the relationship between state and religion, land tenure, the structure and functioning of Fijian institutions, gender relations, the concerns of minority communities and the like. The 
aim was to enable the Commission to increase its knowledge of the local context in which the 1990 Constitution functioned, and to deepen its understanding of some of the issues raised in the submissions. The other set, written by eminent scholars from around the world, focused on systems of power sharing in ethnically divided societies, alternative electoral systems, the place of indigenous and human rights in international law, protection of fundamental rights, and so on.

Early in the Commission's deliberations, the need to view Fiji's constitutional experience in comparative perspective became clear. Malaysia, Mauritius and South Africa, seemed to offer experiences and perspective of particular relevance. Malaysia was recommended by many Fijians. Its pro-indigenous (bumiputra) policies, legislative protection of indigenous interests and their integration into the country's political system, the special place of Malay culture and the overarching role of Islam, the relationship between religion and state, all resonated with issues in submissions made to the Commission. Historically, Fijians had served in Malaya fighting insurgent communism in the 1950s, and the older generation had fond memories of the place. Malaysia was pushed hard by Dr Ahmed Ali, who had been Fiji's High Commissioner there and who had secured the services of a retired Malaysian judge (Yatim Zachariah) as a consultant to the government, but he does not seem to have played an active role in preparing the government (SVT) submission.

The second country the Commission chose to visit was Mauritius, a multi-ethnic island state in the Indian Ocean. At the time of its independence in 1968, two years before Fiji's, it had been lagging behind Fiji in nearly all sectors of the economy. Three decades later, it was ahead in virtually every sphere. The Commission wanted to fathom the reasons for this incredible transformation and see if there was any correlation between the constitutional system and economic performance. There was indeed. The constitution was non-racial and it forged a deep and abiding sense of national unity and identity. When, from my Fijian perspective and background, I asked a political leader how many Indian members there were in 
parliament, he replied, somewhat puzzled: 'I don't know. We don't look at the race of our parliamentarians. We look at the party.' That was true, but only up to a point, as I discovered later.

The third country the Commission visited was South Africa. In the mid-1990s, it was undergoing perhaps the most massive exercise in constitutional engineering in modern times, steering a deeply divided and racially polarized society from it brutal apartheid past towards a non-racial, multiparty democracy. The Commission wanted to gain a sense of the nature of the problems in the transition, particularly the use of the mechanism of a government of national unity to effect change. We learnt in South Africa that the enforced power sharing provision was a transitional measure which would be discarded once the full transition had been made. 'Why should the ANC [African National Congress] with two thirds of the votes share power with the National Party?' ANC Secretary General Cyril Ramaphosa told the Com-mission.

The comparative exercise was immensely educative, reinforcing the fundamental point that each country had devised particular constitutional arrangements to suit their particular social and political needs. There was no one-size-fits-all. Nonetheless, there were certain common threads. Everywhere, there was recognition of the need to share power among the various ethnic groups. Everywhere there was explicit recognition, if not actual institutionalization, of ethnicity. And everywhere there was a strong commitment to an overarching sense of national unity, its importance underlined by a history of ethnic conflict and tension.

\section{SUBMISSIONS}

The most anticipated submissions were from the SVT and the NFP-FLP, and these are discussed below. First, it is necessary to sum up the general thrust of what was presented to the Commission. There was widespread recognition, among both indigenous Fijians and Indo-Fijians, that Fiji's political and social structures, instead of bringing people together, had kept them apart for more than a hundred years, with the result that people 
continued to live, think, and work in racial compartments. Members of both groups noted that, in rural communities, Fijians and Indo-Fijians co-existed amicably happily. Many Indo-Fijian individuals and groups expressed their commitment to working with Fijians towards restoring full democracy and establishing a genuinely harmonious non-racial multicultural society, assuming, of course, that this was what Fijians themselves wanted. Racial cooperation was better than confrontation. Some adverted to the world-wide need to take account of the rights of indigenous people. Fijians, too, stressed that while indigenous interests were paramount, this should not affect the interests and traditions of other communities. No one should feel their interests threatened in what was their own country. A multiracial society was one in which different communities respected one another, interacted, learnt from each other's culture and languages and lived together in trust.

Some thought that a lasting solution would depend on foregoing racial politics and building mutual trust, while others argued strongly that Fiji must abandon the habit, introduced by the colonial government, of thinking, making decisions, legislating and carrying out other activities on a racial basis. The constitution should make people focus first on belonging to the country and only after that on belonging to a particular group. But that trust, some argued, should be built only on the confidence of the different ethnic groups in their own identity in relation to that of the other groups. While the Indo-Fijian population was decreasing rapidly, there was some fear still among the indigenous people that they might one day be swamped and Fiji taken out of their control. However, Fiji's biggest asset was that, despite each group's fears and mistrust, the ordinary people were basically decent and well-mannered, which had enabled Fiji to avoid violence so far.

Many Indo-Fijians expressed their commitment to social and economic advancement of all the people of Fiji. They urged that a new constitution should enable Fiji to solve its serious social and economic problems such as access to land, unemployment, poverty and homelessness, in a spirit of cooperation, trust, tolerance, sound planning, team work and innovative 
and creative use of resources. The country's enormous potential could not be realized until its citizens were united in their diversity, and discussed together such concerns as those of the Fijians about not being in the main economic stream and of Indo-Fijians about mushrooming squatter colonies on the fringes of the urban centres. The Indo-Fijian business community could take the initiative in training young Fijians in business and as apprentices. It was necessary to move away from the stereotype that all IndoFijians were educated and prosperous. Nor was it true that Indo-Fijians controlled the economy. The banking sector was not in their hands, nor was the gold mine. It was also wrong to suggest that Fijians had no significant role in the economy. Whilst they were not well-represented in the visible aspects of commercial life like shop-keeping, transport and tourism, they owned one of the country's most productive asset, land.

Many submissions pointed out that in many rural areas, members of the two communities spoke each other's language. Even so, a number of Indo-Fijians acknowledged that they could have done more to learn Fijian culture, tradition and language. Some Indo-Fijian schools already had a large number of Fijian students, and were promoting the teaching of Fijian to students, but it was not an examinable subject for non-Fijians. Multi-ethnic schools encouraged communication and trust among the children. Although some schools were still categorized as 'Fijian' or 'Indian,' almost 58 per cent of the 672 primary schools and almost 91 per cent of the 142 secondary schools were multiracial. However, stereotypes still took the place of understanding among the different communities of one another's language and culture. Aside from language and culture, submissions also raised the issue of national identity, a common name, the relationship between church and state, equal citizenship and gender equity.

Two issues understandably featured prominently in many submissions. One was land, which was sometimes seen as a more important concern than the constitution, especially for Indo-Fijians whose thirty-year leases under the Agricultural Landlord and Tenant Act were beginning 
to expire and in many cases not being renewed. Many Fijians wanted to be sure that their ownership would be not be disturbed, used as they were to hearing their leaders tell them in the past that if they were not united and resolute in their demands, their lands might slip away from them. Ownership was not a privilege for Indo-Fijians, as reflected in the terms upon which leases were given. Some Fijians thought that some or all state-owned land should be returned to Fijians, which subsequently happened. Freehold land, alienated before Cession in 1874, should also be returned to their rightful indigenous owners, an emotionally appealing but legally fraught proposition even at the best of times. Some submissions insinuated that renewal of leases to Indo-Fijians should be conditional upon their accepting the principle of Fijian political paramountcy. As one submitter told the Commission, 'the question of Fijian leadership in this country is an important equation in the debate [and] it would be naïve to ignore the point.' To 'ignore the relation between tenancy and political power would be to misunderstand the post-1987 Fiji.'

Others disagreed. For Indo-Fijians, the main issue was a constitutional guarantee of the security of tenure. They wanted some obligation placed on the government to provide land for those in all communities who became landless through no fault of their own. For many tenants, the thirty year lease, as provided under ALTA, was insufficient to encourage good husbandry and land improvement. Tenants everywhere would agree with that sentiment. They wanted longer leases, perhaps up to fifty years. Alternatively, if the landowners wanted the land returned, the displaced tenants should be compensated to enable them to start somewhere else. Many wanted land to be viewed from a national perspective. If the leases expired and were not renewed, everyone would suffer, including the landlords. That is indeed what has happened. Once productive cane farms reverted to bush, and former tenants clogged up the squatter settlements around the urban centres of Viti Levu. Although Fijian landlords have belatedly recognized their self-defeating view, many tenants are reluctant to return to the uncertainty of temporary leases. 
The second issue of particular significance was the character of representation in parliament. On this, opinion divided sharply. Many indigenous Fijians saw themselves as having an inviolable, God-given right to rule Fiji for all time. Since it was their leaders (high chiefs) who had ceded Fiji to the United Kingdom in 1874 in the first place, Fiji should at independence in 1970 have been returned to them, and not to the multiracial nation that Fiji had become in the course of the 20th century. The new comers, the vulagi or guests, were entitled to remain in the country where they were born, to work and prosper, but they should never aspire to political leadership. This is the overriding theme of the Fijian nationalist scholar Asesela Ravuvu's provocative, coup-justifying book, The Façade of Democracy. ${ }^{23}$ Some Fijians justified Fijian dominance on the curious grounds of landownership; Fijians owned 83 per cent of all land in Fiji and they wanted that proportion reflected in the allocation of political power. Unless Fijian paramountcy, understood as political control, was accepted by the other communities, some Fijians asserted, Fiji would be fated to go through another, possibly worse, crisis. For the nationalist-minded Fijians, the 1990 Constitution was near-perfect. It had been blessed by the Great Council of Chiefs. Through the preponderant number of Fijians in parliament, it assured their political leadership (the lesson of 1994 seemed to be lost on them). For these and other reasons, many wanted the 1990 Constitution retained. It was suggested that the claim of other races to equality of treatment was itself an abuse of the democratic right which those groups had been accorded. Put simply, the other races, with their superior commercial skills, should help the Fijians, not try to jump ahead of them.

Indo-Fijians saw the 1990 Constitution as having been imposed on them. They regarded it as discriminatory in not allocating seats to communities on the basis of proportionality. Consequently, they saw themselves as relegated to permanent opposition, to third class citizenship, to use their phrase, a state of affairs which did not reflect their earnest desire to co-exist with all the other ethnic groups and make a full contribution to the country and its government. They saw the 1990 Constitution as dividing the people 
along racial lines, so that people focused on the advancement of their own community rather than that of the nation. Because the government was required to be an indigenous Fijian institution, it was perceived as having lost the ability to mediate fairly between the communities. Indeed, many in the Indo-Fijian community regarded the constitution as a mandate for widespread arbitrary discrimination against them. They wanted a new constitution to heal the wounds by including express recognition of a permanent place for them in the country of their birth.

Strident, pro-nationalist views were expected from some quarters. The Methodist Church, for instance, had long declared its hand in favour of Fiji being controlled by the indigenous community and Christianity being installed as the state religion. Various provinces had expressed similar sentiments in the past. The Taukei Movement, ever its fiery self though now in slight disarray, stood up defiantly as the unyielding champion of Fijian rights. 'Blood will flow' sentiments appeared in some submissions, stated in a matter-of-fact manner, not in any violence-threatening way. But all eyes were now on what the SVT would say to the Commission. Its leaders had strongly defended the 1990 Constitution; many were its beneficiaries. And it was, after all, the umbrella organisation for the indigenous community blessed by the Great Council of Chiefs. Yet, it was also true that Sitiveni Rabuka had worked closely with Jai Ram Reddy in setting up the review process, in drafting the Terms of Reference for the Commission and appointing its members.

The SVT submission, a small monograph really, was presented to the Commission not by Sitiveni Rabuka, the leader of the party, but by cabinet ministers Isimeli Bose and Attorney General Etuate Tavai, flanked by supporters and senior party members. ${ }^{24}$ The submission was a strident, uncompromising re-statement of the hard-line Fijian viewpoint. 'The basic premise of the review, the submission said, 'is that the 1990 Constitution is here to stay but that what is desirable in the interests of all communities in Fiji, and to help promote multi-racial harmony and national unity in Fiji, is to make its provisions more considerate of the position and sensitivities of 
all communities in Fiji's multi-ethnic and multi-cultural society. ${ }^{25}$ But that would only be possible if the control of parliament and government was in Fijian hands, a prominent constitutional and national role for the Great Council of Chiefs was prescribed, along with a constitutional guarantee for affirmative support programs for the Fijian and Rotuman communities.

Fijian right to political control was justified because Fijians were the first settlers of the land, having arrived in the islands some 3500 years ago and legitimized by 'internationally recognized principles of sovereignty of the indigenous people based on historical experience and legal status.' The argument was reiterated that Fiji would enjoy political stability only if Fijian supremacy was recognized by the other communities. Fijians would share power from a position of strength, not on equal terms. There was nothing intrinsically wrong with a race-based electoral system; it was a reality that Fiji had acknowledge and accept. The submission was littered with gratuitous insult to the Indo-Fijian community, which rubbed salt on a raw wound. 'The leopard never changes its spots,' the submission said, referring snidely to the Indian community. 'It probably has never occurred to Indians that Fijians do not simply trust them politically.' Indians were grasping, ungrateful and disloyal. 'With what they are now demanding, particularly the barrage of abuse and condemnation of Fijian aspirations, it is obvious that the professed spirit of goodwill has been forgotten.' These words were unnecessary, unprovoked insult.

So, what did the SVT want? Fijians should be recognized as the 'autochthonous inhabitants' of Fiji, and Christianity be the official religion of the state. The President and the Vice President should be appointed by the Great Council of Chiefs. The Senate should comprise 14 Fijians appointed by the President on the advice of the Council of Chiefs, one Rotuman similarly appointed on the advice of the Council of Rotuma, eight appointed by the Prime Minister, five by the Leader of the Opposition and six others by the President from amongst the professions to provide technical and professional advice to the Senate. The House of Representatives would comprise 90 members: 58, or two third, indigenous Fijians and two Rotumans, one 

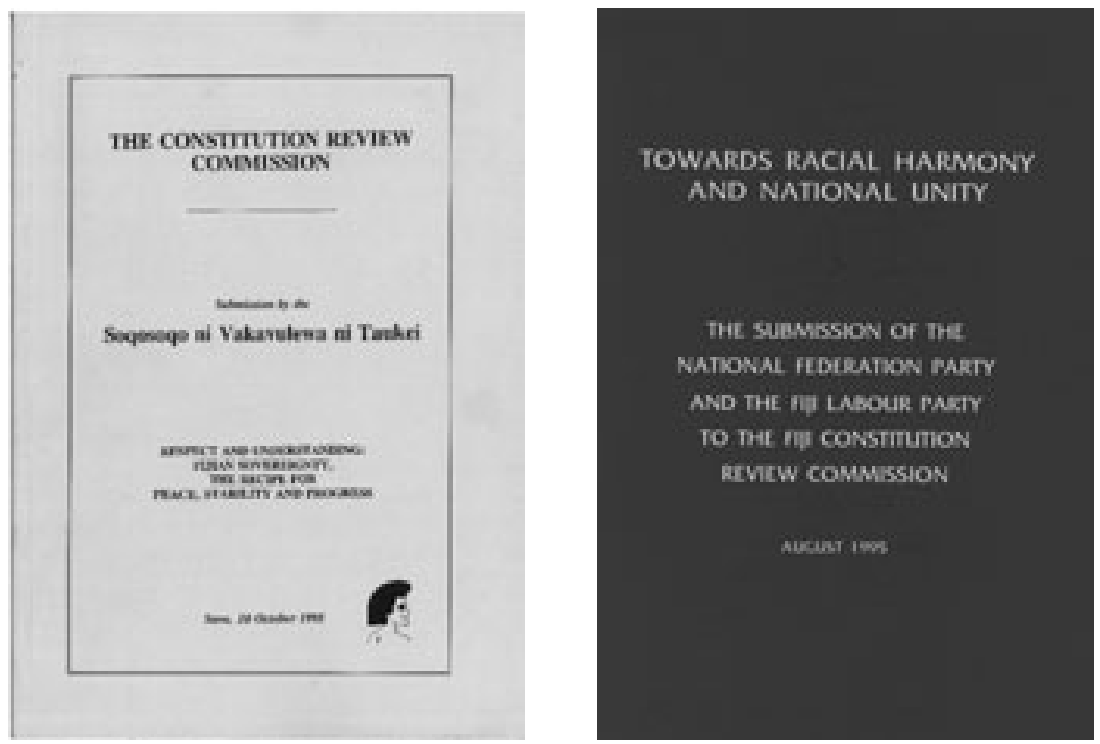

\section{SVT and NFP-FLP contrasting submissions to the Fiji Constitution Review Commission. Both were substantial monographs.}

European, one Chinese, two representing Pacific Islander communities, two Part-Europeans (Vasu), four Muslims and 20 Indians. Fourteen seats might be contested in national or cross-voting constituencies 'provided it did not dilute or interfere with the two-thirds majority for members belonging to the Fijian and Rotuman communities.' Fijian language, customs and culture should be taught as examinable subjects at least till Form Six in all schools in Fiji, and the Great Council of Chiefs should be recognized in the constitution as the 'supreme forum for determining, promoting and protecting the interests and aspirations of the indigenous people in harmony with the trust exchanged in the Deed of Cession of 1874 between Ratu Seru Cakobau and other high chiefs of Fiji on the one hand and Queen Victoria of Great Britain on the other. 
The submission dismayed many people who were hoping for a more accommodating, inclusive and moderate stance from the ruling party, especially since it had raised hopes of reconciliation by working with other parties in initiating the review process. Tomasi Vakatora seemed untroubled by the submission, which increased my anxiety. But he was later to say that the SVT submission was one among many before the Commission, and that it would be given its due consideration in our deliberations. Years after we had submitted our report, I asked one of the SVT leaders about its hard-line submission. 'What did you expect,' he said with a chuckle. 'We put forward our case the best we could and it was for the Commission to make up its mind about it.' Rabuka said at the time: 'The SVT committee felt it had to honestly report these views of the grassroots Fijian people to the Commission as a matter of public and political duty to the people who voted for the SVT.' The view of the ordinary people,' he said, 'even though unpalatable to some people, should not be swept under the carpet.'26

Jai Ram Reddy, who had invested so much energy and political capital into the review exercise, was genuinely disappointed, even angry. 'It is an irresponsible document which fosters division and hatred in our divided society,' he said of the SVT submission. 'It is a recipe not for integration, for bringing our various people together into a united, progressive and peaceful nation. It is, instead, a recipe for further polarization. It negates the very foundation upon which our society is built.' The submission, he said, 'claims to be inspired by Christian belief, yet it is a negation of fundamental Christian values. It is full of hatred of fellow human beings. It is calculated to increase the Fiji Indians' sense of rejection by the indigenous community. Not content to insult, abuse and ridicule Fiji's Indian community, and its leaders, both dead and living, the submission seeks to castigate the entire Indian race here and elsewhere in the same breath. ${ }^{27}$ The SVT submission, Reddy continued, was 'filled with falsehoods and distortions.' 'Contrary to what the SVT claim, Indians have never impeded the advancement of indigenous Fijians or questioned their legitimate rights. It is difficult to es- 
cape the conclusion that the authors of the SVT submission want to create discord among various communities and groups.'

Whether deliberately intended or not, that was the effect the submission had. Reddy began to prepare his people to expect the worst. He was almost philosophical in his public addresses at the time. Some people recall him being deeply depressed. 'Life has never been easy for any individual or community or country,' he told the annual Andhra convention in 1996. 'We can't have peace and happiness all the time. Difficulties must be borne and solutions must be found. We must not lose hope. We must continue our struggle for justice and equality. The good times will come.' People must not be obsessed with success. 'Whether we succeed or not is another matter,' he said. 'But we should not stop trying. Injustice dies out in the end. God watches over us. Learn from your forebears. ${ }^{28}$ Reddy's dismay with the tone and tenor of the SVT submission was clear, but there were also many Fijians who were pained by its strident rhetoric. Among them, strangely enough, was Sitiveni Rabuka. When the parliament convened, he let it be known privately to people that the SVT's submission was SVT's submission but that he would do everything in his power to have the constitution changed. He had heaped all the misery upon the people and he would help remove it himself. Filipe Bole was similarly heard to say that the SVT submission did not reflect the full range of opinion in the GCC or even the SVT. But not all Indo-Fijians were surprised with the submission. Among them was Mrs Irene Narayan who felt 'vindicated' by it because the submission said things she herself had been telling the Indo-Fijian community: that Fijians would never relinquish power to other communities. ${ }^{29}$

The NFP-FLP submission, also a small monograph widely distributed through-out the country, was prepared by the former coalition's constitutional advisor Yash Ghai in close consultation with Jai Ram Reddy and others. ${ }^{30}$ Looking back, it seems surprising that Reddy would agree to a joint submission with Labour, funded by supporters of his own party, especially in view of its attitude and track record, since the 1992 general elections, of attacking the NFP at every opportunity, and of Mahendra 
Chaudhry vowing to end Reddy's political career. Some within the NFP wanted the party to make a separate submission, but Reddy was persuaded by Ghai not to break the coalition for, after all, on matters of the greatest importance to the Indo-Fijian community, the two parties stood side by side. For Reddy, as always, the longer term interests of the Indo-Fijian community came first. This was no time for division and political opportunism. Solidarity was what was needed at a critical time facing his people. It was for this reason that he had backed the Labour candidate Gaffar Ahmed for a by-election in Tavua in 1995 when he was challenged by some of NFP's own supporters who had formed a separate Janata Party.

Jai Ram Reddy presented the NFP-FLP submission with eloquent and dignified advocacy. He pleaded for a non-communal approach to Fiji's myriad problems. 'We have not sought to promote the interests of our supporters at the expense of other people of Fiji for we do not think that that approach is fruitful,' he said. 'We believe that all the people of Fiji share a common destiny, and that the country will not progress unless there is a tolerance and accommodation of different views and interests. The interests that different communities have in common far outweigh what some may perceive to be their separate interests. Our proposals are based on the necessity to build on these common interests.' He reminded everyone of the 'constraints' of Fiji's colonial history,' but added: 'Our leaders face a heavy responsibility, for, if they continue to encourage people to suspect and fear members of other races, Fiji is headed for disaster.' For Reddy, it was a matter of utmost urgency that 'we must move away from using race as the primary basis for the organisation of our country.' The non-acceptance of Indo-Fijians as an integral part of Fiji was a major source of crisis in the country, he added. There was a need to move away from stereotypes which saw Indo-Fijians as 'haves' and indigenous Fijians as 'have-nots.' Much had been made of the significance of the Deed of Cession, Reddy reminded the Commission, but for him, that document held no greater significance than the Independence Order of 1970. The parenthesis opened by one had been closed by the other. And he hoped 


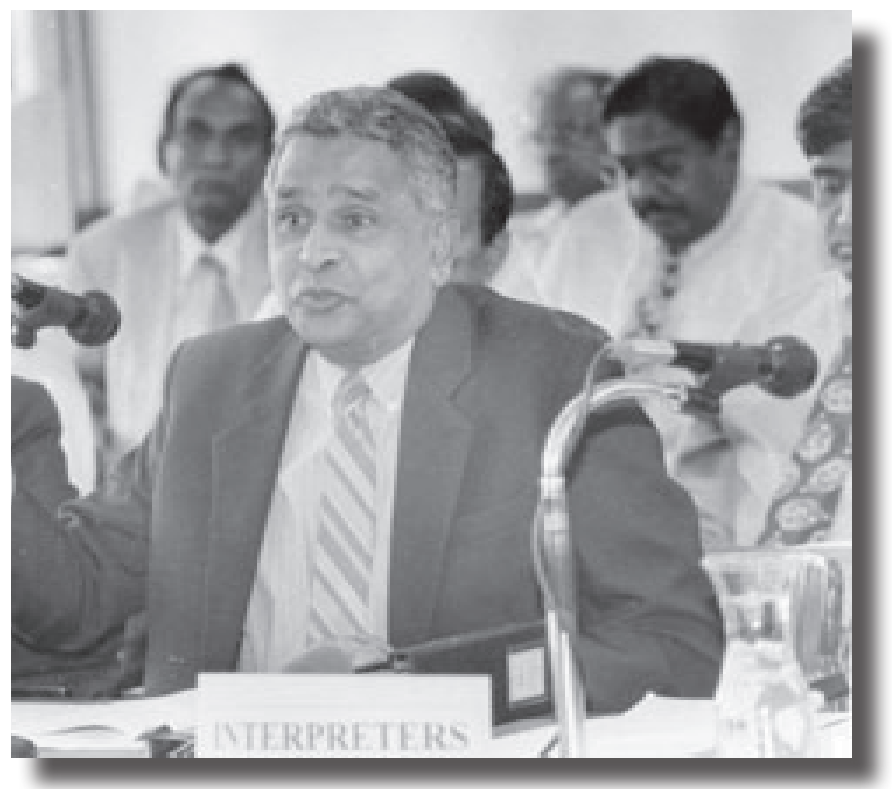

Jai Jam Reddy making the NFP-FLP submission, Sept 1995 at the Parliament Complex. From the author's collection

that the review would lead to another covenant, mutually agreed upon, like the independence constitution.

The NFP-FLP submission agreed, as the SVT submission had suggested, that the Preamble should acknowledge the indigenousness of the Fijian people and include a reference to the Deed of Cession while mentioning the contribution of other communities to Fiji's development. In a further concession, the Coalition agreed to have the Great Council of Chiefs nominate the head of state, and proposed greater autonomy for the body, electing its own chairperson and having its own secretariat. The state should 'have special responsibility to ensure the provision of land, adequate to the needs of non-native communities, in particular the Indo-Fijians who become landless on the expiry of ALTA leases.' Affirmative action programs should be non-racial and available to the disadvantaged members of all communities irrespective of ethnicity. The 
submission recommended the 'proportionality principle' where the share of a community in public service, educational institutions, and official programs would be proportionate to their share in the population. The 71 seat House of Representatives would comprise communal, national and special women members (when necessary), of whom 31 would be elected on communal and 40 on national seats. The communal seats would be single member constituencies (14 each for indigenous and IndoFijians, one for Rotuma and two General Electors) and 40 seats would be contested through the List System of proportional representation. Finally, any party with more than 20 per cent of the seats in parliament would be entitled to representation in the Cabinet in proportion to its seats in parliament.

\section{DIAGNOSIS AND RECOMMENDATIONS}

The submissions from political parties, individuals and community groups, were often moving in the transparency of thoughts and emotions they expressed. For us listening to submissions across the country was a profoundly educational and humbling experience. The country once again listened to a wide range of often diametrically opposed views, but without rancour or ill-will that some had predicted and others feared. People and political parties said their piece and expected the Commission to square the circle, to reconcile the irreconcilable. The Commission had fulfilled an important role in re-starting a sober national conversation about the country and its future. This was no mean achievement in the circumstances, especially in view of the marked polarities of the 1990s. The tensions and uncertainties are difficult to capture now.

It is not possible to cover all areas in the Commission's report. For the sake of brevity, I shall focus on two sets of issues only. The first, and perhaps the most critical, concerned the election to and the composition of parliament. That question lay at the centre of the 'web', as Tomasi Vakatora put it, and was at the forefront of all the submissions because the way power is acquired and used lies at the heart of government. It was also 
the one central area of disagreement between the major parties and communities. And the second concerned the functioning of the institutions of government and issues of social justice and human rights. From the outset, the Commission believed that unless the systemic nature of Fiji's constitutional problems was grasped, there was little hope of devising constitutional arrangements which would not give rise to the same problems in the future. From the evidence before it, the Commission concluded that it was Fiji's constitutional arrangements which had hampered the process of nation building and impeded effective cooperation among the communities, which otherwise had shown remarkable tolerance and respect for each other's traditions. Fiji's constitutional problems, the Commission concluded, arose from four features of the constitutional arrangements. Two were understandable responses to Fiji's multi-ethnic society: the principle that Fijian interests should be paramount, and the communal system of representation; and two reflected the Westminster system of government that Fiji inherited at independence: the role of political parties and the principle that a government must command the support of a majority in parliament. These four underpinned both the 1970 as well as the 1990 Constitutions.

The principle that Fijian interests should always remain paramount was deeply embedded in the Fijian psyche as almost second nature, and deployed by Fijians of all political persuasions. The principle was expressly enunciated by the colonial government from the early years of the 20th century, partly reflecting a genuine concern for the position of indigenous Fijians (for whose culture and traditions colonial officials and Europeans generally had a deep romantic fascination: an idyllic set-up to be preserved for its own sake), and partly serving to deflect the growing Indo-Fijian demand for equal political representation (Europeans hiding behind the Fijian sulu, so to speak), and partly serving to guide political change at a pace acceptable to the colonial state. The notion crept into the colonial political discourse silently and became an uncontested part of the political culture of Fiji. As we have seen, it became the focus of intense negotiations among the 
main political actors as Fiji hurtled towards independence in the 1960s. ${ }^{31}$ But the early colonial government and even the Fijian hierarchy understood paramountcy as a 'protective' principle: that is, in the management of Fijian affairs, in the adjudication of intra-Fijian disputes, the Fijian view, as represented by the Great Council of Chiefs, would prevail, be paramount.

As independence approached, the principle of paramountcy turned from a protective to an assertive one: that is, from paramountcy as a privilege to paramountcy as a right. Fijian now leaders argued that Fijian interests could be secure (paramount) only if they had political control of the country. As other communities dominated the economy, Fijian leaders argued that it was only natural that Fijians should control the levers of political power. Indo-Fijian leaders agreed to the entrenched legislative protection of Fijian landownership, culture and separate system of rural administration. It was the National Federation Party during the independence negotiations which had proposed veto power for chiefs' nominees in the Senate. For indo-Fijian leaders, protecting specific Fijian interests was one thing, equating paramountcy with political control was another. They did not see the paramountcy of Fijian interests as involving the perpetual re-election of a predominantly Fijian government. If the democratic process gave the opportunity, they saw no reason why they should not vote in a government in which they could participate. Differing interpretation of the meaning of Fijian paramountcy, then, was one contentious issue.

Another was the system of representation in parliament. From the very beginning, the electoral system in Fiji had been communal. This arrangement grew out of the colonial state's view that separate representation of the different communities was natural and desirable, not to mention the obvious fact that the system enabled the government to keep the communities apart as much as possible, accentuating its own role as an impartial and indispensible mediator. Until 1966, Fiji had only communal roll, with voters in each community electing members from their own community. Later, the communal rolls were complemented by cross-voting rolls, allowing members belonging to the three main communities to be elected by 
all voters. This system also represented a compromise between the Fijian and European desire for complete communal representation and the IndoFijian ideological commitment to a non-racial common roll. Under the 1990 Constitution, as we have seen, all cross-voting seats were abolished and replaced with communal seats.

The third feature of Fiji's political arrangement was that all parties were essentially ethnic, claims to multiracialism by them notwithstanding. Even the Fiji Labour Party, ideologically non-racial, had been able to attract only motley Fijian support. And the final feature was the winner-take-all Westminster system, where the Prime Minister is the leader of the party or combination of parties that commands majority support in the House of Representatives. In Fiji it meant that one political party, dominated by one ethnic group, was perpetually in power and another ethnic group was continuously out of it. This arrangement, as Reddy pointed out to the Commission, corroded the morale of half the population constantly on the outer and devalued the currency of common citizenship. Nor was the 1990 Constitution working for the people whose interests it was theoretically intended to protect, the indigenous Fijians. The goal of permanent Fijian political unity had been proven to be untenable: the SVT government had fallen on the floor of the House in November 1993 because of dissident Fijian votes, not because of the Indo-Fijian opposition. And the emphasis on race and racial patronage had effectively hobbled the institutions and processes of good governance from which everyone, including most ordinary unconnected Fijians, suffered.

So, what was the way out? The Commission was convinced after listening to the submissions that the people wanted all communities to play some part in the cabinet, and that voters should be able to cast votes for at least some candidates from communities other than their own. They disagreed on the means of achieving that end and the pace in the direction of multi-ethnicity, but the broad goal was widely shared. The Commission agreed that progress towards the genuine sharing of power was the only way to resolve some of Fiji's constitutional problems, the only way to attain 
national unity, racial harmony and the social and economic advancement of all communities. Constitutional arrangements which promoted multiethnic government should be the primary goal. Such arrangements, moreover, should protect the rights and interests of all citizens, particularly of the indigenous communities. And they should provide incentives to political parties to strive for multi-ethnic cooperation, and for the political process to move gradually but decisively away from communal representation. The principle of Fijian paramountcy should be recognized in the old protective sense, in ensuring effective Fijian participation in a multi-ethnic government, and in securing the fruits of affirmative programs of social and ethnic justice based on a distribution of resources broadly acceptable to all. Fijian interests should not be subordinated to those of other communities.

The goal of an inclusive, democratic, open and free multi-ethnic society was reflected in a number of the Commission's early recommendations. Fiji should be named the Republic of the Fiji Islands, which would give all citizens, if they wished, the opportunity of calling themselves 'Fiji Islanders.' The name did not take off. All three principal languages of Fiji - Fijian, Hindi and English — were recognized. The Compact section of the constitution enshrined values and principles which should underpin the governance of the country. These embraced respect for the rights of all individuals, communities and groups, including protecting the traditional ownership of Fijian lands and the observance of lease arrangements between tenants and landlords; the right to freely practice religion, language, culture and traditions; the right of indigenous communities to governance through separate administrative systems; political freedom and full and equal citizenship rights for all, including women; respect for the democratic process; fair and inclusive government and the need to negotiate in good faith to reach agreement to resolve differences and conflicts of interest (instead of resorting to force); and non-racial public policies. A strong and up-to-date Bill of Rights was recommended; and it formed a distinctive feature of the constitution. The Great Council of Chiefs was recognized in the constitution, as the SVT wanted. 
What power the President has, or does not have, has become a matter of conjecture and controversy in Fiji post-2006 military coup. The Commission was clear in its mind that the President should have much the same powers as the Governor General in the Westminster tradition. Executive power would rest with the Cabinet, and the President would be bound to act on the advice of ministers. The ceremonial role of the office of the President would continue to be important, with the incumbent expected to symbolize the unity of the nation, command the loyalty and respect of all the communities and be impartial in the discharge of duties. There would be clearly spelt out matters on which the President could properly act in his or her 'own deliberate judgment,' but within the bounds of the conventions of the parliamentary system of government. Most people in Fiji were happy with the view that the President should be an indigenous Fijian in symbolic recognition of Fijians as the first settlers of the land. The Commission recommended that the President and the Vice President be elected without debate by an electoral college comprising members of both houses of parliaments. The Joint Parliamentary Select Committee (JPSC) rejected this proposal, reposing that power in the Great Council of Chiefs.

The Commission recommended the retention of the bi-cameral Westminster system, but suggested important changes in the composition of the two houses as well as the method of election. Both houses were to be elected. The Senate would comprise thirty five members, two each elected from the fourteen provinces and six appointed by the President on the advice of the Electoral Commission (to represent communities and groups unrepresented or underrepresented in parliament) and one from Rotuma. The Commission was convinced as it travelled around the country that members of all communities had a strong sense of territorial identity through birth and residence as well as shared or complementary interests (passion for football in $\mathrm{Ba}$, for instance). In rural areas, many people were able to speak both Fijian and Hindi; indeed, in several places, some Indo-Fijians indicated their desire to make their submission in the Fijian dialect of the 
area. For these reasons, the Commission recommended that the Senate be elected by voters from all communities resident in the province, to strengthen the sense of common identification with the province and their economic and sometimes social inter-dependence. The result, it was hoped, would be that provincial concerns would be articulated from provincial rather than racial perspective. The JPSC did not agree, recommending instead the more traditional pattern of nominations by the Great Council of Chiefs, the Prime Minister and the Leader of the Opposition. Perhaps some thought that independent provincial representation might lead to the creation of an independent centre of power that might impinge on the legitimate legislative functions of the House of Representatives.

The arrangements for electing members of the House of Representatives understandably attracted the greatest attention nationally and internationally. The Commission approached this delicate task with certain objectives in mind, consistent with the spirit of its Terms of Reference: they should encourage multi-ethnic governments; comply with international standards of equal suffrage; be based on a more open system of representation, and provide a gradual but decisive means of moving away from the arrangements embedded in the 1990 Constitution. Many submissions supported the existing arrangements, and, as seen above, many Fijians wanted to see them even more heavily weighted in favour of the indigenous communities. Equally, many submissions from all communities wanted at least some seats to be filled on a non-racial basis. Many wanted a return to the cross-voting system of the 1970 Constitution, viewed now through rose-tinted glasses and forgetting that the arrangement was fraught and only marginally successful in bringing about more conciliatory politics. The Commission recommended a seventy-seat House of Representatives, made up of forty five seats elected from open non-racial (that is, common roll) constituencies and twenty five from temporarily reserved (communal) seats, with twelve for Fijians and Pacific islanders, ten for Indo-Fijians, two for General Voters and one for Rotumans. The allocation of the reserved seats was based on the actual population size of the different ethnic groups and on past historical factors. 
The fundamental point, beyond the precise figures and projections, was that the allocation was seen to be fair by the different communities, and it mostly was. The twenty five reserved seats represented approximately 36 per cent of the seats in the House of Representatives and open seats 64 per cent, the minimum necessary to allow them to spur the development of multi-ethnic politics. As a further incentive to the emergence of multi-ethnic governments, the Commission recommended that 45 open seats should be elected from fifteen-three member constituencies, the boundaries drawn in such a way as to ensure that the constituencies were heterogeneous while taking into account the traditional criteria such as geographical features, administrative and recognized traditional areas, means of communication and the mobility of the population.

That is, they should be composed of members of different communities to force political parties to appeal for votes from communities other their own. The chances of candidates of a community-based party succeeding would depend on the extent of support from other communities. The level of heterogeneity would naturally vary, given the nature of population distribution (the number of Indo-Fijians in the Koro Sea constituencies could never be large), but the goal of multi-ethnicity was to be aimed for in drawing up the electoral boundaries. The average distribution of 60 per cent of one community and 40 per cent of another was achievable in most areas. The JPSC acknowledged the force of the logic underpinning the Commission's recommendations, but decided in the end to stick with predominantly communal representation. That is, of the seventy one seats, forty six would be contested from racially reserved constituencies and the remaining twenty five from open, non-racial constituencies.

A final important innovation the Commission recommended was in the method of electing members to parliament. Fiji, like most ex-British colonies, inherited the British voting system at independence, best known as the first-past-the-post, in which the winning candidate is the one who gets the maximum number of votes. A logical system when the choice is only between two communities, it is widely considered unfair when there are 
more than two candidates. Further, it denies the voters the possible range of preferences. Acknowledging the critical role electoral systems play in determining political outcomes, the Commission identified and ranked a number of criteria against which to evaluate the available options. These, in order of importance and consistent with the Commission's Terms of Reference, included the encouragement of multi-ethnic governments, recognition of the role of political parties; incentives for moderation and cooperation across ethnic lines; effective representation of constituents; effective voter participation; effective representation of minority and special interest groups; fairness between political parties; effective government and opposition; proven workability; and legitimacy.

All electoral systems meet some of these criteria more than others. In the Commission's view, the Alternative Vote, also known as Preferential Vote, best met all the criteria. The AV is based on the same principle as second ballots, but avoids the need for a second election at a later date. It is in effect a refinement of the first-past-the-post system in that it requires voters to rank candidates in order of preference. To be elected, the candidate must have a majority of votes cast. The AV theoretically provides incentive for vote pooling by requiring the winning candidate to obtain more than 50 per cent, and it allows parties to trade preferences. Again, ideally only moderate parties with conciliatory policies would agree to trade preferences, and persuade their supporters to honour the agreement. Sadly, this principle was observed more in the breach than in observance as political parties, such as the Fiji Labour Party, used the AV system to garner as many votes as it could, going even to the extent of giving first preferences to parties which were diametrically opposed to its own philosophy, as we shall see in the next chapter. For Labour beating the NFP was the main priority and, of course, winning the elections.

\section{THE REPORT AND THE REACTION}

On Friday 6 September 1996, the Commission submitted its report, titled 'Fiji Islands: Towards a United Future,'32 to President Ratu Sir Kamisese 
Mara at a ceremony at Government House. The submission date had been delayed by three months (the Commission's original Terms of Reference required the submission of the report no later than 30 June), which fuelled speculation that the Commission was internally at loggerheads about the most important recommendations. Nothing could have been further from the truth: all the major issues had been resolved by January 1996; but the sheer bulk of material covering a wide range of subjects required an extension. It was generously granted. The final 800 page report was tabled in parliament on 10 October: a significant date in Fijian history - the dates of Cession in 1874 and Independence in 1970. The report was generously received and the Commission's commitment and thoroughness complimented. ${ }^{33}$ What struck Mara and most people in Fiji was that the report was unanimous. That once unthinkable achievement, Mara said, 'means they have achieved consensus and thus given us all an example, and perhaps also an optimism, that the nation as a whole can arrive at such a consensus. ${ }^{34}$

Prime Minister Sitiveni Rabuka, a seemingly changed man now, not the fire-breathing Fijian nationalist and religious extremist of a decade ago, spoke warmly of the Commission's 'painstaking' and 'meticulous' work done with 'outstanding thoroughness and care. ${ }^{35}$ 'We want a Constitution,' he said 'that gives everyone fair and equitable opportunities of full participation in the governance of their country.' An exclusive approach,' he continued 'with sole concentration on one's own communal or political and economic interests, sadly, will not work and can only be counterproductive. National unity and a positive environment for the economic and social advancement of everyone in Fiji must be our overriding goal.' He spoke about the need to take 'good care of one another,' about 'national unity and racial harmony, and about progressive and inclusive leadership. This was the same man whose party, the SVT, had made a hard-line submission to the Commission, advocating Fijian political control at all times.

Jai Ram Reddy commended the Commission for 'producing what is clearly a thorough and comprehensive document, whatever our respective views may be on the specific recommendations contained therein.' 
But comprehensive and rich though the report was, Reddy cautioned, the document was not an end in itself. 'It is just another step in the fulfilment of our collective commitment that we made some four years ago, and have repeatedly affirmed both inside and outside this House, to work towards a consensus that will result in a constitution that is broadly acceptable to all the people of this country.' And he urged his fellow parliamentarians 'as the representatives of all the people of this country ... to make good that commitment.' Reddy had no illusion about the difficult road ahead, given the bitter political legacy of the previous decade and the embers of bigotry and ethnic chauvinism not completely extinguished. Nonetheless, he said, 'I am confident that if we are sincere in the commitment that we have already made, and work hard at the task at hand, a consensus is possible. There is too much at stake for us to allow ourselves to be overwhelmed by distractions and difficulties that we will undoubtedly face. We are bound to succeed if we keep our minds firmly on our ultimate goal: to create a united and prosperous Fiji not only for ourselves but for generations to come.' 'We cannot fail,' Reddy continued, 'and we must not fail and I believe that the people of this country, of all races and political persuasions, expect nothing less from us, their leaders.'

Words of hope and optimism from the three principal leaders of Fiji, but the immediate reaction from (predictable) quarters was different, ominously so. Reddy watched with mounting dismay and a sense of despondency as anger erupted against the report. The Fijian nationalists, led by the ever irrepressible Sakeasi Butadroka and the recently visible champion of Fijian rights (but once a member of the Fiji Labour Party), Iliesa Duvuloco, among others, formed an ad hoc Coalition Against the Reeves Report with a handful of unrepresentative Muslim groups to reject the report, a copy of which was actually torn apart, spat upon and burned in a lovo (earthen oven). ${ }^{36}$ Abdul Faruq Hassan of the Fiji Muslim Political Rights Movement said that the Reeves Report had 'declared war on Fijians and Muslims,' who had been 'stabbed in the back. ${ }^{37}$ The rejectionists threatened to hold protest 
marches throughout the country, but nothing happened. Nonetheless, the nationalists' views were widely aired in the media, causing much concern. More seriously, perhaps, three cabinet ministers had to be reprimanded by Rabuka for working closely with the nationalists in drawing up a campaign plan against the recommendations of the report which they did not find acceptable. ${ }^{38}$

As months passed, an orchestrated campaign was launched to have the report discussed and rejected by the various Fijian provincial councils. At first, the reaction was uniformly hostile, as province after province registered their displeasure at what they saw as the whittling down of the protection of Fijian interests, for showing 'blatant disregard of the legitimate rights of the Fijian people,' to use the words of the Tailevu Provincial Council. ${ }^{39}$ Kadavu Provincial Council, led by its parliamentarian Jim Ah Koy, rejected the report in its 'totality' because the Commission had ignored the spirit of its submission, claiming that it, the Commission's, 'philosophy that the 45 open seats would bring peaceful co-existence and multiracial harmony is based on imaginary ground,' saying that it was 'an utopian vision to create a multifaceted people in an impractical world. ${ }^{40}$ Macuata Provincial Council's Ratu Tevita Vakalalabure said that the Commission's report was 'just good enough to be thrown into the sea. It sold Fijian rights and makes us nothings in our own country. ${ }^{41}$

Senior ministers such as Inoke Kubuabola, Kelemedi Bulewa and Jim Ah Koy, the first two of whom were actually members of the Joint Parliamentary Select Committee, led the anti-report campaign. ${ }^{42}$ It was not immediately clear whether they were articulating their own private opinion or those of their constituents or imposing their own preference on the people. Kubuabola suggested a referendum, while Ratu Finau Mara, son of the President, declared the Commission's recommendations on seat allocation illegal because only those 'who are beneficiaries of the Native Land Trust Act, Rotuman Land Act and Banaban Land Act' were entitled to reserved seats. By Ratu Finau's logic, the 1970 Constitution too was illegal! Others produced even more novel reasons for rejection. In a document that was 
clearly the handiwork of Dr Ahmed Ali, the coup-supporting former High Commissioner to Malaysia and now head of the Policy Analysis Unit in the Prime Minister's office who had admitted advising the authors of the SVT submission, it was argued that since none of the commissioners was a lawyer, they were unqualified to review the Constitution." 'These three men are clearly not jurists. For the purpose of reviewing the Supreme Law, they are to be regarded as laymen and as laymen they are not competent to review the Supreme Law of Fiji. ${ }^{44}$ The fact that the Commission had two legal counsels to assist it was lost on Ali. And it was conveniently forgotten that the committee which prepared the 1990 Constitution was chaired by a non-lawyer, Paul Manueli.

The second ground suggested for rejection was that the Commission had altered the Terms of Reference by adopting a mission statement as the basis of its work. But there was no secrecy about this: the Commission had shared the statement with the full Joint Parliamentary Select Committee at its first meeting in June, a month after beginning its work. And the third reason for rejection was my presence on the Commission allegedly because I was 'biased against the indigenous Fijians, biased against their chiefs and extremely biased against the 1990 Constitution,' that somehow I had exercised preponderant influence on the Commission's thinking. Reddy rubbished Ali for indulging 'in anti-constitutional reform propaganda openly without regard for the fact that he was being paid for by the taxpayers of the country.' Ali denied impropriety but admitted helping the SVT prepare its submission. Reddy was furious at the anti-report campaign emanating from various government circles. 'I can't help thinking that all this is a prelude to sabotaging the whole review process,' adding that 'I have never heard of a government that had set out to discredit a commission that [it] itself had created. ${ }^{35}$ The government's behaviour, vacillating and prevaricating, was curious, to say the least. Rabuka admitted privately to being badly advised. He was being pressured by his hard-line colleagues to reject the report, to stay faithful to the aims of the coup he had executed. But Rabuka was on a roll. He was sympathetic to the advice that he should take a more states- 
manlike approach to the constitution, distance himself from colleagues with parochial, chauvinistic vision. In June 1997, he publicly repudiated the SVT submission that equated indigenous sovereignty with political control.

He told parliament that there was 'no provision in the Draft Convention [on the Rights of Indigenous Peoples] nor is there any intention that there should be provision, that would confer on members of any indigenous community anywhere in the world, inherent rights of paramountcy or predominance over other citizens. For that itself would be a breach of the natural birthright of every individual in any country, to equality before God and the laws of his or her country, as well as the Charter of the United Nations itself. ${ }^{36}$ Instead, Rabuka argued, the intention of the international conventions was to 'obligate the State authorities in the countries concerned to ensure that members of their indigenous communities, as individuals and as groups, are given the same fundamental rights and freedoms as constitutionally guaranteed for all citizens, and further that these indigenous communities are given full rights of self-determination to maintain themselves as a distinct ethnic and cultural entity, and to administer their own affairs to ensure the good governance and welfare of their members.'

Rabuka was right of course. The international conventions authorized full partnership, not paramountcy, of indigenous or other interests. This is precisely what the Commission had been arguing. But for Rabuka to embrace the argument in its totality and to articulate it publicly and against strong opposition to the views held by his senior colleagues was remarkable. By the mid-1990s, Rabuka had grown in confidence and maturity. He had seen the treachery and betrayal of his own people and members of his own party who spread salacious stories about his private life and plotted his downfall. He had deciphered their narrow self-interest masquerading as Fijian interest. And his exposure as prime minister to others beyond his community had broadened his horizon. He put his position to me this way sometime in 1998. His people were saying 'Dabao, Dabao: Press the Peddle, Press the Peddle, Go faster, Go faster.' 'I can't do that,' Rabuka said. 'I have to look at the safety of all my passengers first. 
This is what this job [prime ministership] teaches you.' And the fact that he was dealing with Jai Ram Reddy, who was consistent and transparent in his pubic thoughts and private pronouncements, helped greatly. A rapport was rapidly developing between the two men, chalk and cheese in many ways, and that too at a time when good relations really mattered. Reddy could and did talk to Rabuka openly and frankly about his doubts and fears, and over time Rabuka came to trust him as he could not trust some of his own colleagues in the SVT. Rabuka's exposure to overseas leaders helped change his thinking as did the advice of disinterested parties in Fiji itself, including members of the diplomatic corps. The timing was right.

\section{JOINT PARLIAMENTARY SELECT COMMITTEE ${ }^{47}$}

The first working meeting of the Joint Parliamentary Select Committee took place at the parliamentary complex on 9 October 1996 at which a small bi-partisan subcommittee comprising four members each from the government and the opposition sides was authorized to lay out its modus operandi. It comprised of Jai Ram Reddy, Sitiveni Rabuka, Inoke Kubuabola, Kelemedi Bulewa, Leo Smith, James Raman, Mahendra Chaudhry and Krishna Datt. The Committee decided that the full JPSC of twenty five members would be divided into five sub-committees, each of which would consider specific sections of the long report and report back to the main group in due course. This was a suggestion made by Reddy and adopted by the sub-committee. The step-by-step approach would enable the participants to identify areas of consensus and disagreements for more prolonged discussions and negotiations later on. The JPSC would be chaired by Rabuka, much to the annoyance of some in the SVT, including Isimeli Bose, who wanted him to be there as the advocate of the Fijian people and as a 'sounding board' for his team in the Committee. ${ }^{48}$

Rabuka saw himself as the Prime Minister of Fiji and 'all the people therein,' and his chairmanship to 'ensure that the views of all groups are given a fair hearing and due weight in the consensus.' He had made a com- 
mitment to the review process, and he would see it through. It turned out to be a significant decision. Rabuka had crossed his Rubicon. He severely and publicly chided members of his own party (Adi Litia Cakobau, for instance) who continued to espouse by now a jarring nationalist line. Reddy recalled Rabuka as a decisive and disciplined chair, clearly a man used to leadership. Both Rabuka and Reddy were advised not to become members of any of the five sub-committees, but to remain outside the committee process and fill the important roles of a sounding board, a source of independent advice, breakers of impasse, providers of overarching leadership. It turned out to be a wise decision.

The Joint Parliamentary Select Committee was required to consider the Commission's report and secure the passage of agreed amendments and changes to the constitution. The JPSC obtained a legal draftsman from Australia (Dennis O'Brien of Minter Ellison) to draft sections simultaneously as agreement was reached. No records were kept of the discussions in the subcommittees except for the decisions reached. Bad for historians, but this method of minimal note taking had merit. Most importantly, it encouraged participants to engage in wide ranging and uninhibited discussions of contentious issues, enabling them to express the fears and anxieties of the communities they represented. Parenthetically, the Reeves Commission itself had adopted a similar approach in its own deliberations, recording viewpoints without attribution. All agreements reached were provisional until the very end, giving the commissioners flexibility in negotiation. This approach was Tomasi Vakatora's idea.

Both Reddy and Rabuka spoke at the first meeting of the JPSC subcommittee (along with other members as well). Reddy said:

As representatives of the Indian community, we have no desire either now or at any time in the future to politically dominate the indigenous Fijian community. Just like the indigenous Fijians, we too have our deeply felt doubts, fears and anxieties about our future in this, the land of our birth. We need to move away from the language of dominance to a language of partnership. Like 
any productive partnership, we need to redefine our relationship in such a way that we can all work together for the common good of all our people. The leadership today needs to cast its mind not to the next general election, or indeed to the one after that, but perhaps two generations hence to define the kind of country we would like to see our great grandchildren inherit. ${ }^{49}$

Rabuka urged the members to strive for consensus, and to be sensitive to 'the genuine fears and deep-seated anxieties' of the different communities. 'We can neither coerce conformity nor impose uniformity', he said, urging leaders to 'move at a pace that is acceptable to our people so that they can adjust to changes and absorb [them] peacefully in their lives.' This was a far way away from the SVT submission of just a few months ago. A cautious tone is evident in his statement, the need to make haste slowly, but Rabuka would confound everyone by his deftness and dexterity as the review process unfolded.

Time was of essence, Reddy reminded the members of the sub-committee, no doubt conscious of the angry things being said about the report and the whole review process by many in the media, all suggesting delay or, perhaps better still, complete derailment. The 1990 Constitution itself stipulated that the constitution 'shall' be reviewed before the end of seven years after its promulgation. 'The review is mandatory, and the time frame is prescribed,' Reddy reminded everyone. That meant a very narrow window of opportunity. He suggested the simultaneous drafting by the legal draftsman of issues upon which consensus was reached, so that at the end of the process the sub-committee would 'at least have a draft bill to look at.' His suggestion was accepted. Mindful of the intense discussions that would take place, and acrimony generated, Reddy suggested the suspension of the sitting of both Houses of Parliament in the early part of 1997 to avoid divisiveness which parliamentary debates tended to generate and to deal with the constraints of time. 'We need a period of intense dialogue in an atmosphere of peace and calm if we are to arrive at a consensus.' The suggestion was not taken up. 
There is no written record of the proceedings of the Joint Parliamentary Select Committee, except a written summary of the main conclusions and amendments. The summary begins: 'The JPSC met regularly and at length in a spirit of dialogue and compromise. The JPSC considered in detail the recommendations of the sub-committees and, following its deliberations on the sensitive and onerous issues before it and having regard to the national good for the peace, order and good governance of Fiji, resolved the framework of a new constitution to be adopted by Parliament.' Of the 694 recommendations of the Commission, the JPSC adopted 577, amended 40, and rejected or made redundant 77. Consensus, I have been told, was easily achieved on the non-controversial recommendations concerning the provision for good governance, the structure and functioning of state institutions, the Bill of Rights, and so on.

The bland language of the above summary masks bitter impasse on some of the most important issues, such as those concerning the composition of parliament. Sub-committee C, dealing with these issues, was chaired by Ratu Inoke Kubuabola, and had another hardliner on it, Attorney General Kelemedi Bulewa. Kubuabola would by now be familiar as a Taukei Movement member, one of the instigators and planners of the 1987 coup, and an ardent champion of Fijian nationalism. He had come of political age in the aftermath of the 1987 coups, and racial representation was the only system he knew. As a Fijian communal member, he categorically rejected the idea of forty five open seats. That, he said, would be the derogation of everything the Fijians had gained in the 1990 Constitution and no Fijian politician could ever countenance voluntary political suicide for his people. Fijian politicians were blamed for the impasse. Parenthetically, in one of those strange ironies that abound in Fijian politics, Kubuabola joined Bainimarama's interim military regime as Foreign Minister in July 2009 and became, outwardly at least, a champion of non-racialism. Whether this was rank opportunism or a genuine change of heart, only time will tell.

Fijians, however, were not the only ones who were ambivalent about open seats. Many Indo-Fijians were also reluctant to embrace the dilution of 
the racially-reserved seats, contrary to their public pronouncements. It was not only the Fijians who feared opened seats, Reddy said. 'Indians fear it as much. It is not [only] Fijians who can be outvoted, the same can happen to Indians, given their numbers, given the fact that their population has decreased and they are a minority. ${ }^{50}$ Open seats might throw up uncertainties which could potentially annihilate the community. The risks were just too great in a rapid move away from racial representation. They pointed to entrenched legislation in the constitution, such as the Agricultural Landlord and Tenant Act, which could be jeopardized with the reduction of Indian members in parliament. Then, Fijians could do whatever they liked: manmaani. As Reddy said in 1993, his party would welcome common roll 'albeit on a limited scale. ${ }^{51}$ His mind was turned to another kind of political representation which accepted the reality of race but provided for power-sharing among the major communities. This was paramount in Reddy's mind whatever electoral system was in place.

For all his intransigence, though, Kubuabola and other Fijian hardliners knew that the national mood was for some form of compromise, and that some concessions would have to be made. But it was Reddy who took the lead and suggested a compromise. If the SVT agreed to accept in toto the Reeves Commission recommendations regarding the judiciary, the protection of human rights, the freedom of information and others that covered governance and administration, in other words the things that really mattered, he would consider accepting the reversion of the electoral recommendations, that is, forty six reserved seats and twenty five open. Rabuka, to whom Reddy made the suggestion, agreed to put the proposal to his caucus (it was accepted). The NFP-FLP members of the JPSC were relieved, some even ecstatic at the potential breakthrough, including FLP's Krishna Datt and Shiu Sharan Sharma. This was the best that could be hoped for in the face of the Fijian nationalist intransigence. And it fitted in perfectly with the consociational vision of guaranteed group representation Reddy had in mind. That is how the composition of parliament prescribed in the 1997 Constitution came about. Reddy asked that the constitutional 
settlement should be seen in its proper political context. The agreements that were made, he said, 'were made within the context of Fiji as we found it, a Fiji that was hopelessly divided, is hopelessly divided, a Fiji which had not one but two military coups, a Fiji in which the indigenous people are not prepared to accept a system of open voting at present. ${ }^{, 52}$ At least a start had been made in the right direction, and for Reddy that was a positive development in itself. To those who pointed to the retention of a large number of racially reserved seats, Reddy was blunt: 'The truth is different races perceive their interests differently. It is a fool's dream to think that somehow by adopting a particular electoral system you can just remove ethnicity as an equation in politics. ${ }^{53}$

There was another feature of the 1997 Constitution which had not been recommended by the Commission, but which the JPSC introduced. It was an idea Reddy had been advocating for many years: genuine power sharing between the two principal communities of Fiji through the normal processes of parliamentary democracy. Rejecting the winner-take-all approach of the Westminster system, the JPSC recommended mandatory power-sharing. Any political party with more than ten percent of seats in parliament would be constitutionally entitled to be invited to serve in cabinet in proportion to its size in parliament. Would this not be a prescription for political paralysis? How could two political parties, fighting an election on diametrically opposed platforms, be expected to work harmoniously in cabinet? And what would happen to the role opposition in parliament? Reddy was aware of the potential problems, which is why he still favoured the pre-election coalition arrangement; but this power-sharing arrangement would ensure, when all else failed, that no major political party — which in Fiji meant no major ethnic group, because parties were organized on racial lines - would be excluded from power, as had invariably happened under the 1970 Constitution. 'The multi-party cabinet will not be a grace extended to us but it will be our right,' Reddy said. ${ }^{54}$ And he wondered loudly whether it might not be a good idea to suspend the normal operation of party politics for a while to give the novel approach some time to prove 
its worth. That, in the company of ordinary politicians, was too much to expect. The power sharing arrangement, like the Alternative Vote idea, rested on certain assumptions, among them the expectation that political leaders would eschew the politics of extremism in favour of enlarging the common space, that they would give the new system a genuine try. But that, as history was to show, was too much to hope for.

\section{THE STORMY PASSAGE}

The Constitution (Amendment) Bill, 1997 was introduced in parliament on 23 June 1997 by Sitiveni Rabuka and seconded by Jai Ram Reddy. It was the conclusion of a long and turbulent journey, a conclusion which could not have been imagined just a few years before: Rabuka and Reddy, arch political foes, hammering out a constitution that jettisoned the confrontational values of the past to forge a new destiny for Fiji. But was there, among others in parliament, a genuine change of heart or were members voting for change under duress? Rabuka was the first to speak. 'We cannot make any real progress in promoting national unity in Fiji unless and until we have representatives of all communities sitting together in Cabinet and sitting alongside each other on both sides of this Chamber,' he said. The new constitution was 'an honourable beginning of an adventure into the future.' There would be problems ahead, many challenges to face, but he was 'convinced that the best way of facing and resolving our common problems is to develop honest and free dialogue and to arrive at consensus solutions that are practical and generally acceptable to the majority of our citizens. We have to look to the future in terms of conflict prevention.'

Rabuka must have been aware of rumblings amongst his ranks; many, after all, had been campaigning publicly against the Reeves report. That is probably why he said: 'I make a special plea to all honourable Members to be constructive in your contribution to this debate. This is not the time or occasion for small-mindedness or for grand-standing on parochial and narrow sectional interests. This is not the time to instil and ignite fears based on ignorance and prejudices. We cannot agree on everything nor 
Matt Wilson's specially composed prayer for Fiji with 'Jai' and Sitiveni Rabuka in mind

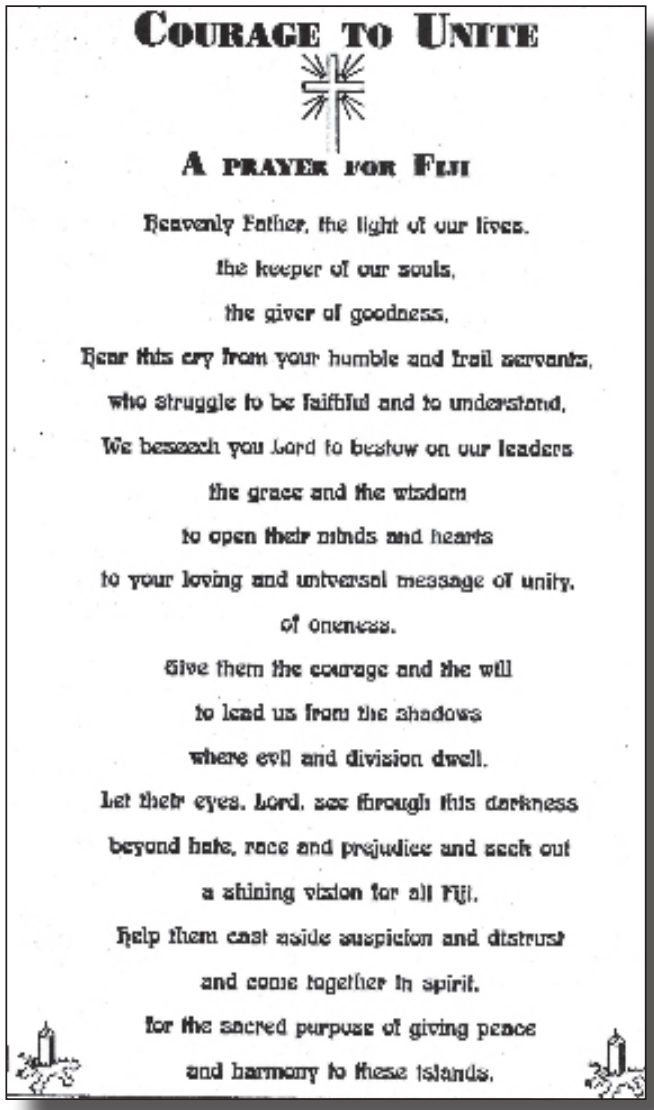

can we expect perfection. There will always be opportunities in the future to improve on this document. That will be in the hands of the younger generation and their descendants who will have the benefit of experience to do so. ${ }^{55}$ He went on in that vein about a new chapter opening for Fiji, about other nations learning from Fiji's experience. But not all of Rabuka's SVT colleagues supported the Bill; many were decidedly lukewarm and ambivalent. The reason for their lack of enthusiasm lay in the perception that, somehow, Fijian paramountcy enshrined in the 1990 Constitution had been whittled away. The aims of the coups, whatever they were, had not been realized. Isimeli Bose, who had taken the lead in presenting the SVT 
submission to the Commission and who was reportedly its principal author, summed up the ambivalence of his colleagues:

My heart likes to believe and wants to believe that the Bill embodies the dream, the vision, the goals and aspirations of many of our people. Indeed, in terms of economy, investment, in terms of trade in the environment of globalization and in terms of the advancement of the country and its people, in the context of liberalization, there is absolutely no doubt the Bill provides the foundation and framework and signals to the world that we are liberated leaders ready to take on the challenge before us. Yet, my head tells me that we have to be pragmatic, to look at realities, and to learn from history. A lot of Fijians, at least those I know, do not like the comprehensive changes we are now proposing. Whilst they have been silent, it is an ominous silence underlying the truth in the culture of silence. Their silence does not mean they have accepted the changes. If an election were held tomorrow, many of us would find it difficult to retain our seats. ${ }^{56}$

Ratu Finau Mara, the parliamentary leader of the Fijian Association Party, spoke similarly:

The Fijians, through their chiefs, surrendered their political, military and spiritual control to the Christian god after the missionaries arrived. The Fijians again through their chiefs surrendered their land and reefs to the United Kingdom through the Deed of Cession. The Fijians again surrendered political dominance of their destiny and fate to a multi-racial Parliament after independence. Now the Fijians are being requested to surrender political control of their own people to multi-party cabinets, by the international community [in collaboration] with local parties, religious groups and political activists. While this is what the word democracy might encompass, I am not certain if the gradual erosion and fragmentation of tribal boundaries is what the Christian God wishes us to surrender. ${ }^{57}$ 
Jonetani Kaukimoce, of the SVT, said that the 'report of the Reeves Commission left most Fijians, most of our provinces, dissatisfied, and the overall feeling was that 'most of the Commission had come to the task with their minds made up, and thus did not objectively give due weight to the submissions made by the Fijians. ${ }^{, 58}$ During the debate, Fijian members, including those who had signed the JPSC agreement (such as Inoke Kubuabola), asked for further changes to meet Fijian nationalist aspirations. One was that Fiji should be made a Christian state. It was an old argument, now only of rhetorical value. Even the President of the Methodist Church, Reverend Dr Ilieta Tuwere, distanced himself from that position, saying that it was more important to live by the Christian faith than to declare the nation a Christian state. Another change the Fijian members wanted was the election of twenty five open seats from provincial constituencies. Reddy rejected the proposal outright, calling it a 'blatant attempt to gerrymander.' There were only two provinces, Ba and Macuata, where Indo-Fijians outnumbered the Fijians. 'From the Indo-Fijian point of view, it will put them out of the frying pan into the fire and it will do nothing to advance the cause of multiracial politics. 59

Facing the prospect of defeat, the hard-line Fijian members demanded a 'free' vote on the JPSC report. Kubuabola led the charge. The constitution, he said, was 'a matter of such importance that freedom must be permitted. There is no point in enshrining several freedoms in our constitution and begin by denying our parliamentarians our right and freedom of choice in what is a matter of conscience. ${ }^{\prime 60}$ It was a fantastic demand of ill-intent. The JPSC report was a political agreement, carefully negotiated by the leaders of all the major parliamentary parties. Now, even those who had signed it wanted the freedom of conscience to vote against it, because the defeat of the agreement was their real motive in asking for a free vote. The Opposition was aghast. But Rabuka agreed with the demand for a free vote, with the proviso that if the Amendment Bill was defeated, he would go to the polls immediately with the JPSC report as the central issue in the campaign. The threat worked, and the critics backed down. Reddy watched the shenani- 
gan and contortions of the government members with deepening dismay. The Bill was passed, he later told me, but with no particular enthusiasm on the Fijian side. The 'unmistakable impression' some of them conveyed was 'of deep suspicion and indeed of distrust.' Rabuka was in a clear minority. Reddy cautioned his people against public celebration of the passage of the Bill, because he knew deep in his heart how uncertain and reluctant the support had been from the Fijian side and how vulnerable Rabuka really was, although he probably did not realize the full extent of his vulnerability. He resolved to stand by Rabuka, to give him all the support he needed to make the constitution work because SVT members were unlikely to.

Strong negative reaction from the Fijian members was expected, but the sharp attack from Labour leader Mahendra Chaudhry caught everyone by surprise. Assuming the pristine moral ground, Chaudhry attacked the Joint Parliamentary Select Committee, and especially Rabuka and Reddy, for what he called 'self-interest and short term contingencies.' The reversal of the Reeves formula for open and reserved seats was condemned, along with the re-introduction of provincial representation for Fijians, and the rejection of the multi-member constituencies in favour of single member ones. 'All those references to multi-racialism that we have been subjected to so far, from both sides of the House, and both inside and outside of Parliament, are just hollow and mere rhetoric as far as the electoral arrangements are concerned,' he said ${ }^{61}$ Chaudhry then rounded on Rabuka and Reddy, without actually naming them. Rabuka and other coup perpetrators 'must show remorse for what they did, and the best way to show this is through an apology to those who were wronged and who suffered as a result of their actions. There is no permanent remedy in just papering over the cracks with a lot of rhetoric about multi-racialism and national unity.' (He had not asked for an apology from Rabuka in 1992, when he had offered his support to Rabuka to become Prime Minister!) And Reddy was accused indirectly of 'selling out' the interests of the Indo-Fijian community again by accepting nineteen rather than twenty reserved seats for Indo-Fijians, which Chaudhry alleged their numbers entitled them 
to. Invoking the name of Mahatma Gandhi several times in his speech, Chaudhry said 'I am only too aware that mine is a voice in the wilderness. The rest of my colleagues are happy enough to settle for the shadow rather than the substance of multi-racialism.'

Chaudhry was right in one respect. His was certainly a voice in the wilderness. And among those who disagreed with him were his own colleagues on the Joint Parliamentary Select Committee, Shiu Sharan Sharma and Krishna Datt, both of whom had been privy to the intense and difficult negotiations which had preceded the final JPSC report. Labour, it should be noted, had members on the sub-committee chaired by Inoke Kubuabola which considered the electoral arrangements and the composition of parliament, and it was the failure of that group to reach a consensus that had led to a request for Reddy to intercede with Rabuka directly. Reddy recalled Chaudhry telling him before he meet Rabuka: 'Jai, make sure the Indian seats are entrenched' For him then to cavil later seems curious. It is possible that Chaudhry was genuine in his convictions, and should be given the benefit of the doubt, though he never raised these issues later when he was Prime Minister.

There is another explanation: political survival. Chaudhry stood to gain everything and lose nothing by criticizing aspects of the constitution in whose formulation he had a hand. He knew the Amendment Bill would be passed anyway, with or without his support. If he voted against it, he might be the only one doing so, and what a great political disaster that would be. Chaudhry was too astute to be caught in a cul-de-sac. By taking the stand he did, he could keep his political power dry and his ideological purity intact and blame the others, especially Jai Ram Reddy, for the shortcomings of the constitution, for its deviations from the recommendations of the Reeves Commission (which he successfully did in the 1999 general elections). Throughout the review process, Chaudhry had played the second fiddle to Reddy: it was Reddy who had the initial discussions with Rabuka on the review of the constitution; it was Reddy who had taken the lead in preparing the Coalition submission; it was Reddy that the Indo- 
Fijian community looked to for guidance on matters of crucial import; and it was Reddy who was emerging as a national leader respected by the other communities. Political survival thus dictated that Chaudhry quickly remove himself from Reddy's shadow and carve out an independent niche for himself. His performance in parliament then was designed, in part at least, to achieve that end. 'The FLP', Chaudhry said, 'will not be a party to sacrificing Fiji on the alter of racial politics once again nor can it be a party to any constitutional arrangement that undermines the interest of any one community in Fiji and is not fair to all its people.' But then he turned around and signed the Constitution Amendment Bill, which was passed unanimously.

Reddy had been boiling inside as he listened to criticisms and calls for amendments to the JPSC report, especially by people who had been members of it, their speeches of pure political opportunism and peculiar venom, the chicanery and duplicity of honourable members of parliament. ${ }^{62} \mathrm{He}$ was at his incisive best. How could people (like Inoke Kubuabola, for instance) sign the report of the JPSC and than stand up in parliament and say with complete impunity and a straight face, 'I disown my own agreement because I am free to do so,' in the name of freedom of speech, especially as they were present on the Committee not in their individual capacities but as representatives of their parties? If that were allowed, agreements would cease to have any meaning at all. Reddy explained why Fiji should not be made a Christian state and why the various declarations on indigenous rights were not applicable to Fiji, asserting that 'there is no treaty or convention in the world that sanctions the discrimination of one group of people by another, in the name of ethnicity or indigenousness.'

Reddy then reminded the House of how difficult it had been to achieve consensus in a deeply polarized atmosphere. When the review exercise began, he told them, the views of the different parties and communities were so divergent, the gulf so great that the 'best we could hope to seek to achieve at this stage was some middle ground where we could meet and which would constitute an accord amongst the majority of people involved.' 
Ground had to be given, and everybody made concessions. 'No one can have it all their way, and also have an accord.' He then turned to those — he had Chaudhry in his sights, no doubt — who decried consensus politics and always spoke from extreme positions, seeking political advantage. Consensus was only possible among men and women of goodwill and good sense, Reddy said. 'Consensus was not for the belligerent and the self-righteous. Consensus making and consensus seeking would be quite foreign to their nature. Let us not allow them to hijack our agreed agenda of securing for our people a constitution that is broadly acceptable now, but leaving the room wide open for any further reform that they may seek and agree upon at a later stage.' This gradual, incremental approach, reaching out and cultivating the middle ground, an integral part of Reddy's political outlook, was an anathema to Chaudhry brought up in the confrontational culture of trade union politics.

Reddy then talked about open and reserved seats regarding which Chaudhry had taunted him. As mentioned, the sub-committee looking at the electoral system and composition of parliament was chaired by Kubuabola and included Labour's Krishna Datt among its members. The committee met from September 1996 to April 1997, without making any progress at all. The Fijians were adamant about retaining all communal seats. They would not move. There was an impasse. On 10 April 1997, Krishna Datt, Deputy Labour leader and member of the committee, approached Reddy and said to him: 'We have reached a deadlock; there is no progress possible. The SVT will not budge, they will not agree to anything but cross-voting; and we have decided in the sub-committee that you should meet the Honourable Prime Minister and talk to him about this issue.' Reddy had not usurped the role and responsibility of the subcommittee, he reminded the House, as was alleged.

Reddy and Rabuka met. Rabuka reiterated that the SVT was not prepared to move from the communal seats. Reddy rejected the proposal for cross-voting because it was a 'discredited system,' which had worked to the great disadvantage to the NFP ever since its introduction in 1966. 
After a long conversation, as already mentioned, Reddy proposed twentyfive open seats and forty five communal seats, and Reddy also suggested entrenching the Indian communal seats. Rabuka provisionally agreed. The two leaders then took the consensus they had reached to their respective caucuses. There was no private deal, as Chaudhry had alleged. The Opposition group, to whom Reddy reported the discussion, included Labour's Shiu Sharan Sharma and Krishna Datt (Chaudhry was overseas attending a conference in Manila), unanimously agreed with the proposal and authorized Reddy to place it before Rabuka. When the two met again, Rabuka asked Reddy to consider reducing the number of Indian reserved seats from the previously agreed nineteen to eighteen, because the General Voters, represented by Leo Smith, insisted on three and not two reserved seats. Smith wanted an immediate answer, but Reddy refused. He would need the weekend to canvass the issue with his colleagues. They did not agree to the proposal for reduction.

When the Opposition group met on 14 April, Reddy explained to Chaudhry, who had by then returned from overseas, his discussion with Rabuka and asked him whether he had any reservations. Chaudhry had, about the number of Indian seats. At the next full meeting of the JPSC, the issue of the Indian seats came up again. Chaudhry then suggested that the nineteen Indian seats could be retained, and the three seats for the General Voters accommodated by increasing the size of the House from seventy to seventy one. The proposal was accepted. There would be attacks on Reddy's credibility and integrity for politically motivated reasons, but that did not unduly worry him. Speaking from 'the depth of my heart,' he said his conscience was clear. 'I have worked very hard and very sincerely to bring this review to a successful conclusion. I am not perfect. I do not know all the answers, and I may have made mistakes in the journey, but my intentions are pure. All I am seeking is a country where people of all races and communities can live as brothers and sisters in peace and harmony.' Would Reddy have jeopardized the agreement he had so patiently fashioned with Rabuka over one additional seat for Indo-Fijians? I doubt it. His mind was 
focused on a bigger picture, a larger momentum, in which one seat would not make much difference.

The constitution which Reddy had worked so tirelessly to achieve was not the end of the journey but just the beginning, he said, and the constitution by itself would not solve Fiji's problems. A broad-based approach, from many fronts, was required to move the country in the direction the constitution was pointing. 'Our educational system must be changed so that the curricula and school texts reflect the multi-racial background and character of the country,' he said. We must learn the languages of the other communities.' The non-indigenous in particular must learn Fijian. In our day to day activities, we must be more open to the influences of other cultures, and we must develop social relations with members of other ethnic groups.'

Nation building was an enormous task that required the concerted efforts of everyone. 'We must not rely only on the Government and public institutions to mediate between the communities. There is a clear role for non-governmental bodies, trade unions, co-operatives, women's and youth organizations to carry forward this national agenda. Social organizations must take responsibility for the promotion of human rights and human dignity. All of us must make a firm commitment through the constitution and in other ways [to build] a united, peaceful, prosperous and just Fiji.' Reddy was speaking the language of reconciliation and reconstitution, of massive social and cultural and not only political and constitutional reform, which lay beyond the comprehension of those whose principal concern was the search for narrow political advantage. A statesman makes the occasion, as the saying goes, but the occasion makes the politician. Speaking during the 'Constitution Awareness Campaign' week in July 1997, Reddy put his finger on the central dilemmas and problems of politics in ethnically divided societies:

Seeking out the middle ground and holding it is not easy in a multiracial society because you are always being clipped from 
both sides of the equation. But we must establish a middle ground, protect it and defend it if we are to remain a harmonious and peaceful society. Now we politicians endlessly talk about progress, prosperity and peace. Let me say that peace, progress and prosperity do not come for the asking. We can have peace, we can have progress, we can have prosperity when we establish a just society. Peace is the product of justice; we need to create a society where all our people irrespective of race, colour, religion or culture feel that they live in a just society. ${ }^{63}$

While Reddy's character and integrity were being assaulted by his own people, with whom he had struggled and suffered for over a decade to achieve a fair and just future for his people, people he thought who knew better but chose to ignore the truth, it was people in other communities who came to appreciate Reddy's vision and purpose and honoured him in the way his own people did not. Among them was the Great Council of Chiefs. As the review process was proceeding through the JPSC, the GCC requested to be kept informed. When they were presented with the reports of the JPSC meetings, the Chiefs wanted certain changes. In particular, they wanted to have Fiji declared a Christian state as an essential ingredient of nation building. The JPSC received the request but, for obvious reasons, declined to entertain it. It was in the course of these exchanges that Rabuka accepted the idea (mooted by Adi Litia Cakobau, though the idea of non-Fijians addressing the GCC had originated with Ratu Josefa Iloilo, who was then the President of the Senate $)^{64}$ of Jai Ram Reddy addressing the Great Council of Chiefs. That would also silence his opponents in the SVT and 'the doubters in the Fijian community,' Rabuka said. 'There was no one better to put the case [of the constitution] than the eloquent Leader of the Opposition. ${ }^{65}$ Rabuka also accepted Reddy's suggestion and Mara (initially) agreed that Sir Moti Tikaram's name be put forward as the next Vice President of Fiji, but when the moment came, Mara changed his mind in favour of Ratu Josefa Iloilo (without consulting or informing Rabuka), thereby scuttling what would have been an important symbolic gesture of reconciliation. ${ }^{66}$ 
The twists and turns of Fiji politics were many, and often mysterious. But the invitation to Reddy stood, and Reddy gave perhaps the finest speech of his political career. As rhetoric, it was almost perfect: the right pitch and fine choice of words, transparent and honest, sensitive without being supplicant, touching the right chord about duty, responsibility and reciprocity, about history and memory, destiny and destinations, and about fate and the future. It was Reddy's finest moment in politics, remembered warmly across time. The speech is reproduced at the end of this chapter. 'Mr Reddy's speech to the chiefs was a defining moment in our history,' Rabuka recalled, 'and sealed the support of the Bose Levu Vakaturaga for the new constitution. ${ }^{67}$ This assessment was widely shared, as already noted. Many leading chiefs had tears streaming down their cheeks as Reddy finished speaking. At his best, he had that effect on his audience. He was given a standing ovation, led by the President, Ratu Sir Kamisese Mara, no less.

A year later, on 29 July, 1998, speaking informally at the launch of the 'Constitution Awareness Campaign, ${ }^{68}$ Reddy gave what he called a 'personal perspective, a subjective perspective' on what had happened over the previous six years as Fiji embarked on its long and arduous journey of constitution-making. He began by recalling the words of a visiting scholar who told him: 'You know, I am a student of politics and I have never known any society where political power was taken away by force, by the use of force, and given back to the people in the way you have accomplished here in Fiji.' He thought the exercise unique. Reddy was clear in his mind what the reason for the remarkable turn of events was. It was, he said, due to 'one simple fact and that is the innate decency and the goodness of the people of this country. I believe that has been the single most important factor that has helped us accomplish this transformation.'

Reddy then spoke about what the constitution sought to achieve and about the problems that lay ahead. The constitution, he said, 'is an attempt on paper to move Fiji away from the confrontational politics of yesterday to a gentler, more consociational politics of the future.' For the constitution to work required 'transformation in each and every one of us.' There 
were many days of despair and agony along the way, but there were two or three qualities that helped the process along. One attribute, Reddy said, was persistence: 'We didn't give up, we didn't walk away, we stuck to the programme that we made for ourselves. And we talked and talked.' But not all the talk took place in the formal setting of the Joint Parliamentary Select Committee meetings. 'There were many conversations, many discussions, much dialogue outside of the formal format where concessions were won or given, where thinking changed, ideas changed, new ideas were brought forward, mooted, accepted with qualification and without qualification.'

This rings true to me; this is how the most difficult issues concerning the composition of parliament were discussed between me and Tomasi Vakatora, away from the formal meetings of the Commission, behind closed doors or at retreats, where ideas could be discussed freely, off the record, leaving ample room for flexibility and change. 'This has been a great journey in communication,' Reddy said, 'and a great journey in learning from others what they think, how they felt, and telling them how I feel or those I represent feel.'

There was much ignorance about what the constitution was about, Reddy went on. And that had been the cause of so much upheaval in the past, the cause of coups. It was of utmost urgency 'to educate our people about what is in the constitution and their rights.' But instead of enlightening the people, the very people who had been involved in the formulation of the constitution were back in their constituencies misleading and misinforming their people. 'Let me be bold enough to say that there has been a constant cry that the interests of the indigenous Fijian people and the Indian people have [been] sold out under this constitution.' That, Reddy said, was a 'monstrous lie,' 'because this constitution does not sell out anything. Like all compromises, it has attempted to seek out the middle ground — a middle ground which caters for the needs, wishes and the aspirations of all our people.' Reddy was proud of the constitution, an accomplishment thought impossible just a few years back. He hoped that for an interim period of five to ten years, all political parties would embrace 
Jai Jam Reddy giving his historic address to the Great Council of Chiefs, 1997. Courtesty of Fiji Times.

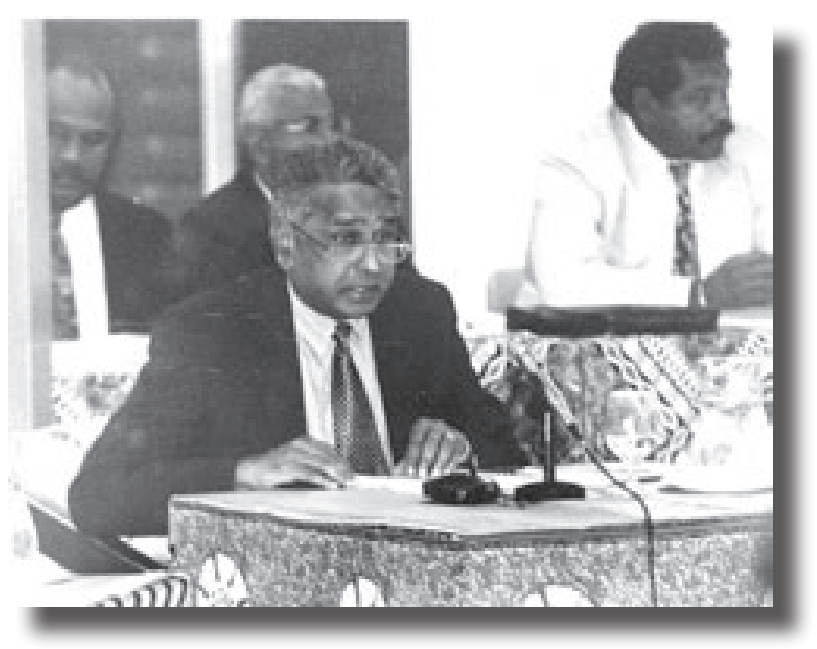

the concept of multi-party government to give Fiji a smooth transition to a new era. Party politics being party politics, that was too much to hope for. Reddy had played his part, and hinted ever so slightly that he might not be around for too much longer to shepherd the constitution through the turbulent days that lay ahead. The 'onus now is on those who will inherit this constitution,' he said. It was an 'enormous burden.' 'It is not a burden anyone can take lightly because if you fail in working this constitution in the way in which it is designed to work, then you will have nobody else to blame but yourselves.'

The mid-1990s would have to be one of the most remarkable periods in Fiji's modern history when old orthodoxies were overturned, and new paths forged in the most difficult and unpredictable of circumstances. It was the same Great Council of Chiefs which had endorsed the coup in 1987, backed Colonel Sitiveni Rabuka 'to the hilt,' sponsored an exclusively Fijian political party to pursue the interests of the Fijian people, and generously supported the course of action of the SVT government. Now, ten years later, despite the prodding of its own influential members, it was backing a non-racial constitution broadly acceptable to the majority of the people of Fiji. Equally remarkable was the transformation of Sitiveni 
Rabuka. To most observers, the Rabuka of 1997 was not the same as the Rabuka of 1987. Then he was a simple military man called upon — as he insisted - to overthrow the Coalition government, variously justifying his actions as a divine injunction to save his people from 'heathens, his cultural and traditional obligations to safeguard the rights and interests of his people, to forestall a bloodbath planned by Fijian extremists. Then, somewhere along the way, Rabuka changed. International contacts and travel, Rabuka said, 'influenced me in my thinking, ${ }^{96}$ along with the broadening and sobering experience of being the leader of a multiracial country. There were still inconsistencies and exasperating off-the-cuff remarks, but he grew in the job, developing a more sophisticated understanding of the political dynamics of Fiji.

Rabuka was encouraged in his moderate path by his adversary, Jai Ram Reddy. Initially both were understandably sceptical of each other. Reddy, after all, was seen by many Fijians as the man who had masterminded the defeat of the Alliance party, and was high on the list of people the Fijian extremists would have been glad to dispose of. But over time, his political opponents came to see Reddy as a mature and responsible leader, a man of integrity and principled tenacity they could trust to keep his word. As Harish Sharma said, 'Reddy is not a double-faced man. Rabuka must have been convinced that both he and Jai are striving towards a common cause of nation building. ${ }^{, 70}$ Trust, that rarest and most precious of gifts, was what Jai Ram Reddy was also able to win from the Fijian people. He had passed their test of fire, agni pariksha, as no other non-Fijian leader in postcolonial Fiji ever had, or was likely to in the foreseeable future. 


\section{INTERLUDE}

\section{REMARKS AT THE PRIZE-GIVING CEREMONY OF QUEEN VICTORIA SCHOOL, MATAVATUCOU, 27 NOVEMBER 22, 1997}

I am grateful to the principal of your school for inviting me to be with you this afternoon. As I put together some thoughts to share with you, I found myself reflecting on my own school days. I was pleased that I am not yet that old that my memory had faded.

Many recollections came flooding back. I remember all the mixed emotions one feels on an occasion such as this - sadness and loss, happiness and accomplishment and some nervousness about the future. You have reached the end of one stage of a journey - and the next stage is soon to begin. For the seventh formers, the new journey is a major change as you go on perhaps to other educational institutions or even begin a career.

Yes, for the seventh formers, the emotions of today will be the keenest. I can relate to your happiness and your sadness. Happiness because you must feel a sense of achievement and relief that a phase in your lives has come to an end, and another, perhaps more challenging and exciting, is about to start. You will be feeling a sense of sadness because you will be leaving an institution that has been part of your life for several years and that you have come to care about and perhaps to love. Some of you will be leaving good friends behind. Many of you will have established a bond with your teachers. You will be sad to part company with those who have taught you, have cared for you and generally acted as guide, philosopher and friend. You will bid farewell to the familiar, peaceful and friendly surrounding of this institution for the last time as students. 
For those of you who are leaving, this must also be a day of thanksgiving. Thanksgiving for the unique privilege you have had to be part of this distinguished institution. QVS has a long and proud history. It has produced many distinguished leaders in every facet of our lives - from politics, to the professions and in traditional roles. Here you have had the benefit of teachers who are well trained and qualified to give you the best that our education system can offer. The physical facilities at the school are among the finest in the country. So you can truly be grateful for what QVS has given to you. I am sure that as years go by, you will be able to look back at your years at Queen Victoria School, with pride and an abiding sense of satisfaction.

A vast majority among you will return to the school in the new year. You will have earned your holidays after a year's academic work. For those of you who return remember that this opportunity will not present itself again. You must make the most of it. While not neglecting your sporting and other extra-curricula activities, you must aim for academic excellence. The world outside is becoming extremely competitive. Excellence is the key to success and you must lay the foundations for your own standards of excellence here, with the help of the school.

We live in extremely challenging times, with the world around us changing at a dizzying pace. We are witnessing a communications revolution in our time. The television, satellites, radio, newspapers, magazines, computers, fax machines, the internet - all are increasingly becoming part and parcel of our daily existence. They have a profound impact on the way we think and the way we do things. Profound changes are also taking place in the social and political aspects of our society. All of you will need to meet these challenges, as you adapt to and help shape a new exciting future for all of us here in Fiji. As I said earlier, many of you will move on to other 
tertiary institutions where you will receive further training to meet the differing needs of our country — in politics, in commerce, in government administration, in law, the military, the police, in agriculture and so forth. All of you here this afternoon, and many thousands of young people around the country of different races and sexes, will determine the future direction of this country.

I would urge you today to think very hard about what I am going to say next. The choice for you is this: you can be part of a wholesome, united and prosperous Fiji where men and women - and children too - from all our races and political persuasions can live in peace and harmony. Or you can be part of a nation torn by racial strife and religious disputes — a nation at odds with itself. The young people of this country are uniquely placed to show us the way and to correct some of the mistakes made by my generation. 1997 has been a momentous year in Fiji's history, a year when we have, together, laid the foundations for an exciting new future. I am referring here of course to the amended 1997 Constitution which was unanimously approved by both houses of parliament and the Bose Levu Vakaturaga. These amendments seek to achieve a number of broadly based objectives.

Firstly, they aim to remove all forms of discrimination against people or groups based on race or gender. In this respect, the new constitution reaffirms those universal values enshrined in a number of international charters and conventions including the United Nation's charter itself. Secondly, the constitution, while recognizing the existence of separate ethnic communities within the nation, seeks to take the country away from purely ethnically-based politics to a more multiracial system. Thirdly, the constitution seeks to create strong incentives for Fiji's diverse communities to decisively move away from the confrontational type of politics to greater cooperation. 
One of the most positive measures is the introduction of provisions which require that henceforth Fiji should have multiparty government rather than single party government. In the past, single party government has usually meant one race government — or it has been perceived as that. This new approach should usher in a new era of peace, harmony and representative rule.

The aims of the new constitution can be achieved only if the people of Fiji, and particularly the young, respond to the challenges it throws up. Fiji is a multiracial and multi-religious country. This means that often there are great diversities in thought and expectation between the communities. Fiji can prosper and progress only if these diversities are harmonized — and gaps that exist between our peoples are narrowed and bridged.

To achieve our national goal of peace and harmony and progress, there has to be a dramatic change in attitudes in our society. We need to move away from purely ethnic pre-occupations to a more national approach to our problems. We all need to understand that at the end of the day we are one people pursuing the same ends peace, security, and progress for ourselves and our children. These can be better secured if we learn to work together and live together. That is the great challenge before all of us, and particularly the young. It is the challenge I present to you today.

You belong to a proud race of people. You have much to be proud of. While you must be firmly rooted in your own culture, language and traditions, you must also recognize you lose nothing, but gain much, by learning of, and about, the language, culture and ways of other communities around you. We live in a interdependent world - cultural isolation is no longer an advantage, it is a distinct disadvantage.

The next century is a little over two years away. If we are to be ready as a nation for the next millennium, we need to act urgently on our 
plans for a just and democratic society. I sincerely believe we in Fiji can build a model society, the kind that all human beings long for; a society where the basic needs of all citizens are satisfied, rich and poor, and all our languages, cultures, and art forms flourish and give us a sense of fulfilment. History has allowed us to dream freely; there is no embarrassment in dreaming of greatness for our country.

We must be well-informed and alert, build on existing strengths, keep a questioning mind, be unafraid of new ways of thinking and doing things, and remain in control of our national destiny. It is upon you — the young — on whom the responsibility falls for taking this country forward, united and in harmony with itself. The teaching you have received in this great school will help you develop not only your own lives, but the life of our country. Thank you and God Bless you all.

\section{JAI RAM REDDY'S ADDRESS TO THE BOSE LEVU VAKATURAGA, JULY 1997}

Ni sa tiko saka na Turaga na Presideti, na I Liuliu no noda Matanitu, na Gone Turaga na Tui Nayau, na Sau ni Vanua ko Lau

Ni sa tiko saka na Turaga na I Liuliu ni Bose Levu Vakaturaga, na I Talai ka Prime Minister ni noda vanua

Ni sa tiko saka Turaga kei na Marama bale, lewe ni Bose Levu Vakaturaga

Ni sa tiko saka na Turaga kei Marama lewe ni Bose Veika Vakaitaukei

Ni sa tiko saka na Turaga kei na Marama lewe ni Matabose e Cake, I Seneti

Today I come before you deeply moved by what this moment means - to you, to me, and to all the people of our motherland. In a time 
which future generations will remember as a defining moment for this country, the grandson of an indentured labourer answers the call of the Bose Levu Vakaturaga. And together we keep an appointment with history.

Never before has an Indian been invited to address this august body. I am honoured and humbled to be the first. And I am grateful for the opportunity to share my thoughts with you in person. I have made many speeches, in many places, and on many high occasions. But what I have to say this morning is for me the most important of them all.

The very fact of my being here says more about the true spirit of this young nation than any words can express. Our presence together in this forum is symbolic of the emerging mood of great optimism that is abroad in this land. We come to put the final seal on a troubled era and to open a new chapter of hope. And with your indulgence I will try and do justice to the occasion.

I come before you to speak from my heart. I come to speak to you of history, and of the making of history. I come to speak of fear and of the end of fear. I come to speak of truth and destiny.

Chiefs of Fiji, this Council and its members, together and individually, represent a great and binding power for this nation. Since time immemorial your ancestors have provided leadership and guidance for the Fijians. In ancient days, the chiefs of these islands were called upon to nurture and protect a people and their culture.

Yet they were not always united in this task. There sit here today men and women whose forebears were sworn and bitter enemies. Fiji was divided, torn asunder by war and hatred. Yet out of the fires of conflict the warring chiefs of Fiji slowly forged a common identity — recognizing that failure to do so could lead to continuing death and destruction. Those who, with Ratu Seru Cakobau, ceded these islands to Queen Victoria, did so in the belief that uniting to put an end to conflict would preserve their identity and way of life. And so it did. 
Since the creation of this high Council, the Bose Levu Vakaturaga has been the source of Fijian unity. Through the turbulence of the past 100 years, successive generations of chiefs have passed down the wisdom of those who went before. You are the inheritors of this legacy.

Chiefs of Fiji, many of you descend directly from those far-seeing leaders who joined Ratu Cakobau in the cession of Fiji. So, too, the strands of history that led from their momentous decision to bring us to this day and this far.

From the coming of colonial rule, through Girmit, through world wars and depression, through profound social and technological changes, independence and coups, time and chance have brought together many threats which Ratu Cakobau and his fellow leaders could never have imagined. But, I would humbly suggest that, just as they were called upon to bind together a divided people for the mutual good, so is this great Council assembled here today, called upon again. You are called upon to be a foundation of unity for the islands your ancestors set upon the road to modern nationhood. Chiefs of Fiji, with the greatest respect and humility, I submit that you are chiefs, not just of Fijians, but of all the people of Fiji.

I said I would speak to you of truth. Plainly and honestly, then, I say to you this: the Indians of Fiji, brought to these shores as labourers, did not come to conquer or colonise. We, their descendants, do not seek to usurp your ancient rights and responsibilities. We never have. We have no wish, no desire, to separate ourselves from you. Fiji is our home. Fiji is our only home. We have no other. We want no other.

Our ancestors came to this land in search of a better life, in search of a future they dreamed of for their children and their children's children. Though they travelled to these islands long, long after your ancestors, surely the dreams and hopes of those who landed from the Leonidas were no different from those who came ashore after the epic earlier voyages from the West. 
Let me reaffirm that we honour your place, and the place of your people, as the first inhabitants of Fiji. We recognize, and have always recognized, the unique and special role of this Council. We seek not domination, indeed, we cannot dominate - we are not the majority ethnic group in his multicultural nation: you are. What we seek is partnership. We seek a country whose children of all races grow up with a deep understanding and respect for each other's cultures, languages and traditions. We seek a country which encourages the best and the brightest - indeed, encourages all its people, or all races - to work together. We seek not to threaten your security, but to protect it. For in your security lies the basis of our own.

Chiefs of Fiji, I said I would speak to you of fear. This country has for far too long lived with fear, and we have for too long let fear stand between us and what we can become. You and your people have been afraid for your identity, for your way of life. You have been afraid of being dispossessed in the land of your ancestors, of being swamped by migrant people. For our part, Fiji's Indians — and to some extent other communities — have been afraid of always being second-class citizens, condemned to perpetual insecurity in the place of our birth, doomed to be eternal vulagi.

Atsome point in our history, there may have been justification for the fears of both communities. Indeed, politicians of both groups have at various times, capitalised on those fears, maybe with the best of intentions, but for their own ends. The political system from the independence period places emphasis on communal solidarity. All too often, it seemed to be, sadly, the Fijians for the Fijians and the Indians for the Indians.

In the struggle for votes, Fijian politicians found themselves aligned with Indians who were on the political fringes of their own community. Similarly, the Indians were associated with Fijian politicians removed from the mainstream of Fijian thought. There was intense rivalry, which, in turn, bred resentment. The Fijians felt the Indians were fragmenting 
their people and Indians felt the same. In a way, elections became selfdefeating. We had allowed fear to become our driving force - and there was fault on both sides. I think many of us who were involved see now that we were wrong. Yet, at the time, we seemed locked into this pointless cycle of inter-communal rivalry.

Chiefs of Fiji, I said, too, that I would speak of an end to fear. I reach out to you today, then, and I seek your blessings for a better way of life, a way without the fear that for so long cast its shadow over us. For the last several months, a multiracial, multiparty parliamentary committee, has been on a quest for a new direction in our national politics. This committee, as you know, comprises representatives of the main political parties, speaking for the vast majority of the electorate.

I am so proud to tell you, that for the first time, all of these parties are speaking with one voice. We have attained what previously seemed unattainable. We have found a comprehensive middle ground. By confronting our fears honestly and openly, we have let light into the dark corners of the national soul — and found hope. It is our belief that we have agreed on a constitutional formula which will encourage us — Fijians, Indians and everyone else - to stand together. We want to convert what has been a culture of confrontation into a culture of cooperation. In broadly-based national government, we can complement each other and concentrate together on the vital needs of a developing nation.

Perhaps the most far-reaching and visionary change advocated is the requirement for the leader of the parliamentary majority to have minority parties join cabinet, in proportion to the numbers they have in the House. Unlike the traditional Westminster system of confrontational government, this model demands that major political parties work together. If we can succeed, we may well find ourselves serving as an example for other multiracial nations. And, like the Prime Minister and other members of this committee, I believe we can make it happen. There is a risk, but it is a risk worth taking. And I pledge to you my unwavering 
determination to do everything in my power to help it succeed. Like the chiefs of old, we must stand together, or we will surely fail.

I know that you have been closely observing constitutional developments. You have shared with us some of your concerns and I am sure they will come up during your meeting. It is not my place to report on the specifics. But I can assure you that issues you raised were given the most serious consideration by the entire committee. What I can say is this: I am convinced that indigenous interests you have solemn obligation to protect are in no way weakened under the arrangements we are now proposing. The protection of Fijian interests is in fact strengthened. No laws relating to the Fijian people or their land can be amended without the consent of the Fijian people.

In particular, this Council's nominees in the Senate would effectively retain a veto option over such legislation. The new constitution also specifically directs the parliament of Fiji to make provisions for the application of customary laws. These must have regard to customs, traditions, usages, values and aspirations of the Fijian and Rotuman people. In a further indication of the unanimous support of all other communities for the special place for the Bose Levu Vakaturaga, the new constitution leaves full authority for the appointment of the President and VicePresident of Fiji with this Council.

Though the Reeves report had suggested a different arrangement, the committee felt authority should remain with the chiefs. The Indian leadership fully supported this provision. We did so out of the respect we hold for this Council. We did so in the belief I spoke of earlier - that the members of this Council are not just the chiefs of indigenous Fijians, but of all Fiji.

In our deliberations we have been conscious that it is not just the eyes of Fiji that have been upon us. The international community, too, is intensely interested in the solutions we are finding. We should, therefore, 
all be proud that our consensus not only satisfies the aspirations of Fiji's people. It will also win the acclamation of the world.

This opens the way for us to once again take our rightful place in the Commonwealth. I know this is your wish. It is the wish of Fiji's Indians as well. Like you, we look to the Crown as a noble and comforting symbol of unity. May the day soon some when Her Majesty can stand before you — indeed before us all — restored as the Queen of Fiji.

Chiefs of Fiji, you have done me a great honour today and I shall never forget it. Neither will the Indians of Fiji. We have written a page of our history this morning. So it is fitting that I conclude by speaking of making history.

In one his nation's darkest hours, that courageous and visionary American leader Franklin Roosevelt, said, and I quote: 'To some generations much is given; of other generations much is asked. This generation has a rendezvous with destiny.' Much was asked of Ratu Cakobau's generation of chiefs. Much is asked of this generation of chiefs. Much is asked of us all.

Let us, therefore, gather our courage and set ourselves, united, to the finishing of the noble task to which our history, our heritage, and our beloved motherland now call us. This generation must keep its rendezvous with destiny. And then, to future generations, much will be given. My Almighty God bless you, and all our people. 


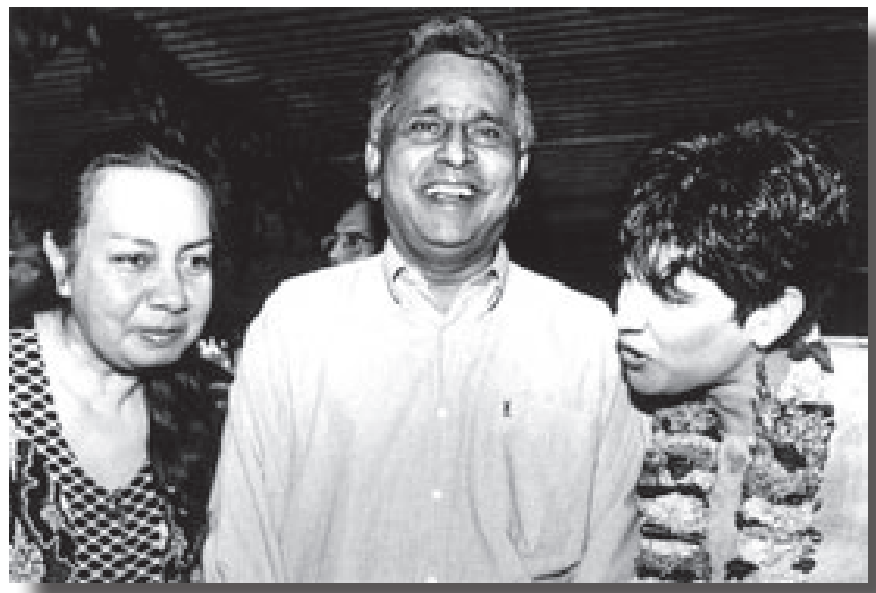

With Emelita Wilson and Imrana Jalal.

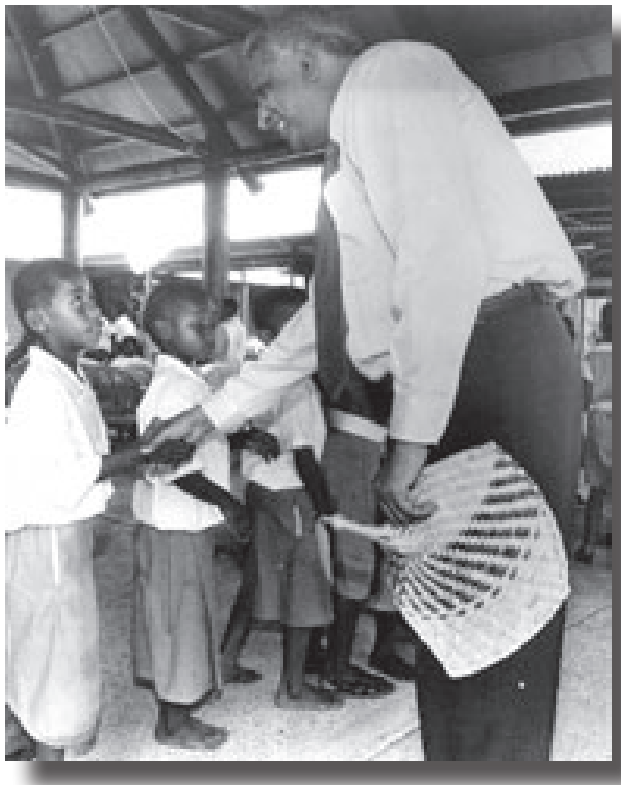

With Fijian Primary

School students. 
Reaching out, being feted after the passage of the 1997 Constitution.

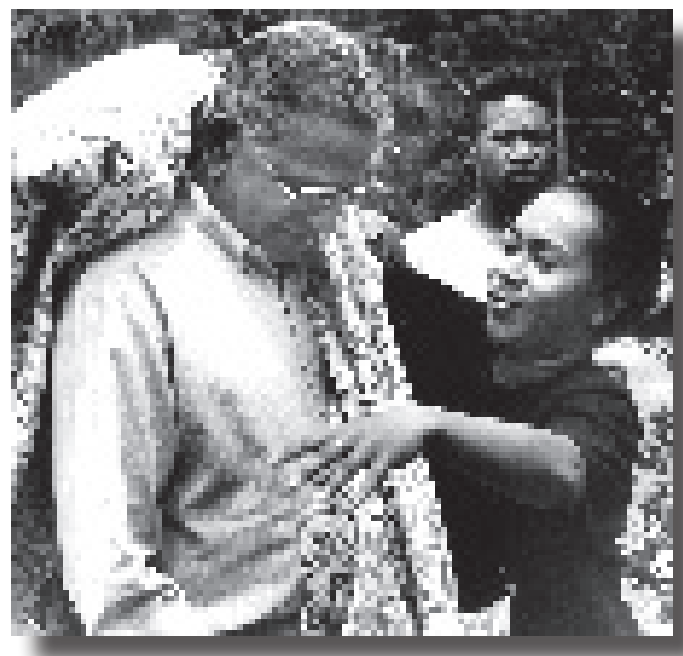

With Chief Emeka Anyaoku, Secretary General of the Commonwealth, at his home in Lautoka

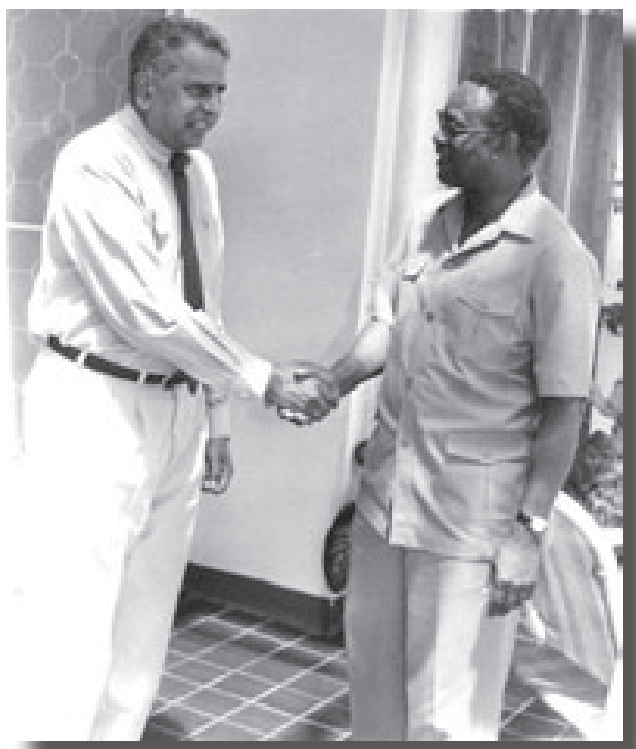




\section{ANOTHER WAY: \\ ADDRESS TO THE NFP CONVENTION, 1996}

When I spoke to you at Labasa last year, I detailed for you the review process to that date. I also addressed you at length on the Terms of Reference for the review, how that was arrived at, and how they were appropriate and fair to all interests. I also talked to you about the appointment of the Review Commission. It is important today for me to pick up the events since then.

You will recall that the Commission consisting of Sir Paul Reeves (as Chairman), Dr Brij Lal and Mr Tomasi Vakatora commenced work about the middle of 1995. You are also aware that before the appointment of the Commission, our party started preparatory work on our submission to the Commission. As early as 1993, we had engaged the services of Professor Yash Ghai for this purpose and his services proved invaluable in the discharge of that responsibility. At a meeting of the Working Committee held in this very hall on the 13th August, 1995, Professor Yash Ghai and I explained in great detail the submission for the approval of the party. On the 24th day of August, 1995, the National Federation Party made its submission to the Commission at Suva jointly with the Fiji Labour Party. The submission has been printed in a book form and is available for those of you who may be interested in it. The submission was comprehensive, and well received by people of all races in Fiji.

We sent copies of these submission to all the members of Parliament, to all Senators, to representatives of foreign governments and to our supporters and well wishers.

Today, I would like to record our gratitude and heartfelt thanks to Professor Yash Ghai and to Jill Cottrell who assisted him in compiling the submission. Funding for this mammoth task came from our supporters and well wishers and I would also like to record my 
appreciation to them for their contribution. I also wish to record my appreciation to the government which gave us a sum of $\$ 37,500$ towards meeting the costs of preparing and presenting the submissions. I am also happy to report that supporters of National Federation Party throughout the country came forward in large numbers to make their views known to the Commission. I thank them also. The review process is coming to an end. The Commission was to report to the President at the end of June 1996. I am advised that there will be some delay in this due to the complex nature of work involved, and the very extensive consultations that had to be undertaken. We can now expect the report to be handed to His Excellency the President towards the end of July or early August.

\section{WHAT AFTER THE REPORT?}

The process, after the Report is handed to the President, will be both difficult and delicate. How the political leaders, parties and the people handle the Report may well determine its destiny.

It is my belief that it will be unfortunate if the recommendations of the Commission were to become the cause for political posturing - or political football, if you like, before we have all had an opportunity to study and reflect upon the recommendations calmly and dispassionately. The Report will be nothing more than recommendations - but they will be recommendations of a Commission which will have arrived at them after a long, exhaustive, and painstaking inquiry. The credential of the Commission is beyond question - and they were appointed by consensus arrived at between all political parties represented in Parliament.. The recommendations, whatever they might be, will deserve the utmost respect and consideration. We should commit ourselves to respond to the Report in a responsible manner bearing in mind the considerations I have just mentioned. 
It is expected that after the cabinet has had an opportunity to look at the Report, it will be tabled in both Houses of Parliament. Thereafter, a Joint Select Committee that was appointed by Parliament, again by consensus in August 1994, will begin to discuss the Report. This will, I have no doubt, prove to be a most difficult phase in the entire process. As you are aware, and my critics never cease to remind me, the 1990 Constitution is entrenched. What this means is that in order to effect any changes to the constitution all parties, senators and representatives of the Great Council of Chiefs, must agree to the changes. For the exercise to succeed we need an abundance of goodwill on all sides. There has to be an appreciation that an unjust and discriminatory constitution will in the long term be very harmful to this nation, and that there are international norms and standards of constitutional propriety that cannot be ignored. Tolerance and accommodation are at the heart of the exercise. We made a commitment to this process four years ago. We remain committed to seek out solutions that are just and enduring.

When we started, there were those who said that the review process will never get under way in earnest. It did. Then they said that there will never be an agreement on a fair and acceptable Terms of Reference. There was. Then they said that the ruling party will never agree to an overseas chairman and a balanced and independent Commission. It did. It is the same company that say that there will no meaningful and acceptable changes to the constitution. I cannot help thinking sometimes that they almost wish that this will not succeed, only so that they can say, 'We said so.'

Let me give them some thought for comfort. If at the end of the process so far we get a fair report from the Commission, that itself will be an achievement, irrespective of what is done to that Report. An independent assessment will have been made to the 1990 Constitution by a credible Commission for the first time since its 
promulgation. The world will be able to judge for itself the merits and the demerits of the 1990 Constitution and what we have been saying about it.

If the process fails to produce the desired result, it will not be due to lack of trying on our part. We will have tried and failed. Not otherwise. But let us not be negative.

This process has come a very long way. Indeed, it has come such a long way that there is no turning back. The government has repeatedly committed itself both here and at other forums elsewhere not only to the review process but to actual reform that will take us to a constitution that is acceptable to all the communities in Fiji. As recently as the 20th of May 1996, the Prime Minister repeated this commitment in the House of Representatives in the course of a debate on a motion moved by Hon. David Pickering on the economy of Fiji.

\section{INFORMAL MEETINGS}

I also wish to report to you that there have been several informal meetings between us and representatives of government. While these meetings are informal, they have given us a useful opportunity to continue to contribute towards creating an environment in which meaningful dialogue on the constitution and other important issues can take place in the future.

The NFP, consistent with its stated objectives, will continue to participate in a sensible way in the ongoing dialogue. We place great value on these informal contacts. Let us not forget that when we started on this journey by deciding to participate in the elections under the 1990 Constitution, we drew heavy criticism. We were told the changes that we desire can never be accomplished by such a process. Since then by consistent application, through dialogue, through negotiations, we have accomplished much. We were able 
to agree upon the Terms of Reference for the Review Commission, Terms that have come to be widely accepted as fair and reasonable. We have been able to agree upon the composition of a Commission of three able, dedicated, and competent commissioners. Their independence and neutrality is accepted without question.

We have also agreed to the composition of and Terms of Reference for the Select Committee that will look at the Report of the Commission. All this required much patience, perseverance and goodwill. All this seemed difficult, if not impossible, when we commenced this journey. I remain convinced that this process can be brought to a successful conclusion. A constitution that is acceptable to all the communities in Fiji is within our collective reach.

Let me also say that the solutions are here in Fiji and within the grasp of the leaders and people of Fiji. We can and must arrive at a constitutional compact that is just and fair, and will hold up to any international scrutiny.

\section{GOVERNMENT OF NATIONAL UNITY}

You have heard and read a great deal about the so-called Government of National Unity. There has been endless speculation about our party's position on the issue. Let me clear the air once and for all.

First and foremost, no one has invited the National Federation Party to join in any Government of National Unity. So the question of agreeing to join or not to join such a government does not arise.

Secondly, I have no doubt whatsoever that the current constitution does not lend itself to the formation of a Government of National Unity of any kind. Indeed, the one national issue over which we differ with the government is the imposed 1990 constitution. This division has to be narrowed and resolved before we can entertain any thought of going into a Government of National Unity. 
Thirdly, having said that, let me say that we support the principle of Government of National Unity. Indeed, I have said many times before that it is the only way forward for this country. But, we must lay the correct foundations for such a government to be durable and to have credibility in the eyes of the people. I hope that the constitutional review process and the resulting constitution will lay the foundations for such a government to be formed for the benefit of all the people of this country.

Improving inter-communal relations is not only my business or the business of politicians. Each one of you as individuals have a contribution to make. The many races here are totally inter-dependent. We are all brothers and sisters. We need to lift ourselves above the many apparent differences that divide us and look to those larger and more enduring values that unite us. The people of Fiji will only have a bright future if they accept the truth of this assertion.

ALTA

Another issue of great concern to us is the impending expiry of all agricultural land leases. There appears to be some confusion between the expiry of leases as distinct from [the] expiry of ALTA.

ALTA is entrenched law. It will not and cannot expire. The only way to change ALTA is by an Act of Parliament. For such an Act to pass, you need to secure the majority prescribed by the constitution. ALTA does not and will not expire. What will expire is the leases.

Wherever a landowner agrees to renew expired lease, he must do so within the ambit of the provisions contained in ALTA. For example, ALTA prescribes that agricultural leases must be for at least 30 years. There is nothing in ALTA which stops or prevents any landowner from renewing his tenants' lease.

There is yet another confusion that exists about ALTA. ALTA does not apply only to native land. It applies equally to state owned land 
and to freehold land. Furthermore, it affects all agricultural leases and not only sugar cane leases. Agricultural leases include all types of farming, including dairy farming, poultry and bee keeping. Thus ALTA affects all tenants' right across the board. Unfortunately, because the sugar sector is both organized and highly politicized, public discussion on ALTA tends to centre around sugar cane leases only. Let us not forget that the future of non-sugar cane farmers, most of whom are poor and unorganized, is equally important.

ALTA affects three types of land and I will deal with these separately for clarity.

\section{PRIVATELY OWNED FREEHOLD LAND}

There must be hundred of tenants on privately owned freehold land. Many of these are tenants in the non-sugar growing areas such as Sigatoka Valley, Bua, Cakaudrove, Navua, Nausori, Tailevu and other parts of Fiji. Equal number of these leases are to be found in the sugar growing areas.

This category of tenants and their future is rarely mentioned in public discussions on the subject. The government has yet to say what is being done for the future of these tenants. Are they going to be left entirely at the mercy of their landlords? When will these category of leases begin to expire and in what numbers? Has anyone attempted to find out, including the ALTA Unit that was created some time ago?

When the government says that only 48 or so ALTA leases are expiring in 1997, I do not believe it takes into account this category of leases. I do not see any good reason why these leases should not be extended immediately by law in the same way as was done in 1976 . The hardship that will befall this group of tenants if they were left to the mercy of landlords will be horrendous. I believe that in that event most of them will be evicted. 


\section{STATE LEASES}

Then there are the State leases. These are leases over land owned by the government. Much of this land formerly belonged to the CSR Limited. There are other leases as well on State land, land outside the sugar belt, and all not necessarily freehold. Some will be State Schedule 'A' and Schedule 'B' land. Again, I have never understood why these leases have to be for the same duration as native leases. For example, why should a tenant of a State agricultural lease be granted only 30 years' lease? When 'commercial' or 'residential' leases in urban centres are granted, they are for either 75 or 99 years. But for the tiller of the land, be it sugar cane farmer, rice farmer or a subsistence farmer, is his pursuit not as much 'commercial' as the undertaking of a shop keeper?

The government should set an example by granting long term agricultural leases in respect of State land. Such a policy will encourage most needed investment in the agricultural sector, particularly investment in long term tree crops. This is one category of land where there are no competing claimants as, for example, may be the case with native land where the owners may wish to reclaim their land for their own use. And as in the case of privately-owned freehold land, I do not see any reason why these leases cannot be extended by law.

\section{NATIVE LAND}

Then there are leases on native land. This is both difficult and sensitive issue and has to be handled accordingly. And given the fact that $83 \%$ of all land in Fiji is communally owned by the indigenous landowners, it is not surprising that the majority of the tenants are to be found on native land.

When I spoke to you last year at Labasa, I told you that government policy was to allow the issue of renewal of these leases on a case-by- 
case basis, and essentially, as an exercise between the landowners and the tenants. If that policy had remained unchanged tenants whose leases expire, say in 1999 or 2000, would not know at this stage whether their leases will be renewed or will not be renewed. Since I spoke to you last year, there has been a change of policy. The Minister for Agriculture has now stated that the Native Land Trust Board is undertaking a comprehensive survey of all native leases, and by the end of 1996 will have ascertained exactly how many native leases will be renewed and how many will not be renewed. It must follow from what I have just said that it is impossible for any tenants on native land to know now whether his lease will or will not be renewed. This is unsatisfactory from the tenant's point of view, I know. I also understand that this exercise could have and should have started as early as 1992, as the problem was there staring us in the face.

Be that as it may, I express the hope that at least the size of the problem will be much clearer at the end of 1996 in so far as native leases are concerned. Here I will repeat what I said last year. The State cannot assume the role of a facilitator only. It has to be more actively involved in the search for solutions to the very sensitive and difficult problem or else we will have widespread chaos and suffering. On the one had it is the undoubted rights of the landlord to his land and do as he chooses with it. On the other is the State's responsibility to ensure that the tenants are not impoverished by dispossession. There is the need to protect the national economy. And perhaps the fourth factor is to understand the sensitivity of not only those who own the land but also those who do not own any land. And that unfortunately has a communal dimension in Fiji. The problem has haunted Fiji for generations. It is one of the many factors that contributes to heavy migration of Indo-Fijians from Fiji. Temporary solutions were invoked as in 1966 and 1976. The time has come for us to seek more enduring and permanent solution to this problem. 
In this regard may I say that there have been some encouraging signals from people in government. I hope these are real.

\section{$\operatorname{ACT}(\mathrm{ALTA})$}

Then there is the question of Act - the legislation itself. From reports in the media it is clear that the government is undertaking a review of the legislation. The Act has been in place for some thirty years. Clearly a review is essential as many aspects of the Act from experience have been found to be unsatisfactory. But these aspects do not only relate to the concerns of the landlords but also of the tenants. There is much in the Act that the tenants want changed, particularly the rent-fixing mechanism - its frequency and so on. I hope that the government will soon initiate discussion with the representatives of the farmers and the opposition parties on this critical issue. Any attempt to impose solutions unilaterally will only bring forth resentment and resistance.

Before I conclude on this subject of land generally, let me tell you that some very useful discussions have taken place between the National Federation Party and the government. I believe the government is aware of the depth of the feeling within the tenant communities about their future on this critical issue. We will continue these discussions in the same spirit as with the discussion on the review of the constitution, and for the sake of our country's future and those of our children. I hope solutions can and will be found.

For us to achieve anything on this front, we have to move away from simply 'politicking' about land. Bold and brazen 'headlines' in the media will not help resolve this issue. As with the constitution, this issue calls for intense discussions, quiet negotiations, tact and goodwill on all sides if we are to get anywhere.

Having said all that on the subject of land, let me say that by far the most critical and the most challenging issue we face today is the review of the constitution. Only when a representative and just 
political order emerges will we be able to begin to resolve the other issues, be it land, law and order, poverty or whatever.

\section{LAW AND ORDER}

This is a very worrying matter. People are shocked at the levels to which criminal activity has escalated in the country in recent years. Deviance is legion in Fiji. This situation cannot be allowed to continue. We all have a role in this. Prevention, detection and deterrence of criminal activity can never be the sole responsibility of the police and the courts. Society also has a role, and a critical role at that.

Let us begin at home. In recent years there have been a speight [sic] of housebreaking and robberies in which the thieves have targeted jewellery and money. Jewellery snatching from unsuspecting women in public places such as bust stands, markets and streets has become common place. Many of our sisters who marched yesterday will bear testimony to this. The question we need to ask is where is the jewellery going? Who are the receivers? Lest we forget, if there were no receivers there would be no thieves. We need to take a position on this. All those who receive stolen jewellery, indeed any stolen goods, are our enemies.

It is important that they understand what they are doing to all of us. The law relating to receivers is in need of urgent review, and the courts need to treat receivers with the utmost severity. Society must make its contempt for receivers of stolen jewellery and goods plain. They do not deserve any sympathy whatsoever.

When people cannot be safe in their own homes, when the sanctity of the home is invaded with impunity, when occupants therein are wantonly beaten up, robbed and even raped, one is obliged to ask: why? What has gone wrong with society? Indeed one has to ask if we ourselves are not part of the problem. There is an old English 
adage which says that an Englishman's home is his castle. The truth is that everyone's home should be his castle. What this means is that you must be prepared to defend that castle. The right of self defence is sacred, and well recognized by the laws of all civilized societies including Fiji. Could it be that we ourselves offer little or no resistance to the invasion of our person and property? We can say all we like about the police and the government. But let us not forget that there is no way a policeman can be posted at each home while you go to sleep. Firstly, self preservation, and the preservation of your property, wife and children, is your responsibility. Are we doing enough in this direction? These are some questions that each one of us will need to ask and answer. Just the other night we all saw on television the sight of Suva Magistrate's court registry in the aftermath of the break-in there. Even our courts are no longer safe, not to mention exhibits and files. There is an alarming blatancy about the way in which crimes are committed in the society.

White collar crime is also on the increase. Look at what went on at the National Bank of Fiji, with the result that an important national financial institution has been brought to its knees. I express the hope once again that those responsible for criminal acts at the National Bank of Fiji will be brought to justice swiftly. I am surprised that despite the findings of Adams and Aidney, and more recently, the Reserve Bank of Fiji, not a single charge has been laid against anyone to date.

Referring to the law and order situation in the country, the National Economic Summit sub-committee report notes, and I quote:

The increase of complaints against some lawyers, police brutality, embezzlement, fraud and white collar crime highlights the ripple effect of the general decline in our institutions. All of this contributes to and appears to promote the instability and deviance prevalent in Fiji today. 
The committee observed that this will continue for some years until the leadership improves through enlightenment, national dialogue and commitment in improving our political processes. There the committee was talking about leadership at all levels of society, including political, religious, trade unions and so on.

I want to conclude on this subject by sounding a word of warning. The reasons for crime are varied and complex. There are many factors at work, both social and economic. We all need to join hands in combating this social problem. It is tempting but highly dangerous to communalize this social problem.

\section{FREEDOM OF THE PRESS AND CONTROLS}

Just a few days ago we witnessed a very depressing and distressing episode when a columnist writing for the Fiji Times was 'gagged' by the government's threat to cancel his work permit. It will have come as a great relief for thousands of people when government reversed that decision. It was a foolish and short-sighted decision in the first place. Nonetheless, this episode comes in the wake of threats by government in recent months to introduce some legislation to regulate and control the media.

Is freedom of expression under threat in Fiji? If it is, it represents a dangerous turning point in the life of this nation. Fiji was a colony of the British Crown for close to a century before we gained independence in 1970. Liberal British traditions combined with Christian values, later reinforced by other tolerant cultural traditions, helped foster a relatively free and open society. The parliamentary system, the rule of law, including the courts and the common law traditions, respect for human rights, including freedom of speech, are all part of that tradition. In 1970, a Bill of Rights was included in the constitution which guaranteed these freedoms. The Bill is repeated in the 1990 Constitution (with exceptions). 
It seems to me that these traditions are now threatened by some systems and values that are alien to this country. We are now told we need take Malaysia and Singapore as models in this area. God forbid! Do we really need any foreign models, when our own has served us well over the years, and they are cherished and valued by the people of this country? Any attempt to gag the press now when we are attempting to address national issues such as the review of the 1990 Constitution and ALTA may prove to be disastrous. It will send out altogether wrong signals. Freedom of the press is an important protection for minorities and marginalized groups. Indeed it is vital for a healthy society.

However, if the government does decide to bring any such measures, then we will be bound to join forces with all those who cherish these freedoms and raise our voice in opposition.

The next twelve months or so are critical. We are truly at the crossroads. The decisions we make and the actions we take will decide the future of this country. Fiji's future lies in moulding this country into a truly multiracial nation. That will require time and concerted effort at all levels of society. It will require patience. It will require creativity. But it is possible. It has to be done because really There is No Other Way. 


\section{NOTES}

1. This quote is from an address to the Fiji Youth and Students League during the visit of Mr Baleshwar Aggraval, undated.

2. After brief period as an independent (founder of the Fiji Democratic Party), Bole joined the military-led interim administration as Education Minister and a vocal supporter of the coup.

3. Quotes from a copy of the paper in my possession.

4. Quotes from a copy in my possession.

5. See Hansard, 14 Sept. 1993.

6. Fiji Focus (A ministry of Information organ), June, 1994.

7. Including my former graduate student, the late Tevita Baleiwaqa, to a conference in Bangi, Malaysia!

8. There were some who felt that Tuivaga's acceptance of the position might embroil the judiciary in unnecessary controversy. See Richard Naidu's assessment in The Review Magazine, Feb. 1995.

9. Quotes of JPSC meetings are from its minutes in Reddy's papers.

10. Daily Post, 10 Dec. 1994.

11. Daily Post, 6 Feb. 1995.

12. Some of Thompson's thoughts on and affection for things Fijian can be found in his 'Ratu Sir Penaia Memorial Lecture' to the Great Council of Chiefs on 18 July 1995.

13. For a reflection on Sir Ian Thompson, see Joni Madraiwiwi, A Personal Perspective: The Speeches of Joni Madraiwiwi (Suva: Institute of Pacific Studies, 2008), 266-269.

14. For a background, see his From the Mangrove Swamps, privately published, 1999.

15. The words are YP Reddy's, who was once with the Alliance Party.

16. Vakatora, From the Mangrove Swamps, 105-106.

17. See Harish Sharma's letter 'NFP record,' in Fiji Times, 13 Apr. 1997. 
18. Interview with Madhur Singh, Fiji Times, 25 May 1996.

19. Reddy has told me that Labour also mooted the name of Richard Naidu, who had once been Dr Bavadra's spokesman and subsequently qualified as a lawyer.

20. Hansard, 22 Sept. 1993.

21. Bob Norton, who was in the audience, reminds me that I had 'fallen' into a trap laid by the nationalists. I now recall being irritated by Duvuloco who spoke to the Commission inebriated.

22. These are available in Brij V Lal and Tomasi Vakatora (eds), Fiij in Transition and Fiji and the World: Research Papers of the Fiji Constitution Review Commission (Suva: University of the South Pacific, 1997). The transcripts of the proceedings are at the Fiji National Archives and on microfilm at the Pacific Manuscripts Bureau.

23. Asesela Ravuvu, The Façade of Democracy: Fijian struggles for political control, 1830-1987 (Suva: Reader Publishing house, 1991).

24. 'Respect and Understanding: Fijian Sovereignty, The Recipe for Peace, Stability and Progress: Submission to the Constitution Review Commission,' 10 Oct. 1995, 129 pp.

25. Quotes are from the submission in my possession. In an interesting irony, nearly all the historical quotes in the submission, justifying the Fijian position, were lifted word for word, comma after comma, from my book, Broken Waves: A history of the Fiji Islands in the 20th century (Honolulu: University of Hawaii Press, 1992). Isimeli Bose was at university with me. He gave me an autographed copy of the submission, with the words: 'To my friend Dr Brij Lal. I hope you will enjoy it!'

26. See also Review Magazine, Nov. 1995

27. Review Magazine, Nov. 1995, 17.

28. Speech reported in Fiji Times, 8 Apr. 1996.

29. This is based on notes of conversation Robert Norton had with Mrs Narayan and other leaders at the time. 
30. 'Towards Racial Harmony and National Unity: The Submission of the National Federation Party and the Fiji Labour Party to the Fiji Constitution Review Commission,' Aug. 1995, 72 pp.

31. A summary is in my A Bomb Lies Buried: Fiji's Road to Independence, 1960-1970 (Canberra: State Society and Governance in Melanesia Monograph, ANU E Press, 2008).

32. Published as Parliamentary Paper no. 34 of 1996.

33. See, for instance, Donald Horowitz, 'Encouraging electoral accommodation in divided societies,' in Brij V Lal and Peter Larmour (eds.), Electoral Systems in Ethnically Divided Societies" Fiji Constitution Review (Canberra: National Centre for Development Studies, 1997), 21-37, and Yash Ghai, 'Recommendations on the electoral system: the contribution of the Fiji Constitution Review, ibid, 147-59

34. From his speech in parliament tabling the report.

35. Words from the Hansard of the proceedings in the House of Representatives.

36. Daily Post, 12 Sept. 1996.

37. Daily Post, 12 Sept. 1996.

38. Fiji Times, 26 Sept. 1996.

39. Fiji Times, 1 Apr. 1997.

40. Daily Post, 23 June 1997.

41. Daily Post, 19 Oct. 1996.

42. Daily Post, 12 Feb. 1997.

43. This is Jone Dakuvula's assessment also. See Daily Post 7 Apr. 1997

44. Daily Post, 28 Jan. 1997.

45. Daily Post, 29 Jan. 1997.

46. Hansard, 30 June 1997.

47. An incisive discussion of the process of negotiations is in Jill Cottrell and Yash Ghai, 'The Role of Constitution Building Processes in Democratization: Constitution Making in Fiji: Context and Process,' unpublished paper for International IDEA in my possession. 
48. Daily Post, 24 Sept. 1997.

49. Daily Post, 10 Oct. 1996.

50. Pacific Islands Monthly, Sept. 1997, 24. Robert Norton has commented in private communication that AD Patel had always insisted that this would not matter, that the crucial thing in common roll was equality among individual voters, equality of citizenship. 'Without doubt, this was AD Patel's crucial claim.'

51. Daily Post, 26 May 1993.

52. Pacific Islands Monthly, Sept. 1997, 24.

53. Ibid.

54. The Review Magazine, Jan. 1998, 23.

55. Hansard, 23 June 1997.

56. Hansard, 30 June 1997.

57. Hansard, 30 June 1997.

58. Hansard, 27 June 1997.

59. Hansard, 30 June 1997.

60. Hansard, 26 June 1997.

61. Hansard, 30 June 1997.

62. Hansard, 30 June 1997.

63. Quote from a transcript of the speech, in the Reddy papers.

64. This is what he said: 'Maybe this apex of Fijian forum should try to entertain non-Fijian leaders to attend and observe. And when it happens they may address certain topics or issues to bring us together and I think it could be fruitful ... Fijians have always maintained that we are landowners and we are the indigenous [people] of the country. But I think we should also appreciate the contribution made towards the nation by other communities in Fiji. Other communities have contributed a lot and we have to consider that aspect of being together.' Adi Litia welcomed the idea. See Fiji Times, 6 June 1997.

65. Sitiveni Rabuka, Pacific Distinguished Lecture, The Australian National University, July 1999, 42. 
66. Sir Moti Tikaram has confirmed to me that Rabuka approached him with the proposal and that he told him to proceed only if he had done his 'homework' properly. Private communication, 30 Sept. 2009.

67. Rabuka, Pacific Distinguished Lecture, 45.

68. From a copy of his speech given to me by Kamal Iyer, then an administrator at the office of the Leader of the Opposition.

69. Pacific Islands Monthly, Sept. 1997: especially a visit to Europe, speculates Reddy.

70. Review Magazine, Jan. 1998, 20. 


\section{CHAPTER 9: THE DÉNOUEMENT}

\section{There is an evening coming in}

Across the fields, one never seen before

That lights no lamps Philip Larkin

Now the dream decays

The props crumble. The familiar ways

Are stale with tears trodden under foot R S Thomas

he sun was a ripe orange over the Nadi Bay as dusty campaign vehi-
cles festooned with leaves and frayed party flags began arriving at the Nadi Sangam Secondary grounds at the back of the tourist town. In the corrugated iron shed there sat perhaps two dozen exhausted party supporters and hangers-on, drinking kava, killing time and pondering the events of the day and of weeks of what had been a gruelling campaign. This was the end of the road, with little else to do but to sit and wait for the results. Long gone by now was the euphoria of the early days when wild grog-talk floated around meetings predicting a massive victory for the party. Jai Ram Reddy was depressed and withdrawn, more than he usually was. He had been unwell, too, with erratic high blood pressure and a mini-stroke - a transient ischemic attack — he had suffered in Ba in 1998 — sometimes barely able to keep up with the hectic pace of the rallies and the media interviews. The experienced campaigner that he was, he knew in the latter stages of the campaign that he was gone. He had read the voting shed trends and the general mood of the voters accurately, and there seemed little he or anyone else could do to reverse the trend. But the occasion demanded a valedictory speech from him. He stood up to give what would turn out to be the last campaign speech of his political career in Fiji. The National 
Federation Party had fought a good fight, he told his supporters, and he was proud of the principled way it had conducted the campaign. In life as in politics, one had to stand up for certain principles. He and his party had been honest and truthful with the people. He repeated the themes of the importance of multiracial cooperation and partnership, which was the only way forward for Fiji. He would accept the verdict of the voters, whatever it was. And whatever was to be the fate of individual candidates, the party, he said, would live on. Then, he sat down to a tired, desultory applause.

Later that evening, party supporters and officials gathered at the Natabua High School to witness the counting of votes. At the beginning, there was mild optimism. An outright victory seemed unlikely now, but a substantial number of seats were assured. From around the country came estimates of a 'fifty-fifty-chance.' I had been following elections long enough to know that that calculation spelled desperation, a euphemism for certain impending defeat. As the counting proceeded through the night and into the early hours of the morning, the extent of the devastation began to become clear. One by one, everyone had lost. The NFP did not win a single seat. Reddy's nemesis, Mahendra Chaudhry's 'Peoples Coalition,' comprising Labour, the Party of National Unity and the Fijian Association, won thirty seven of the seventy one seats, including all the Indian reserved seats. Rabuka's party, which had fought the election as NFP's coalition partner, did not fare much better either, winning only 8 Fijian seats.

Ironies abounded. Against all odds and all expectations, Mahendra Chaudhry was appointed prime minister, a prospect that had appeared implausible just a few weeks, even days, before the elections, and that, too, in coalition with a political party, the Fijian Association, whose overtures for political support to form government in 1992 Chaudhry had rebuffed. Ratu Sir Kamisese Mara, who not a long ago had been regarded as the evil genius behind the country's recent political troubles, was now hailed as an ally, a wise statesman providing sage advice to an inexperienced incoming administration. On the other side of the political divide, Jai Ram Reddy had joined hands with the SVT leader Rabuka whom he had refused to 
support - but whom Chaudhry had supported — for Prime Minister a few years back.

The two dominant figures of contemporary Fijian politics, widely praised for their leadership in the constitution review exercise, overnight became generals without armies. Rabuka resigned from parliament to become a (commoner) chairman of the Great Council of Chiefs and the Commonwealth Secretary General's peace envoy to the Solomon Islands. For Reddy, also widely respected and admired for his contribution to the national healing process, the results were a fateful replay of history. His party under the leadership of AD Patel had played a leading role in Fiji's independence struggle, but was consigned to the wilderness of the Opposition benches for a generation in the post-independence years. Now, once again, Reddy and his party were dealt a crushing blow and destined for a place on the margins in the nation's affairs after helping deliver to the Indo-Fijian community and to the nation as a whole, the best constitution they ever had, and laying the foundations of a truly multiracial democracy in Fiji.

Jai Ram Reddy was under enormous pressure from his supporters to stay on to lead the party. People would one day come to their senses and realize the mistake they had made. Then his guidance at the helm would be much needed. Reddy was unmoved. He would remain a mentor and advisor, if that was what people wanted, but an active career as party leader was over for him. ${ }^{1}$ Reddy had been a reluctant candidate in the first place, accepting an open seat at the last minute, much to the agony of his close supporters, and eschewing the Lautoka communal seats which he had won in the past and which offered better prospects. But all that was now history. 1997 would be his last campaign, Reddy told friends with palpable relief. He was at the end of his political career. He might not even see the full parliamentary term to conclusion. Reddy was deeply hurt and disappointed, not necessarily at his own defeat, although that would have been natural enough: the first and only in his long political career; but at the eclipse of the vision that the constitution had enshrined. Having masterminded it, Reddy would no longer be in the political arena to defend and protect his handi- 
work from critics who were aplenty. People had not grasped the enormity of the achievement, Reddy lamented. This was a home grown constitution, passed unanimously by the Senate, the House of Representatives, and the Great Council of Chiefs. The constitution was the envy of the developing world, especially of ethnically divided societies, and his own people had shown scant regard for it. Perhaps the achievement had come too easily, he thought, without too much sacrifice for people to fully appreciate the enormity and significance of what had been accomplished in the most difficult of circumstances, and against considerable odds.

\section{THE ROAD TO 1999}

A general election was in the offing once the 1997 Constitution had been promulgated by parliament. Even as the Constitution Amendment Bill was being debated, Rabuka threw out a challenge to his colleagues on both sides of the House. 'Let us not just talk about the concept of multi-party government,' he said during a parliamentary debate, 'let us act on it. Let us start with it now so that we can develop the habit of working together well before the next General Elections.' And he repeated what he had been saying on many previous occasions: 'We have to move away from the ethnic divide that for the past five years has been a divisive and unhappy feature of this Chamber.' There were some within the NFP who cautiously welcomed the idea to capitalize on the euphoria which had gripped the country after the passage of the Constitution Amendment Bill, but Reddy vetoed it. 'We have to go to the people first to get their mandate before we take the next step,' he said. Besides, there was still a lot of leg-work to be done in preparation for the elections: constituency boundaries demarcated, registration lists drawn up, candidates selected, a manifesto prepared, and so on, and he did not want, just yet, to relinquish the important responsibilities that came with the office of the Leader of the Opposition. Reddy also did not want to be tainted with the mess the SVT government had created. He would then be an easy sitting target for his opponents. But he left no doubt in anyone's mind that he would go to the next elections in coalition with Sitiveni 


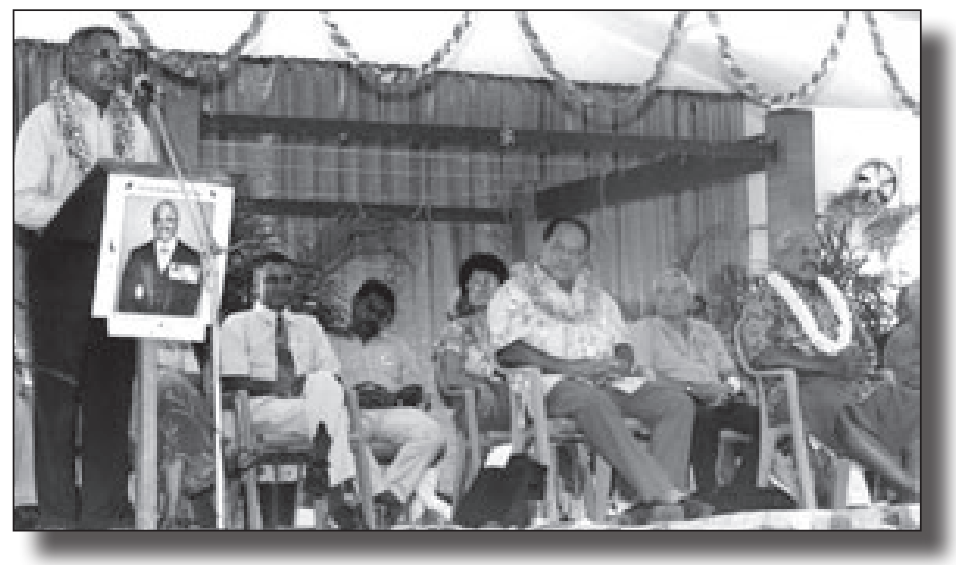

Lauching the SVT-NFP-GVP Coalition at Kshattriya Hall, Suva, 1999. Seated from right: David Pickering, Sitiveni Rabuka, Robin Stork, Mere Samisomi, Viliame Cavubati, Wadan Narsey. Courtesy Fiji Times

Rabuka's party. Reddy told Rabuka, 'You will not be isolated. We want a partnership. We don't want to go back.'

Meanwhile, there were other matters to attend to. Among them was canvassing support for Fiji's re-admission to the Commonwealth. On 9 September 1997, Rabuka wrote to Indian Prime Minister, Inder Kumar Gujral, about the promulgation of the new constitution with its non-racial and power-sharing features, and sent Reddy to brief the Indian leaders in person. Reddy also briefed them on the land question. He was well received in New Delhi. But Mahendra Chaudhry was not far behind. He travelled to India, on his own initiative, to meet both Prime Minister Gujral as well as Opposition Leader Atal Behari Vajpayee to talk to them about the 'long term future and security of people of Indian origin in Fiji, ${ }^{2}$ as if Reddy could not be trusted to represent their interest, or was in some way short changing them. The Indian leaders, Chaudhry said 'are expected to raise the concerns I had relayed to them regarding the Indian people.' His visit was widely criticized, but Chaudhry had a clear agenda: he was trying to paint Reddy in a particular light and himself as the true leader of the IndoFijian community who most cared about them. 
It was not immediately clear what issues Chaudhry raised with the officials in New Delhi, but one most likely would have been land, in particular the plight of the Indo-Fijian tenants due to the imminent expiry of their leases under the thirty year Agricultural Landlord and Tenant Act (ALTA). An attempt was made to tie ALTA and the Constitution together in Fiji's attempt to get re-admission to the Commonwealth. One without the other was useless, it was said, and Fiji should not be re-admitted unless the ALTA issue was resolved. But the two, though both important, were quite different. The land problem would have to be resolved through political dialogue with the Fijian landlords, not by taking it to the court of international opinion, Reddy said. He had already initiated dialogue with Rabuka on the subject. He hoped that the optimism generated by the constitutional review process would bear fruit in the discussions on the other issues. That, indeed, was the joint position of both the NFP and Labour. 'It is only after equal citizenship rights have been secured for all communities in Fiji,' a joint statement in February 1997 said, 'that we can begin to look at other national issues of concern, including the problem of land. Arriving at a fair constitution broadly acceptable to all the communities in this country is the first hurdle to be overcome, and given paramountcy over all other considerations. ${ }^{3}$ But now for obvious political reasons, the two issues were conflated.

When pushed, Reddy asked: 'How will staying out of the Commonwealth help resolve the ALTA problem?' In a statement, Reddy said that 'Fiji's re-entry into the Commonwealth has nothing to do with the leases expiring under the Agricultural Landlord and Tenant Act. In fact, NFP's support for Fiji's re-entry into the Commonwealth would help resolve the land problem. 'The Commonwealth espouses certain values which binds member states. Being out of the Commonwealth does not bind the Fiji government to adhere to those values and principles. By being in the Commonwealth, it is possible to raise grievances and concerns in that forum. Far from being a hindrance, our re-entry into the Commonwealth will help the resolution of ALTA. ${ }^{4}$ Chaudhry's strident utterances, on the other 
hand, said his colleague Tupeni Baba, would only 'confuse, cloud and aggravate the positive atmosphere in the country'. '[O]ne thing Mr Chaudhry can be sure of when he returns [from India], editorialized the Fiji Times, is that 'he will be isolated even more. The forward drive by the majority of the leasers and the people of this country is too powerful for any one man to stop. ${ }^{6}$ The paper would turn out to be wrong; one underestimated Chaudhry at one's own peril. Chaudhry had another more precise and urgent agenda: Jai Ram Reddy. He had Reddy in his gun sights throughout the 1990s. Recall his promise to 'finish NFP off.' It was politically necessary for him to run Reddy down at every opportunity, to denigrate his every contribution no matter how big or small, and to shore up his own fortunes, especially among the Indo-Fijians. That he did single-mindedly and with great success between the promulgation of the constitution in 1997 and the general elections in 1999.

Elections involve many painstaking tasks: selecting candidates, preparing an election manifesto, seeking partnership with other like-minded political parties, getting a feel of the mood of the electorate, organizing rallies and pocket meetings, scrutinizing voter registration rolls. From the 1990s onwards, Reddy had been reaching out to NFP's non-traditional constituencies, seeking their views and their inputs. To that end, he wanted the infusion of fresh blood into the party. He was on the lookout for credible candidates. He asked me to sound out Imrana Jalal, the Suva lawyer, feminist activist and then newspaper columnist, if she might be interested in contesting the Suva Indian communal seat left vacant by the death of the incumbent Harilal Patel. Imrana declined on account of her young family, but wanted the door kept open for the future. Reddy was then able to entice economist Wadan Narsey for the Suva seat, who entered parliament in August 1997 in an un-contested by-election, emerging later as an effective Opposition Finance spokesman.

There were other new faces in the line-up as well: educationist Keshwan Padiyachi, senior social welfare officer Manjula Verma, medical practitioners Bijend Prasad Ram and Mridula Sainath, academic Biman 


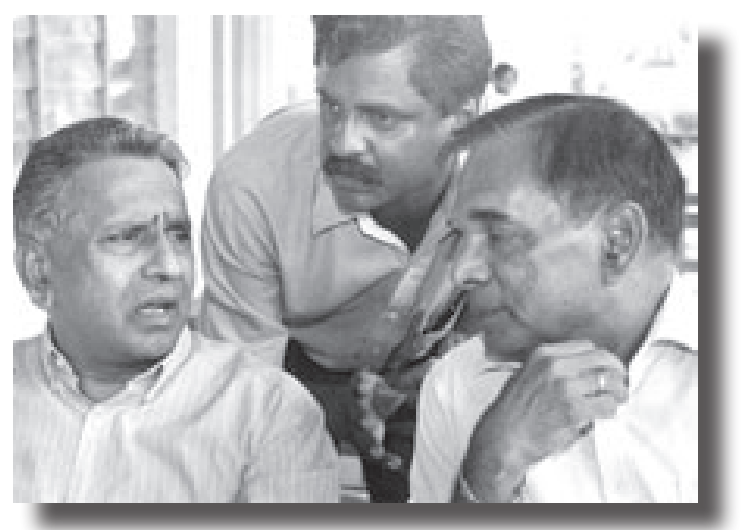

Consulting with Deputy NFP Leader Harish Sharma and Ba Mayor Praveen Bala. Courtesy of Fiji Times

Prasad, senior school vice-principal and principal Vijendra Prakash and Savitri Chauhan respectively, and head teachers Davendra Pratap and Ram Lajendra, trade unionists Jagnnath Sami, Diwan Shankar and Attar Singh (James Raman was already in parliament), big and small businessmen (Vinod Patel, Satish Gulabdas, Harnam Singh Golian, Maan Singh, Dhirendra Kumar) and community workers (Mohammed Rafiq, Azam Khalil, Parmod Chand, and Aptar Singh). By the late 1990s, Reddy had gathered around him men and women of exceptional talent and aptitude. The eclectic 1999 line-up was, arguably, the finest the NFP (or Labour, for that matter) had ever presented to the electorate. 'At the end of the day,' Reddy remarked, 'the quality of government will be decided by the quality of its members." The team also had regional and cultural balance as well. These things matter among Indo-Fijian electorates. There were South Indians, North Indians, Gujaratis, Muslims, Sikh. For the first time in the party's history, three women were given what was generally thought to be 'winnable seats.' On this issue, Chandra Reddy had a large hand in persuading her husband to cast his net more widely.

Most of the newcomers were neither politically inclined nor possessed an experience of politics. Indeed, many expressed distaste for its raw and 


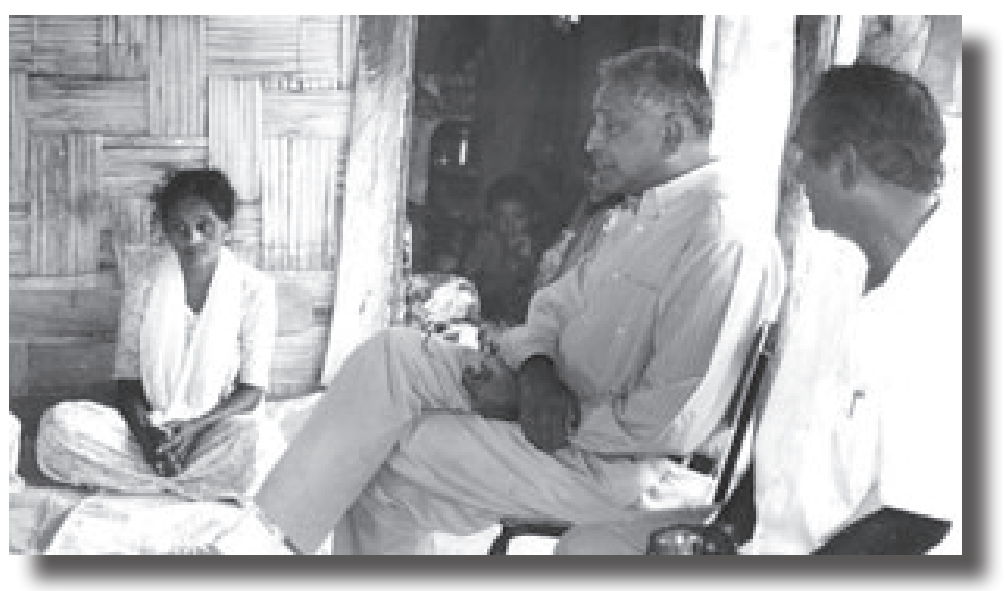

Listening on the campaign trail, 1999. Courtesy of Fiji Times

rough character. Some former Labour Party members or others leaning in that direction, were wary of joining a 'communal' party such as the NFP, but they joined because they saw a genuine opportunity to make a difference. The time was right. Fiji seemed to be the cusp of a new era. Progressive political change and social reform seemed within grasp. A divisive past could finally be put to rest. Another, perhaps equally important, reason was the leadership of Jai Ram Reddy. He had won the sceptics and the critics over with his honest, inclusive and transparent approach, and his sensitivity to the concerns of the indigenous community. They saw in Reddy a leader open to fresh ideas and the possibility of change, unafraid of genuine intellectual debate. Reddy did not seem personally ambitious for power. He was the glue that bound the team together.

With the prospective candidates' list in train, talks began about a coalition. Reddy had already said that he would go into coalition with the SVT, the mainstream Fijian party, and the General Voters Party headed by David Pickering. Reddy was not universally supported in this initiative. Some senior members thought that NFP should fight the elections on its own and then, if need be, join the SVT in government. The constitution provided for power sharing anyway, so there was no need to embrace a 
Fijian party pre-election. Some warned of the Rabuka 'curse.' Coming too close to him would be disastrous for the party, just as it had been for Labour in 1994. Indo-Fijians, people said, had not forgiven Rabuka, and Chaudhry would do his best to ensure they did not. They warned of the perils of being laden with the SVT's baggage. ${ }^{8}$ Supporting Rabuka for Prime Minister, as Chaudhry had done, was for many less heinous a crime than consummating a relationship with him and the SVT.

Reddy prevailed. He argued that a pre-election coalition was the only way to proceed. A coalition, he said, 'that shares common goals, ideas and policies is more likely to succeed than a post-election multi-party government of hitherto mutually hostile forces.' Another compelling case for a pre-election coalition was the need to bring together the different racial groups as partners in the electoral process in order to reduce communal tensions that had historically characterized elections in Fiji. He wanted to put an end to the long years of political rivalry between the different communities and to usher in a new era of political cooperation - consistent with the aims and objectives of the constitution. 'The valuable experience we have acquired during the making of the new constitution and the immense goodwill that has been shown by the Fijian people can be made the basis for solving many of our difficult problems such as ALTA, crime, unemployment, health and education. They cannot be solved through confrontation but by working together.' 'You can't go into an election with battle lines drawn, acrimonious and divisive,' Reddy said, 'and then magically come back after the elections and say to everybody: please come and join us in this government of multi-party cabinet so that we can all together govern this country. You must understand human nature: it doesn't happen this way. ${ }^{10} \mathrm{He}$ asked his people to take a longer term view of things. He told a thousand-strong rally in Nadi in February 1999 that 'We should learn from the past and live in the present which offers new openings. We don't want to fight for leadership. We can run the country in partnership with the SVT and at the same time ensure equal say and representation in parliament. Let us not repeat the situation which led to the 1987 coup — the fear of being 
ruled. As long as the SVT is the voice of the Fijian people, we have to work hand in hand with them; we have to compromise with them.' Then he asked: 'What progress have we made in our political life by hanging on to this Fijian/Indian attitude?'11

This, by the late 1990s, was pure Reddy: focused on the long term interests of his community and the nation at large, rather than seeking narrow political advantage for his political party. There are some in the NFP who still question the wisdom of a pre-election coalition with Rabuka, but I think the decision was correct. There was the point about capitalizing on the momentum created by the promulgation of the constitution that Reddy mentioned. Having worked together with Rabuka so closely throughout the 1990s, Reddy could not, in good conscience, discard his partner-in-crime, so to speak, on the eve of the election for narrow political gain. The two had embarked on the journey together, and together they would see it through to the end, an unhappy end as it turned out. Reddy believed that the SVT represented the majority of the Fijian community. What Reddy did not know, and what no one had any way of knowing, was a silent ideological drift within the Fijian electorate away from Rabuka after 1997, although the sullen faces in parliament and the reluctant support for the Constitution Amendment Bill should have signalled trouble. Everyone was caught up in the euphoria of the moment. There was no way of assessing the impact of the withdrawal of the nominal sponsorship of the SVT by the Great Council of Chiefs, or the distancing from the party of influential chiefs, such as Ratu Mara. Had Reddy not gone with Rabuka, Labour would have played the issue to the hilt, portraying Reddy as a treacherous man who had left his political friend in a lurch, stabbed Rabuka in the back. 'Stabbing in the back' is a familiar refrain in Indo-Fijian politics.

\section{THE CAMPAIGN}

Reddy was at pains to emphasize throughout the campaign that he had not joined a 'Rabuka government' and that, as the Leader of the Opposition, he had been at the forefront of efforts to demand greater transparency 
and accountability from the government. As examples, he pointed to the Stephens' enquiry and the National Bank of Fiji saga. His demands for an enquiry into the NBF debacle had strained his relations with the government. His coalition with the SVT was not about the past, but about the future, about a new era of political cooperation. The coalition agreement with the SVT and the UGP provided that if the coalition won the elections, the leader of the SVT would become prime minister and the leader of the NFP the Deputy Prime Minister. This, a perfectly sensible approach in the context of the times, was decried by Labour as cowardice on Reddy's part, an unwillingness to lead, a repeat of April 1977 which had paralyzed the Indo-Fijian community. A radio interviewer asked: 'Mr Reddy, you are a seasoned politician, why don't you want to become Prime Minister?' Reddy replied, 'You have answered your own question, my friend. I am a seasoned politician: that is why I have taken this approach.' For Reddy, it did not matter who the prime minister was; what was important for him was that the vital interests of his people and of the country were catered for. Sir Vijay Singh thought the NFP's agreement with the SVT was an admission of the inferior political status of the Indo-Fijians. The NFP, he said, had 'declared itself disqualified from entry to the Muanikau manor.'12 Reddy said that he had signed the deal 'because it allowed fair development of the Indian community with other communities', adding 'If I wanted the post, I would have sold your rights a long time ago to become Prime Minister.'13

Another cornerstone of the NFP-SVT-GVP agreement was the sharing of the open seats. One option was for the three political parties to go their own way and, within an overarching agreement, compete for those seats. Reddy rejected that idea. Coalition partners could not compete amongst themselves and still manage to convey the impression of coherence. Clarity of purpose and conviction were necessary. They, therefore, agreed to share the open seats, with the SVT getting foourteen and NFP eleven. The two parties agreed to give their first preference to each other's designated candidates for the open seats, and not field parallel candidates, or support 
independents or candidates from other parties. The Coalition would last until the next elections, with the parties agreeing to work together as coalition partners even if one of the parties won enough seats to govern in its own right. It was the spirit of power sharing rather than the strict letter of the law that underpinned the Coalition. The agreement finally provided for regular consultations to develop policy or resolve difficulties, but agreed to 'respect particular party positions in agreed areas where special group in-

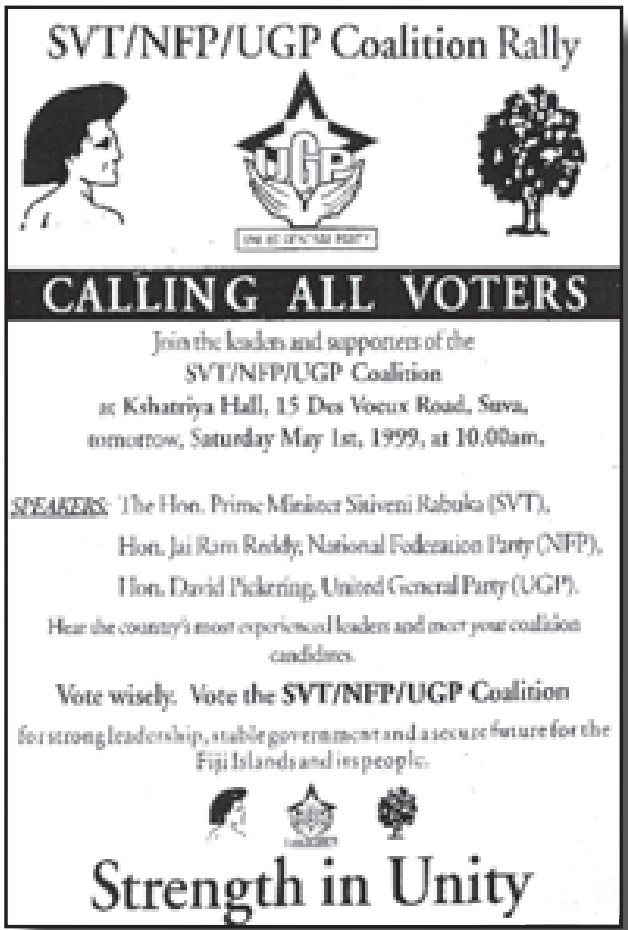

Campaign advertisement for the 1999 elections. Courtesy of Fiji Times terests may be involved.'

This escape clause was similar to the one Reddy had negotiated with the Western United Front in 1982. It was necessary because there were areas where two parties had diametrically opposed positions. The privatization of public assets was one, and it served to highlight the difficulty the Coalition had in mounting an effective campaign as a cohesive unit, something which Labour exploited mercilessly. A major policy achievement for one party was a policy disaster for the other. The SVT government had sold 49 per cent of Amalgamated Telecom Holdings to the Fiji National Provident Fund and 51 per cent of the National Bank of Fiji to 
Colonial for $\$ 9.5$ million, ostensibly to promote competition in the private sector. It had also sold 17 per cent of Air Pacific for nearly $\$ 27$ million to foreign airlines 'to strengthen the airline's international network and [increase] tourist arrivals,' and 51 per cent of the Government Shipyard for $\$ 3$ million to improve its 'competitiveness and [win] international orders.' These sales, the government argued, would free huge financial resources for growth in the private sector and enable it to 'focus more on improving the efficiency of its operations in the priority sectors, i.e., core and essential services. ${ }^{14}$

The NFP, for its part, opposed privatization of state enterprises which were yielding high returns or covered strategic assets such as the international airport and shipping facilities, those which were undertaken purely to obtain funds to cover the recurrent financial deficits or which resulted 'in private companies obtaining monopolies which can be subsequently used to exploit consumers.' It supported the privatization of only those government-owned enterprises in which the government had no 'legitimate economic or social rationale for being involved, which were inefficient and constituted a drain on the tax-payer funds through subsidies and grants,' and where 'there were no significant compensating benefits to society in terms of employment, local resource use, or necessary social service.' All this was fine academic language, nuanced and measured, but communicating it to the electorate in clear, unambiguous terms, was another matter. The Peoples' Coalition, for its part, was upfront: 'strategic utilities such as water, electricity, telecommunications and civil aviation facilities must remain in public hands.' The sharpness in the clarity of message mattered. And it made a difference.

Another issue dividing the NFP and the SVT was the status of state land. As already mentioned, there are two types of 'Crown' or state land in Fiji: Schedule A (land owned by landowning mataqali deemed to have become extinct at the time of Cession), and Schedule B (land which was unoccupied and had no claimants when the Native Land Commission met in the 1870s and 1880s). These lands were managed by the government 
of the day for the benefit of the country as a whole. In the early 1990s, facing pressure from landless Fijians, the government devised a bill to return these lands to them and transfer their management to the Native Land Trust Board. For the SVT, conscious of the needs of its primary constituents, the indigenous Fijians, the policy made sense: it was the fulfilment of a policy adopted a long time ago of returning to Fijians what was thought to be rightfully theirs in the first place. The NFP was mindful of the impact this policy would

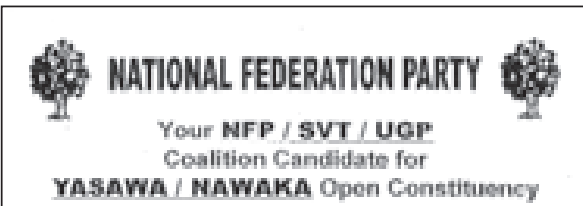

JAI RAM REDDY

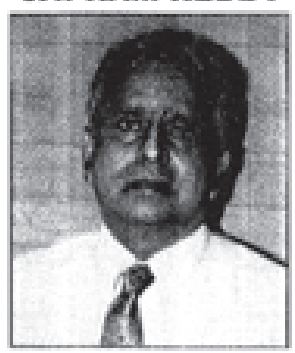

VOTE

\section{JAI RAM REDDY}

\section{NFP. Ca-operating for a better Future}

Campaign advertisement for the 1999 elections.

Courtesy of Fiji Times have on Indo-Fijian tenants facing the imminent expiry of their leases.

The NFP also criticized the government's policy of setting aside $\$ 2$ million for purchasing freehold lands and giving them to the Fijians. It had been particularly vocal in its criticism of the setting up of the Viti Corps, a government initiative to provide agricultural training to unemployed Fijian youth on a freehold property in Navua it had purchased for $\$ 7$ million. Many in the Indo-Fijian community had hoped that this valuable piece of land could be used to re-settle farmers from around the country whose agricultural leases were beginning to expire. But the logic of the 1990 Constitution was still at play: the government had no electoral incentive to address the concerns of the non-Fijians. By the time it came around to it, it was too late. The NFP also disagreed with the government's strategies 
for creating employment and strengthening economic growth, and with its racially-oriented poverty alleviation programs. In the end, the trouble for the Coalition boiled down to this: the SVT could not loudly and in good conscience highlight its pro-Fijian policies, which had borne fruit in the past, for fear of alienating the supporters of its Coalition partner, while the NFP had to soften its public record of opposing the government.

Reddy kept saying that the two parties were not standing on the joint record on these issues; he acknowledged the failures and the criticisms of the past, but said they were standing on their promise to work together in the future. The choice people faced was clear, Reddy said. 'We can either go back to the failed and divisive politics of the past which pitted one community against another, fostered hostilities and suspicions in a political culture productive of ethnic chauvinism and exclusivism. Or we can embrace a new path and nurture a new culture of cooperation and conciliation. ${ }^{35}$ 'I have no qualms about going into this Coalition,' Reddy told a meeting at the Kshattriya Hall in Suva. 'This is imperative if we are serious about continued social harmony and solving the real problems facing the country.' He would never forget 1987, he said, 'but we must remember that we have a responsibility to our children. It is to the future we must look, not to past failings. ${ }^{36}$

The NFP-SVT-GVP coalition was opposed by the Peoples Coalition comprising the Fiji Labour Party, the Fijian Association Party and the Party of National Unity. Each party had its own unique history and distinctive political agenda, but all three were united by one common aim, one overriding ambition: to remove Rabuka from power and, for Labour, to dethrone Jai Ram Reddy as the leader of the Indo-Fijian community. Labour's history has already been chronicled. PANU was a spectacularly misnamed western Viti Levu-based party, the brainchild of Apisai Tora, the quintessential chameleon of Fiji politics: founder of the Western Democratic Party which he had merged with Isikeli Nadalo's Fijian National Party to form the National Democratic Party, member of the NFP, Alliance, All National Congress, the Fijian Association Party, leader of the Taukei Movement. All 
that said, Tora was consistent in one thing at least: his advocacy of the interests of western Fijians, who, he had long felt, had been rendered marginal in the larger Fijian scheme of things dominated by the eastern maritime Fijian establishment. PANU was his vehicle for representing western Fijians and redressing their grievances.

PANU had the blessing of prominent western Fijian chiefs, including Tui Vuda (and the Vice President) Ratu Josefa Iloilo, Tui Nawaka, Ratu Apisai Naevo, Tui Sabeto, Ratu Kaliova Mataitoga, Tui Vitogo, Ratu Josefa Sovasova, and Marama na Tui Ba, Adi Sainimili Cagilaba: an impressive list, but perhaps chiefs who lacked their past influence. ${ }^{17}$ Tora initially broached a seat sharing arrangement with the SVT which would acknowledge his influence in the west. But SVT regarded Tora as a spent force, and was unwilling to cede seats in the west to PANU. Tora then approached Labour, which responded favourably. It was a coalition of convenience. Labour gave Tora a wider platform, which Tora no doubt hoped to enlarge for his own agenda. In return, Tora gave Labour the promise of western Fijian support and assistance in resolving the problem of expiring leases. The land issue was serious. On the eve of the elections, Ba chiefs, who command the largest province in Fiji, wanted 87 per cent of the leases not to be renewed (34, 634 out of 39, 725 ha); and in Sabeto, Nawaka, Nadi and Vuda; and the chiefs wanted 92 per cent of the leases not renewed (12, 728 out of 13, 704 ha). Tora held, or gave the appearance of holding, the trump card. The Fijian Association was the third member of the Peoples' Coalition, led since its founder Josefata Kamikamica's death in 1998 by Adi Kuini Bavadra Speed.

The Peoples' Coalition was a loose structure with a minimal set of understandings, which invited attack from the rival coalition. 'It is not a coalition, it is a cocktail,' mocked Reddy. 'It is a sham and yet another attempt to con the people of Fiji. ${ }^{18}$ Who would lead the Coalition if they won the elections, Reddy demanded. This was one issue the Peoples' Coalition had not yet resolved. Chaudhry himself had said before the elections that bearing in mind the political sensitivities in Fiji, a Fijian should lead the 
country, and Dr Tupeni Baba was being presented at various rallies as the next Prime Minister of Fiji. 'I promise you that they will fight over the post of the Prime Minister if they win the general elections,' Reddy remarked. ${ }^{19}$ That they did, with grave consequences for the party's internal unity and long term future. But Labour's public position was that the party with the largest number of seats would provide the Prime Minister. Would that leader be a Fijian? The answer was the same. That stance provoked this response: 'The Fiji Labour Party leader publicly said it is stupid to name a leader when the parties are fighting an election separately, said Reddy. 'Indeed, how can political parties fighting an election separately call themselves a coalition? 20

The Peoples' Coalition similarly had flexible arrangement about the allocation of seats in the open constituencies. In some constituencies, they agreed to support a common candidate, while elsewhere it fielded parallel candidates. Where this happened, the Coalition partners were given their second preferences. This caused confusion, but voters were told to trust the party leaders and to leave the matter in their hands; they knew best. In some places, the strategy caused problems. PANU, for example, had expected, as a Coalition partner, to be allowed to field candidates in the western constituencies with substantial Fijian population: after all, it was an exclusively Fijian party, but Labour disagreed, and fielded its own, poaching some of Tora's prominent supporters and potential allies. Tora's own seat was contested by Labour whose candidate beat the PANU leader! Outmanoeuvred, Tora refused to attend any of the Coalition rallies. Towards the end of the campaign, he became a vocal critic of the Labour Party, chiding Labour president Jokapeci Koroi for not forgiving Rabuka and accusing Chaudhry of treachery. ${ }^{21}$ Tora refused to give preference to his coalition partner, the Fijian Association Party, which had also fielded candidates against his own party in the west. Chaudhry had won this round, but it would turn out to be a pyrrhic victory. Tora would have the last laugh.

Another political party which was formed on the eve of the elections, which would raise Reddy's ire, was the Veitokani ni Lewenivanua 
Vakaristo (VLV), or the Christian Democratic Alliance. Its support came from several different sources. First, there were those who opposed the 1997 Constitution. Rabuka and his party had 'failed the Fijian people miserably, the VLV charged. ${ }^{22}$ Rabuka had given away too much; he had 'exploited the indigenous Fijian institutions for his own glorification even to the extent of selling out on the rights and interests of Fijians.' Unless the 'core interests' of the Fijian people were addressed, there would be no political stability in the country. 'It will be fruitless and a waste of effort for all those who have been trying to build and make Fiji a better place for all to live in.' In essence, they wanted to restore those provisions of the 1990 Constitution which would have kept power in Fijian hands and so given substance to the notion of Fijian paramountcy. Other members and supporters of the VLV came from sections of the Methodist Church which wanted to turn Fiji into a Christian state. ${ }^{23}$ The very public blessing given to the party by the President of the Methodist Church, Reverend Tomasi Kanailagi, and the presence within it of such fire-breathing figures such as Manasa Lasaro and Taniela Tabu, was powerfully symbolic. The re-introduction of the dreaded Sunday Ban was on the cards again.

The VLV also had the support of members of the chiefly establishment. To prove their chiefly connections, they made traditional approaches to Ratu Sir Kamisese Mara (Tui Nayau) and Adi Lady Lala Mara (Tui Dreketi), as well as Tui Vuda, Ratu Josefa Iloilo. Most people believed that Mara was quietly endorsing the VLV. Close members of his own immediate family were contesting the election on the VLV ticket, including his daughter, Adi Koila Mara Nailatikau, his son-in-law, Ratu Epeli Ganilau, and Poseci Bune who was expected to 'strengthen and consolidate the Mara/Ganilau dynasty. ${ }^{24}$ Fairly or unfairly, Mara was accused of harbouring dynastic ambitions. Many Fijians also remarked on his rather cool relations with Rabuka for a whole host of reasons. Rabuka's accusation that there were other 'instigators of the coup,' and that he was the fall guy who had refused to fall, was interpreted to mean Mara's complicity. ${ }^{25} \mathrm{His}$ comment, in Lau of all places, that the SVT's commoner candidate could be 
more accessible to the electorate than a chiefly one, raised further questions about his loyalty to chiefs. Ratu Mara had never forgiven Rabuka for his dismissive comments about chiefs and their proper role in society, but about himself in particular: a towering banyan tree under which nothing grew, or would be allowed to grow.

The final VLV line-up included besides Bune, Ratu Epeli Ganilau, Koila Mara, nationalist, coup-supporting academic Asesela Ravuvu, trade unionist Salote Qalo and lawyers Kitione Vuataki and Naipote Vere. Reddy asked the voters to be wary of parties like the VLV, founded as they were, at least on paper, on principles of exclusion and intolerance. 'Will the Christian Democratic Alliance respect all the religions of this country?', he asked. 'Will they want to share political responsibility with the Indian people the way that Mr Rabuka and the SVT have?' He added: 'This is a time for reconciliation, moderation, and tolerance of all races, religions and cultures that grace this beautiful land of ours. This is not a time to support parties or coalitions which support religious intolerance. ${ }^{26}$ There was nothing unusual about the formation of the VLV itself. There were other parties with a similar agenda, variously aggrieved with the successful passage of the 1997 Constitution. The problem arose in the allocation of preferences. Although VLV was not formally a part of the Peoples Coalition, Labour courted its support and in all twenty two constituencies the VLV contested, it placed the party ahead of the NFP in the allocation of preferences: to a party that wanted Fiji declared a Christian State, the Sunday Ban re-introduced and the constitution changed. This was the politics of cynical opportunism at its best, or worst, clearly a breach of the spirit which underlined the Alternative Vote system. Labour operated on the principle of 'my enemy's enemy is my friend.' And in the bargain, Labour had tacitly gained the support of influential chiefs behind VLV as well.

The NFP itself had placed the VLV last in its preferences. Despite its competition with Labour, it had placed it ahead of the VLV 'as a matter of principle and morality.' 'This is politics devoid of any morality', Reddy retorted. 'The way Labour is fighting the election is very dangerous to the 
people and the country because they are stopping at nothing to get into power. This is power politics at its crudest. ${ }^{27}$ How could Labour do this, he asked? 'I find it is quite disgusting that a social democratic party like Labour which says it stands for some basic human values is lending its support to a group of people who neither believe in democracy nor the legitimate freedoms of other people.' 'There has to be some morality in politics,' Reddy said. 'It is very well to say that Labour is to bring down the government and the coalition between SVT and NFP, but at what cost? ${ }^{28}$ Stewart Firth, then a professor at the University of the South Pacific, put the preference trading issue this way: 'Normally a political party which is committed to and believes in what it preaches would give its second or third preference to another party that shares its political views. The Fiji Labour Party and Christian Democratic Alliance are very different - from one extreme to another - when you consider their stand on the land, Constitution and Sunday Ban. So what are they telling their voters? Are they saying that if they can't get into parliament with what they are offering, the voters can have a party with totally different policies and ideologies? The way I see it, it is just about getting into power. ${ }^{29}$

Labour's reaction to Reddy's tongue lashing was to counter attack. What about the SVT giving the Fijian Nationalists preference over Labour? Were they not members of the same coalition? NFP retorted that it was attacking Labour, not its Coalition partners, for its allocation of preferences. The fact was that NFP had little control over the preference allocation of its Coalition partner, but subtle points such as this got lost in the campaign. For Labour, NFP was its chief political enemy, and its destruction was their primary goal. Elections, moreover, were not about morality, but about wining seats, enough hopefully to form government. That was the end, the means did not matter. And no one believed that Mahendra Chaudhry, a devout Hindu (a devotee of Lord Hanuman, no less), would ever compromise his faith and agree to Fiji becoming a Christian state. People laughed off NFP's Devendra Pratap's claim that Hindus and Muslims would be converted to Christianity if Labour won 
the elections, as well as Manjula Verma's advice for the Indo-Fijians to save up money to buy lamps and candles because all lights would go out with Labour's victory. Politics was all a numbers game, people said, and that for many was what elections were all about. ${ }^{30}$

VLV won two seats and formed a part of the Chaudhry government. The party was then quietly dissolved, its purpose having being served: putting Bune and Koila Mara into cabinet. All that talk about Christian State and Sunday Ban was just that: talk, nothing more. Bune eventually joined Labour and became a senior minister in the Peoples' Coalition government, but fell out of favour with Chaudhry and was expelled from the party in 2006 for questioning the leader's judgment and thereby — so it was said — undermining party solidarity. Not only Bune but anyone in the party who crossed swords with Chaudhry, including party General Secretary Krishna Datt and Vice President Tupeni Baba, soon found themselves on the outer, even expelled. Chaudhry would brook no criticism, no challenge to his authority.

\section{ISSUES IN THE CAMPAIGN}

For Jai Ram Reddy, the main issue in the campaign was the constitution and the need to give it time to realize its full potential. The need for people of different ethnic groups to work together for a better future for all was the constant theme he espoused throughout the campaign, almost to the exclusion of more mundane but electorally important issues, some of his colleagues thought. What Fiji needed most of all was political stability: 'Experience around the world shows that political stability is a precondition for economic and social progress', he said. 'Without political stability we will not be able to achieve anything. Political stability will lead to enlightened and progressive policies which, in turn, will generate business confidence, investment, economic growth and, above all, job for our unemployed. ${ }^{31}$ Reddy emphasized his Coalition's pragmatic, problem-solving attitude through dialogue and negotiation. 'We all know what problems are,' Reddy argued: 'Unemployment, crime, the ALTA issues, scholarships for 
our children, poverty, housing, water, roads, electricity, pollution, and the basic one, how to grow the economy.' It was very easy for political parties in election campaigns to promise to solve all the problems without telling voters how they would do it. 'But what the voters must think about is this: which political party and coalition will be best able to provide the country with workable solutions to the range of problems facing us? Not theoretical pie-in-the-sky ideas, but real practical solutions that can be achieved and sustained?’

Labour knew that the constitution was Reddy's and NFP's strong suit, and sought systematically and relentlessly to downgrade its importance as an issue in the campaign. For it, the constitution was an accomplished fact and therefore a non-issue. Labour's Krishna Datt told pocket meetings that Reddy's role in the review process and in the formulation of the constitution had been greatly exaggerated. The spade work had been done by the Reeves Commission and the Joint Parliamentary Select Committee on the Constitution, of which he, too, was part. Reddy was merely the figurehead of a large and diverse team. Datt was forgetting that he had to seek Reddy's intervention to break the impasse on the composition of parliament which his committee had been unable to resolve for eight months. In Lautoka, a Labour candidate reportedly dramatized the 'non-importance' of the constitution by holding the Peoples Coalition manifesto in one hand and the constitution in the other and asking 'Which of these two documents will put food on your table?' 'This,' he said, as he held up the manifesto and flung the constitution to the ground. This was not an isolated incident; it was a part of Labour's overall campaign strategy to cut the ground from under Reddy's feet.

Reddy pleaded with the Indo-Fijian voters to give Rabuka a second chance. The man had done the coup, he agreed, but he had also helped give the country a new and fairer constitution. Labour, in an opportunistic expression of outrage, vowed never to forgive the coup maker, and Sir Vijay Singh asked why Rabuka should be rewarded for rectifying a grievous mistake he had made in the first place? As he wrote, 'In restoring the 
democratic constitution, Rabuka did the Indians no favour.' He had merely 'restored what he had stolen in the first place. He is deserving of some mitigation. If you were a criminal in court and you did some thing right, the court would deal with you lightly but it won't reward you. ${ }^{32}$ This was a harsh, unforgiving judgment on Rabuka and what he had been able to accomplish in the most difficult of circumstances, and in the face of opposition from within his own party. Sir Vijay forgot that Rabuka was not the sole instigator of the 1987 coups. Some of Sir Vijay's own former colleagues in the Alliance party, and now Rabuka's bitter opponents, had joined the colonel in 1987 to overthrow the 1970 Constitution. And, of course, Labour had lent him support to become prime minister in 1992. But these subtle points were lost. Reddy attacked Labour's strategy of constantly ridiculing and belittling Rabuka: 'It would be ludicrous for any Indian leader at this point in time to be involved in trying to unseat him because I believe that it is not only impractical but it will create more problems for the very people we say we are representing. The position is that we have taken the leadership as it is. It is not for we Indians to say who the Fijians should choose as their leader under the present constitution, no more than it is for the Fijians to say who the Indians should choose as their leader. The important thing is for the leadership of the respective communities to try and work together to resolve the major issues. ${ }^{33}$ The more Reddy appeared to 'defend' Rabuka, the more Labour attacked him, with increasing vitriol.

If Rabuka was one target for Labour, Reddy was another. Jokapeci Koroi described Reddy as a 'second fiddle player' for agreeing to let the SVT leader become Prime Minister, even in the unlikely event of the party winning more seats than the SVT. Reddy, like Rabuka, she said, 'cannot be trusted. ${ }^{34}$ She ridiculed Reddy's approach of moderation and reconciliation. Reading a fiery speech prepared for her, she had told Labour's annual conference at Khalsa College in Ba in June 1996 that the Indo-Fijian community must always 'agitate and demand its rights.' 'I do not believe that your rights which were taken away by the barrel of a gun will be returned to you by the signing of a document. In all countries, the aggrieved communities 
have [had] to fight for their rights. Look at India and South Africa. Fiji is no exception,' she said, 'so forget about dialogue, consensus and cooperation on the issue of your rights. Your rights are not negotiable. To give in now would be to subject your children to another girmit. ${ }^{35}$ This theme was repeated throughout the campaign.

And all the old, tired tirades were dredged up again: Reddy running away from Fiji at the 'height of the crisis,' of 'selling out Indian interests.' I recall a Labour meeting in Meiguniah, Nadi, at which Chaudhry told his audience (the settlement had a sizeable Muslim community in it) that on this occasion he would not speak about the campaign but about Jai Ram Reddy who, he claimed, had 'stabbed Mr Koya in the back.' 'How could you trust a leader who could do this to his own people?' This was a blatant way of firming up Muslim support for Labour, which was for the most part in its camp anyway. Reddy's alleged treachery was a common theme throughout the campaign. If betrayal of his leader was one sin, another was Reddy's betrayal of the Indo-Fijian community. This he was alleged to have done most grievously by not supporting Siddiq Koya over ALTA (for reasons already covered before). Had he done so, Labour argued, Indo-Fijian tenants, whose leases were expiring, would not be facing the tragedy they were. Agricultural Landlord and Tenant Act itself was branded as a 'noose around the neck' of the Indo-Fijian community, and for this Reddy was responsible! We have come across these accusations before, but what was interesting now was that the NFP was engaged in a constructive dialogue with the SVT government to find a solution to this perennially intractable problem which had bedevilled every Indo-Fijian leader since the 1960s when the ALTO leasing arrangement first came into existence.

Reddy defended ALTA as an entrenched piece of legislation. ALTA was to the tenant community what NLTA (Native Land Trust Act) was to the indigenous landowners, he argued. And, contradicting Chaudhry, he pointed out the benefits of ALTA. 'Far from selling them [Indo-Fijian tenants], we got them 30 years reprieve. We had the choice of either taking 
30 years or allowing the uncertainty to continue. The landowners wanted their land back. It was a matter of making a judgment, apart from other improvements that were done to ALTA in favour of the tenants. ${ }^{36}$ 'There can be no doubt whatsoever, that it has been this long-term security of tenure that has helped to underpin the soundness of the sugar industry in Fiji, NFP's Discussion Paper on ALTA said. 'By the nature of sugar cane farming, the benefits of investments, whether in new plantings of cane or major capital improvements of drainage or purchase of cane transport trucks, are inevitably long-lasting.' Farmers, it said, 'have been able to borrow (and financial institutions to lend) with full confidence that their investments into their agricultural enterprises will return them appropriate benefits over the long-term, commensurate with their financial and labour sacrifices. ${ }^{37}$ Reddy was 'reaching out to those who own land, and influencing the government.' 'Influencing people,' Reddy said, 'who are in a position to make the critical decisions that will resolve ALTA. I can't see how thumping the table and making all kinds of threats through the media can resolve the land problem. ${ }^{38}$

To resolve the land-lease impasse, the NFP proposed a number of measures, including providing market incentives to landowners to lease their land, government assistance with the payment of premium for lease renewals in cases of genuine hardship, full or partial compensation for exiting tenants, and assistance with the resettlement of displaced tenants. But perhaps the most novel aspect of the NFP proposal was for the government to act as a 'buffer landlord.' In this proposal, the government would act as a 'financial buffer' between the landlords and the tenants. It would lease land from Fijian landowning units at rentals lucrative enough for landlords to voluntarily lease their land rather than re-claim it. The government would then 'on-lease' the land to the tenants at rentals which would enable tenants, following best practice farming, to make an adequate living from the land. The difference between the rentals paid to the landowners and rentals from the tenants would be met by the government from the public coffers. It was an imaginative proposal with the potential to unlock the impasse, but 
before the NFP could proceed with the proposal, the elections intervened. The point unknown to the public was that much thought was being given to a difficult problem behind the scenes in an effort to get the government on board the proposal.

Labour reminded the electorate of the SVT record in government and cleverly implicated the NFP in the mess as well, calling it the RabukaReddy record. Truth and fairness were early casualties in the campaign. Mismanagement of public office, corruption at the top echelons of government, alarming crime rate, high levels of unemployment, enforced redundancies in public enterprises brought about the government's privatization and corporatization policies, the high cost of living in an economy deep in recession with two consecutive years of negative growth, the dreadful state of the public infrastructure: clogged up river systems prone to flooding, rundown roads and disrupted water supplies: all these were grist to Labour's campaign mill, and they made the most of it. This, Labour told the electorate, was the 'true' record of the SVT government. The electorate understood. The sight of redundant workers milling forlornly around the Nadi International Airport while the election was in progress, reinforced the image of the government as arrogant and uncaring. The NFP said little; for Labour the pictures of workers out of jobs, on the streets and all facing a bleak future, were a god-send. 'The NFP,' Labour president Jokapeci Koroi remarked, 'has been an ineffective opposition, frequently actively supporting the repressive measures of a government whose sole aim is to remain in power permanently. ${ }^{39}$ Koroi probably knew the truth, but all this was a part of linking Reddy to Rabuka and his government's policies; and the Indo-Fijian electorate believed her.

Labour's criticisms carried weight with a weary and worried electorate, but the party also promised new policies and initiatives of its own, which appealed to the poorer sections of the community living on the outer social and economic fringes of society. It would remove the ten per cent Value Added Tax and customs duty from basic food and educational items, review taxation on savings and raise allowances for dependants, provide social secu- 
rity for the aged and the destitute, and lower income rates on housing loans. If elected to power, Labour promised to repeal legislation requiring farmers to pay back the $\$ 27$ million cash grant and crop rehabilitation loan made to the drought-stricken farmers in 1998; establish a Land Use Commission, in consultation with landowners and tenants, to identify and access vacant lands; and oppose privatization of strategic utilities such as water, electricity, telecommunications and civil aviation. 'We also believe that the overall control of the exploitation of natural resources such as forestry and fisheries must remain in State hands to maintain their sustainability. We will, therefore, reverse all moves to restructure and privatize them. ${ }^{40}$

These words were music to the ears of Fiji's poor who believed Labour's rhetoric. But also interesting was the receptiveness of the message among the Indo-Fijian diasporic community, principally in Australia and New Zealand. Many had left Fiji after the coups of 1987 and had never forgiven Rabuka for carrying out the or Reddy now for working with him. There is a deep unforgiving streak in the Indian psyche which is difficult to explain but which is real. Grudges can be held for decades, even generations. Labour's strident anti-Rabuka rhetoric struck a chord with them. They contributed in various ways to Labour's cause but mostly through fund raising. NFP's former supporters overseas were, by contrast, more detached from the developments back home, less passionate about the cause of their former party. Labour was also able to tap into the resources of the Australian Labor Party, especially advice about the distribution of preferences. ${ }^{41}$ The ironic thing about the 1999 general elections was that Labour, supposedly the poor peoples' party, was far better funded than the NFP which was mercilessly portrayed as the party of and for the rich.

The Indian communal seats saw a two-way contest between Labour and the NFP. Labour won 109, 284 of the 165, 886 Indian communal votes (65.9 per cent of the first preference votes) and the NFP 53, 071 votes (32 per cent), but no seats at all. Labour fared well in both rural as well as the urban constituencies, its electoral dominance evenly spread across the board. Among the Fijian parties contesting the elections, the SVT won 67, 214 or 
39.5 per cent of the first preference Fijian communal votes, VLV surprisingly 21 per cent (35, 758), Fijian Association Party 32, 395 (19 per cent) and PANU 16, 353 (9.6 percent). The obvious question that arises is: why did Rabuka and Reddy, the two dominant political figures of the decade, fare so poorly, Reddy losing his seat and his party failing to win a single seat?

Rabuka's defeat was caused by several factors. His government's scandal-ridden performance was one of them. For many ordinary Fijians, life had not improved much since the coups. As Tamarisi Digitaki put it a year before the elections, 'at the grassroots level, the standards of living have remained largely unchanged from ten years ago. While his [Rabuka's] government's performance on the national and international fronts has been commendable, it is in the rural areas that the goods have failed to be delivered. Poor roads, water supply, communication services, education facilities and shipping services to the islands only give rural people more reason to vote the government out of office. ${ }^{42}$ Rabuka himself conceded that the complacency of his parliamentarians and a dormant party structure had cost him votes, saying that 'while party leaders were busy resolving national issues, no one was really looking into bread and butter issues affecting supporters. ${ }^{43}$ The same could accurately be said of Reddy.

Rabuka's pursuit of more moderate, conciliatory politics was always going to be fraught, facing the danger of being outflanked by extremist parties. The simple, inescapable truth is that political parties which court moderation in multi-ethnic societies tempt fate. Rabuka was accused of selling out Fijian interests, just as Reddy was accused of playing second fiddle to the Fijians. Rabuka faced other difficulties. He was not fully in command of the party he headed. The Fijian reserved seats were contested on provincial lines, where the selection of candidates was done in consultation with the leadership of the Provincial Councils. In some cases, candidates preferred or endorsed by the party were over-ruled by the provincial councils. Provincial concerns and interests took priority over party policies and national platforms. Back in the Fijian hinterland, Rabuka's role in the review and promulgation of the constitution was a distinct negative. 
Not to be discounted as a serious factor in Rabuka's defeat was the desertion from his camp of people who had supported him before. They included the leaders of the Methodist Church, people like Manasa Lasaro and Viliame Gonelevu, who were angry with Rabuka for embracing a more moderate, multiracial stance. They were bent on punishing him. Now they had a party of their own, the VLV, which repudiated Rabuka's reforming policies and accused him of being a traitor to his own people. Compounding Rabuka's difficulties was the disdain and disapproval of leading chiefs who were 'uncomfortable with a commoner being in power,' and who believed that 'Fijian leadership should always remain with the chiefs. ${ }^{34}$ Ratu Mara's disparaging assessment of Rabuka was no secret, fuelled, it was said, by envy at Rabuka's success in getting the new constitution through parliament and his increasing national and international stature, as well as by personal dynastic ambitions. Rabuka's anti-chiefly remarks, while appreciated by many commoners, infuriated powerful chiefs, Ratu Mara among them. Recall that he had called Mara the huge banyan tree under which nothing grew, could grow or be allowed to grow.

\section{REDDY'S EXIT: BADKA KNOWS BEST}

Reddy's defeat is more complicated. Some suggested that the Indo-Fijian voters had taken revenge against Rabuka for the coups of 1987, and that Reddy's pre-election coalition with the SVT had cost them the election. There may be a grain of truth in this view. But it was Labour, not Reddy, who had elevated Sitiveni Rabuka to prime ministership in 1992, so punishing Reddy seven years later makes little sense. Similarly, the pre-election deal may have cost some votes, but an alternative course would probably not have made much difference either. In the public mind, Reddy was already linked to Rabuka through their close cooperation in the constitution review process. Campaigning alone might have made it easier for NFP but that would have gone against the grain of what Reddy had been working towards for the better part of a decade. Reddy was adamant that the decision the NFP had taken was the correct one. The Coalition, he said, 'was 
based on some very fundamental principles. And you don't abandon your coalition partners because they have done something wrong or they may be suddenly becoming unpopular which is what people are saying we should have done.' He did not see it that way. 'I saw the SVT as the mainstream Fijian party. They were founded by the chiefs. They seem to have the support of the Fijian people. The important thing is that all these things we did with the utmost good faith because we believed in something. We believed that Indian and Fijian people and everybody else must be brought together in government. ${ }^{35} \mathrm{He}$ had been honest about his intentions with the people. So, the Coalition decision was not a 'grievous error of principle as well as strategy' as Sir Vijay R Singh had argued.$^{46}$ On the contrary, it was a principled initiative with an overarching goal of national reconciliation.

Reddy faced the same problems as Rabuka did. His overwhelming focus on the two pressing national issues - the constitution and expiring land leases - led to the neglect of the party's electoral infrastructure. The once powerful Working Committees, pale shadows of what they had once been, were rusting in the rural areas. In contrast, the Labour machinery was well oiled and ready. The Fiji Public Service Association, of which Mahendra Chaudhry was the general secretary, covered the public service. The National Framers Union (NFU), of which Chaudhry again was the General Secretary, galvanized the farming community. No one believed Labour's claim that the NFU was separate from the Fiji Labour Party: in name, perhaps, but not in deed. And the Fiji Teachers Union, of which Pratap Chand, a Labour candidate, was the head, reached out to the teaching fraternity in the community. Primary school teachers in rural communities exercised, as they still do, enormous influence, and they were in the Labour camp. So, farmers, teachers and public servants were on Labour's side, or leaning in that direction. The NFP's structure was less focused. It had its Management Board, chaired ably by businessman and hotelier YP Reddy. It was effective in fund raising and making the higher party machinery more efficient and business-like, but the links to the grassroots remained un-rejuvenated. 
'Mr Reddy is entitled to expect that a grateful electorate will reward him at the polls for his formidable achievements in restoring race relations,' Sir Vijay Singh wrote, 'and for bringing about a much acclaimed constitution.' 'Unfortunately, public memory is often short on that which one has delivered, long on expectations yet unrealized. ${ }^{.47}$ After the elections, he wrote of the causes of NFP's defeat with biting sarcasm: 'The NFP's determined pilgrimage to the political mortuary began with its belief in its own invincibility.' The party had neglected its roots and the lessons of recent history which had seen Labour make significant gains into its traditional heartland. 'Indeed, the NFP leadership became increasingly estranged from its traditional constituency: farmers and their working sons and daughters. Any view that did not echo their own was most unwelcome and heightened their blood pressure. The leadership preferred the society of its own urban business and academic friends. It was a case of intellectual incest. ${ }^{48}$

Not quite, but there was a kernel of truth in the claim. Much was left on Reddy's shoulders alone. Throughout the 1990s, Reddy talked about new directions and new thinking about a new future. His message would have been more appealing to the middle class and others with a long term views of things. But this segment of the Indo-Fijian community had declined substantially since the coups of 1987. Many of the best and the brightest had left or were leaving, and others were preparing to relocate. An important base of the National Federation Party had eroded substantially, while Labour's traditional base of workers, teachers and farmers had remained largely intact. Labour appealed to those who were desperate, direct victims of government policies: four hundred redundant employees of the Civil Aviation Authority, fiteen thousand garment factory workers and their families threatened with job losses, squatters and residents of low-cost Housing Authority flats, Telecom Fiji, Fiji Sugar Corporation and in the public service already reeling from a 20 per cent devaluation of the Fijian dollar. To these people, addressing the immediately pressing social and economic problems was more important than saving for the rainy day. 
If NFP's loss in the urban areas was understandable, its loss in the cane belt, which had once been the stronghold of the National Federation Party and where it had been launched some thirty years ago, was puzzling. The influential role of the National Farmers Union has already been noted as well as the controversy about ALTA and the non-renewal of leases. Chaudhry had effectively placed himself as the leading champion of the farmers and Reddy as indifferent to their welfare. He seized upon the socalled 'Cash Grant' issue to galvanize the farmers to his side, and according to many seasoned party observers, this was one issue which hurt the NFP especially badly in the cane belt. ${ }^{49}$ The cane growers had suffered badly as a result of drought the previous year, and the farmers, led by the National Farmers Union, demanded that the government pay cash grants to cane farmers who had lost their crop as a result of the natural calamity. They went on a strike to dramatize their cause.

The strike and the delayed harvest cost around $\$ 17.5$ million. It was an emotionally wrenching moment in the cane belt. Nonetheless, the tax payers could not be expected to bail out the drought-stricken farmers. As Reddy said, 'anyone with a modicum of intelligence should be able to see that cane farmers are not the only people who have suffered as a result of the drought.' In fact, the worst sufferers, he said, were the rural labourers, the mill workers and the subsistence farmers, all of whom depended on the sugar industry in way or another. No government, Reddy said, 'could indiscriminately give money (cash) to all the victims of a drought anywhere in the world.' So this call for government 'grant' was a gimmick from the beginning. The assistance to the tune of $\$ 8$ million would come from the Sugar Cane Growers Fund, and it wouldn't be in the form of a straight out grant but a loan, which the farmers would have to start paying off the following year (1998) at the rate of forty cents plus per tonne of cane harvested. This would be in addition to repaying other loans they got. Further, the assistance promised by the loan was really an illusion. The amount of loan the farmers would get at the rate of $\$ 2$ per tonne would not be sufficient anyway to indemnify them against the losses in 
production. Meanwhile, they would have depleted the source of funds and would not be able to access it in the event of real need in the future.

There was another point to consider. A charge was being made on the Fund without the consent of the growers themselves, whose funds they were, overseen by their elected representatives on the Sugar Cane Growers Council. The consultative process was vital. For Reddy, the depletion of the Fund would be hugely tragic 'because anyone with the long term welfare of the farmers in mind must understand that this is the only capital that the cane farmers of Fiji have, and we have heard again and again about their indebtedness.' He continued: 'I think one can say quite candidly without in any way exaggerating the situation that other than their homes, clothes and imminently expiring leases, this is the only asset these cane farmers have.' And he was 'irked' at the way in which the Fund had been 'played around for purely political reasons.' Reddy warned the farmers about what was happening and what was at stake for them. 'Let me say this to the cane farmers of Fiji: If and when this money is distributed, you are getting no more and no less than what is yours anyway. That is it. That is what you are getting, but remember this: if there is a hurricane in December and all your houses get blown off; if there is another drought next year and the year after, and you have no where to run to, remember who to blame.' '[I]f these few hundred dollars are given out now or in the next month or two months, six months down the road, eight months down the road, these farmers would have nothing to fall back on.' 'I feel sorry for the growers,' Reddy said, 'they have become like chattels. They are treated like chattels; they are not treated like human beings.' He meant treated in this fashion by Mahendra Chaudhry and the Fiji Labour Party. 'They are treated like dice on a chessboard, to be moved, to be manoeuvred, to be used and discarded.'

The next day, the Fiji Times carried the headline: 'Reddy hits out at Cash Grant.' This was gross misreporting of what Reddy had actually said, the 'figment of the imagination' of the journalist who wrote the story, as Reddy put it. Even so, the experienced politician that Reddy was, he knew 


\section{CASH GRANT CORRESPONDENCE}

Hon Jai Ram Reddy

Leader of the Opposition

Parliament Office

PO Box 2352

Government Buildings, Suva

Hon Sitiveni Rabuka OBE (Mil) OstJ MSD

18 June 1998

The Prime Minister

Minister with Special Responsibilities for the Constitution and

Minister for Regional Development and Multi-Ethnic Affairs

$4^{\text {th }}$ Floor, New Wing, Government Buildings

SIVA

\section{Dear Prime Minister}

I spoke to Minister Filipe Bole this morning on the subject of Government assistance to farmers to rehabilitate their crops lost due to the drought.

I am genuinely concerned that in the current circumstances, particularly with the imminent expiry of ALTA leases, there are thousands of farmers out there who will not be able to provide the necessary collateral to borrow. Without capital they will not be able to rehabilitate their crops. That in turn will adversely affect the sugar production and the national economy. More tangible ways must be found to help these farmers rehabilitate their crop. I hope your Government has not closed the door on the subject of assistance to farmers to rehabilitate their crops. In this respect I point out that crop rehabilitation may be some way into the future when the rains come, and we are now in the middle of our normally dry season.

I would suggest that there be further dialogue on this matter between Government and all other interested parties in the sugar industry at an early date

Yours sincerely

(Sgd) Jai Ram Reddy 


\section{REPLY}

22 June 1998

Hon Jai Ram Reddy

Leader of the Opposition

Opposition Office, Parliament Complex

Veiuto SUVA

\section{Dear Mr Reddy}

On receipt of your letter of $18^{\text {th }}$ June, 1998, I immediately asked the Minister for National Planning, Hon Senator Filipe Bole, to convene a meeting of the Ministers concerned to give further consideration to the assistance to be provided by Government to the Sugar Industry in the rehabilitation of the cane crop.

Senator Bole duly did that this morning. He convened a meeting of the relevant Ministers together with the Chairman of the Fiji Sugar Commission, the Chief Executive of the Sugar Cane Growers Council, and the Managing Director of the Fiji Sugar Corporation .

Following these discussions, the Sub-Committee of Ministers has made recommendations as summarised in the attached paper.

Before these recommendations are placed before Cabinet tomorrow afternoon, I thought I should refer them to you to see, and I would greatly value comments you may wish to make.

As you will see, the Government approach continues to be that the implementation of the cane crop rehabilitation scheme should be a joint undertaking between the Sugar Industry and Government.

The change now proposed is to make the necessary amendments to the law allowing the Cane Growers Fund to disburse the balance of the $\$ 27$ million in the Funds as grants rather than loan.

Likewise, Government support for the cane crop rehabilitation scheme will now be as a direct grant to the Fiji Sugar Corporation in the purchase of essential inputs, and no longer as an interest-free loan as Government had decided earlier. 
You will see that the cash assistance to the cane farmers will come from the $\$ 8$ million which the Sugar Growers Fund has set aside to assist the farmers in need with their living expenses. This will also include assistance in meeting with their land lease rent obligations.

I very much hope that this package of assistance will cover in a satisfactory manner the assistance needed by the Sugar Industry as a whole.

Looking to the future, I hope we can agree that perhaps a portion of the proceeds from sugar export sales, and in particular the difference between sales at the market price and sales at the special Lome Sugar Protocol Price, can be used to augment the Growers Fund in financing future expenses, such as cane price support scheme and/or a crop insurance scheme.

Yours sincerely

(Sgd) SL Rabuka

straight away the potential damage that the erroneous headline had done to his image. 'It is ammunition to my detractors,' he said, and hoped that the newspaper was 'not deliberately playing into the hands of these detractors.' Fiji Times reporting on political events in Fiji had unobtrusively taken an anti-Reddy and anti-NFP stance for sometime. In the campaign, the offending front page of the newspaper was laminated and presented as gospel truth, yet another example of Reddy's treachery. 'We are not saying this,' the speakers would say, 'this is what the Fiji Times is saying.' And, of course, the newspaper would never publish a lie. The issue was settled firmly in Chaudhry's favour in the public mind.

Reddy's great strength was also his weakness. No one, not even his opponents, doubted his integrity and sincerity of purpose. Privately, many Labour people greatly admired him as a leader and statesman. 'Right man, wrong party,' some said to me. But he could not emote with the public. There was certain aloofness to Reddy, which he recognized as just part of his nature. Chaudhry had an enviable 'grassroots touch,' sitting crossed-legged on 
a rough sack-covered earthen floor, drinking kava and swapping stories and information with his supporters. He had his ears close to the ground. People respected and trusted Reddy; they respectfully called him 'Vakil Saheb, (Honourable Lawyer Sir), but no one could ever imagine him sitting on the floor talking to the people. He was as reserved, even seemingly remote, as Chaudhry was gregarious and approachable. Hardly anyone in the party except its most senior officials called Reddy 'Jai' or 'Jai Ram,' while Chaudhry was often simply and endearingly 'Mahen.' Chaudhry understood the changing nature and mood of the electorate, to which he himself had contributed greatly. He was fondly referred to as 'Badka,' elder Cousin or Brother. Labour was portrayed as poor peoples' party, of farmers and labourers, while the NFP was portrayed as rich men's party. The name Labour itself had a certain almost mystical appeal to the poorer sections of the community, and Mahendra Chaudhry was their messiah. Labour chose candidates who were 'close' to the people, went to funerals and weddings and community functions, were 'one of them.' Their qualification to stand for parliament was for many a secondary consideration. Leave it to 'Badka': he knew best, people said. Getting into parliament was of paramount concern, in fact the only concern. 'It is a travesty of parliamentary system of government if we have people who come here and read speeches they have not compiled,' Reddy once said in parliament, reading speeches 'compiled by other people we do not see, we do not hear. ${ }^{50}$ It was a fine point that failed to register with the electorate. For his part, Reddy chose candidates who were highly qualified professional people who could be counted upon to contribute meaningfully to public debates and to the formulation of policy. 'Man-for-man' they were far better than Labour candidates in terms of experience, talent and education, but they lacked the one thing that now mattered most to the electorate: the grassroots touch, the willingness and ability of candidates to be an intimate part of their social world, to be there, with them, when they were needed.

In election campaigns, sometimes words which are not uttered publicly but whispered on the side can have subtle influence. Religion, culture, regional origins of people all come into play. Former NFP parliamentarian 
Karam Ramrakha once told me about the Ka, Kh, Ga (the first three letters of the Hindi alphabet) of Fiji Indian politics, and how these were cynically exploited by politicians during elections. $\mathrm{Ka}=\mathrm{Katta}$ $($ circumcised $)=$ Muslim $=$ Siddiq Koya; Kha=Khatta (Sour)=South Indians= Jai Ram Reddy; Ga=Gujarati= AD Patel. Translation: The Indo-Fijian community was predominantly North Indian, and yet all its major leaders in modern times had been

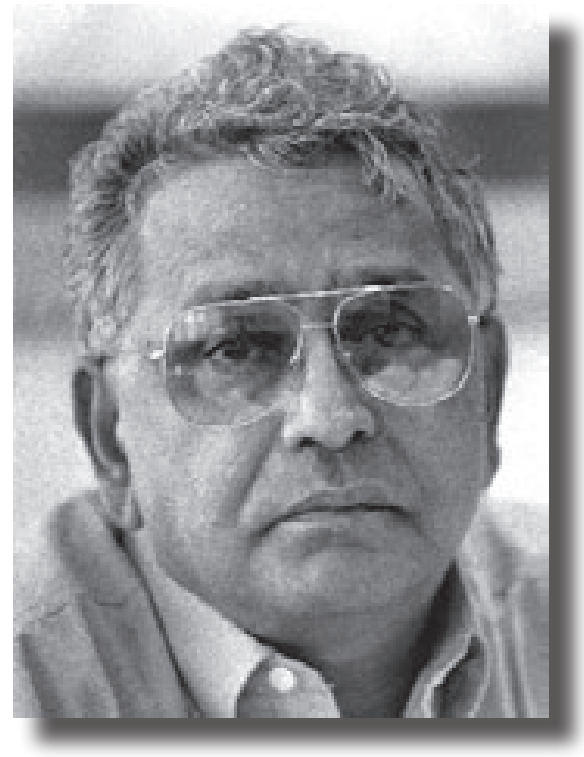

1999: The End of the Line.

Courtesy of Fiji Times 'outsiders': a Gujarati, a

Muslim and a South Indian. Wasn't it time to elect a North Indian, Mahendra Chaudhry, as the leader of the community? Blatant appeal was made to North Indian pride — and prejudice — though with what effect among urban Indo-Fijians it is difficult to tell. Many said that the NFP was not only rich peoples' party, it was also a South Indian party, pointing to its backing by some notable South Indians. Numbers don't bear out the claim, but the allegation stuck. I recall being told of a Labour candidate in Nadi (Shiu Sharan Sharma) who was a North Indian married to a South Indian. Among the North Indians, he passed himself off as a 'bhaiya' (brother) and among the South Indians as 'anna,' the Tamil word for brother. This sort of petty politics has long roots among Indo-Fijians. In the 1950s, for example, similar tactics were used against AD Patel: 'Apna Hai to Gair Kyun?' Why someone else when you have one of your own (a non-Gujarati candidate opposing him). What effect did this sort of insidious campaigning had 
on the voters is difficult to gauge, but it could not have worked to Reddy's advantage. Even more damaging to the NFP was the claim by some dropped North Indian parliamentarians that the party was South Indian. ${ }^{51}$

Another of Reddy's problems was that he was also fighting against the tradition of Indo-Fijian politics (of which he had once been a part) which thrived on grievance and chest thumping us-versus-them agitation. In that scenario, any perception of closeness to and cooperation with leaders of other ethnic communities and political parties was always seen as a sign of weakness, of having 'sold out.' Siddiq Koya had paid the price for cooperating with Mara in the early 1970s, and Reddy was now being rebuked for working with Rabuka. Chaudhry was comfortably at home in the old grievance-laden agitational style of politics long characteristic of cane belt campaigning. Rabuka was bad and should never be forgiven; Reddy was bad and should be rejected outright; ALTA was a sell-out of the farming community, and Reddy was responsible for that; Reddy had accepted a reduction of Indian reserved seats in the constitution, capitulating to Fijian pressure; Reddy ('Run-Away-Reddy') had decamped to New Zealand at the 'height of the crisis' in 1987; Reddy had stabbed Siddiq Koya in the back; Reddy was a 'second fiddle player' for agreeing to the SVT providing the Prime Minister if they won the elections; Reddy had stood between the farmers and the cash grant that was surely their due; Reddy, in short, was for Chaudhry 'a disgrace on the Opposition benches,' a man 'whose prime concern is his own survival,' and who as the Leader of the Opposition 'was greasing up to government. ${ }^{52}$ Harsh, unforgiving words from a man who knew the truth about Reddy's true record, and who was able to persuade people to believe him. Badka was Badka, after all.

Reddy, by contrast, was not running a political campaign in the old accustomed style of Fiji politics, seeking narrow advantage for his political party. He was in fact running a campaign of education of a type rare in Fiji, raising broad nation-building issues he had talked about throughout the 1990s. He was, in truth, leading a fundamental political transformation, not a narrow political campaign. He was talking about ideas, about a new vision 
for Fiji that transcended its past. He was asking people to lift their eyes to a new horizon, to look at the possibilities that could be nurtured by the new constitution. 'Our strategy is simple,' he had once said. 'It is based on sincerity of purpose and on the recognition of the fact that the only way to move forward is through dialogue and discussion, and to create an environment in the country where people are beginning to think again.' Noble sentiments but fatal in a do-or-die battle in which Labour was making a determined effort to appeal to the lowest common denominator in the electorate.

Reddy talked about the need for better understanding of the different cultures and traditions in Fiji. 'Is it not a shame that we do not speak each other's language? Why do we not speak each other's language after 100 years of existence on these islands? Has not our education system failed us miserably? Why have we not taught Indian children Fijian and Fijian children Hindi and let English be our common language.' 'We think we know our neighbour but we really do not, because we are not able to communicate with our neighbour in a language where you are able to convey to him your inner feelings, not just thoughts and logic but also your emotions, and those emotions are very important. We need to understand each other's emotions and then we may see the beginning of solutions.' He did not spare his own people who, he said, had not done enough to learn Fijian culture and traditions. He told them to be more sensitive to Fijian concerns and aspirations. 'There must come a time in the life of this nation,' Reddy said, 'when the many aspirations we talk about merge and become one. A mighty collective force, our collective aspiration, that will help propel this country into the 21st century, as a great nation, a shining example to the world, and to borrow that expression, The Way the World Should Be.' That, sadly, for him was not to be. He paid the ulitmate price for demonstrating the capacity to appreciate, respect and accept that a different perspective can be as valid as one's own, for traversing the chasm between rhetoric and practice of Fijian politics. Reddy's experiment in multiracial co-operation was also an epiphany, possible when those of goodwill are prepared to make themselves vulnerable and trust one another. 


\section{INTERLUDE}

\section{REFLECTIONS ON A POLITICAL TRANSFORMATION SYDNEY, 10 APRIL, 1999}

As I speak to you tonight, our country is turning yet another page in its history. We are in the midst of an election campaign which takes us farther along that course to reconciliation, rebuilding and unity mapped out in the 1999 Constitution. By mid-May, we will have a multi-racial, multi-party government founded on power sharing, consensus and equality, principles which underpin the new Constitution. I confidently expect that the coalition formed by the Soqosoqo Ni Vakavulewa Ni Taukei with the National Federation Party and United General Party, will have the numbers to form an administration and a cabinet. In accordance with a formal coalition agreement, the leader of the SVT is to become Prime Minister, and the leader of the National Federation Party Deputy Prime Minister. Some of our NFP members will be appointed as ministers.

For the first time, Ladies and Gentlemen, the elected representatives of the Indians of Fiji will play a full part in the governance of the nation. For the first time, the main Fijian, Indian and General Elector parties have joined together in a momentous union. It is another light of hope for the future.

I have come here to seek your support for what we are trying to achieve for our country. I know that although many of you have made a fresh start and created new lives for yourselves in Australia, your love for the islands of your birth is still strong. It is part of you. It is natural those memories of the Fiji islands are never far away and that you should think often of those friends and relatives you left behind. It is natural that you should want the best for your 
homeland - even though you are separated from us by distance and personal circumstances.

And so I am here to tell you about what men and women of goodwill, of all races, have done to bring about the transfiguration of the Fiji islands. Many of you are known to me personally. You are my friends. And I am sure you will share with me that vision of what we want our country to become.

I ask you first to consider how far we have travelled in the last 12 years - from the grim days of the military take-over and the persecution, discrimination and repression that followed. I see here people who suffered at that time, people whose lives were torn apart, who saw the very foundations of their society in ruins.

But, you know, it is a long road that has no turning and we have witnessed what that means in recent years. For a time, after 1987, it appeared that the schisms that kept our population apart could not be bridged, that we were fated to remain in the darkness.

Then, gradually, perceptibly, a change began. We in the National Federation Party saw that there was a way ahead. The time for anger was past. The time for recrimination and blame was past. This meant we have to transform our political thinking, putting behind us the old, rigid ways of racial competition and confrontation. We concentrated on the realization that the people of Fiji needed each other; that we were all citizens of one country, with common concerns, needs and aspirations. We began a painstaking and deliberate mission of reaching out to the Fijian people, of reassuring them that we had no wish to dominate and take power exclusively for ourselves.

We went into the 1992 elections, under the former Constitution, with one objective - to create trust and goodwill and a spirit of co-operation. We were convinced that from this would come an 
environment for change. From there we could go forward to a Constitution which recognized the rights and freedoms of all, which enshrined equality and fairness, which honoured the position of the indigenous community 'without relegating the Indians and the minority groups to a second-class status.

My friends, we discovered that the main Fijian leaders were willing to accept our hand of friendship. They too saw that a nation divided would never be all that it could become. The inherent goodness, kindness, and compassion of the Fijian people were manifested in the political dialogue that started in the early 1990s. Those of us from both sides who began that process opened our hearts and our minds to each other. We put our fears and insecurities on the table; we confronted them. And we found that it was possible to develop a common view of where we wanted the Fiji islands to go.

I now pay tribute to Sitiveni Rabuka, the man many of you, understandably, blamed for what happened in 1987. I too had reason to regard him as less than a friend. I tell you tonight that Sitiveni Rabuka has had the courage, the foresight and the conviction to do what many thought was impossible. He has risen to great heights as a leader by demonstrating unequivocally that he is committed to the unity and harmony of the Fiji Islands, that he wants to shape a society where we can all feel secure, where all races combine, in respect and equality, and pursue a common purpose — the welfare of our nation. He has done this at some cost - but he is not deterred. He will not be deflected from the course he knows is right. I have worked with him now for a number of years and can vouch for his sincerity in the search for the new Fiji.

From the start of our NFP policy of constructive engagement, Sitiveni Rabuka has been an influence for good. We began to detect tangible signs of the new mood not long after the 1992 elections. By 1993, I was able to tell a multi-racial gathering in Suva that I had 
never known a period when so many people were so committed to the idea of national unity and identity.

There was further evidence of how we were managing to reduce racial differences when two months later I was invited to speak at the closing celebrations in Suva of the International Year of the' World's Indigenous People. That emotional moment reflected on how remarkable it was that this celebration was closed by a nonindigenous citizen, that the organizers had seen fit to invite the grandson of an Indian indentured labourer to be chief guest. It was a reflection both of the tolerant and welcoming nature of the Fijians and of the Fiji we could build together.

As we proceeded with the intricate and delicate negotiations for transforming our country we inevitably encountered difficulties, deadlocks and opposing positions. But through quiet persistence, careful diplomacy and patience, consensus grew. Finally, through the efforts of the Joint Parliamentary Select Committee on the Constitution, we reached agreement on the appointment of a commission, to be headed by Sir Paul Reeves. It would gather the views of the population and make recommendations for a successor Constitution. Our nominee on that commission was Dr Brij Lal, who is with us tonight. I offer my heartfelt thanks to Dr Lal, Sir Paul and the other commissioner, Mr Tomasi Vakatora, for producing a unanimous report which laid down a blueprint for reconciliation and progress. Within the pages of that document were the ideas and recommendations which formed the basis for the making of the 1997 Constitution.

Ladies and gentlemen, that road I spoke of had yet another turning in June 1997. Through an initiative of the Prime Minister, I was honoured to speak to the Great Council of Chiefs. I confess it was a humbling and, yes, overwhelming experience. Never before had a Fiji Indian addressed that august body. We were breaking new 
ground. It seemed that all the complex strands of our past came together on that day. Speaking on behalf of the Indians of Fiji, I told the chiefs that their forefathers had created unity from warfare. Now they were called upon to be a source of unity for the islands their illustrious ancestors had set upon the road to modern nationhood. I went further. I submitted that they were chiefs, not just of the Fijians, but of all the people of the Fiji islands.

I am sure you will bear with me, if I repeat two other extracts from that I speech because they capture much of what I tried to communicate:

The Indians of Fiji, brought to these shores as labourers, did not come to conquer or colonize. We, their descendants, do not seek to usurp your ancient rights and responsibilities. We never have; we have no wish, no desire, to separate ourselves from you. Fiji is our home. Fiji is our only home. We have no other. We want no other. Our ancestors came to this land in search of a better life, in search of a future they dreamed of for their children and their children's children. Though they travelled to these islands long, long after your ancestors, surely the dreams and hopes of those who landed from the Leonidas were not that different from those who came ashore after the epic voyages from the west.

The memory of that meeting of the Great Council of Chiefs will remain with me to my dying day. All of us present had kept an appointment with history. The distance between us was closing — and the future called.

You are all aware that the constitutional reforms we sought are now the supreme law of the land. They received the support of all sides of the House. What we negotiated is not just our Constitution. It came from the elected representatives of all the communities of the Fiji islands. It has been widely accepted by the population at large. We can all hold our heads high knowing that we have banned all 
forms of discrimination, that the democratic freedoms and rights of the citizenry are fully protected and that the special place of the indigenous community is totally secure. We have an electoral system that is fairer than the one we had at independence, that encourages multi-racial co-operation and introduces voting for open seats where candidates from all our ethnic groups can seek the support of all the voters.

There is provision for a multi-party, multi-racial cabinet. I would suggest to you that we in the Fiji Islands have given an example to the world of what can be accomplished by harnessing the forces of goodwill and understanding in constructing a just society. Having said this, I must add that we have no illusions that the road before us will be easy. There will be hurdles and difficulties that we must resolve with the same concentrated purpose that has brought us this far.

Recently I attended a meeting in Paris where participants from 29 countries addressed topics relating to plural societies. Many enlightened initiatives came from that gathering with the sole purpose of promoting peace, tolerance and harmony in societies formed of differing ethnic and cultural groups. I was proud to be there knowing that we in the Fiji islands, in our own way and through our own efforts, had progressed with the task which many divided nations have found it so hard to accomplish. But I was reminded, too, that although we have avoided the kind of hell into which other countries have descended, we can take nothing for granted. Racism and extremism are always there, in every country. It is not hard to kindle the flames of latent bigotry and to place grievances in a destructively racial context. We must be ever vigilant in the Fiji islands in protecting our nascent culture of tolerance, respect and compromise. We still have leaders who prefer confrontational and 
aggressive approach, who do not hesitate to ruthlessly manipulate communal feelings for their own ends.

The SVT, the NFP and the UGP choose the middle ground. It is there that we will find the policies for a truly multi-racial government, sensitive to the needs of each citizen.

The coalition is not something that was conjured up for an election. The seeds for our pact were sown several years ago as we co-operated with the Fijian leaders in resolving our constitutional problems. The 1997 Constitution calls on us to come together as a country. The coalition gives practical shape to that fundamental precept. It is the result of all that [that] the three community groups have been able to achieve through co-operative endeavour. We have a proven track record and a strong moral base. It is in my considered view the political grouping most likely to succeed for the Fiji islands. While our opponents are still struggling to decide how they will allocate the 25 open seats in parliament, we can point to an agreement on this that was reached in a matter of minutes. All the fundamentals are in place.

We can tell the people exactly what will happen when we win the election. They know who the Prime Minister will be and who is to hold the office of Deputy Prime Minister. They understand how the cabinet portfolios are to be shared and the basis on which an SVT-NFP-UGP government will manage the affairs of the state.

Let me touch briefly now on that vexed question of ALTA, the Agricultural Landlord and Tenant Act. The issue of expiring leases is not easy. But I assure you that we are making good progress and that a solution will be found. A year ago, the problem looked to be intractable. But now, through application of the same co-operative spirit which marked our constitutional negotiations, we are beginning to see some results. There has been a great change in the attitude of the Native Land Trust Board, through the efforts of the Prime Minister, 
other ministers and Fijian members on a Joint Parliamentary Select Committee. Consequently, 82 per cent of the leases that expired in 1997 are being, or will be, renewed. We have been told in the JPSC, by none other than the General Manager of the Native Land Trust Board, that most, if not all, of the remaining tenants, will be offered 50 year leases for their house sites.

We are doing everything humanly possible, Ladies and Gentlemen, to create an environment in which maximum goodwill prevails and the maximum number of leases are renewed. Meanwhile, plans are proceeding for resettlement, where this is necessary, and there is the possibility that those who are resettled will receive 75 -year leases.

I ask you to consider what the outcome would have been if we had followed the course favoured by some - and that is to posture and to grandstand and provoke. The answer is clear.

Ladies and gentlemen, you have heard me referring to Fijians and Indians and General Electors. That is how it always has been. But want to add this: under the 1997 Constitution we now have a common name - Fiji Islander.

You have listened tonight to one of those islanders. Jai Ram Reddy is no longer an Indian from Fiji. He is a Fiji islander, born and bred. In the Koros and the settlements, the towns and the cities, the Fiji islanders are embarking on a historic journey of discovery.

We go forward as God's children, born equal, with the same rights and liberties and the same hopes for our country. It is this great truth that inspires us as we walk together towards that bright dawn of the third millennium and all the promise it holds. Thank you for listening, thank you for your continuing concern for the Fiji Islands and for your support. 


\section{NOTES}

1. 'I am out of polls, Reddy,' Fiji Times, 4 June 2001.

2. Daily Post, 16 Sept. 1997

3. The document made available to me courtesy of Kamal Iyer.

4. For this I draw heavily on material at the NFP headquarters, Tamavua, courtesy of Kamal Iyer.

5. Fiji Times, 11 Sept. 1997

6. Fiji Times, 10 Sept. 1997.

7. Review Magazine, Jan. 1998, 23.

8. See Sir Vijay R Singh, 'No Other Way,' Fiji Times, 27 Apr. 1999.

9. Daily Post, 26 Mar. 1999

10. From a speech at the launch of the 'Constitution Awareness Campaign' at Parliament House, 29 July 1998.

11. Fiji Times, 8 Feb. 1999

12. Fiji Times, 14 Apr. 1999

13. Fiji Times, 22 Mar. 1999.

14. From a Ministry of Information Press release (undated) ca 1998.

15. Fiji Times, 22 Mar. 1999.

16. Fiji Times, 2 May 1999.

17. Review magazine, May 1998.

18. Daily Post, 18 Apr. 1999.

19. Daily Post, 18 Apr 1999.

20. Daily Post, 18 Apr. 1999.

21. Fiji Times, 7 May 1999.

22. All the quotes are from the party's campaign literature in my possession.

23. Daily Post, 31 Mar. 1999.

24. Daily Post, 29 Mar. 1999.

25. Comment made at Girmit Centre, Lautoka. See Fiji Times, 25 Apr. 1999. 
26. Fiji Times, 26 Apr. 1999.

27. Fiji Times, 3 May 1999.

28. Fiji Times, 30 Apr. 1999.

29. Fiji Times, 27 Apr. 1999.

30. Based on my personal observation of the 1999 campaign.

31. From Reddy's final campaign address, 5 May 1999.

32. Fijilive, 19 May 1999

33. Fiji Times, 25 May 1996.Although spoken three years before the elections, they were repeated in the 1999 campaign almost word for word.

34. Fijilive, 28 Apr. 1999.

35. Address to the FLP Annual Conference, 1 June 1996.

36. Review Magazine, Apr. 1998, 17

37. I thank Kamal Iyer for making this document available to me. See also Biman Prasad, 'Resolving the Land Lease Problem in Fiji: A Way Forward,' Pacific Economic Bulletin, 21:2 (2006), 177-193.

38. Review Magazine, Apr. 1998, 18.

39. Daily Post, 2 Apr. 1999.

40. Peoples' Coalition manifesto

41. As ALP strategist Dale Keeling told Bob Norton, the whole strategy was to maximally exploit the preferential voting system to turn ideological opponents into tactical friends. Personal communication.

42. Review magazine, Feb. 1998.

43. Review magazine, June 1999; also Daily Post, 21 May 1999.

44. Review magazine, June 1999.

45. Review magazine, June 1999.

46. Fiji Times, 18 May 1999.

47. Fiji Times, 16 Feb. 1999.

48. 'Election Triumph and Tragedy,' Fiji Times, 18 May 1999. 


\section{IN THE EYE OF THE STORM}

49. I draw on material preserved at the archives of the National Federation Party, and thank Kamal Iyer for access to it.

50. Weekender, 7 May 1994.

51. For this I am grateful to former NFP President Jagindar Singh.

52. Review Magazine, Apr. 1998. 


\title{
CHAPTER 10: THE ROAD TO ARUSHA
}

\author{
In the deserts of the heart \\ Let the healing fountain start \\ In the prison of his day \\ Teach the free man how to praise \\ W H Auden
}

\begin{abstract}
A fter the elections, Jai Ram Reddy returned to his private practice in 1 Lautoka. But starting all over again was not easy for someone who had been away from the law for so many years, when the field of law itself, its practice and its needs and demands, had moved on. He rented an office in the city and made a start, but after a hectic lifetime in the public arena, mundane matters of criminal and civil litigation did not engage his imagination or spirit. For several months, he was listless, brooding, withdrawn. His friends and colleagues were concerned. He deserved better. There was talk of Reddy succeeding Sir Timoci Tuivaga as Chief Justice. He would have been an excellent choice, Sir Timoci told me. But since there was no vacancy at the top yet, Sir Timoci sounded Reddy out for the President of the Fiji Court of Appeal. Reddy mulled over the invitation and eventually agreed. He was appointed over the initial objection of the Labour members of the Parliamentary Sector Committee on the Judiciary who, according to Ofa Duncan, feared that constitutional cases might come up and Justice Reddy could use his position to wreak revenge on them for his defeat. Reddy was appointed in early 2000, but resigned in August of that year after the overthrow of the Peoples' Coalition government. He was not only a lawyer and judge, he said, but also one who had been intimately involved in the formulation of the constitution, and he couldn't in good conscience continue on the bench as if nothing had happened when anti-democratic
\end{abstract}


forces were running rampant, wrecking state institutions and making a mockery of the things that mattered most to him, affronting his sense of professional honour and personal integrity. He would remain in office until the hostages were released, and then he would leave.

Reddy's resignation was not to last long. The following year, after the restoration of the constitution by the courts, he was invited back to his old job, much to the relief of people like the Attorney General Qoriniasi Bale, who regarded Reddy as one of his mentors and who had been a Reddy supporter from the very beginning. This time, Reddy told himself, he would serve out his five year contract. He was now more reconciled with the past, more settled in his Domain quarters. The old laughter and gaiety and dinner parties were beginning to return to the Reddy household. But just when things were beginning to settle down to a pleasant routine, the Fiji Government nominated Reddy for a judicial appointment to the United Nations' International Criminal Tribunal for Rwanda. Initially, it was expected to be a part-time, on-call appointment, which would enable Justice Reddy to continue with his Appeal Court work. By the time it was realized it would not be this way, it was too late, Bale told me this with some regret because Justice Reddy was beginning to restore a semblance of efficiency and regularity to the work of the Court. Reddy was appointed to the Tribunal by the United Nations General Assembly on 21 May 2003. He finished his term in December 2008.

The Tribunal was set up by the United Nations in Arusha in 1994. Its purpose was to prosecute people responsible for committing genocide in that country and other breaches of international humanitarian law between January and December 1994.' Sometimes called 'a tropical Switzerland in the heart of Africa' for its high elevation, mild climate, and scenic beauty, Rwanda has a sad and haunting history. Rwanda is what might be called an ethnically divided society comprising two principal communities, the Hutu and the Tutsi. Tutsis, traditionally herdsmen, were an immigrant community who had arrived in Rwanda some six hundred years back from the northern parts of Africa. Although the Hutus, the first settlers of the land, outnumbered them in landownership and personal wealth, they were no match for 
the Tutsis. Under Belgian colonial rule, the divide between the two communities created by history, culture and custom, was deepened as the Tutsis were given privileges, in government employment, for example, that were not accorded to the Hutus. Animosity between the two groups increased. In 1956, the Hutus led a rebellion against the Tutsis, with the loss of over one hundred thousand lives. Many Tutsis dispersed to neighbouring countries, formed a militia under the Rwandan Patriotic Front, and waited for their turn to strike.

A Hutu-led government came to power at independence in 1962, and the discrimination against the Tutsis continued. In 1990, the Patriotic Front attacked the Hutus and a civil war began. Three years later, a ceasefire was arranged through the agency of the United Nations, and an attempt made to devise a multi-party cabinet to accommodate the two communities. But the Hutus, viewing themselves as victims of generations of Tutsi power and privilege, refused to countenance any Tutsi presence in government. In April 1994, a plane carrying Rwanda's president was shot down, and Tutsis were immediately suspected of involvement in the attack. This led the Hutus to launch their 'final solution' to the Tutsi 'problem.'

The mass killing of Tutsis began. Almost one million people died before the horrific violence was brought under control. The genocide took place in the full glare of the international media. 'Although on a large scale,' one report said, 'this genocide was carried out entirely by hand, often using machetes and clubs. The men who'd been trained to massacre were members of civilian death squads, the Interahamwe ('those who fight together'). Transport and fuel supplies were laid on for the Interahamwe - even remote areas were catered for. Where the killers encountered opposition, the Army backed them up with manpower and weapons. The State backed the Hutus and 'politicians, officials, intellectuals and professional soldiers deliberately incited (and where necessary bribed) the killers to do their work.' The report says that 'Tutsi men, women, children, and babies were killed in the thousands in schools. They were also killed in churches: some clergy colluded in the crime. The victims, in their last moments alive, were also 
faced by another appalling fact: their cold-blooded killers were people they knew - neighbours, work-mates, former friends, sometimes even relatives through marriage.'

ICTR's task was to determine whether the accused committed genocide, crimes against humanity and war crimes in Rwanda. Over the course of its work since 1994, some seventy persons were arrested, including the Prime Minister and fourteen government ministers, prominent administrators and military officers, leaders of the media and representatives of the clergy. Of these forty two persons were tried. Six were acquitted, eight pleaded guilty and the rest received life imprisonment. During his five and a half years at the Tribunal, Judge Reddy usually served in Trial Chamber I with Judge Eric Møse of Norway and Judge Sergei Alekseevich Egorov of Russia. He was the presiding judge in one trial, Mpambara, and a member of the bench in three others: Gausmbitsi (Mayor of a region of Rwanda), Serugando, and Basogara and others (Military One case).Basogara was by far the most complex case Judge Reddy heard in Chamber 1.The trial and the judgment made international headline. The case involved four military officers who were charged with multiple counts of genocide. The case lasted 408 trial days, during which 242 witnesses were heard. The Chamber rendered over 300 decisions, and the transcripts from the proceedings amounted to more than 30,000 pages. The written judgment of 18 December 2008 was 606 pages long. It was a monumental trial, unprecedented in the Tribunal's history. Three of the accused received life sentences, and the fourth was acquitted.

Judge Reddy is reluctant to talk at length about his Arusha work and experience, partly because some of the Tribunal's judgments are on appeal. And then there is his lawyerly caution and reticence to remember as well, his reverence for the protocols of the law, as Peter Thomson put it. But there is no doubt that Jai Ram Reddy made an indelible impression on the work of the Tribunal. His principled stance won him the admiration of many, including the legal officers of the Tribunal, who assisted the Trial Chamber in drafting the rulings and judgments. Wrote one of them upon 
Judge Reddy's retirement:

It has been such a great pleasure working with you these past few years. You have been a great example of a fair and just judge. Some judges bear the title of honourable by virtue of their position, but you do because of your wisdom, fairness and a sense of justice. Even though your mandate technically expires today at midnight, you will always remain the consummate judge. ${ }^{2}$

Fellow judges were equally laudatory in their praise of Judge Reddy's contribution. Former President of the International Criminal Tribunal for Rwanda, Judge Eric Møse wrote:

During his time in Arusha, Judge Reddy made significant contributions to international criminal justice. He was an extraordinary judge, fair and efficient. In all his activities, he demonstrated his eminence, constantly maintaining the highest standards of judicial and human integrity. He was highly respected and admired. It was a sheer privilege to sit with Judge Reddy on the bench. He immediately saw the core of the matter, irrespective of its complexity. When addressing intricate legal problems, he drew on his extensive judicial experience, profound insight and a human touch. He possessed the rare gift of being open-minded but yet principled, cooperative but firm. His commitment to fairness was unwavering. He was an appreciated colleague and a treasured friend. Judge Jai Ram Reddy has left his mark on the world map. ${ }^{3}$

These are very high words of praise indeed from a distinguished international judge, but they are not surprising to those who have followed Reddy's long public career in Fiji. Integrity, fairness, a commitment to principles, clarity of thought, capacity for insight and a human touch, combination of firmness with flexibility: he displayed all these qualities in abundant measure throughout his career. It is just that his opponents chose not to see them. Reddy is glad he went to Arusha, although at first, having just resumed work as President of the Fiji Court of Appeal, he was reluctant to uproot. The Arusha experience enriched Reddy. New 
areas opened up to him, both jurisprudential as well as geographical. He found the demanding work at the Tribunal intellectually fulfilling. He was widely respected by his peers and his contribution appreciated. Away from Fiji, on another continent, he found a peace of mind and heart and the opportunity to explore and savour things that would have been denied him in his own homeland. At long last, he found the honour and the warmth of appreciation and respect his own people had denied him. But then, the consolation, I suppose, is that prophets seldom receive recognition among their own people in their own lifetime.

Jai Ram Reddy is now in 'transition to retirement,' as he puts it, his working life almost complete. He left ICTR in December 2008, and declined an offer in May 2009 to be short-listed for a seat on the UNsponsored Kenya Constitutional Court to spend more time with his family in New Zealand. He has the time now to relax, savour the small pleasures of life and reflect on a lifetime spent on the centre stage of public life with friends and former colleagues. Many of the old protagonists are either gone or in limbo. Ratu Sir Kamisese Mara passed away in 2004 after a long ailment, a lonely and broken man, removed from Government House in 2000 by the military combating the George Speight insurgency, his legacy of chiefly leadership of a united Fijian society overturned by George Speight-led insurrection, and his cherished Nehruvian dynastic ambitions unrealized. Sitiveni Rabuka lingered on the public stage for some years after resigning from parliament following the 1999 general elections as a Commonwealth envoy to the Solomon Islands, as (a commoner) chairman of the Great Council of Chiefs, and as a newspaper columnist and political commentator, increasingly finding solace in his faith, but a man very much on the margins of his society and far removed from the national stage upon which he had once played such a prominent role. Mahendra Chaudhry still heads the Fiji Labour Party and may yet make a political come back: that he cannot be written off is one of the important lessons of recent Fijian politics. He is far too skilled to be trapped easily, but even his strongest supporters concede that he is no longer the widely adored leader of his party he once 
was, that his once stellar reputation for probity and judgment has dimmed and that his hold on his followers has fractured.

The Indo-Fijian community which Jai Ram Reddy led for a generation now lies hobbled in a cul-de-sac after a brief moment of hope and opportunity in the late 1990s. None of the problems facing it have been resolved. The land lease problem continues to fester. The sugar industry, which once formed the backbone of the country's economy and for which Indians were brought to Fiji in the first place, is visibly dying a slow death. Poverty levels are increasing as more and more displaced Indo-Fijians find a temporary shelter in the congested squatter settlements around Fiji's towns and cities. Race relations are outwardly calm but strained below the surface as accusations fly about who supported or did not support the 2006 coup, which deposed a democratically elected government headed by an indigenous Fijian. The consociational political pact which Reddy so patiently negotiated over a decade to resolve the country's constitutional conundrum and to give his people their just place in the broader scheme of things, now lies discarded. In so many ways and on so many fronts, Fiji is back to square (minus) one. Lewis Carroll's words in Through the Looking Glass are apposite: 'Now here you see it takes all the running you can do to keep in the same place. If you want to get somewhere else, you must run at least twice as fast as that.' Jai Ram Reddy's fate epitomizes the tragedy of modern Fiji: a country endowed with enviable human talent and natural resources better than most island nations of the Pacific, but strangely prone to self-inflicted wounds that hobble its prospects and dent its future, a veritable Churchill's Russia in the Pacific: 'a riddle, wrapped in a mystery, inside an enigma.'

Reddy now lives in New Zealand and makes periodic visits to Fiji to meet with family and friends still living there. But wherever he lives, Fiji is ever close to his heart, although he makes no public comment about the country. There is quiet distress at the state the country finds itself in: the violence and treachery of its leaders, the mounting human suffering, the erosion of the values of a decent, fair and humane society, the corruption of public morality, the lost opportunities and, above all, the betrayal of prom- 
ise: all this when everything once seemed so within reach. 'The promises have gone,' as a Stanley Merwyn poem says somewhere, 'Gone, gone, and they were here just now.' Nonetheless, as Reddy repeatedly said throughout the 1990s, despite all the setbacks and pitfalls, the deceptions and the deviousness, human beings live with the eternal hope that someday, somehow, the clouds of misery and despair will lift, that there will always be a dawn at the end of even the darkest night. Kali raaton ke aage savera bhi hai.

To end, I return to the beginning, to my conversation with Jai Ram Reddy on that hot, humid day on Teidamu Hill in April 2003. To my question about how he finally assessed his life in politics in Fiji, his emphatic reply was: 'It has been a wasted thirty years.' Reddy's deep disappointment at his defeat is understandable, but Theodore Roosevelt is worth quoting again: 'Far better it is to dare mighty things checkered by failure, than to take rank with those poor spirits who neither enjoy much nor suffer much, because they live in the gray twilight that knows not victory or defeat.' Defeat, as we all know, is not by any means the worst of failures. Not to have tried is the true failure. Jai Ram Reddy's rare achievement was to have witnessed and endured the worst that Fiji had to offer and still find hope and optimism in his fellow countrymen, someone who rose above the disunity and divisions that afflicted his country and his people, and, for a brief shining moment, managed to make hope and history rhyme. The glass-flat waters of the Nacilau Point still beckon as ever.

\section{NOTES}

1. All of this discussion is based on material easily accessible on the internet. My limited understanding of the Rwandan crisis is based on Christopher C Taylor, Sacrifice as Terror: The Rwandan Genocide of 1994 (Oxford: Berg, 1990), and Gerard Prunier, The Rwanda Crisis, 1959-1994. History of a Genocide (London: Hurst and Company, 1995). I thank Anthony Regan for bringing these two books to my notice.

2. For obvious reasons, the identity of the correspondent cannot be revealed.

3. From a letter to me, 19 Feb. 2009. 


\section{BIBLIOGRAPHICAL GUIDE}

Tor obvious reasons of space, I have kept reference to the published lit1 erature on modern Fiji in the text to a bare minimum. Professional researchers would (or should) know where to look for them, while lay readers are not likely to be particularly in need of them except for the occasional reference. What follows, therefore, is only a brief and selective guide to the published literature on modern Fiji.

For a general history of modern Fiji, see Brij V Lal, Broken Waves: A history of the Fiji Islands in the 20th century (Honolulu, 1992). The colonial foundations of Fiji are covered in JD Legge, Britain in Fiji, 1858-1880 (London, 1958) and Peter France, Charter of the Land: Custom and colonisation in Fiji (Melbourne, 1969). For the sugar industry, a good starting point is Michael Moynagh, Brown or White? A history of the Fiji sugar industry, 1873-1973 (Canberra, 1981). A recent account is in Padma Narsey Lal, Ganna: Profile of the Fiji Sugar Industry (Lautoka, 2008).Transition to independence is surveyed in Brij V. Lal, A Time Bomb Lies Buried: Fiji's Road to Independence, 1960-1970 (Canberra, 2008), his edited collection, Fiji: British Documents on the End of the British Empire (London, 2006) and in various research papers of Robert Norton covering political developments in late colonial Fiji. His Race and Politics in Fiji (St. Lucia, rev. ed. 1990) is an important study from an anthropological point of view. For two accounts on or by two of the leading figures in the independence debate, see Brij V Lal, A Vision for Change: AD Patel and the politics of Fiji (Canberra, 1997), and Ratu Sir Kamisese Mara, The Pacific Way: A Memoir (Honolulu, 1997). Deryck Scarr's biography of Ratu Mara, Tuimacilai: A life of Ratu Sir Kamisese Mara (Adelaide, 2009) came out too late to be of benefit to this study. 
The historical origins of the Indian community in Fiji are covered adequately in KL Gillion, Fiji's Indian Migrants: A history to the end of indenture in 1920 (Melbourne. 1962), and Brij V Lal, Chalo Jahaji: On a journey through indenture in Fiji (Canberra and Suva, 2000). Adrian Mayer's Peasants in the Pacific: A Study of the Fiji Indian Rural Society (Berkeley, 2nd ed 1973) is invaluable. Grant Anderson's Indo-Fijian Smallfarming: Profile of a Peasantry (Auckland, 1974) treats the important theme of cane farming among Indo-Fijians. John Kelly's A Politics of Virtue: Hinduism, sexuality and counter-colonial discourse in Fiji (Chicago, 1991) is an important anthropological study of the cultural politics of the Indo-Fijian community in the 1920s. For the political angle on this period, see KL Gillion, Fiji Indians: Challenge to European Dominance, 1920-1947 (Canberra, 1977). Ahmed Ali's From Plantation to Politics: Studies on the Fiji Indians (Suva, 1980) is useful for its perspective on the Muslims.

On Fijian society, an accessible introduction is in Asesela Ravuvu, Vaka Itaukei: The Fijian Way of Life (Suva, 1983); an earlier romanticised version is in GK Roth, Fijian Way of Life (Melbourne, 1953). Cyril Belshaw, Under the Ivi Tree: Society and Economic Growth in Rural Fiji (Berkeley, 1964), and Ray Waters, Koro: Economic Development and Social Change in Fiji (London, 1969) provide two acute analyses of the economic dilemmas facing the Fijian people on the eve of independence. OHK Spate's The Fijian People: Economic Problems and Prospects (Suva, 1959) is very much worth consulting still. Isireli Lasaqa, The Fijian People before and after Independence, 1959-1979 (Canberra, 1984) is also worth consulting for an indigenous Fijian take on developments affecting his people. An account of the Fijian leader, Ratu Sir Lala Sukuna, is in Deryck Scarr, Ratu Sukuna: Soldier, Statesman, Man of Two Worlds (London, 1980). Sukuna's papers published in Fiji: Three-Legged Stool (London, 1984) are worth consulting for a chiefly view of things.

EK Fisk, The Political Economy of Independent Fiji (Canberra: 1970) offers an orthodox race-based analysis of Fiji's economic and development dilemmas on the eve of independence. On the state of the Fiji economy 
at the time of the first coup of 1987, a good starting point is Rodney Cole and Helen Hughes, The Fiji Economy, May 1987: Problems and Prospects (Canberra, 1988). On the coup itself, there are several studies from a variety of viewpoints and ideological predispositions. For three studies, see Brij V Lal, Power and Prejudice: The Making of the Fiji Crisis (Wellington, 1988), Robert Robertson and Akosita Tamanisau, Fiji-Shattered Coups (Sydney, 1988), and Deryck Scarr, Fiji: The Politics of Illusion: The Military Coups in Fiji (Kensington, NSW, 1988). A special issue of The Contemporary Pacific, edited by Brij V Lal, (vol. 2: 1, 1989), is devoted to the 1987 coup and its immediate aftermath. Kenneth Bain provides a personal perspective in his Treason at Ten: Fiji at the Crossroads (London, 1989). Arlene Griffin provides a sample of literary and creative responses to the events following the first coup in her edited volume, With Heart and Nerve and Sinew: Post-Coup Writing from Fiji (Suva, 1990).

The 1990s politics are covered in my Another Way: The Politics of Constitutional Reform in Post-Coup Fiji (Canberra, 1998) and in my Islands of Turmoil. Elections and politics in Fiji (Canberra, 2006). Among scholarly journals where important contemporary Fiji material is published, these are the most noteworthy: The Journal of Pacific History, Pacific Economic Bulletin, Asia Pacific Viewpoint, The Contemporary Pacific: A Journal of Island Affairs, The Journal of Pacific Studies and occasionally in Pacific Studies.

Among the now defunct Fiji newspapers worth consulting for the period covered in this book, special mention should be made of The Review: A Magazine, The Weekender, Pacific Islands Monthly, Islands Business, The Hindustani, and the Fiji Sun. All these newspapers and many others are available at the National Archives in Suva, which remains the pre-eminent place for research on Fiji. The Pacific Manuscripts Bureau at The Australian National University contains much valuable Fiji material not available elsewhere, including the archives of the Fiji Independent News Service. The Noel Butlin Archives of Business and Labour and the Pacific Archives at the Menzies Library of The Australian National University 


\section{IN THE EYE OF THE STORM}

are also worth consulting for private papers relating to Fiji, including this author's. The Public Records Office at Kew Gardens, United Kingdom, has the most complete set of correspondence on colonial Fiji. 
Advani, LK, advice to participate (1992), 491

Advocacy, art of, 64

Ahmed, Gaffar, 16

Albert Park, violence (1987), 376

Ali, Ahmed, 1972 elections, 123

GNU proposal, 204, justifying 1987 coup, 370, 371

Ali, Shamima, 66

Alliance Party, Mara's dominance of, 29 formation and leaders, 91-2, government (1966), 93, Indo-Fijian members, 125, NFP Coalition offer, 151-2, protest against education policy, 306-07, arousing Fijian fears, 331, 1987 campaign, 332-33, defeat, 337, proposed investigation into, 357 , members in coup cabinet, 370

ALP delegation, report (1987), 414-15

ALTA debate, 132ff, UCV, 133, Reddy's defence of, 685-86

Alternative Vote, 602

ALTO provisions, 73, calls to revoke, 95

Amery, Julian, visit and views, 86-88 Andhra Sangam, Reddy's address, 28 Apted, Jon, 578

Arayana, Swami Bhaskar, 16 Arend Lijphardt, 438 Avinasananda, Swami, 51

Awasthi, Abhay, 122
Badri Maharaj, 83

Bahamas Model, 98

Bain, Kenneth, on Reddy, 384

Balaganpathy, MR (SVH principal), 54

Bale, Qoriniasi, 63, 358-59

Barrett, Wesley on Reddy, 174, 355

Bavadra, Dr Timoci, President, FLP, 311, criticism of Lau, 327-28, accepting victory, 1987, 338, plea for peace, 363 , court challenge to GG, 374, death of 487-88

Baxter, Alison Quentin, 578

Belonger Status, claim by Koya, 101

Benegal, Shyam, 47

Berlin, Isiah, xviii

Bokini, Ratu Ovini, 359

Bole, Filipe, 358-59, 365 on constitutional review role, 567-68

Borron House, 347, 367

Bowden, Herbert, 93

Brown, Doug, 92

Bulewa, Kelemedi, 6

Butadroka, Sakeasi, 128, 235

Butler, David, 192, 398

By-election (1968), 94

Cain, Rev. J, 47

Cakobau, Ratu George, 1968 by-elections, 95 , views and background, 165-66

Cane harvest boycott, 400

Cannibal Remark, 231 
Carroll Report, $227 \mathrm{ff}$

Carter, John, 124

Cash Grant fiasco, 693ff

Chapman, Mary, 10, 33, 65

Chaudhry, Mahendra, on Reddy's address to GCC, 10, 'wipe NFP off', 16, contrast with Reddy, 21-22, and NFU, 80, contesting byelection, 304-05, talk with Harish Sharma, 313, quest for dominance, 452-53, ascendancy in FLP, 488-89, on JPSC Report, 618-19. See also Fiji Labour Party, NFU

Chief Justice, appointment by George Cakobau, 166

CHOGM on Fiji, 412

Churchill, Winston, 14, 32

CIA, coup claim discredited, 385

Civil service, racial imbalance, 198, 200

Clark, Ramsay, advice, 491

Coalition government, incarceration, 346-47, protest against, 358-59, 362, harassment of supporters, 411-12

COLA (Cost of Living Allowance) debate, 285

Colonial rule, beginnings of, 67

Committee of 24, 88, 97, 126

Common Roll (1929), 84

Commonwealth, re-admission to, 665-66

Compact (1990 Constitution), 598

Consociationalism, 18, 438

Constitutional conf. (1965), 88ff, outcome, 90

Constitution (1970), 103, (1990), 586ff

Constitution (1990), view on, $586 \mathrm{ff}$

Constitution Amendment Bill, passage, $614 \mathrm{ff}$

Constitution Review, Terms of Reference, 518, sub-committee, 516-17, beginning, 532-33
Constitution Review Commission, role, composition, controversy, 571-73, Terms of Reference, submissions, 579-88, diagnosis and recommendations, 594-606

Constitutional Reform (1961), 85-86

Cooke, Sir Robin, 574

Coulter, JW, 59

Council of Advisors) GG's), 380-81, 82

Coup, 345ff, Rabuka's justifications, 365-66

CSR, Sangam education, 40-41, entry into Fiji, 75-76

Culture of Corruption, 522

Daryl Tarte, 51-367

Datt, Krishna, Secretary General, FLP, 308, 311-12, 621, 683

Dawai, Ratu Napolioni, 213

Deed of Cession, 67

Delaibatiki, Nemani, 352

Demographic transformation, xviii, 31

Denning Award (1969), 25, 51, 79, 139

Deuba Accord, 405-07

Diners Club, 502

Dove-Flower, healing, 192

Drasa Indian School, 49

Dugu, Isireli, 364

Duncan, Ofa, 713

Dunstan, Don, 578

Durie, Eddie, 574

Durutalo, Simione, criticising NFPFLP merger proposal, 489, 494-95, on Rabuka's GNU proposals, 515

Education, ethnic disparities, 81

Education Commission (1969), 245

Elbe, 42, 56

Election campaigns, changing culture, 453-54 
Elections (1966), 9, (1972), 124, (Apr. 1977), 142, 159, 161-62, (Sept.), 171-76, (1982), 217ff, Fijian backlash, 236, 242-45, (1987), 320ff, Mara's address, 329, (1992), boycott controversy, 490-93, 503ff, (1994), 528ff, (1999), 662-63, 671ff Electoral system, nature of, 596-97 Eliot, TS, 32 Elliot, CE (CSR), 40

Fairlie, Henry, 4, 15

Falvey Committee, 387ff, minority report, 396

Falvey, Sir John, Member for Communications, 86, 371, on ALTA, 135

Federation of Cane Growers, 79

Federation Party, launch of, 79, reaction to 1965 constitutional conference, 90-91, exclusion from Executive Council, 93, walkout (1967), 94, rifts in 96. See also NFP

Fiji Public Servants Association, 311

Fiji Court of Appeal, 713

Fiji High Court Judges, intervention in May 1987, 371-73

Fiji Labour Party, launch and manifesto, 305, 311, boycott campaign, 494, 495-97. supporting Rabuka for Prime Minister, 506, preference allocation (1999), 681-82, victory (1999), 688. See also Chaudhry

Fiji Muslim League, support for Fijian demands, 392, 397

Fiji population shift, 70

Fiji Principals Association, Reddy's address to, 439

Fiji society, compartmentalisation of, 41
Fiji Teachers Confederation, 307-08 Fijian, anger at Reddy, 20, fears, 31, call for independence, 97 , political consolidation, 196, backlash (1982) elections, 242-45, village, middle class, 325, changes in, 326, plea for unity, 330, division amongst, 502, paramountcy, 586-87, 596-97

Fijian Association, influence, 125-26

Fijian Association Party, 4, Reddy's address to, 440

Fijian Nationalist Party, 127-28, platform and appeal, 146, 148, support for Chaudhry, 507, 509-10

Firth, Stewart, preference allocation, 681 Flower-Dove factions, 172, (1982), 226. See also Dove

Foster, Sir Robert, 7, 10, 97, 104

Four Corners, 227ff, Fijian reaction, 232

French nuclear testing, debate, 449

Fiji Trade Union Congress, opposing wage freeze, 309.

Gandhi, Rajiv, 384

Ganilau, Ratu Sir Penaia Ganilau, and the 1977 constitutional impasse, 165 , civil service racial imbalance, 199, speech at GCC meeting in Bau (1982), 243-44, appealing for calm, 363, suspicion of coup sympathy, 367 , accommodation, 377-78, threat to farmers, 400 , acceptance of presidency, 413. See also Governor General

Gavidi, Ratu Osea, 1982 loss, 235

Gavoka, Joveci, 243

Great Council of Chiefs, veto powers, 103, 1933 resolution, 361, emergency meeting (1987), 377, Reddy's address to, 440 
General Voters Party, Reddy's address to, 440

George, Sir Telford, 574

Ghai, Yash Professor, 407, 483, advice to

participate in 1992 elections, 491, 566

Gillespie, Rosemary, 227, 230, 240

Girmit conditions, 43-44

Givertz, Don, 10, 570

Government of National Unity, 204ff, 514, 567.

Gordon, Sir Arthur, 67, 74-75

Governor General, statement (1977) 158, Path to Normalcy, 387-88

Govind, Kishor, seconding Fijian

Nationalist Party motion, 129

Grant, Sir Clifford, 158

Great Council of Chiefs, address by

Reddy, 10, 625ff, reaction (1982),

243-44, support for Fijian political

control, 393-94, launch of SVT, 500

Greenwood, Anthony, 91

Gujral, Inder, 665

Handley, Ken QC, on ALTA, 135

Hasan, Said, 77

Hawke, Bob, 375

Heseltein, Sir Michael, 383-84

Hindi Movies, 60

Hindu-Muslim schism, 160-62

Hurricane Relief Fund, controversy over, 357

Iloilo, Josefa, 6

Independence negotiations, 98

Inder, Stuart, Mara's revelations to, 237

Indian Alliance members, wooed by

NFP, 194-95, grievances, 195

Indirect Rule, 69

Indo-Fijian, complacency, 19, changing electorate, 26, cultural politics, 27, 30, forgotten leaders,
31-32, amnesia, 32, peasantry,

58-59, unity, 194, fears, 334-45, despondency, 85, 386, view on

1990 constitution, 586, communal politics, 686-89

Interim Administration (1987), composition, 370

International Criminal Tribunal for Rwanda (ICTR), 1, 64

Isireli Dugu, invading parliament, 364

Jagriti, 51

Jahajibhai, 48

Jakeway, Sir Derek, and the formation of Alliance Party, 91-92

Jalal, Imrana, 63, 66, 667

Jeddere-Fisher, Arthur, 62

Joint Parliamentary Select Committee, 519 , role, composition, report, 570-71, 617-22

Kabara, Matai, 365

Kamikamica, Josefata, assessment of

Reddy, 4, criticism of Rabuka, 527

Kamma traits, 47

Kangani system, 43

Kellock, Thomas QC, 99

Kermode, Sir Ronald, nomination for CJ, 166

King, Martin Luther Jr, 367

Kisan Sangh, formation of, 76-77, and

Alliance affiliation, 80

Knox-Mawer, Ronald Judge, 63

Kochar, Sonu (Indian High

Commissioner), allegations

against, 237, 238, 242

Koroi, Jokapeci, 684

Koya, Siddiq, style of politics, 11-12, relations with Reddy, 13, criticism of, 122, rift with Mara, 127-28, 


\section{INDEX}

on Butadroka's motion, 130-31, on ALTA, 134-35, 138, on Sugar Price Stabilization Fund, 139-140, rift with Rudrananda, 140, attacked, 141, 144-45, leadership tie, 155 , political retreat, 192-93, Letter, 239-241, 242, contest with Irene Narayan, 292, 294, reaction to 1985 by-election, 299-300, protest against, 300-01, opposition to NFP-FLP coalition, 313, 317-18, 319, against boycott strategy, 493

Kubuabola, Inoke, planning the coup, $365,605 \mathrm{ff}$

Kuppuswamy, Sadhu, 49-50

Kurusiqila, Apenisa, on Reddy, 33-34, facilitating role, 570

Lal, Brij V, Commissioner, 576, 577-78

Land, reservation and use, 200-03, 204 Land Tenure, 71

Land transfer (Crown Schedule A\&B), 512

Lands Claims Commission, 71

Lange, David, 316, 375

Lau, criticism of, 375

Leader of the Opposition, role, 444-45

Leadership, Reddy's views on, 15

Legislative Council, evolution and composition, 82-83

Leweniqila, Militoni, 6, 345, 358, 365

Lewis, Justin QC, 62, 63

Lodhia, Hargovind on Reddy's 'honesty,' 4, 52

Look North Policy (1987), 479

Macmillan, Harold, 'Winds of Change' 40
Maddocks, Sir Kenneth, 85

Madraiwiwi, Joni, 7, 63, 349, 356, 378

Maha Sangh, formation of, 78

Maharaj, Navin, FLP boycott strategy, 493

Maitoga, Atunaisa, 155

Malaysia, lessons for Fiji, 98

Manilal Maganlal Doctor, 83

Manning, Peter (ABC), 232

Manueli Committee (FCIAC), Terms of Reference, submissions to, 481-86

Mara, Ratu Sir Kamisese, on AD Patel, 7, on relations with Reddy, 7, on relations with Chaudhry, 8, leader of the Alliance, 29, Member for Natural Resources, 86, constitutional conference (1965), 89, on 1968 by-elections, 95, rift with Koya, 127-28, on Butadroka's motion, 130, accolades, 141, approach by SB Patel, 148, rejecting NFP's coalition offer, 151, appointment as minority prime minister, 158 , criticism by Indian Alliance, 195, on land reservation, 202-03, on GNU, 207, on Western United Front, 216, on Bau resolutions (1982), 244, and Carroll Report, 227, 230-31, Russian allegation, 237-38, plea for Fijian unity, 330, silence (May 1987), 363-64, conceding defeat (1987), 338, member, Interim Administration, 370, accusations by David Lange and Bob Hawke, 375, on Rabuka's 'Minimum Demands,' 410, encouraging Rabuka's rivals, 435-36, 501-02

Maddocks, Sir Kenneth, 85 
Maharaj, Badri, 83

Manilial, Maganlal Doctor, 83

Maraj, James, 292

Marella House, controversy, 329, 357

Mataitoga, Isikeli, 371

Matatolu, Koresi, 6

Mavoa, Jonati, 171

McGusty, VWT, 77-78

McKinnon, Don, 10

Member System, introduction of, 86

Method of Voting, 102

Methodist Church, support for Fijian political control, 392, view of 1990 constitution, 587

Mishra, Ghananand, 63, 166

Monson, Sir Leslie, 98-102

Moosad, PND, 55

Møse, Eric, 64, 716-17

Munro, Sir Robert, 353

Muslims, demand for separate representation, $84-5$

Naidu, Richard, on Reddy, 33, attacked, 402

Nailatikau, Epeli, 370

Naqvi, Syed, 160-61

Narayan, Irene Jai, attacked by Koya, 138, accolade, 141, letter to Mara, 153-54, denying contacting Governor General (1977), 162, on racial discrimination in scholarship allocation, 197, Alliance liability, 335-6, 337

Narsey, Wadan, 667

Nata, Joe, 7

National Democratic Party, 98, 125

National Farmers Union, 80

National Land Commission, Mara's reaction to, 324-25

Native Regulations, 69
Nayudu, Sir Venkata Reddy, 47

National Bank of Fiji crisis, 448-49

National Federation Party, internal struggles, 27, 29-30, paradox of loss (1999), 20, constitutional talks, 100-101, division and decline, 121ff, split over ALTA, 138, 140, factions, 143, victory (Apr 1977), 148 , coalition offer to Alliance, 151-52, leadership tie, 159, failure to form government, 159, Russian allegations against, 237-38, walkout from parliament, 286-88, contest for leadership, 292, by-election, 296-7, Suva Declaration, 456, triumph (1994), 531-32, candidates (1999), 667-68, preference allocation, 680-81, defeat (1999), 688, weakened base, 692. See also Federation Party

NFP Youth, 292, 295-96

NFP_FLP Coalition, 313, seat sharing formula, 414, manifesto, candidate selection, 317, victory, 337, NFP under-representation in cabinet, 354, 356, letter to Governor General, 368-9, visit to UK, 383, representation on Falvey Committee, 389, submission to Falvey Committee, 395, submission to Manueli Committee, 483-84, fracture, 489, submission to CRC, 592-93

NFP-SVT coalition agreement, 670-73

NFP-WUF Coalition, 215

NFU, formation and role, 503-04

Nicole, Hurst report, 309

Nimmo, Sir John, 62

Nishant, 47 


\section{INDEX}

NLTB, 72-73, criticism of, 323-24,

North India, migration from, 43

Nuclear issue, 316

O’Neal, Tip, 16

Operation Taukei, 125

Opposition, problems of leading in Fiji, 30-31

Pacific Review, founding of, 52

Palmer, Bruce, 63

PANU (Party of National Unity), 677

Paramanandam, Vijay, 26, on NFP reconciliation, 192 , attacks by 234 , 235,241

Parliament by Proxy, 26

Patchett, Professor Keith, 406

Patel, AD, xii, xiii, 5, 10, and SVH, 54, on ALTO, 73-4, on Muslim separatism, 84-85, Member for Social Services, 86

Patel, RD, resignation, 123, attack on Koya, 141

Patel, SB, 77, approach by Koya, 148

People Power, 26

Peoples Coalition, 676-78

Pillay, Armugan, 195

Pillay, Manikam, 53

Pine project, 211-12

Political landscape, changing, 25-26

Political leaders and lieutenants, 24-25

Politics of principle, 22-23

Preference allocation (1999), 23

Public Emergency Regulations, following Sept coup, 398-99

Public Order Act, 362

Queen Victoria School, Reddy's address to, 443
Rabuka. Sitiveni, 5, relations with Reddy, 8-9, GNU proposal, 209-10, justifying the coup, 365-66, shifting blame, 366, GCC support and celebration, 378, Minimum Demands, 409, attitude towards chiefs, 435 , President of SVT, 500-01, race for Prime Minister, 504ff, betrayal by colleagues, 526-27, 1999 election attacks on, 683-84

Rabukawaqa, Sir Josua, 231

Race, Jeffrey, 227

Rakkha, Balwant Singh, 1985

by-elections, 296-298

Ramakrishna Mission, 16, 50-52

Raman, James, on wage freeze, 310-11

Ramaphosa, Cyril, 582

Ramphal, Sridath. 384, 412

Ramrakha, KC, resignation from NFP, 123, on Mara, 127, on Koya's leadership, 144, denying contacting GG, 162, rift with Reddy, 173, on GNU and Mara, 207-08

Ratu Osea Gavidi, on pine harvesting, 213, See also WUF

Ratuva, Steven, on Reddy, 33

Ravindranathan, CP, 355

Ravuvu, Asesela, 586

Reddy, Jai Ram, early political career, 4-5, relations with Fijian leaders, 6 , address to GCC, 10 , on Chaudhry as successor, 16-17, consociationalism, 18 , contrast to Chaudhry, 21-22, 489, brunt of Fijian anger, 20, approach to Coalition, 22ff, assessment, 33, ancestral background, 42ff, girmit, memory of, 44, on SVH contribution, 54 , early education, 
55, legal career, , 62ff, appointment to Senate, 121 , statement over radio (1977), healing NFP rifts, 142-43, 149-51, radio statement (1977), 167-69, visit to the US, 193-94, reconciliation efforts, 195, racial imbalance in the civil service, 198, on land reservation, 201-02, on GNU, 206, 208-09, 515, Reddy on WUF Coaltion, 215, 'Toilet Remark,' 222-24, and Carroll Report, 228ff, 1982 victory, 234, response to Russian allegation, 238, 240 , reaction to Bau resolution, 245-46, COLA debate, 285-86, resignation as NFP president, 304, Coalition negotiator, 314, 319, lashing of NFP dissidents, 319-20, initial reaction to coup, 346 , congratulatory letters, 352-53, meetings in New Delhi, 384-85, on CIA connection, 385, rejecting Muslim separatism, 397, Deuba Accord, 405-6, 408, address to the Year of the Indigenous People, 443, on NBF saga, 448-49, motion on French nuclear testing, 449-451, approach to politics, 454-56, rejecting the 1990 Constitution, 478, 486, on Bavadra, 488, opposing boycott option, 492-93, plea for Indo-Fijian unity, 510-11, criticism of SVT budget, 523, Pillar Principles, 568-69, view of SVT submission, 590-91, address to the GCC, 624-25, defense of ALTA, 136-37, 666, 685-86, on JPSC report, 620-21, 1999 defeat, 690ff, to Fiji Court of Appeal, 713 Reddy, Chandra, 65, 349
Reddy, KS, 53

Reddy, Sanjiva, 47

Reddy, Sesha, 56-57

Reeves, Sir Paul, Chair, CRC, 574-75

Reluctant politician, Reddy, 15

Richards, Sir Arthur, 51, 72

Ringamoto, Walter, 574

Robinson, Sir Hercules, 67

Roosevelt, TR, xviii, 720

Rouse, Graham, 28

Rudrananda, Swami, 51, 53, on Kisan Sangh, 77, on ALTA, 136

Russian Allegations, against NFP, 237-38

Sadhu Bashist Muni, 58

Saheb, Shaukat Ali, 55, 91

Sahu Khan, Shams-Ud Dean, 163

Sanday, Jim, 370

Sangam, 51

Sangam, CSR assistance with schools, 40-41, founding of, 49, and

Ramakrishna Mission, 51

Scholarship allocation, controversy over, 145, 197

September coup (1987), 410

Sharma, Harish, NFP President, 304, 313, 314

Shepherd, Lord, 99, 102

Sherani, Faiz, 223

Singapore-style cabinet, controversy over, 224-5

Singh, Kuar Battan, 149

Singh Devendra, 1985 by-election, 298

Singh, Anil, NFP Youth President, 292, 295-96

Singh, James Shankar, criticism of Mara, 195

Singh, Kuar Battan, 149

Singh, Natwar, 384

Singh, Sir Vijay R, admission to NFP, 


\section{INDEX}

195, and Carroll Report, 229-30,

233, on Reddy's resignation from

parliament, 289, on NBF saga, 449

Siwatibau, Savenaca, 349

Smith, Trafford (on ALTO), 74, 93

Socialist International, controversy about, 235

South India, emigration from, 42ff, castes, 46-47

South Indians, prejudice against, 48 , education, 50, and Kisan Sangh, 78

Spate, OHK, xvi

Speed, Adi Kuini, Leader of the

Coalition, 488

Speed, Clive, 227, 230

Speight, Sir Graham, congratulating Reddy, 355, 574

Sreenivasan, TP, 332, 364

St Joseph's Secondary, Reddy's address to, 443

Stanner, WEH, 58

Stephens saga, 447

Stinson, Peter, 370

Street Commission, 99

Stuart, HA, 47

Stuart, Ken, 62

Sugar Price Stabilization Fund, 139, 140

Sri Vivekananda High, 16, transfer of, 53-54

SVT, launched, 500, criticism of 501, pro-Fijian policies, 512, submission to CRC, 588-89

Sykes, Joseph (PSC Chair), 198

Tabua, Inoke, 242

Tarakinikini, Filipo, 376

Tarte, Daryl, 51

Taukei Movement, 361-62, demands, 395, threats, 401ff, view of 1990

Constitution, 587
Tavai, Etuate, 6, 451

Tavaiqia, Josaia, 6

Tax Free Zone, 479

Telanganna rebellion, 47

Third Coup claim, 528, 529, 530

Thomson, Peter, 3, 7, 383, 716

Thomson, Sir Ian, 574, 575

Three-legged stool myth, 41

Toganivalu, David on Butadroka's motion, 132

Toganivalu, Julian, for NFP leadership, 173

Toganivalu, William, 6, on Belonger

Status, 101, offer of Speaker, 358

Tora, Apisai, western Fijian demands,

213, protest against Coalition, 360-61

Trade Disputes Act, 311

Tripartite Forum, disbanding of, 309

Tuisawau, Mosese Ratu, 6

Tuivaga, Sir Timoci, appointment as

Chief Justice, 166, 713

Tuwere, Ilaita, 570

Unimproved Capital Value (ALTA), 133

Usher, Len, 191, on 1987 campaign, 338, blaming Reddy, 407-8

Vajpayee, Atal Behari, 490, 665

Vakalalabure, Tevita, 243

Vakalelewa ni Pasifika, 51

Vakatora, Tomasi, on 'Toilet Remark' 224, on COLA debate, 285-86, on

Rabuka's Minimum Demands, 410, Commissioner, CRC, 576

Veitata, Taniela, 345

Venkateswaran, AP, 384

Verrier, Lindsay Dr, 152, 165

Vesikula, Timoci, threats, 399, 401-02

Vieuto, Coalition incarceration at, 347

Vishnu Deo, 84 
VLV Party, Reddy's view of , 678-79

Volunteer Teachers Scheme, 306

Vosailagi, Bulou Eta, rejecting

Coalition government, 316

Wage Freeze, 309-10

Wakaya Letter, 86

Walker, Charles, on Reddy, 191, resignation over COLA, 309

Walters, General Vernon, 316

Ward, RG, 326

Watt, Lindsay, 292

Western United Front, 213

White, Eireen, 90

White, Sir John Commission, 240

Wilson, Emelita, 66

World War II, changes following, 42

Zachariah, Yatim, 581 


\section{ABOUT THE AUTHOR}

Brij Vilash Lal, grandson of a girmitiya, was

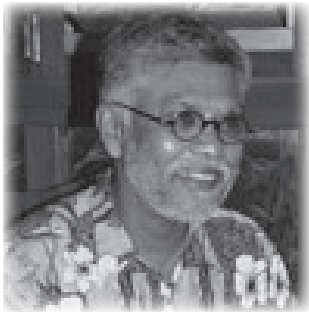
born in the remote, pre-modern village of Tabia on the island of Vanua Levu. After high school in Labasa, he received his tertiary education at the University of the South Pacific, the University of British Columbia, and The Australian National University. He has been an academic all his adult life. He was awarded the inaugural Distinguished Pacific Scholar Medal by the UNESCO-sponsored International Council for the Study of the Pacific Islands and the Centenary Medal of the Government of Australia for his contribution to the Humanities there. A Fellow of the Australian Humanities Academy and an Officer of the Order of Fiji, he was honoured by the Fiji Millennium Committee for his scholarship and named as one of seventy-five people who helped shape Fiji's 20th-century history. Recently, he was selected as the only living of five distinguished historians of the Pacific Islands to have made significant contributions 'Beyond the Ivory Tower.' Dr Lal also played a practical role in the recent affairs of Fiji as a member of the Fiji Constitution Review Commission whose report formed the basis of the now-abrogated but once widely praised 1997 Constitution. He has been a staunch critic of coups in Fiji. Dubbed a 'Trouble Maker' by some and 'Conscience of the Nation' by others, he was deported from Fiji by the military regime in November 2009. Dr Lal has been at The Australian National University since 1990 where he is a Professor of Pacific and Asian History. He is married to the Environmental and Resource Economist Padma Narsey Lal, and they have two grown up children, Yogi and Niraj. Apart from work, his abiding passions include exploring the Australian bush with friends and, when time permits, following the game of cricket. 
